\title{
NUREE G--0750
}

NUCLEAR REGULATORY COMMISSION

ISSUANCES

OPINIONS AND DECISIONS OF THE

NUCLEAR REGULATORY COMMISSION

WTH SELECTED ORDERS

January 1, 1996 - June 30, 1996

Volume 43

Pages 1 - 358

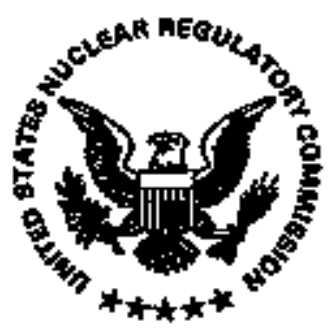

RECEIVED

MAY 02 1997

OSTI

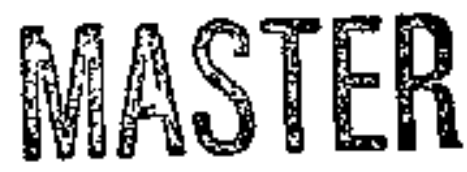

Prepared by the

OTtice of Information Resofurees Managemtent

U.S. Nuclear Regulatory Commission

Washington, DC 20555-0001

(301-415-6844)

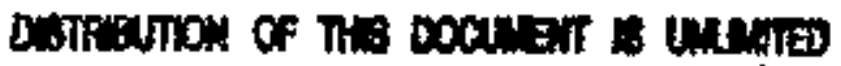




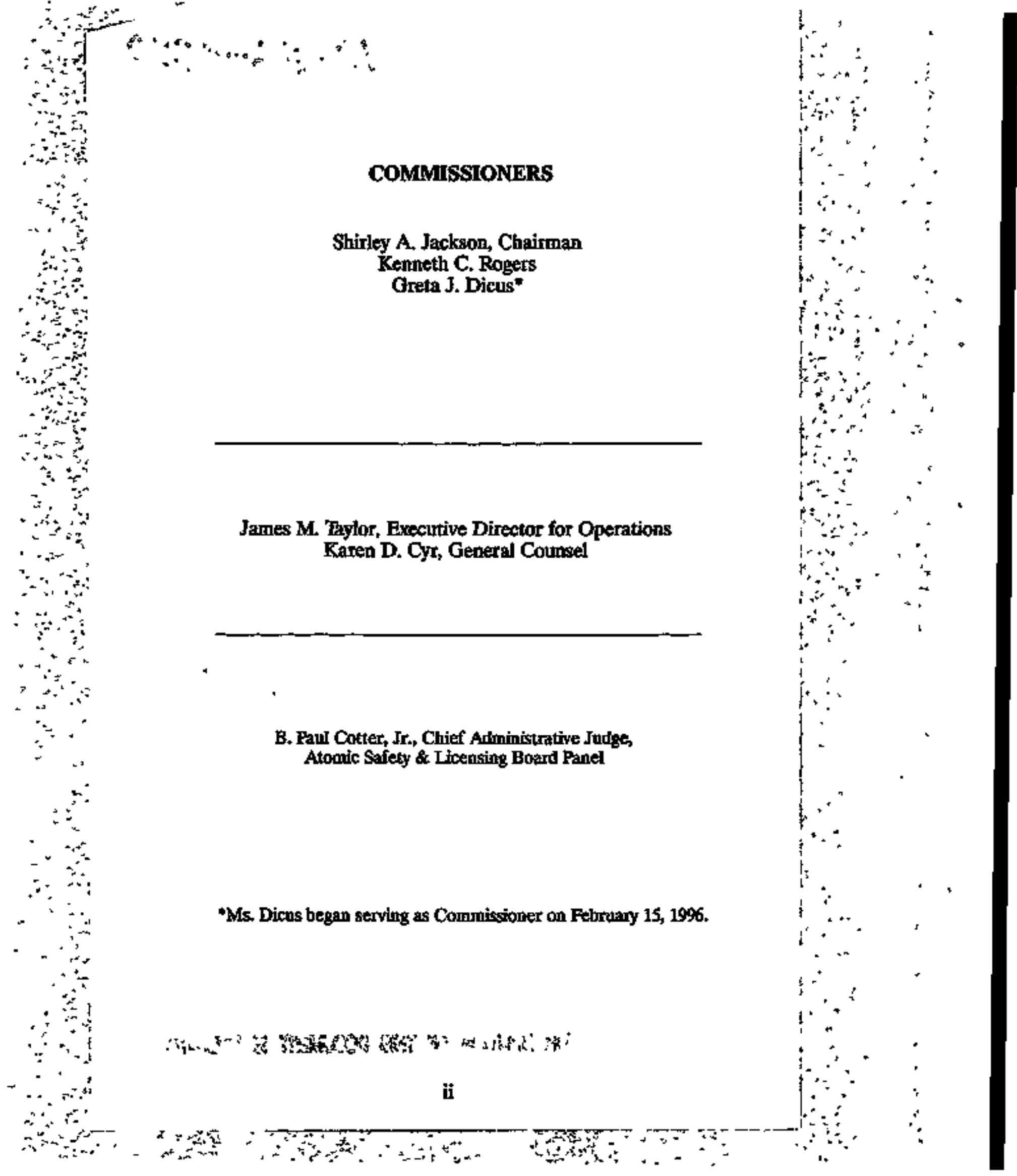




\section{Avalable trom}

Superintendent of Documents U.S. Govemment Prirting Office P.O. Box 37082

Washington, DC 20402-93203

A year's subscription consists of 12 sofiboutrod issues, 4 indexes, and 2-4 herdboend editions for thls publication.

Single copies of this puttication are availatite from

National Technical lntomation Service Springfiold, VA 22161

Enors in this pubullation may be reported to the Office of Imformallon Resources Management

U.8. Nuclear flegutation Commission

Washington, DC 20560-0001 (301-415-6844)

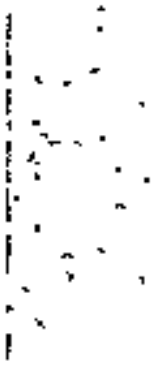

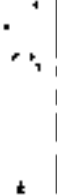

. 1

$+$ 


\section{DISCLAIMER}

This report was prepared as an accourt or work sponsaned by an agency of the United States Goverument. Neither the United States Governument nor any agency thereaf, nor

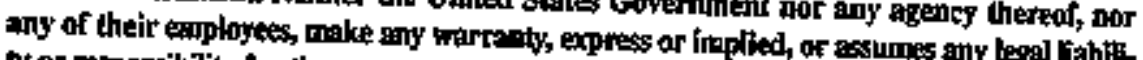
ty or responsibility for the acturacy, completeness, ar usefolness of any informmation, apparatus, product, or proces destosed, ar represents that its use would not finfinge privatidy owned rights, Reeretence herrein to any spectic conumertint product, process, or servive by

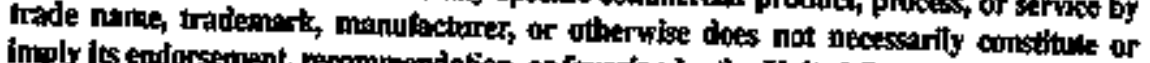
imply its endorsement, recommendation, or favgriog by the Un'ted Staites Goveringent or aly atency theres. The views and opinions of attians exprested hereip do not necessarily state or refiect those of the United States Gowernumeat or any agency thereof.

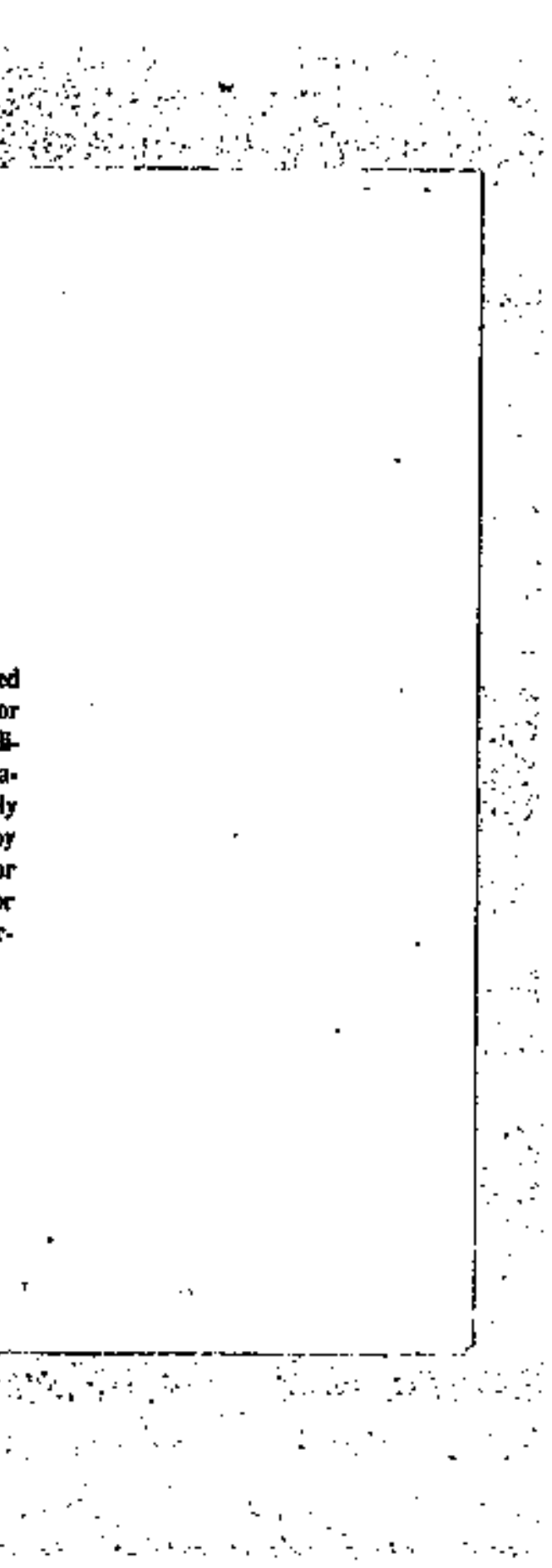




\title{
ATOMIC SAFETY AND LICENSING BOARD PANEL
}

\author{
B. Paul Cotter, Jir * Chief Administrative Judge \\ James P. Gleasom, Deputy Chief Administrotive Judge (Executive) \\ Frederick J. Shon," Deputy Chief Administrative Judge (Technical)
}

Dr. George C. Anderson Charles Bechhower" Peter B., Bloch" G. Peul Bollwatk III* Dr. A. Dimon Callihan Dr. James H. Capenter Dr. Rtchard F Cole* Dr. Thomas E. Eleman Dr. George A. Fergason Dr. Harry Foreman

\section{Members}

Dr. Richand F Foster Dr. Darid L Hetrick Emest E Hïl Dr. Frank F. Hocper Elizabeth B. Johnson Dr. Charkes N. Kellber* Dr. Jerry R. Zline* Dr. Peter S. Lam* Dr. James C. Lamb III Dr. Emmeth A Lebike
Dr. Benneth A. Mecollom Marshall E. Mitter Thomas S. Moore" Dr. Peter A Morris Thomas S. Murphy" Dr. Richand R. Partzek Dr. Harry Rejn Lester $\mathbf{S}$. Ruberstein Dr. David R. Schink Dr. George F. Titey

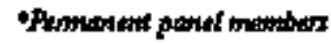

\section{䜣}


This is the forty-third volume of isstances ( 1 - 358) of the Nuclear Regulatory Commission and its Atomic Safety and Eicensing Boards, Administrative Law Iudges, and Office Directors. It covers the period from January 1, 1996 to June 30, 1996.

Atomic Safety and Licensing Boards are anthorized by Section 191 of the Atomic Energy Act of 1954. These Boards, comprised of three menbers conduct adjudicatory hearings on applications to construct and operate nuclear power plants and related facilities and issue initial decisions which, subject to internal review and appetlate procedures, become the final Commission action with respect to those applicalions. Boards are drawn from the Atomic Safety and Licensing Board Panel, comprised of lawyers, nuclear physicists and engineers, environmentalists, chemists, and economists. The Atomic Energy Commission first established Licensing Boards in 1962 and the Panet in 1967.

Begiminiz in 1969, the Atomic Energy Commission authorized Atomic Safety and Licensing Appeal Boards to exercise the authority and perform the revieur functions which would otherwise have been exercised and performed by the Contrission in facility licensing proceedings. In 1972, that Commission created an Appeal Fanel, from which are drawn the Appeal Boards assigned to each licensing proceed ing. The functions performed by both Appeal Boards and Licensing Boards were transferred to the Nuclear Regulatory Commiston by the Entrigy Reorganization Act of 1974. Appeal Boarts reptesent the final tevel in the aunainistrative adjudicatory process to which parties may appeal. Parties, however, are permitted to seek discretionary Conmission review of certain board nulings. The Commission also may decide to review, on its own motion, various dectsions or actions of Appeal Boards.

On Juse 29, 1990, however, the Conmission voted to abolish the Atomic Saffety and Licensing Appeal Panel, and the Panel ceased to cxist as of June 30, 1991. In the future, the Conmission itself will review Licensing Board and other adjudicatory decisions, as a matter of discretion. See 56 Fed. 29 \& 403 (1991).

The Commission also has Administrative Law Judges appointed pursuant to the Adninistrative Procedure Act, who preside ower proceedings as directed by the Commission.

The bardbound edition of the Nuclear Regulatory Commission Issuances is a final compilation of the monthly issuances. II inclades all of the legal precedents for the agency within a sir-month period. Any opinions, decisions, desials, memoranda and onders of the Commission inadvertently omitted from the monthy sof tbounds and any corrections submitted by the NRC legal staff to the printed sofubound issuances are contained in the hardhound edition. Cross references in the text and indexes are to the NRCI page numbers which are the same as the page numbers in this publication.

Issuances are refiered to as follows: Commitstion-CLI, Atomic Safety and Licensing Boauds--LBP, Administrative Law Judges-AL', Directors' Decisions-$D D$, and Decesions on Pettions for Rulemaking--DPRM-

The summaries and headnotes preceding the opinions reponted herein are not to be deemed a part of those opinions or to have any independent legal significance. 


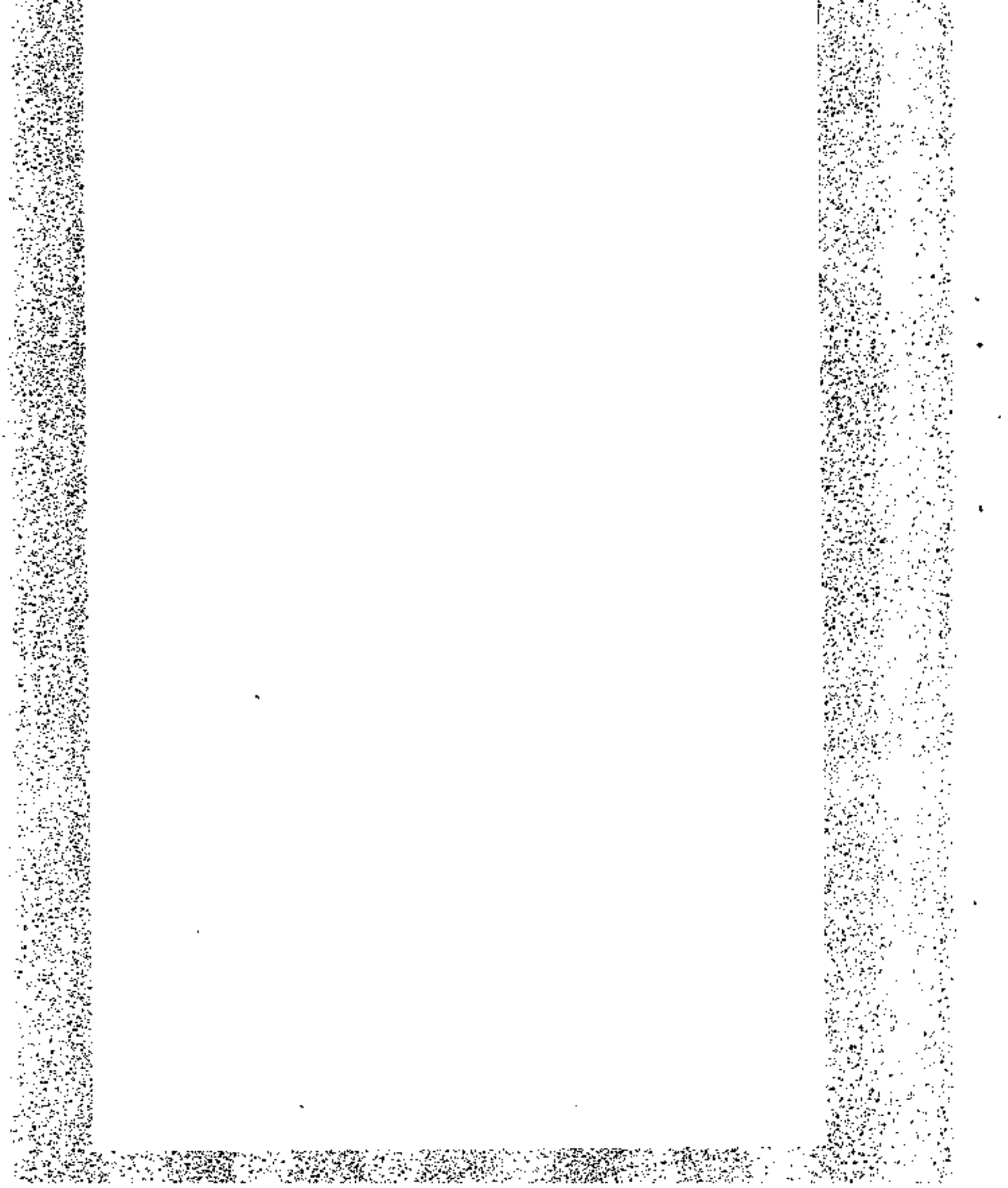




\section{CONTENTS}

Issuances of the Nuclear Regulatory Commission

CLEVELAND ELECTRIC ILLUMTNATING COMPANY, et al

(Pency Nuclear Power Plant, Unit 1)

Docket 50-440-OLA-3

Otder, CLI46-4, March 7, 1996

$\$ 1$

KERR-MCGEE CHEMICAL CORPORATION

(West Chicago Rare Earths Facility)

Docket 40.2061-ML

Order, CL1-96-2, Febreary 21, 1996

13

SEQUOYAH FUELS CORPORATION and GENERAL ATOMICS

(Gore, Oklahoma Site)

Docket 40.8027-EA

Memorandum and Order, CLI-96-3, February 27, $1996 \ldots \ldots \ldots \ldots .16$

YANKEE ATOMIC ELECTRIC COMPANY

(Yankee Nuclear Power Station)

Docket 50-029

Memorandum and Order, CLI-96-1, January 16, $1996 \ldots \ldots \ldots \ldots \ldots$ I

Memorandum and Order, CLI-96-6, April 1, 1996 ............ 123

Dacket 50-029-DCOM

Memotandurn and Order, CLI-96-5, March 7, $1996 \ldots \ldots \ldots \ldots \ldots$. 53

Memorandum and Order, CLI-96-7, June 18, $1996 \ldots \ldots \ldots \ldots \ldots .235$

Issunces of the Atomic Safety and Licensing Boards

EASTERN TESTING AND INSFECTION, INC.

Dockets 030-15373-EA, 030-32163-EA

Memorandum and Order, LBP-96-9, May 10, $1996 \ldots \ldots \ldots \ldots \ldots \ldots .211$

Memorandum and Order, LBP-96-11, June 11, $1996 \ldots \ldots \ldots \ldots \ldots .279$

GEORGLA INSTITUTE OF TECHNOLOOY

(Georgia Tech Research Reactor, Atlanta, Georgia)

Docket 50-160.Ren

Third Prehearing Conference Order, LBP-96-8, April 30, $1996 \ldots \ldots \ldots 178$

Memorandum and Order, LBP-96.10, May 16, $1996 \ldots \ldots \ldots \ldots .231$

GULF STATES UTLITIES COMPANY, et al.

(River Bend Station, Unit 1)

Docket 50-458-OLA

Mermorandum and Otdet, LBP-96-5, March 29, 1996

vii 
LOUISIANA ENERGY SERVICES, L.P.

(Claiborne Earichment Center)

Docket 70-3070-ML

Partjal Initial Decision, LBP-96-7, Aptil 26, 1996. . . . . . . . . . . . . I42

NORTHEAST NUCLEAR ENERGY COMPANY

(Millstone Naclear Power Stalion, Uait 1)

Docket 50-245-OLA

Memorandum and Order, LBP-96-1, February 7, $1996 \ldots \ldots \ldots \ldots \ldots+19$

Order, LBP.96-6, April 15, $1996 \ldots \ldots \ldots \ldots \ldots \ldots \ldots \ldots \ldots \ldots+140$

ONCOLOGY SERVICES CORPORATION

(Harrisburg, Pennsylvania)

Docket 030-31765-CivP

Memorandum and Order, LBP-96-3, March 28, 1996 ............ 93

RADIATION ONCOLOGY CENTER AT MARLTON (ROCM)

(Marlion, New Jersey)

Docket 30-32493-CivP

Memorandum and Order, LBP-96-4, March 28, $1996 \ldots \ldots \ldots \ldots .101$

SEQUOYAH FUEI.S CORPORATION

Docket 40-8027-MLA-3

Initial Decision, LBP-96-12, Jane 21, $1996 \ldots \ldots \ldots+\ldots+\ldots \ldots+\ldots+290$

YANKEE ATOMIC ELECTRIC COMPANY

(Yankes Nuclear Power \$tation)

Docket 50-029-DCOM

Memorandust and Order, LBP-96-2, March 1, $1996 \ldots \ldots \ldots \ldots \ldots .61$

Issuances of Directors' Decisions

ALL REACTOR LICENSEES WTTH INSTALLED THERMO-LAG FIRE BARRIER MATERIAL

Director's Decision, DD-96-3, Apri] 3, 1996

ARIZONA PUBLIC SERVICE COMPANY

(Palo Verde Nuckarat Generating Stacion, Units 1, 2, and 3)

Dockets $50-528,50-529,50-530$

Director's Decision, DD-96-4, June 3, 1996................. 309

Director's Decision, DD-96-8, June 25, 1996............... 344

CONSOLIDATED EDISON COMPANY OF NEW YORK

(Indian Poidt, Units 2 and 3)

Dockets 50-247, 50-286

Director's Decision, DD-96-6, June 10, 1996, . . . . . . . . . . 333

vitii 


\section{PECO ENERGY COMPANY}

(Peach Bottom Atomis Power Station, Units 2 and 3)

Dockets 30-277, 50-278

Final Director's Decision, DD-96-5, June 10, 1996

PORTLAND GENERAL ELECTRIC COMPANY

(Trojar Nuclear Plant)

Docket $50-344$

Director's Decision, DD-96-7, June 14, 1996.

338

SACRAMENTO MUNICIPAL UTILITY DISTRICT

(Rancho Seco Nuclear Generating Station)

Docket 50-312

Director's Decision, DD-96-7, June 14, 1996............... 338

SOUTHERN CALFORNIA EDISON COMPANY

(San Onafte Nuclear Generating Station, Unit 1)

Docket 50-206

Director's Decision, DD-96-7, June 14, 1995............... 338

YANKEE ATOMIC ELECTRIC COMPANY

(Yankee Nutclear Power Station)

Dacket $50-029$

Direcior's Decision, DD-96-1, February 22, $1996 \ldots \ldots \ldots \ldots \ldots \ldots, 29$

Supplemental Director's Decision, DD-96-2, March 18, $1996 \ldots \ldots \ldots$ to9

Director's Decision, DD-96-7, Jute 14, 1996............... 338

\section{Indexes}

Case Name Index $\ldots \ldots \ldots \ldots \ldots \ldots \ldots \ldots \ldots \ldots \ldots \ldots \ldots \ldots, \ldots \ldots \ldots$

Legal Citations Index $\ldots \ldots \ldots \ldots \ldots \ldots+\ldots \ldots \ldots+\ldots \ldots+\ldots \ldots \ldots+\ldots, \ldots$

Cases $\ldots \ldots \ldots \ldots \ldots \ldots \ldots \ldots \ldots \ldots \ldots \ldots \ldots \ldots \ldots \ldots \ldots \ldots \ldots$

Regulations $\ldots \ldots \ldots \ldots \ldots \ldots \ldots \ldots \ldots \ldots \ldots \ldots \ldots \ldots \ldots \ldots \ldots$

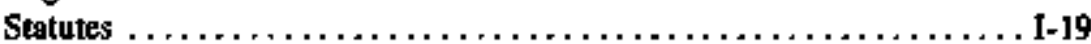

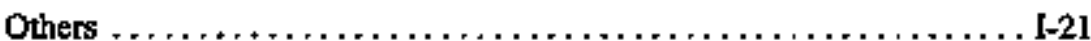

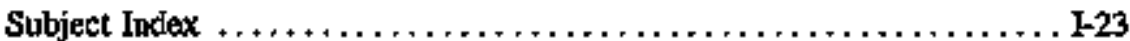

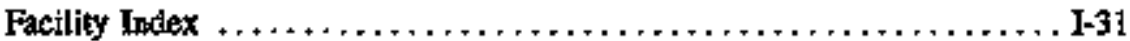


UNITED STATES OF AMERICA

MUCLEAR REGULATOAY COMMUSSION

\section{COMAISSIONER:}

Shirley A. Jackson, Chaimen'

In The Matter of

\section{YANKEE ATOMIC ELECTRAC COMPANY}

(Yankeo Nucloar Power Btation)
Docket No. 50-029

(Decommisstonting Pien)

Jarusary 16, 1996

The Commission refers to the Atornic Safety and licensing Board, for a ruling on standing and contentions and with guidarice on several novel issues and a suggested expedited schedule, pleadings filed regarding Petitioners' intervention in a proceeding to consider approval of a plan to decomnission the Yankes. Nuclear Power Station ("Yankee NPS").

The matter now before the Connuission follows the Comunission's recent reinstatement, in light of a decision by the First Circuit Count of Appesas, of is pre-1993 policy of providing an opportunity for an axjodicatory hearing on nuclear power reactor decommissioning plans.

\section{RULES OF PRACTICE: HNGKVENION PETIMION}

Where a pelitioner has not expressly requested a hearting on its petition, but where it setms clear from the petition as a whole thes a hearing is what the petitioner desires, the Commission will not disniss that pelition soleby on the basis of such a technical pleading defect.

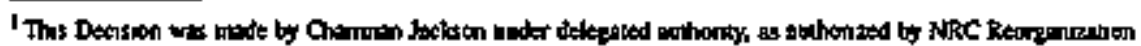

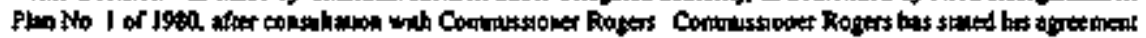
Wrh the Destsion
} 


\section{RULES OF PRACTICE: STANDING TO INTERVENE}

In order to establish standing to interwene in a proceeding, a petitioner must demonstrate that ( $\mathrm{l}$ ) it has suffered a distinct and palpable harmt that constitutes injury-in-fact withir the zone of interests arguably protected by the governing stante; (2) that the injury can fairly be traced to the challenged action; and (3) that the injury is likely to be redressed by a favorable decision.

\section{RULES OF PRACTICE: STANDING}

As the Commission has noted on other occastons, a prospective inlervenor may not derive standing to partitipate in a proceeding from another person who is not a party to the action or is not a nutember of its organization.

\section{RULES OF PRACTICE: STANDING TO INTERVENE; ADMISSIBILITY OF CONTENTIONS}

Once a party demonstrates that it has standing io intervene on its own accord, that party may then raise any contention that, if proved, will afford the party relief from the injery it reties upon for standing.

\section{RULES OF PRACTICE: ADMISSIBILITY OF CONTENTIONS (LIMITATION)}

The Commission construes the provision in 10 C.F.R. \$2.714(g), in accordance with the relevant case law, i, $e_{\text {, }}$ that an inlerweror's contentions may bo limiled to those that will afford ti relief from the injuries asserted as a basis for slanding.

\section{REGULATIONS: DECOMMISSIONING}

A fair reading of the Commission's decommissioning rules at 10 CFR. $\$ 50.82$ is that it is for the licensee in the first instance to choose the decommissioning option and that neither the DECON nor the SAFSTOR oplion can be deeined unacceptable a priori.

\section{REGULATIONS: DECOMMISSIONING}

The principal criterion for judging a decommissioning alternalive is the proposed time required for decommisstoning completion. I0 C.F.R. $\$ \$ 0.82$ (b)(1)(i). Both the SAFSTOR and the DECON altemalives would, in 
general, meet the criterion in that section and in the Final Gentric Environtmenfal Impact Statement on Decommissioning of Nuclear Facilities (GEIS).

\section{REGULATIONS: DECOMMISSIONING}

In addition to moeling the "time" requirement in 10 C.F.R. \$ \$0.82(b)(1)(i), decommissioning plans must also meet other applicable NRC regulations, including the "as low as is ressonably achievable" (ALARA) requirement in 10 C.E.R. \$20.110l(b).

\section{REGULATIONS; INTERPRETATION (PART 20)}

One of the putposes of revising 10 C.F.R. Part 20 was to change the status of ALARA from the hortatory suggestion in old 10 C.F.R $\$ 20$. (c) to the mandatory requirement in the corrent 10 C.F.R. $\$ 20.110$ l(b); thus, ALARA is an essential pert of Federal Radiation Ptotection Guidance.

\section{REGULATIONS: DECOMMISSIONING}

While a licensec's choice of decommissioning options is not beyond all challenge, such a challenge to a licensee's choice of alcernative decommissioning procedures cannot be based solely on differences in estimated colloctive occupational doses on the order of magniurde of the estimates in the GEIS.

\section{REGULATIONS: RADIATION PROTECTION STANDARDS; INTERPRETATION (10 C.F.R. Part 20)}

A licensee's actions do not violate the ALARA principle simply because some way can be identified to reduce radiation exposures further. The practicality and the cost of the measures required to achieve these reductions as well as "other societal and socioeconomic considerations" must also be taken into account. See i0 C.F.R. $\$ 20.1003$ (definition of ALARA).

\section{RULES OF PRACTICE: RADIATION PROTECTION STANDARDS}

The Commission will generally find that exposures are ALARA when further dose reductions would cost more than $\$ 1000$ or $\$ 2000$ for each personrem reduction achieved. See generally "Regulatory Analyses Guidelines," NUREG/BR-0058, Rev. 2 (1995). 


\section{REGULATIONS: DECOMMISSIONING}

The essential purpose of the requirement in 10 C.F.R. $\$ 50.82$ is to provide "reasonable assurance" of adeçuate fundthig for decomblissioning. Thus, to be entitled to relief, a petitioner needs to show not only that a licenses's decommissioning cost estinate is in emor, but that there is not reasonable assurance that the correct amount will be paid.

\section{NRC: ENFORCEMENT ACTIONS}

To the extent that a petitioner's contention alleges "illegal" past conduct in violation of NRC regulations, those allegations are more properly the subject of a separate enforcement action.

\section{MEMORANDUM AND ORBER}

\section{INTRODUCTION}

Thes malter is before the Commission on a pettion by the Cutizens Awarepess Network ("CAN") and the New England Coalition on Neclear Pollution ("NECNP") (collectively "Petutioners") in response to a Notice of Opportuntty for a Hearing pubtished in the Federal Register. See 60 Fed. Reg. 55,069 (Oet. 27, 1995). The Petitioners seek to imervene in a proceeding to consider approval of a plan to decommsssion the Yankee Nuclear Power Station ("Yonkee NPS"), submilted by the Yankee Atomic Electnc Company ("YAEC" or "Licensee"), which holds a possessian-only license for Yankee NPS. The NRC Staff and YAEC have now filed answers to the peticion. We have granted Petitioners' motion seeking leave to file a reply and considered the reply in isstring this Order. This Order refers the pleadings to the Atomic Safety and Licensing Boatd ("Licensing Board") for appropriate acton with guidance on several novel issues raised in this proceeding and a suggesled expedited schedule.2

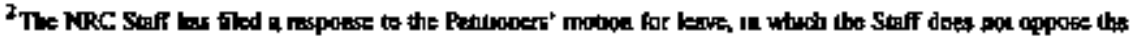

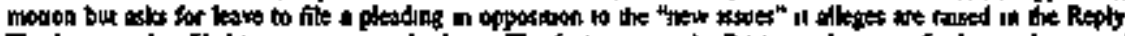

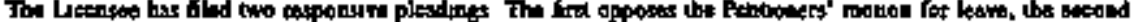

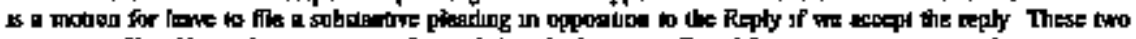

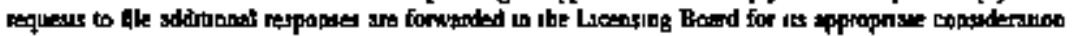




\section{BACKGROUND}

We have discussed the backgraund of this maner before at scme length. Suffice it to say that we have reinstated our pre-1993 policy on providing an opportunity for an adjudicatory hearing regarding the possible approval of nutlear power reactor decoumissioning plans in light of a decision by the U.S. Court of Appeals for the First Cireuit. See genterally Citizens Awareness Network v. NRC, 59 F.3d 284 (1st Cir. 1995); Yankee Atomic Electric Co. (Yankee Nuclear Power Station), CLI-95-14, A2 NRC 130 (1995). In eccord with that pre1993 policy, we offered an opportunity for a bearing on the untinished portion of work to be completed under the proposed Yankee NPS decommissioning plan, which had previously been approved by the NRC Staff. See 60 Fed. Reg. 55,069 (Oct. 27, 1995), supra.

In order to obrain such a hearing. Petitioners must satisfy the regairements of 10 CF.R. \$2.714. Thus, Petitioners must (1) demonstrate that they have standing to interveae and (2) stbmit at least one valid contention. In this case, as required by the expedited procedures announced in the Federol Register Notice, id., Petituoners submitted a supplemental petítion containing five proposed contentions. The Licensec and the Staff have responded, arguing that: (1) Petitioners have not requested a hearing; and (2) all proposed contentions are inadrrissible. Petitioners bave, in turn, replied to Liceasee's and Staff's objections end advocated the adunissibitity of each of the proffered contentions.

We refer the matter to the Atornic Safety and Licensing Borard (Licensing Board" or "ASLB") to rute on standing and contentious and to conduct any necessary further proceedings. In so doing, we construte the original petition as requesting a bearing and not just intervention in the proceeding in the ovent a hearing is requested by someone else. While Petitioners may be faulted for not expressly reguesting a hearing in their original petition, it seems clear from the petition as a whole that this is what they desire, and their reply confirms this. Accordingly, we decline the suggestions by the Staff and the Licensee that we dismiss the petition solely on the besis of a technical pleading defect.

\section{GUIDANCE TO THE LICENSING BOARD}

We expect that many of the issues raised by the Petitioners and related pleadings will be resolvable within the framework of the NRC's regulations and case law. However, in order to expedite this proceeding and to avoid future delay, we are providing guidance to the Licensing Board on several novel issues raised by the pleadings. 
provide an adequate basis. As for the asserted dose savings, we note that the 900 person-rem figure is besed on estimates for decommissioning of a much larger nuclear plant than the Yankee NPS. ${ }^{6}$ But different dose estimates may be expected at the Yankee NPS. Furthermore, Yankee's decommussionung plan has already been partially implemented, and the results of that implementalion (which should be available for rovtew) may reduce the anticipated octupational dose.

In any event, the 900 person-ren figure, being a generic estimate, is nectessarily somewhat speculative as applied to a particular faclity. The differences in occupational exposure between the DECON and SAFSTOR alternatives could in actual practice be less than 900 person-rem, or pertaps not much at all. Among the few inevitable uncertainties are the actual conditions of the facility after several decades, and the amount of institutuonal memory held by plant management and workers regarding the facality configuration and the extent and location of contaminasuon. It is one thing to review a licensee's choice of alternative procedures and actsons when that review can be based upon relabvely certain data in the here and now; if may be quite another thing to review a licensee's chonce besed on estimates of doses that will occur 30 or more years in the future. Given that our rules treat DECON as a generally acceptable alternative, despite the acknowledged likelihood of reduced occupational dose under SAFSTOR, wo conclude that a challenge to the Licensec's chosce of the modified DECON option unstead of SAFSTOR cannot be based solely on differences in estimated collecuve occupational dose on the order of magniude of the estimates in the GEIS

We beileve that this position as applied in this case is entirely consistent with the ALARA concept. The Pettioness appear to recognize that a lrcensee's actions do not violate the ALARA proncsple simply because some way can be Jdentufied to reduce raduation exposures further. The practucality and the cost of the measures required to acheve these reductions as weil as "other societal and socioeconomic considerations" must also be taken unto sccount. See 10 C F.R. $\$ 20.1003$ (definıtion of ALARA) As a matter of agency practuce, the NRC will generally find that exposures are ALARA when further dose reductions would cost more than $\$ 1000$ or $\$ 2000$ for each person-Jems reduction achueved. See generally "Regulatory Analyses Gudelınes," NURECGBR-0058, Rev. 2, announced in 60 fed. Reg. 65,694 (Dec 20, 1995). Applying that analysis here, the "value" of a 900 person-rem occupational dose reduction would be no more than about $\$ 2$ million

In the case before us, all parties appear to agree that the cost estimates for both the DECON and SAFSTOR altematres are an the order of $\$ 200$ mullon

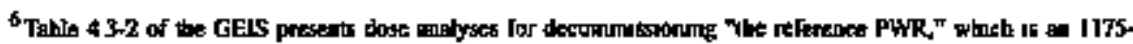

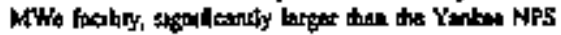

$\because \therefore$

$\therefore=$
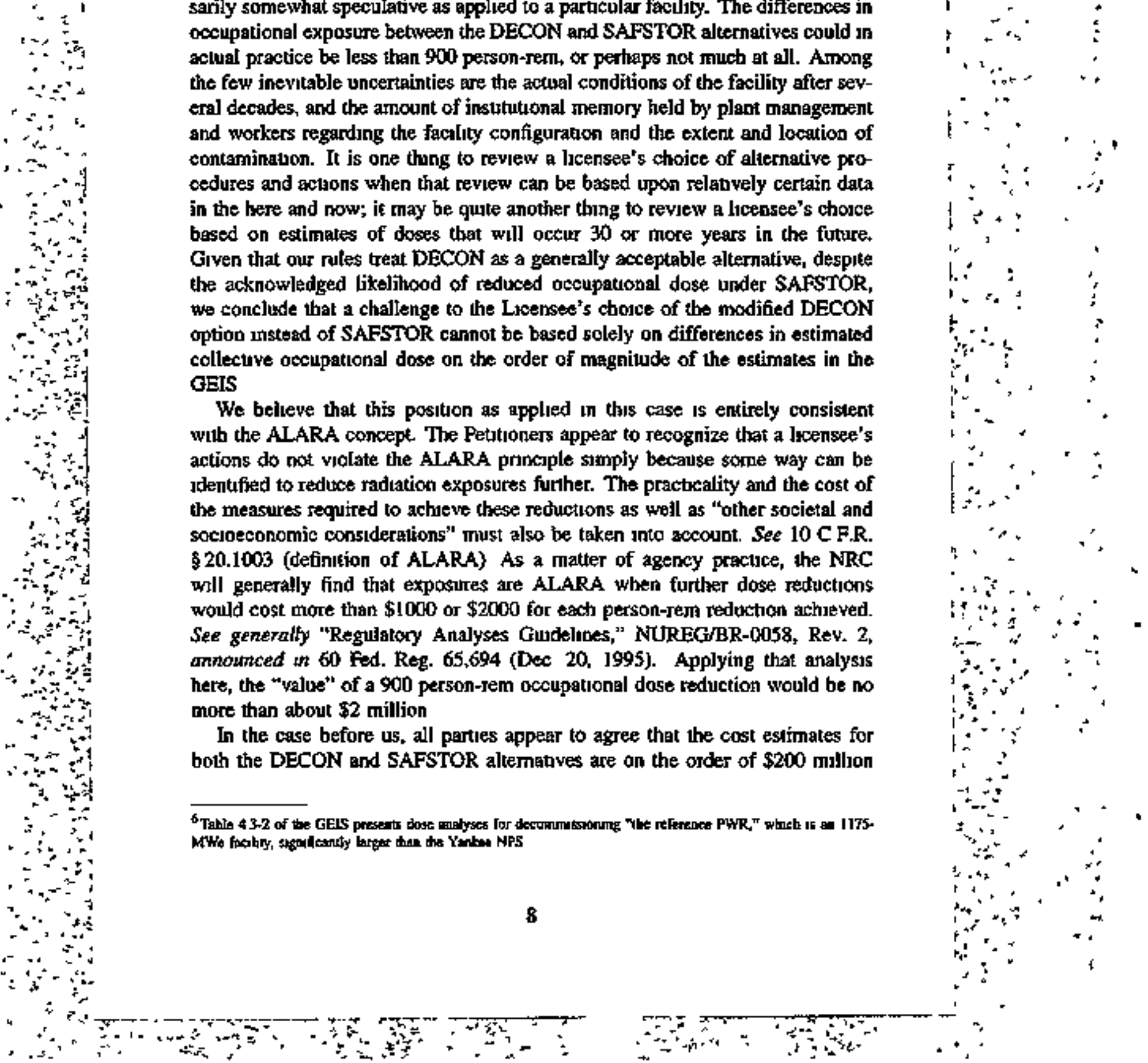
and lie within $\$ 10$ million to $\$ 15$ million of each other. The estimates (especially Petitioners" "present valus" estimates) are highly dependent on difficull-lopredict yariables like interest, discount, and infation rates and waste disgosal ices. In short, it is not possible to say with great assurance whether switching from DECON to SAFSTOR might actually save money, as Pettioners contend, or wheher over the next 30 years additional costs considerably in excess of $\$ 2$ million might be incurred. In these circumstances we do pot believe that potential dose reductions on the order of 900 person-rem can have ALARA significance, unless there is some extraordinary aspect to the case not apparent to us from the pleadings that the Licensing Board may tncover on its own review.

\section{Decommissioning Cost Update}

In Contention C, Petitioners allege, inter alio, that YAEC's "updated cost estimale," submilted under I0 C.F.R. \$ 50.82(b)(4), is "not reasonsble." Petition at 20. The essential purpose of this requirement in section 50.82 is to provide "reascnable assurance" of adequate funding for decommissioning. Thus, a contention that a licensee's estimate is not "reasonable," slanding alone, would not be sufficient in and of jtself because the potential telief would be the formalistic redraft of the plan with a new estimate. The issue seems important here because the Licensee maintains that it has funds or socess to funds to pay for decommıssioning, even if it costs more than it currently estimates. Thess, to be entided to relief, Petitioners will geed to show not only that the estimate is in error but that there is not reasonable assurance that the arrount will be paid.

\section{Renedy for Past Conduct}

In Contention D, Petitioners challenge allegedly "illegal" past conduct of the Licensee and seek a remedy for that conduct. To the extent that the contention alleges that YAEC has violated NRC regulations, those allegations are more properly the subject of separate enforcement action. The focus of this procteding is prospective only - the future decommissioning of the remainder of the facility under the propased decomnissioning plan.

\section{EXPEDITED SCHEDULE}

As we noted in CLL-95-14, we inlend to expedite this proceeding. We have already expetited the proceeding by requiring the filing of contentions with the petition to intervene. In an Appendix to this Order, we provide the Licensing Board with a suggesled expedited schedule for the proceeding, subject slways,

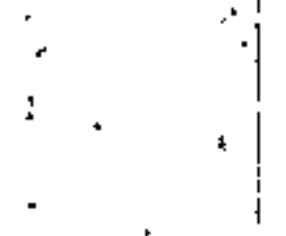


of course, to the demands of basic fairness. We will not require the Licensing Board to adtere to the following schedule to the letler and, indeed, we expect the Licensing Baird to conduct its custonarily thorough inzquiry using all the tools normally at its disposal and following its customary practices and procedures under 10 C.E.R. Part 2, Sutpant G (allthaugh a modification of ustal discovery rules is suggested in the schedule). Howsever, we expect that the Licensing Board will, if it declimes to adopt our proposed schedule, adopt an equally expedited schedule which will generate a final initial decision by, at the latest, the middle of July 1996.

\section{v. SUMMARY}

We hereby refer all pleadings in this matter to the Atomic Safety and Licensing Boerd for processing under the Licensing Board's normal practices and procedures, sabject to the guidance expressed above, and with the proposed schedule provided in the Appendix below. We expect the Licensing Board to act expeditiously with the gasl of issuing a final initial decision by or about the middle of July 1996.

It is so ORDERED.

For the Commission

JOHN C. HOYLE

Secretary of the Corntsission

Dated at Rockville, Marylank, this I6th day of January 1996. 


\section{APPENDLX}

\section{PROPOSED EXPEDITED SCHEDULE FOR YANKER HEARTNGS}

\section{Action}

Inter wening

Commission Order Refering Case to ASLB

No. of Days

Date

ASLB Ruks on Conlentious:

28

Day 0

Duning this ptriod, the ASLB shotuld bold its normal special prebearing conference and take whatever sieps it feels necessary to narrow the issues before it, including. if necessery, additional briefing and oral argument. The ASSLB_should then rule on preliminary matters including the admissibilicy of Pecitioners' proposed contentions.

Discovery Completed:

During this period, the ASLB should require the parties to expedite discovery. If necessary, the ASLB may adopt the mandatory discovery procedures used in Rule 26(a)(1)-(3) of the Federal Rules of Civil Procedure.

Prefiled Testimony (by all parties) and All

Motions for Sumuary Disposition:

Day 28

During this petiad, all parties shoold pwepare and submitit any prefiled testimony and mottons for summary disposition.

ASLB Rules on Surnmary Disposition Motions: During this period, the parties should complete briefing and any orat argument (if necessary) om motions for summary disposition and the ASLB should rule on the motions.

ASLB Starts Hearing (if needed)

ASLB Completes Hearing

Proposed Findings by Intervenors/Licensee

Proposed Findings by Staff

ASLB Fibs Initial Decision

21

Day 49

21

Day 84

Day 63

$\begin{aligned} 7 & \text { Day } 91 \\ 14 & \text { Day I05 } \\ 21 & \text { Day 126 } \\ 7 & \text { Day 133 } \\ 28 & \text { Day I6I }\end{aligned}$

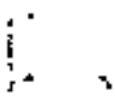




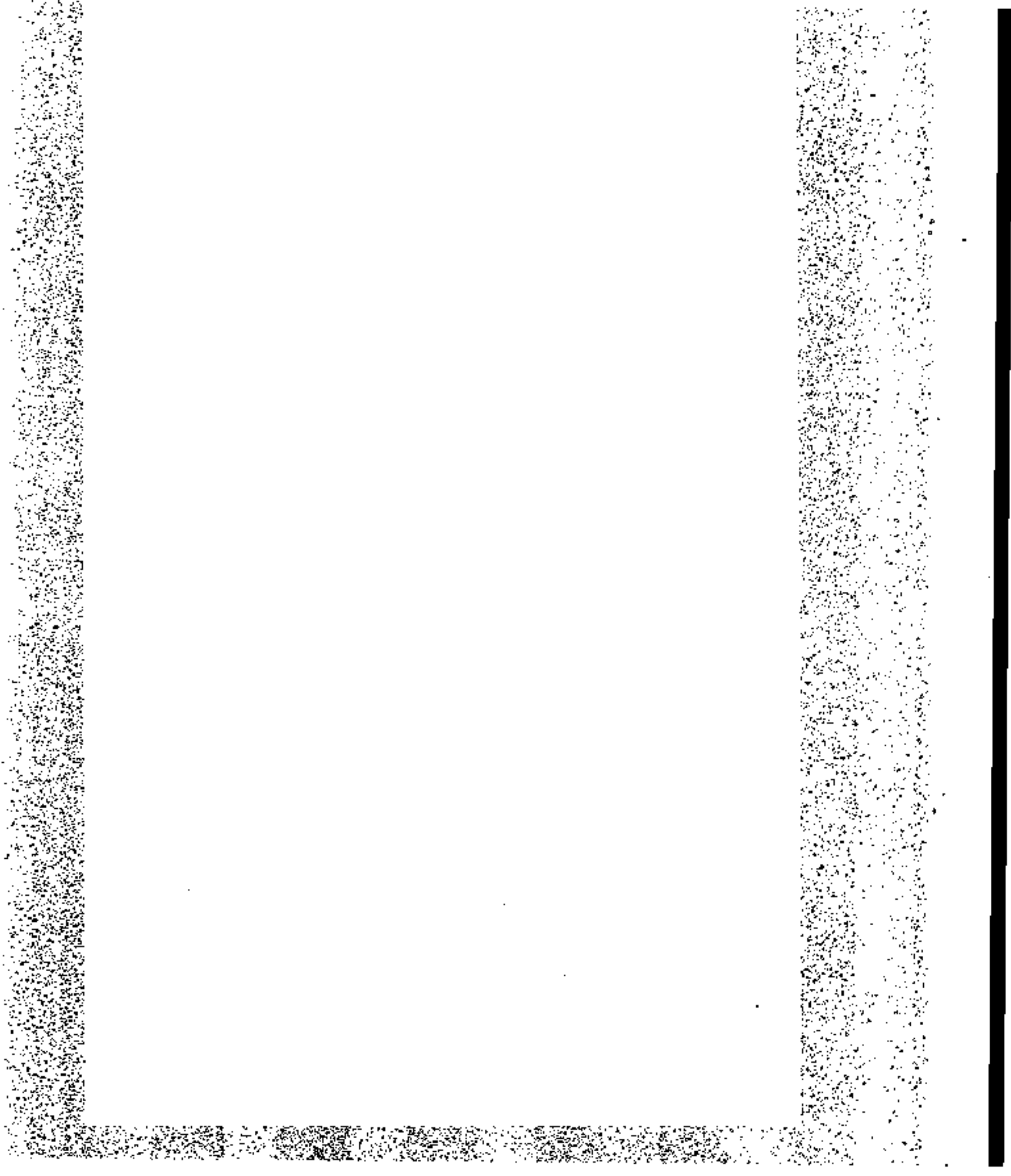


UNITED STATES OF ANERICA

NUCLEAR REGULATORY COMMISSKON

CONAISSTONERS:

Shirfoy A. Jackson, Charman

Kenneth C. Rogers

Greta d. Dicus

in the Matter of

Docket No. 40-2051-MiL

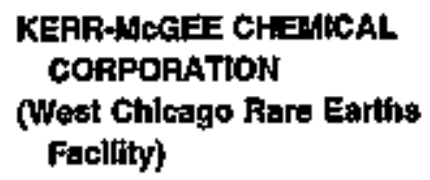

Febrtary 21, 1996

The Commission considers a request by the Licensee to terminate this proceeding as moot and to vacate the proceeding's underlying dectisions. Because this proceeding solely conceros the Licensee's request for onsite disposal of mill cailtngs, and all parties concur that the Licenset no longer seeks onsite disposal, the Commission terminates the proceeding as moot. The Commission chooses as a policy matter to vacate and thereby eliminate as precedent all three underlying decisions in this proceeding.

\section{RULES OF PRACTICE: VACATUR}

The Commission is not bound by judictal practice and need not follow judicial standards of vercatur.

\section{ORDER}

This proceeding came before the Commission in March 1991, when KerTMcGee filed a petition for review of Atonic \$afety and Licensing Appeai Boand decrion ALAB-944, 33 NRC 81 (1991). The proceeding concerns KenMeGec's application for NRC authorization to disposo of mill tailıgge by onsite 


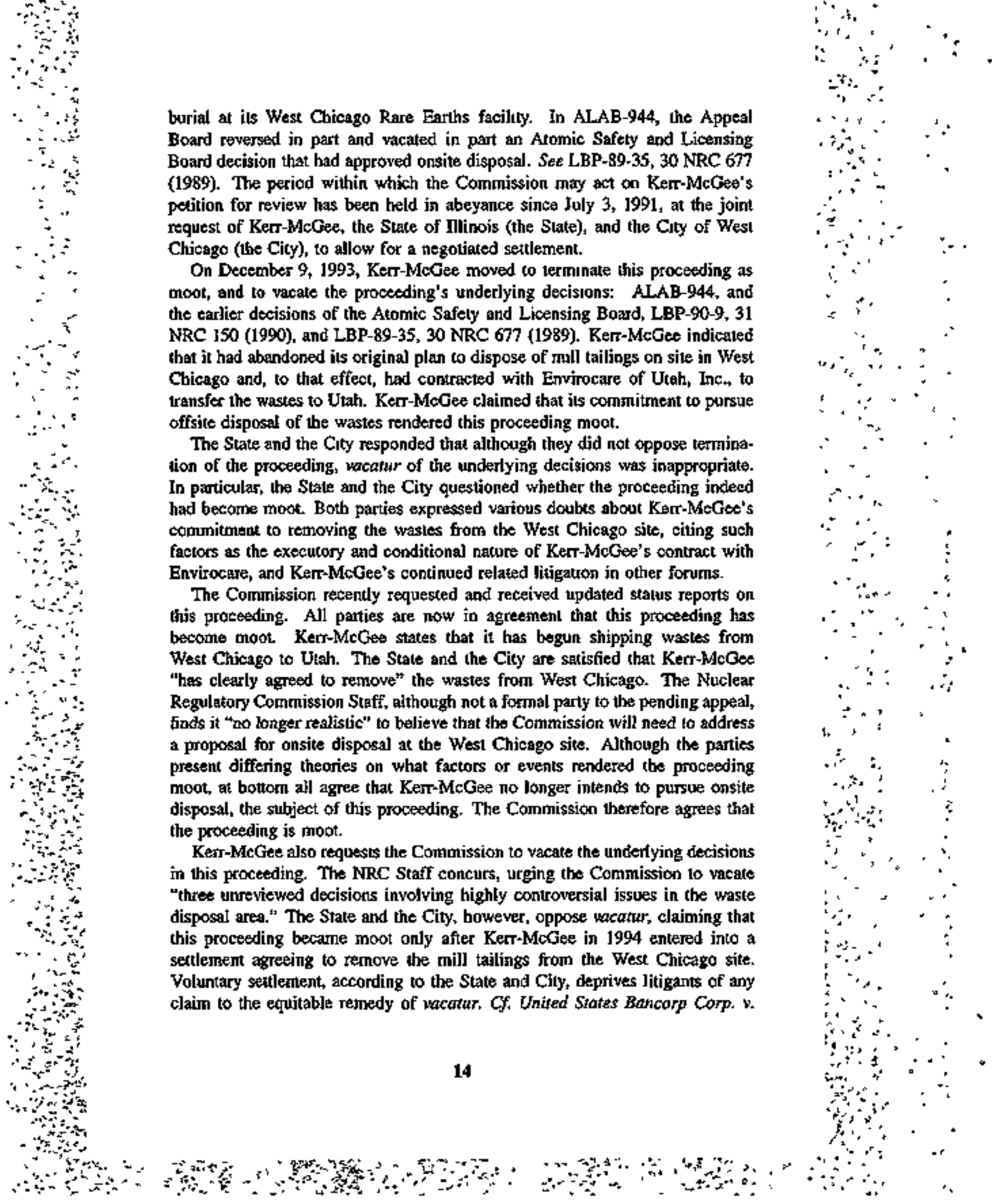


Bonner Mall Portnership, 115 S. Ct. 386 (1994). Kerr-MeGee and the NRC Staff do mot agree that the 1994 seltlement is what Jendered the Commission proceeding moot, and instead argue that the proceeding became moot in 1990, when the Commission - over Kem-McGee's objection - transferred regulalory jutisdiction over section II (e)(2) byproduct material to the State of Illinois.'

In short, the parties to not agree on precisely why this long-pending case is moot, but do agree that there no longer is any point to Commission review because of Ken-McGos's commitment to move the mill lailings off site. The Commission, in any case, is not bound by judicial practice and need nor follow the Bancorp ruling. In these circumstances, and because these unreviewred Board decisions involve complex questions and vigorously dispuled jplerprezations of agency provisions for disposal of byproctuct material, the Comnission as a policy mater chooses to vacate and thereby eliminate as precedent all thrte underlying decisions in this proceeding. This will permit any similar questions that may come up to be considered anew, without the binding influence of an apparently controversial Appeal Board decision that the Commission bas not had the occesion to review.

By vacating the decisions, the Commission does not intimate any opinion on their soundness. Without engaging in a full inguiry into the merils - which no party any longer requests, and the Cornmission sees no compelling reason to undertake on its own - the Corninission cannot properly evaluate the analyses of the Licensing and Appeal Boads.

This proceeding is terminated as moot, Kerr-McGee's application for onsite disposal is deemed wilhdrawn, and the following decisions are vacated: ALAB-944, 33 NRC 8I (199); LBP-90-9, 31 NRC 150 (1990); LBP-89-35. 30 NRC 677 (1989).

It is so ORDERED.

For the Commission

JOHN C. HOYLE

Secretary of the Commission

Dated at Rockville, Maryland, this 2lst day of Febrtary 1996.

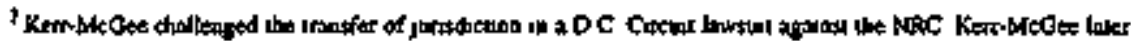

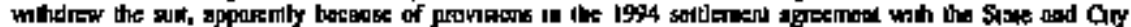

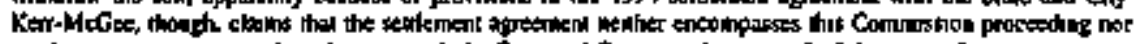

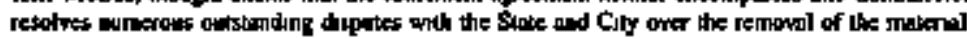




\title{
UNITEO STATES OF AMERICA NUCLEAR FEGUIATOAY COMMISSION
}

COMMISSHNERS:

\author{
Shirley A. Jackson, Chaiman \\ Kenneth C. Rogers \\ Greta J. Dieus
}

In the Matter of

\author{
SEQUOYAH FUELS CORPORATION \\ and GELERAL ATONHCS \\ (Gore, Oklahoms Site)
}

Docket No. 40-8027-EA

(Decontamination and Decommlssioning Funding)

February 27, 1996

The Commisstion grants the Intervenors' petition for review of the Atomic Safety and Licensing Board's Momorandum and Order approving a jotnt settlement agreement between the Licensee. Sequoyah Fuels Corp., and the NRC Staff. The Commission also permits the State of Otlahoma to file a brief amicus curiae to aid the Commission in its review of the Board's order.

\section{RULES OF PRACTICE: PARTICIPATION BY AN INTERESTED STATE OR LOCAL GOVERNMENT}

A state that does not seek party stalus or to participale as an "interested state" in the proceedings below' is not permitted to file a petition for Commission review of a licensing board roling. If the Commission takes review, the Comurission may permit a person who is mot a party, including a state, to file a brief amicus cariae. 10 C.F.R. $\$ 2.715$ (d). 


\section{MEMORANDUM AND ORDER}

The Intervenors in this enforcement procesting, Native Americans for a Clean Environment (NACE) and the Cherokee Nation, have filed a petition for Commission review of the Atomic Safety and Licensing Board's Memorandum and Order, LBP-95-18, 42 NRC 150 (1995). The Stale of Oklahoma also filed a petition for review and motion for leave to file an amendment to its original petition. The NRC Staff, the Licensee Sequoyah Fuels Corporation and its parent, General Atomics (GA), oppose Commission review. In accordance with the considerations discussed in 10 C.F.R. \$2.786(b)(4), the Conumission bas decided that review of LBP-95-18 is approprtate.

The record does not show, nor does the State of Oklahoma contend, that it is a party to this proceeding. It also did not participate as an "imterested State" before the Licensing Board pursuant to 10 C.F.R. \$2.715(c). Therefore, il may bot file its own pelition for review!' Nevertheless, our regulabions provide that if the Commission takes review of a Board order a person who is not a party may be permitted to file an omicus curiae brief, if the person requests by motion to file such a brief. 10 C.F.R. \$2.715(d). The Commission views the State's petition for review and subsequent motion as fulfilling this requirement. Accordingly, the State will be pernitted, along with the parties, to provide a brief on the matters discussed below.

In LBP-95-18, a majority of the Board concluded that a jotirt settlement agreement between the NRC Staff and SFC is in the putbic interest. 42 NRC 150 (1995). Juxdge Bollwerk did not join the majority and in a separate statement raised several issues which in bis opinion meriled further inquiry before reaching a final conclusion about whether to approve the settlement agresment. 42 NRC at $156-59$.

Answers to the following questions would aid the Commission in its review of this matter;

1. Does SFC lack the ftnancial resources to provide any surety instrument to guarantee additional funds for cleanup beyond the $\$ 750,000$ letter of credit?

2. Under paragraph $S$ of the agreement, what process does the NRC \$taff intend to implement to ensure proper and timely review of SFC's annual audited financial statements?

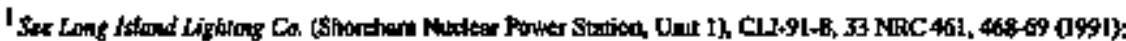

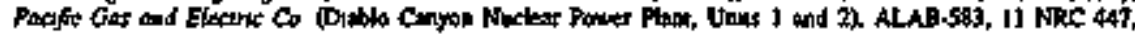
448-49 (1980).
} 
3. What prejudice, if any, will oceur if the Comunission were to deiny final approval of a settement with SFC until after the NRC Staff and General Alomits conclude their settlement negotiations?

Answers to these questions may address some of the inquiries raised by Judge Bollwerk in his separate slatement. In thejr briefs, the parties and the State should also address the remaining matters raised by Judge Bollwerk.

Pursuant to 10 CF.R. $\$ 2.786$ (d), the Commssion sets the following briefing schedule:

1. The Interventors and the State (hereinafter "Petitioners") shall file their briefs within 21 days after service of this Order. Their briefs shall be no longer than 25 pages wach.

2. The NRC Staff, SFC, and GA shall fite their responsive briefs within 21 days after service of the Petitioners' brief. Their responses shall be no longet than 25 pages each.

3. Within 10 days after service of the responsive briefs, the Petitioners may file reply bnefs. Their replies shell be no longer than 10 pages each.

Briefs in excess of 10 pages must contain a table of contents, with page references, and a table of cases (alphabetically arranged), statutes, regulations, and other authorities cited, with references to the pages of the brief where they are cited, Page ltmutations on brtefs are exclusive of pages containing a table of contents, table of cases. and of any addendum containing statutes, rules, regulations, etc.

IT IS SO ORDERED.

For the Corntopsion

JOHN C. HOYLE

Secretary of the Commussion

Dated at Rockville, Maryland, this 27th day of February 1996. 
UNITED STATES OF AWERICA NUCLEAR REGULATOHY COMMISSION

ATOMIC SAFETY AND LICENSING BOARD

- Before Adminlstrat|ve Judges:

Jempe P. Gleason, Chailman

Dr. Fichand F. Colo

Dr. Potor S. Lam

In the Matter of

Dockst No. 50-245-OLA

NORTHEAST NUCLEAR ENERGY COMPANY

(4hillstone Nuclear Power Slation, Unit 1)

February 7,1990

\section{MICMORANDUM AND ORDER \\ (Ruling on Intervention Petition)}

We have before us the request for a bearing and petition to intervene in this proceeding on the license amendment applicalion fled by Northeast Nuclear Energy Company (NNECO) for its Milstone Nuclear Power Station, Unit I, which is located in New London County, Connecticut. The petition challenging the amendment was filed by We the People, Inc. (WTP), the Seacosst AntiPollution League (SAPL), the New England Coalition on Nuctear Pollution (NECNP), and Mr. Donald W. Del Core. Generally, the petilion asserts that the proposed license amendment would permit the routune offloading of the full reactor core to the spent fuel pool during refueling which, in turn, would present a signjficant increase in the risk probability and consequences of an accident involving the spenl fuel pool, thereby resulting in injury to the Petitioners.

For the reasons sed forth below, the petition on behalf of Mr. Del Core and WTP is granled and the petition on behalf of NECNP and SAPL is denied. 


\section{BACKGROUND}

On July 28, 1995, NNECO submitted a license amendment application seeking to add new technical specifications to its operating license for jis Mitlstone Nuclear Power Station, Unit 1. The change would require that (i) the reaclor be sthcritical for at least 100 hours before the start of reactor refueling; (2) the spent fuel pool bulk temperature be maintained at less than or equal 1o $140^{\circ} \mathrm{F}$; and (3) two trains of shutdown cooling be operable during reactor refusting openations. In a letler accompanying the applicalion, NNECO states that these changes will permil the practice of full tcore offoading as a nommal end-of-cycls event.'

On August 30, 1995, the Staff published in the Federal Register a proposed "no significant hazards determination" pursuans to 10 C.F.R. \$50.91 and a notice of opportunity for hearing concernjog the amendment request." In jesponse to the notice, a bimely request for hearing and petition lo intervene was filed on behalf of WTP, SAPL, NECNP, and Mr. Del Core. ${ }^{3}$ The Applicant and Staff each filed enswers opposing the pelition" and the Petitioners then filed a "Correcled Request." Besides making certain spelling and typographical cortections, this filing contained a jist of twelve (12) "mernber supporters" assocjated with WTP living in the neighborhood of the Millstone plant and an assertion that Mr. Del Core would face inereased risk to bis gerson and property if the license amendment were granted. ${ }^{5}$ Thereafter, the Petitioners filed a Memorandum of Law in support of their pelition. ${ }^{6}$ We then issued an order setting a final deatsline for any further amendments to the petition. ${ }^{7}$ The Applicants and the Staff filed responses to the Petitioners' Memorandum ${ }^{3}$ and Petitioness subsequertly filed on Decenter 4, 1995, an affidavit of a WTP menber."

After challenging most of the factual allegations set forth in the Petitioners' filings, NNECO argues that neither the organizational Petitioners nor the judj-

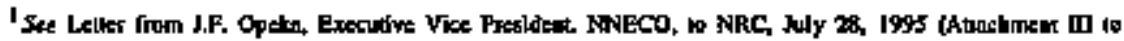

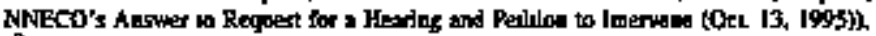

${ }^{2}$ 60 Fed. Reg. 45,172 (Autg, 30, 1995)

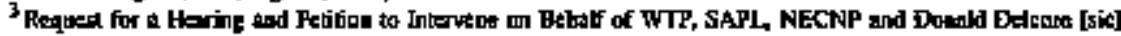
(5epe 28. 1995).

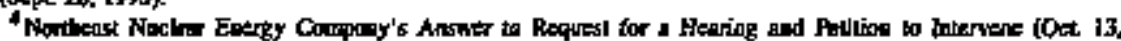

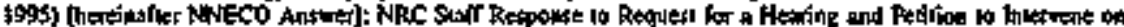

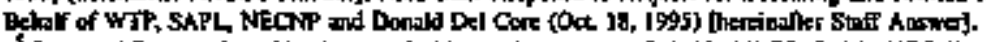

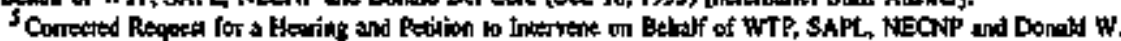
Del Coke (Oed. IR, 19\%) (hereinafier Corscied Fequest].

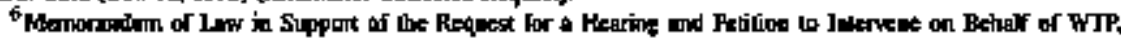

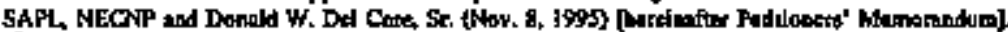

${ }^{1}$ Onder (Nav. 7, 1995) (nopalplisted).

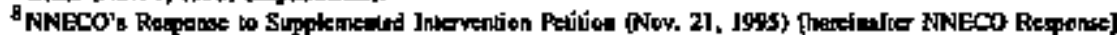

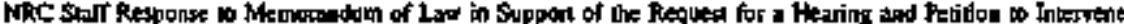

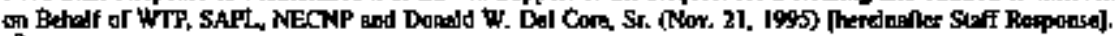

9 Affidowi of Glen Cheney.
} 
vioual Petitioner has standing to intervene in this license amendment proceeding. For its part, the Staff generally does not address the faclual metits of the Petitioners' allegations. Although the Staff argued that none of the Petitioners bad standing to intervene, ${ }^{10}$ the Staff changed its position with respect to Mr. Del Core. In its latest iling, the Staff states that Mr. Del Core has argugbly made (although not articulated very well) a cass for standing based upon his allegation of radiological baru to his health, safety, and property." Accordingly, the Staff no Jonger objects to Mr. Del Core's participation in the proceeding.

It is aoted that on Nowember 9, 1995, the \$taff issued License Amendment 89 to NNECO for its Mitlstone Nuclear Power Station, Unit 1. That amendmeat did not add the tectirical specifications to the facilicy license requested by NNECO. Instead, the amendment added a license condition to the facility license that permits the same activities. ${ }^{12}$

\section{PETITIONERS' STANDING TO INTERYENE}

The recital of the requirements for standing in the Commission's most recent decisions regarding standing are all quite similar. Hence, we quote the discussion trom Georgin Tech, CLI-95-12, its most recent discussion on this subject:

Under section 1894 of the Actmic Entrgy Act (AEA). the Commistion must grant a hearing upon the request of any person "vinose inteated pray be affected ty the proceeding." 42 U.S.C. \$2239(a). To deteraine whether a potitioner has alteged a sufitcient interest to intervent, tat Conmtsolon has long applied judrelal concepts of standing. Cleveland Electric

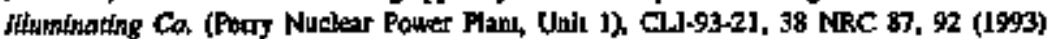
(Pern). For standing, the petibioner mist allege a conerese and particularized filjury tha to

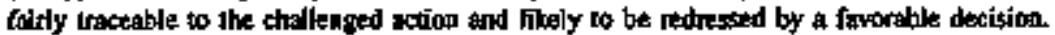
See generally Lujan w. Defenders of Whdift, 112 S. C1. 2130, 2136 (1992); Perry, 38 NRC al 92. Injoxy way be actuel of theatened. Kelley v. Stlith 42 F,3d 150I, 1508 (6th Cir. 1995); Widemess Saciegy v, Griles, 824 F.2A 4, 11 (D.C. Cir. 1987). . .

An organization may base ils standing on atther imsmeditate tor threntened imiury to its

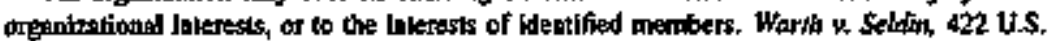

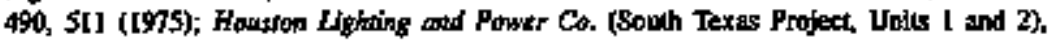

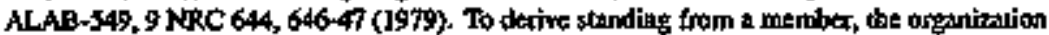

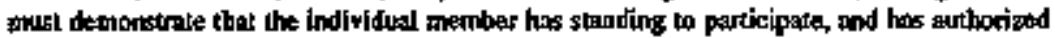

\footnotetext{
${ }^{10}$ Surf Answer at 4 -9.

11 Sidf Rutponat at $9-10$.

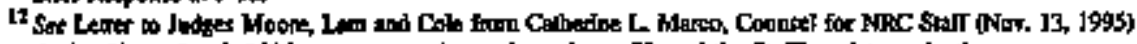

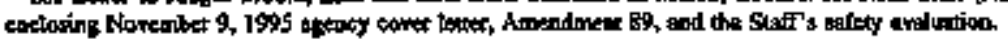




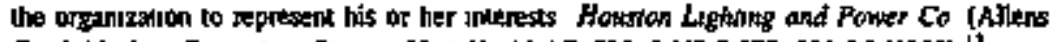
Creek Nuclear Geseralung Staum, Unut I). Al_AB-595, 9 NRC 377, $190-96$ (1979) ${ }^{\text {19 }}$

To determine whether any of the Petioners have the requisile standing to challenge NNECO's license atnendment applicalion, we first consider the three pettioning ofganizations, WTP, SAPL, and NECNP bofore considering the petulionung individual, Mr. Del Core.

According to the Peittioners' original and comected intervention request, WTP is a Massachusetis-based nonprofit corporation with is principal office In Rowley, Massachusetts, whose primary perpose is to support employees of ouclear licensees and the NRC who may face retaliatory action for brunging forward allegations of license violations or nuclear safety 2ssues. WTP alleges that the organization has worked with Mullstone employees on safety issues and seferences one employet, George Galaus, as consulting with WTP on the Licensee's furel offloading practices. The petitions state that individuals "associated" wuth WTP live in the "neighborhood" of the Millstone cornplex and it lists by name twelve memkers with addresses in Connecticut towns."

Next, the peiztion stales that SAPL is a New Hampshire nonprofit corporation wilh its principal place of business in Portsmouth, New Hampshire. It clalmist that SAPL has members luving in Massachusetts and New Hampshure wibin 10 miles of the Stabrook nuclear facslity and that SAPL participsted as an intervenor in the licensing proceedings for the Seabrook Station The petition forther alleges that the operator of Seabrook Station, like NNECO, is a subsidiary of Northeast Utilities, so it can be expected that full-core offloading during refoeling also will be undertaken at the Stabrook Statuon, thereby inereasing the risk and consequences of a spent fuel pool accident th that muclear plant. ${ }^{15}$

Finally, the peltion declares that NECNP is a nonprofit cotporation with its principal place of business in Brattleboro, Vermom, and that it has been an active wojee in Now England on nuclear safecy issues for 25 years. It states that NECCIP intervened in the Vermont Yankee and Sesbrook lucensing procecdings and that NECNP has members residing within $\mathbf{5 0}$ miles of both the Seabrook and the Millstone nuclear plants. ${ }^{15}$

Although an organization may bave standing in its own gght to intervene in an NRC adjudicatocy proceeding, none of the three organizations has sought to demonstrate an injury to ils organizational interests. Nowhere in the intervention petituon, corrected reguest, or supporting memorandum do the Petitioners

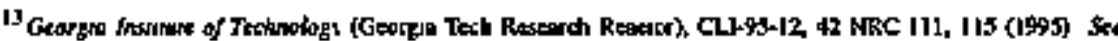

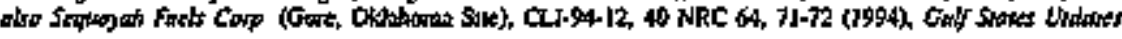

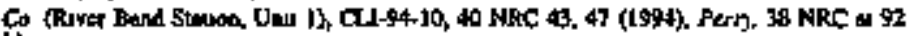

it Renivas for Henring at 4, aed Comeded Request an 2.3

15 at $5-6$

16 Id at 4
}

$-n+2$

$\div$

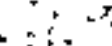

$=-2$

$1+2-2$

$\therefore$ 然
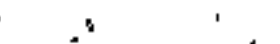
identify any organizational interest of WTP, SAPL, or NECNP that is harmed or threatened with injary by the ticense atnendment at issue. Thus, none of these organizations has standing in its own right to intervene. However, WTP, SAPL, and NECNP seek to establish standing to intervene as the representative of one or more or its members. For such representational starding the petitioning orgarization must show that at least one of its members suffers "immediate or threatened injury as a resule of the chaltenged action of the sort that would make out a justiciable case had the members themselves brought sutt."'1? Eurther, agency case law teaches that the organization must identify at least one member by name and address and provide "some concrete indication that, in fact, the member wistes to have that [member's] interest representited in the procoeding." "Is Moreover, that concrele indication of representational authorization should be provided "preferably by affidaviL"Is

Here, two of the three petitioning organizations, SAPL and NECNP, have not complied in any respect with the requirements for eslablishing standing as representative of one of their members. The Corrected Request, as indicated, sets forth a list of garnes and adkresses of twelve WIP members who purportedly live in the "neighborhood" of the Millstone plant, but the petition is silent with respect to the names and addresses of any SAPL or NECNP members. Accordingly, these Petitioners bave provided no "concrete indication" from any member of their organizalions that a representatton of their interests has been anthorized in this proceeding. This, despite the fact that their supporting memorandtum recites the requisiles for representational standing;

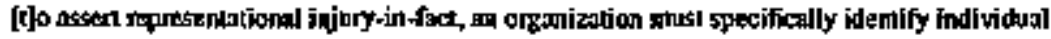
mombers oy name and address, identify how that member ony be affected and show thel the argantzakion is authorlzed to requex a hearing on betwalf of the member, Parjif Gas \&

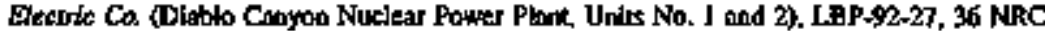
196, $199(1992){ }^{30}$

Accordingly, SAPL and NECNP have faikd to demonstrate that they have standing to intervene as the representative of onc of their members. ${ }^{\text {II }}$

In considering WTP's standing posture, Petitioners' Conrected Request fails to estatilish that the twelve (12) WTP members, with Connecticut residences,

\footnotetext{
17 Warth, 422 US, an SII.

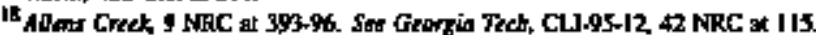

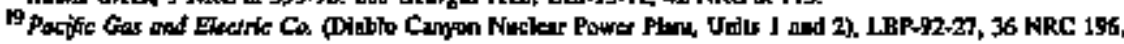
199 (1992).

3 Palitioners' Mandoripdent at 5 .

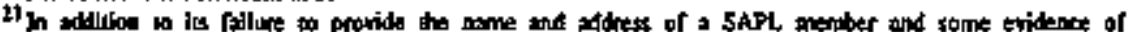

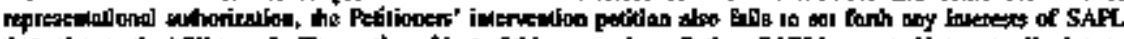

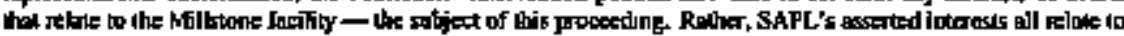

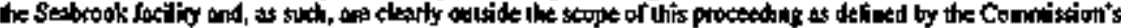
hearing mource
} 
authorized WTP to represent them in this proceeding. On December 4, 1995, WTP attempted to cure this deficiency by filing an affidavit of one of these members, Glen Cheney, wherein Cheney states that he and the other eleven members wished to be represented by WTP.

This filing ignores our scheduling order of November 7, 1995, whereit we stated that "the Petitioners shall bave until Tuesday, November 14, 1995, to flo any andended intervention potition. After that date, the Licensing Board will not entertain any further anended ox corrected intervention request." 2 . Petitioners' counnsel's letter stated that

[I] view of the posinon of bolh the NRC graff and the Lacelsee, that the organkalional

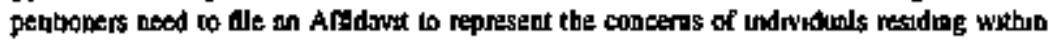

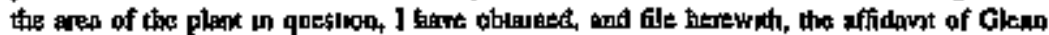
Cheney, Hating that he, and the ather indrelduals hasted on the corrected pelition do degire to tave toer unierests represented ihrough we The People, Inc ${ }^{\text {th }}$

The Commission has declared in its Statement of Poltcy on the Conduct of Licensing Procezdings that "[f]aimess to all involved in NRC adjudicatory procedures requires that every partcipant fulfit the obligations imposed by and in accordance with applicable law and Commission regulations," "224 Petitioners' counsel has participated in NRC adjudicatary proceedings for 20 years, 25 and there is oo excessing this deficiency based on a lack of familiarily with agency procedures.

The presiding officer in this proceeding elected not to hold a special prehearing conference and, as indicated, set November 14, 1995, as the cutoff date for amending petitions. ${ }^{*}$ Being ont-of-timt, WTP should have addressed the five latentess factors required by 10 C.F.R. \$ 2.714(o)(3) on December 4, 1995, when it attempted to amend its petition by filing the Cheney affidayit. ${ }^{2 n}$ Failing that, WTP has rot denonstrated standing in this proceeding as a matter of right. However, as explained sutasequenty, in an effort to expedite and develop the record of this proceeding, the Board has decided to exercise its discretion and grant WTP's petition for intervention. We also hold that the amented petition's attempl to authorize representation by eleven (11) other induvduals listed in Petitioners' Corrected Request of October 18, 1995, has no validity. Under the

\footnotetext{
220ter (Nor 7. 1995) a 2 (tuapublubed)

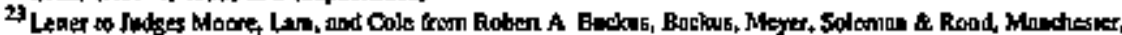
NH (Dec 4, 1995)

240U.81-8, ta MRC 452, 454 (1981)

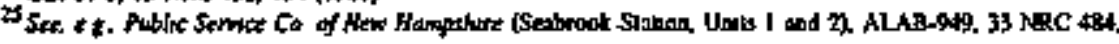
48S (I991), $d$, LEPP 76-4, 3 NAC 123 (1976)

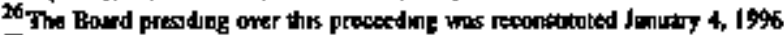

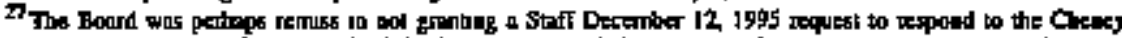
IF

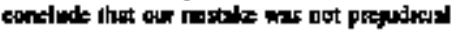


Commission's practice, axerments by one member of an organization by affdavit that other members have authorized representation would not satisfy the requirenent thal those members have given some "concrete indication" that a representation of their interest is authorized ? $^{28}$

The Pelitioners' Request for Hearing argaes a case for standing under the Commission's proximily presumption for indjviduals who tive within 50 miles of the Millstone plant. We turn to that argument because it forms the basis for the ctaim that Mr. Del Core has standing to intervent.

In construction permit and operaung license proceedengs, Commission case law recognizes a proximity presumption that persons who live, work, or othexwise have contact with the ares around a nuclear plant have standing to intervene. ${ }^{29}$ That presumption is based on an unsurprising premist, $i \mathrm{e}$., that the construction or operalion of a nuclear power reactor carnes with it "clear implications for the offsite environment "30 so that indiviousals sesidng in reasonable proximity to the plant are likely in at least some small way to be injured in their persons or property by a plant accidere, and thus such persons fall within the geographic zone of interests protected by the Alomic Energy Act." Similarly, agency case law reognuzes the same presumption in license amendment proceedings that involve "major alterations to the facilty with a clear potential for offsite consequences" or other circumstances that present "such obvious potential for offsite consequences."

According to the corrected intervention request, Mr. Del Core lives in Uncasville, Connecticut, within 20 dutes of the Mijlstone plam, and he owns properly within the Emergency Planning Zone for the facilty. This clearly would be sufficient for gaining intervenor status th construction permit or operating license proceedings.

The Pettioners' case relies, in part, on the Appeal Board decision in ALAB522.35 That determination involved a license amendment to expand the capacity of the spent fuel pools at both of the North Anna nuclear power plants. In reversing the Licensing Bowrd's ruling denying the petitioness inlervention, the Appeal Board found the proxinity presumption applicable. In this license amendment case, a residence near the Millstone piant also intpticates the proximity presumption because the license amendment at issue, even though not isvolving a major alteration of the plant, may involve the potential for offsite

${ }^{28}$ Alims Crat ALAB S35, 9 NRC in 396

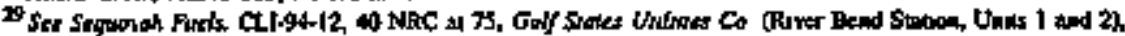
ALAB-183, T AEC 222, 226 (I9TA)

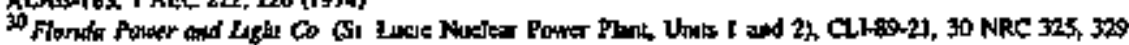
(1985)

${ }^{31}$ See Raver Bend, ALAB-183, I AEC ar 223-24 \& as

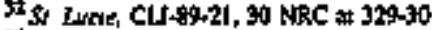

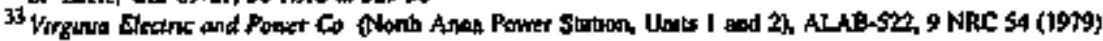




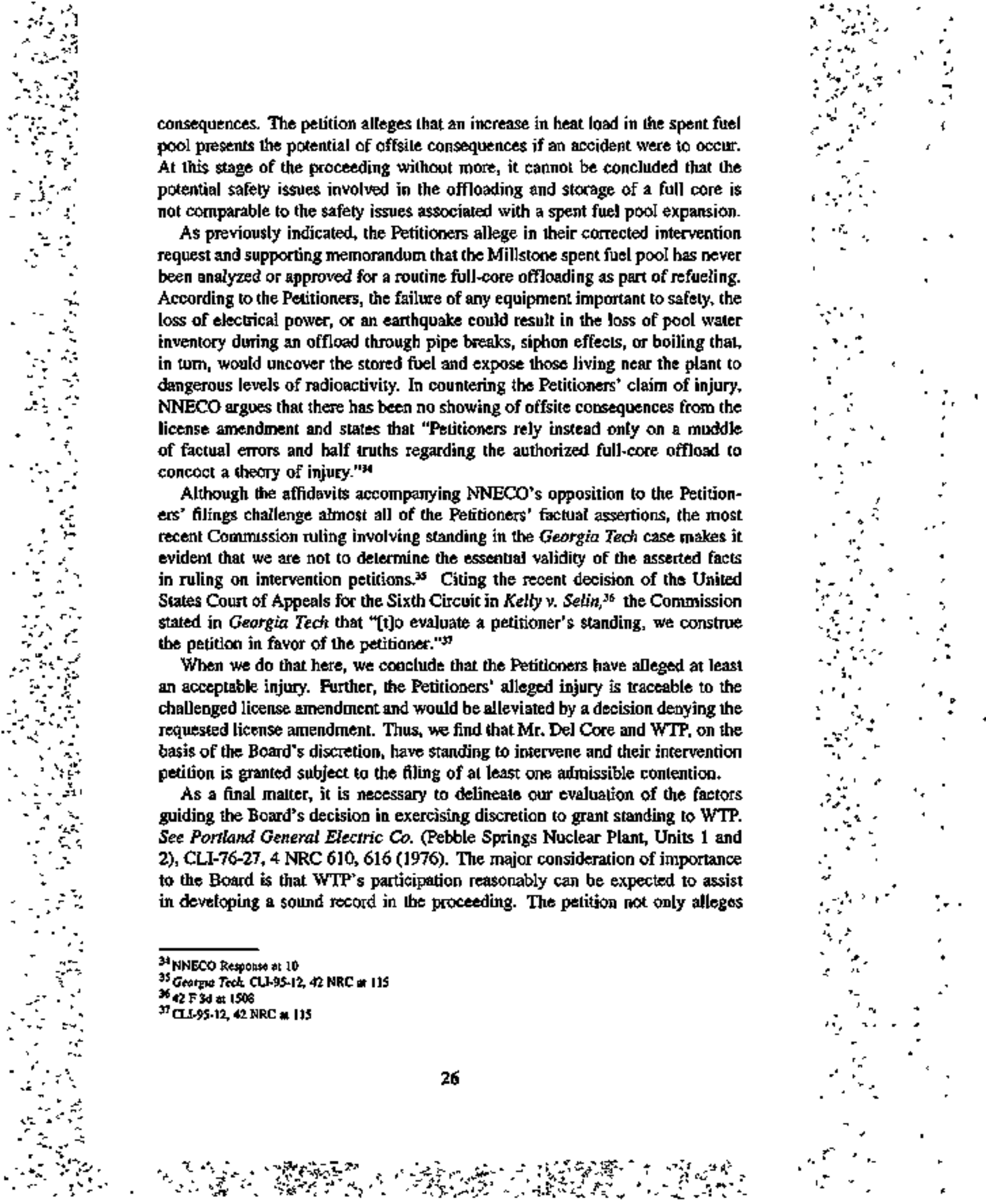


a previous Involvement of the organization with Milistone employees on safely issues but specific consultation with employee George Galatis on offloading practices at the plant. These may involve safety issues in the proceeding and information that might not otherwise be available in the case. Wo have no basis for concluding that WTP's participation wilt brosden or delay the proceeding and, as set forth previously, a favorable ruling would redound to the berafit of WTP and its members.

\section{CONCLUSION}

For the foregoing reasons, it is hereby ORDERED that:

1. The request for hearing and petition to intervene filed on behalf of New England Coalition on Nuclear Pollution and Seacoast Anti-Pollution League is denied;

2. The request for hearing and petition to intervene filed on behalf of Donald W. Del Core, Sr., and We the People is granted, contingent upon the filing of an admissible contention as set forth in 10 C.F.R. ₹ 2.714; and

3. The Petitioners above shall have 30 days from the date of service of this Order to file contentions.

In aceordance with the provistons of 10 C.F.R. $\$ 2.7144$, this Order may be appesled within to days afler ils service.

\section{THE ATOMIC SAFETY AND LICENSING BOARD}

James P. Gleason, Chairman ADMINISTRATIVE JUDGE

Dr. Richard F. Cole ADMINISTRATTVE JUDGE

D. Peter S. Lam

ADMINISTRATIVE JUDGE

Rockville, Maryland

Febnuary 7, 1996

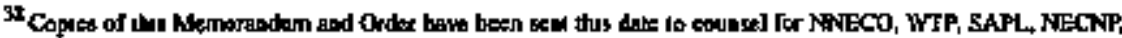

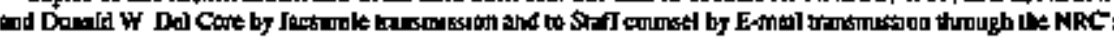
oudb-ates neawork
} 
LNITED STATES OF AMERICA

NUCLEAR REGULATORY COMMISSION

\title{
OFFICE OF NUCLEAR REACTOR AECULATION
}

\author{
Waliam T. Russell, Drector
}

In the Matter of

\section{YANKEE ATONAIC ELECTRIC Cousparty \\ (Yanked Nuolear Power Station)}

Docket No. 50-029

(Lictonse No. DPF-3)

February $\approx 2,1906$

The Director of the Office of Nuclear Reactor Regulation denies in part and grants in part a petition dated January 17, 1996, submitted to the Nuclear Regulatory Commission (NRC) by Citizens Awareness Network and Now England Coalition on Nuclear Pollution (Petitioners), requesting that the NRC take action with respect to five activities conducted by Yankee Atomic Electric Company (YAEC or Licensee) at the Yankee Nuclear Power Station in Rowe, Massachusetts (Yankee Rowe or the factlity). The petition was also moot in part. The petition rexuests that the NRC comply with Citizens Awareness Network Inc. v. Unifed States Nuclear Regulatory Commission and Yankee Atomic Electric Co., 59 F,3d 284 (ist Cir. 1995) and immediately order. (A) YAEC not to undertake, and the NRC Staff not to approve, further major dismantling activities or other decommissioning activities, unless such activities are necessary to ensure the protection of occupational and public bealth and safety; (B) YAEC to cease any such octivities; and (C) NRC Rejion I to reinspect Yankes Rowe to feterminte whether there has been compliante with the Commission's Order in CLI-95-14, 42 NRC 130 (1995), and to issue a report within 10 days of the requested order to Region $L$

The Pelitioners' request that shipments of low-level radioactive waste be prohibited is denied because that activity is pemissible, prior to approval of a decommissioning plan, under the pre-1993 interpretation of the Commisston's decommissioning regulations. Petitioners" request that four other activities be prohibited is moot, although the activities would have been pernissible, prior 
to approval of a decommissioning plan, under the pre-1993 interpretation of the Commission's decomnijssioning regulations. Additionally, Petitioners' request for an inspection of Yankee Rowe to detennine compliance with CLI-94-14 and an inspection report was granted.

\section{DIRECTOR'S DECISION UNDER 10 C.F.R. \$2.206}

\section{INTRODUCTION}

Av "Emergency Motion for Compliatree with Circuit Cotrt Opinion" (petition\}, dated January 17, 1996, was submitted by Citizens Awareness Nelwork and New England Coalition on Nuclear Pollution (Petitioners). Petilioners requesled that the United States Nuclear Regulatory Commission (NRC or Commission) take action with respect to activities conducted by Yankee Atomic Electric Company (YAEC or Licensee) at the Yankee Nuclear Power Station in Rowe, Massactusets (Yankee Rowe or the facility).

By an Order of the Comousssion dated January 23, 1996, the Entergency Motion was referred to the NRC Staff for treatment as a petition pursuant to 10 C.F.R; $\$ 2.206$ of the Commission's regulations. The Conmisstion ordered the Staff to respond to the emergency aspecis of the petition in 10 days and to issue a decision on the petition as a whole within $\mathbf{3 0}$ days.

Petitioners request that the NRC comply with Citizens Awareness Network Inc $v$. United States Nuclear Regulatory Commission and Yankee Atomic Electric Co. 59 F.3d 284 (Ist Cir. 1995) (CAN v. NRC). Specifically, Petitioners request that the Commission immediately order.

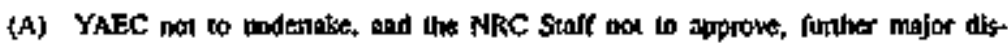
manuling activities or pther tecommissionàng getivities, unless such axtivities due

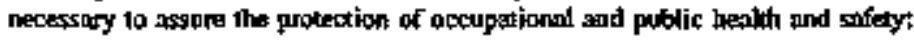

(B) YAEC io cease any such aclivities; and

(C) NRC Region I to reinspect the Yantsee Nuclear Power Station in Rowne Mas. sachusers (Yankee Rowe) to determine bhelber there bas been complience with

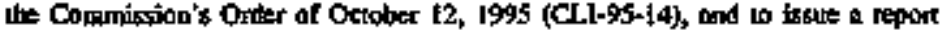
within kan daye of the requested ondor to Repion $L$

As the bases for their requests, Petitioners state that:

(1) CAN v. NRC nequires the cessetion, and proh'tits commentement, of decomonis-

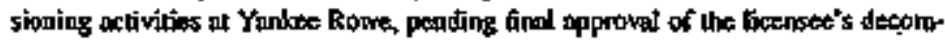
missioning plen after opportunity for a haxing Ctl-95-14 forbids YAEC fma 


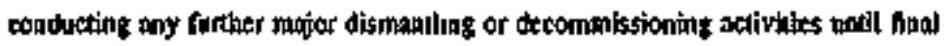
approwal of its tecommissioning plan after completion of the bearing process;

(2) CAN v. NRC obEges the Commóssion and the Stalt to prowde an opportuaity to inlerested persons for a hearing to approve a decommissioning plab;

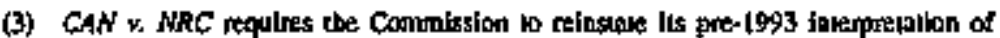

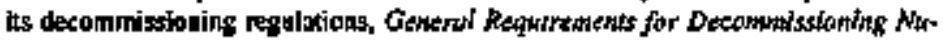
clear Facillies. S3 FR 24,018, 24,025-26 (Jone 27, 1988), limiling the scopte of

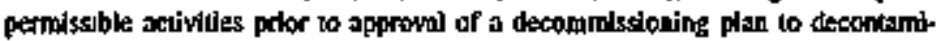
untion, minor component disnssembly, and shipment and storage of spea! twel, ti permitied ty the eperting lifense andios 10. C.F.R. \$50 59. Under Lang Island Lighting Co. (5horetimm Theleas Power Stolion, Unit 1), QL[-90.08, 32 NRC 20t.

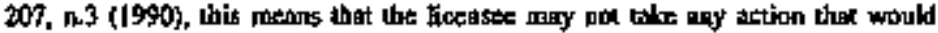
menlerially aftect the methods ar options xailabte for decommissipning or thal would substankeally increase the costs of decommissionicg, prior to approval of a decommissiouitos plan. Under CL1-91-2, 33 NRC at 73, n5, and CL1-92-2, 35 NRC al 61, n.7, other decombntissioning activities, th addition to mojor ones, ate prohitited, including offyite stipments of kop-kevel mdionclive waske prodnced by decommisstouting activilies, anlil after approval of a decommissioning plan;

(A) deconmistiouing ectivities permitied by NRC Inspection Manoel, Chopier 2561.

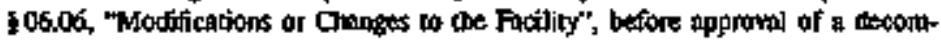
missioning plas ars limiled ta maintenanke, removal of relotively small modionative components or nog-radfoselive componenks, and characterization of the plast or sives

(5) YAEC is conducting decompissioning activities with the opprovil of the NRC

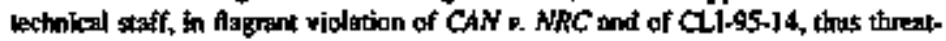
ening to sendes the decommissioning process nugarory and to depsive Petetioners of their hesting rights under Section 189a of the Acomte Energy Act;

(6) by lenter taned October 19. 1995, YAEC described nine decommbssioning xetrities

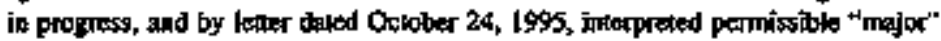
diamenting as remoral of non-radioxtive malartal required to suppert safe stornge of spen foel and of those portions of the facilities which nevidn, of to support future dismantement;

(7) by letter tated November 2, 1995, the NRC slaff apptoryed the activilies degctibed by the libentise in its lenter of Detober 19. 1995:

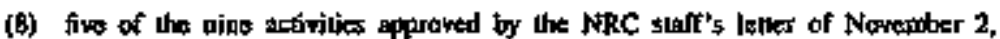

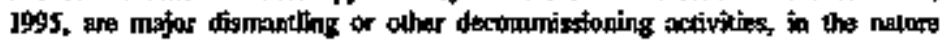
of Component Rembral Projex activities, protubited, ontil afler approwal of a decompitsioming plen, by CAN v. NRC and CLJ-95-14. Pelitioness object tox (a) eompleting ramowal of the stmainder of the Upper Nontron Stield Tnok; (b) remowal of Componenl Cooling Water System pipes and eompontents and Sptont Fuel Cooling System pipes and compouents; (c) Fuel Chnle isolstion; (d) Spent Fiel Pool ofectrical endait installotion; and (c) codionctive waste shipments. Potitioners do

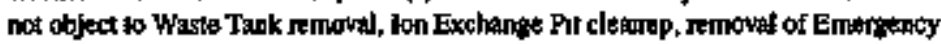
Dieced Generelort, or the Brookhaves Nalianal Laboratory Cable Sampling Project. 


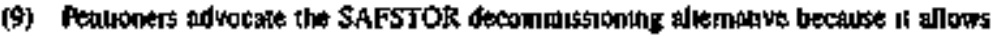
levels of radioscluvity and watle wolumes lo decreate, thus redueibg occupationd

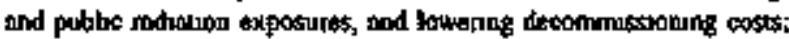

(10) NRC Inspection Repot No 50-2955-05 (Decendber 16, 1995) concludes that the

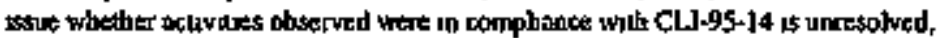
tral approves YABC's proposed acuviues, contray lo the roqurrements of NRC Inspection Manuel, Chapter 2561, \$0506, "Modtilextuons or Changes in the Faciling (March 20, 1992), and

(It) YAEC's cnkenos Tor perrossible decommssioning aclivilues, that any actirky in-

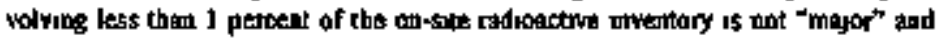
moy lake phoce before approvas of a decommussenong plan, vfolaks CAN v hRC becanse it would allow complelion of decosinissioning before any tecomnassion.

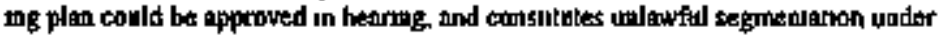
the Nolumpel Eavironmentonl Polky Aat

By letter dated Ianuary 29, 1996, Yankee Atomic Electric Company responded to the petition. YAEC supplenented its response by lelters dated February 15, 1996, February 21, 1996, and February 22, 1996, and by an E-mail message to the NRC Staff on Jentary 31, 1996.

By letter dated February 2, 1996, the NRC Staff denied in part and granted in part Petitioners' requests for emergency action. The pettion was also found moot in part. Petitioners' requests thet the NRC take emergency action to order (A) YAEC not to undertake and the NRC Staff nol to approve further major dismantling activitits or other decommissioning activitues, unless ascessary to ensure the protection of oceupational and public health and safety and (B) YAEC to coase any such activities were found moot in part and devied in part. Petitioners' request for emergency action to reguire NRC Region I to reinspect Yonkee Rowe to determine whether YAEC bas complted with the Commission's Order of October 12, 1995 (CLI-95-14), and to issue a report within 10 days after the Commission orders such an inspection, was granled.

Petitioners then requested the Commission to reverse the NRC Staff's February 2, 1996 decision on the emergency aspects of the petition. See "Citizens Awareness Network's and New England Coalition on Nuclear Pollution's Motion for Exercise of Plenary Commission Authority to Reverse NRC Staff 2.206 Decision, and Renewed Endergency Request for Compliance with Circuit Court Opjuion." By Order dated February 15, 1996 (unpublished), the Commission declined to grant the emergency relief requested, as there was no showing that the Licensee would take any aclion before the 155uance of a Director's Decision on February 22, 1996. The Commission directed the NRC Staff to adtress the argttments advanced by Petitioners in their February 9 motion in this Decision. with the exception of the new issues raised on page 13 of the motion, which are to be addiressed it a supplementary 10 CF.R $\$ 2.206$ decision.

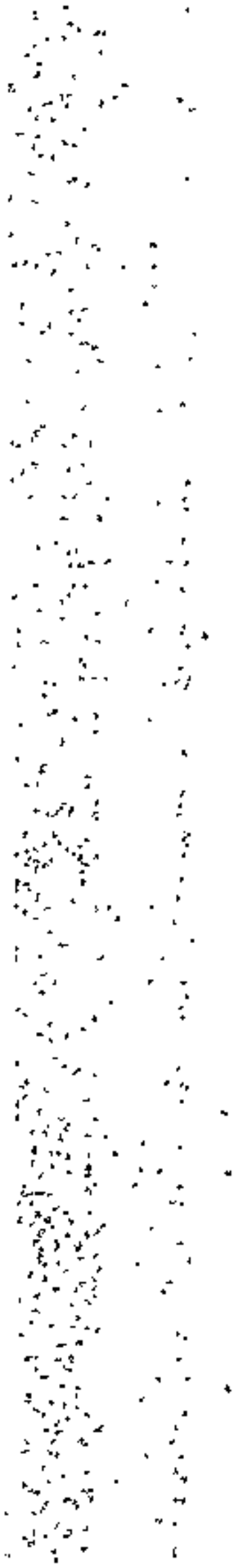


For the reasons discussed below, Petitioners' requests that the NRC prohibil YAEC from undertaking or continuing five of the nine activities evaluated by the NRC Staff's letter of November 2, 1995, are moot in part and denied in part of the rine activities, all with the exception of cadioactive waste shipments were completed before submission of the January 17, 1996 petition. Accordingly, Peationers' request for relief with respect to (1) completing renoval of the remaindes of the upper neutron shield tank, (2) removal of the component cooling water system pipes and components and spent fuel cooling system pipes and components, (3) fuel chute isolation, and (4) spent fuel pool electrical conduit installation is moot. Pettioners' request for relief with respect to radioactive waste shipments is denited. As explained below, all five conlested activities were permissible, before approval of a decommissioning plan, under the pre-1993 interpretation of the Commission's decommissioning regulations. and thes are in compliance with CAN v. NRC and CLI-95-14. Pelitioners' request that the NRC inspect Yankec Rowe to determine compliance with CLI.95-14. and issese an inspection report, was granted.

\section{BACKGROUND}

On February 27, 1992, YAEC announced its intenlion to cease operations permantently at Yankee Rowe. On August 5, 1992, the NRC issued a license amendment to limil the license to a possession-only license. 57 Fed. Reg. $37,558,37,579$ (Aug. 19, 1992).

In late 1992, YAEC proposed to initiale a Component Removal Project (CRP). On December 20, 1993, YAEC submitted a decommissionting plat based on a phased approach, starting with DECON, then SAFSTOR, and then finally dismanlement Notice of Receipt of Decommtssioning Plan and Request for Comments was published in the Federal Register. (59 Fed. Reg. 14,689 (Mar. 29, 1994)).

On Jamiary 14, 1993, and on June 30, 1993, the Comunission issued two Staff Requiremenss Memoranda which, in pertinent part, interpreted the Comnission's regulations to permit many decommissioning accivities prior to approval of a deconumissioning plan, as long as the activities do nol viofale the terms of the existing license or 10 C.F.R. \$ \$0.59 with cerlain additional restrtietions. \$ee "Staff Requirements - Briefing by OOC on Regutalory Issues and Options for Deconumissioning Proceedings (SECY-92- 382), 10400 a.m., Tresday, November 24,1992 , Commtssioner's Conference Room, One White Flint North, Rockville, Maryland (Open to Public Attendante)" (January 14, 1993) and "SECY-92-382 - Deconnmissioning - Lessous Learned" (June 30, 1993).

On several occasions between late 1992 and early 1994, CAN asked the NRC to offer an opportunity for an administrative hearing regarding decornmissioning 
activities conducted by YAEC at Yankee Rowe. The Commission denied esch such request. CAN sought judicial review and challenged the denizls and the Jamuary 14, 1993 interpretation of the Commission's decommassioning regutations.

On July 20, 1995, the United States Court of Appeals held that the Commission had: (1) failed to provide an opportunity for hearing to CAN, as required by section 189 of the Alomic Energy Act, in connection with the Comnisston's dectsion to permit the CRP decommissioning activities; (2) changed its pre-1993 interpretation of its decommissionung regulations without notice to the public and in violation of the Administrative Procedure Acl; and (3) umpentissibly allowed the Licenset to conduct CRP decomunssioning activities prior to compliance with the National Environmental Polrcy Act requirement to conduct an enviounmental analyss or environmental impact statement. CAN y. NRC, 59 F.3d at 291-92, 292-93, and 294-95 (1st Cir. 1995) The court remanded the matter to the Commission for proceedings consistent with the court ${ }^{t} s$ optinion.

In response, the Commission issued a Federal Register notice advising: (1) that the Commission did not iniend to seek further review of CAN v. $N R C$; (2) that the Commission understood that decision to require a relurn to the interpretation of NRC decommissioning regulations that were in effect prior to Jamuary 14, 1993; and (3) Lhat the Commission was requesting public comments on whether the Comnussson should order YAEC to cease ongoing decominusstoping activlues pending any required hearugs and any olher matters connected with that 1ssur. See 60 Fed. Reg. 46,317 (Sept. 6, 1995).

After consideration of comments filed in response to that notice, the Conmission implemented CAN v. NRC by issung CLI-95-14, 42 NRC 130 (1995). In CLI- 95-14, the Commussion renstated its pre-1993 joterpretation of its decommissioning policy, required the issuance of a notice of opportunity for an adjudicatory hearing on the Yanket Rowe decomroussioning plan, beld that YAEC may not conduct further "major" decommassioning activities at Yankec Rowe until approval of a decommissioning plan after completion of any required hearing, and drected YAEC to unform the Comunission within 14 days of the steps it is taking to come inlo complsance with the remstated interpretation of the Commission's decommisstoning regulauons. CLI-95-14, supra.

Pursuatit to CLJ-95-14, a proceeding is now under way to offer an opportunity for hearing on the Licensee's decommissioning plan for Yankee Rowe. Petiboners have sought interventton and a hearing.

As of July 20, t995, when the cover issued CAN * NRC, YAEC had completed its Component Removal Project. In response to CLI-95-14, by letters dated October 19 and 24, 1995, YAEC Idenlufied nine ongoing activities that YAEC believed were permissible under CAN v. NRC and CLİ-95-14.

In its letter of November 2, 1995, the NRC Staff evaltated those nine aclivities and found them permissible under the Comprission's pre-1993 interpretation

?

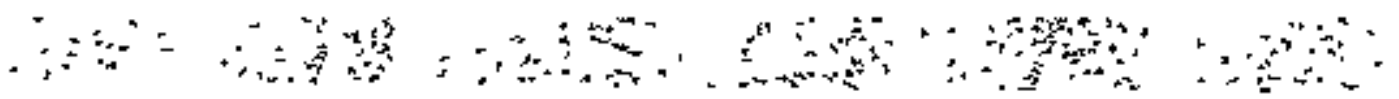


of its decommissioning regulations, and thus under CAN v. NRC and CLI-9514. The Staff also identified certain activities, although not proposed by the Licensee, which may not be conducted before reapproval of a decommissioning plan. Those activities include dismanclenent of systems such as the main reactor coolant system, the lower neutron shield tank, vessels that have significant radiological contamination, pipes, pumps, and ather such components, and the vapor contaner (containtment). The Steff alsa identitied segmentation or removal of the reactor vessel from its support structure as a major dismantlement not to be conducted umlih after the decommissioning plan is reapproved.

\section{TV. DISCUSSION}

A. The Nine Activitles Were Permissible, Prior to Approval of a Decommisstoning Plan, Under the Commission's Pre-1993 Interpretation of Its Decommissloning Regolations, and Thus Are Permissible Under CAN v. NRC and CLI-95-14

Petilioners contend that five of the nine activities evaluated by the NRC Slaff's letter of Nowember 2, 1995, are major dismantling or other decommissioning activities prohibited until after approval of a decommissioning plan, by $C A N$ v, NRC and CLI-95-14, Specifically, Petitioners object to: (1) completing removal of the remainder of the upper neutron shield tank; (2) removal of componen cooling water system pipes ard components and spent fuel cooling system pipes and components; (3) fitel chute isolation; (4) spent fuel pool electrical cotdut installation; and (5) radioactive waste shipments. Pelitioners do not object to waste tank removal, ion-exchange pit cleanup, removal of emergency diesel genesators, or the Brookhaven National Laboratory Cabse Sampling Project. Petitioners acknowledge that completion of waste tank removal and ion-exchange pit cleanup are required for safety reasons. Petitioners also acknowledge that the removal of the emergency diesel generators is permissible because they are not radioactive, and that the Brookhaven National Laboratory Cable Sampling Project is a research project unrelated to decommissioning. Of the nine activities, all with the exception of radiosetive waste shipments were completed before submission of the January 17, 1996 petition.

Under the Commission's pre-1993 interpretation of its decommissioning regviations, a licensee "may proceed with some activities such as decontamination, minor companent disassembly, and shipment and storage of spent fued if the setivities are pemitted by the operating license and/or $\$ 50.59$," prior to final approval of a licensee's decommissioning plan, ${ }^{1}$ as long as the sctivity does not

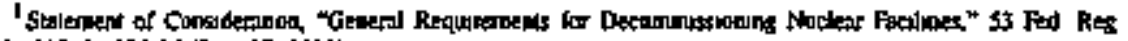
$24,018,24,025-26$ (It) 27,1988$)$ 
core during defueling and shìpped off site for processing or disposal as low-level waste

- Alt helium circulators remowed and shipped off site for disposal

- Core region consiraiot devices (imernals) temoved and approximately one-half shipped off site for disposal

- About fitty core metal-clad refiector blocks (top layer of core) removed and stored in fuel storage wells

- Removal of remaining hexagonal graphite reflector elements, defueling etements, and metat-clad reflector blecks begun

- Prestressed concrete reactor vesset (PCRV) top cross-head tendons and some circumferential tendons detensioned

- Some detensioned tendens removed from PCRV

- Work initiated to cut and remove PCRV liner cooling system piping presenting interferences to detensioning of PCRV tendons

- Astrestos insulation completely removed from piping under PCRV

Activities such as botmal maintenance and repaits, removal of small radioactive components for storage or shipment, and removal of components similar to that for maintenance and repair also were permitted prior to approval of a decommissioning plan under the Commission's pre-1993 interpretalion of the Commission's decommissioning regulations. See NRC Inspection Manual, ch. 2561, \$06.06 (Issue Date: 03/20192).4

Of course, licensees are afso permitted to complete or to conduct aclivities required for compljance with safety requirentents before approval of a decommissioning plan. In addition, special consideration must be given to activities required to comply with other federal and state safety requiremonts. See Memorandum of Utaderstanding Between the Nuclear Regulatory Commission and the Occupational Safety and Health Administration, "Worker Protection at NRC-licensed Facilities" (Oct. 21, 1988), 53 Fed. Reg. 43,950 (Oct. 31, 1988). See also NRC Inspection Manual, ch. 1007, "Interfacing Activities Between Regional Offices of NRC and OSHA," Petitioners concede that completion of activities alteady under way is permissible if completion is requtued for intrediate safely purposes.

The Staff's November 2, 1995 letter evaluated the nine activities identítited in YAEC's letter of October 19, 1995, based on the Commission's pre-1993

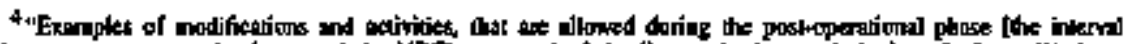

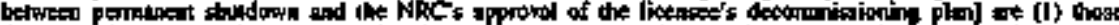

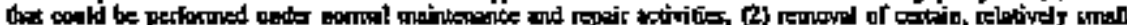

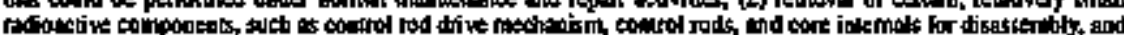

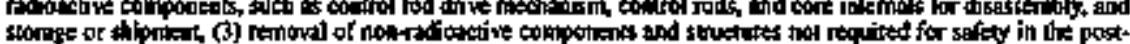

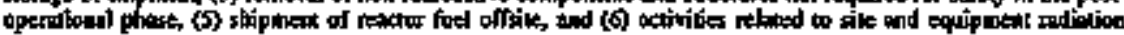
od combarinetion chastaterion"
}

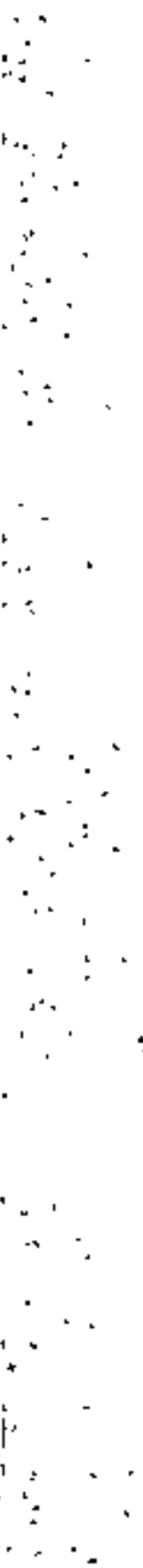


for removable lead contamisation. ${ }^{6}$ Licensee personisel were and are required to enter the area in order to conduct surveillances to monitor radioactive contamination and for compliance with fire protection requirements.

In view of the above, this activity was permissible for safety reasons, and, therefore, woukd bave been allowed in a comparable situacion before approwal of a decommissioning plan, under the pre-1993 interpretation of the Commission's decommissioning regulations.

\section{Waste Tank Removal (Acfivity Decay and Dilution Tank)}

Petitioners concede that conpletion of this activity was requited for safety reasons.

\section{Remoust of Component Cooling Water System Pipes and Components and Spem Fuel Coofing System Pipes and Components}

Contrary to Petitioners' assertions, the Staff's February 2, 1996 letter did not "abandon" the Novenber 2, 1995 rationsle for finding this activity permissible. The Staff's February 2 leater repeated the November 2 maionale and provided a more detailed explanation for the Slaff's conclusion that this activity is permissible under the pre-1993 jisterpretation of the Commission's decomtrissioning regulations.

The Lxeensee had instatled a stlf-contained spent fuel pool cooling system, isolated from the flute components and installed conduit to allow future electrical isolation from other systems, in order to enhance safery and integrity of the spent fuel pool for prolonged storage of fuel. As a result, the component cooling water systent pipes and components and spent fuel cooling systent pipes and components were tendered redundant and were no longer useful.

Rerrovil of the no-longer-useful pipes and components was not decommisstoning, but maintenance that would have been allowed, before approval of a decommissioning plan, under the pre-1993 interpretation of the Commission's decommissioning regulations. ${ }^{\top}$ Petitioners emoneously contend that Eemoval of

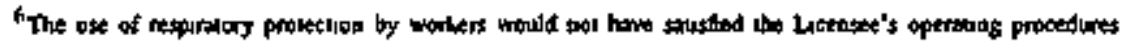

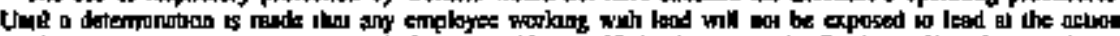

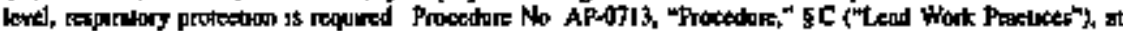

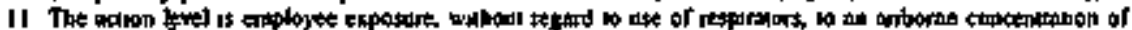

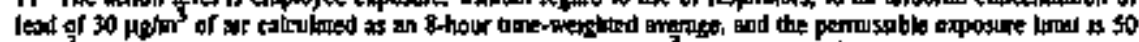

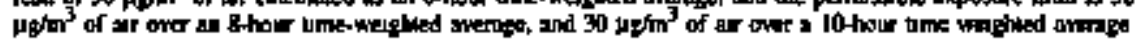

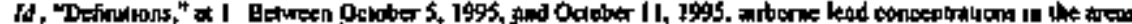

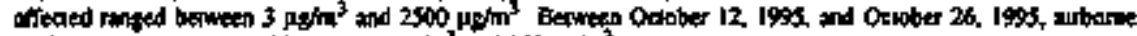

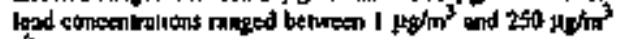

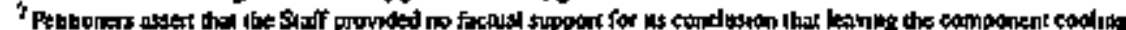

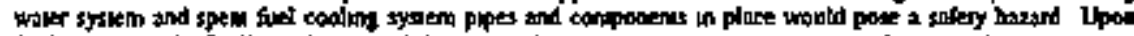

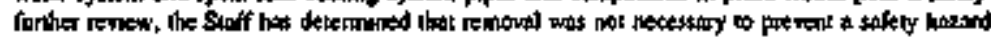

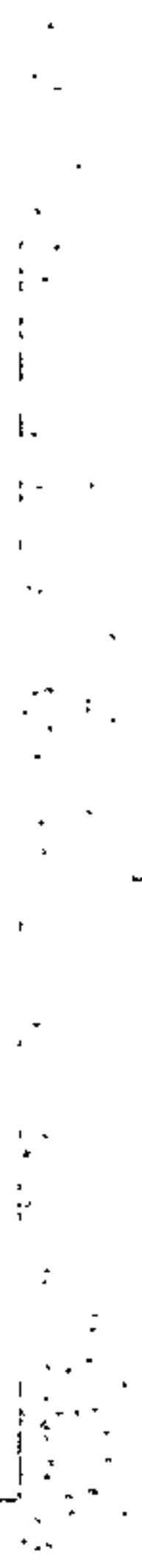


As part of the NRC Bulletin 94-01 project, one 8-foct lenglh of this 12-inchdiameter fuel chute pipe was renowed from the top of the lower lock valve and a blank flange placed over the lower lock valve so that the valve could be encased in concrete. This, in effect, made the valve part of the SFP wall. The removat of this section of pipe also eliminaled a potential leak path through the pipe out of the SFP wall.

Isolation of the fuel chute, accomplished by removing the lowest flanged pipe section and sealing the lower portion of the fued chule with concrete, elitininated a freezing and siphon hazard. Sealing the fuel chule with concrete prevents accumwation of water in the fuel chute. Accumulated water could freeze during severe winter weather and possibly damage the lower lock valve outside the spent fuel pool wall, thus opening a kak path tear the botlom of the spent fuel pool.

Petilioners incortectly maintain that the Licensee did not need to remove the upper fuel chule in order to comply with NRC Bulletin 94-01. The Licensee did not remove the upper fuel chute. The Licensee has fastened a blank flange at the wall of the VC by wedging open a flanged joirt. This was a maintenance activity. This btank lange is normally in piace and was removed, in the past, when fuel transfer operations took place. These transfers are now prohibited by the POL. The fuel cinute isolation project was necessary to prevent potential siphon and freezing risks, was one of the actoons determined to be an adeguate response to NRC Bulletin 94-01, and brought the Licenset into compliance with NRC requixements.

In any ovent, this activity is not decommissioning, bet maintenance and a safety upgrode that would have been allowed under the pre-1993 interpretation of the Commission's decornmissioning regulations.

In view of the above, this activity was peronissible, before approval of a decommissioning plan, under the pre-1993 interpretalion of the Conanission's decomurssionting regulations.

\section{Removal of Emergency Diesel Generators}

Petitioners acknowledge that xemoval of the emergency diesel gentrators is a permissibite activity prior to final approval of a deconmissioning plan.

\section{Spent Fuel Pool ENectrical Conduit Installation}

This activity involwed underground instailation of a power cable and its protective covering and did not involve the removal of mdiotcive material. The modification also enhanced the irtegrity and long-term safe storage of spent fuel in the spent fuel pool, by isolating spent fuel pool potwer supplies from potential

41 
problents that could be cansed by power circuits in other systems or heavy load implacts at the plant. The activity was part of the Licensee's owerall project to enhance the safety of the spent fisel pool by establishing independent systens dedicated to spent fuel pool neliability.

The conduit installation was also consistent with NRC Bu[letin 94-01, specifically the first requested action, which involves ensuring the integrity of structures and systems, necessarily inciuding electrical systems, required for containing. cocling, cleaning, level mouitoring and makeup of water in the spent fuel pool. The conduit installation project enhanced integrily of the spent fuel pool by ensuring operability and adequacy of structures and systems required for spent futel pool integrity, specifically the electrical system.

Petitioners object that the November 2, 1995 letter implies that this activity is a decomunissioning activity because it will provide a separate power supply for funure decommissioning activities. Petitioners contend that there is no presert threat to the integrity of the spent fuel pool, and that as long as the Licensee perfoms no major dismantlentent activities, there is no immedjate need for conduit instalation.

While it is true that conduit installation will isolate the spent fixel power supply from potential problems associated with furture decommissioning of other systens, conduti installation al so serves the larget punpose of isolating spent fuel pool power supplies from poteotjal probtems that coeld be caused by power citcuits in other systems at the plant, wholly apart from the conduct of any decommissioning activities. This activity represems a safety enhancement.

In view of the above, this activity was permissible, before approval of a decomnissioning plan, under the pre-1993 interpretation of the Connission's deconrunissioning regulations.

\section{Bropkhmen National Laboratory Cable Sampling Project}

Petitioners acknowledge that this activity is a research project unrelated to decominissioning.

\section{Radioctive Materials Shipments}

Under the pre-1993 interpretation of the Comunission's decommissioning regulations and 10 C.F.R. \$ 50.59, the NRC has permitted shipment of radioactive waste and contamúnated components prior to approval of a decommissioning plan, as long as it does not materially and demonstrably affect the methods or options available for decomumissioning or substantially increase the cost of decommissioning, and because such shipments do nol constitute a "major" activity. 
NRC Staff practice prior to 1993 permitted activities such as shipment of waste of contaminated components at a permanently defueled facility pursuing decommissioning. Prioe to approval of a decommissioning plan, the licensee may dismantle and dispose of nonradianctive components and structures noc roquired for safety in the sbutdown condition. After isstuance of a possession-only license, the licensee also maty dismantle and dispose of tadioactive components not required for sefety in the shutdown condition, provided that such activity does not involve major structural or other major changes and does not foreclose alternative decommissioning methods or materially affect the cost of decommissioning. Long Island Lighting Co. (Shoreham Nuclear Power Station, Unit 1), CLI-91-8, 33 NRC 461, 471 (1991), approving Staff recommendalions in SECY-9]-129, "Status and Developments at the Shoreham Nuclear Power Station" (May 13, 199!), See also NRC Inspection Manual, ch. 2561, \$\$ 06.06, 06.07 (Mar, 20, 1992); Fort St. Vrain Nucleas Generating Station Amendrnent No, 82 to Faxility Operating License No. DPR-34 (Possession-Only License, May 21, 1991); and Rancho Seco Nuclear Generating Stztion Anendment No. 117 to Facility Operating License No. DPR-54 (Possession-Only License, Mar. 17, 1992),

Pelitioners contend that the February 2, 1996 letter of the NRC Staff applied the post-1993 interpretation of the Comnistion's decommissioning regutalions to determine that shipment of low-level radioactive waste is permissible,' based on the Staff's citation to SECY-92-382 and the associated June 30, 1993 SRM. The particular language Petitioners point to is:

\section{Shipment of contamingted reactor intemals aeeded for opemalion could procesed afler lesunnce

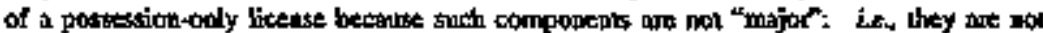

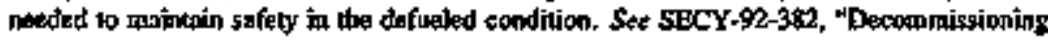 - Lessons Leaned" (Ntwember L0, 1992) and Staff Requinements Memoradum, "SECY. 92-352 - Desomtrilssioning - Lessons lentued" (hane 30, 1993).}

The Staff's February 2, 1996 letter derived this language from a discussion at pages 22-24 of \$ECY-92-382, "Decomunissioning - Lessons Learned"

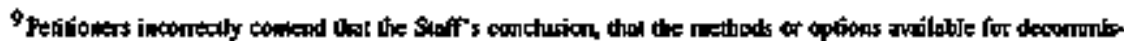

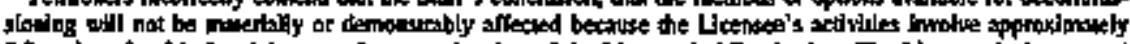

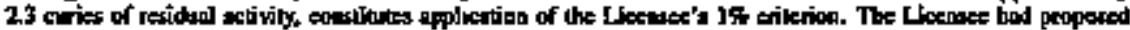

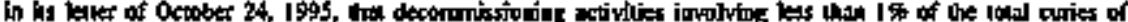

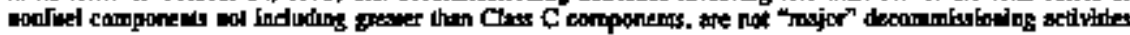

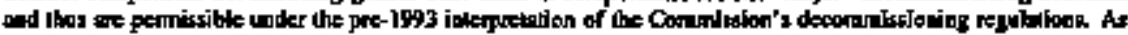

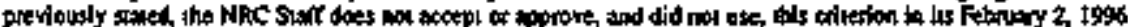

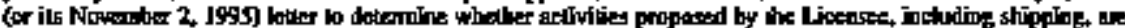

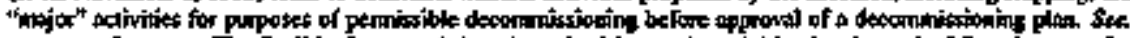

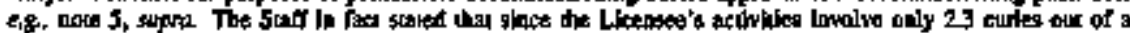

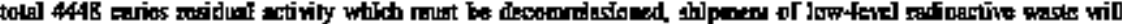

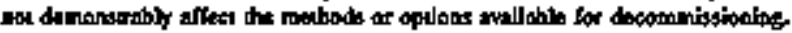

ì

,

,

$\cdots$
$\vdots$
$i$

$i^{n}$

$\because$

$+$

I...

,

2 .

$\therefore$

$\because$

,

,

',

,

r.

$\checkmark$

-

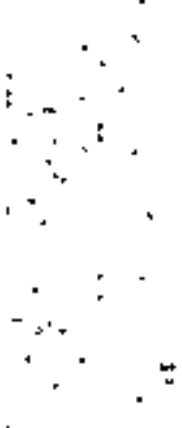

43 
The Commission had in permitted shipment of low-level waste prior to approval of a decommissioning plan under its pre-1993 interpretation of its decommisstoning regulations, as explained above. SECX-92-382 accuratedy stated that the Conumission had in fact permitted shipment of not only low-level radioactive waste and some components, but also some reactor intemals, before approval of a decommissioning plan. ${ }^{10}$ The particular reference to "major" componeats in SECY-92-382 was in the context of permissible shipment of waste; that language did not define "major" for the puspose of determining what components may be dismantled or removed prior to approval of a decommissioning plan. No component can be shipped unless it is first removed or dismantled, and authority to ship a component aiready removed or dismantled does not ipso facto constitute authority to remove or dismantle the component in the first place. Likewise, the citation in the NRC Staff's February 2, 1996 letter to Petitioners was not intended to define "major" for the purpose of determining what components could be dismantled or removed prior to approval of a decommissioning plàn, but referred to what could be shipped. The Staff's reference to SECY92-382 was nate in the context of permissible shipanents only, not pernissible component dismantitug or rennoval. Regrettably, the Staff's February 2, 1995 reference to SECY-92-382 may bave been insufficiently detafled to make the purpose of the reference clear.

In the case at hand, the Licenses's proposal was to ship low-level radioac. tive waste." The NRC Staff's conclusion that the Licensee's proposad to ship radioactive waste ${ }^{12}$ is pernissible under the pre-1993 interpretation of the Conmission's decommisstoning regulations was based on the understanding that the proposal was to ship low-level radioactive waste, and was not intended to be and was not a determination that the removal or dismanlling of major components was permissible under the pre-1993 interpretation of the Commission's decomnissioning regulations, ${ }^{3}$ under CAN v. NRC. or under CLI-94-14.

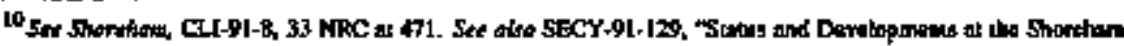

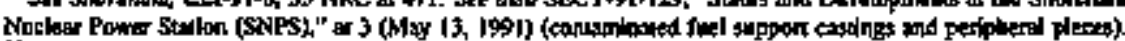

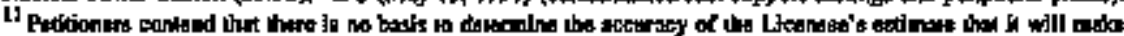

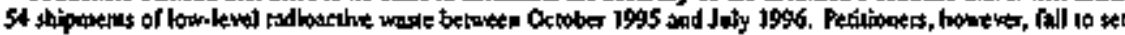

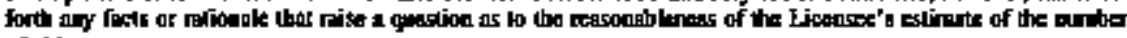
of shipments.

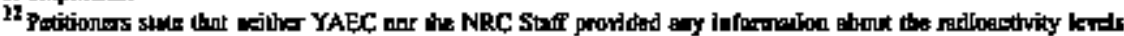

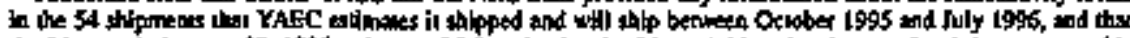

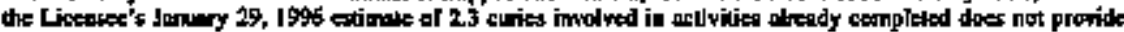

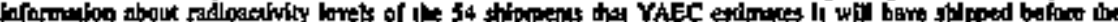

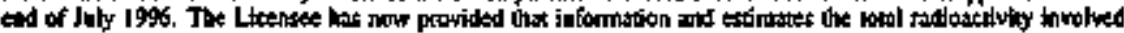

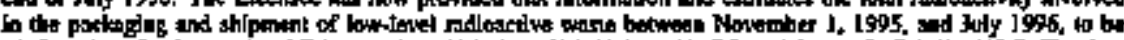

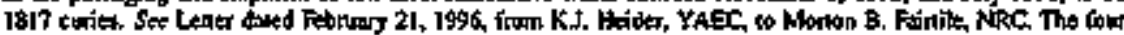

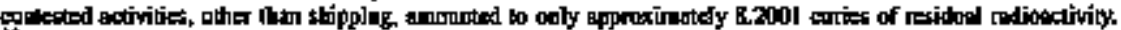

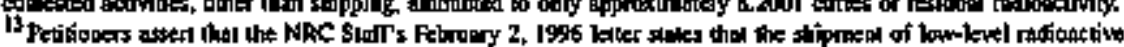

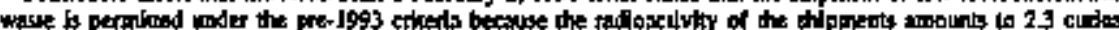
(Combers)
} $\therefore$ - 
The Commission's decisions in Shoreham CLI-9[-2, 33 NRC at 73 n.S, and Rancho Seca, CLI-92-2, 35 NRC at 61 n.7, do not, as Petitioners contend, prohibit shipment of low-level radioactive waste. No issue concerning such shipments was addressed in those decisions. The language cited by Petitioners paraphrases the general guidelint, that "major dtsmantling and other acivities that constitute decomnissioning under the NRC's regulations must await NRC approval of a decommissioning plan," and is derived from the 1988 Statement of Consideration, "General Requirements for Decommisstontmg Nuclear Factilities," supro. As explained above, it was agency practice before 1993 to permit shipment of kow-level radioactiwe waste and contaminated components before approval of a decommissioning plan.

Rather than store low-level radioactive waste on site for extended periods, it has long been agency policy that such waste should be shipped to disposal sites if the ability to dispose of waste at a licensed disposal site exists. Shipping of waste at the earliest practicable time minimizes the need for cventual waste reprocessing due to possibly changing burial ground requirements and reduces occupational and non-occopational exposures and potential accident consequences. NRC Generic Letter 81-38, "Slorage of Low-Level Radiogetive Wastes at Power Reactor Sites" (Nov. 10, 1981).

Petitioners contend that YAEC may not ship low-level radioactive waste because the Yankee Rowe possession-only license does not permit it. ${ }^{\text {t4 }}$ Although Petittoners are correct that mo langitage in the Yanke Rowe POL expltitly states that shipment of low-level madioactive waste is authorized, the Yankee Rowe POL does authorize that activity. Section 1.H of the POL, issued Augusi 5, 1992, authorizes Yankee Rowe to receive, possess, and use byproduct, source, and special nuclear materials in accordence with the Commission's regulgsions in 10 C.F.R. Parts 30, 40, and 70. Authority to ship low-level madioactive waste is conferred upon al] byproduct material, sounce material, and special nuclear material licensees by NRC regulations in 10 C.F.R. Parrs 30,40 , and 70. Byproduct materisls licensees, source materials licensees, and special nuclear

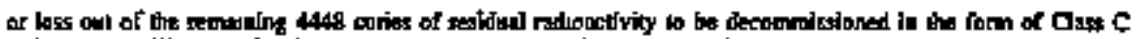

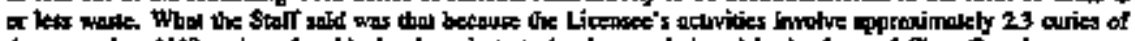

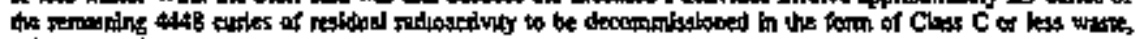

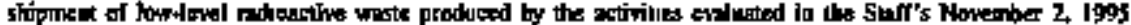

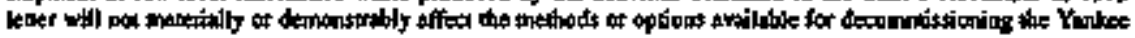
Rolve sice.

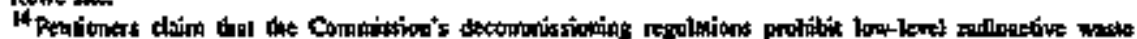

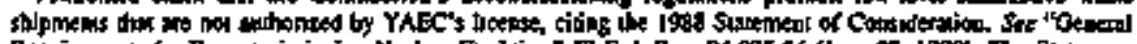

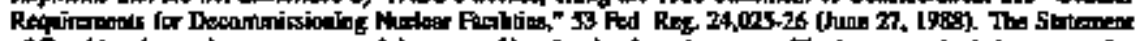

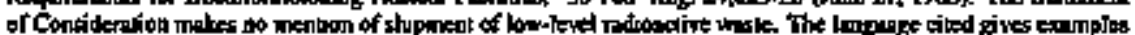

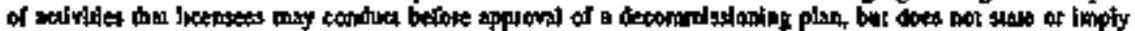

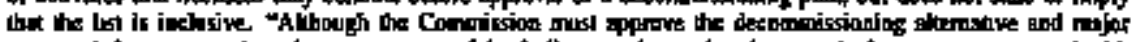

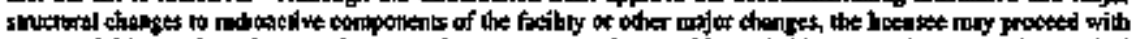

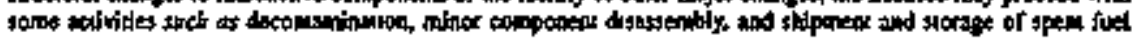

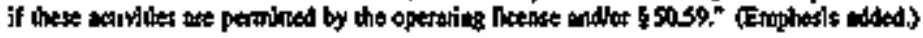

$+2$$$
\therefore
$$$$
\text { is }
$$ 


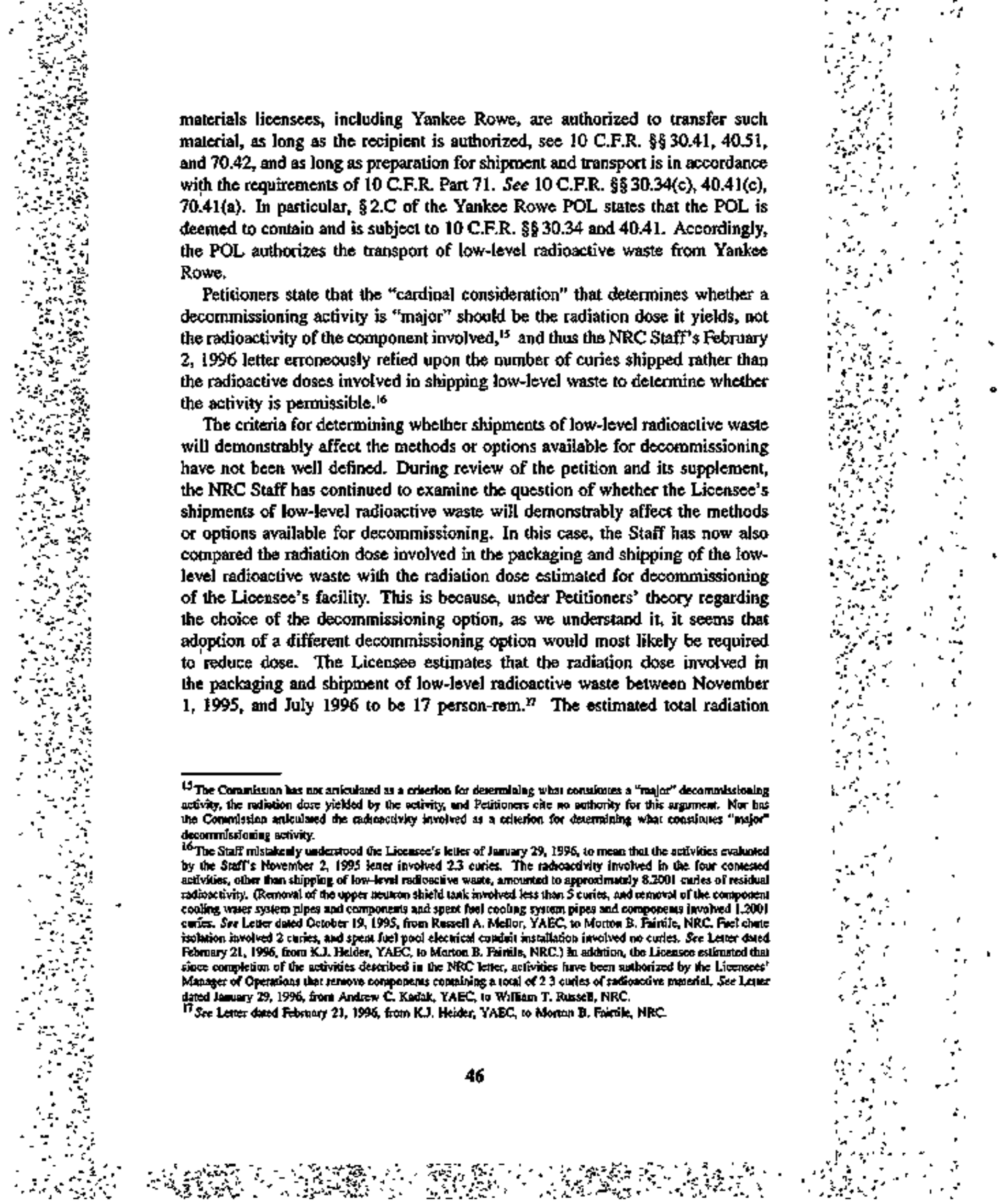


exposure for decommissioning the facility is 755 person-rem. ${ }^{18}$ The estimated dose frotn packaging and shipping is approxinately $2 \%$ of the total dose from decommissioning. As can be seen, most of the dose will be incurned in activities other than shipment of low-level radioactive waste. As the Commission has previously held in this cast, even potential dose teductions on the order of 900 person-rem, untess there is some extraordinary aspect to the case not apparent, cannot nave ALARA significance such that one decommissioning option would be preferable to onother. ${ }^{19}$ Accordingly, the Staff concludes that the Licensee's shipment of low-level radioactive waste will not demonstrably affect the methods and options avaitable for decomntssioning

In view of the above, the shipments of low-level radioactive waste between Oclober 1995 and July 1996, before approval of a deconnmissioning plan, is permissible under the pre-1993 interpretation of the Commission's decommissioning regulattons.

\section{B. The Five Contested Activities Will Neither Individually Nor Collectively Substontistly Increase the Costs of Decommissioning}

YAEC estimates the cost of shipment and disposal of all low-level radioactive waste between the October 1995 issuance of CLI-95-14 and the scheduled date of completion of the hearing in mid-July 1996, to be $\$ 6.5$ million, or approximately 1.75 s of the estimated $\$ 368.8$ million total decomntssioning cost. It would be speculative to conclude that the decommissioning method proposed by Petitioners, SAFSTOR, would be less expensive. There is no evidence that the Licensee's shipments will increase decornmissioning costs or that continued storage of the waste will decrease the ultimate costs. Thus, the Staff concludes that YAEC's shipment of low-level radioaclive waste will not substantially increase the costs of decommissioning.

Petitioners erroneously contend that the cost of shipments of Jow-level radioactive waste could be reduced by postponing the packaging and shipment of low-level waste, prestumably because sone waste may decay to levels such that the volume of waste that will requite shipment would decrease. Delay will not significantly reduce the volume of waste shupped because the waste is not segregated by the radioactive isotope involved, and some of the radioative isotopes inwolved have very long half-lives, i.e., nickel-63 has a half-life of 100 years. Cobalt-60, which has a half-life of 5.27 years, was the isotope selected by the Petitioners to postulate a reduction in waste volume. Moreover, delay costd

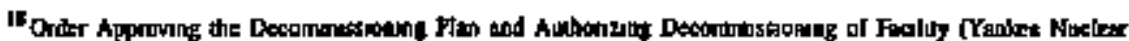

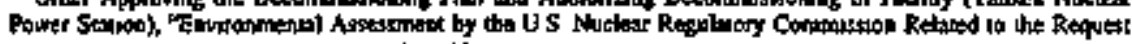

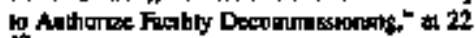

19.2195-I, 43 NRC I (1995) 
possibly increase deconumissioning costs because shipping and butal costs may increase.

The Licensee estimates costs for the five activities contested by Petitioners to be $\$ 6.5$ million for shapments of low-level waste between October 1995 and July 1996 and $\$ 2.4$ million for the four other contested activities, ${ }^{20}$ for a total of $\$ 8.9$ millon, or $2.1 \%$ of the $\$ 368.8$ mullion estimated total decommissioning costs. These is no evidence that these activities will gave rise to conseguences that witl increase the total cost of decommissioning. Accordingly, the five contested aclivities wilt not substantially increase decommissioning costs, either individually or collectively.

\section{Petitioners Request for an Inspection and Inspection Report Was Granted}

Petitioners' request for teinspection of Yanke Rowe to determine compliance with CEI-95-14 and for issuance of an inspection report was granted. NRC Region I inspected the Yankee Rowe faclity for a second time on December 518, 1995, to determine compliance with CLI-95-14. NRC Inspection Report No. 50-029/95-07 was issued January 31, 1996. The Inspection Report concludes that the Licensee's activities were conducted in accord whth the specifications of the Staff's November 2, 1995 letter. The irst inspection was conducted in October 1995, before the provision of techuical guidance or criteria to assist the Region it determining tompliance with CLL-95-14. Subsequently, the NRC Staff issued its lecter of November 2, 1995, evaluating the nine activties, all of which are permitted by CAN v. $N R C$ and CLI-95-14, as explained above.

Petitioners claim that the January 31. 1996 Inspection Report merely repeats the Staff's trroneous unterpretation of the Commission's decommussioning standards, and this constitutes no relief. The inspection report explucttly states that the nine activities evaluated by the Staff's Novenber 2, 1995 letter were inspected and that the Licensee limuted the scope of its work to those activities. Petitioners' disagreement with the Staff's conclusion that the nine actuvities are in coxplasnte with CAN v. NRC and CLI-95-14 does not consitute dentiat of Petituoners' request for an juspection and an inspection report to determine compliance with CAN v. NRC and CLI-95-14.

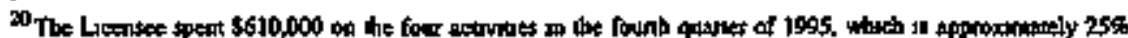

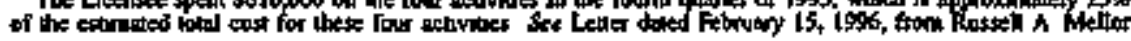
to Martos a Eantate

$\because r$

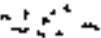

$\therefore 4$.

$+1$

, $N$ is

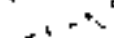

$\div \infty$

$=015$ 


\section{CONCLUSION}

For tht Jeasons given above, Petitioner's request that shipments of low-level radioactive waste be prohibited is denied, and Petitioners' request that four other activities be probibited is moot.21 Additionally, Petitioners" request for an inspection of Yankee Rowe to deteruine compliance with CLI-95-14 and an inspection report was granted.

As provided by 10 C.F.R. \$2.206(c), a copy of this Decision will be filed with the Secretary of the Commission for the Commission's review. The Decision will become the final action of the Commission 25 days afier issuance, unless the Commission on its own motion institules review of the Decision within that time.

\section{FOR THE NUCLEAR REOULATORY COMMISSION}

William. T. Russell, Director

Office of Nuclear Reactor Regutation

Dated at Rockville, Maryland, this 22d day of February 1996.

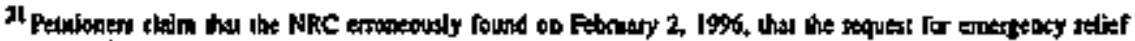

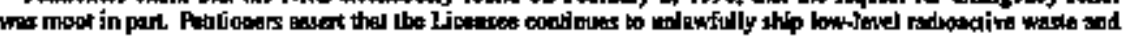

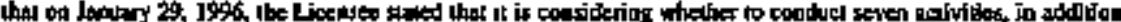

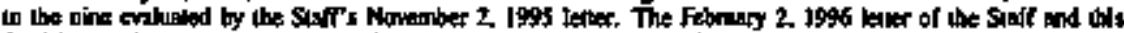

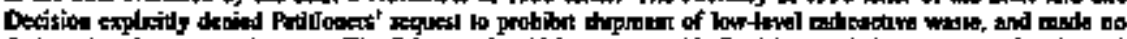

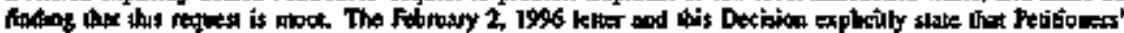

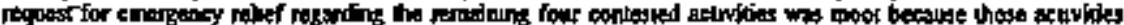

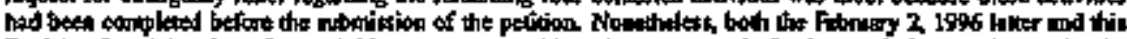

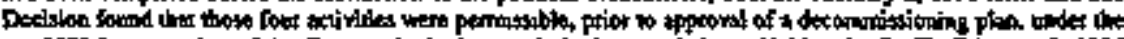

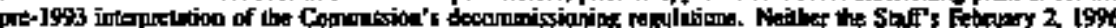

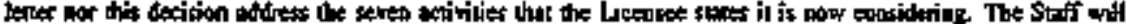

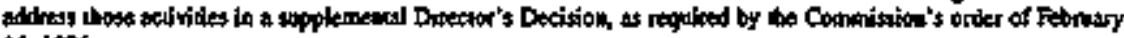
15, 1996.
} 
UNITED STATES OF AMERICA NUCLEAR REGULATORY COMNISSION

COMMISSJONERS:

Shirley A. Jackson, Chaiman

Kennath C. Rogers

Crosta J. Dicus

In the Matien of

Docket No. 50-440-OLA-3

\author{
CLEVELAND ELECTRIC ILLUMNATTNG \\ COMPANY, ot al. \\ (Perry Nuclaar Power Plant, \\ Unit 1)
}

Warch 7, 1996

The Commission grants the Clevelsnd Electric Illuminating Company's petition for review of the Alomic Safery and Licensing Board order, LBP-95-17, 42 NRC 137 (1995). The Board's order granted the Intervenors' motion for summary disposition and terminated the proceeding.

\title{
ORDER
}

Pursuant to 10 C.F.R. \& 2.786(b), the Cleveland Elecaric Blluminating Compa. ny (Cleveland Electric) has petitioned the Conumission for review of Atomic Safety and Licensing Board order LBP-95-17, 42 NRC 137 (1995). The Licensing Board's order granted the motton for summary disposition subritted by Intervenors Ohto Citizens for Responsible Energy, Inc. (OCRE), and Ms. Susan L. Hilatt, and terminated this proceeding. The Intervenors oppose review of the decisian. The NRC Staff does not oppose review. The Staff's position is thal LBP-95-17 misinterprets NRC regulatory requirements and exceeds the scope of the proceeding.

The Commission has decided to grant review of LBP-95-17. The parties to the review proceeding shall be Cleveland Electric, the Intervenors, and the NRC Staff. 
1. Within 30 days after service of this Order, Cleveland Electric and the NRC Staff may file their briefs, which shall be linaited to 25 pages each.

2. Within 30 days after service of Cleveland Electric's and the NRC Staff's briefs, the Intervenors shall file their responsive brief, which shall be limited to 35 pages.

3. Within 15 days afier service of the responsive brief, Cleveland Electric and the NRC Staff may file a roply brief, which shall be linited to 10 pages each.

In addition to the argunients the parties choose to present, the Commission directs all parties to address the significance for this casse of 5 U.S.C. \$ 551(8) and (9) (defining "litense" and "licensing").

Any brief in excess of 10 pages must contain a table of contents, with page references, and a table of cases (alphabetically arranged), statutes, regulations, and other authorities cited, with references to the pages of the brief where they are cited. Page limitations on briets are exclusive of pages containing a table of contents, able of cases, and of any addendum containing statutes, rites, regulations, etc.

It is so ORDERED.

\author{
For the Commission
}

JOHN C. HOYLE

Secretary of the Commission

Dated at Rockville, Maryland, this 7th day of March 1996. 
UNTED STATES OF AMEAICA

NUCLEAR REGULATORY COMAISSION

COMNSSWNERS:

Shirley A. Jackson, Chatrmen

Kenreth C. Fogers

Greta J. Dleus

In the watter of

Docket No. 50-029-Dcon

(Decommlssioning Plan)

YANKEE ATOWIC ELECTHIC

COWPANY

(Yankee Nuclear Power Station)

March 7, 1986

The Commission declines to disqualify two Commissiomers or the NRC Staff from participating in the case; indicates that it plans to review the Litensing Board's March 1 decision (LBP-96-2, 43 NRC 61 (1996)); suggests appropriate aseas of inquiry for the parties' briefs; and keeps in place the cunrent stay of the Board decision, pending Commission review of LBP-96-2.

\section{RULES OF PRACTICE: MOTIONS POR RECUSAL (OR} DSOUALHICATION)

It is Commission prattice that the Conmissioners who are subject to a recusal motion will decide that motion therrselves, and may do so by issuing a joint decision.

\section{RULRS OF PRACTICE: MOTIONS FOR RECUSAL (OR DISQUALIFICATION)}

A prohibited corntmunication is not a concern if it does not reach the uttimate decision maker. 


\section{RULES OP PRACTICE: MOTIONS FOR RECUSAL (OR DISQUALIFICATION)}

Where a prohibited cotnmenication is not incomporated into advice to the Comnission, nisver reaches the Conmission, and has no impact on the Commission's decision, it provides no grounds for the recusal of Commissioners.

\section{RULES OF PRACTICE: MOTIONS FOR RECUSAL (OR DISQUALIFICATION)}

Commission guidance does not constitute factual prejudgment whefe the guidance is based on regulatory interpretalions, policy jidgments, and tentative observations about dose estimates that are derived from the public record,

\section{RULES OF PRACTICE: MOTIONS FOR RECUSAL (OR DISQUALIFICATION); DISQUALIFICATION}

Where there are no facts from which the Commission can reasonably conclude that a probititited communtication was madt with any comupt motive or was odner than a siruple mistake, and where a Report of the Ofoce of the Inspector Gereral confirms that an innocent mistake was mede and that the Staff was got guilty of any actual wrongdoing, and where the mistake did not ultimately affect the proceeding, the Connuission will not dismiss the Staff from the proceeding as a sanction for baving made the prohbbited communication.

\section{RULES OF PRACTICE: STAY OF ORDER}

Where the Commission jissues a stay wholly as a matcer of its own discretion, it does not need to address thit factors listed in 10 C.F.R. $\$ 2.788$.

\section{MEMORANDUM AND ORDER}

\section{INTRODUCTION}

The Petithoners in this expedited proceeding, the Citizens Awareness Network (CAN") and the New England Coslition on Nuclear Pollution ("NECNP") (collectively "Retitioners"), challenge the adequacy of the decomnissioning plan prepared by the Yankee Atonic Electric Company ("YAFC") for its shotdown nuclear porier reactor near Rowe, Massachusetts ("Yankee NPS"). On March l, 1996, the Atowic \$afety and Licensing Board ("Licensing Board") issued a 
58-page decision dismissing Petitioners' request for a hearing on the ground that Petitioners had fatled to proffer a litigable condention. See LBP-96-2, 43 NRC 61 (1996) ('LBP-96-2").

Currenly before the Comunission are two motions filed by Petitioners: ouc seetking clarification and modification of a February 27 stay order issued by the Cominission ${ }^{\mathrm{I}}$ and one stekjog reconsikieration and recission of the Contritssion's January 16 decision neferring Petitioners' five proposed contentions to the Ljeensing Board and providing guidance on certain legal and policy questions. See CLI-96-I, 43 NRC 1 (1996) ("CLI-96-1" ${ }^{\text {th }}$. The latter motion also seeks recusal of two Commissioners and disgualification of the NRC Staff from further participation in the case.

In the instant Memorandum and Order, the Commission: (1) declines to disqualify two Commissioners or the NRC Staff from participating in the case; (2) indicates that it plans to review the Licensing Board's March I decision and suggests appropriate areas of inquiry for the parties' briefs; and (3) keeps in place the current stay of the Baand dectsion, pending Commission review of the Board decision.

\section{BACKGROUND OF CLI-96-1}

On January 16, we issued CLI-96.1, in which we referred Petitioners' petition to intervene and related pleadings to the Licensing Board with: (1) instructions to treat the pelition as a request for a hearing. (2) guidance on selected issues including Petitioners' proposed Contention A; and (3) a proposed expedited schedute. At the same time, the Secretary issued a separate document, entitled "Notice of Appointment of Adjudicatory Employes and of Communication Covered by to C.F.R. \$2.781(c)" ("Notice"), which advised the parties: (1) that a nember of the NRC Staff had been appointed as an adjudicatory employee; and (2) that there had been a communication in violation of the separalion of functions restriclions contained in 10 CF.R. \$2.781(a) and that this communicabion was being placed on the record in axcordance with 10 C.F.R. $\$ 2.781(\mathrm{c})$.

The Notice informed the parties that the comminticalion had occurred between a member of the NRC Staff and a member of the Office of the General Counsel ("OGC"), which was advisiong the Commission on the preparation of CLI-96-1. In addition, the Notice advised the parties that the communication felated to Petitioners' proposed Contention $A$ and attached a mernorantum deseribing the

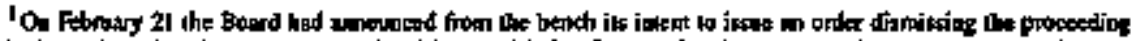

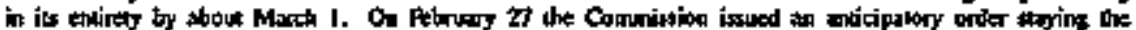

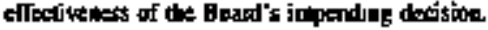


cornmenication. Finally, the Notice stated that the communication did not affect the advice OGC rendered to the Commission, did not result in a change to the language in any proposed draft of CLI-96-I, and was itself not commuricated to the Commissioners or any of their personal stafis before the Commission issued CLI-96-1.

On Jamuary 26, 1996, Peitioners fled their motion for reconsideration and Jescission of CLI-96-1. Finst, Pelitioners challenge the guidance we provided to the Licensing Board on proposed Contention $A_{\text {, arguing that we "prejuxige[d] }}$ contestes facts," Motion for Reconsideration at 1, based "on ex parre comnuntications and other factual information which petitioners have not bad the opportunity to controvert." Id at 2 . As a result, Petitioners contend, the Commission has "grieviously prejudiced [their] opportunity for a full and fair hearing . . ." Id. See generally id at 7-15. Moreover, argue Petitioners, because the guidance was based upon "an ex parte communication," the Commission should rescind that guidance. Id at 15-18.

Second, Petitioners argue that, based upon the facts as stated in the Nolice, the Commission shoukd issue an Order directing the Staff to show cause why it should not be dismissed as a party from the procteding as a sanction for the conduct tdeatified in the Notice. See generatly id at 18-19. Third, the Pexilioners argue that Chsirman Jackson and Commissioner Rogers should recuse themselwes from any further consideration of this case because the guidance on proposed Contention A prejudged factual issues and rested on an improper commmication (despite the Notice's statement to the contrary) See genteratly id at 20-21.

\section{ANALYSIS}

\section{A. Commission Recusal}

We begin with an analysis and discussion of the third issue, whether Chairman Jackson and Commissioner Rogers should recuse themselves from further proceedtings in this matter:

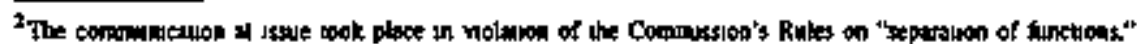

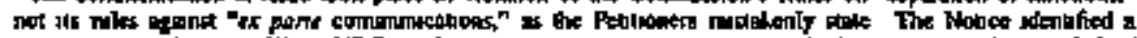

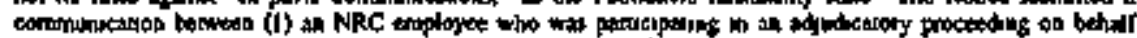

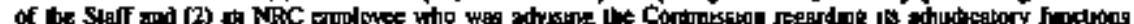

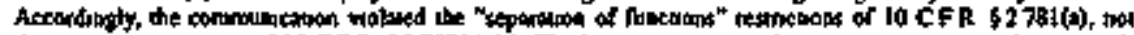

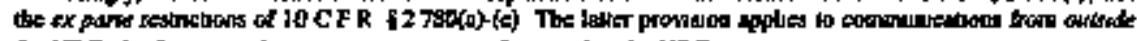

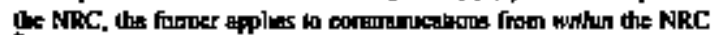

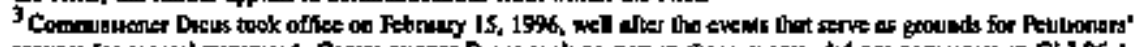

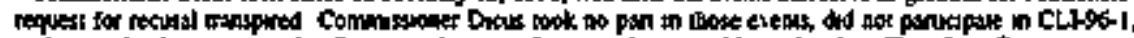

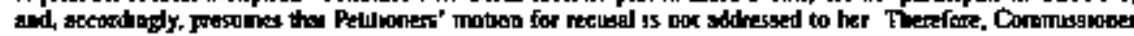

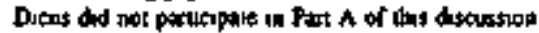

(Corrosused)

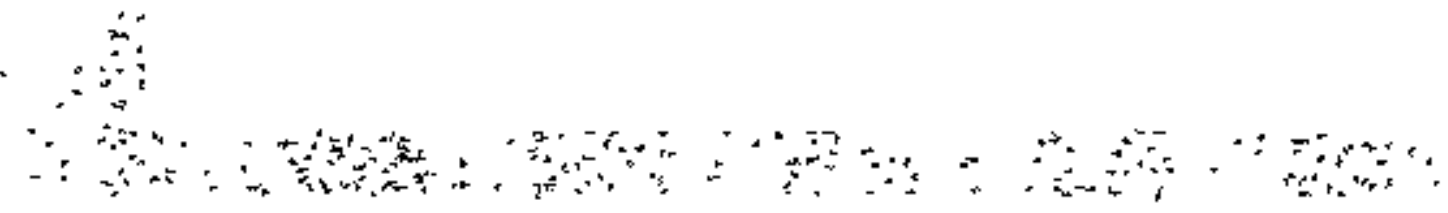




\section{Septaration of Functions Violation}

We first address the separation of functions violation as an asserted growad for rectsal. Pelitioners offer no facts supporting theit motion to recuse because of the separalion of functions violation other than those applarent from the Notice. For the reasons stated below, the facts as stated by the Notice do not warrant recusal by the Commissioners from this proceeting.

On January 16, the same day that CLI-96-1 and the Notice were issued, the Commission's Office of the General Counsel ("OGC') forwarded the Notice to the Acting Inspector General of the Commission for any appropriale sction. OGC also provided a copy of the Petilianers' motion to the Offoce of the Inspector General ("OIG"). The Commisston's OIG has the duty and obligation to conduct independem audits and investigations under the Inspector General Act of 1978, as amended, Pub. L. 95-452, 5 U.S.C. App. See generally 10 C.F.R. 81.12(d). The OIO promptly initiated an investigation inlo the circumstances of the communication at issue and completed that intestigation on Fobruary 23, 1996.

The OIO's Report of Investigation provides a complete record as to bow and why that conmunication occurred." As is clear from the Notice and confirmed by the Report, the communication was not provided - eicher directly or indirectly - to Chaiman Jackson or Commissioner Rogers, or to any of their personal staffs, prior to the decision to issue CLI-96-1. See generally OIG Report at 12. I3. Thus, there is no factual support for Petitioners' assertion that the communication was "jmplictly relied on." Motion for Reconsideration at $\mathbf{1 6 .}$ A prohibited communication "is not a concern if it does nol reach the ultionate decísion maker." Press Broadcasting Ca, Inc. v. FCC, 59 F.3d 1365, 1369 (D.C. Cir. 1995), citing ATX, Inc. v. U.S. Deportment of Transportation, 4I F.3d 1522, 1527 (D.C. Cir. 1994), and Peter Klewet Sors' Co. v. U.S. Army Corps of Engineers, 714 F.2d 163, 170-71 (D.C. Cir. 1983).

Moreover, we would also observe that an essential thrust of the NRC Staff communicalion - that the ALARA doctrine should not be applied in reviewing a licensec's choice of decommisstoning option - is inconsistent with the Commission's assumption in CLI-96-1 that an ALARA challenge to a ticensee's decommissioning option choice con properly be made if an adequate basis is provided. See CLI-96-1, 43 NRC at 7.

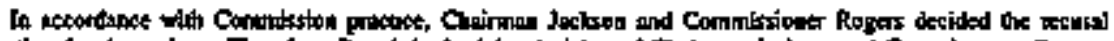

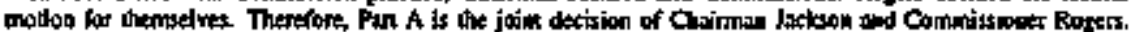

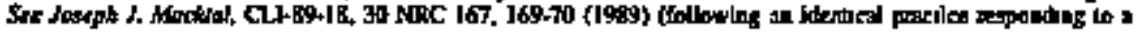

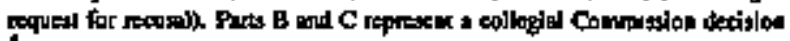

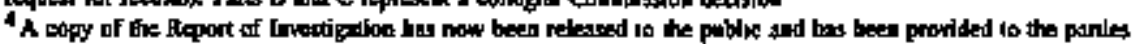
wh the Menandurn and Ondar,
} 


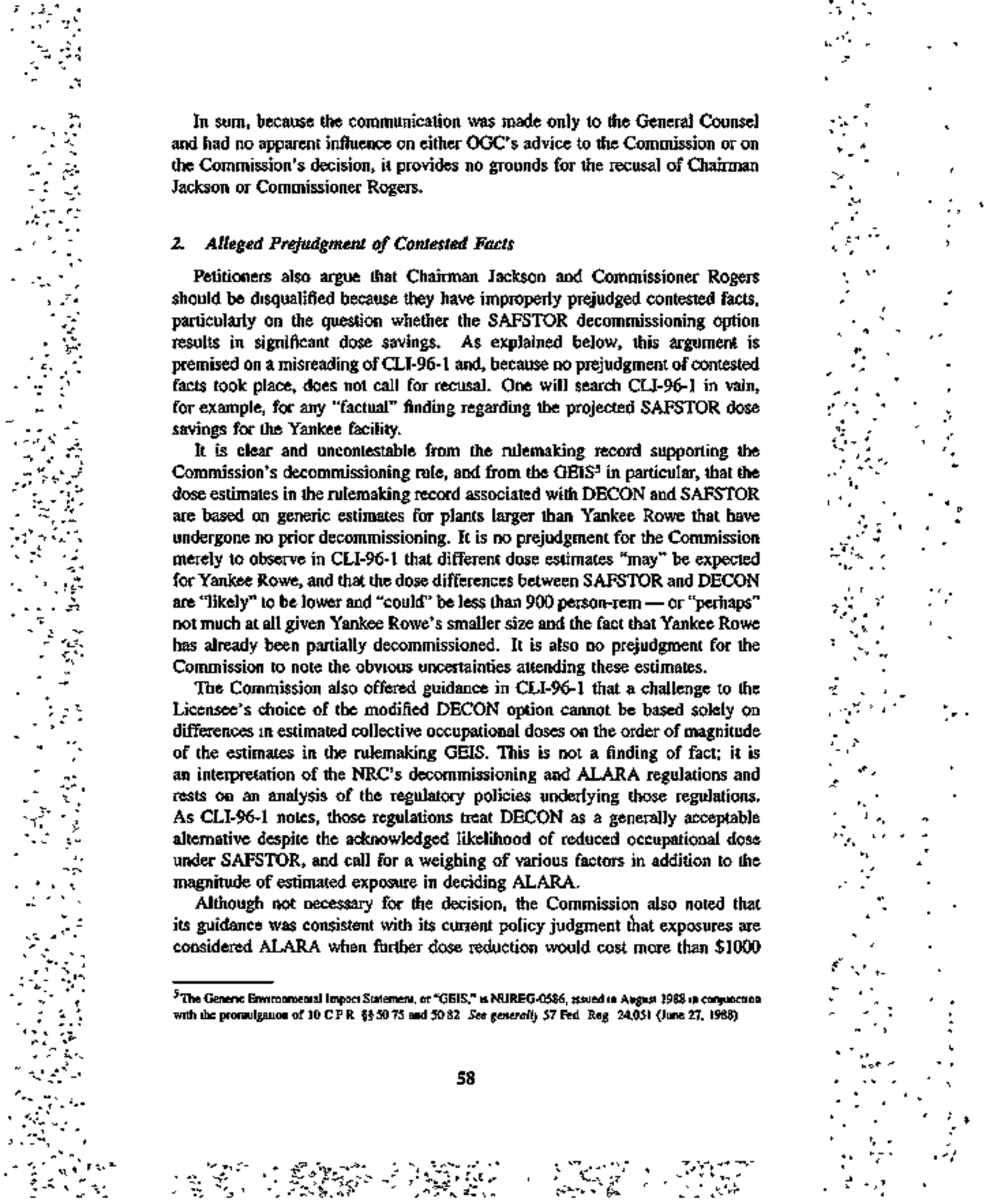


or $\$ 2000$ for each person-rem retuction achieved. Such policy judgments do not prejudge contested facts. Further, the use of cosi estimates appearing in Petitioners' own pleadings merely constitutes an analysis of the basis proffered for a contention and does noc constitute a merits conclusion on the validity of those estimates.

Ftrally, the Commisston stated in CLL-96-1 that its guidance regarding regulatory significance of a dose reduction on the order of 900 person-rem associated with switching to SAFSTOR was not applicable if "there is some extraordinary aspect to the case not apparent to us from the pleadings that the Licensing Board may uncover on its own review." CLI-96-1, 43 NRC at 9. This statement alone puts to rest any concern about prejudganent since it left sufficient leeway for the Licensing Board to reach its own initial conclusion if the record so warranted.

In sam, regulalory interpretations and policy judignents, and tentative observations about dose estimates that are derived from the public record, are not factual prejudgments. Futhermore, the Commission provided the Licensing Board with sufficient fexibility to consider the matters in dispute consistent with the Comrmssion's rules. Thers, Petitioners' allegalions of prejudgment constitute no basis for Jectusal of Chairman Jackson or Commissioner Rogers. ${ }^{6}$

\section{B. Dismisral of Staff as a Party}

Pelitioners offer no facts beyond the "Notice" to support their argument that the Staff should be dismissed from the proceeding. But there are no facts in the Notice from which we could reasonably conclude that the communication was made with any corrupt motive or was other than a simple mistake. Moreover, the OIG Report confirms that an innocent mistake was made and that the Staff is not guilty of any actual wrongdoing. See generally OIG Report at $7.12,13$. We are unwilling to order a dismissal of Staff from the proceeding on the basis of a mislake that ultimately did not affect the proceeding. Thus Petitioners' reguest for the Commission to order Staff to show cause why it should not be dismissed as a party to the proceeding is denied.

\section{Commission Appellate Review of LBP.96-2 and the February 27th Stay Order}

Under 10 C.F.R. \$2.714a(a), Petitioners have the rigbt to appeal the Licensing Board's March 1 dexision to dismiss their contentions, LBP-96-2, and we

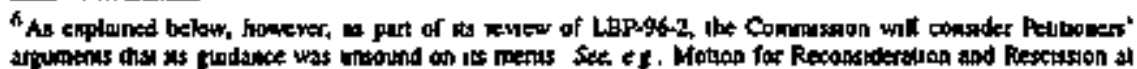

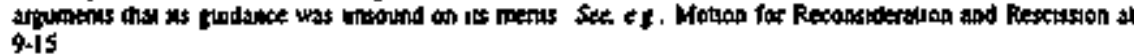


anticipate that they will do so. On appeal, the parties' briefs may address all issues bearing on the Licensing Board's decision, jncluding the applicability of the Commission's guidance in CLI-96-1 and any issues related to reconstidening that guidance not decided in today's order. See note 6, supra.

Because of the complex and novel decommissioning issues involved in this cast, we issued an anticipatory stay of LBP-96-2 on February 27th and now have decided, wholly as a matter of discretion, ${ }^{7}$ to keep that stay in effeet penting completion of Commission review of the Licensing Board's decision. See Sacramento Muntcipal Utility District (Rancho Seco Nuclear Generaling Station), CLI-93-3, 37 NRC 135, 152 (1993). In addition, if the Commission affing LBP-96-2, it will follow its eustomary practice of issuing a sbort bousekeeping stay to facilitate orderly judicial review. See, e.g., Sacramento Municipal Ufility District (Rancho Seco Nuclear Genecaling Station), CLI-92-2, 35 NRC 47, 61 (1992).

\section{CONCLUSION}

For the foregoing reasons, Petitioners' Motion for Reconsideration and Partial Rescission is donjed insofar as jt strtks Commission recusal and Staff disqualification. The Commission will noview LBP-96-2 after appeal and briefing under 10 C.F.R. \$2.714a. The effecliveness of LBP-96-2 is hereby stayed pending that review.

It is so ORDERED.

For the Contmission

JOHN C. HOYLE

Secretary of the Commission

Doted at Rockville, Maryland, this 7th day of March 1996.

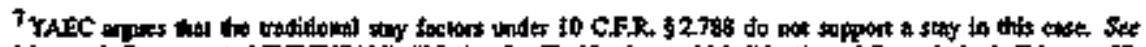

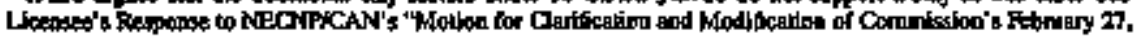

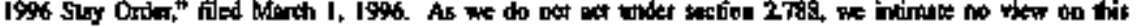
quasulion.
} 
UNITED STATES OF AMERICA NUCLEAR RECULATORY COMMISSION

\section{ATOAK SAFETY AND LWENSENG BOARD}

Before Administralive Judges:

G. Paul Bollwerk, III, Chairman

Dr. Jerry R. Kline

Dr. Thomes S. Eleman

In the Malter of

Docket No. 50-029-DCOM (ASLBP No, 96-713-01-DCOM)

\section{YANKEE ATOHIC ELECTRIC COMPANY \\ (Yanken Nuciear Power Station)}

Worch 1, 199s

In this proceeding concerning challenges to various aspects of the decommissioning plan for the Yanke Nuclear Power Station, based on guidance furnished by the Conmission to CLI-96-1, 43 NRC 1 (1996), the Licensing Board concludes that the citizen groups petitioning to intervene have established their standing but have failed to presem a litigable contention, which regutes that the proceeding be dismissed.

\section{RULES OF PRACTICE: STANDING TO INTERVENE (INJURY IN FACT; ZONE OF INTERESTS)}

To comply with the basic standing requirments, a pelitioner must denkonstrate that (1) it has suffered or will suffer a distinct and palpable barm that constitutes injury-in-fact within the zone of interests arguably protected by the governing statute; (2) the injury is fairly traceable to the challenged setion; and (3) the injury is likely to be redressed by a favorable decision. See CLI-96-1, $43 \mathrm{NRC}$ at 6. 


\section{RULES OF PRACTICE: STANDING (REPRESENTATIONAL); STANDING TO WNTERVENE (AUTHORIZATTON)}

When an organization seeks to intervene on behalf of its members, that enticy must show that it has an indivioual member who can fulfill the necessary elements to establısb standing and who bas authorized the organzation to represent his or her interests. See CLI-96-1, 43 NRC at 6.

\section{RULES OF PRACTICE: STANDING TO INTERYENE (NUCLEAR POWER REACTOR DECOMMISSIONING)}

Interwenor organzations established their standing to intervene and seek relief regarding alleged health and safety or environmental injaries that may be visited upon their menbers who reside and engage in vancus activities in the area within 10 miles of a puclear lacilify to be decomntssioned. Because some, even of minor, public exposures can be anticipated from the decontrussioning process, the Licensing Board is not "un a position at this threstiold stage to nte out as a matter of certainty the existence of a reasonable posstbulity" that decommissioning might have an adverse umpact to those, such as petitioners" members, who live or recreate in such close proximity to the facility, or use local waste transportation routes. Virgtnia Electric and Power Co. (North Anna Nuclear Power Station, Units I and 2), ALAB-522, 9 NRC 54, 56 (1979).

\section{RULES OF PRACTICE: STANDING TO ENTERVENE (ADMISSIBILITY OF CONTENTIONS)}

Petitioners who have eslablistied thejr standing to present a contention that seeks modification or rejection of a nuclear facilty decontomissioning plan so as to avowd health and safety or environenental injury to the public also can persue any contenton alkeging such modification/rejectron relref based on circumstances such as purported occupational exposure to facllity workers from decommissioning activitues. See CLI-96-1, 43 NRC at 6.

\section{RULES OF PRACTICE: CONTENTTONS (ADMISSIBILITY)}

Under 10 C.F.R. $\$ 2.714(\mathrm{~b})(2)(\mathrm{ii})$-(ij), to be admissible a contention musit contain a specific statemerin of an issue of fact or law raised or controverted in a proceeding that is supported by a "basis" of alleged tacts or expert opinions, together with references to specific sources and documents that establish those facts or opimions. The basis must be sufficient to show that a genuine dispute exists with the applicant on a material issue of fact or law. Moreover, while the intervenor need not prowe its case at the contention stage or present factual 
support in affidavit or evidentiary form sufficient to withstand a summary disposition mation, it nontheless must make a minimal showing that naterial facts are in dispute such that a further inquiry is appropriate. And, of course. any contention must fall within the scope of the issues set forth in the notice of opportunity for hearing on the proposed licensing action. See Georglo Institute of Technology (Georgia Tech Reseanch Reactor), CLI-95-I2, 42 NRC 111, 11718 (1995).

\section{RULES OF PRACTICE: CONTENTIONS (ADMISSIBILITY) DECOMMISSIONING: CONTENTIONS (ADMISSIBILITY)}

In challenging the contents of a decommissioning.plan fashioned pursuant to 10 C.F.R. $\$ 50.82$ (b)(1), (2), a contention not only must aflege some content deficiency in the decommissioning plan, but that this perported deficiency has some health and safety significance for the decommissioning process as a whole. Put anoher way, to craft a litigable contention faulting a decommissioning plan for a deficiency in content, besides providing a basis sufficient to guestion the plan's mocuracy, there must also be a showing that a genuine disputed material issue of fact or law exists about whether the purported shoricoming has some tangible negative impact on the overall bbility of the decomaissioning process outlined in the plan to protect the public health and safety. Cf. Public Service Co. of New Hampshire (Stabrook Stalion, Units 1 and 2), AL,AB-942, 32 NRC 395, 414 (I990) (contention that purported emergency planning exercise deficiency precludes a finding of reasonable assurance that protective measures cant and will be laken must show that exercise revealed more than minor or isolated flaw in plan and that plan flaw can only be remedied through significant plan revision).

\section{DECOMMISSIONING: FINANCLAL ASSURANCE (ADMISSIBILITY OF CONTENTIONS)}

A litigable contention asserting thal a reactor decommissioning plan does not comply with the funding requirements of 10 C.F.R. $\$ 50.82(b)(4)$ and (c), must show not only thal one or more of a plan's cost estimate provisions are in error, "but that there is not reasonabte assurance that the amoum will be paid" CLI96-1, 43 NRC at 9. A petitioner must establish that some reasonable ground exists for concluding that the ticensee will not have sufficient funds to cover decommissioning costs for the facility. 


\section{RUEES OF PRACTICE: CONTENTIONS (RESPONSE TO OB,JECTION TO ADMISSION)}

A petitioner should bo permitted to respond to challenges to a contention before the contention is dismissed. See Houstor Lighting and Power Co. (Allens Creek Nuclear Generating Station, Unit 1), ALAB-565, 10 NRC 521, 325 (1979).

\section{NEPA: RULE OF REASON}

The "rule of reason" governing National Environnental Policy Act (NEPA) inderpretation provides that an agency netif not consider "remote and speculative risks." Limerick Ecology Action v. NRC, 869 F.2d 719, 739 (34 Cir. 1989).

\section{RULES OP PRACTICE: CHALLENGE TO COMMISSION REGULATIONS; CONTENTIONS (CHALLENGE OF COMMISSION RULE)}

A contention basis concerning a transportation cask accident that relies on a seport postutaling an accident scencrio with conditions that fall within the paramelers of J0 C.F,R. $\$ 71.73$ (c) governing cask accident tesi conditions is not subject to dismissal under I0 C.F.R. $\$ 2.758$ as improperly challenging that accident test condituon regulation.

\section{RULES OF PRACTICE: CONTENTIONS (SUPPORTING DOCUMENTATION)}

A document put forth by an intervenor as supporting the basis for a contention is subject to scrutiny both for what it does and does not show. When a report is the central support for a contention's basss, the contents of that report are what are before the Board and, as such, is subject to Board scrutiny, both as to those portions of the report that support an intervenor's assertions and those portions that do not

\section{NEPA: REMOTE AND SPECULATIVE EVENT}

Because only acciden scenarios that are not "remote and speculalive" need be the subject of a NEPA analysis, if the information in any intervenor-proffered document regarding such a scenario fails to indicate that this threshold has been crossed, then a contention challenging NEPA compliance based on a failure to analyze thal scenario need not be adenitted. See Vermont Yankee Nuclear Power

64
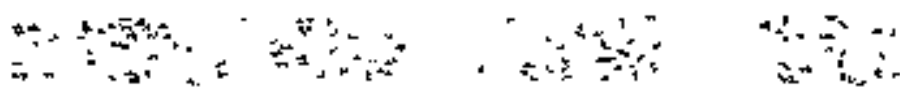
Corp. (Vermont Yankee Nuclear Power Station), ALAB-919, 30 NRC 29, 44-47

(1989), remanded for additional findings, CLI-90-A, 31 NRC 333 (1990).

\section{MEMORANDUM AND ORDER \\ (Denyirg Petition to Intervene)}

By a petition to intervene and sapplemental intervention petition dated November 30, 1996, the Citizens Awareness Network, Inc+ (CAN), and the New England Coalition on Nuclear Pollution (NECNP) ask that the agency convene an adjudicatory hearing. As their intervention petition makes clear, in that hearing Pelitioners wish to challenge the validity of various health and safety and environmental aspects of the decomnissioning plan proposed by Licensee Yankee Atomic Electric Company (XAEC) for the Yankee Nuclear Power Station (YNPS or Yankee Rowe) located in Franklin County, Massachusetis, near the town of Rowe. The Commission referred their intervention petition to the Alomic Safety and Licensing Board in a January 16, 1996 memorandum and order. See CLI-96-1, 43 NRC I (1996). In doing so, the Commission directed that the Board rule on CAN's and NECNP's standing to interwente and the admissibility of the bive contentions they bave proffered and then conduct any further proceedings.

In response to the Commission's referral, on February 21, 1996, we conducted a prehearing conference regarding Petitioners' standing and their contentions. See Tt. at 1-234. At the conference, counsel for Petiojoners, YAEC, and the NRC Staff made orl preseptations and answered Board questions regarding various aspects of these matters.' At the conclusion of these presentations, we advised the participants that the Board intended to issise a finding that CAN and NECNP have standing to intervene in this proceeding but that they have failed to present any litigable contentions. Below, we set forth our formal rulings on the issues of standing and the admissibility of their contentions.

\section{BACKGROUND}

The CANNECNP petition that is now before us was filed in response to an October 26, 1995 Commission notice of consideration of issuance of an order and opportunity for hearing regarding the YAEC plan for decommissioning the

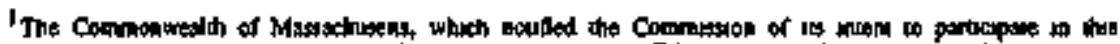

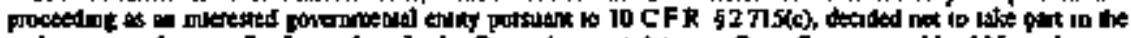

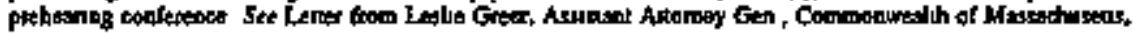

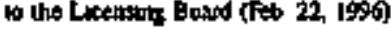


Yankee Rowe fatility. See 60 Fed. Reg. 55,069 (1995). As is detailed in that notice and prior Commission notices and isstances regardung the plan, see 60 Fed. Reg. 46,317 (1995); CLI-95-14, 42 NRC 130 (1995), the Oetober 26 notice was a direct response to a July 1995 directive from the United States Coust of Appeals for the First Circuit requiring that a hearing opportunity be afforded to CAN and other interested persons prior to agency approval of the YAEC decommissioning plan.

As is outlined in the citcuit court's opinuon, Citizens Awareness Network, inc. v. NRC, 59 F.3d 284, 288-90 (Ist Cir. 1995), after a February 1992 declaration of its intent permanently to cease operation of Yankee Rowe, YAEC obtained a possession-ouly license that revoked ts authority to operale the facility. See 57 Fed. Reg. 37,558 (1992). In Oetober 1992, prior to the submission of a facility decommissionng plan or decommissioning eovironmental report, YAEC proposed that the agency approve an "early component removal project" (CRP). Undes the terms of the CRP, the ulility would be permutted to dismantle and remove various reactor components that would account for some $90 \%$ of the nonfuel, residusl radionclivity at the facilsty. YAEC proposed shipping sone of these itens to the low-level radioactive waste (LLRW) disposal faciltty in Bamwel], South Carolina, for permanent disposal and stortng others in the facility Spenk Fuel Pit. Although CAN disputed the propnety of this request and asked for an adjudicatory hearing, in January 1993 the Comtuission, through the vehicle of a Staif Requirements Mesporandum, adopted a new policy on decommissioning that sanctioned the CRF. YAEC then began to dismentle the facility and make shipments to the Barnwell LLRW facklity in accordance with the CRP.

CAN continued to assert that it was entiled to a hearng on the CRP ard facility decomnissionung and ullimately joitiated the ercult coure litigation referenced aloove. Mtanwhile, in December 1993 YAEC submilted a decommissioning plan ast environmerat report concerning Yankee Rowe. See Yankee Atomic Electric Company, Yankee Nuclear Power Station Decommissioning Plan (rev, 0.0 Dec. 1993); Yankee Atomic Electric Company, Decommsissioning Environmental Report (Dec. 1993) [hereinafter Enviroumental Report]. In its plan, YAEC proposed to implement a modifed version of the so-called DECON decommissionng optuon, under which it would seek to complele decommissioning on a more expedited basts than is the case under the other available decommissioning alternative, the longer duration SAFSTOR option. ${ }^{2}$ After

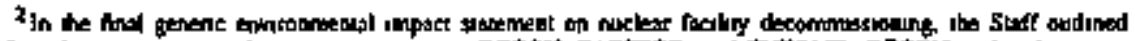

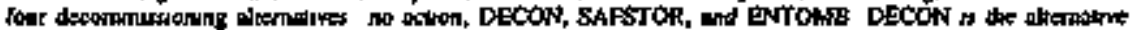

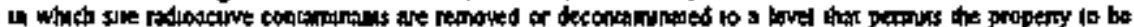

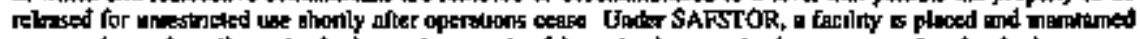

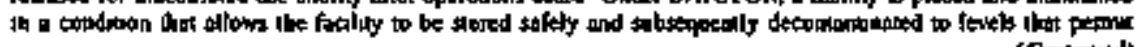
(Condoniced)
}

$+4 \times+4$

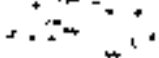

$\therefore$

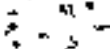

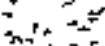

$\because 2$

$\therefore=25$

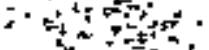

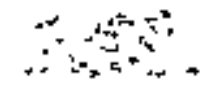


conducting a review of these documents and supplemental materials submilted by YAEC, in Febriary 1995 the Staff issued an order - accompanied by a safecy evaluation report and an enviromnental assessment - that approved the YAEC decommissioning plan. See 60 Fed. Reg. 9870 (1995); see also Safety Evaluation Report by the [NRC] Related to the Request to Authorize Facility Decommisstoning, Yankee Nuclear Potwer Station, Yarkee Atomic Electric Company, Docket No. 50-29 (Feb. 14, 1995) [bereinafier SER]; Environmemal Assessment by the [NRC] Related to the Request to Auhorize Facility Decommissioning, Yanke Nuclear Power Station, Yankee Atomic Electric Company, Docket No. 50-29 (Dec. 14, 1994) [herejoafter EA]. The decomsisstioning plan subsequently was adopted as two volumes of the facility's Final Safety Analysis Report. See Yankee Atomic Electric Company, 1-2 Final Safety Analysis Report, Yankee Nuclear Power Staion, Rowe, Massachusetts (rev. June 1995) [hereinafter FSAR].

With CAN's cincuit court litigation victory in July 1995, the Comnission instituted a reassessment of CAN"s hearing tequests and the Staff's approval of the YAEC decommissioning plan. This resulted in the reinstatement of the Commission's prior policy prohibiting "anajor" decompmissioning activities prior to approval of a decompinissionting plan and the issuance of the October 26, 1995 notice of opportunity for hearing referenced above. See CLI-95-14, 42 NRC at [36. CAN and NECNP responded to the nolice with the November 30, 1995 intervention pelition now before the Board.

Rather than referring the petition immediately to a Licensing Board, the Commission decided to consider the petition and any answers thereto. After receiving responses to the petition from YAEC and the Staff ond a reply to those responses from Petilioners, the Commission issued its January 16, 1996 Inemorandum and order, CLI-96-1. In addition to referring the petition to the Board, that issuance prowides the Botrd with guidante concerning CAN's and NECNP's slanding to intervetse and the admissibility of their Contentions A, C,

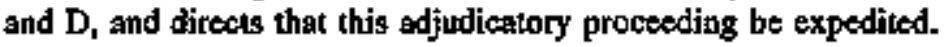

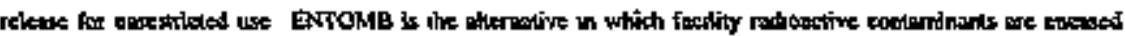

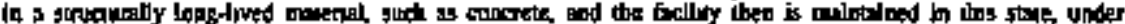

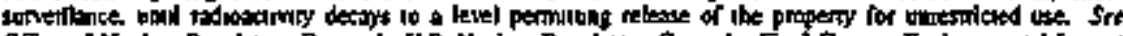

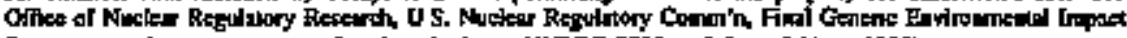

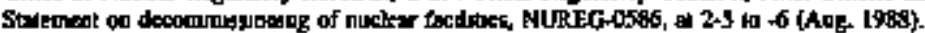

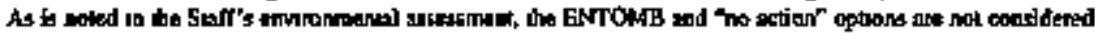

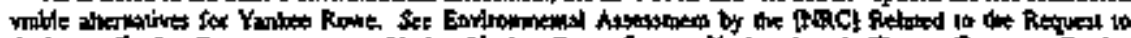

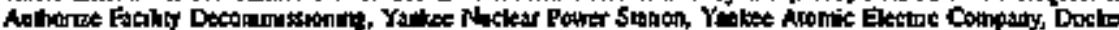

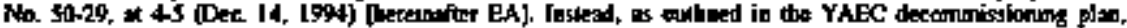

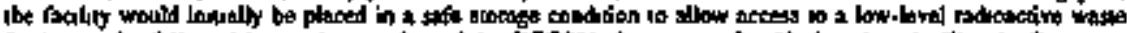

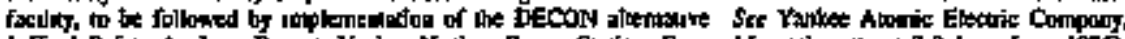

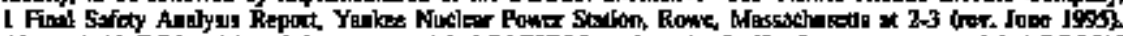

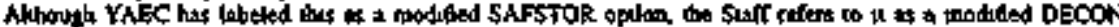

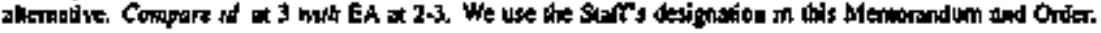


In connectuon with our delermination regarding Petitionets'standing and contentions, in addition to the Commission's guidance issuance, see CLI-961, $43 \mathrm{NRC}$ at 5-9, the Boand now has before it the followizg pleadings: ${ }^{3}$

1. [CAN/NECNP] Petition to Intervene and Supplemental Petition to Entervene (Nov. 30, 1995) [hereinafter Intervention Petition].

2. Licensee's Answer to [CAN/NECNP] Petition to Intervene and Supplemental Petition to Intervene (Dec. 15, 1995) [hereinafter YAEC Response].

3. NRC Staff's Response to Pettion to Intervene and Supplemental Petition to Intervene Filed by [CANNECNP] (Dec. 20, 1995) [bereinafter Staff Response].

4. [CAN/NECNP] Rep]y to Licensee's and NRC \$laff's Responses to Their Petition to Intervene and Supplemental Petition to Intervene (Dec. 24, 1995) [heteinafter CAN/NECNP Reply].

5. Further Reply of [YAEC] to [CAN/NECNP] Reply to Licensee's and NRC Staff's Responses to Their Petition to Intervene and Supplemental Petition to Intervene (Jan. 25, 1996) [hereinater YAEC Reply].

6. NRC Staff's Reply to [CAN/NECNP] Reply to Lisensee's and NRC Staff's Answers to Their Petition to Intervene (Jan. 25, 1996) [hereinafter Staff Reply].

In ruling on Pelitioners' intervention petition and contentions, we first address the queslion of their standing to intervene, and then deal with their contentions seriatim.

\section{STANDING}

As the Commission noted in CLI-96-1,43 NRC at 6, to comply with the basic standing requirements petitioner must demonstrate that (1) it has suffered or will suffer a distimet and palpable barm that constitutes injury-in-fact within the zone of interests arguably protected by the goveming statute; (2) the injury is fairly traceable to the challenged action; and (3) the injuty is likely to be redressed by a favorgble decision. Moreover, when, as here, an organization such as CAN or NECNP seeks to intervene on behalf of its members, see Intervention Petition at 2, that entity must show that it has an individual member who can fulfill these pecessary elements and who has authorized the organization to represent his or her inlerests. See CLI-96-1, 43 NRC at 6.

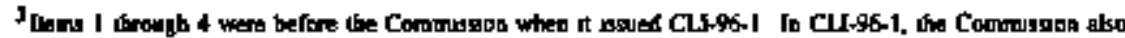

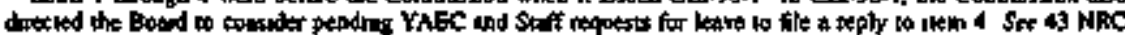

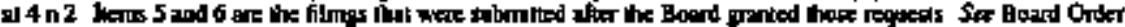

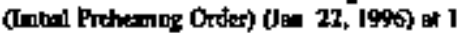
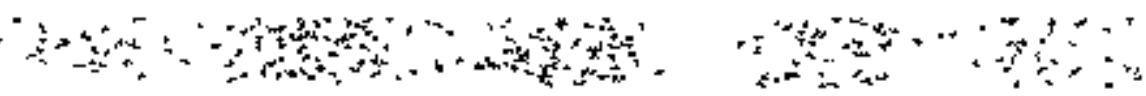

,

;

.

,

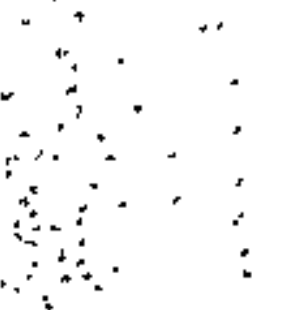

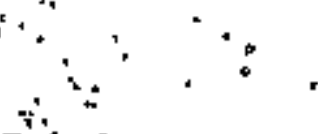

$\because$.

itr.

$\because$

$e^{2}+$

$12=8$

$\frac{3}{3}$

$i$

i

$\therefore ;$

$\therefore$

$i^{1}$

?

,
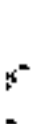

$-$

$-$

$+3$

' $\because$, =

-,.

$\therefore$

ब.

,

ars

-

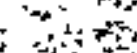

型

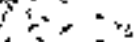

$58 a^{2}$

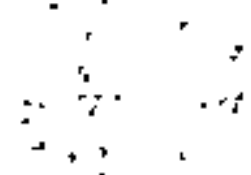

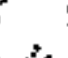

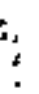


various activities in the area near 10, but outside of, the Yankee Rowe facility. Given that sone, even if jainor, public exposures can be anticipated from the decommissioning process, see Office of Nuclear Regulalory Research, U.S. Nuclear Regulatory Comun'n, Final Generic Environmental Impact Statement on decommissioning of nuclear facilities, NUREG-0586 (Aug. 1988) at 4-7 to-8 [bereinafter FGEIS]; EA at 22-24, we do not find ourselves "in a position at this threshold stage to ntlo out as a matter of certainty the existence of a reasonable possibility" that decommissioning might hove an adverse impact to those, such as Petitioners' members, who live or recreate in such close proximity to the facility, or use local waste transportation routes. Virginta Electric and Powgr Co. (North Anna Nuckear Power Station, Units 1 and 2), ALAB-522, 9 NRC 54, 56 (1979). As such, Petitioners have standing to present any contention that secks modification or rejection of the YABC decommissioning plan so as to avoid health and safery or environmeatal injury to the public. And, as the Commission's guidance in CLI-96-1 indicates, 43 NRC at 6, they also can pursue any contention alleging such modification/rejection relief based on cireumstances stuch as purported occupational exposure to Yankee. Rowe workers from decommissioning activities. ${ }^{5}$

With Petitioners' standing thus established, we consider the five CAN/ NECNP conlentions.

\section{CONTENTIONS}

Under 10 C.F.R. $\$ 2.714$ (b)/2)(ii)-(iti), to be admissible a contention must contain a specific stalement of an issue of fact or law raised or controverted in a proceeding that is supponted by a "basis" of alleged facts or expert opinions, together with references to specific sources and documerks that establish those facis or opinions. The basis must be sufficient to show that a genuine dispute exists with the applicant on a material issue of fact or law. Moreover, while the intervenor need not prove its case at the contention slage or present factual

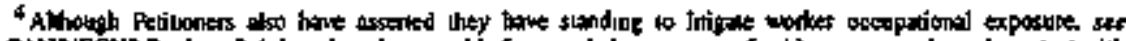

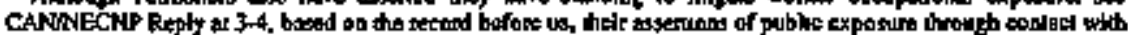

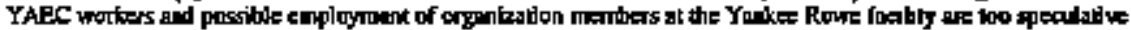
to support uoch sanding

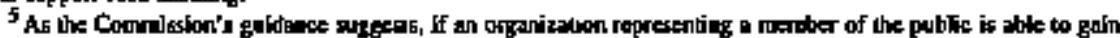

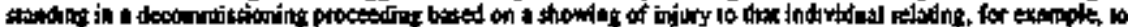

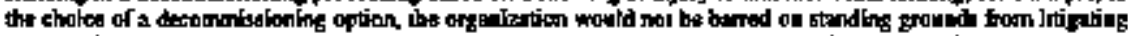
a conkentiog thel a change in the decommissioning option is apprepriate becsure of the cexupational exposine k

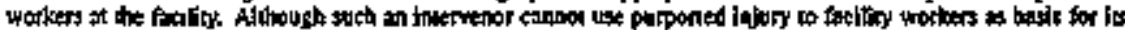

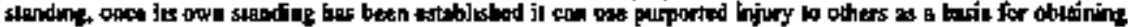

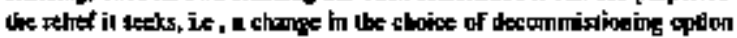

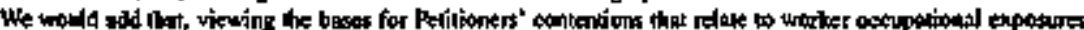

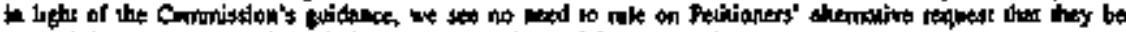

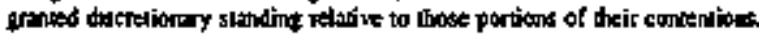


support in affidavit or evidentiary forn sufficient to withstand a summary disposition motion, it nanetheless must make a minimal sbowing that material facts are in dispute such that a further inquiry is appropriate. See Georgia Irstiturte of Technology (Georgia Tech Research Reactox), CLI-95-12, 42 NRC 11], 117-18 (1995). And, of course, any contention must fall within the scope of the issues set forth in the notice of opportunity for hearing on the proposed licensing aclion, ste id., which in this instance is "whether an order approving the [YAEC Yankee Rowe] decommissioning plan should be issued," 60 Fed. Reg. at 55,070. We assess Petitioners' contentions under these standards.

\section{A. CANNECNP Contention A}

Petitioners' first contention reads as follows:

CONTENTTON A: YAEC's proposed decommlssioning plon tholates 10 C.F.R

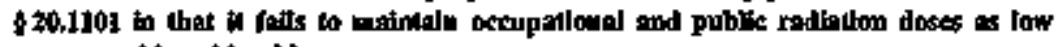
as rexsonably achlevable.

Intervention Pettition at 7 (emplasis in onginal). Pelitioners provide tur "bases," with accortpanying "subbases," for this contebtion, which can be summarized as follows:

(1) YAEC's choice of the DECON decommisstoning option does not meel the standard

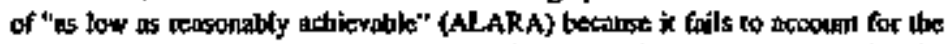

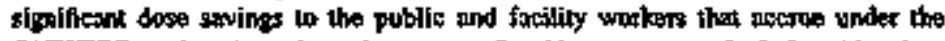
SAPSTOR option tbrugh onsike slonge for thinty years, particularly laking into pcocalnt:

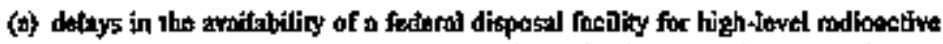
paste (HLRW) that wall postpone release of the sils for unestricted use, thentby negating one of YAEC', expressed bases for doosting DECON with tes tigher occupational exposures:

(b) the bighter cost of DECOW based on (i) the present value of the cost of decolpmissicaing, (ii) proposet tost sawings reinted wo histe volume reduction during SAFSTOR, and (iii) improved decommissionjag knowledge and understomiting grined trom other decommissioning efforts during the exkended sionge period favor the adopition of SAFSTOR; and

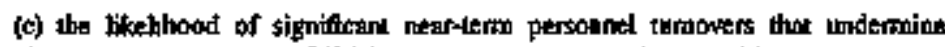
YAEC's assumplion thx DECON jacteases the pakential for bating advanlago of experienced plant persemnel.

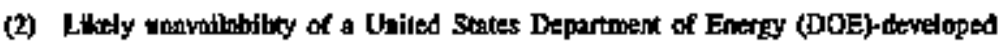
molti-porpose camister for the ansite storage transportation, and offiste disposal of HLRW and greoter than Closs $C$ waste means that if YAEC closes lis Spent

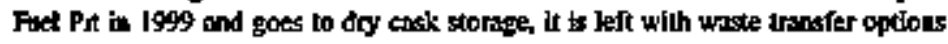


reductions." We thus find that Petitioners have failed to provide support for their Contention A sufficient to establish a disputed material factual or legal issoe metiting further inquiry.' Accordingly, we dismoiss this contention.

\section{B. CANANECNP Contention B}

Petitioners' second contention provides:

CONIENTION B: The proposed decoommsslonting plan for [Yankee Rowe] does

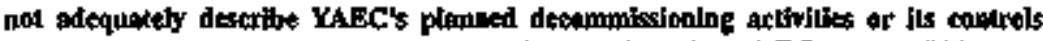
and Ilmils on procedures and equipment, in violation of 10 C.F.R. 5.50.82(b)(1) and (2).

Intervention Petition at 14 (emphasis in original). Pecitioners again provide several bases, with subbases, in sopport of this contention. As bases for this conlention, Petitioners assert that the plan is inadequate because it is unreasonable in its assumptions that:

(I) An LLRW reposilory will be avalable in Masgachusents by 2003.

(2) The ppeal auckear ftel now stoved in the onstite Spent Furl Pit will be transfored to onsice thy ansk stemige by 1999 and ihen stipped to a DOE HIRW mepository by 2018 .

See id, at 15-16,

With regard to the first assumption, citing purported differtlies in Massachuseits and elsewhitere stith siting an LLRW repository and a jecent guberaatorial proposal to eliminate the Commonwealth's LLRW repository siting board and negoliate contracts for out-of-state disposal, Petitioners maintain that the plan onust be revised to acconnodate (a) a lengthy delay in in-state site availability, and (b) the possibitity of out-of-state shipunent to a distant repository

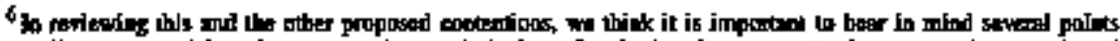

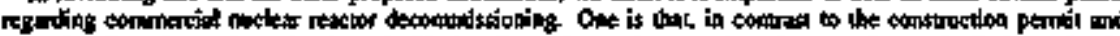

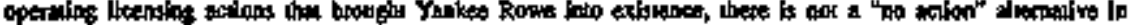

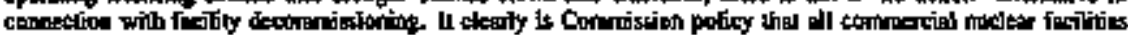

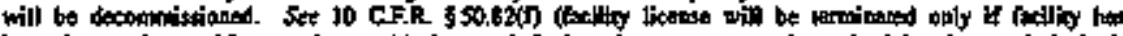

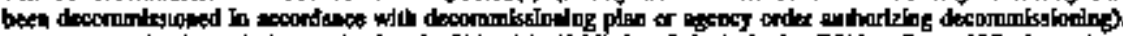

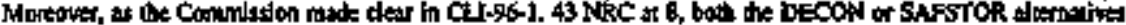

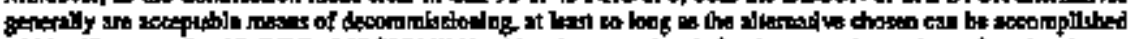

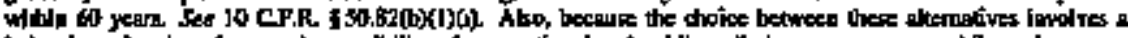

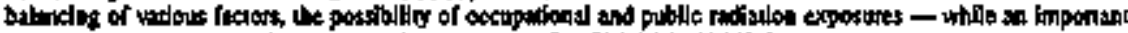

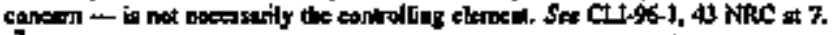

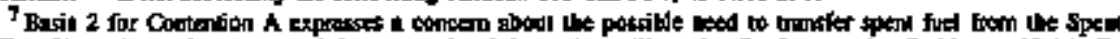

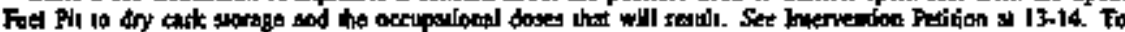

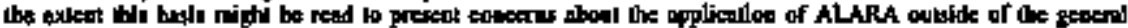

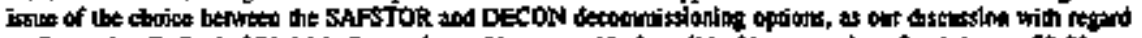

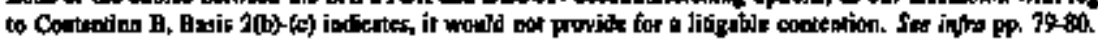


information that would have to be submitted in a seactor decommissioning plan, should provide sufficient criteria to determine what is an acceptable plan. See id. at 24,025 . Unfortanately, in the intervening 8 years oeither the regulatory guide nor an SRP has been developed for a Jeattor decommissioning plan, see Tr. at 83-84, 97, which leaves us without specific guidance when it cones 10 determinimig exartly what a decommissioning plan must contain to fulfill the requirements of section $50.82(\mathrm{~b})(1)-(2)$.

Nonetheless, in providing guidance to the Board on Petitioners' Contention C. Which concerns the adequacy of the cost estimate provisions in the decommisstoning plan pursuant to 10 C.F.R. $\$ 50.82$ (b)(4), the Commisston bas furnished a set of interpretative principles that appear equalyy applicable to the plan's other provisions. In its January 16 memorandutn and order, the Commission indicated that a contention chalkenging the "reasonabileness" of a plas's cost estimate provissions would not be sufficient because the potential relief woukt be no more than "the formalistic tedraft of the plan," Rather, the Commission declared, the petitioner must show not only that one or more of a plan's cost estinate provisions are in error " "het that there is not reasonable assurance that the amount will be paid." CLI-96-1, 43 NRC at 9.

What the Commission appears to be saying with this guidance is that, notwithstandiag a licensee's general obligation to provide the agency with complete and accurate information, an allegation that some portion of a decommissioning plan's cost estimate provisions must say something different or something more is not, in and of itself, an acceptable basis for a contention challenging the adequacy of the estimate. Rather, in the context of an adjudicatory challenge to a deconminssioning plan's cost estimale provisions, an allegation about the plan's completeness or accuracy is worthy of further inquity obly if it is coepled with a showing that the alleged deficiency has some independent bealih and safely sigoificance (e.g., that the additional anount atributable to inaccurate cost estimates cannot be covered by the Licensee's funding proposal).

Nothing in the Commission's menorandum and order indicates that the application of this guidance is limiled to the cost estimate provistions of a decambissioning pian. In the context of otr ingusicy tunder Contention B, this guidance translates into a requirement that a contention musst oot only allege some content deficiency is a decommissioning plan, but that this purported deficiency has some health and safely significance for the deconomissioning process as a whole." Put another way, to craft a litigable contention faulting a decommissioning plan for a deficiency in content, besides providing a basis

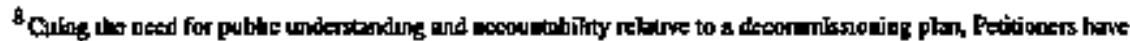

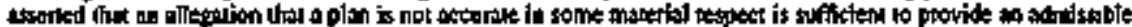

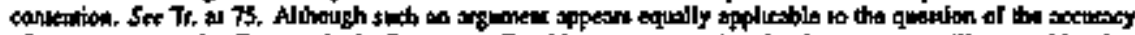

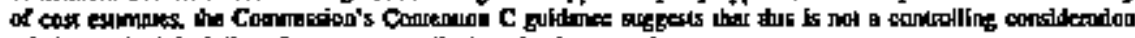

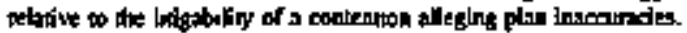




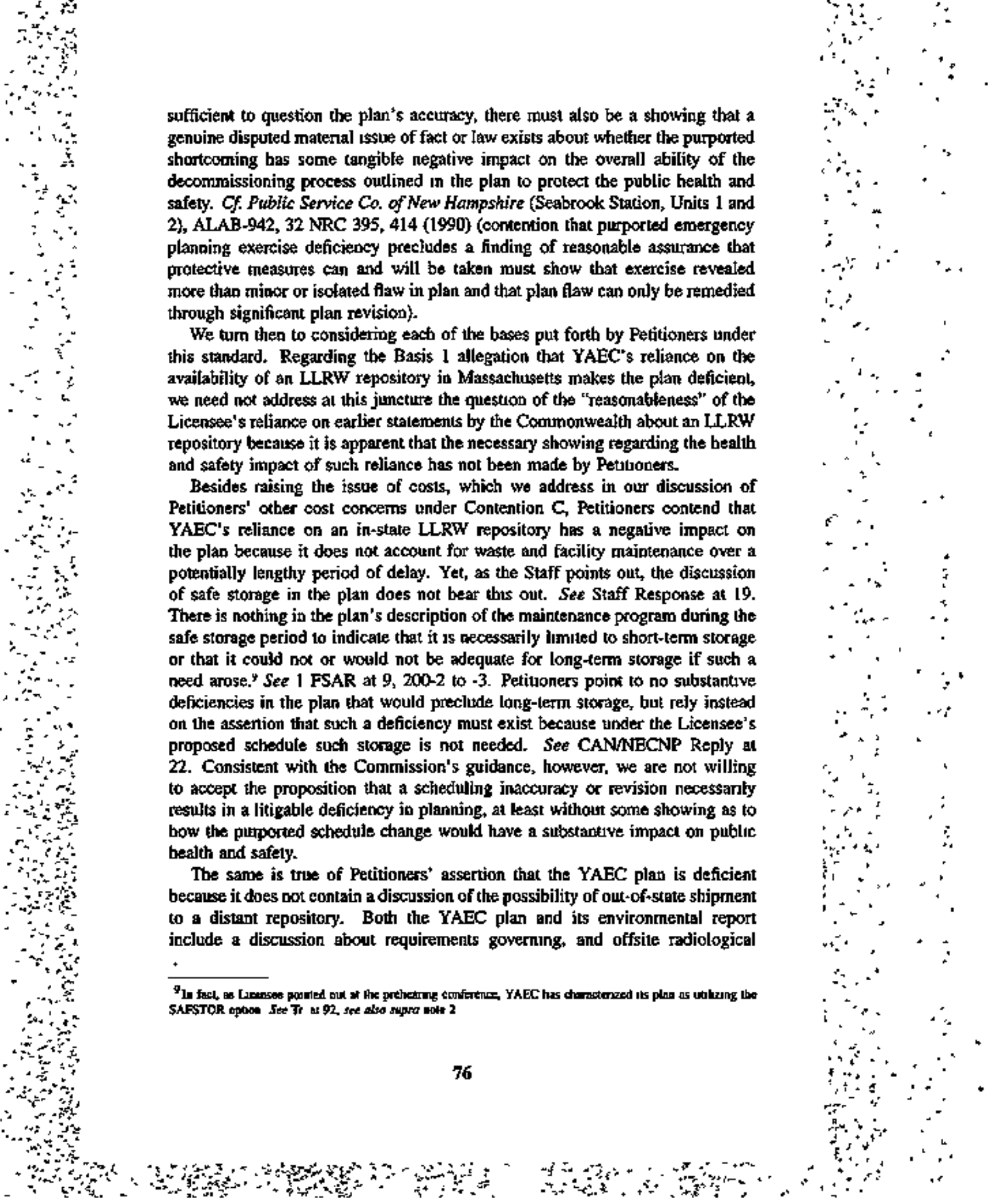


impacts resulting from, the shipment of radioactive materials. See 1 FSAR al 402-1; 2 td. at 514-6 to -7; Environmentel Report at 5-4 to -5. In fact, the YAEC environmental report declares that "[s]ince the total shipment-miles for unansportation of radioactive waste from decommissioning [Yankee Rowe] is significantly less than those assumed by the [F]GEIS, the risk to the health and safely of the public from decommissioning [Yankee Rowe] is bournted and delermined to be acteptable by the [FIGEIS." Envirommental Report at 5-5; see also id. at 4-15 to-16. Nothing Petitioners have provided suggests that the shipment of low-level waste to distanl states, such as Texas or California, encompasses health and safecy considerations beyond those covered in the decommissioning plan or the environmental report ${ }^{\text {Ho }}$ As such, this transportation concern affords no basis for adimflting Contention B.

Tuming next to their noncost bases regarding onsite and offsite HLRW storage, ${ }^{t 1}$ we note that some question exists regarding Petitioners' ability to raise health and safety and environmental matters relating to spent fuel. Statements in the regulations and the FGEIS indicate that decommissioning is not to be deemed to include the operational activities of "the removgl and disposal of spent fuel." See 10 C.F.R. $\$ 50.75$ (c) n+1; FGEIS at 2-5. Assuming, however, that their present bases are not excluded by season of this apparen limitation, with the seeming admissions of both the Licensee and the Staff that any estimate of when an HLRW repository will be open has a high tegree of uncertsinly, see YAEC Response al 17, \$taff Response at 19, the 1993 GAO leslimony and the 1992 DOE capacity report arguably do present at least a genuine factual dispute about when ali Yankee Rowe spent fuel will be interred in a repository. See Intervention Petition at 16-17 \& on.35-36. In its response, the Staff makes the point that in reviewing the plan's provisions relating to storage of spent fuel, it concluded that, consistent with the provisions of 10 C.F.R. $\$ 51.23(\mathrm{a}){ }^{12}$ the acceptable period during which the Licensec could ust any combination of wet or dry spent fuel safe stofage methods runs through 2030. See Slaff Responste

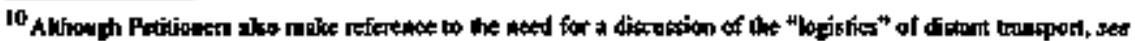

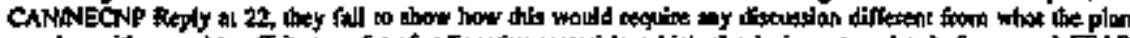

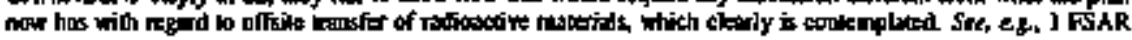
at 40?-1.

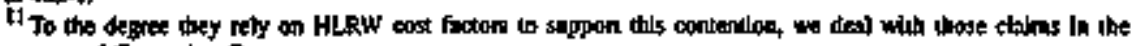

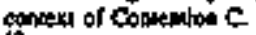

it Seation SI.23(a) or 10 C.R.R. protides

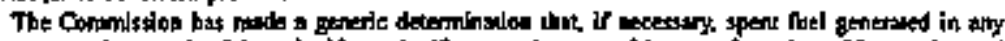

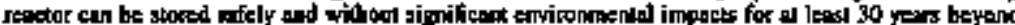

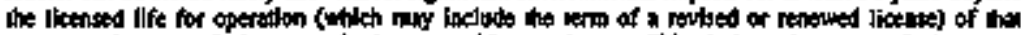

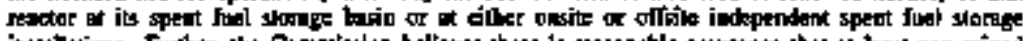

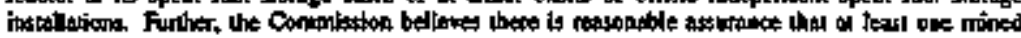

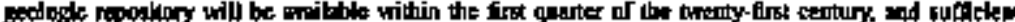

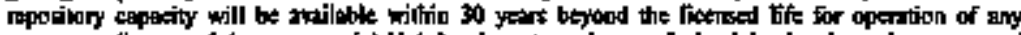

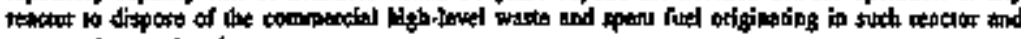

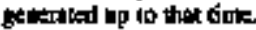

...

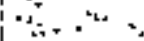

$\because$

$\because+\cdots$

$\because$

$\therefore=$

$\therefore$
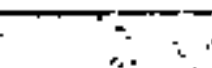

+
.+

$\therefore \therefore a$

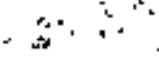

i. $\because$ 


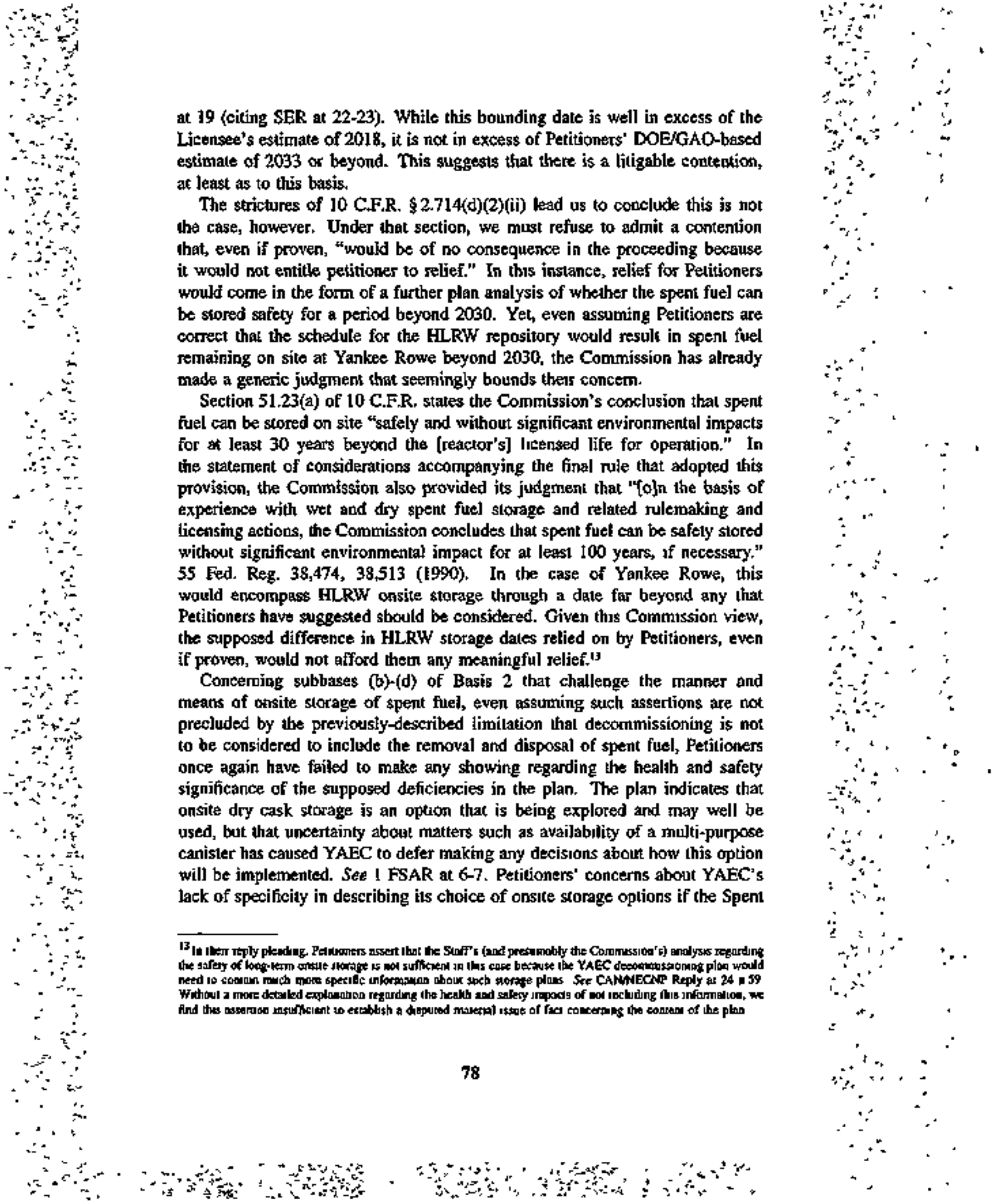


Fuel Pit is closed and how YAEC will accomplish the transfer of HLRW if dry cask storage is used - including the possibility of using a dy transfer method and the need for $\mathrm{B}$ change in existing facility Technical Specification 3.2 limits on cask usage over the Spent Fuel Pit - all are based on the puimise that the lack of any detailed description establishes a substantive deficiency in the decommissioning plan that can be litigated in this proceeding.

Wo are unable to agrec. The agency's decormonissioning plan regulations provide that if there is a delay in a major dismantlement activity because of a decision to place a facility in storage. planning for such activities may be less decailed, with the caweat that updated detailed plans must be submitted tater and approved prior to the start of the activities. See 10 CF.R. 850.82 (d). A similar principle appears relevant in this instance,

As the Staff points out, YAEC's use of dry cask storage is subject to the requirements of 10 C.F.R Part 72. See Staff Response at 15. This would inciuds the provisions of 10 C.F.R. $\$ 72.40$ as they relate to the licensing of an independent spent fuel storage installation (ISFS1). See Tr. at 108-10. Thus, when and if YAEC chooses to close its Spent Fuel Pit and move to dry cask storage, that choice must undergo an agency approval process that provides for, among other things, consideration of whether there is compliance with ALARA objectives and a public heanng opportunity regarding the ISFSI application. See 10 C.F.R. \$5 72.44(d), 72.46; see also Sacramento Municipal Utitity District (Rancho Seco Nuckear Generating Station), LBP-93-23, 38 NRC 200, 246 (1993) (given pendency of separale proceeding regarding ISFSI, contention asserting decommissioning plan environmental assessment inadequate because of lack of analysis for ISPSI emissions not admissible).

In addition, an agercy approval process exists relative to YAEC's choice of a storage cask. Prior to being utilized, a cask design undergoes certification through the agency approval process in 10 C.F.R. Part 72, Subpart L. Then, under the genteral licensing provisions governing the use of certified casks, prior to employing the cask YAEC would be required to make a written determination that, among olher things, operational restrictions have been established to meet ALARA objectives and YAEC's activities do not involve any unteviewed safety issues or technical specification changes that would require a license amendment (and be subject to an adjudicatory hearing). See 10 C.F.R. \$\$ 72.104, $72+212(b)(2),(4)$.

In connection with Peticioners' concem about the lack of a multi-purpose canister and YAEC's possible use of a dry method to transfer spent fuel and other HLRW from a nontransportation cask to a transportation cask, its own description of this possibility portends the need for an agency approval process. The dry transfor method highlighted by Petitioners is still in the development stage by DOE and another utility and apparenly has not been reviewed by the NRC. See Intervention Petition at 18; CAN/NECNP Reply at 25 n.63; Tr. 
at 112-13. As such, at least as presented by Petitioners, this transfer method constitutes an activity involving an unreviewed safety issue that, whether as part of the ISESI licensing process or otherwise, would need agency approval (and be subject to an adjudicatory hearing). See lo C.F.R. $\$ \$ 72.40$ (a)(5), (13), $72.46,72.48(c)+72.212(b)(4)$.

And as with the use of dry cask storage, an agency approval process also is involved prior to the transfer of spent fuel from the Spent Fuel Pit into the storage casks. As ail the parties agree, with the limitations it iniposes, Technical Specification 3.2 must be changed before this can be accomplished. See Intervention Petition at 18. YAEC Response at 19, Staff Response at 20. This, in turn, would require a license annendment that, under existing agency regulations, would be subject to challenge in an adjudicatory hearing by any intervenor with standing and litigable contentions. See 10 C.F.R. \$ S0.59(c).

Thus, with regard to YAEC's choice to utilize dry cask storage, YAEC's choice of a cask type. YAEC's choice to employ a dry transfer method, and YAEC's choice to chantge Technical Specjication 3.2, there is another agency approval prosess that must be followed prior to undertaking any of these activities. Given these later epproval mechanisms, all of which may provide for an adjudicatory hearing, we are umabto to conclude that the alleged lack of detaited discussion in the decommissioning plan regarding these possible activities establishes there is a disputed material issue of fact or law regarding a significant health and safety deficiency in some aspect of the decommissioning process such that litigation on Contention B should go forward." This, combined with Petitioners' failure to make the reculisite showing regarting any of the ather bases pot forth in susport of Contention B, requires that we dismiss this contention as well.

\section{CAN/NECNP Contention C}

The third CANNECNP conienlion is stated as follows:

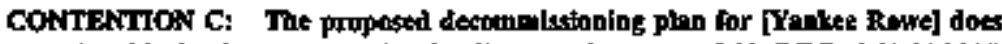

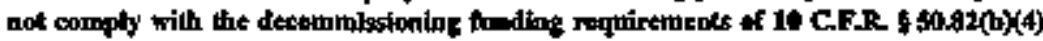 or (c).}

Intervention Petition at 19 (emphasis in original). Further, Petitioners provide four separate bases (and some subbases) for this contention, which can be synopsized as follows:

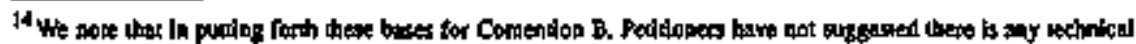

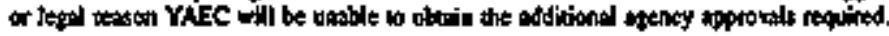


(1) The YABC decommissioging cost extimate for Yankee Rowe required by 10 C.R.

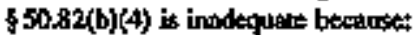

(a) it ts besed on the uareasonabie asgumption that an ELRW slte will be swoileble $\rightarrow$ Massachusens by the year 2003;

(b) if its assmmpion that DOE-sepplied malli-parpose canistess will be arailatite for dry storuge is incorred, whidh is Jkely, YADC will have to parchase corks that will and as mach as \$2.5 million to deoommissioning costs;

(c) $\mathrm{i}$ is based on the unfesconable assumplon that an HLRW itpositury will be avrailable is time to complete spent fuel shopoments by 2018;

(d) the 123 percent contingency factor used to cover unforeseet future develogments is grossly inadequate; and

(e) It does aot include the costs of lead, mercury, and abeslos abntemeat.

(2) The decommissioning cost estimbte does not prowide a comparison of the cost

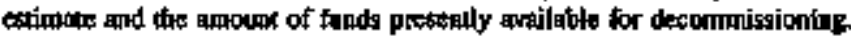

(3) The decominissioning plon falls to provide suffictent haformation lo demonstrale thax any of the thee fanding soutes mentioned - contrfbutions made under the provisions of the existing Power Conuracts betwen YAEC and its formot power ensesnters, contnbotion invegiments annings, and tax loss carrybacks - will assure the arsilabiluty of the funds needed to meet all decommissioning expenses.

(4) The decommisstoning plan does an prowide an adegume description of the urast sccout crealed to hald the Rower Cortronct rewenues.

See Intervention Petition at 20-27; see also CANNECNP Reply at 26-32.15 YAEC and the Staff once more contest the adequacy of each of these bases. See YAEC Response at 19-23; Staff Response at 21-22; YAEC Reply at 9-11; Staff Reply at 5-7.

As we noted in connetion with Contemtion B, see supra p. 75, the Cornmission bas provided us with certain guidelines tegarding the admissibility of utsis conlention. In its Janury 16 memorandum and order, the Commisstion stated that, in and of itself, a contention challenging the "reasonableness" of a decommissioning plan's cost estimate provisions was not litigable "because the potential relief wontd be the formalistic redraft of the plan with a new estimate." CLI-96-1, 43 NRC at 9. Rather, the Cormisston declared, the Petitioners must show not only that one or more of a plan's cost estimate provisions are in error, "but that there is not reasonable assurance that the amount will be paid." Id. Thus, under these Commission gajdelines, Petitioners must establish that sompe

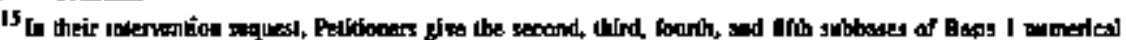

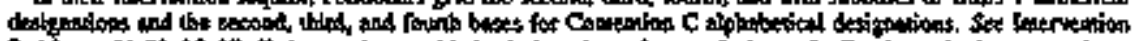

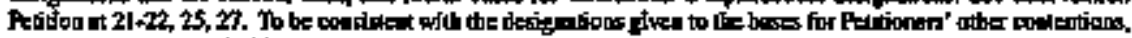

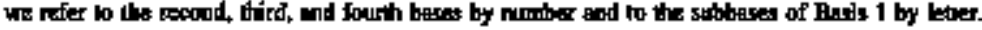

81

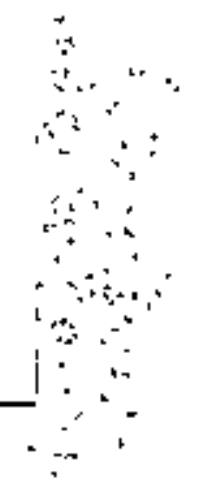


the full cost of decomnissioning; and (3) the passibility that power purchasers may contest their obligation to pay the full cost of decommissioning because they did not have the full benefit of revemes from Yankee Rowe operation due to its premature shutdown. See id. at $3 \mathrm{l}-32 \mathrm{\&}$ n.8I.

None of these purported deficiencies is sufficient to create a material factual dispute concerning the ability of the power purchasers to honor their existing contraclual obligation to fund Yankee Rowe decommissioning fully. ${ }^{17}$ In connection with the 1988 FERC ratemaking case, Petitioners note that YAEC sought to turn aside an FERC staff attenpt to lower its rate of return by establishing, among other things, that various risks associated with the operation of those uti]ities that were its power purchasers merited YAEC's then existing higher return rate. The case, however, is pot sufficient to support Petitioners' assertion given that the FERC categorically rejected YAEC's risk arguments relative to the purchasers, a determination the Commission subsequently reiterated." See Yankze Aromic Electric Co., 40 FERC \$61,372, 1987 WL 118208, at *19-120 (FERC [987); Yankee Atomic Electric Co., 67 FERC $161,318,1994$ WL 270437, at *17-*18 (FERC 1994). Pelitioners'assertions that the power purchiasers might default on their obligations in the event of YAEC fund misuanagement or because they did not receive the benefil of ftll lifetime operation of Yankee Rowe also are insufficient because those ciaims lack any factual support relating to the power purchasers. Petitioners have failed to place these allegations outside the realm of mere speculation so as to warran further inquiry.

Petitioners thus have not established there is any disputed meaterial factual or legal issue regarding the ability of the power purchasers to meet their existing coniractual obligation to pay all the costs of Yankee Rowe decomnissioning.

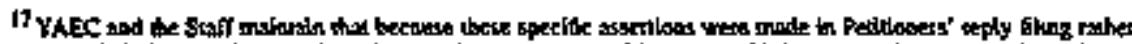

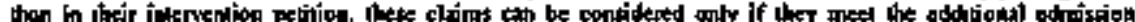

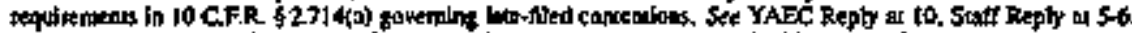

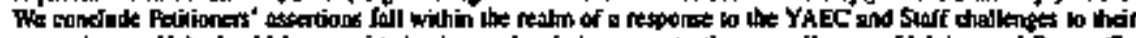

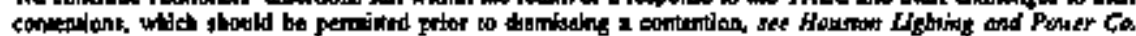

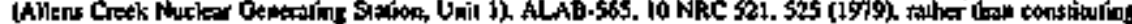

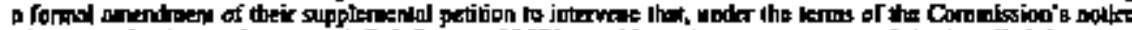

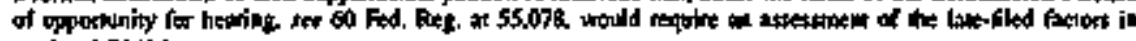
seation 27J4(0).

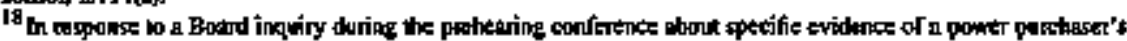

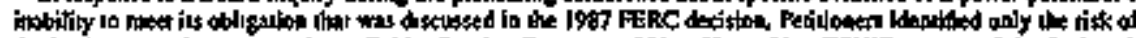

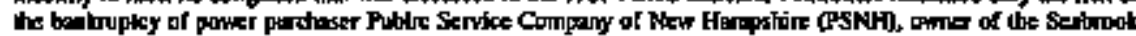

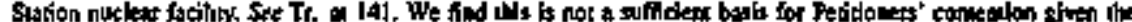

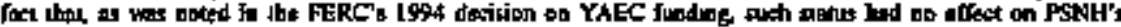

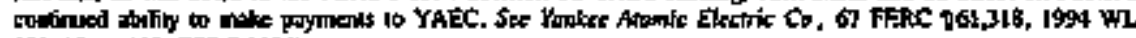
270437, if *IT (FERC I,994)

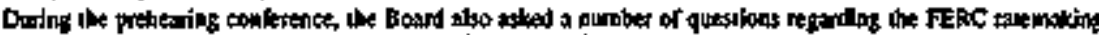

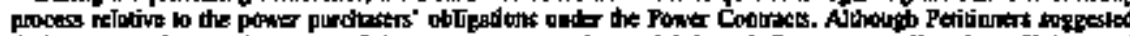

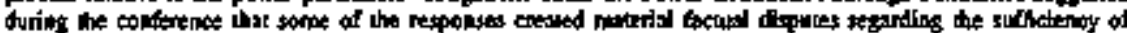

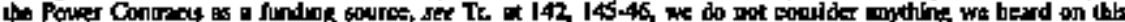

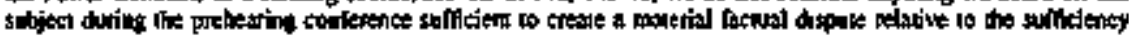
of the Powit Comprocts as a deconmigsianing funding source. 
Tn the exient that the contention alleges that YAEC has ylobled NRC regutiulons, those allegations are more properly the subject of sepsefale enforcemed actions. The foens of

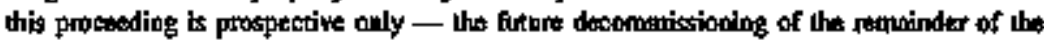
facility under the proposed decommissioning phas.

43 NRC at 9. The Commission thus appears to beliteve that if Petitioners desire to pursue the relief uney seek in this contention, a petition under 10 C.F.R. $\$ 2.206$ requesting Staff enforcement action is the appropriale mechanism. We heard nothing during oral argument at the prehearing conference that would call into question the Commission's gutidante in this regard. Accordingly, we dismiss this contention also.

\section{B. CANMRCNP Contention E}

Pelitioners' last contention stales as follows:

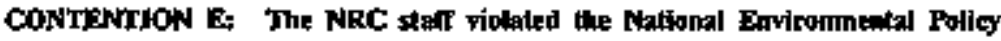
Ace by tofing to prepare a suppitentadel Ervironmentel Impact Slatement for be decoumissiening of [Yankee troure].

Intervention Petition at 30 (emphasis in original). As regulatory support for this contention relating to agency compliance with the National Environmental Policy Act of 1969 (NEPA). Petitioners rely on 10 CF. $\$ 51.92$ (a)(2), noting that under its terms the Staff must prepare a supplenental environmental inpact statement (SEIS) for a proposed action whenever there are "signtititant new cifeumstances or information relevam to environmental conceros and bearing on the proposed actions or its impacts."

As the basis for Contention E, Petitioners assert that the Slaff erred in its conclusion that, because the impacts associated with decommissioning are bounded by the conditions evaluated in the FGEIS on other regulatory standards, an environmenlal assessmment tather than a site-specific environmental impact statement is necessary in connection with the Yankee Rowe decomonissioning plan. According to Petitioners, a number of environmental impacts specifec to Yankee Rowe that were not considered in the FGEIS for nuclear facilty decommissioning mandate the preparation of an SEIS, including those impacts regarding:

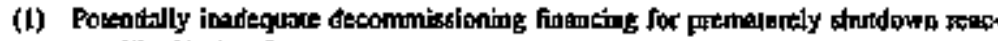
bors like Yantes Rowne.

(2) Projected occupationol dose estimates that exceed the doses arlielpoted for Yanisee Rowe deconmistioning in the FGEIS.

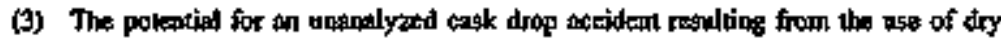
cask slorage for sperl Evel. 


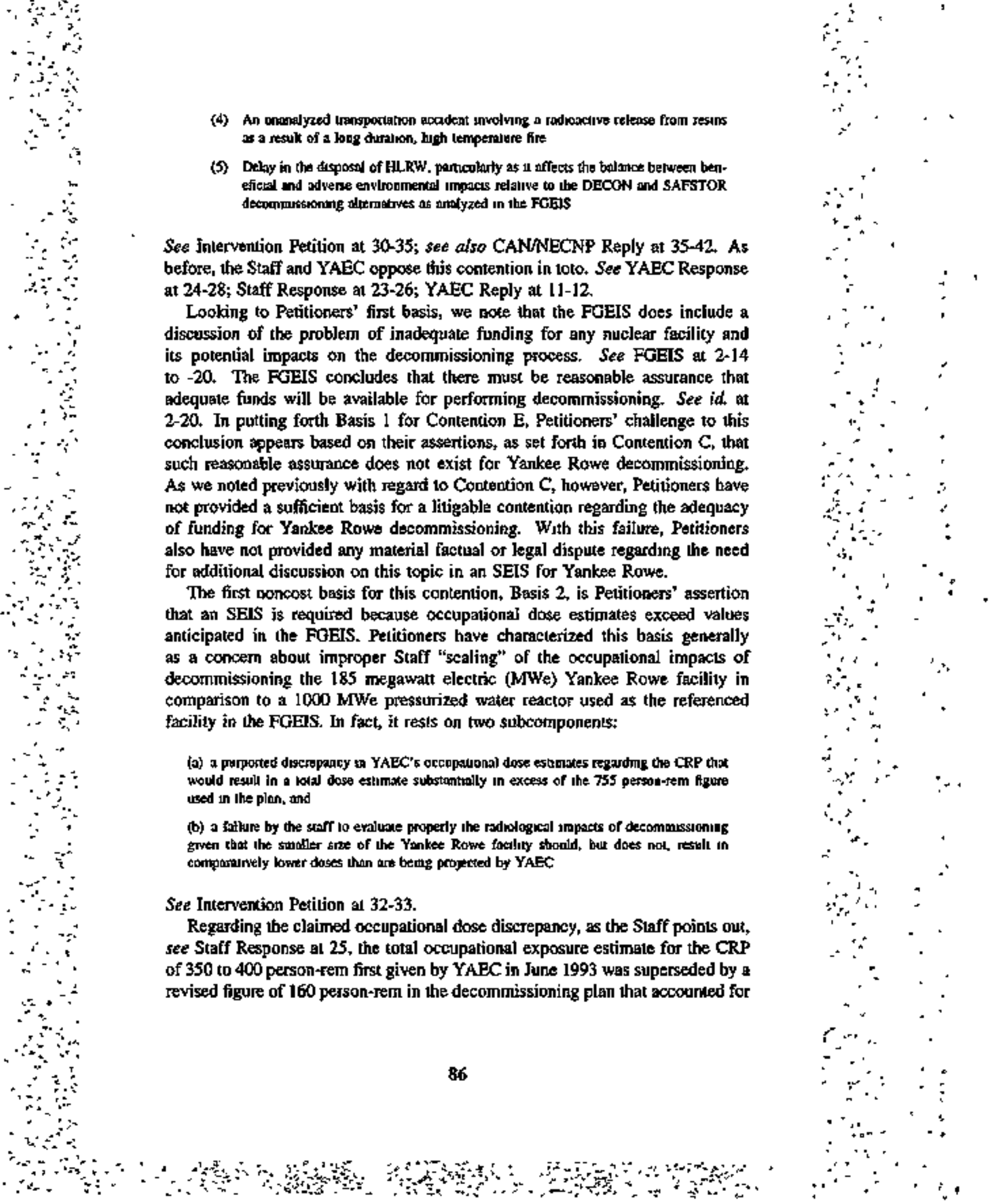


CRP implementation experience. See 2 PSAR at 507-4, -15. Having presented nothing that would suggest that the more recent figure is incorrect (as opposed to simply different from the eatlier figure), Petitioners have fatled to establish a disputed material issue of fact that warrants further litigation.

On the question of scaling, Petitioners maintain that the FGEIS occeppational expasure figure of 1215 person-tem used is not an appropriale bounding figure for the Yankee Rowe facility, given its smaller stze. They suggest that a figure of 513 person-rem should be used for Yanke Rowe, as is set forth in the August 1979 addendum to the June 1978 report that was used in the FGEIS to derive the 1215 person-rem accupational exposure figure for the $1000 \mathrm{MWe}$ reference plant. See R.I. Smith and L.M. Polentz, Technology, Safely and Cosis of Decommisstioning a Reference Pressurized Water Reactor Power Station, NUREO/CR-0130, at 2-4 (addendum Aug. 1979) (Table 2.1-2). And, using this 1979 figure in comparison to the YAEC estimgte of 755 person-rem, see EA at 22. Petitioners maintain that there is a difference in occupational exposure of at least 200 person-sem, the radiological inpact of which has not been accounted for in the FGEIS or the Siaff's EA. See Intervention Petilion at 32-33.

For their part, both the $S$ taff and the Licensee assert that such a comparison is irrelevant, because the FGEIS determitnation relating to occupational exposures was footed not on the relative size of the estimated exposures from different capacity plants but on a comparison of the estimated ocxupational exposures from decommissioning with those exposures arising fram facility operalion. See Staff Response at 24. YAEC Response at 25. And, according to YAEC, the comparison cited favorably in the FGEIS in connection with the $1000 \mathrm{MWe}$ reference reactor is on a par with that for the Yankee Rowe DECON option. ${ }^{21}$ See YAEC Response at 25. Felitioners respond by declaring that the FGeIS does not incorporate such an assessment relative to the occtupational doses arising from the DECON alternative, but makes a judgmeat only that both the DECON or SAFSTOR options are acceptable. See CAN/NECNP Reply at 37.

It is apparent that the FGEJS assessnent of the impacts of occupational exposure does rest on a comparison of the impacts of exposure during the decommissioning process with those arising during facility operation and makes a judgment that stich impacts are acceptable. That this should be so is not

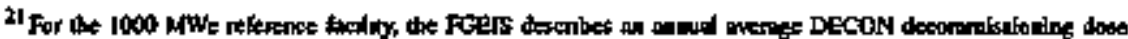

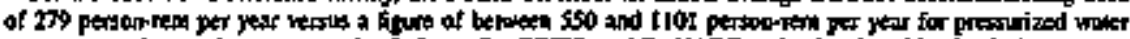

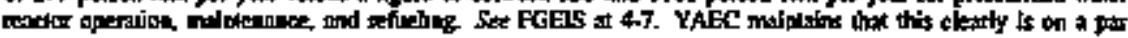

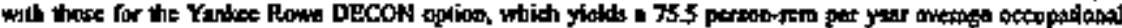

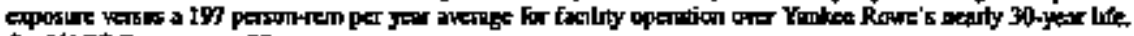
See YAEC Reqponse a 25.

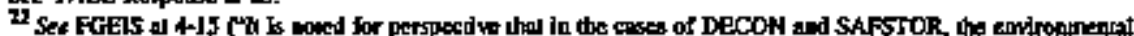

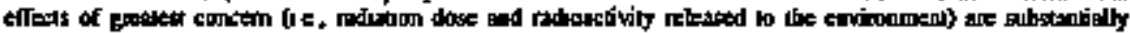

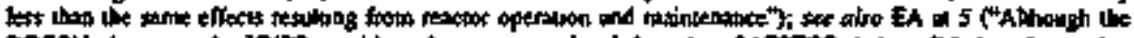

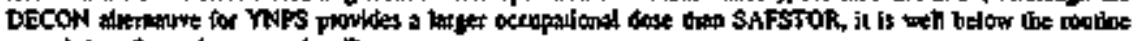

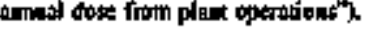


Petitioners as support for this basis, which we conclude on its face does not set forth an accident scenario that requires NEPA consideration.

The "rule of reason" governing NEPA interpretation provides that an agency need not consider "renote and speculative risks" Limerick Ecology Acrion $v$. NRC, 869 F.2d 719, 739 (3d Cir. 1989). In Basis 4, Petitioners assert that the FOEIS evahuation of transportalion impacts did not inclede any analysis of a 1988 Sandia National Laboratories (SNL) report on the consequences and risks of highway accidents involving transported low specifle activity (LSA) waste. ${ }^{26}$ That reporl describes a hypochetical "worst case" traffic accident scenario involving a transportation cask containing reactor spent ion-exchange resins," which generally have the highest specific activity levels of all LSA materials, in amounts that are at the regulatory maximum for shipping. As outlined in the report, a hypothetical trafic accident results in the transportation cask coming open. Once the cask is open, all the resins spill, and then are ignited by a futl spill fire. See Robert M. Ostmeyer et al., The Potential Consequences and Risks of Highway Accidents Involving Gamma-Emitting Low Specific Activity (LSA) Waste, SAND87-2808, at 1, 15-16, 49 (Aug. 1988) [hereinafter SNL Accident Report] 2a

Although seemingly based upon cask breach conditions that fall within the boundaries established by the agency's trasisportation regulations for testing transportation casks, the report nonetheless declares that "at accident resulting in a spill of resin is considered to bave a very low probability." \$NL Accident Report al 17. Further, the report states that the critical circumstance of the presence of a fire to ignite the resins - the copdition that causes a radioaclive

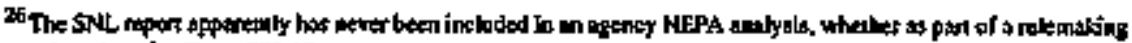
of ntherwise \$t Tr. at 209-10.

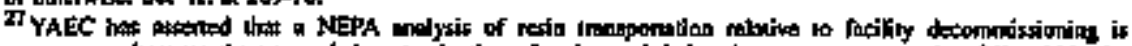

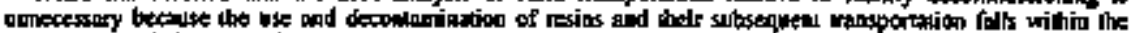

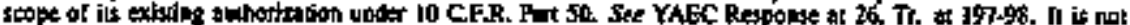

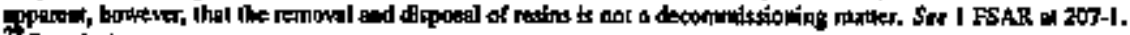

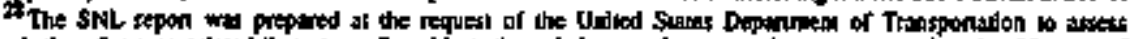

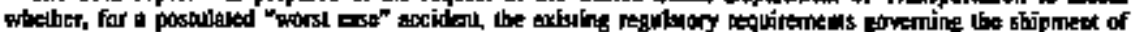

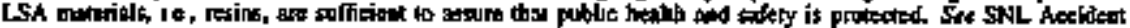

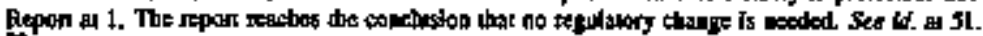

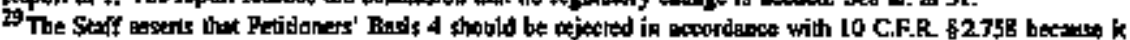

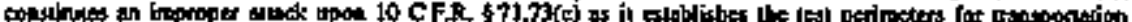

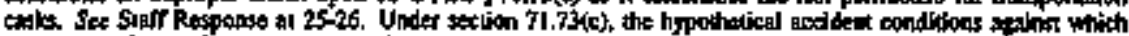

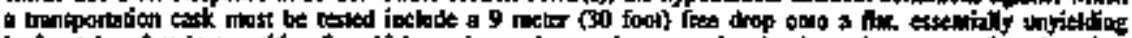

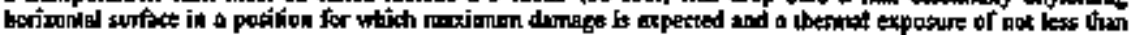

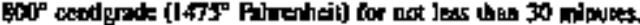

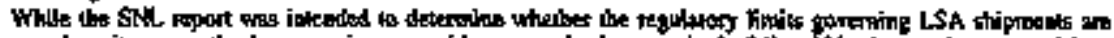

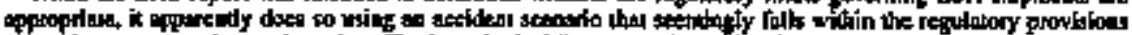

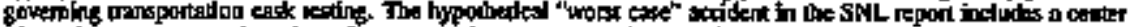

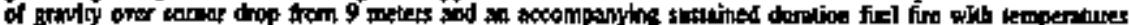

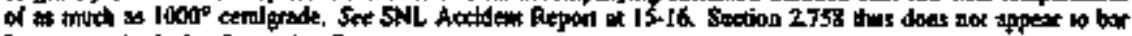
Pelilioners' bats for Conkention E.
} 
release - would appear in "[0]nly a small fraction of the transport accidents that lead to a spill of spent jon-exchange resin" $/ d$ at 18 .

A doctument put forth by an intervenor as the basis for a contention is subject to scrutiny both for what it does and does not show ${ }^{30}$ Because only bccident scenarios that are not "remole and speculative" need be the subject of a NEPA analysis, if the information in any intervenor-proffered document regarding such a scenario fats to indicale that this threshold has been crossed, then a contemtion chatlenging NEPA compliance based on a failure to analyze that scenario need not be adnitted. See Vermont Yonkee Nuclear Pawer Corp. (Vermont Yankee Nuclear Power Station), ALAB-919, 30 NRC 29, 44-47 (1989), remanded for addtional findings, CLI-50-4, 31 NRC 333 (1990). The description of the bypotherical accident in the SNL report, which incorporates a chain of eveots including a low probability cask breach sccident followed by a fire of similarly remote probability, does not exceed this level. ${ }^{31}$ Accordingly, as presented by Petitioners, the SNL report does not provide an admissible basis for Contention C.

Finally, the requirement of 10 C.F.R. \$51.92(n)(2) that there be "signifcant new cireumstances or information relevant to environmental concems and bearing on the proposed action or its impacts" once again is not folfilled by Petitioners' Basis 5 assertion that an SEIS is needed to discuss the impact of the purported delay in the availability of an HLRW repostiory upon the balance between the DECON and SAFSTOR atternatives. The FGEIS already casiains an analysis of the environmental impacts of the SAFSTOR option in the event it became necessery to incorporate a longer period of onsite HI.RW storage.

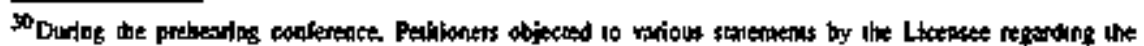

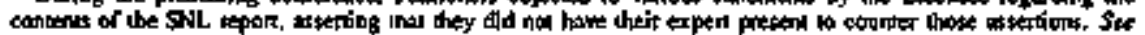

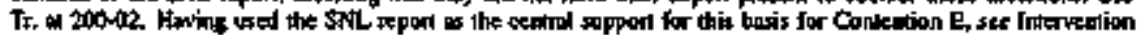

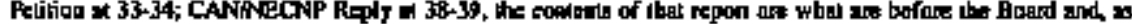

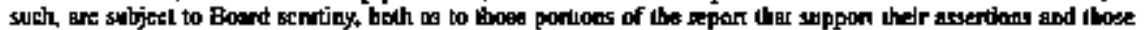
portions thut do wot.

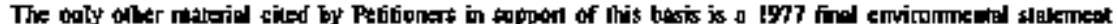

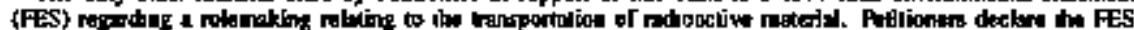

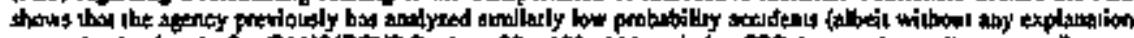

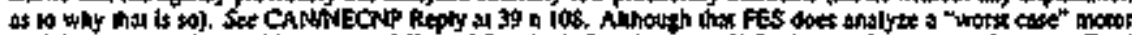

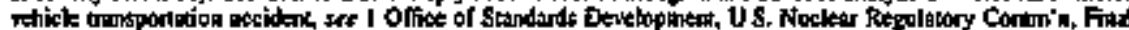

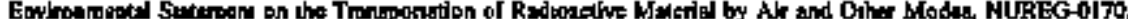

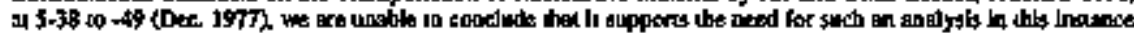

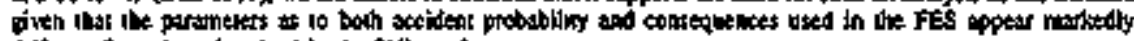
differen from thase inrohed in ile SNL shacty.

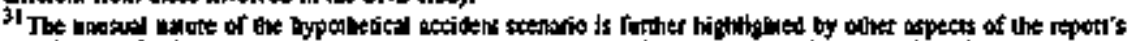

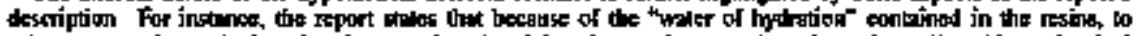

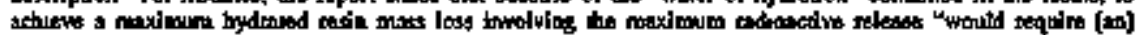

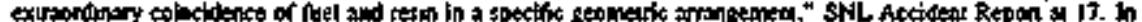

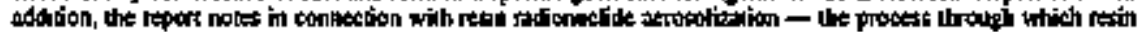

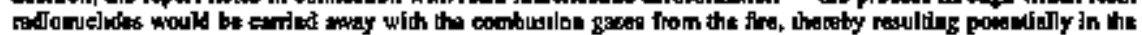

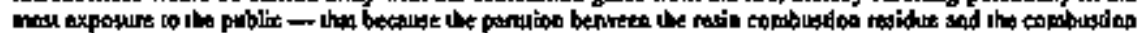

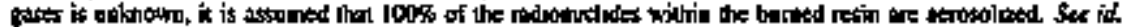


While the FGiEIS notes that "[t]he active phase of maintaining the spent fint in the pool is not considered to be part of the regulatory requirements for decommissioning, it nonetheless goes on to observe:

Considention was given to the situation where, at the ead of the reaclor operation life, it is not possthlo 10 dispose of waste off sive tor a Timited peried of time, but noc exceeding

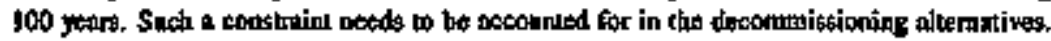
Based on an annlysis by [Bstielle Paeife Northwest Inobocatories] of the technology, safety and cost considenations on steption of decommissioning altemalives, it is concluded than SAFSTOR is an acceptably viable altenative. While DECON and convertion of the spent

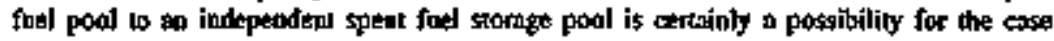
where 미 cther radloaclive wasles can be removed offstte, there does not appent lo be any

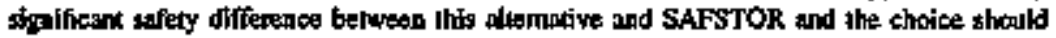
be a Lienges decision.

FGEIS at 4-20 (citation and footnote ormilted). With this environmental analysis already in the FGEIS, nothing presented by Petitioners establishes there is a material factual or legal dispute about whether an SEIS containing additional information is necessary to conform with the requirements of section $51.92(\mathrm{a})(2)$.

It also seems apparent that, while couched in terms of NEPA compliance arising from a neti to rebalance an altered alternative, what Petitioners really posit with this basis is another challenge to the Licenseets ctroice of the DECON rather than the SAFSTOR decommissioning option. In line with the Commission's guidance in CLI-96-1, 43 NRC at 8, absent a showing grounded in dose eslimates or other information that is outside the analylical boundaries of the FGEIS, such an objection does not produce a litigable issue under NEPA either.

There thas being go litigable basis for Contention E, we dismiss it as well.

\section{CONCLUSION}

Based on Petilioners' showing that (1) several of their members live and recreate close to the Yankee Rowe facility and utilize local waste shipnent rotres; (2) there is some reasonable basis for believing that their proxinity to the facility and use of local waste routes can result in an injury to their health and satery or environmental interests as those interests are protected onder the Alomic Energy Act and NEPA; and (3) those affecled members have authorized representation of their interests, Petitioners CAN and NECNP have established their standing to intervene in this proceeding. As to each of their five contentions, however, utilizing the guidance provided by the Commission in CLI-96-1, we find that Pelitioners have failed to establish either that "s genuine dispute exists with [YAEC] on a material issue of law or fact" or that the contention, if proved, would entitle them to any relief. See 10 C.F.R. $\$ 2.714(\mathrm{o})$ (2)(iit), (d)(2)(i)- 
(ii). Consequently, we must deny their intervention request and temuinate this proceeding.

For the foregoing reasons, it is, this first day of March 1996, ORDERED that:

1. The November 30, 1996 petition to jalervere and stpplemental petition to intervene of Petitioners CAN and NECNP is denied and this proceeding is dismissed.

2. In accordance with the provisions of 10 C.F.R. $\$ 2.714 a(a)$, as it rules upon an intervention petition, this Memorandurn and order may be appealed to the Commission within 10 days after it is served.

\section{THE ATOMIC SAFETY AND LICENSING BOARD \\ G. Paul Bollwerk, III, Chaiman ADMINISTRATIVE JUDGE \\ Jeny R. Kline \\ ADMINISTRATIVE JUDGE \\ Thomas S. Elleman \\ ADMINISTRATIVE JUDGE}

Rockville, Maryland

March 1, 1996 
UNITED STATES OF AMERICA NUCLEAR REGULATORY COMMISSION

\title{
ATONIC SAFETY AND LCENSNG BOAAD
}

Before Administralive Judges:

G. Paul Bollwark, Dil, Chaimian

Dr. George C. Anderson

Dr. A. Dixon Callihan

In the Matter of

Docket No. 030-31765-CivP

(ASLBP No. 95-705-01-CTyP)

(EA 94-CA6)

(Byproduct Malerlals

Llcense No. 37-28540-01)

\author{
ONCOLOQY SEAVICES \\ CORPORATHON \\ (Harrisburg, Pennsylvania)
}

March 28, 1996

\section{MEMORANDUM AND ORDER \\ (Approving Settlement Agreement and Dismissing Proceeding)}

On April 24, 1995, the NRC Staff issued an order inposing a civil penalty in the amount of $\$ 280,000$ on Oncology Services Corporation (OSC) for alleged regulalory violations relating to activitios under Byproduct Materials License No. 37-28540-01. 60 Fed. Reg. 21,560 (1995). That licenst authorized OSC to possess and ose certain byproduet materials under specifed conditions at six facilities in Pennsylvania.' The violations at issue were identified during a December 3-18, 1992 NRC inspection in conecetion with a November 1992

\footnotetext{
${ }^{3}$ LEc

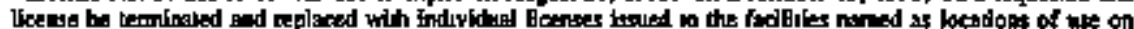

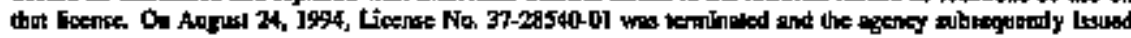

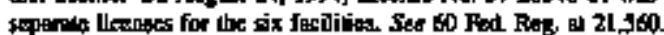

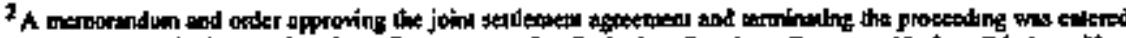

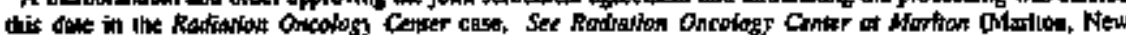
Je(12y). LBP-96-4, 43 NRC IOL (I996).
} 
radiation misadministration incident at OSC's Indiana (Pencsylvania) Regional Cancer Center (JRCC), and December 8, 1995 inspections of OSC facilities to Exton and Lehightom, Penusylvania, This proceeding was convened in response to OSC's May 18, 1995 request for a hearing regarding the civil penalty order.

By filmg dated February 12, 1996, OSC and the Staff ask that we apptove a settlement agreement they have provided and disciiss this proceeding. Their request is part of a motion filed jointly by the parties in this proceeding and the pending Radiation Oncology Center at Mariton (ROCM) adjudication, Docket

\author{
ATTACHMENT 1 \\ UNITED STATES OF AMEPICA \\ NUCLEAR REGULATORY COMMIISSION
}

In the Matter of

Dooket No, D30-31765-Civp

(ASLEP No. 94-708-01-CivP)

(EA \$4-D06)

(Byprodut Material

License $\mathrm{AO} .37-28540-01)$

ONCOLOGY SERVICES COFPORATION

In the Matter of

Docket No. 030-32493-CivP

(ASLBP No. 95-700-02-CivP)

(EA 93-072)

(Byproduct Material

License No. 29-286e5-D1)

\title{
RADIATION ONCOLOGY CENTER AT MARLTON
}

\section{JOINT SETTLEMENT AGREEMENT}

On May 31, 1994, the staff of the Nuclear Regulatory Commission (Staff) issued a Notice of Violation and Proposed Imposition of Civil Penalties (OSCNOV) to Oncology Services Corporation (OSC). Also on May 31, 1994, the Staff issued to the Radiation Oncology Center at Marlton (ROCM) a Notice of Violation and Psoposed Imposition of Civil Penalty (ROCM-NOV). Both OSC and ROCM share common ownership. On August 31, 1994, both OSC and ROCM filed responstes 10 the respective NOVs, admitting some of the violations and denying others. "Response of Oncology Services Corporation to Nolice of Violation and Proposed Impostion of Civil Penalties and Answitr to a Notice of Violation," "Response of Radiation Oncology Center at Marlton to Notice of Violation and Proposed Imposition of Civil Penalty and Answer to a Notice of Violation," Augusi 31, 1994. Both OSC and ROCM supplemented their Jesponses on Octaber 4, 1994, and on December 1, 1994, ROCM provided additional dacumentation to the NRC selative to the alleged violations.

After consideration of OSC's and ROCM's responses, the Staff, or April 24, 1995, issued an "Order Imposing Civfl Monetary Penalies, - \$280,000" 
(OSC Order) to OSC and "An Order Imposing a Civil Monetary Penalty $\$ 80,000^{\prime \prime}$ (ROCM Order) to ROCM. Oncology Services Corp., Harrisburg, PA; Order Imposing Civil Monetary Penalties, 60 Fed. Reg. 21,560 (May 2, 1995); Radiation Oncology Center at Marlion, Marlton, New Jersey: Order Imposing a Civil Monetary Penalty, 60 Fed. Reg. 21,570 (May 2, 1995).

Both ROCM and OSC requested hearings on May 18, 1995. On May 30, 1995, separale Atomic Safery and Licensing Boards were designated. Oncology Senvices Corporation, Harrisburg, Pennsylvania; Establishment of Atomic Safety and Licensing Board, 60 Fed. Reg. 29,901 (Jume 6, 1995); Radiation Oncology Center at Marlion, Marlon, New Jersey; Establishment of Atomic Safety and Licensing Board, 60 Fed. Reg. 29,901 (june 6, 1995).

The Staff, OSC, and ROCM, agree that it ts in their respective interests and in the gublic interest to setle these enforcement actions and agree to the following terms and conditions:

1. OSC and ROCM withdraw their respective requests for hearings.

2. OSC and ROCM agree to pay a single civil penalty in the anount of $\$ 140,000.00$ in twelve (12) equal monthly installments in accordance with paragragh 6 of this Seulement Agrement. In the event that payment is not received by the fifteenth of the month, in accordance with paragraph 6 , the Staff will provide written notice of such fact via facsimile transmission to the attention of Marcy E. Colkitt, General Counsel, at (412) 463-3569, with a conforming copy sent via express mail to the Offices of Marcy L. Colkitt, 176 Tutherspuings Lane, Indiana, Pennsylvania 1570 I and lies Cooper, Williamson, Fiedberg \& Jones, One Norwegian Plaza, Potsville, Pennsylvania 17901. A printed facsimile transmission report from an NRC facsimile machine is proof of the provision of such notice. In the event of a change of facsimile number, OSC and ROCM agree to promptly inform the Staff in writing of any such change and provide the new facsimile number. Any notice sent via facsimile prior to the Staff's recejpt of such notificatson of a change of facsimile number will be deemed to be in compliance with the nolice requirements of this paragraph.

3. If any instalimert remains unpaid for a period of thirty (30) days or more, provided the Staff has given the requisite notice to OSC and ROCM in accordante with the procedures described in paragraph 2 , the Staff may, in its eiscretion, consider this Settlement Agreenent as materially breached. In the event of a material breach of this Settlement Agreement, the full amotubt of the civil penalites imposed on OSC, $\$ 280,000,00$ (plus interest and admmistrative charges, less any payments already made hereunder'). will beconse due. In this tvent, OSC agrees to waive any right to contest or seck review of the imposition of the civil penaltites before the NRC or in any court. Also, in the eveat of a material breach of this Settlenent Agreement, the full amount of the civil penalty imposed on ROCM, $\$ 80,000.00$ (plus interest and adminisirative charges, less any payments already made hereunder), will becorne dve. In this event, ROCM 


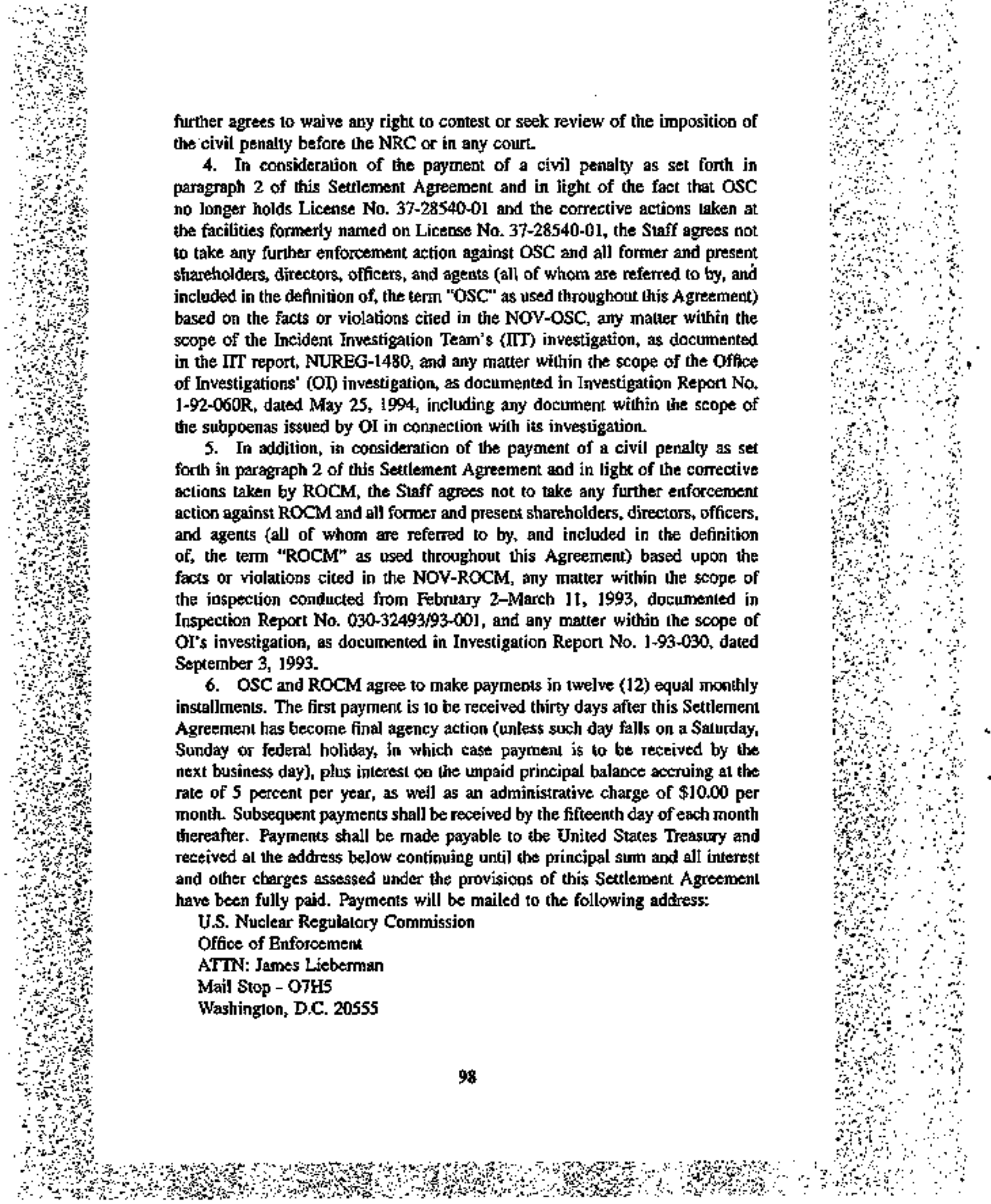


The following is a schedule of monthly installmeats:

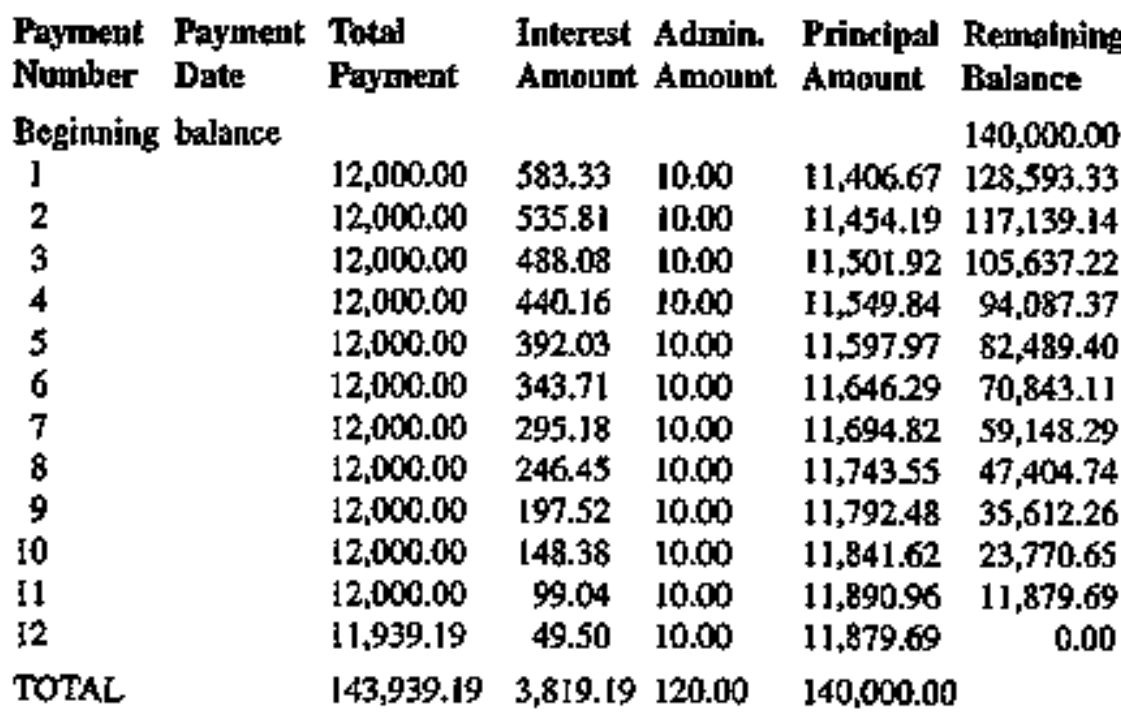

7. In the event of a malerial breach of this Settemem Agreement, OSC and ROCM agree to pay all reasonable collection costs, court costs, and attoray's fees incurred by the Nuclear Regulatory Comnission and/or the United States for any appropriate collection actions taken by the Nuclear Regulatory Commission and/or the United Stales. However, in no event will these costs oxceed $5 \%$ $(\$ 18,000)$ of the total civil penalties imposed by the \$taff's April 24, 1995 Orders.

8. Filuture or failures by the Staff to exercise any night in this Setlement Agreement with respect lo a malerial breach shall not be construed as a waiver of its right to exercise the same or any other right at any time thereafter.

9. With the exceplion of challenging the receipt of the requisite notice described in paragraph 2, in the event of a material breach of this Settlement Agreement, both OSC and ROCM do hereby anthorize and empower a United Stales Attorney, any of his or her assistants, or any attorthey for or on behalf of the NRC or the United Stales to enler and confess judgnent against OSC and ROCM for the imposed civil penatties in the amount of $\$ 280,000$ against OSC and $\$ 80,000$ against ROCM, with interest as deseribed in paragraph 6 , less payments actually made (such paymerts will be apportioned equally between OSC and ROCM), in any coert of record, Federal or Stale; 10 wajve the issuance and service of process upon both OSC and ROCM in any suit on the obligation; to waive any venue requirement in such suit; to release all errors which may interwene in eutering upon such judgment or in issuing any execution thereon; 
and to consent to immediate execution on said judgement. Both OSC and ROCM do hereby ratify and confirm all that said attorney may to by virtue hereof.

10. The Staff, OSC, and ROCM agree that this Seltitement Agreement shall pot constutute and slalt not be construed to constitute any admission or admissions in any regard by eillter OSC or ROCM of any matters set forth by the NRC in elther the NOV-OSC or NOV-ROCM.

11. The Staff, OSC, and ROCM also agree that the matters upon which the NOVs were based have not been resolved as a result of this Settlement Agreement. This Settlement Agreement shall not be relied upon by any person or other entity as proof or evidence of any of the matters set forth in the NOVs.

12. For good cause shown, the Staff may, in writing, extend the time to complete any aclion sel forth in any proviston of this Selliement Agreement.

13. The parties agree and understand that this Settement Agreement is only binding on the NRC, OSC, and ROCM, and only relates to NRC's authority to take civil enforcement action. This Setlement Agreement shall be binding upon the legal representatives, successors and assigns of each of the parties hereto.

14. The Staff, OSC, and ROCM shall jointly move the Atomic Safety and Licensing Boards designated in the above-captioned proceedings for orders approving this Seltement Agreenent and temunating the proceedings.

In Witmess Whereof, the partes have caused this Settlergent Agreement to be executed by therr authorized representauves.

\section{FOR ONCOLOGY SERVICES CORPORATION AND RADIATION ONCOLOGY CENIER AT MARLTON}

Marcy L. Colkatt

Secretary and General Coensel

for Oncology Services Corporation

and Secretary and General Counsel

for Radiation Oncology Center at Mafton

Dated at Rockvile, Maryland, this 20th day of Febratary 1996.
FOR THE NRC STAFF

Marian L. Zobler

Counsel for NRC Staff

Richard G. Bachmann Counsel for NRC Staff 
UNITED STATES OF AMERICA

NUCLEAR REGLLLATOAY COMMISSION

ATOAIC SAFETY AND LLCENSING GOARD

Before Administrative لudges:

Charles Bechhoefer, Chaimman

Dr. James C. Lamb III

Lester S. Rubenstein

In the Matter of

Docket No. 30-32493-CivP (ASLBP No. 95-709-02-CivP)

(EA 98-072)

(Byproduct Materials

License No. 29-26695-01)

\section{FADIATION ONCOLOGY CENTER \\ AT MARLTON (ROCH) \\ (Marlion, New Jersey)}

March 28, 1996

The Licensing Board approves a joint settlement agreement goversing both this civil penalty procesting and a related proceeding and terminates this proceeding. (Simultancously, the Licensing Board in the other civil penally proceeding approved the jeint agreement with respect to that proceeding. See LBP-96-3, 43 NRC 93 (1996).

\section{MEMORANDUM AND ORDER}

\section{(Approving Settlement Agreement and Terminating Proceeding)}

On April 24, 1995, the NRC Staff issued an Order Imposing Civil Penalty to Radiation Oncology Center at Martion (ROCM or Licensee). The Order sought a civil monetary penalty of $\$ 80,000$ for a violation consisting of a failure to ensure that radiation safety activities were performed in accordanco with 


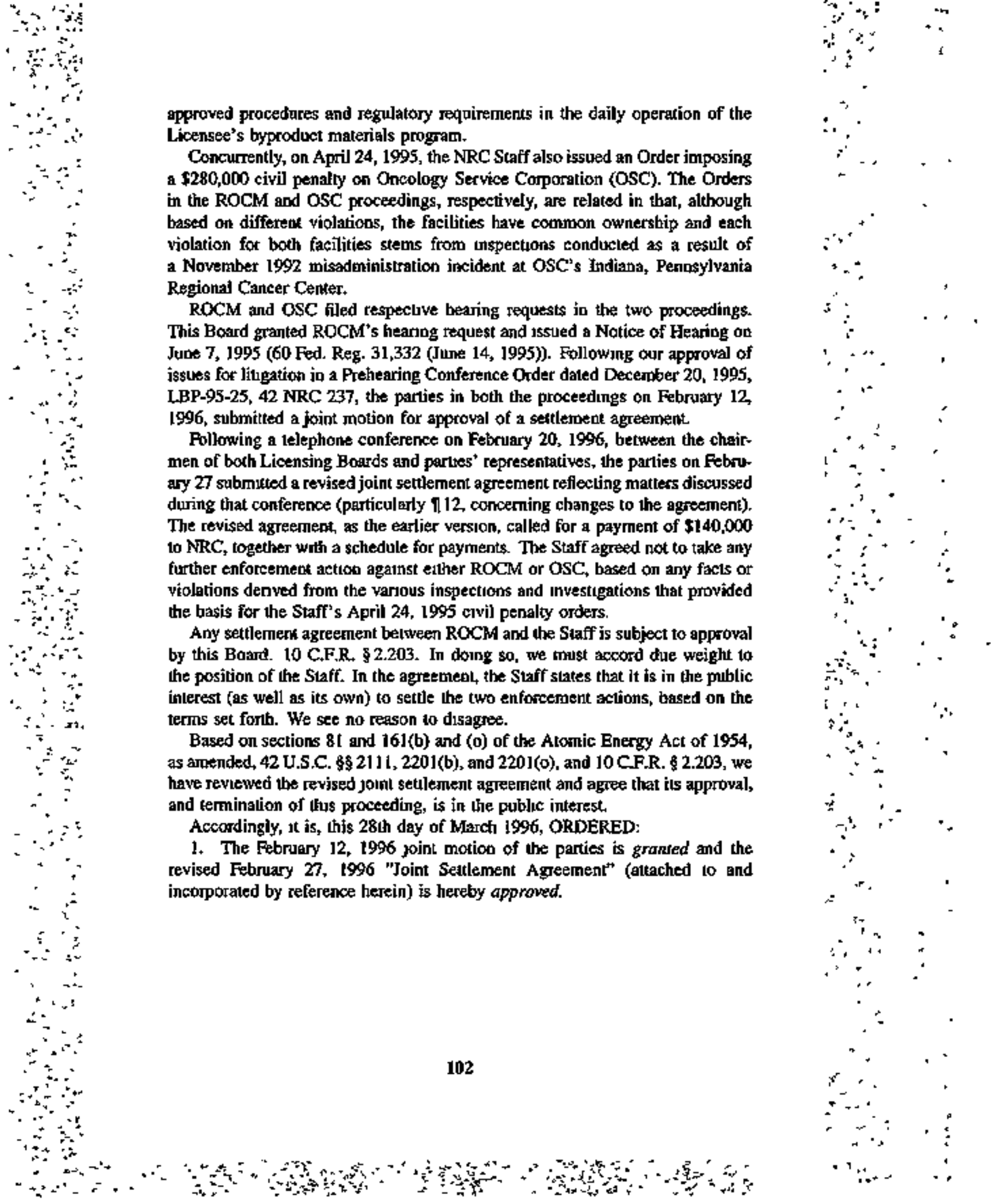


2. This proceeding is terminared.*

THE ATOMIC SAFETY AND

LICENSING BOARD

Charles Bechhoefer, Chairman ADMINISTRATTVE JUDGE

Lester S. Rubenstein ADMINISTRATIVE JUDGE

James C. Lamb III ADMINISTRATIVE JUDGE

Rockwille, Maryland, March 28, 1996

-5te LBP-96-3, 43 NRC is (I996). for gimallar arder keminding OSC proceeding.

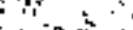

$\because n=0$

$\because \therefore \quad \because$

$\because \div \quad \therefore$
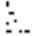

$\therefore \quad \therefore \quad \therefore$ 
(OSC Order) to OSC and "An Order Imposing a Civil Monetary Penalty \$80,000" (ROCM Order) to ROCM. Oncology Services Corp., Hartisburg PA; Order Imposing Civil Monetary Penalties, 60 Fed, Reg. 21,560 (May 2, 1995); Radiation Oncology Center of Marlion, Mariton, New Jersey; Order Imposing a Civil Monetary Penalty, 60 Fed. Reg. 21,570 (May 2, 1995).

Both ROCM and OSC requested hearings on May 18, 1995. On May 30, 1995, separate Alomic Safery and Licensigg Boards were designated. Oncology Services Corporation, Horrisburg, Pennyivania; Establlshment of Atomitc Safery and Licensing Board, 60 Fed. Reg. 29,901 (June 6, 1995); Radiation Oncology Center at Marlon, Marton, New Jersey: Establishment of Atomic Safety and Licensing Board, 60 Fed. Reg. 29,901 (June 6, 1995).

The Staft, OSC, and ROCM, agree that it is in their respective interests and in the public interest to settle these enforcenent aclions and agree to the following terms and conditions:

1. OSC and ROCM withdraw their respective requests for hearings.

2. OSC and ROCM agree to pay a single civil penaly in the amount of $\$ 140,000.00$ in twelve (12) equal monkhly instsllments in accordance with paragraph 6 of this Settlement Agreement. In the event that payment is not received by the ffteenth of the mronth, in accordance with paragraph 6 , the Staff will provide willen notice of such fact via facsimile transmission to $7 j$ the atiention of Marcy L. Colkitt, General Counsel, at (412) 463-3569, with $\because$ a conforming copy sent via express mail to the Offices of Marcy L. Colkitt, 176 Timbersprings Lane, Indiana, Pennsylvanja 15701 and Iles Cooper, Williamson, Fitedberg \& Jomes, One Norwegian Plaza, Pottsville, Peansylvania 17901. A printed facstmile transmission report from an NRC facsimile machine is proof of the provision of such notice. In the event of a change of facsimile number, $O S C$ and ROCM agree to promptly inform the Staff in writing of any such change and provide the new facsimile number. Any nolice sent via facsinilo prior to the Staff's receipt of such notitication of a change of facsimile number will be deemed to bo in compliance wilt the notice requirements of this paragragh.

3. If any instaltment remains unpaid for a pertod of thirty (30) days or mores provided the Staff has given the requisite notice to OSC and ROCM in accordance with the procedures described in paragraph 2, the Staff may, in its discretion, consider this Settlement Agreement as materially breached. In the event of a material breach of this Settement Agreennent, the full anount of the civil penalties imposed on $O S C, \$ 280,000.00$ (plus interest and administrative charges, less any payments already made berzumder), will becorne duc. In this event, OSC agrees to waive any riglt to contest or seek review of the imposition of the civil penalties before the NRC or in any court. Also, in the event of a material breach of this Settledent Agreement, the full amount of the civil penalty imposed on ROCM, $\$ 80,000,00$ (phus inlexest and administrative charges, less any payments already made hereunder), will become ofue. In this evem, ROCM 
further agrees to waive any right to contest or seek review of the inposition of the civil penalty before the NRC or in any court.

4. In consideration of the payment of a civil penalty as set forth in paragraph 2 of this Settement Agreement and in light of the fact that OSC no longer holds License No. 37-28540-01 and the corrective actions taken at the facilities formerly tamed on License No. 37-28540-01, the Staff agrees not to take any further enforcement action against OSC and all former and present shareholders, directors, officers, and agents (all of whom are refened to by, and inc[uded in the dentition of, the term "OSC" as used throughout this Agreenenl) based of the facts or violations cited in the NOV-OSC, any matler within the scope of the Incident Investigation Tearn's (111) investigation, as documented in the ITT report, NUREG-I480, and any malter within the scope of the Office of Investigarions" (ON) investigation, as documemed in Invesligation Report No. 1-92-060R, dated May 25, 1994, including any document within the scope of the subpoenas issued by $\mathrm{OI}$ in connection with ils investigation.

5. In addition, in consideration of the paymens of a civil penalty as set forth in paragraph 2 of this Setlement Agreement and in light of the corrective actions taken by ROCM, the Staff agrees not to take any further enforcement action against ROCM and al] former and present shareholders, directors, officers, and agents (all of whom are referred to by, and included in the definition of, the term "ROCM" as used throughout lhis Agreenent) based upon the facts or violations cited in the NOV-ROCM, any matter within the scope of the inspection conducted from Febsuary 2-March 1I, 1993, documented in Inspection Report No. 030-32493/93-001, and any matter within the scope of OI's investigation, as documented in Investigation Report No. 1-93-030, dated September 3, 1993.

6. OSC and ROCM agree to make payments in 1welve (12) equal monthly installments. The first paymert is to be received thirty days after this Settlement Agreement has becorne final agency action (unless such day falls on a Saturiay, Sumday or federal holiday, in which case payment is to be received by the next bessiness day), plus ixterest on the unpaid principal balance accruing at the rate of 5 percent per year, as well as an administrative charge of $\$ 10,00$ per month. Subsequent payments shall be recteived by the ffiternth day of tach month thereafier. Payments shall be made payable to the United Stales Treasury and received at the address below continuing until the principal sum ath all interest and other charges assessed under the provisions of this Settlement Agreement have been fully paid. Payments will be mailed to the following address:

U.S. Nuclear Regulatory Commission

Office of Enforcement

ATTN: James Lieberman

Mail \$top - O7H5

Washington, D.C. 20555

$\therefore, \ldots$

$: 3$
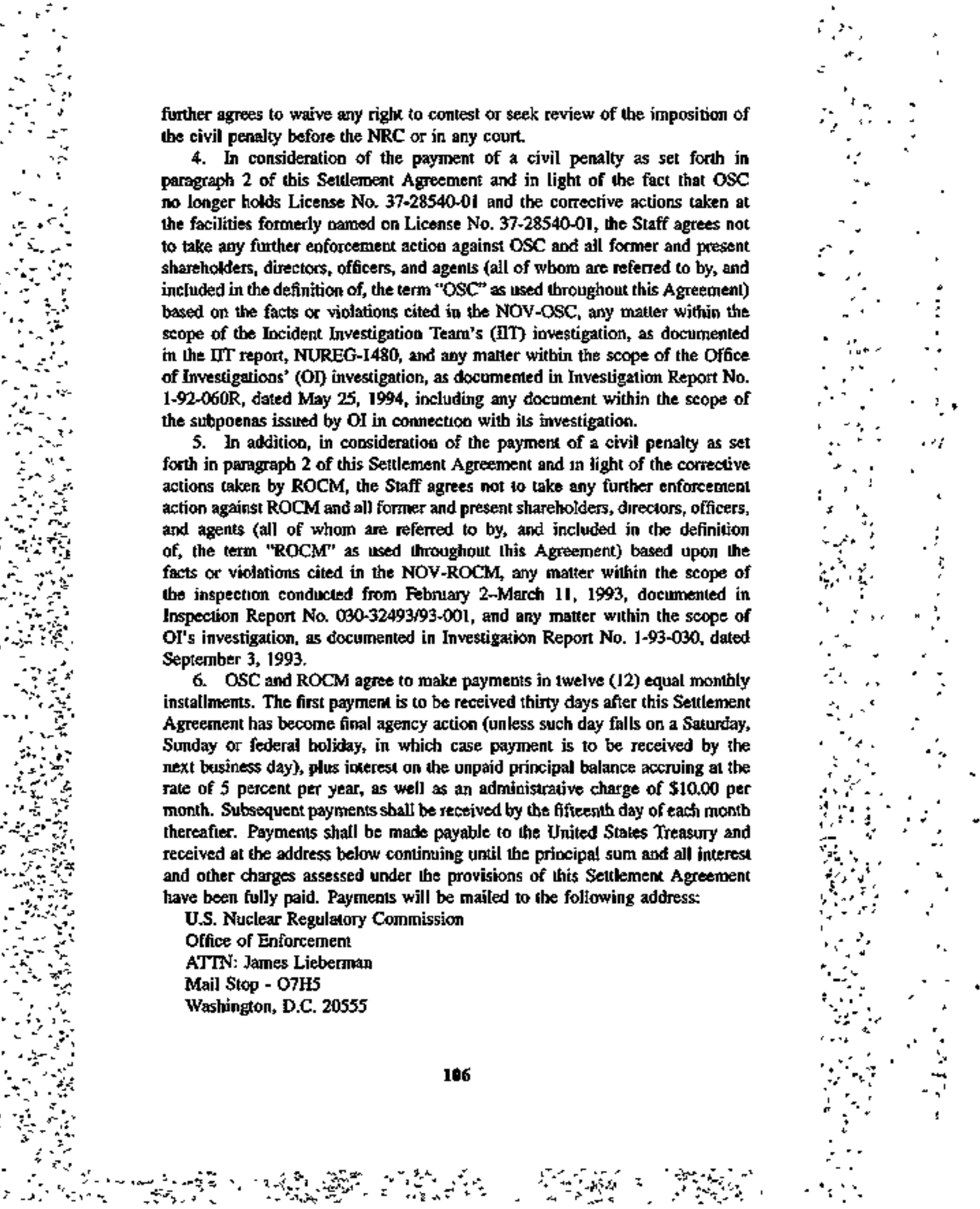
The following is a schedule of inonthly installinumos:

\begin{tabular}{|c|c|c|c|c|c|}
\hline $\begin{array}{l}\text { Payment Paymeant } \\
\text { Namber Date }\end{array}$ & $\begin{array}{l}\text { Total } \\
\text { Payment }\end{array}$ & $\begin{array}{l}\text { Interest } \\
\text { Amount }\end{array}$ & $\begin{array}{l}\text { Admin. } \\
\text { Ampount }\end{array}$ & $\begin{array}{l}\text { Priacipal } \\
\text { Amount }\end{array}$ & $\begin{array}{l}\text { Remaining } \\
\text { Balamce }\end{array}$ \\
\hline Beginning balance & & & & & $140,000.00$ \\
\hline 1 & $12,000.00$ & 583.33 & 10,00 & $11,406,67$ & $128,593,33$ \\
\hline 2 & $12,000.00$ & 535.81 & 10.00 & $11,454.19$ & $117,139.14$ \\
\hline 3 & $12,000.00$ & 488.08 & 10.00 & $11,501,92$ & $105,637,22$ \\
\hline 4 & $12,000.00$ & 440.16 & 10.00 & $11,549.84$ & $94,087,37$ \\
\hline 5 & $12,000,00$ & 392.03 & 10.00 & $11,597.97$ & $82,489.40$ \\
\hline 6 & $12,000,000$ & 343.71 & 10.00 & $11,646.29$ & $70,843.11$ \\
\hline 7 & $12,000,00$ & 295.18 & 1000 & $11,694.82$ & $59,148.29$ \\
\hline 8 & $12,000,00$ & 246.45 & 10.00 & $11,743.55$ & $47,404.74$ \\
\hline 9 & 12,00000 & 197.52 & 10.00 & $11,792.48$ & $35,612.26$ \\
\hline 10 & 12,00000 & 148.38 & 10.00 & $11,841.62$ & $23,770.65$ \\
\hline 11 & $12,000,00$ & 99.04 & 10.00 & $11,890.96$ & $11,879.69$ \\
\hline 12 & $11,939.19$ & 49.50 & 10.00 & $11,879.69$ & 0.00 \\
\hline TOTAL & $143,939.19$ & $3,819.19$ & 120.00 & $140,000.00$ & \\
\hline
\end{tabular}

7. In the ovent of a materiat bresch of this Settlement Agreement, OSC and ROCM agree to pay all reasonable collection costs, court costs, and attorney's fees incurred by the Nuclear Regulatory Commission and/or the United Stales for any appropriate collection actions taken by the Nuclear Regulatory Commission and/or the United States. However, in no event will these costs exceed 5\% $(\$ 18,000)$ of the total civil penalties imposed by the Stoff's April 24, 1995 Orders.

8. Failure or failures by the Staff to exercise any rtght in this Settlement Agreement with respect to a material breach shall not be construed as a waiver of its right to exercise the same or any other right at any time thereafter.

9. With the exception of challenging the receipt of the requisite notice described in paragraph 2 , in the eveat of a material breach of this Sectlement A greement, both OSC and ROCM do hereby authorize and empower a United Slates Allomey, any of his or her assistants, or any attomey for or on behalf of the NRC or the United States to enter and confess judgtrent ageinst OSC and ROCM for the imposed eivil penalites in the amount of \$280,000 against OSC and $\$ \$ 80,000$ against ROCM, with interest as described in paragraph $\mathbf{6}$, less payments actually made (such payments will be apportioned equally between $O S C$ and ROCM), in any court of record, Federal or State; to waive the issuance and service of process upon both OSC and ROCM in any suit on the obligation; to waive any venue requirement in such suit; to release all errors which may intervene in entering upon such judgment or in issuing smy execution thereon; 
and to consent to immediate execution on said jud gment. Both OSC and ROCM do hereby ratify and contitm all that said attomey may do by virtue hereof.

10. The Staff, OSC, and ROCM agreo that this Settlement Agremment shall not constitute and shall not be construed to constitute any adpission or admisstions in any regard by either OSC or ROCM of any matters set forth by the NRC in either the NOV-OSC or NOV-ROCM.

11. The Staff, OSC, and ROCM also agree thel the matters upon which the NOVs were based have not been resolved as a result of this Setiement Agretmeat. This Settlement Agrement shall not be redied upon by any person or other entity as proof or evidence of any of the matters set forth in the NOVs.

12. For good cause shown, the Staff may, in writing, extend the time to comptete any action set forth in any provision of this Settlement Agreement.

13. The parties agree and understand that this Settlement Agreement is only binding on the NRC, OSC, and ROCM, and only relates to NRC's authority to ake civil enforcement action. This Settlement Agreement shell be binding upon the legal representalives, successors and assigns of each of the parties bereto.

14. The Staff, OSC, and ROCM shall jointly move the Atonic Safety and Licensing Boards designated in the above-captioned proceedings for orders approving this Settlement Agreenent and terninating the proceedings.

In Witness Whereof, the parties have caused this Settlement Agreement to be exectted by their authorized representatives.

\section{FOR ONCOLOOY SERVICES CORPORATION AND RADIATION ONCOLOGY CENTER AT MARLTON}

\author{
Marcy L. Colkitt \\ Secretary and General Counsel \\ for Oncology Services Corporation \\ and Secretary and General Counsel \\ for Radiation Oncology Cerxer al Marton
}

Dated at Rockville, Maryland, this 20th day of February 1996.
FOR THE NRC STAFF

Marian L. Zobler Counsel for NRC Staff

Richard G. Bachmann Counsel for NRC Staff 


\title{
OFFICE OF NUCLEAR REACTOR REGULATION
}

\author{
Williom T. Aussell, Director
}

In the Matter of

Dockat No. 50-029

\section{YANKEE ATOBIC ELECTRIC COMPANY}

(Yankee Nuclear Power Stalton)

Warch 18, 1998

The Director of the Office of Nuclear Reactor Regulation denies a supplemental petition dated February 9, 1996, filed with the Nuclear Regulatory Commission by Citizens Awareness Network and New England Coalition on Nuclear Pollution. The supplemental pecition requests that the Commission: (1) reverse the Eebruary 2, 1996 decision of the NRC Staff on the emergency aspects of a January 17, 1996 potition filed pursuant to 10 C.F.R. $\$ 2.206$, and (2) require Yanket Atonic Electric Company to cease six unlawful decommissioning activittes and to direct the Staff to cease approving or acquiescing to such unlawful decoutnissioning activities. By Order dated February 15, 1996, the Conmission declinet to reverse the February 2, 1996 decision of the NRC Staff on the emergency aspects of the January 17, 1996 petition, and directed the NRC Slaff to address the arguments advanced by Petitioners at page 13 of the supplemenmal petition in a supplementary section 2.206 decision.

The Director denied the request to prohibit the conduct of six activities identifted at page 13 of the supplemental petition becauss they ane perntissible, prior to approval of a decommissioning phan, under the pre-1993 interpretation of the NRC's decombutissioning regulations, and thus under Citizens Awareness Network Inc, v, U.S. Nuclear Regulatory Commission and Yarkee Atomic Electric Ca. 59 F.3d 284 (1st Cir. 1995). 


\section{SUPPLEMENTAL DIRECTOR'S DECISION UNDER 10 C.F.R $\$ 2.216$}

\section{NTRODUCTION}

On Jandary 17, 1996, Citizens Awareness Network and New England Coal:ton on Nuclear Pollution (Petitioners) subruitted an "Ennergency Motion for Conpliance with Circuit Court Opinion" (petition). Petitioners requested that the United States Nuclear Regulatory Commission (NRC or Comusission) take action with respect to axtivities conducted by Yankeo Atonic Electric Company (YAEC or Licensee) at the Yankee Nuclear Power Station in Rowe, Massachusetts (Yankee Rowe or the facility). In particular, Petitioners requested that the NRC conoply with Citizens Awareness Network Inc. $v_{+}$United States Nuclear Regulatory Commission and Yankee Atomic Electric Co, 59 F.3d 284 (1st Cir. 1995) (CAN $v_{*} N R C$ ), and that the Commission immediately order YAEC not to undertake ant the Staff not to approve, and YAEC to cease, further major dismbantling activities or other decommissioning activities, unless such activities are necessary to onsure the protection of oceupational and public health and safefy. Petitionets requesled that the Commission prohtibit five of nine activities that the Licenses proposed to contuel prios to approval of a decommissioning plan, which activities were evaluated by the Staff in a letter dated Nowember 2 , 1995.

By letler dated February 2, 1995, the NRC Staff declined to take emergency action to probibit the Licensese's stipment of low-level radioactive waste, and found that Petitioners' request to prohibit four other activities was moot.

By a supplemental petition, Petitioners requested the Commission to reverse the NRC Staff's February 2, 1996 decision on the emergency aspects of the petition, and contended that the Staff had implictly approved six additional activities, which the Licenses identifted for the first time as under consideration in its IEntary 29, 1996 response to the petition, although the activities are not minor alterations to the facility. (A seventh actuvity was mentioned, but $\mathrm{cot}$ contested). See Citizens Awareness Network's and New England Coalition on Nuclear Pollution's Motion for Exercise of Plenary Compinission Authority to Reverse NRC Staff 2.206 Opinion (February 9, 1996).

By Order dated Fobruary 15, 1996, the Cotnumission directed the Licensee to provide the NRC with at least 2 weeks' advance nolice before engaging in any of the seven new activities identified at page I3 of the supplemental petition, and directed the Staff to adorress the arguments advanced by Petitioners at page 13 of the supplemental petition in a supplementary 10 C.F.R. $\$ 2.206$ docision.

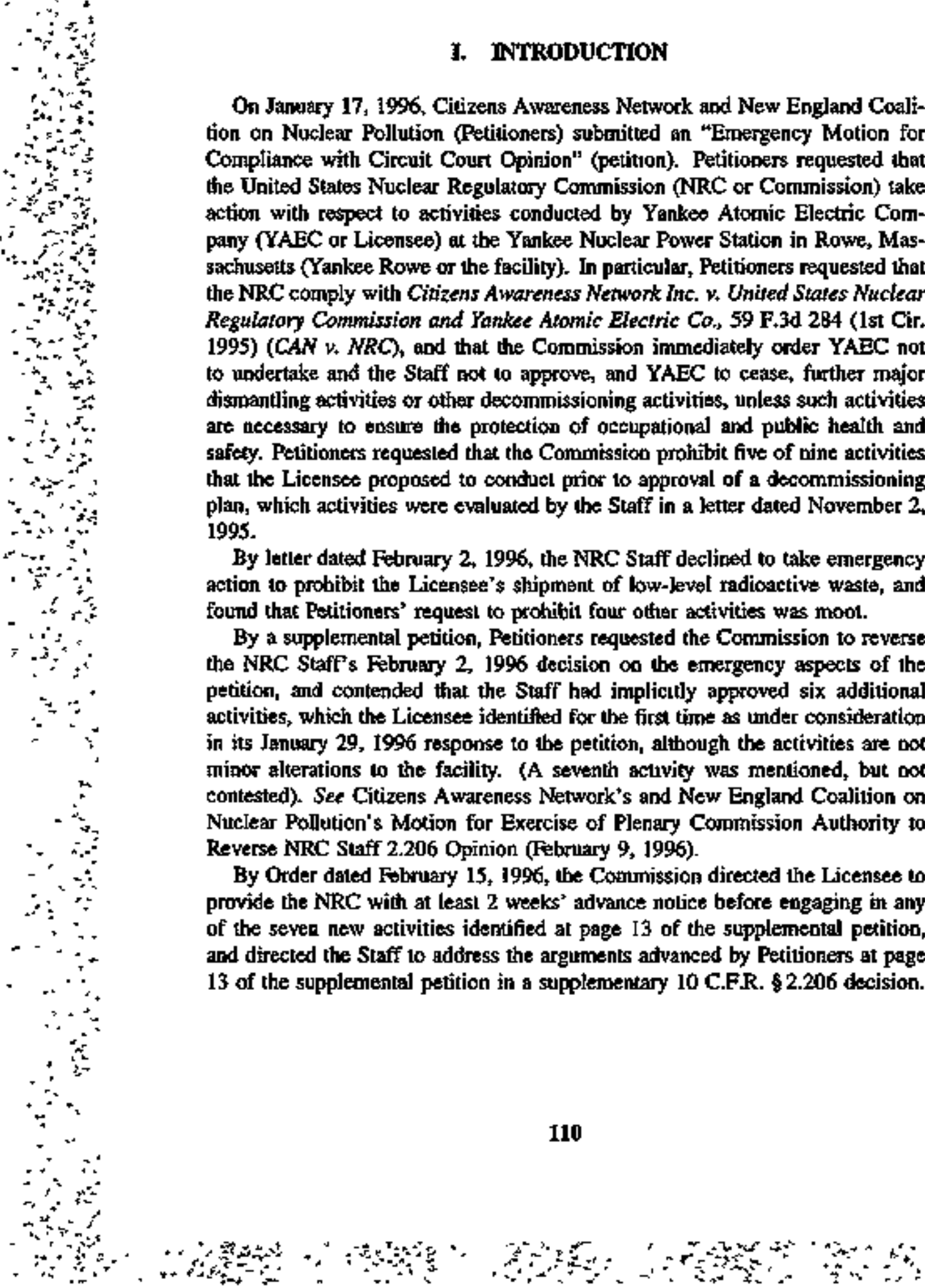


By letter dated February 16, 1996, the Licensee notitied the NRC Staff and Petitioners that YAEC intended to commence five activities between March 1, 1996, and March 25, 1996.

On Fervary 22, 1996, the Staff issued a Director's Decision (DD-96-1, 43 NRC 29) on the petition as a whole. The Staff denied Petitioners' request to prohibit the Licensete's shipments of low-level radioactive unaste, and found four other activilies consested by Petitioners to be moot.

By letter dated February 27, 1996, the NRC Staff requested the Licensee to supply information regarding the seven activities identifted by the supplemental petition, plus informetion regarding four other activities identified as ongoing in the Licensee's January 29,1996 response to the petition. The Licensee responded by letler daled February 28,1996 , providing information regarding the eleven activities plus an additional activity, removal of the spent fuel pool upender. Three activities were ongoing, and the remaining nine were scheduled to comenence between March 1, 1996, and April 22, 1996.

By letter dated March 1, 1996. the Staff nocified the Licensee that three activities scheduled to commence March 1, 1996, are permissible, before approval of a decommissioning plan, under the pre-1993 interpretation of the Commission's decommissioning regulations, and thus, that there was no reason to sake emergency action to prevent YAEC from starting or to order discontinuance of the ongoing activities. Additionally, the Staff found no health or safety reason for immediate NRC action.

The Staff has evaluated the six ongoing and planned aclivities contested by the supplemental petition and the fre additional activities identified in the Licensee's letters of January 29, 1996, February 16, 1996, and February 28, 1996. Two activities, removal of miscellaneous equipment outside the vapor container bioshield wall and preparation for decontamination' of the main coolant syslem (removal of spool pieces) were completed in February 1996. For the reasons discussed betow, the Statf has concluded that the activities are permíssible, prior to approval of a decommissioning plan, under the pre-1993 interpretation of the Commission's decommissioning regutations. Accordingly, Petitioners' request that the NRC projibit YAEC from undertaking or contiming the six contested aclivities identified at page 13 of the supplentental Motion is denied.

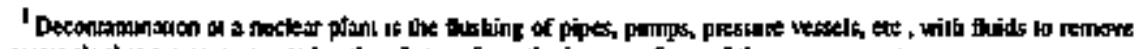

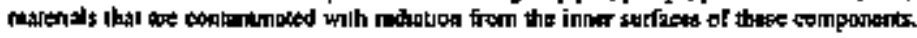

$$
\text { ; }
$$$$
\text { , }
$$$$
\text { ' }
$$$$
\text { . }
$$$$
\because
$$ 


\section{BACKGROUND}

As explaned in detail in DD-96-1, Petitioners sought judieial review of certain NRC actions, related to the Licensee's Component Retuoval Project (CRP). Petlioners chatlenged the CRP as an umpermissible ativity, before the approval of a decommissionting plan, under the pre-1993 interpretation of the Commission's decomnissioning regulations.

On July 20, 1995, the United States Court of Appeats held, in part, that the Connission had: (1) kailed to provide an opporturity for hearing to $\mathrm{CAN}_{\text {, }}$ as required by section 189 of the Atomic Energy Act, in connection with the Commission's decision to permit the CRP decommissioning activities; and (2) changed its pre-1993 interpretation of its decommissioning regulations without notce to the public and in violation of the Administrative Procedure Act. CAN v. NRC, 59 F.3d at 291-92, 292-93. The courl remanded the matter to the Cornmission for proceedings consistent with the court's opinion.

The Comntrission implespented CAN ע. NRC, in part, by issuing CLI-9514, 42 NRC 130 (1995). In CLI-95.14, the Commission reinstated its pre1993 interpretation of is decommissioning policy, required the issuance of a totice of opportumity for an adjudkatory hearing on the Yankee Rowe decommissioning plan," held that YAEC may not conduct further "Tmajor" decommissioning activaties at Yankee Rowe until approval of a decommissioning plan after completion of any requited bearng, and directed YAEC to inform the Comrnission within 14 days of the steps it is taking to come into complianee with the reinstated interpretation of the Commission's decontrissioning regulations. CLI-95-14, supra.

\section{Drscussion}

A. The Licensee's Planned and Ongoing Activities Are Permissible, Prior to Approval of a Decommissioning Plan, Under the Commission's Pre-1993 Interpretation of Its Decommissioning Regulations, and Thus Are Permissible Under $C A N$ v. NRC and CLI-95-14

Potitioners contest six of the sewen activities they mention in the supplemental pestion on the ground that they do not constilute minor alterations to the facility,

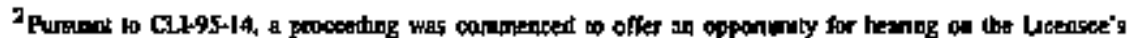

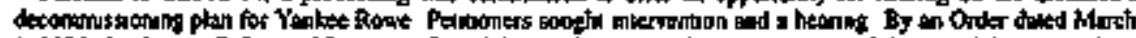

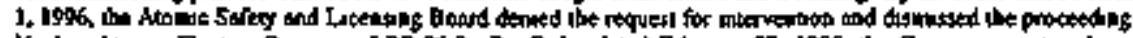

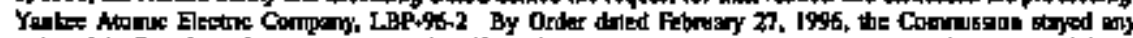

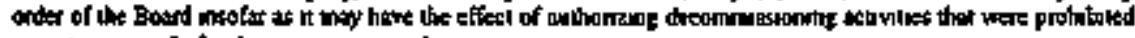

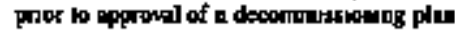

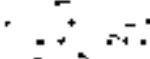

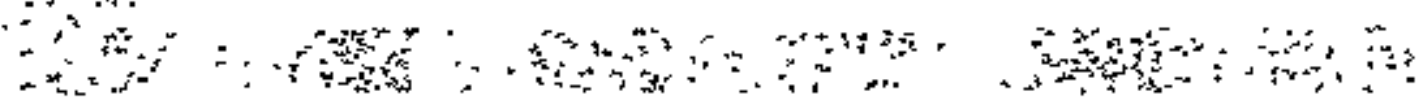


and thus are not permissible before approval of a decommissioning plan under the pre-1993 interpretation of the Commission's decommissioning regulations. Specifically, Petitioners object to: (1) consolidation of sedirsent in the reactor vesset; (2) removal of miscellaneous safety injection building equipment; (3) installation of a temporary electrical system; (4) removal of pipe on the exterior of the vapor container; (5) removal of main coolant system insulation; and (6) installation of a temporary waste processing system. Petitioners do not object to decontamination of the main coolant system. The Staft has ajso evaluated the following five activities identified by the Licensee in its tetters of January 29 , 1996, February 16, 1996, and February 28, 1996: (1) preparation for decontamination of the main coolant system - removal of spool pieces; (2) removal of miscellaneous equipment outside the vapor contaimer bioshteld wall; (3) remoral of primary auxiliary building tanks; (4) removal of turbine building insulation; and (5) removal of spent fuel pool upender.

Inder the Commission's pre-1993 interpretation of its decommissioning regulations, a licensee "may proceed with some activities such as deconkamination, minor component disassembly, and shipment and storage of spent futel if the activities are permitted by the operating license and/or $\$ 50.59^{*}$ prior to final approval of a licensee's decomtumissioning plan, ${ }^{3}$ as long as the activity does not involve major structural of other changes and does not materiakly and demonstrably affect the methods or oplions available for decommissioning or substantially increase the costs of decommissioning. Long Istand Lighting Co. (Shoreham Nuclear Power Station, Unit i), CLI-90-8, 32 NRC 201, 207 n.3 (1990); Long Island Lighting Co. (Shoreham Nuclear Power Station, Unit 1), CLI-91-2, 33 NRC 61, 73 n.5 (1991); and Sacramento Mutuicipal Vtilly District (Rancho Seco Nuclear Generating Station), CLI-92-2, 35 NRC 47. $61 \mathrm{n.7}$ (1992).

Activities such as normal maintenance and repairs, removal of smalt radioactive components for storage or shipment, and removal of components similer to that for maintenance and repair also were permitted prior to approval of a decommissioning plan unier the Commission's pre-1993 Interpretation of the Commission's decommissioning regulations. See NRC Inspection Mapual, ch. 2561. 806.06 (Issue Date: $03 / 20192$ ). 4

Under the pre-1993 interpretation of the Commission's decommissioning regulations, examples of activities that were conducted at various facilities under

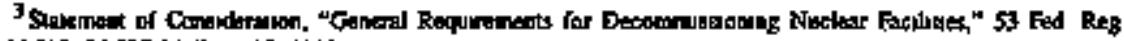
24,018, 24,025-26 (Juno 27, 1988)

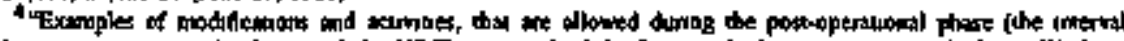

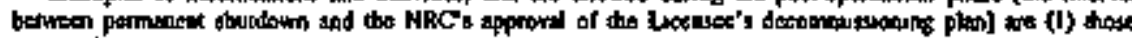

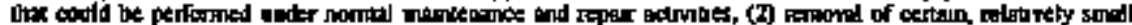

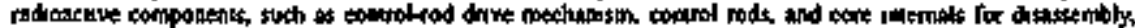

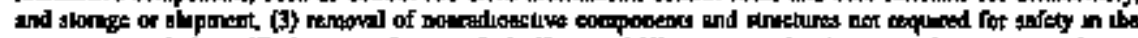

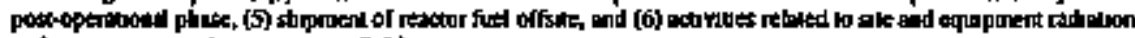

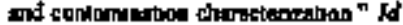


a possession-only license, and which the Staff considered permissible before approval of a decommissioning plan included:

Shorehams

a. Core bormes in biologital shietd wall

b. Core horings of the reactor pressure vessel

c. Regenerative heat exchanger removal and disassenbly

d. Various sections of reactor water cleanup system piping cut out and removed to determine effectiveness of chemical decontamination processes being used

e. Removal of approximately half of reactor pressure vessè insulation and preparation for disposal

f. Removal of tuel support castings and peripheral pieces removed and shipment offsite for disposal at Barnwell, 'South Carolina

g. Reactor water cleanup system recirculation holding pomp removed and shipped to Jantes A. FitzPatrick Nockear Power Plant

h. Control-rod drive pump shipped to Brunswick Nuckear Station

j. One full set of control-rod blade gutdes sold to Carolina Power and Light Company

j. Control-rod drives removed, cleaned, and stored in boxes for salvage

k. Process initiated for segmenting and removing reactor pressure vessel cavity shield blocks

l. Process initiated for removal of instrument racks, tubing, conduits, walkways, and pipe insulation presenting interferences for decommissioning activittes and/or removal of salvageable equipment

Fort St. Vrain ${ }^{6}$

a. Control-rod drive and orifice assemblies and control rods temoved from core during defueling and shipped offsite for processing or disposal as low-level waste

b. All helium circulators removed and shipped offsite for disposal

c. Core region constraint devices (internals) removed and approximately one-half shipped offsile for disposal

d. About 50 core metal-clad reflector blocks (top layer of core) removed and stored in fuel storage wells

e. Removal of rentaining hexagonal graphite reflector elements, defeniing elements, and metal-clad reflector blocks begun

f. Prestressed concrele reactor vessel (PCRV) lop cross-head tendons and some circumferential tendons decensioned

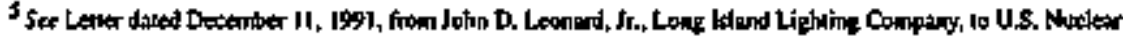
Regulatory Cormission, Dockes Ma. 50-322.

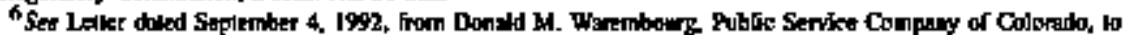

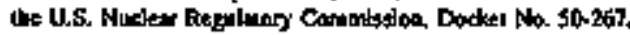


g. Sothe detensioned tendoms rentoved from PCRV

h. Work initiated to cot and remove PCRY liner cooling system piping presenting interferences to detensioning of PCRV iendions, and

i. Asbestos insulation completely rencoved from piping under PCRV

In its letter of Nowember 2, 1995, the NRC Staff identified certain activities, although not proposed by the Licenste, which may not be conducted before seapproval of a decomnissioning plan. Those activities inclsde dismantlement of systerns such as the main reactor coolant system, the lower neutron shitld tank, vessels that bave signifeant radiological conlamination, pipes, pemps and other such components and the vapor contatner (contajnment). The Staff also identified segmentation or removal of the reactor vessel from its support structure as a major dismantement not to be conducted until after the decommissioning plan is reapproved.

Upon review of the supptemental petition and the Licensee's leuers of Jankary 29, 1996, February 16, 1996, and Fubruary 28, 1996, the Staff concludes that the eleven planned and ongoing activities are permissible, prior to approval of a decommissianing plan, under the pre-1993 interpretation of the Commission's decommissioning regulations.

\section{Consolidation of Sedinem in the Reactor Vessel}

This item is a decomamtuation activity. It inwolves flushing loose radioactive material from the bottom of the reactor vessel (RV) and binding it in a solid mass inside the RV, in a centralized volume and, thus, displacing the contamination from the lower bead of the vesset. This artivity resulis in a large reduction of external dose during later removal and shipping of the vessel, antd in a reduction of external dose to personnel who must perfortn day-to-day maintenance and monitoring activities.

In view of the ahove, this activity is pecrnissible, before approval of a decommissioning plan, imder the pre-1993 interpretation of the Commission's decommissioning regulations.

\section{Removal of Misstettaneous Sqfoty Injection Building Equipment}

This activity entails the removal of mechanical and electrical equipment and some seismic reinforcement that is no longer required in the Safely Injection Building. The components involved in this activity are small, and constitute a miaor decommissionting activity. Similar activities were conducted at the Shoreham plant prior to decommissioning plan approval. See items $c$, d, and g, above. Accordingly, this activity is permissible prior to approval of a 
decommissioning plan under the pre-1993 interpretation of the Comunission's decommissioning regulations.

\section{Installation of a New Electrical System}

This activity is not decormutissioning. This activity is part of the Licensee's overall project to enharce the safety of the spent fuel pool by establishing independent systems dedicated to spent fuel pool reliability, and is consistent with NRC Bulletin 94-01, "Potential Fuel Pool Draindown Caused by Inadequate

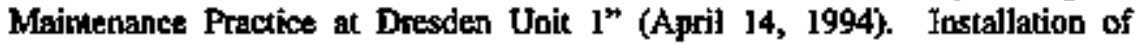
the new electrical system involves instaltation of power supply and switching capabitity to the previously installed electrical conduit, which contut installation the Staff found to be permissible prior to approval of a decommissioning plan. See DD-96+1. Section III.A.7.

Accordingly, this activity is permissible before approwal of a decommission. ing plan under the pre-1993 interpretation of the Commission's decommissioning regutations.

\section{Remowal of Pipe on the Exterior of the Vapor Cantainer}

These pipe lines are tocated outdoors beneath the vapor container and are in secondary-side systems, such as piping canrying stem from the secondary stide of the steam generator to the urbine. Bectuse this involves the removal of piping from the secondary side, it is nol a major decommissioning activity. Similar activities were conducted at the Shoreham plant (see items d and $\mathrm{g}$, above) and at the fort St. Vrain plant (see item $b_{4}$ above) prior to approval of the decommussioning plans.

In view of the above, this activity is permissible, before approval of a decomurissioning plan, umder the pre-1993 interpretation of the Comnission's deconsmissioning regulations.

\section{Rentowal of Matin Coolant System Instatation}

This insulation will not be removed until after the decoriamination of the main coolant system. This insulation is not a major component and its removal is, therefore, not a major decommissioning acúvity. Similar activities were conducted at the Shoreham plant (see item e, above) and at the Fort St. Vrain plant (see ilem $j$, above) prior to approval of the decommissioning pians.

In view of the sbove, this activity is permissible, before approval of a decommissioning plan, ander the pre-1993 interpretation of the Commission's decommissioning regulations.

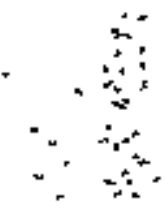

$\therefore ;$
$\therefore=$
$\therefore=$ 


\section{Installation of a Tenporary Waste Processing System}

This activity is not decommissioning. It is permitted by the Defueled Tecbnical Specifications, an appendix to the POI. The activity involves installation of a liquid waste processing system designed to process spent fuel poot water by removing contaminants. The aclivity will increase assurance of satisfactory long-term operztion of the spent fuel pool and is, therefore, a safety ephancement.

In view of the obove, this activity is permissible, before approval of a decommissioning plan, under the pre-1993 interpretation of the Commission's decommissioning regulations.

\section{Prepardion for Decontamination of the Main Coolant System - Removal of Sposl Pieces}

This is a decontamination activity that involved the removal of eight spool pieces, and was completed in February 1996. It was part of an ongoing project, preparation of pipe flanges for the chemical decontanination of the main coolant system.

Because this action is in preparation for decontamination and without which decontamination could not proceed, this activity is permissible. Decontamination is permissible, before approval of a decommissioning plan, wnder the pre1993 interpretation of the Commission's decommissioning regulations. In any event, the petition, insofar as it can be inferred to request action in this matter, is moor.

\section{Removal of Misceltoneous Equipment Outside the Vapor Container Bitoshield Wall}

This activity involved the resnowal of heating and ventilating equipment from the Vapor Contininer, and was completed in mid-February 1996. The components removed are minor and do not constitule a major decommissioning activity. Sirnilar activitjes were conducted at the Showeham plant prior to approval of the decommissioning plan. Sez trems $c$ and d, above.

Accordingly, this activity is permissible, before approval of a decommissioning plan, under the pre-1993 interpretation of the Commission's decommissioning regulations. In any event, the pefítion, insofar as it can be inferred to request action in this matter, is moot. 


\section{Removal of Primary Auxitiary Building Tanks}

This activity involves the removal of four low-pressure or drain tanks from the primary auxiliary building, because they ane not needed to stpport operation of the spent fuel pool. Two of the tanks were removed during February 1996. Similar activities were conducted at the Shorebam plant prior to approval of the decommissioning plan. See items $\mathrm{c}, \mathrm{d}_{\text {, }}$ and $\mathrm{g}$, above. This is not a major decommissioning aclivity because the renoved equipment involves minor components.

In view of the abowe, this activity is permissible, before approval of a docommissioning plan, under the pre-1993 inlerprelation of the Commission's decomonissioning regulations.

\section{Removal of Turbine Bullding Insulation}

This is an ongoing activity involving the removal of mon-radioactive material from a noncontaminated area of the plant. This is not a decommissioning activity.

Accordingly, this activity is permitssible, before approval of a decompinissioning plan, under the pre-1993 joterpretation of tine Commisston's decommissioning regulations.

\section{I1. Removal of Spent Fuel Poot U Dendtar}

This deviee was used during reactor operations to transfer fuel, during relosd outages, into the vapor contsiner. The upender is not needed to support storage of fuel in the spent fael pool. The upender is not a major component or structure and, therefore, this is not a major deconosissioning activity. Sirmilar activities were condusted at the Shoreham plant (see items $d$ and $f$, abowe) and at Fort St. Vrain (see item a, above) prior to spproval of the decommussioning plan.

In view of the above, this activity is permissible, before approval of a decommissioning plan, under the pre-1993 interpretation of the Commission's decommissioning regulations.

\section{B. The Eleven Ongoing and Planned Activities Wit Neither Individually nor Collectively Substantially Increase the Costs of Decommissioning}

YAEC estimates the cost of the six activities contested by Petitioners and the five additional plannex and ongoing activities to be approximpately $\$ 6.0$ million.? YAEC estimates the cost of the proviously contested five activitas to be $\$ 6.5$

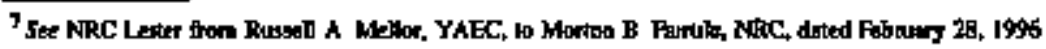


miltion. See DD-96-1, Section III.B. The toala cost of all wetivities that have been evaltrated by the Staff is approximately $\$ 12.5$ miltion or $3.4 \%$ of the estimated $\$ 368.8$ million total decormixsioning cost. It would be speculative to conclude that the decomnissioning method proposed by Petitioners, SAFSTOR, would be less expensive. Moreover, there is no evidence that the conbined activities will give rise to consequences that will increase the total cost of decommissioning. Thus, the Staff concludes that there is no evidence the combined activities will substantially increase the casts of deconminissioning.

\section{The Autvities Coutested by Petitioners Will Nelther Indlividually nor Collectively Demonstrably Affeet the Methoils or Options Avilable for Decommissioning}

As the Stafi explained in DD-96-1, the criteria for determining whether the Licensee's planmed and ongoing activities will demonstrably affect the methods or options available for deccmmissioning bave not been well defined. During review of the petition and the supplemental petition, the NRC Staff has continued to examine the question of whether the Licensee's activities will demonstrably affect the methods or options available for decommissioning. In this case, the Staff has now atso compared the radiation dose involved in the contested activities with the radiation doses estimated for decommissioning of the Licensee's facility. This is because, under Petitioners' theory regarding the choice of the decommissioning option, as we understand it, it seens that adoplion of a different decommissioning option would most likely be requited to reduce dose.

The Licensee estimales that the radiation dose inwolved in the six activities contested by the supplemental petition is 23.6 person-rem. The Licensee estimates that the radiation dose involved in shipment of low-level sadioactive waste, conlested in the petition, is 57 person-sem. The Licensee estirnates that the radiation dose involved in the other four activities contested by the petition is 24,7 person-rem. ${ }^{\text {lo }}$ Accordingly, the radiation dose involved in all activities contested

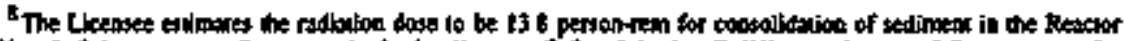

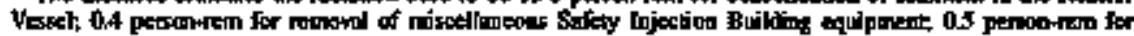

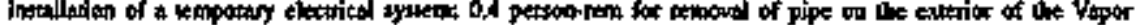

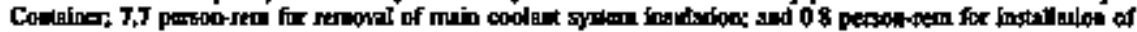

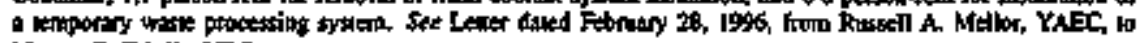
Morton B. Fintik NEC.

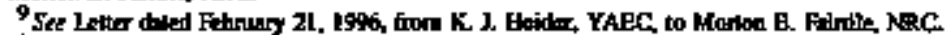

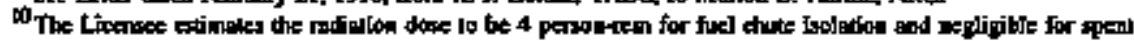

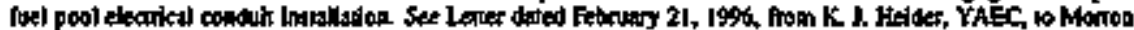

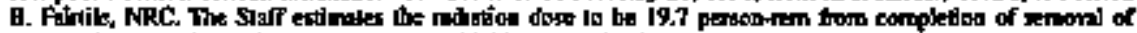

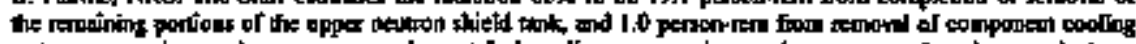

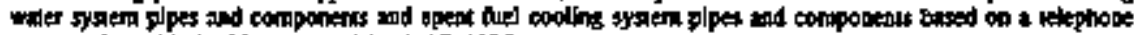

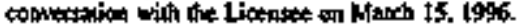


by Petitioners is approximately 65.3 person-rem. Thus, the ostimaled dose from the contested attivities is less than $10 \%$ of the total 755 person-Iem estinate for total radiation exposure from decormmissioning Yanke Rowe," The Staff estimates that the remaining estimated dose from decommissioning activities at Yankee Rowe is, at the most, approximately 358 person-rem.12 Thus the estimated dose from the activities contested by Peticioners is approximately 18.3\% of the remenning dose from decommissioning the facility. ${ }^{13}$ Accordingly, the Siaff concludes that the contested activities will not demonstrably affect the methods and options available for decommissioning.

It is not possibte to determine with precision how much of the 65.3 personrem itwolved in the contested activities might be avoikable by using the SAFSTOR oplion, i.e., by delaymg completion of thost activities for several docedes to allow for radioaclive docay. But even of the entire 65.3 person-rem could be courted as part of the potential SAFSTOR dose savings (an unlikely situation), the SAFSTOR dose savings slitl availabte is substantially more than the 65.3 person-rem "lost" by carrying out the contested activities now. Thus, even in an unlskely worst case, the SAFSTOR option would be substantially preserved. Accordingly, the Stafi concludes that the contested activities wil] not demonstratly affect the methods and options available for decomnissioning,

In sum, the NRC Staff will not take action to halt relatively minor YAEC activities, many of which are closely simflar to ones allowed at Shoreham and Fl. St. Vrain, where there is no evidence that these activulies are consuming a significant portion of the remaining radioactive dose at Yankee Rowe. In the Staff's judgment, the prohibition against dismanlling major systems, such as the reactor vessel and other resctor components with substantial contamination, ${ }^{\text {th }}$ sufficiently preserves the possibility of ultinately moving to the SAFSTOR option, should that be the result of the still-petuting challenge to YAEC's decommissioning plan.

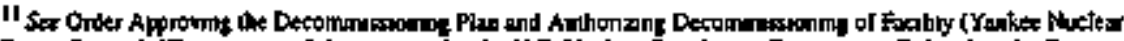

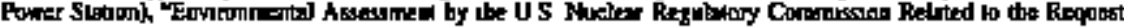

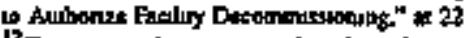

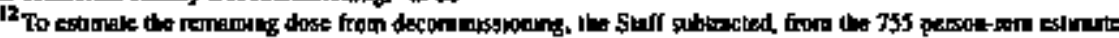

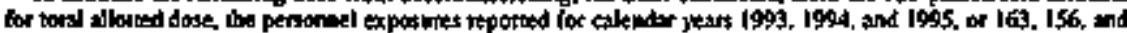

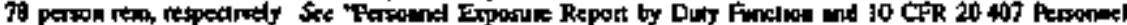

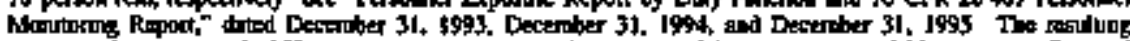

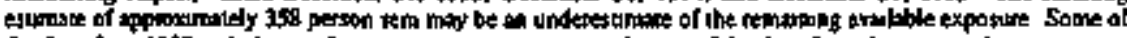

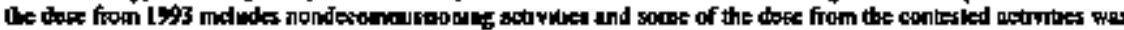

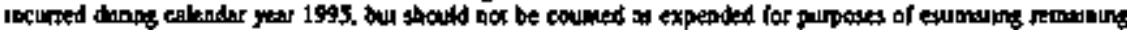
dose

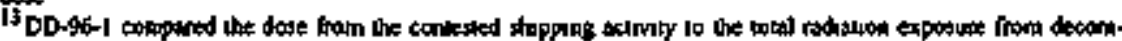

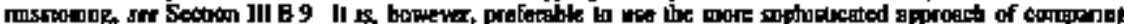

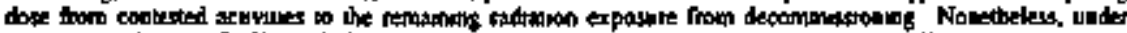

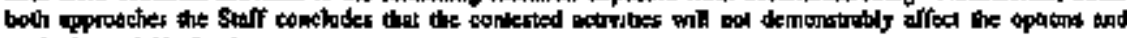

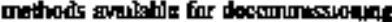

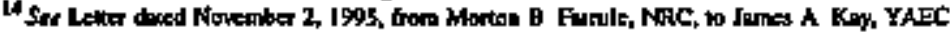

in $i=0$

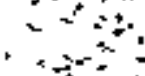

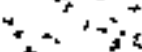

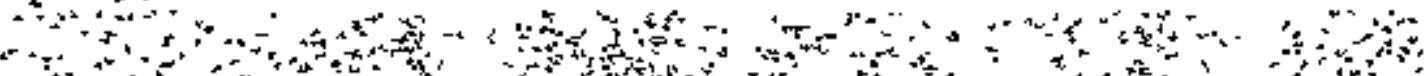

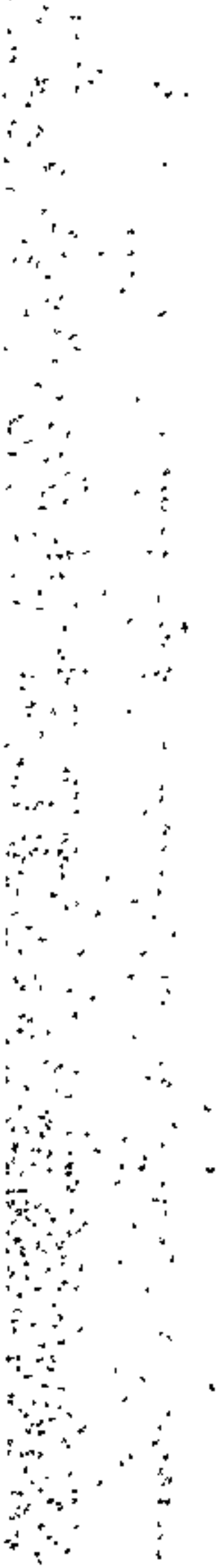




\section{CONCLUSION}

For the reasons given above, Petitioner's request to prohibit six activities is denied. Those activities, plus an additional fiwe activities identified by the Licensee as plansed or ongoing, are permissible prior to approval of a decommissioning plan under the pre-[993 interpretation of the Commission's decommissioning regulations.

As provided by 10 C.F.R $\$ 2.206(c)$, a copy of this Decision will be filed with the Secretary of the Commission for the Conunssion's revew. The Decision will becone the final action of the Commussion 25 days after issuance, unless the Commission on its own motion institutes neview of the Decision within that time.

\section{FOR THE NUCLEAR} REGULATORY COMMISSTON

Dated at Rockville, Maryland

$\because \quad$ this 18th day of March 3996.

Wultam T. Russell, Ditector

Office of Nuclear Reacior

Regulation

$\therefore 1$

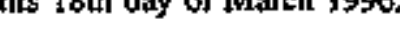

$+$

$\therefore \therefore$

:

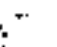

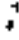

7

$\therefore$ 
UNTED STATES OF AMERICA

NUCLEAR REGULATORY COMMISSION

COUMUSFIONERS:

Shirley Ann Jackson, Chairman

Kenneth C. Rogers

Greta J. Divers

In the Matter of

Docket No. 50-029

(For Relief Uncler

10 C.F.R. \$2.206)

YANKEE ATOMIC ELECTRIC

COLPANY

(Yenkee Nutlear Power Station)

Aprll 1, 1996

The Commission reviews, stz sponte, the denial by the Director of the Office of Nuclear Reactor Regulation, under 10 C.F.R. \$ 2.206, of two emergency motions filed by Petitioners challenging activities by the Licensee in decommissioning the Yankee Nuclear Power Station. These petitions follow the Commission's reinstatement of its pre-1993 interpretation of NRC decomnissioning regulations, which prohibit a licensee from undertaking "major" decommissioning activities pending NRC approval and prior to the opportunity for a hearing.

The Commission affirms the Director's Decisions, finding no abuse of discretion. The Conunission issues uhis Memorandum Opinion to describe the reasons why it has decided not to disturb the Director's denisal of the two petitions. The two decisions now become final agency action in this malter.

\section{NRC: SUPERVISORY AUTHORTTY}

The Commission retgins plenary abthority to review Director's decisions. 10 C.F.R \&2.206(c)(1). 


\section{NRC: SUPERVISORY AUTHORITY}

NRC regulations specifically provide that the Cornmission will not entertain appeals from the Director's decision, see 10 C.F.R. \$2.206(c)(2) (1995); however, the Commission may undertake sua sponte review of each deniaj of a 2.206 petition to ensure that the Director has not abused his diseretion. See 10 C.F.R $\$ 2.206(c)(1)(1995)$.

\section{NRC: AUTHORITY}

If the Conmission takes no action to reverse or modify a Director's decision within twerty-five (25) days of issuance of the decision, it becomes final agency action. 10 C.F.R. \$2.206(c)(1).

\section{NRC: AUTHORITY}

The Commission can extend the sud sponte review lime to consider whether it will take feview of a Director's decision.

\section{NRC: HEALTH AND SAFETY RESPONSIBILITES}

Where there is no evidence that potential small oceupationat exposures will violate Commission regulations in 10 C.F.R. Part 20, the Commission cannot find pnblic health and safety hazards justifying an enforcenent action to halt a licensee's dectonurissioning activities.

\section{NRC: DECOMMISSIONING}

It is clear from past Commission statements and from ptior NRC \$laff practice that some "preliminary" or "Ininor" activities bave always been permitted in advance of NRC approval of a decomunissioning plan.

\section{NRC: DECOMMISSTONING}

Although the Commisstion did not explicitly linit, in its Statement of Considerations accompanying the 1988 decommissioning rule changes, the scope of decontamination allowed, it is clear that a ticensete may not complets decommissioning prior to NRC approval by simply "decontaninating" the entitre factlity. But, it is equally clear that some decontamination is allowed.

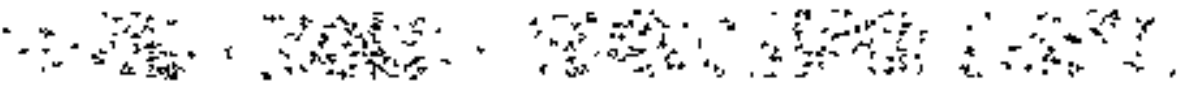




\section{NRC: DECOMMISSIONING}

While the Commission has not had occasion to define terms such as "majos" dismantling in prior contested decommissioning cases, such as Shoreham and Rancho Seco, the Comnission has consistently contenplated that a ticensee could conduct a range of activities that were not "blajos" in advance of decommisstoning plan approval.

\section{NRC: DECOMMISSIONING}

Actual pre-1993 practice at shutdown plants was the undertaking of some minor disassembly and decontamination prior to deconmissioning plan approval, and the NRC elecled not lo interfere with those activities.

\section{REGULATIONS: INTERPRETATION}

Agency practice, of course, is one indicator of how an agency interprets its regulations. See Power Reactor Development Co. v. International Union, 367 $\because \quad$ U.S. 396, 408 (1961).

\section{NRC: DECOMAISSIONING}

The NRC's Statement of Considerations for the 1988 decommisstioning rule and its pro-1993 decistons and pratice contemplated that a ticensere would be able to conduct some minor or prelinisary work ptio to aporoval of a decommissioning plan. Clearly, bowever, at \$ome point such work is no longer "minor" or may vitiate decommissioning alternatives. At that point a licensee must cease work pending NRC approval of the decommissioning plan following any hearing that hes been requested on the plan.

\section{NRC: DECOMMISSIONING}

Further Conmission action to develop and enforce more precise guidelines on what activities can or cannot be done prior to decomurissioning plan approval would not be an effective use of limited NRC resources, based on a single case and given the likely isstuance in the neer future of a new decommissioning rale.

\section{NRC: DECOMMISSIONENG}

Where the estimated person-rem exposure from a licensects minor decommissioning activilies represents a ressonably small portion of the total estimated dose originally available for possible SAFSTOR treatment, the undertaking of 
those deconmmissioning activities does not compromise a meaningful SAFSTOR option or the bearing process in which petitioners are participating.

\section{NRC: DECOMMISSIONING}

The Commission will halt decommissioning actovities, "Jninor" or not, that indıvidually or cumulatively threaten the continued viability of the SAFSTOR decommissioning alternative when it is the subject of an adjudicatory hearing.

\section{MEMORANDUM AND ORDER}

\section{INTRODUCTION}

This matter is before the Commission on stua sponte revrew of two Director's Decisions issued by the Director of the Office of Nuclear Reactor Regulation under 10 C.F.R. \$2.206 (1995). These two decisions are DD-96-1, 43 NRC 29 (1996), and DD-96-2, 43 NRC 109 (1996), as a supplement to DD-96-1. These decisions were in response to two pleaslings ${ }^{1}$ filed by the Cittzens Awareness Network and the New England Coalition on Nuclear Pollotion (eollectively "Petitioners"), who bave challenged the plan by which the Yanke Atomic Electric Company ("YAEC") proposes to decommission the Yankee Nuclear Power Station ("Yankee NPS"), located near Rowe, Massachusetts. YAEC has an NRC license to possess, but not operate, the Yankee NPS facility.

We referred both pleadings to the Staft for considerathon under section 2,206. See Unpublishied Orders in this docken dated Jamuary 23, 1996, and Fobnuary 15,1996 . In the latter order we also declined to reverse the Staff's denial of emergency relief, dated February 2, 1996, which had been requested in the Petitioners' first pleading and the dential of which haxt been challenged in the Petutioners' second pleading. 2 In both onders we stated that we retained plepary authority to revtew the Director's Decisions, see 10 C.F.R. $\$ 2.206$ (c)(1), and that we would take appropriate action if we found that our regulations were being violated.

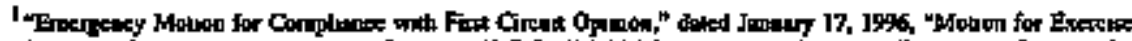

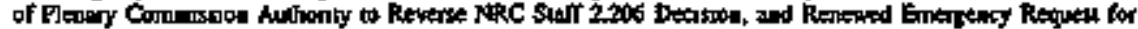

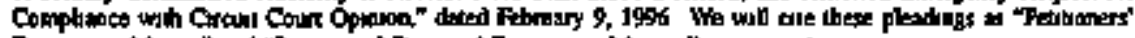

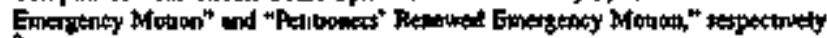

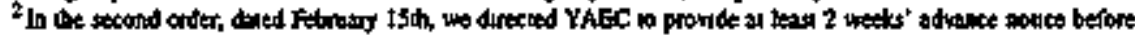

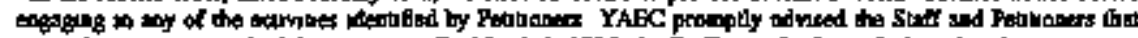

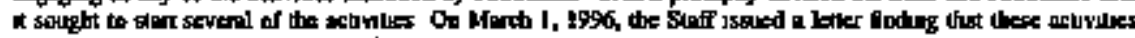

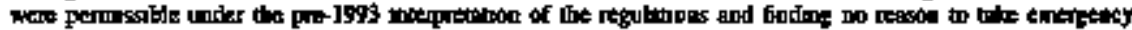
mowos ro proveat these searised
} 


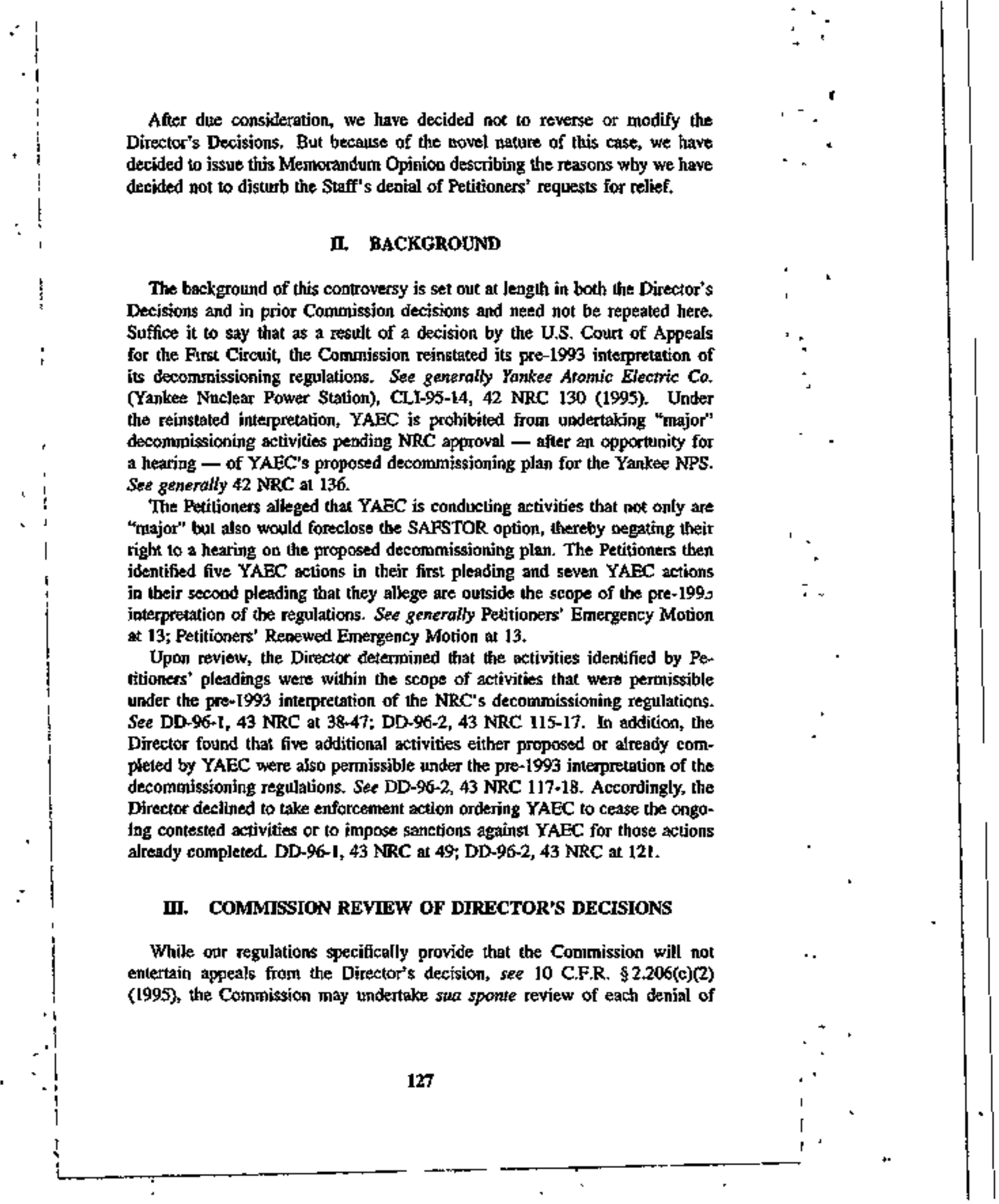


a 2.206 petition to ensure that the Director has not abused his discretion. Ste 10 C.F.R. \$2.206(c)(l) (1995). If the Contmission takes no action to reverse or modify the Director's Decision within twenty-five (25) days of issujug the decision, it becones final agency action. Id. Here, to allow us to review these two Director's Decisions together, we have extended the sua sponte review period for DD-96-1 for a brief period."

\section{ANALYSS}

\section{A. The Contested Activtties Do Not Constitute a Threat to the Public Heallh and Safety}

The Petitioners do not allege in either pleading that the contested activities constitute an immunent threat to the public health and safety. Moreover, it is clear from a review of the two Director's Decisions that the only potertial radiation doses could come from small occupational exposure in the plant and from shipment of low-level waste to a disposal facility. There is no evidence that these exposures will violate Cominission tegutations in 10 C.F.R. Part 20, thich specifies maximum limins for public and oceupational exposure, or cause any imenizent or substantual health and saiely hazard. Accordingly, we find no public health and safery hazard justifying an enforcement action halting YAEC's activities.

\section{B. The Director's Decisions Are Reasonable}

One problem that faced the Director in considering the contested activities was the absence of clear prior Cormuission guidance on what specific activities are perpissible prior to approval of a decommussioning plan. But it is elear from past Commission statements and from prior NRC Staff practice that some "preliminary" or "minor" actjvities have always been permitted in advance of NRC approval of a decommissioning plan.

First, the \$tatement of Constiderations accompanying our (988s decoummissioning rule changes explicilly allowed licensees to tproceed with some activities such as decontamination [and] minor component disassembly . . . if those activities are permitted by the . . . license and/or \$ 50.59." 53 Fed. Reg. 24,018, 24,026 (June 27, 1988). However, we did not define the word "munor" and we did not place any explicit limit on the scope of "decontansination." Clearly, a licensee nizy not complete decommissioning priox to approval of a dexommis-

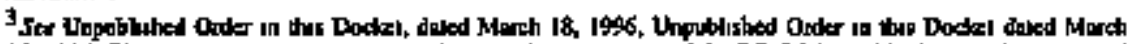

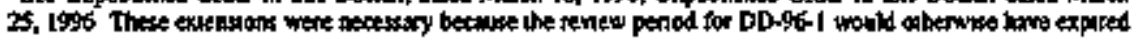

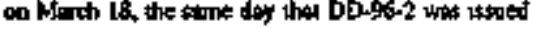

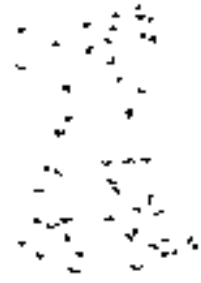


sioning plan by simply "decontaminating" the entire facility. But it is equally clear that some decontamination is allowed.

Second, while our pre-1993 guidance directed licensees to refrain from actions that would "materially and demonstrably" affect decommissioning options or "substantially increase" decomnissioning costs, Long Island Lighting Co. (Shoreham Nuxlear Power Station, Unit 1), CLI-90-8, 32 NRC 201, 207 n.3 (1990), we never have had occasion to define these terms. Likewise, while we held that "major dismantling and other activities that constitute decomnissioning must await NRC approval of a decommissioning plan[]" see Long Island Lighting Co. (Shoreham Nuclear Power Station, Unic 1), CLI-91-2, 33 NRC 61, 73 n.5 (1991); Sacromento Muntcipal Utility Distriet (Rancho Seco Nuclear Generating Station), CLL-92-2, 35 NRC 47, 61 n.7 (1992), we never have had occasion to define further what these phrases mean.4 But one thing is apparent: The Commission consistently contemplated that a licensee could conchut a range of activities that were nol "major" in advance of decommissioning plan approval.

Third, as the Director has stressed, acwal pre-1993 practice at shutdown plants such as Shorehan and Fort St Vrain was to undertake some minos disassembly and decontamination prior to decommissioning plan approval. See, e.g., DD-96-1, 43 NRC at 35-37; DD-96-2, 43 NRC at 113-15. The NRC saw no problem wilh such activities and elected not to interfere with them. The Director found that many of the activities reviewed in DD-96-1 and DD-96-2 are quite similar to the activities that the NRC did not hall in those earlier cases. See, e.g. DD-96-2, $43 \mathrm{NRC}$ at 116. Agency practice, of course, is one indicator of how an agency interprets its regulations. See Power Reactor Development Co. v. Intemational Union, 367 U.S. 396, 408 (1961); see also Marin v. OSHRC, 499 U.S. 144, 156-57 (1991).

In sum, the Statement of Considerations for the 1988 decommissioning rule and our pre-1993 decisions and practice contemplated that a licensee would be able to conduce some minor preliminary work prior to approval of a decommissioning plar. Clearly, however, at some point such work is no longer "minor" or may vitiate decommissioning alternatives. At that point a licensee Inust cease work pending NRC approval of the decommissioning plan following any hearing that has been requested on the plan.

Given this state of affairs, we conclude that the activities reviewed in the two decisions before us today may reasonably be viewed as within the scope of activities that are pertulissible under the pre-1993 interpretation of our regulations. The oyerall scope of the contested activities does not constitute

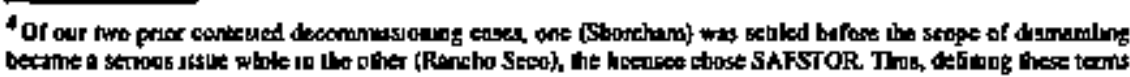
her newit bean required 
so large a portion of the overall decombrissioning project that it compromises the decorumussioning plan approval procedures. See Part C, infra. And, as the Ditector explained, these activities (individually and collectively) are quite minor and, indeed, very similar to those utwdertaken at Shorebam and Fort $\$$. Vrain under the pre-1993 interpretation of the decommissioning regulations.

Further Commission action now to fine-tune the protess would require development and enforcement of more precise guidelines on what activities cen or cannot be done prior to decomutssioning plas approval. But this would not be a sensible allocation of linited agency respurces, given (1) the alreadycompleted activities at Yankee NPS (doring the time prior to the count of appeals decision and the Comnission's eesponse to it in CLI-95-14), and (2) tie posture of the adjudication (with a Licensing Board decision dismissing Peticioners' contentions now on appeal to tie Commisston), and (3) the likely issuance in the near future of a new Combrission rule substantially altering the process accompanying decommissioning. We are loath to expend additional Commission and Staff Jesources on a single case that ratses no imminent public bealch and safety concerns. Such linited agency resources are far better used elsewhere, such as overseeing cumrently operating planis.

Thus, the Commission sees no need to second-guess the \$(aff's reasonable judganents in the peculiar circumstances of this case.

\section{Despite the Dental of Relief, Major Decommissining Activities A wait Approval of the Hecommissionng Plan}

Neither DD-96-1 nor DD-96-2 relaxes the strict guidelines issued by the Staff to YAEC in the aftermath of CLI-95-14. Those guidelines expressly probibit YAEC fron dismantling those najor systerns or conponents still remaining at Yankee NPS, such as the quain reactor coolant system, the lower peutron shield tank, and the reactor vessel itself. See Letler from Morton B. Fairtile, NRC, to James A. Kay. YAEC (Nov. 2, 1995). The Director reaffurmed those stria guidelines in his most recent decisions. See DD-96-1, 43 NRC at 35; DD-96-2, $43 \mathrm{NRC}$ at $115,120$.

As the Director indicated in DD-96-2, the estimated dose from the YAEC activities that Petitioners contested in their Emergency Motion and Renewed Emergentey Motion is approximately 65.3 person-rem, while the total eslimatid dose frota all remaining decommissioning activities (prior to the start of the

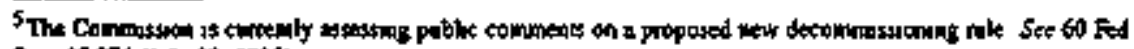
Rep 37,774 (Jabs 20, 1995)
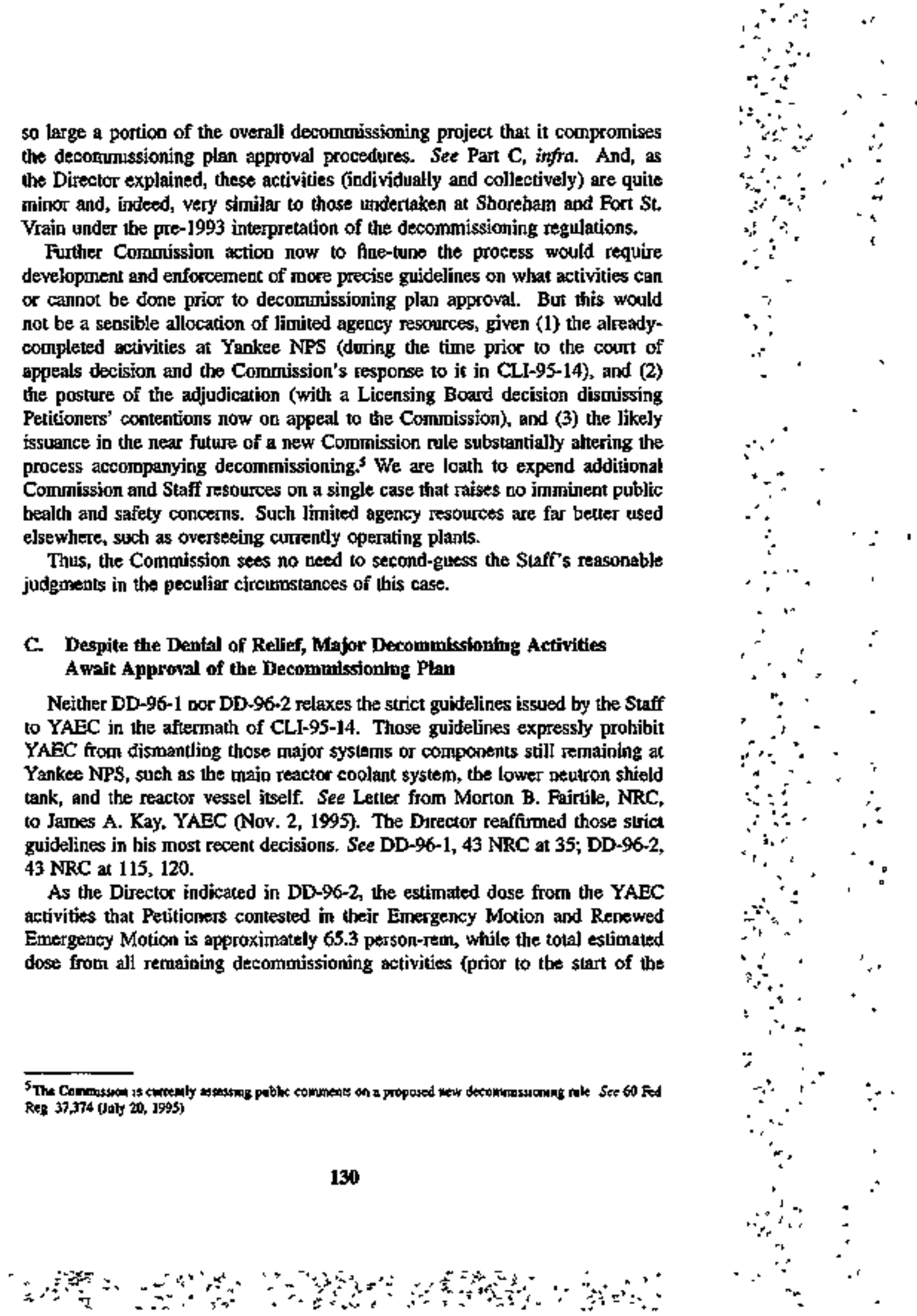
contested activities) was approximately 358 person-rem. ${ }^{6}$ As the Director also pointed olx, it is not at all clear how much of the 65.3 person-rem might bo awoited even if YAEC and the NRC ullimately wee to enbrace the Petitioners preferred SAFSTOR opion. In our judgment, 65.3 person-renn represents a Jeasomably small portion - approximately $18 \%$ - of the lotal dose originally avaitabte for possible SAFSTOR towatument and, therefore, the contested activities do no compromise a meaningful SAFSTOR option or the hearing process in which Petitioners ars participating.?

In short, despite the various minor activities YAEC has undertaken, a substantial portion of the remaining facility remains available for possible application of the SAFSTOR option, should that be the restut of the Petitioners" challenge to YAEC's proposed decommissioning plan. Accordipgly, we cannot accept Petitioners" claim that their hearing rights witt be "eviscerate[d]." See Emergency Motion at 19, if YAEC conducts the contested activities.

\section{Future YAEC Activities}

For the reasons stated above, we agree will the Director that the aclivities he has found permissible may reasonably be temed "minor." In addition, they do not compromise decommissioning alternatives because they affect only a relatively small portion of the estimated remaining radioactive dose inventory. But it is also troe that an accumulation of "minor" activities could so eviscerate the SAFSTOR option that a halt would be necessary.

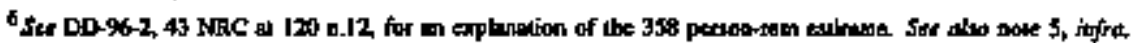

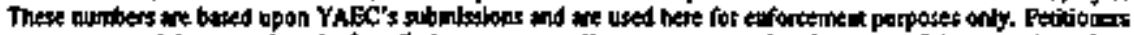

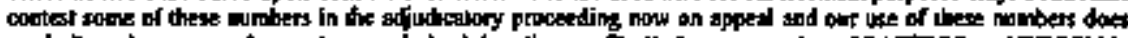

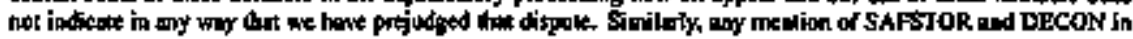

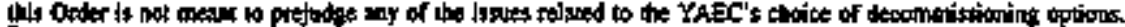

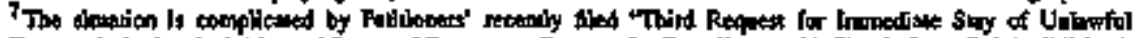

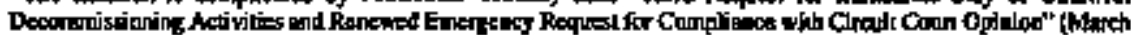

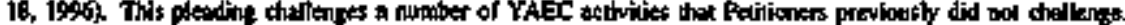

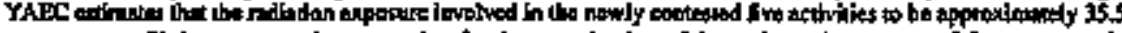

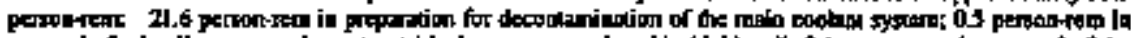

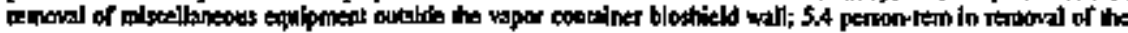

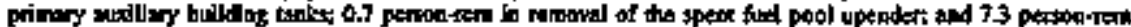

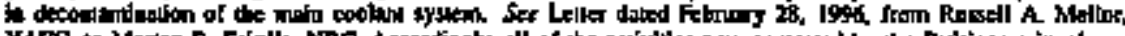

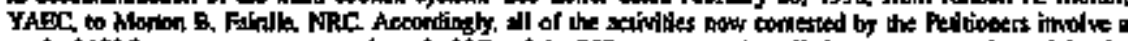

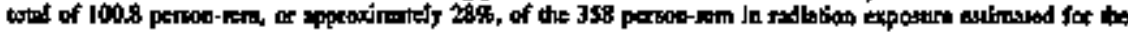

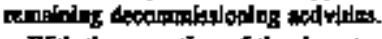

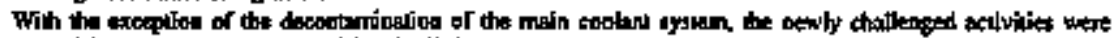

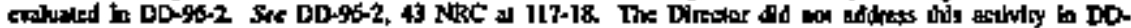

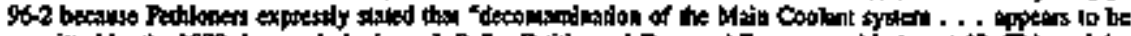

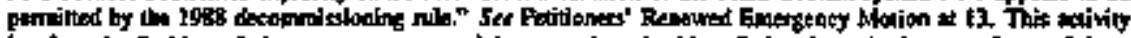

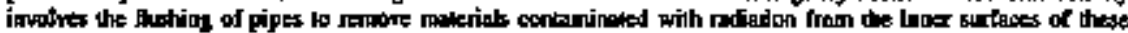

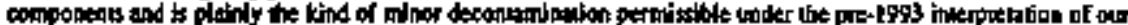

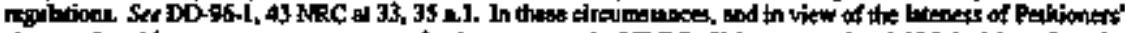

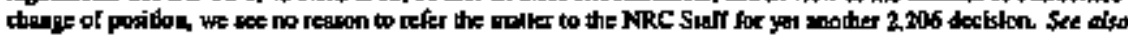
notre 9. isfra 
It is our understanding from our Staff that YAEC currenty plans no further "minor" activities (with radioactive dose consequences) beyond those tound permissible in the Diteclor's Decisions. This understanding supports the couclusion that the SAFSTOR optuon remans viable pending fieal approval of YAEC's decorminissioning plan. Should this understandjog prove false, and YAEC propose additional activities, "minor" or not," that undrviounally or cumulatively would threaten the contınued viability of SAFSTOR, the Comrnusson stands ready to call a halt to such activities.

\section{v. CONCLUSION}

We hereby revew and affirm DD-96-1 and DD-96-2, both of which now become final agency action. Commossioner Dicus has abstained from this decision and provided a separate statement whtch is attached.

It is so ORDERED.

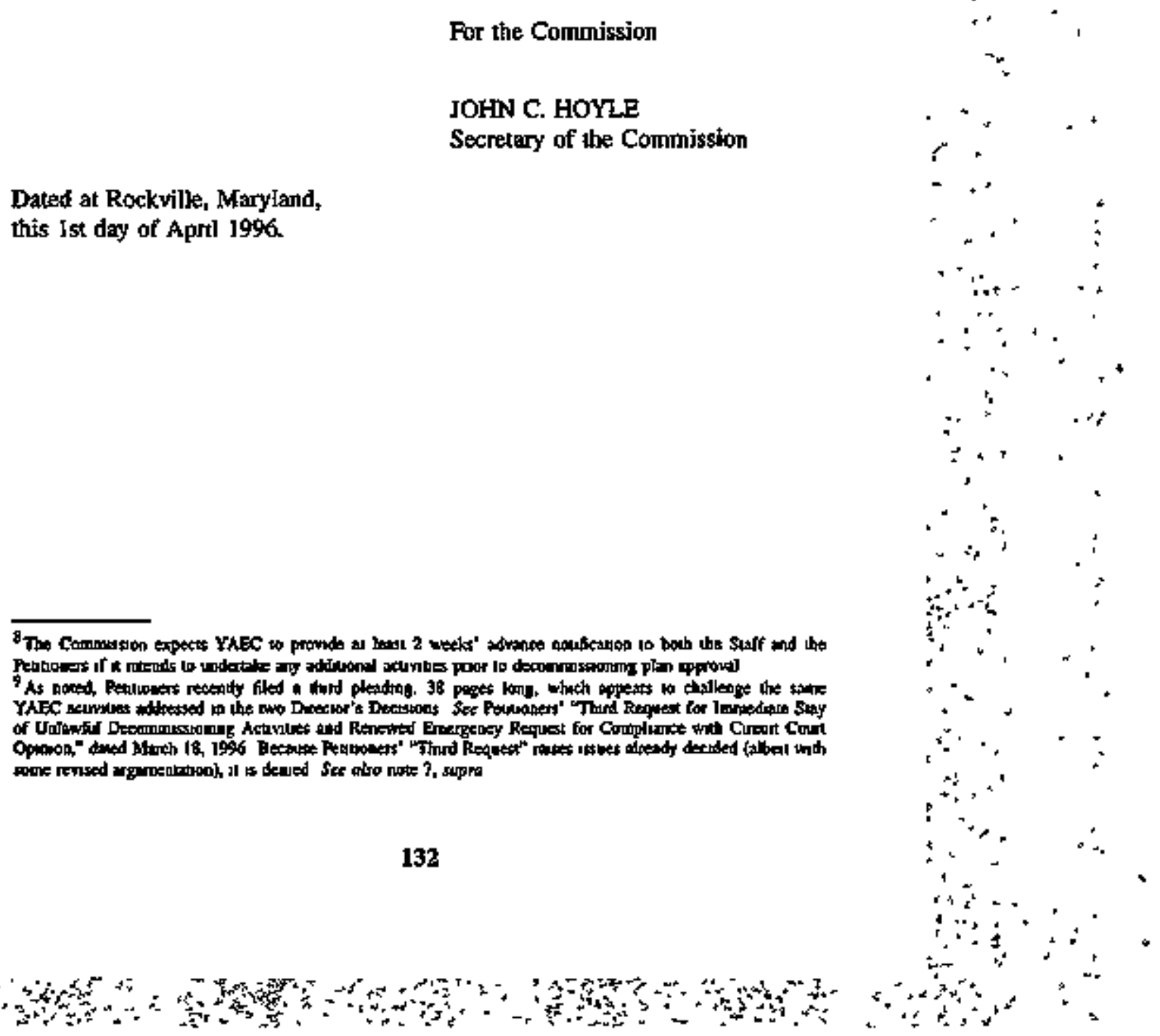




\section{SEPARATE STATEMENT OF COMMISSIONER DICUS}

Given the extensive and lengthy litgative and tectinicat hislory of this proceeding, the multiple technical issues involved in the current Order in this proceeding, and my relatively short time with the Commission, it would take me some time to become fully informed and act upon the issues in this Order, unlike several procedural issues in this proceeding on which I have previously particjpated. Because 1 would view it as a disservice to both Petitioners and the Licensee in this procteding to delay a final decision on the Director's Decisions being addressed in the current Order, I have determined to abstan from votıng $\because \quad$ on this particular Order. 
+

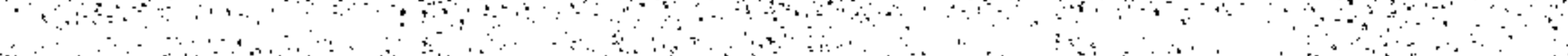
A (a) ofor 
UNITED STATES OF AMERIGA

NUCLEAR REGULATORY CONAHSSNON

\section{ATOMIC SAFETY AND LICENSING BOARD}

Bofore Adminlstrative Judges:

B. Paul Gotter, Jr., Chairman

Dr, Picherd F. Cole

Dr. Peter \$. Lam

In the Matter of

Docket No. 50-45\%-OLA

(ASLBP NO. O3-680-04-OLA)

\section{GULF STATES UTIUTIES}

COMPANY, et at

(Fiver Bend Station, Unlt 1)

Warch 29, 1998

The Licensing Board grants a motion of the bankuptcy trustee of the Intervenor, Cajun Electric Cooperative, to terminate its litigation, without prejudice, contesting a license amendiment requested by Gulf States Ubilities.

\section{TERMINATION OF PROCEEDINGS: TBRMINATION WIHOUT PREJUDICE}

Under Rule 41 of the Foderal Rules of Civil Procedure, a voluntary dismissal of a court action is generally without prejudice to the action being reinstituted at a later date. Although there is no provision in the Commission's Rules of Praclice thal corresponds to the voluntary dismissal procedure in Rule 4l, the Board found that those provisions were applicable in this case, especially since the public inerest theoretically would be served if Cajun could later establisb that additional financial assurances were needed. Moreover, the Board found that it was unfair to impose a form of punishment, such as a bar of future action,

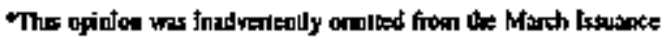


against an Intervenor whose decisions were being directed by a person (the banisuoplcy trustet) with legal responsibilities other than trose that supported the original petition.

\section{MEMORANDUM AND ORDER \\ (Grabt of Motion to Terminate Proceeding)}

\section{BACKGROUND}

On January 25, 1996, Ralph R. Mabey, the court-appointed Banknuptcy Trustes ("Thustee") for Intervenor Cajun Electric Power Cooperative, Inc. ("Intervenor"), filed with this Board a "Withorawal of Contention and Motion for Termination of Hearing" ("Tnstee's Motion").' The Motion seeks to withdraw the Intervenor's only contention and to teminate its litigation confesting a license amendment requested by Gulf States Utilities Company for its River Bend Station nuclear reaclor. ${ }^{2}$ The Motion seeks termination of the proceeding "without prejudice."

The NRC Staff suppouts the Trustee's motion insofar as it withdraws the admitted contention and asks that the hearing be terminated. However, the Staff lakes exception to the Trustee's request that the contention be withdrawn without prejudice. The Staff does not believe that the Trustee can wilhdraw Cajun's contention without prejudice "given the posture of the proceeding before the Licensing Boasd." The \$taff would have the Board dismiss the praceeding wirh prejudice.

In support of bis request to withdraw Contention 2 withost prejudice, the Trustee states that Cajon

is not withdrnwing its Petition to Intervene, as arended and supplerpented, or any of the other tasues, matters or contentions contahed therreln . . . .

.. Cojal continues to heve concerats aboux EOl's lack of fieadefal qualincallons,

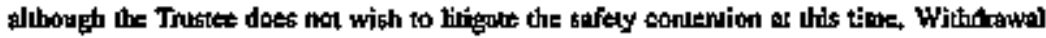

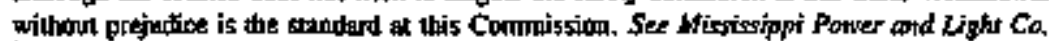
(Grand Galf Nuclear Stalion, Units I and 2), LBP-73-41,6 NEC 1057 (1973). . .

The Trusteo requests that the ASLB keminate the heoring proceeding. Since Conkention 2 ts the ooly contention and Cajw is the ofly intervenor. withdrawal should bring thits hearing

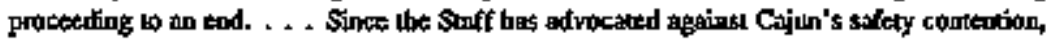

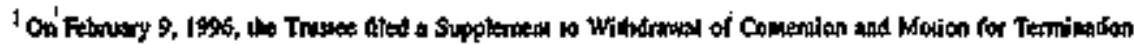

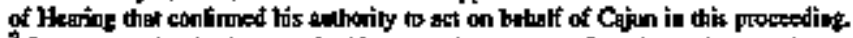

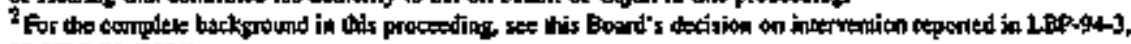
39 NRC 31 (199)].

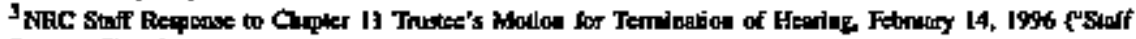
Reponson is 1 . 


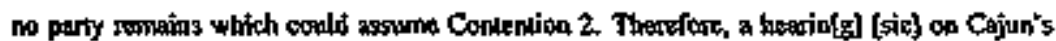
Coctention 2 would serue no purpose st th's time.

\section{Trustee's Motion at 7.}

Countering the Trustee's position, the Staff argues that dismissal of the Intervenor's contention without projudice is somehaw beyond the Board's jurisdiction, which the Staff insists is limited to "considering Cajun's petition for jntervention and readering a decision on any contentions that might be admitted." Staff Response at 2. The \$taff says Grond Gulf, relied upon by the Iotervenor, is noc apposite because that proceeding apparently continued afler the intervenor in question withdrew its contentios. The Grand Gulf Lisensing Boars ruled that, following a volantary withdiawal, an intervenor may teinstilute its intervention upon "good cause shown," the same slandard as that for untimely indervention found under 10 C.F.R. $\$ 2.714$ (a). In other words, in an operating license proceeding, the intervenor, upon good cause shown, could again intervene in the ongoing proceeding. However, the Staff reiterates that "[t]his proceeding will not be an ongoing proceeding once the Trustee's consention is withdrawn." Id. at 3. The Staff argues that since withdrawal of the only atmiuted contention in a proceeding brings the proceeding to an end (citing Houston Lighting and Powar Co. (South Texas Project, Units 1 and 2), ALAB-799, 21 NRC 360, 382 (1985)), "the Trustee's umopposed withdrawal of Cajum's contention must result in a Licensing Boart decision granting the Truslee's request and terminating the proceeding with prejudice." Id. (emphasis supplied).

\section{ANALYSIS}

There ts no guidance in Commission rules addressing the situation before us. It is clear that the Trustee desires, in the best interest of Cajon's bankruptcy, to end Cojun's inwolvemert in this proceeding. And the Trustee clearly acknowledges his understanding that the withdrawal of the only contention submitted by the only intervenor in the proceeding "bring[s] this hearing proceeding to an end." Trustee's Motion at 7. Howewer, it is also inoplicí in the Trustee's statements that the Truslee does not wish Cajun to bo barred from litigating its concerns at some future time. Therefore, the Trustee exprosses his desire to have the contention dismissed without prejudice. In appears that the Trustee is following the guidance of Rule $4 \mathrm{l}$ of the Fideral Rules of Civil Procedure.

Under Rule 41 of the Foderal Rułes of Civil Procedure, a voluntary dismissal of a court action is generally withous prejudice to the action being reinstituted at a later date. Although there is no provision in the Commission's Rules of Practice that corresponds to the voluntary dismissal procedure in a court becion, 
we see no good reason why those rules should not be applicable here, especially since the public interest theoretically would be served if Cajun cant later establish that additional financial assurances are needed. Financial assurante is an issue of renewed current importance given the industry's iransition to a more competitive environment.

Moreover, even if it were within our power to bar futare action, there is a consikeration of faimess at play here. Cajun is withotrawing its contemion and seeking the termination of this proceeding under the duress calsed by its own fiscal situation. As the Trustee stated in his Motion

I bebeve that the crediks of Cajun Electric's estate will be benefilted by the savngs realized

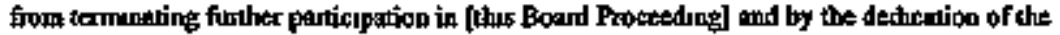

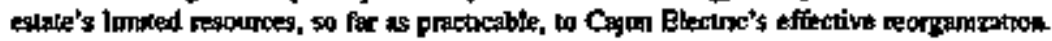

Trustee's Motion at 6. White the Truster's current actions may be binding on Cajum in the ovent Cajun is rehumed to debtor-jo-possession status, it would be unfair to impose a form of punishumemt, such as a bar of future action, against an Intervenor whose decisions are now being directed by a person with legal responsibilities other than those that supported the original intervention petition.

\section{ORDKR}

For atl the foregoing reasons and upon consideration of the entire record in this matter, it is, this 29th day of March 1996, ORDERED 
That the motion of Cajun Electric Cooptrative to withdraw its contemuion and terninate this proceeding, shall be, and it bereby is, granted and the proceeding is terminated without prejudice.

THE ATOMIC SAFETY AND

LICENSTNG BOARD'

B. Paul Colter, Jr, Chairman

ADMINISTRATIVE JUDGE

Dr. Richard F. Cols

ADMINISTRATIVE JUDGE

Dr. Peter S, Lam

ADMINISTRATIVE JUDGE

Rockville, Maryland

March 29, 1996 


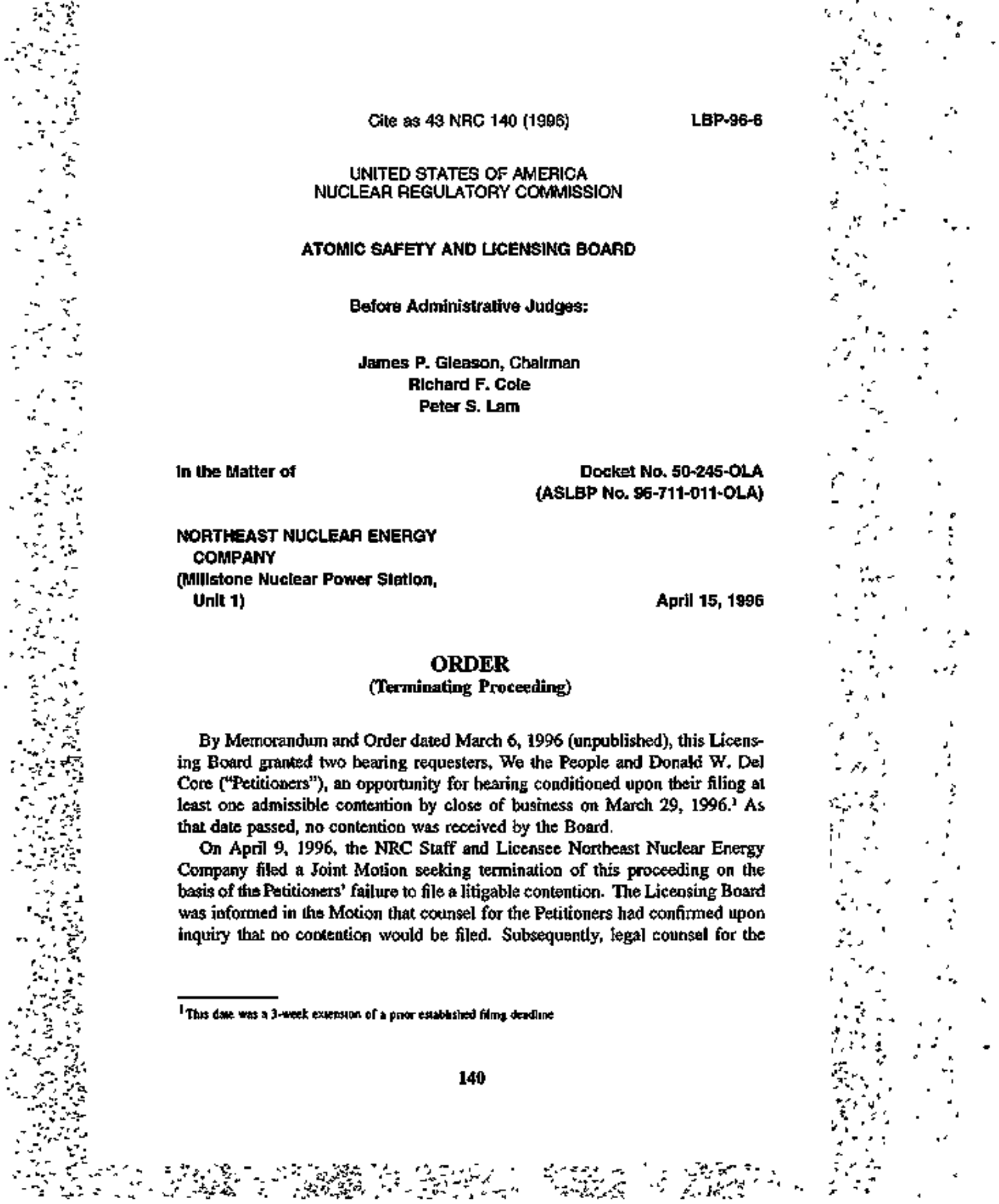


Licensing Board celephoned counsel for the Petitioners to verify this statement. ${ }^{2}$ Counsel for the Petitioners confirmed that no contentions would be filed in this matter and that further efforts to Jitigate issues surrounding the Milstone Plant would not be pursued due to a "lack of funds." Counsel for the Board was also informed that no response to the Joint Motion would be forthcoming and that the Board should take whatever actions were necessary to teminate the proceeding.

In Ifght of the record before us, it is, this fifteenth day of April 1996, ORDERED that this proceeding is teminated.

FOR THE ATOMIC SAFETY

AND LICENSING BOARD

James P. Gleason, Chairman

ADMINISTRATIVE JUDGE

Rockuitle, Maryland

April 15, 1996

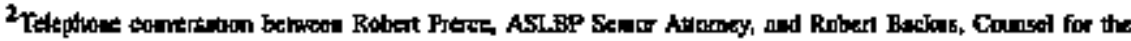
Poutueners, Appl II, t\$996 
Cilo 48 NRC 142 (1990)

LBP.96-7

\author{
UNITED STATES OF ANERICA \\ NUCLEAR REGULATORY COHAMSSION
}

ATOWIC SAFETY AND LICENSING BOARD

Before Administrativo Judgos:

Thombas S. Moore, Chatiman

Bicherd F. Cole

Frederick J. Shon

In the Matter of

Docket No. 70-3070-14L.

(ASLBP Na. 9t-64t-D2-ML)

(Spetial Nuclear Matorial Libense)

\title{
LOUISLANA ENEREY SERVICES, L.P.
} (CAtaborne Enrichment Center)

Aprll 26, t996

In this Partial Initial Decision in the combined construction pentit-operating license proceeding for the Claiborne Enrohment Center, the Licensing Board ressolves in favor of the Applicant Intervenor's contentions $H$ concerning the adequacy of the Applicant's emergency plan and $\mathrm{L}$ and $\mathrm{M}$ concerning the sufficiency of the Applicent's safeguards measures.

\section{RULES OF PRACTCE: BURDEN OF PROOF}

The Commission's rules of practice for the conduct of formal adjudicatory hearings provide in IO C.F.R. $\$ 2.732$ that the applicant has the burden of proof in the proceeding. Thus, in order for the applicent to prevatl on each contested factual issue, the applicent's position must be supported by a preponderance of the evidenoc. Philodelphia Electric Co. (Limerick Generating Station, Units 1 and 2), ALAB-819, 22 NRC 681, 720 (1985); Paciffe Gas and Electric Co. (Diablo Canyon Nuclear Power Plant, Units 1 and 2), ALAB-763, 19 NRC 57!. 577 (1984). See t Charles H. Koch, Jr, Administrative Law and Practice \& 6.44 (1985). 


\section{GMERGENCY PLAN(S); REQUIREMENT FOR MATERIAL LCENSE}

Under the Conunission's regulatory scheme for emergency planning at certain facilities possessing and using special nuclear material or source and byproduct material, an emergency plan for responding to the hazards of an accidental release constitutes one of the Applicant's procedures that must be found adequate under 10 C.F.R. $\$ \$ 0.32$ (c) and 70.23 (B)(4) to protect health and minimize danger to life or property.

\section{REGULATORY GUIDES: STATUS}

A regaletory guide, however, only presents the Staff's view of how to comply with the regulatory requiremenls. Such a guide is advisory, not objigatory and, as the guide itself states at the bottom of the first page: "Regufatory Guides are not substitutes for regulations, and compliance with them is not required."

\section{FUNDAMENTAL NUCLEAR MATERLAL CONTROL PLAN(S):} ENRICHMINT BACח.TTIES

The Comnission's material control and accounting regulations require thas the licensee of an enrichment facility "shail establish, jimplement, and maintain a NRC-approved material control and accounting system," 10 C.F.R. \$74.33(a), through the crestion of a fundamental melear matertal control plan. 10 C.F.R. $\$ 74.33$ (b).

\section{TECINICAL ISSUES DISCUSSED}

Eunergency plan; safeguards procedures.

\section{PARTIAL INITIAL DECISION \\ (Resolving Contentions $\mathrm{H}, \mathrm{L}$, and $M$ )}

I.

This Partial Initial Dettision resolves contentions $\mathrm{H}, \mathrm{L}$, and $\mathrm{M}$ filed by the Intervenot, Citizens Against Nuclear Trash ("CANT"), in this conbined constration perait-operating license proceeding. The application of Louisiana Enorgy Strvices, L.P. ("LES" on "Applicant") seeks a license to possess and use byproduct, source, and special nuelear material in order to enrich uranium U's 
to a maximum of $5 \%$ by weight. LES would provide enrichment services using a gas centrifuge process at the Clatboute Enrichtnent Center ("CEC") it intends to build in Claibome Parish, Louisiana, on a site about 5 miles bortheast of the town of Homter.

Pursuant to the amendments to the Atomic Energy Act ("AEA") contained in the Solar, Wind, Waste, and Geothermal Power Production Incentives Act of 1990, Pub. L. No. 101-575, 104 Stat. 2834, uranium enrichment facilities, with one exception not relewant here, are no longer licensed under chapter 10 of the AEA as production facilities. Rather, facilities such as the CEC now are licensed pursuant to chapter 6 , section 53 , and chapter 7 , section 63 , as licenses for sousce and special muclear materiai. These amendments to the AEA also simplified the licensing process by requiring only the issuance of an environenental impact statement and a single formal adjudicatory hearing for construction and operation followed by an inspection to verify that the facility has been constructed properly.

In its intital notice and order for this proceeding, 56 Fvd. Reg. 23,310 (1991), the Commission directed that the Licensing Boasd determinit whether the application salisfies the standards set forth in 10 C.F.R. $\$ \$ 30.33,40.32$, and 70.23 as well as the Itequtements of 10 C.F.R. Pant $\$ 1$. Additionally, it ordered that certain special standards and instructions must be satisfied so that the Commission could determine whether the issuance of a license will be inimical to the common defense and security of the United States and will not constitute an uniezsonable risk to the health and safety of the public. Those special standaris and inseruetions includs the draft General Design Criteria for wranium enrichment cortained in the Advanee Notice of Proposed Rulemsking in 53 Fod. Reg. 13,276 (1988); the criteria coutained in NUREO-1391, "Chemical Toxicity of Uranizan Herafiuoride Compared to Acule Effects of Radiation" (19S1); the financtial protection regajirements of 10 C.F.R. $\$$ 140.15-17 and Part 140, Appendix A; the creditor regulations in 10 C.F.R. \& \$0.81 dealing with the creation of ereditor interests in a uranium enrichnent facility; and the creditor regulations in 10 C.F.R. $\$ 70.44$ concerning the crestion of creditor interests in special nuclear material.

The Commission's initial notice and order also directed that the proceeding be conotucted pursuant to 10 C.F.R. Part 2, Subparts $G$ and I. Among other things, the Subpart $G$ rolies of practice for the contuct of formal adjudicatory hearings provide in 10 C.F.R. $\$ 2.732$ that the applicant has the burden of proof in the proceding. Thus, in order for the applicant to prevail on each contested factual issue, the applicant's position must be supported by a preponderance of the evidence. Philadelphia Electric $C_{0}$. (Limerick Oenerating Station, Units 1 and 2), ALAB-819, 22 NRC 681, 720 (1985); Pacific Gas and Electric Co. (Diablo Canyon Nucless Power Plant, Units 1 and 2), ALAB-763, 19 NRC 571, 577 (1984). See 1 Charles $\mathrm{H}$. Koch, $\mathrm{Jr}_{7}$ Admintistrative Law and Practice \$6.44

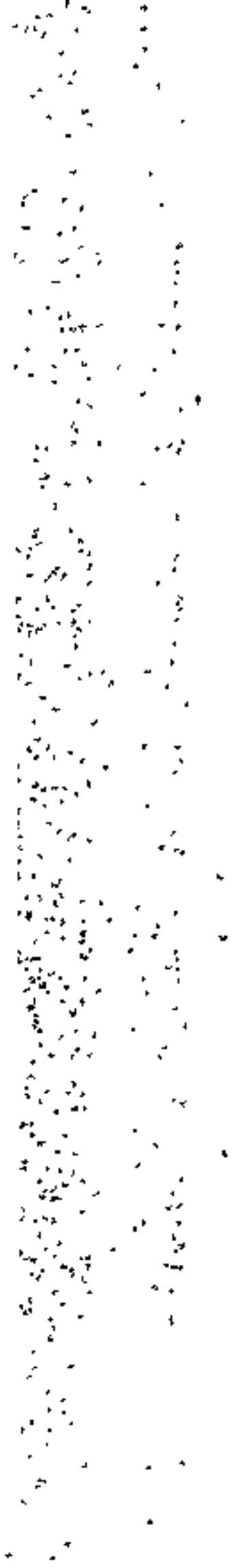


(1985). Consistent with the Commission's burden of proof rule and purstant to the stipulation of the parties, the applicant presented its case on the admitted contentions first, followed by the Intervenor, and then the NRC Staff.

II.

CANT's contention H concens the adequacy of the Applicant's emergency plan for the CEC. Under the Commission's regulatory scheme for emergency planning at facilities possessing and using special nuclear material or source and byproduct material, an emergency plan for responding to the bazards of an accidental release constituses ont of the Applican's procedures that noust be found adequate under 10 C.F.R. $\$ 40.32$ (c) and 70.23(a)(4) to protect health and minimize danger to life or property. The information that must be contained in the Applicant's emergency plan is set out in t0 C.F.R. \$\$ 40.3](j) and 70.22(i). Although the regulations do not require an ennergency plan if the Applicant can demonstrate that the intake and dose to a member of the public from an accidental release would not exceed certain protective action guides, LES has not made such a showing in its lictnst application. Accordingly, LES must demonstrate that the CEC emergency plan meers the requirtments of the Comsoission's regulations.

In the statement of considerations actompanying the final emergency plan regulations for fuel cycle and other material licenses, the Commission set forth the rationale for the rule. That background matejial provides the poper contexs for understanding the regulatory requirements with respeet to the information thet must be included in the Applicant's emergency plan. In promulgating the regulations, the Commission indicated that for emergency planning purposes accidents at facilities with significant quantities of uranium bexafluoride such as the CEC were of greater concern than facilities that possessed only smoll quantities of that material. The Commission stated:

The mpture of a large heoted cylinder of $\mathrm{UF}_{\mathrm{b}}$ is $2 \mathrm{~s}$ exception in that both the probebltiky of a large relesse and the cossequences dae lo the cheminent toxlelty of the reteased motertal

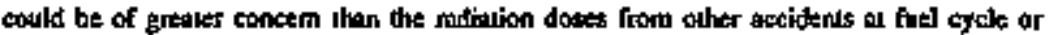

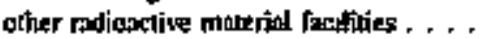

Airbome seleases doe to a severe axcldent at these licensed facilities are bely to occur capidly wilh Jiale wamiac. The only types of aceidens identifled in NUREG-J140 for which

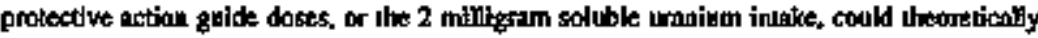
be excoted are in furc, a UP, cylinder rupture, and a criticaling accident Releases from a fro coutd stor evas before the fire is detected or shorily thereafier. Puras travel time 10 neoriy people is likely to be no more that a few minutes. Releases would usually end whon

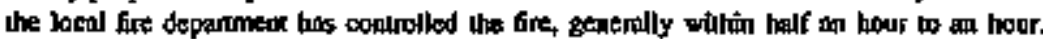
Retroses of UF ans likely to start without waning and be of shot duration. Many other ascidental releases could aso star withouk waming and be of shon durtion As a resulk, 


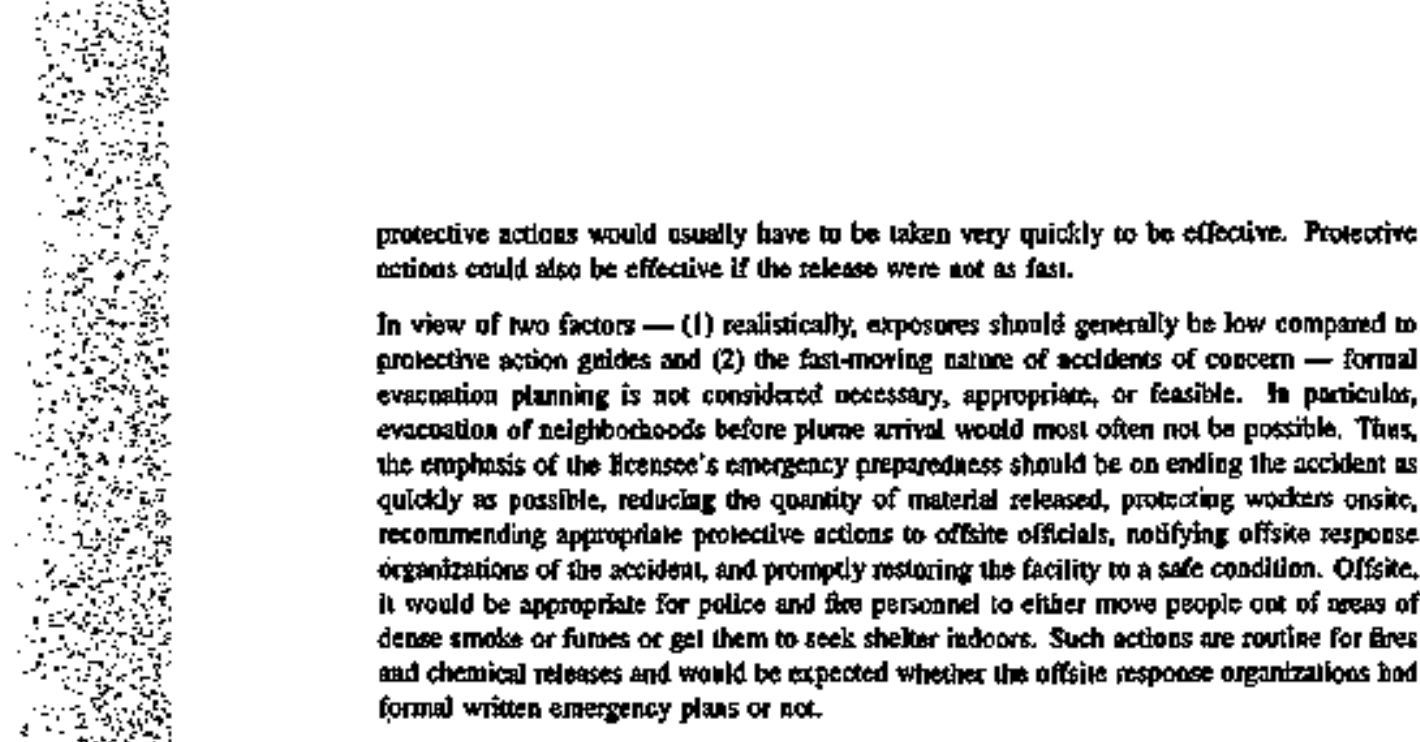

54 Fed, Reg. 14,051, 14,052 (1989).

In response to public comments to the effect that there was no need for emergency plans at material license facilities, that the proposed protective action dose guidelines were 100 conservative, that engineered saifeguards could prewent accidents, and that compliance costs did not justify the benefits, the Commission determined thet the rule nevertheless should be issued. Specifically, it stated:

Any system of enginereted safiguands is considened to have some possibitity of failone. No system could ever the perfect Therefore, the NRC hos diecided to nequire another level

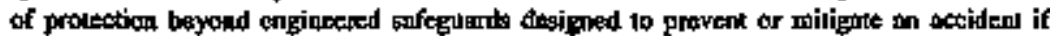

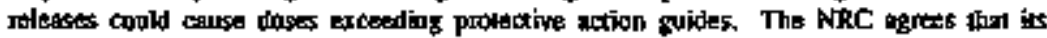
duse cakculalions we very congervative and that doses from an actual accident are likely to be far hower than enculatid. Newertheless, the NRC considers the collenleted dases to be possible ewen if improbahle. The NRC recogrizes that the costs to licensees tend to exceed

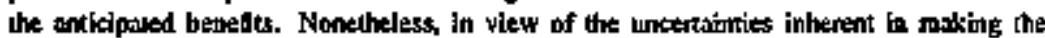
cost-benefir babmes, and contideting in any ewert the limited adtibiobal financial borden

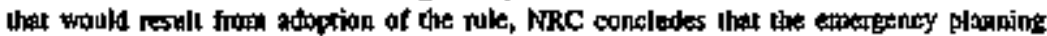
menguses are desirable to protecl bonith. While the NRC agreas that in many ingtances it wavld not be possible to reduce expospres of filte besause thene would not be enough lime, the NRC belteves that in some instences there would be a possibility of raducing

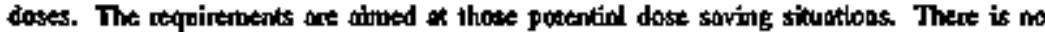
requiremenk, serted of implied, thel the emergeacy response would diways be eflective in reducing axposures aftsice or thet specified dose kevels wontd not be bxceeded Instead, the requirement is that the licensee be prepared to lake some practicat stops than could, In faronibte circumsianes, reduce radiation exposune to the public.

\section{Id. at 14,056 .}

Finally, in rejecting comments that offsite notification systems, infomational brachures, emergency planning zones, and response gutdelines should be adopted, the Commission memarked: 
Toe NRC belleves thal the normally awsilable capabilities of Siotes and local goveromenls for nesponding to industrial emergeacies atd the nocmally atrillable mitiological health capabilities of Slates will be adequate to deal wilh accidents at fuel cycte and other radioscthe materfal licensees. These radidogical emerzencies wogld inwolwe small (not life threstening) doses, small arens, and small munabers of people. The polkatial risks are much lower than

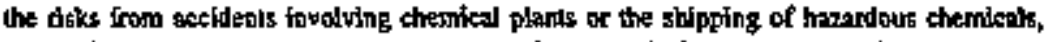
to woich states and local governmerns routipely respond. In othet woris, the respontse to

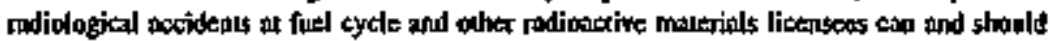
be haadled by State and local goverwments as part of their normel emegency response capabllity withod addulional sesoures.

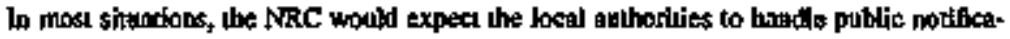
tion and ruponse on an ad hoc basts, the way those authorities woold handle a luck or mil

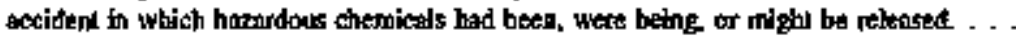

The NRC inlenlionally did nol estnbtish emerzency plankung zones, deciding inskend to defte the oftsite response is lerms of when offile fesponse organizations should be notified. The NRC concludes that dose projections during an accident would not be possible. Thus, the size of the response would be dlewted mainly by the proclicality of respodse actions.

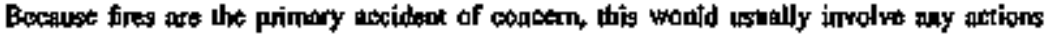
offstie lint coutd reduce the exposure of people to smoke from the fire . . . .

$\cdots$

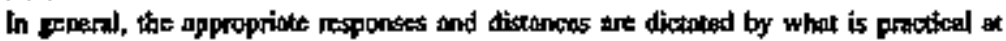
The thme the accldent accurg. Police and emergency personnel huve generally been quile proflckent in banding simlor types of energencies, such as trokk and rill accldents.

Id. at 14,057 .

The NRC Staff has published guidance as to how to comply with the emergency plan segulations in Regulatory Guide 3.67, "Standard Format and Content for Emerigency Plans for Fuel Cycle and Materials Facilities" (1992), That document, bowever, only presents the Staff's view of how 10 comply with the regulatory requirements. Such a guide is advisory, not obligatory and, as the guide itself states at the bottom of the first page: "Regulatory Guides are not substitutes for regulations, and compliance with them is not required." Thus, it is the Commission's emergency plan regulations by which the Applicant's emergency plan must be juxged and it ts the regulations, not the guide, that moust be found to bave been met in the first instance. See Pacijic Gas and Electric Co, (Diablo Canyon Nuclear Power PJant, Units I and 2), ALAB-644, 13 NRC 903, 937 (1981).

CANT's contention $\mathrm{H}$ asserts that the license application for the CEC does not provide reasonable assucance that the public bealth and safely will be adequately protected in the event of an emergency at the plant. Although CANT proffered numerous supporting bases for this contention, only len were allowed - $\mathrm{H2}$, $\mathrm{H3}, \mathrm{H4}, \mathrm{H5}, \mathrm{H} 6, \mathrm{H} 7, \mathrm{H1O}, \mathrm{H} 17, \mathrm{H2O}$, and $\mathrm{H} 23$. Each of these bases will be adơressed seriatim.

In support of its position on contention $H$, the Applicant presented the testimony of Peter G. LeRoy, the Licensing Manager of the CEC, who directed 


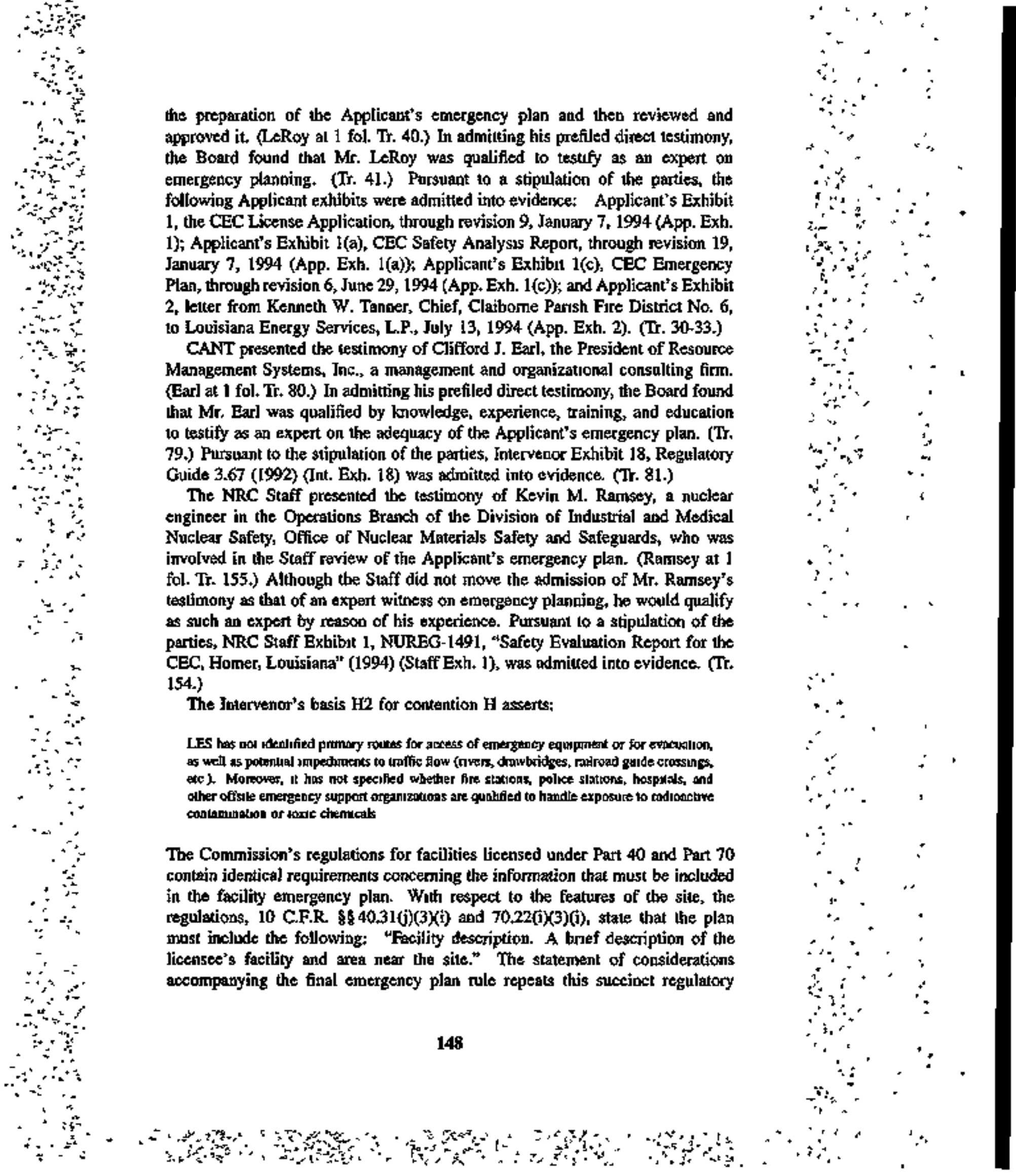


language and then states that "[c]he purpose is to provide the reader with enongh basic infortnation to evaluate the licensee's plan. Significant nearby facilities, such as schools, should be included in the site area description." 54 Fed, Reg. at 14,054 .

In contrast to the brevity of the factitity description provision of the emergency plan rogulations, the Slaff's Regulatory Guide 3.67 expands exponealially the information about the facility that should be included in the plan. That guidance first calts for a description of the licensed activities conducted at the facility including the type, form, and quantities of radicactive and other hazardous material present on the site. Next, it requires a description of the facility that includes a detailed scale drawing of a prescribed size containing fivo caltogonies of geographical features plus a bar scale and compass indirating north. Fintally, the guidance cells for a description of the area near the site that includes six cotegories of information located and identified on an area site map or en gerial site photograph. The third informetional catcgory calls for the identification of the primary routes for site access and evacuation and the identifieation of traffic flow impediments. The fourth informational category requitres the "[]]ocations of fure stations, police slations, bospitals, and other offstle emergency support organizations (specify whether qualified to handite expossure to radioactive contaminalion of toxic chtmicals)." (Int. Exh+18: Rog. Guide 3.67 \$ 1.3.)

Contrary to the Intervenor's first claim in basis $\mathrm{H} 2$, the primary roules for access to the CEC and evacuation from the facility are included in the CEC Emergency Plan. (App. Exh. 1(c), Fig. 1.3-4; \$1.3; LeRoy at 13 fol. Tr. 40.) Further, the LES Licensing Manager, Mr. LeRoy, in his prefiled direct testimony indicated that there are no impediments to traffic flow. He also stated that the same type of entergency vehicles that would respond to the CEC in the event of an energency regularly use the roads ascessing the facility. (LeRoy at 13-14 fol. Tr. 40.) In like vein, the NRC Staff's witness, Mr. Ramsty, stated in bis prefiled direct testimony that the CEC Energency Plan descriplion of the site area was adequate. (Ramsey at 4 fol. Tr. 155.) The Intervenor presented no eviderce to support its claim. Thus, we tind that LES has met its burden on this claim in basis $\mathrm{H} 2$ and this claim canrot be sustained.

The Intervenor's second clain in basis H2, i.e., LES has not specified whether energency orgarizations ans qualified to handle radioactive contamination or toxic chemicals, also cannot be sustajned. CANT's expert, Mr. Earl, identified 10 C.F.R. $\$ \$ 0.31(j)(3)(0)$ and 70.22 (j)(3)(j) and the Commission's brief statement about the facility description provision in its statentent of considerations accompanying the promulgation of the emergency plan rule, see infra pp. 148-49, as the foundation for the facility description requtrentent. He also asserted that Regulatory Guide 3.67 "prescribes the criteria for an 'acceptable' energency plan." (Earl at 4 fol. Tr. 80.) Indeed, CANT's claim is taken directly 
from that regulatory guide and parrots its language. But, as we have previously indicated, such Staff guidance is tool a regulation and compliance with $i t$ is not mandaiory. Rather, we musi judge the adequacy of the CEC Emergency Plan by the requirements of the Comunission's regulations. Hert, we simgly canmot find that the regulatory requrements of 10 C.F.R. $\$ 4031$ (j)(3)(i) and $70.22(i)(3)(i)$, which call only for “[i] brief description of the licensee's facility and area near the site," mandate that the CEC Emergency Plan must include qualíication information about the ability of emergency support organizations to handle exposure to radioactive contamination or toxic chemicals. Even the NRC Staff, as the author of the guxdance, concedes this point in is proposed findings when it states that "[a]lthough the regulatory guide suggests that Applicant specify whether the local fire stations, poltce stations, bospitals and other offsite emergency support organizations are qualified to handle exposure to sadicactive contanination or toxic chenicals, the regulations call ondy for a deseription of the facility and ares near the site." NRC Staff's Proposed Findings of Fact and Conclusions of Law Regarding Contentions H, L, and M (Oct. 21, 1994) al 20.

Moreover, the premise underlyung the Commission's emergency plan regulations is that "the nornally available capatilities of States and local governments for responding to ibdustrial ernergencies and the normally available radiological health capabilities of States will be adequate to deal with accidents at fuel cycle and other radioactive material licensees." 54 Fed. Reg. at 14,057. Further, the Connuission stated that "[p]chice and ennergency personnel have generally been quito proficient in banding stinilar types of enpergencies, auch as truck and rarl accidents." Id. Thus, contrary to the Intervenor's clairl, wa cannot find that the CEC Emergency Plan does not comply with NRC regulations for nor specifying the qualifications of mergency organizations when such information is not required by those regulations.

Nonetheless, even though the information called for in Regulatory Guide 3.67 is not required by the Commission's regulations to be included in a facility emergency plan, the Applicant has committed to meet the Staff's guidance. Mr. LoRoy stited unequivocally that "LES is commutted to miset regulatory requirements and will conform to the guidance set forth in Reg. Guide 3.67." (LeRoy at 10 fol. Tr. 40.) Normally, an applicant's commitments are made to the Staff and, as such, are a matter for the Staff to enforce. Here, however, LES made this commitnent before us as part of its evidentiary case in support of license awthorization. In these circumstances, we cannot ignore the Applicant's commitment if we are to preserve the integrity of the hearing process. Thus, we must insist that the Applicant meet its voluntary contritunent to exceed the requirements of the regulations on this matler and conform the CEC Emergency Plan to Regulatory Guide 3.67 .

This agency guidance requires that an emergency plan inclucie an arta map or aerial photograph of the site indicating onsite and near site stuxctures. On 
this photograph or map the Staff guidance calis for the Applicant to include the Jocations of the various offsite emergency support organizations. (Int. Exh. 18: Reg. Gujde 3.67 \$ 1.3.) Along with marking the locations of such emergency organizations on the map, it instructs the applicant to specify whether each organization is qualified to handle exposure to radiological contanination or 1oxic chennicals. Although the CEC Emergency Plan contains the requiste map locating the offsite energency organizations, the map carries no legend or other marking denoling the qualifications of each offsite organization to handle radiological or toxic chemical exposure. (App. Exh. 1(c), Fig. 1.3-4.) The Applietent must, therefore, tevise the CEC Emergency Plan to make this gmendment so that the LES plan conforms to its voluntary combitupent to us.

Rather than impose a license condition to ensure that the Applicant makes the pecessary revision to the CEC Emergency Plan, we believe that it is more approprate in the cincimnstances to request thal the Staff issue a brief supplement to the SER before any license is issued indicating that the Applicant has mate the approfriate anomdment and thus met its voltnatary commitment to us. Moreover, because the Applicant's commituent to conform its ermergency plan to the Staff's regulatory gutdance was not limited to this one matter, the Staff should ensure that the entire plan conforms in all respects to Regulatory Guide 3.67.

Even though the Applicant has not specifically noted ou an srea map whether the emergeacy response organizations are qualified to handle exposure to radioactive contamination or toxic chernicals as called for by the Staff guidance, we are satisfied that the CEC Emergency Plan contains sufficient information for us at least reasonably to infer that all energency response organizations are qualified or, as a result of plantued trainigg, will be qualified to handle exposure to radioactive contamination or toxic chemicals by the time the facility commences operation. (Id $\$ \$ 4.3,5.5 . I .1,5.7,7.2 .3,11.0$; LeRoy at 15-I6 foI. $T_{r}$ 40; Tr. 93, 96.) Further, the NRC Staff's witness, Mr. Ramsey, indicated that, under the training regimen of the plan, the emergency response organizations would all be qualified to handle radioactive and chemical contamination. (Tr. 165-66.)

Moreover, the Interventor offered no evidence that the various offsite entergency response organizations were not qualified in this regard. Rather, the Intervenor's expert, Mr. Earh, testified that the applicable Staff gaidance requires that the Applicant's emergency plant contain sufficient intomation about the knowledge, skilks, and abilities of the personnel of such ofganizations to permit independent evaluation whether they can successfully perform their planued doties. The quantity and type of information that Mr. Earl seeks to have included in the emergency ptan, however, is much more extensive than the simple notation of qualtifications called for by Regulatory Guide 3.67 and far exceeds the Commission's regulatory requirements. Thus, rather than offer testimony or other evidence that the offsite emergency organizations are, in fact, not quati- 
fied, of that the planned training will not make them qualified, the Intervenor merely claims there is not enough information or delafl in the plan to determine qualifications. We do not agree that the infomation contained in the Applicant's entergency plan is insutficient to determine the qualifications of the emergency response organizations. In any event, the level of information fo the emergency plan that CANT asseris is necessary is oof the regulatory standard for jutging the adequacy of the CEC Emergenky Plan nor is it the standard of the NRC Staff guidance. We find, therefore, that the Intervenor's second clain in basis H2 cannot be sustained.

In basis H3, CANT asserts:

The Enerency Plan does dox include the following tems: a list of all hanudous chemicals

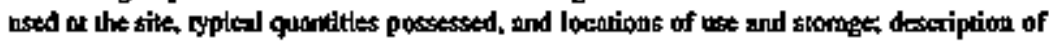
stack heights, typical stack flon rrtes, and the elficiencies of andy enimion control dovices: or idealfiketion of communicaklon and assessment centers, assembly and refoestion areas, ind process and tomge aress.

Contrary to the assertions set forth in CANT's original basis H3, all of the missing itens are now contained in the CEC Emergency Plan and that information has been foond acceptable by the NRC Staff. (App. Exh. I(c) \& 1.2, Tabtes 1.2-I to 1.2-4; LeRoy at 2[-22 fol. $T r_{+} 40$; Ramsey at 5 for. Tr. 155.) Thus, we find that LES has met its berden on the claims conlained fo basis $\mathrm{H} 3$ and these claims cannot be sustained.

In basis H4, the Intervenor asserts:

\begin{abstract}
LES does not identify and describe each type of cadlosclire maledals vecident for which actlons my be aeeded to peevent or mitrimize exposare of persons off-site to mdiattan or adicactive materfals. For all accideols that are postulated pursuant it DG-3005 \$\$2.LI and

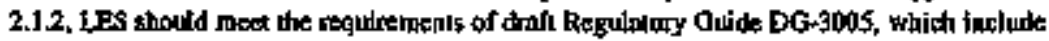
idemifying the expossuro kevels al the sits bourdary (i.,., the levals potanlially affiectipg

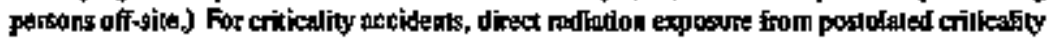
accidents shoold be eraluated in addluton to the dose from relested codroactive materials.
\end{abstract}

With respect to the various types of accidents that may occur at a facility, the Comunission's regulations, 10 C.F.R $\$$ 40.31(j)(3)(ii) and 70.33(i)(3)(ii), require the facility emergency plan to provide "[a]n identitication of each type of accident for which protective actions may be needed." In the statement of considerations accompanying the emergency plan rule, the Commission stated in regard to this provistion that

[thpically, the axcidents of concrem are fires iavolvins redionctive materials, selenses of krje quantites of oranium hexaluoride and crlikelities lowolylug high-entated umolum or 
plutontum Releases of hazardons dremsests that coold alfent the rodrological safety of the

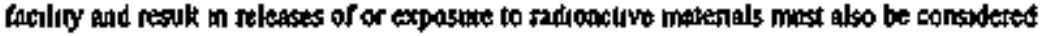

54 Fet. Reg. at 14,054 .

Contrary to the finst claim in CANT's basis 4, the CEC Emergency Plan tdentifies and describes each type of accident with potential offsite consequences. The Applicant's listing of postulated accidents (i.e.. those events involving UF, releases that could exceet NRC exposure guidelines) includes those caused by natural phenomena, a nutelear criticality event, and various other accident scenarios. The plan also includes a listing of abnormal operational events that could result in a release of UF, beyond the site boundary. (A.pp. Exh. I(c) $\$ \$ 2.1 .1,2.1 .2 ;$ LeRoy at 24 fol. Tr. 40.) Additionally, the CEC Emergency Plan identifies the accident with the maximum exposure level at the site boundary as occurring from an autoclave heater malfunetion accident. The plan states that maximum exposure from all other postulated accidents would be less than that occurnng from this bounding accident. (App. Exh. l(c) \& 2.1; LeRoy at 24 fol. Tr. 40.) Finally, the Applicant's plan evaluates at the site boundary the direct radiation expostre and the dose from released radioactive material from a critcality event. (App. Exh. J(c) \$2.1.1.2; LeRoy at 25 fol. Tr. 40) Thes, the CEC Energency Plan adequately identifies the type of accidents for which protective actions may be neded as requited by the Comtaission's regulations, Additionally, the NRC Staff found that the Applicant's identification and description of accidents in the plan is adequate. (Ramsey at 5 fol. Tr. 155.)

The Intervenor presented tho testimony to stuport its specific claims in basis H4. Rather, its expert, Mr. Earl, generally challenged the adequacy of the CEC Energency Plan for nor providing sufficient details about each postulated accident, including such information as the nature, location, tíning, and consequences of the accident He also criticized the Applicanl's description of postulated accidents for failing to include the potential size and scope of the accident, the mitigating actions that wouk need to be undertaken, and the consequences of deley or failure to take timely mitigative actions. (Earl at 14 15 fol. Tr. 80.) Once again, however, Mr. Earl seeks a level of information well beyond what is required by the Comunission's regulations or even the NRC Staff regulatory guidance for the identification and description of the type of accidents for which protective actions may be aeeded. Funther, some of the information be seeks, suth as that concerniog mitigating actions, is required by other regulations and appears in other parts of the CEC Einergency Plan. (See 10 C.F.R. \$\$ 40.3I(j)(3)(v) and 70.22(i)(3)(v); App. Exh. l(c) \$ 5.3.) Most importantly, ti his call for greater detait, Mr. Earl did not review or evaluate the Applicant's Safely Analysis Repont, which is prominently referenced in the postulated accident identification section of the CEC Emesgency Plan. (Earl Tr. 117-18.) The Applicanl's SAR contains an analysis for each of the 
postulated accidents set out in the emergency plan. That analysis includes a full deseription of the accident, its causes, and consequences. (App. Exh. 1(a) 89.2.) The Commission's regulations do not require that the level of detail contained in the Applicant's SAR with respect to postulated accidents be set forth in the emergency plan. Indeed, the Staff's regulatory guidance specifically recognizes that such detailed infonmation may be fncorporated by referente in the emergency plan. (Int. Exh. 18: Regulatory Gutde 3.67 at 1.) Accordingly, the Applicant has met its burden on the claims contatined in basis $\mathbf{H} 4$ and these clatins cannot be sustained.

CANT's basis 5 for contention $\mathrm{H}$ asserts:

LES has prowided few delails to meet the requiremeuls of DG-3005 \$3.2. For exaraple,

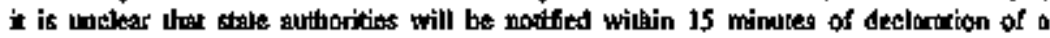
Silte Area Emergency, and who will notisy them; whether the NRC will be notifled wilhin I hour, and who will aotify bi whe bas the authorily 10 recommend and thitiote on-sile and off-sils protective actions, and toder whol conditions these actinis will be taken. As

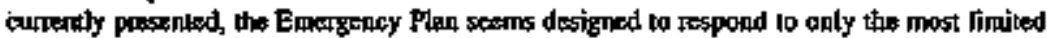
emergency stuations.

The Commission's regulations, 10 C.F.R. $\$ \$ 40.31(j)(3)$ (viii) and 70.22(i)(3) (viii), require that the facility emergency plan include

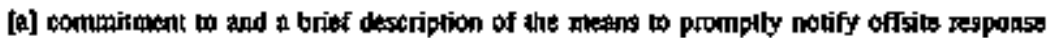
prganizntions and request of fille assistance, including medical assistance for the Irealmend of eoplaninated injured onsite uokkers when approptiate. A conteol poinl musi be eslablished. The notficztion and coordingtion must be planasd so that unavalifnblily of some personnel,

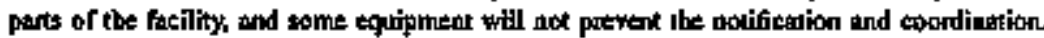

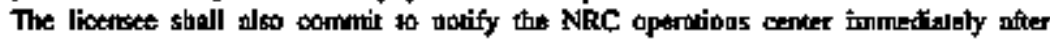
nutifibation of the approprials ollsike response organizations and not later than one hour atter the hicengee doclores an emergency [footnote omitued].

Contrary to the various elaims in Intervenor's basis H5, the CEC Emergency Plas contsins all necessary information required by the Conntssion's regulations dealing with the notification of authorities. (App. Exh. 1 (c) $\$ \$ 3.2 .1,3.2 .2$, 4.2.1, 43. 4.4, 5.4; LeRoy at 26 fol. Tr. 40) The plan clearly identifies the CEC Emergency Coordinator as the LES official responsible for notifying state and local authorities and the NRC (App. Exh. I(c) \&8 3.2. I, 3.2.2, 4.2. I; LeRoy at 26 fol. Tr. 40) and a current telephone listing of all offsite response organizations is maintained in the Emergency Plan Implementing Procedures ("EPIP") for the plan and verified and updated quarterly. (App. Exh. 1(c) \&\& 4.3, 7.8.) The classification scheme covering all incidents at the facility establishes and clearly defines two categories of events, i.e., an aler and a site area emergency, based 口pon a threshold release of UF, (Jd \$\$3.0, 3.1.) Upon the declaration of an alert or site emergency the plan requires that the CEC Emergency Coordinator 
[n]otiry] the appropdate ofisice atzststance organizadons and the Nuclear Regulabry Comraission (NRC). The offsite orgenizalions wath be nolified wilhin 15 minstes of declering an Alter, [munedintely tollowing notificalion of the oftsile assistance enganizations, the NRC wil be notifed. In all castes, the NRC will be notibed wilhin I hour of deciading an Altit.

(Id. \$3.2.t at 3.5.) Further, the plan provides that the CEC Emergency Coordinator is responsible for recommending and initiating onsite prolective aclions and for recommending offsite pcotective actions to the appropriate state and local authorities. (Id. $\$ 3.2,1,3.2,2$; LeRoy at 26 fol. Tr. 40.) Under the plan, initiation of offsite protective actions is left to the discretion of the appropriate offsite authorities. (LeRoy at 26 fol. Tr. 40; App. Exh. 1(c) \$3.3.) Leaving the responsibility for the initiation of offsite protective actions in the hands of state and local authorities is, of course, the premise underlying tho Commission's emergency plan nule. See 54 Fed. Reg. at 14,052, 14,057. Finally, and contrary to the last claim in Intervenor's basis HS, the CEC Emergency Plan, laken as a whole, is designed to respond to the full range of potential events and accidenis at the facility. (LeRoy al 27 fol. Tr. 40; App. Exh. l(c).) In this regard, the NRC Staff's witness, Mr. Ramsey, staled that the Staff found that the provisions in the emergency plan for notifying offsite response organizalions and recommending proiective actions are adequate. (Ramsey at 5 fol. Tr. I5S.) Based upon this evidence, we find that the Applicant has met its busden on the claims contained in basis $\mathrm{HS}$ and that these cjaims cannof be sustained.

In tis testimony, CANT's expert largely ignores the Intervenor's clains in basis $\mathrm{H}^{\mathrm{S}}$ and the Intervenor presented no other testmonty or evidente directly to support them, Rather, Mr+ Earl asserts that the Applicant's plan farls to provite sufficien detoil to demansirate thal offsite authorities carl or will be notified within 15 minules. Mr. Earl faults the plan for not providing the title of the state and local authorities who will receive notification from the CEC and, in the case of the Claiborne Parish Sheriff's Department, the title of the persou who will retransmit the notification to the firefighters, hospital, or highway patrol. Additionally, Mr. Earl claims that the plan neither states nor demonstrates that the oftsite personnel needed to respond to an emergency can be notified promptly or arrive at their duly stations in lime. Similarly, he asserts that the emergenty plan fails to demonstrate that notificalion for effective offsile protective actions can be accomplisted in a timely fashion. (Earl at 17 fol. $\mathrm{Tr}_{\mathrm{r}} 80$.)

The Commisston's emergency plan regulations require the Applicant to provide "a brief description of the means lo promptly notify offsite response organizations," 10 C.F.R. $\$ \$ 40,31(j)(3)(v i i i)$ and $70.22(j)(3)(v i i i)$. This reguJalory requitement simply does not require the level of delsiled information that the Intervenor's expert asserts is essential for an emergency plan. Nor does the Commission's regulatory requirement of "a brief description" require a demonstration that the Applicant's enoergency plan will accoriplish the various 
notifications. Likewise, the agency's regulations do nol require, Mr. Earl would have it, that the Applicant's plan demonstrate that the offsite entergency response organizations can respond to their duty stations "In time." (Earl at 17 fol, Tr. 80.) We note, however, that even though such a demonstration is unnecessary, the ovidentiary record amply supponts the conclusion that Clabome Fire Distritt No. 6 volunteer firefighters can and will timely respoud to the CEC and that the dispatch process through the sheriff's office is adiequate. (LeRoy at 19-20 fol. Tr 40; Tr. 82-95, We have no basts to copelude, and the Intervenor has provided us none, that the CEC Energency Coordinator will not make the requised notifications in a timely manner as set forth in the Applicant's plan.

CANT's basis Ho asserts:

In moch of Its operdion, the LES plant will be opesaing with a skeletol 4-6 person sheft It is uncles who will have emergency tesponse audionty whed a full operaung crew is not peseat

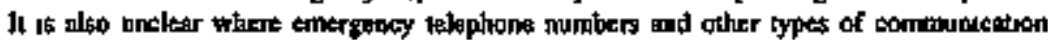
uill be placed in the facihty, whether all shift personnel wall have had adequale traunis in emergency procedures, whether there will be shifl personel all all imes with authorxy to underiake erourency measures

The claims in Intervepor's basis H6 generally relate to the responsibilities of CEC personnel and the adeguacy of the training of shaft personmel. With respect to the former, the Commission's regulations, 10 C.F.R. $\$ 840.31(j)$ (3)(vii) and 70.22(i)(3)(vii), provide that the emergency plas must include "[a] brief description of the responsibilities of licenset persontul should an accident occur, including identification of personnel responsible for promptly notifying of fsite response organizations and the NRC; also responsibilities for developing, maintaining, and updating the plan." With regard to training, the Commission's regulations, 10 C.F.R. \$ $40.31(j)(3)(x)$ and $70.22(i)(3)(x)$, state that the facility plan most contain

[a] bnel descroption of the frequescy, performance objeclives add phas tor the trang

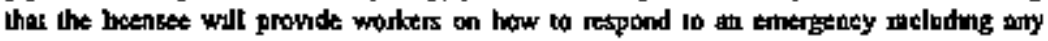

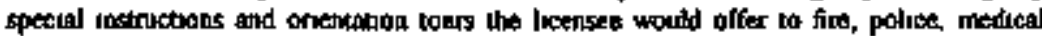
and other enpergency personnel The tranisg shab famlizerize gersonnel with srie-spectic

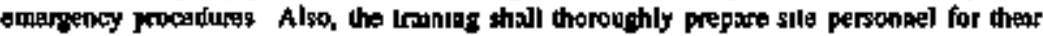
responsibilites in the exert of accadent scenanos postulated as most probable for the specilic stle, including the use of kan traming for such trentands

The Intervenor's assertions in basis $\mathrm{H} 6$ that the emergency plan fails to delineate who has entergency response authority when a foll operating crow is not prestnt and whether shift personnel have authority to undertake entergency measures art without mert. The CEC Entergency Plan provides that during nonregular hours, stch as backshifts and wetkends, when the full complement of station personnel are not present, the facility always is staffed with at least a shift

$\therefore+4$

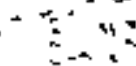

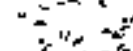

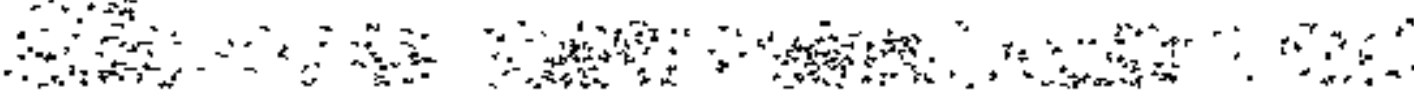
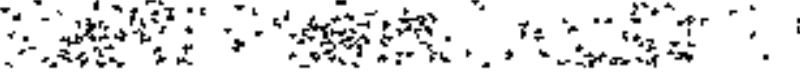
superviser, four operators, and the requisite number of security personnel. (App. Exh, 1(c) \& 4.2.) Because the number of security personnel on site at any given time is protected safoguards information, the mergency plan does not include this information. The plan provides, however, that under emergency conditions during nooregular hours the CEC Emergency Organization is staffed with the shift supervisor as the CBC Energeney Coordinator, who has the authorily and responsibitity unilaterally to inítiate any emergency actions. (Id. \$̧ 4.2, 4.2.1.) Further, the plan provides that during an emergency the operators assume the mantike of CEC Operations Shift Ttehniciants and the security personned fulfill the CEC Emergency Organization's security funclions. (Id. \& 4.2.) The applieable organization chart in the pian for the CEC Emergency Organization indicates that the security personnel perform fire control, first aid, evacuation, and search and rescue doties during an emergency. (Id. Table 4.2-1.) The plan slso provides that in an energency occuning during nonregular hours, the remainder of the CEC Energency Organization is staffed by persons summoned to the facility and that the procedures for such stafing will be set forth in the EPIP. (Id \$ 4.2.) According to the NRC Staff's witness, the Staff found that the Applicant's entergency organization staffing was adequate. (Ramsey at 6 fol. Tr. 155.) Thus, contrary to CANT's clains, the Applicant's plan meets the requisement of the Commission's regulations for "[a] brief description of the responsibilities of lietnste personnel" in an emergency doñing nontegular hours. We find, therefore, that the Applicant has met its burden on these clatims in basis $\mathrm{H} 6$ and these claims cannol be suslained.

In basis H6, the Intervenor also claims that the Applicant's plan fails to detail clearly where emergency telephone uumbers and other types of communications will be placed in the facility. Additionally, CANT's exper,. Mr. Earl, asserts in his prefiled direet testimony that the plan fails to describe comnunications channels to summon offsite assistance and that the plan provides insufficienl detail to demonstrate that skeletal shifts will have the necessary qualifications to fight 6res and prevent or mitigate accidents. (Earl at 18, 19 fol, Tr. 80.)

Conrary to these assertions, the Applicant's plan provides that the offsite telephone numbers of all emergency personnel that may be needed at the plant wijl be placed in the control room, which is the prinary Emergency Operations Center, and also in the Adminisiration butlding securicy station, which is the secontary Emergency Operations Center. (App. Exh. J(c) $\$ 4.2$; LeRoy at 28 fol. Tr. 40.) The plan also details the four communications systens at the CEC: (1) the facility telephone system; (2) the public address systern; (3) the alarm system; and (4) the lwo-way madtos. In indicates that these systems are designed so that a single failure in one system does not leave the facility without communications capability. Further, the systems are designed with reduodant devices for emergency conditions and backup power is supplied to essential devices to ensure communicalions during abnormal conditions. The plan states 
CANT's basis $\mathrm{H} 7$ asserts:

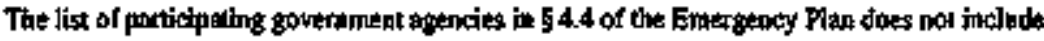

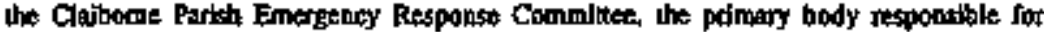
coordinating and responding to emergenctes in Claibora Parith. Nor does the list intedude the Homper Fre Deparimonl, the largest and closost such agency in the juristiction.

Contrary to the Intervenor's original claims in basis H7, the list of participating govermment agencies in the CEC Energency Plan now includes the Cleiborne Parish Emergency Response Contrittee, which is the local representative of the Loutisiana Entergency Response Comnission. (App. Exb. J(c) \& \& 4.3, 4.4; LeRoy at $35 \mathrm{fol}$. Tr. 40.) The plan also includes an agreement letter with that committee confirming its participation with the Applicant in planning for and assisling in the management of any ernergency at the CEC. (App. Exh. 1(c), Appendix at 11-9.) Futher, because the CEC is located in Claiborne Parish Fire District Na, 6, which includes the Lisbon Volntteer Fire Department, that nearby constivent fire department is the primary responder and it is included on the plan's list of participating gowemment agencies. (ld, \$4,3.) The fire department in Homer, Lauisiana, only provides backup to Claibome Parish Fire District No. 6 so it is not included in the list of primary parlicipating government agencies. (LeRoy at 30 fol. Tr. 40.) We find that the Applicant has met its burden on the clains contained in basis $\mathrm{H} 7$ and these claims cannot be sustained.

In basis H!O, the Intervenor asserts:

For each participeting govemment agency, $\$ 44$ of the Emergency Plan fols to descethe the

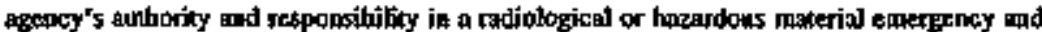

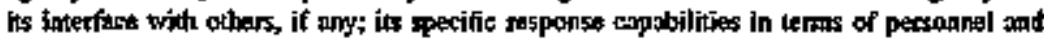
resources avilable; or what gumor controi arringernegts have been made wilh the agency or orgotizition.

As in the case of CANT's bases H5 and H6 these claims tergely implicate the responsibility and the notification and coordination provisions of the Commisstons regulations, 10 C.F.R. $\$ \$ 40.31$ (i)(3)(vij), (viji), and 70.22(i)(3)(vii), (viii).

Contrary to the Inlervenor's claims, the Applicant's emergency plan sets out the authority and responsibility of each participating government agency for a radiological or hazardous material emergency. (App. Exh. 1(c), Table 4.4-1.) The plan does not detail how those government agencies inlerface with each other but such interface is not a regulatory requirement or a required measure under the NRC Staff's regulatory guidance. (See 54 Fed. Reg. at 14,057; Int. Exh. 18: Regulatory Guide 3.67 \$ 4.4.) The Applicant's expert, Mr. LeRoy, testified that in responding to emergencies in Claiborne Parish it is the practice of the various emergency response organizations for each orgarization to operate within its owr area of responsibility and that these organizations have had no 


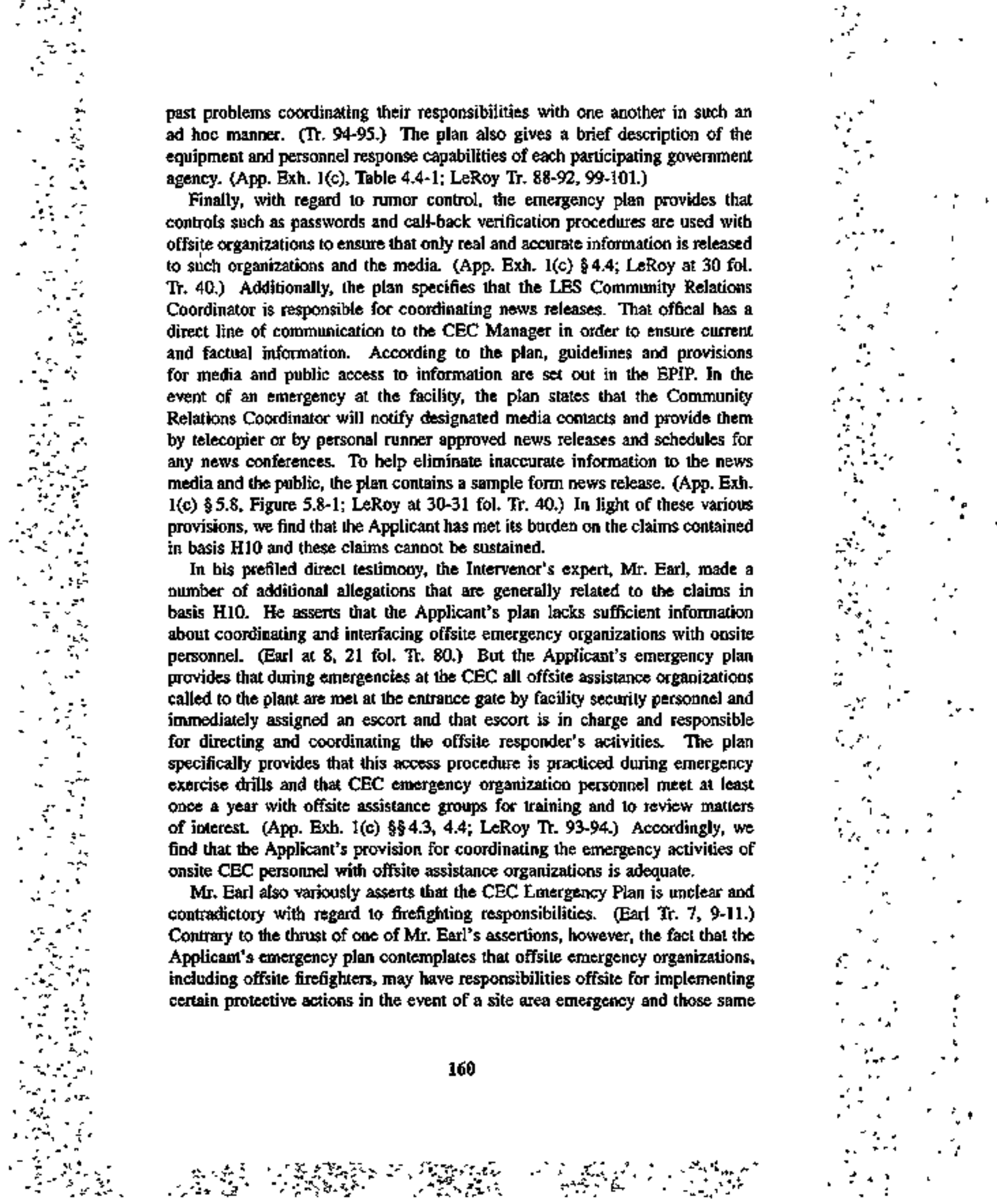


organizations, including offsite firefighters, also may have responsibilities onsite at the facility to respond to a fire or other situation duning that same site area ensergency does not make the plan ambiguous or contradictory. (App. Exh. 1(c) $\$ \$ 3.1 .2,4.3$.) The participating government agencies have the capability to perform both offsite and onsite functions and the Commission's regulations specifically anticipate that dual role for emergency response organizations. 54 Fed. Reg, at 14,052.

Mit. Eart also asserts that the Applicant's plan is ambiguauts as to the onsite responsibility of offsite fire departments for fighting fires at the site. Although we do not find that the various provisions of the CEC Emergency Plan that Mr. Earl telies upon stepport his assertion, we are troubled by the testimony of the Applicant's expert, Mr. LeRoy, that appears to contradict stetements in the CEC SAR and the Staff's SER and thereby introduces such an ambiguity. The Applicant's SAR states that "[c] he igtent of the facitity fire brigade is to be a first response effect designed to supplement the local fire department for fires at the plant and not to replace locel fire fighters." (App. Exh. 1(a) \$ 11.3.1.1.2.) The Staff's SER copies this same statement. (Staff Exh. 1 10.4.3.) In his prefiled direct teslimony, however. Mr. LoRoy slated that "the off-site fire fighting capability will be retied upon as a backup to on-site fire fighting capabilities." (LeRoy at 19 fol. Tr. 40.) Mr. LeRoy's testimony appears to contradia the statements in the Applicanl's own SAR and the Staft's SER. This matter is important because the intended rale of the onsite fire brigade may affect the number of tre brigade members needed and the kind of training the brigaxie should receive. To correcl any anbiguity introduced by Mr. LeRoy's testimony regarding the role of the offsite fire departments, the Applicant shall amead the CEC Emergency Plan to include a clear statement of the function of the offsite fire department with respect to onsile fiefighting responsibilities. If the function of the onsite fire brigade now differs from the role set forth in the SAR, the Appliteant shall revise the SAR accordingly. Simtlarly, if additional training or the size of the brigade must be increased because of the changed role of the onsite brigade, the emergency plan should be revised to reflect this changed role. The Staff shall ensure that the SER, which it introduced into evidence, reflects the correct role of the onsite fire brigade. Any necessary changes should be included in a supplement to the SER. If the function of the onsite fire brigade differs from the role described in the SER, the Staft shall ensure that the size and training of the brigade are sufficient to meet such a differing role.

CANT's basis H17 asserts:

LES has prowided no proposed measunes for dutifigating the conseguences of accldenls at the CEC for the off-sioe poblic. LES akso fails to describts, in the evest of a waming of impending dopper, the criteria tupt will be uset in dewide whether a stads prochess or the entios lociliky will be shut down and the sleps thast will be caken to ensure a safe ordexty shuddown of equipment. 
The Commission's regulations, to C.F.R. $\$ 40.31(j)(3)(v)$ and $70.33(i)(3)(v)$, require the factlity energency plan to contain "[a] brief description of the means and equipunent for ruitigating the consegpuences of each type of eccident, tncluding those provided to protect workers onsite, and a description of the porgram for maintaining the equipmont." The regulatoons, 10 C.F.R. $\$ \$ 40.3](j)(3)(x i)$ and $70.33(i)(3)(x j)$, furcher require that the plan iaclude "[a] bnef description of the means of restoring the faciltty to a safe condition after an accident."

Contrary to the claims in basis H17, the Applicant's energency plan ade. quately describes the mitigating aclions to be taken by plant operating persoone] during an accident. (App. Exh. 1(c) \$5.3; LeRoy al 32 fol. Tr. 40.) The plat specifically provides that in the event of a situation where releases could reach offsite persons, the CEC Emergency Coordinator makes recommendations to offsite authorities concerning safeguards for offsite persons. Specific recommendations would depend upon the even in progress and meteorological condilions but, in the worst case, could ixclude advising people to go indours, close all doots and windows, and tom off any ventatating systems drawing air from the outside. In order to familiarize offsite persons with the potential hazards of the CEC and the implementation of emergeacy measures, a brochuce is sent to each home within one mile of the facility descnbing the operation of une CEC and what could be expected during a serious emergency at the facility. (App. Exh. 1(c) \$ 5.44.) Under the provisions of the Applucant's energency plan for the classification of accidents, the decision to shut down the facility or isolated systems and how that is done is kef to the discteton of the CEC Emergency Coordinator (App. Exh. 1(c) \& 3.2; LeRoy at 32 fol. $T r_{+} 40$ ) The NRC Staff's wilness, Mr Ransey, jodicated that the Staff found the Applucant's description of mitigating actions in the plan adequate. (Ramsey at $7 \mathrm{fol}$. Tr. 155.) The Inlervenor presented no tesumony in support of its clams in basis H1O. We find that the Applicant's ptan satisfactorily complies with the mitigation and shutdown requirements of the Commission's regulatoons. The Applicant has met its burten with respect to the clanns contarned in basis $\mathrm{Hl} 7$ and these claums cannot be sustained.

CANT's basis H20 alleges:

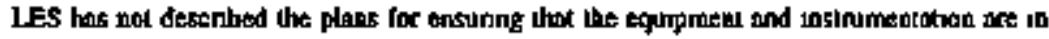
good workung condition and that an adequate slock of soppliess is manniaued, nor has LES

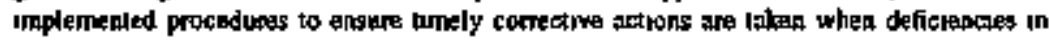
supples are noted, as required by DG.3005 \$76

The clatins raised in basis $\mathrm{H} 20$ also implicate the provisions of the Commission's regulations on the mitigation of the consequences of an accident.

The Inlerversor offered no lestimony in support of its clatms in basis $\mathrm{H} 2 \mathrm{O}$. Contrary to these claims, however, the CEC Energency Plan specifically

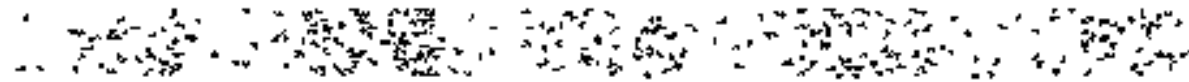


describes the emergency equipment and supplies that are avatlable at the facility and their locations. (App. Exh. 1(c) $\$ \$ 5.4 .2,6.4 .4$.) The plan also provides that the emergency equipment and supplies are inventoried and tested as appropriate once per quarter to ensure that the supplies and equipment are available in emergencies. (App. Exh. l(c) $\$ \$ 5.4 .2,7.6$; LeRoy at 33 fol. Tr. 155.) Additionally, the NRC Staff's witmess, Mr. Ramsey, indicated that the Staff finds that the provisions in the plan for inventory and maintenance are adequate. (Ramsey at 7 fol. Tr. 155.) Although the Applitint's emergency plan does uot contain any explicit procedures for corrective actions when deficiencies in emergency equipment or supplies are discovered, the Applicant's witness, Mr. LeRoy, stated in his prefiled testimony that LES will implement procedures to ensure timely corrective actions when deficiencies in emergency equipnsent ot supplies are found. (LeRoy at 34 fol. Tr. 40) In this regard, the NRC Staff's witness indicated that the Staff found it acceptable, and consistenl with its regulatory guidance, for the Applicant to deal with corrective actions in the facility EPIP. (Ramsey at 7 fol. Tr. 155.) Wo find, therefore, that the Applicant's provisions in the plan for the irventory and maintenance of emergency equipment and stpplies comply with the applicable requirements of the Commission's regulations. The Applicant has met its burden on these claims and the claims contained in basis $\mathrm{H} 20$ cannot be sustained.

The last admitted beses for contention $\mathrm{H}$, basis $\mathbf{H 2 3}$, asserls:

The Appendix oo the Emergency Plan kacks the following Informalion:

- The teiter from Homer Memotial Hospltol does not specify for how mony pesple the hospiand may be able 10 trobspont and provide tratugency carce including decondamination. This information should be specitient. If these facilties, coupled with those from Nonth Cloibome Hospital, are inadequate to proyjde Irealment for a creduble nupber of contaminoted ar chemically thjured intivaduals, then further redical services agresments stould be sapplicd.

b. Agrement letters are not supplied from the Clabornt Parish Emergency Planaing Commltee, the Homer Fure Deparimeal (which is larger and closer to the plank site than the Eisbou departinent); the Homer Polke Deparmeat; or the Louisiana Emergenty Response Commisstion.

c. The available resouress of the Listom Votuaker Fire Departmeal, Clajberne Parish Sherif's ofice, and the Lorisians Hughway Patro ane nol specifed. Thws, it is impossible

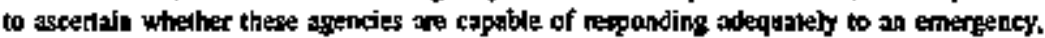
of whether they have the jurisdlctional authonky to adequalely respond to in emergetcy.

The Inlervenor's claims in basis $\mathbf{H} 23$ implicate portions of the notificalion and coordination provisions of the Commission's regulations, J0 C.F.R. $\$ 40.3$ l(j) (3)(viii) and 70.22(i)(3)(viii).

Although the agreement letuer from Homer Memorial Hospilal in the Applicant's energency plan does not specify how many people the hospital can cransport and treat in the event of an energency at the CEC, that informalion is 
provided elsewhere in the plan. The plan states that Homer Memorial Hospital is capable of handling five persons in its emergency room and the entergency roon has a staging area with twelve overflow beds. (App. Exh. J(c). Table 4.4-I; LeRoy Tr. 100.) The plan undicates that the hospital has six staff physicians and that 6ive specialists are on call. (App. Exh. 1(c), Table 4.4-1,) The Applicant's expert, Mr. LeRoy, explained that the emergency room is always staffed with at least one physician, one registered uturse, one licensed practical nurse, and two nurses* aides. (LeRoy Tr. 99.) Additionally, the plan provides that physticians associaled with the hospital and hosptal personnel participate in antutal training involving the transportation and treatmen of radiologically contaminaled patients and their role in providing emergency support. (App. Exb. 1(c) \& 5.7.) The hospital agreement letter also states that the hospital will store near the emergency room the CEC-provided emergency supply kit and permit its quarterly isventory by CEC. (Id., Appendix at 11-2.)

Further, the emergency plan indicates that two ambulances from Metro Ambulance are available to trassport patients and that 17-minute belicopter service to Shreveport medical facilities is available. (Id., Table 4.4-1) The plan states that in the event of an injury to facility personnel, Homer Memorial Hospital is contacted and provides for ambulance transportation from the plans to the bospital. If the injured individual is radiologically contaminaled, the person is acompanied to the hosptial by a qualified health physics represeniative. (Id. 85.6.) The plan also includes an agreement letter with Metro Anbulance. (App. Exh. 1(c), Appendix at 11-4.) The Applicant's expert, Mr. LeRoy, explained that Metro Ambolance always has two ambulances in Cläborne Parish, one in Homer and one in Haynesvilk, and that the company has more than 30 ambulances in nothern Lonisiana parishes that can be moved to provide coverage in an entergency. (LeRoy Tr. t00-01.)

We find that the Applicant has met its burden on the claims in basis $\mathrm{H} 23 \mathrm{a}$ and these claims cannot be sustained. There is no regulatory requirenpent dictating the specific information that must be contained in the Applicant's agreenent letters. Rather the Commission's regulations tequire that the emergency plan contain a commitmeat and brief description of the means to obtain offsite assistance for injured contaninated workers. Here, we find that the Applicant's plan, incluouing the agreenent letters, provides the necessary commitment and brief description for transporting and treating any credible muber of contarninated injured individuals.

The Intervenor's claims in basis H23b also are without meric Contrary to CANT's assertion, the Applicant's plan includes an agreememt letter with the Claiborne Parish Emergency Planning Committee. That committee is the local representative of the Louisiana Emergency Response Commission. (App. Exh. 1(c), Appendix at 11-9; LeRoy at 35 fol. Tr. 40.) As previously indicated, Claibome Parish Fire District No. 6, which includes the Lisbon Votunteer Fire
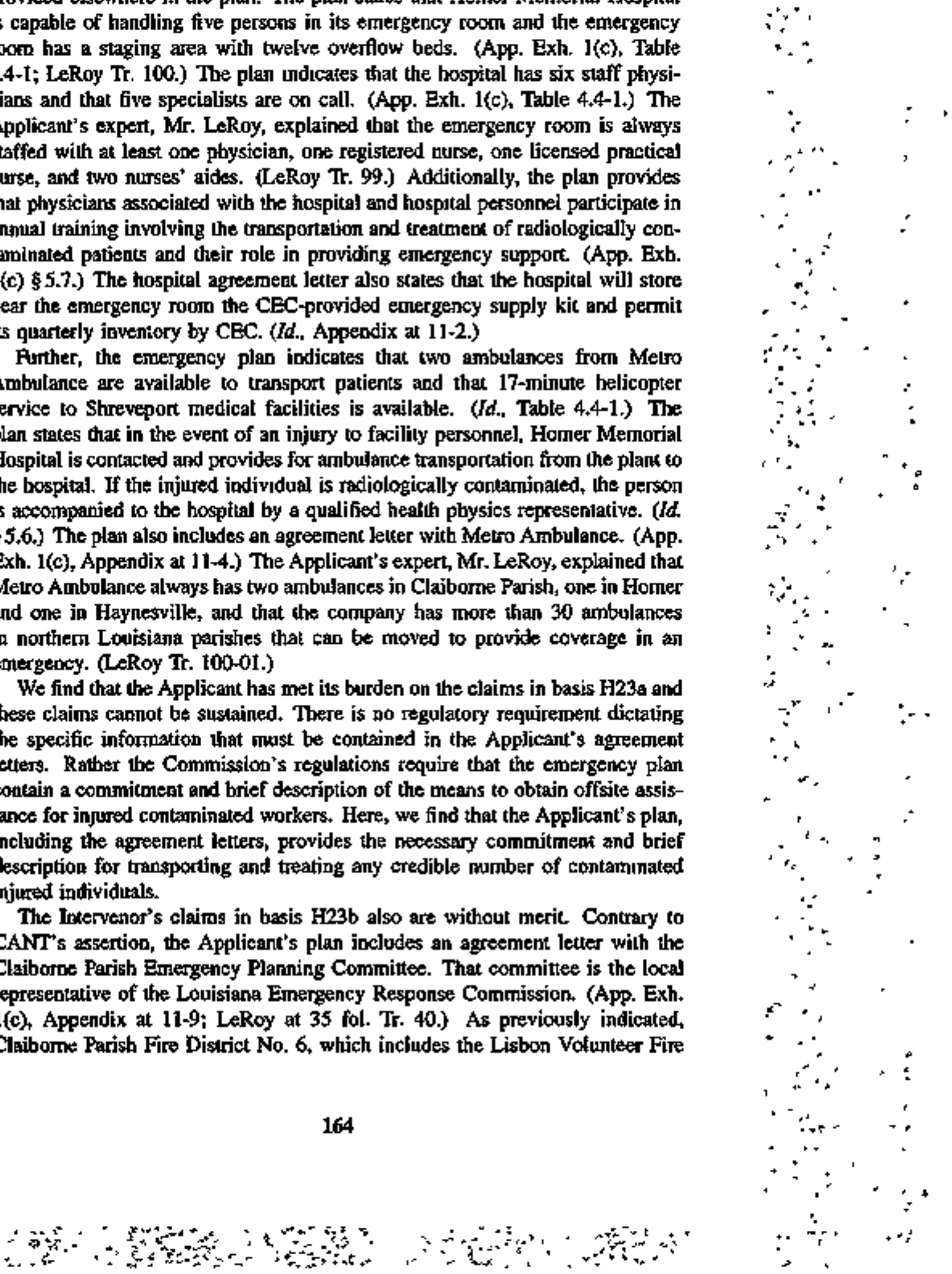
Department, has jurisciction over the geographical area of the CEC and is the primary responder to fires at the facility. The Applicant's plan includes an agrement letler with that emergency response organization. (App. Exh. $l(c)$. Appendix at I1-6; App. Exh. 2) The Homer Fire Department provides backup to the primary tesponder. Similarly, the Claibome Parish Sheriff's Department, not the Homer Police Departmenl, has jurisdiclion over the geographical area of the CEC and the Applicant's plan includes in agrreement letter with the Sheriff's Department. (App. Exh. 1(c). Appendix at 11-7.) Accordingly, we find that the Applicant bas met its bunden on the claims contained in bases H23b and these claims mor be sustained.

Likewise, the Intervenor's claims in basis H23c are without merit. The Applicant's plan specifies the available resources of the Lisbon Volunteer Fire Department, which is a component of Claibome Parisb Fire District No. 6. (ld, Table 4.4-I.) The response capabilities of the Claiborne Parish Sheriff's Department and Loutșiana Highway Patrol are aot incleded in the CEC Emergency Plan. The Applicanl considers that information proprietary because it selates to the physical security of the facility. During the proceeding, the Inlerwenor failed to take the necessary steps to obtain that information so CANT cannol now be heard to complain that it lacks the necessary information to determine whether the capabilities of those responding ageneies are adequate. We find, therefore, that the Applicant has met its burden on the claims contained in basis H23c and these claims cannot be sustained.

In addition to the foregoing findings on contention $\mathrm{H}$, we have carefully considered all of the Intervepor's other elains and assertions concterning the CEC Emergency Plan and fod them to be without merit. We conclude that the CEC Emergency Plan complies with the Commission's emergency plan regulations and that contertion $\mathrm{H}$ cannot be sustained. With regard to those matters where the plan fails to comply with the Slaff's regulatory guidance, the Staff shall ensute that the Applicant makes all appropriate additions and amendments to the plan and its implementing procedures before issuing any license. As previously indicated, in order that we may ascertain that the Applicarn has mex its commilment to us, we request that the Staff issue a brief supplement to the SER indicating the recessary amendments LES has made so that the CEC Emergency Plan fully conforms to the \$tiff's regulatory guidance.

\section{III.}

CANY's contentions $L$ and $M$ cotocen the adequacy of the Applicant's Furdamental Nuclear Material Control ("FNMC") Plan for detecting and preventing the unlawful production of enriched uranjum al the CEC. In this regard, 10 C.F.R. 870.22 (b) provides that a ticense applicalion to possess special nucleter 
material or to operate a uranium enrichment facility must contain a fult description of the applicant's program for control and accounting of the special nuclear material of any enrichmeat equipment in order to show how compliante will the Commission's material control and accounting ("MC\&A") regulations will the accomplisted.

The Comnission's MC\&A regulations require that the licensee of an enrictrment facility "shall establish, implement, and maintain a NRC-approved material control and accounting system," id. $\$ 74.33($ a), through the crealion of a fundamental muclear material control plan. $I d . \$ 74.33(b)$. That regulation further provides that the licensee's MC\&A system must achieve níne enumowated performance objectives, including the ability to "Tp]rotect against and detect production of uranium enriched to 10 percent of more in the isotope $U^{23}$ " and "[p]rofect against and detect unauthorized production of uranium of low strategic significance." Id $\$ 74,33(\mathrm{a})(2)$ and (3). To meet these gentral perfomance objectives, the regulation also requires that the licensee establish, document, and matintain, inter alia,

[a] datection program, independent of prodoction, thal mowides high assurance of telecting

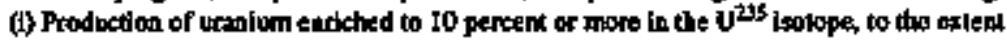
that SNM of moderave strategic signtitcance could be produced withln any 370 calendar day period;

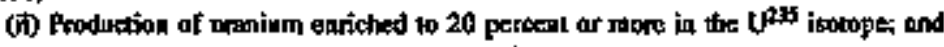

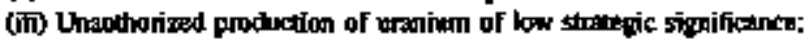

ld. 574.33 (c) (5). Finally, in order to anthorize a license for an enrichanend facility, the Commission's regulations require that we find the applicant's MC\&A plan adequate. Id. \$70.23(a)(6).

Because CANTs contentions $L$ and $M$ involve the sane geperal safeguards subject matter, the contentions were combined for bearing. (Tr. 189-90.) The Inlervemor's contention $\mathbf{L}$ asserts:

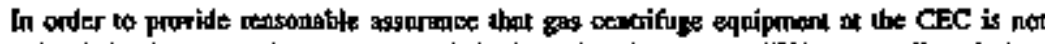

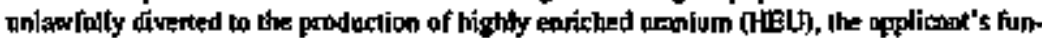
danental muclear molesial control (FNMC) phan should require contineous or frequent onzifne entidiment moniloring for all cascodes. To ensure the effectiveatess of such mopiloring the plat should stipulace minimum process pipe janer diameters of 110 millimeters or grexter

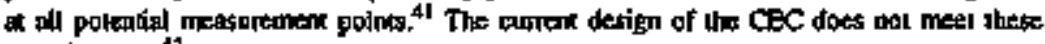
specilifenlions:" 12

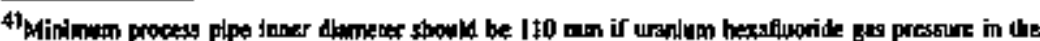

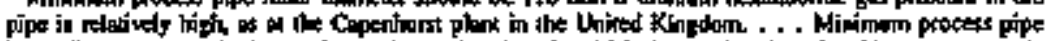

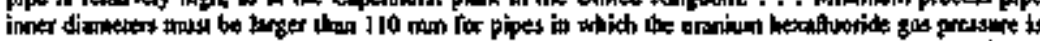

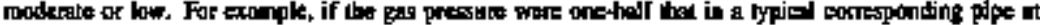

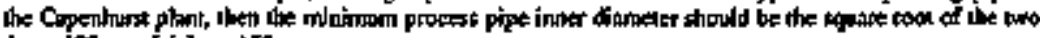
imes $100 \mathrm{~mm}[\mathrm{akc}]$, or $155 \mathrm{~mm}$

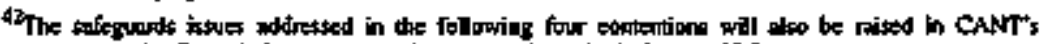

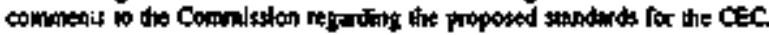


In a similar vein to its first safeguards contention, CANT"s contention $M$ asserts;

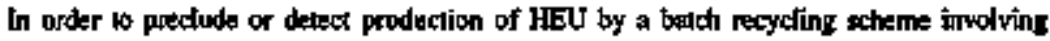
misuse of semplifeg pors, process valves, andfor flanges, the applicant's FNhCC plan should require effecliwe monitoring by reliable techuical means which acturately keep track of exployes atcess to the proctess conaection loctations.

To support its position on conteptions $L$ and $M$, the Applicant presented the testimony of a two-wiuness panel comprised of Peter G. LeRoy and Erich F. Kraska (LeRoy-Kraska fol. Tr. 194.) As Licensing Manager for the CEC, Mr. LeRoy directed the preparation of the CEC FNMC Plan and reviewed and approved it. Mr. LoRoy also is an NRC-authorized derivative classitaer. (LeRoy-Kraska re L at 1-2 fol. Tr. 194.) Mr. Kraska is employed as a sentor technical manager by Urenco Investments, Inc., one of the general partners of LES. He is responsible for ensuring that the CEC is designed in acoordanee with the informalion transferred to LES by Urenco. Mr. Kraska assisted in tho development and review of the CEC FNMC Plan to ensure that the Applicant's safeguards program is consistent with equivalent security programs at Urenco's European facilities that are based on Euratom and International Atomic Energy Agency ("IAEA") requirenents. Because Mr. Kraska does not have agency clearance for classified information developed in the United States, he has not had access to the classified portions of the CEC FNMC Plan. (LeRoy-Kraska re $\mathrm{L}$ at 2-3 fol. Tr. 194.)

Pursuant to a stipslation of the parties, the following Applicant exbibits were admitted into evidence: Applicant's Exhibit 1(b), the Classified Addendum to the CEC SAR (App. Exh. 1(b)); Applicant's Exhibji 1(d), the CEC FNMC Ptan (App. Exh. 1(d)); Applicant's Exhibit 1(f), the CEC Physical Security Ptan (App, Exh. I(f)); and, Applicant's Exhibit I(g), the CEC Security Plan for the protection of classifed matler and information (App. Exh. J(g)) (Tr. 31) Each of these Applicant exhibits contains proprielary informlation pursusat to 10 C.F.R $\$ 2.790$ (d) (1), classified information, or both. Although these exhibits are part of the decisional record of the proceeding, they are not publicly availabie. In particular, all twelve chapiers of the CEC FNMC Plan (App. Exh 1(d)) contain proprietary information and, in addition, Chapter 9 describes the clandestine prevention prografn and is classified as confidential national security information.

The NRC Siaff supponted the position of the Applicant on contentions L and $M$ and presented the testionony of a panel of witnesses made up of Donald R. Joy and Bruce W. Moran. (Ioy-Moran fol. Tr. 243). Mr. Joy is a senior physical scienlist with the NRC in the area of matertal control and accounting, with experience in safeguards inspections of furel fabrication facilities. He helped write the Commission's regalations on material control and accounling for enrichment facilities in JO C.F.R $\$ 74.33$ and the Staff guidance on those 
C.F.R \& 74.33 without using such technology. (Tr. 216-18.) We overnuled the Applicand's objection and admitted Ms. Hunt's prefiled direct testimony. In sa nuling, we indicated that, consistent with Rule 703 of the Federal Rules of Evidence, the Applicant and the Staff could attengt to establish though crossexamination the lack of factual foundation for Ms. Hunt's expert opinion and that we would decide the appropriats weight to give her testimony. (Th. 225-26.)'

In resolving contentions $L$ and $M$, we initially ume to the case the Intervenor seeks to brild from Ms. Hunt's testimony. Because CANT's argument is succinctly set out in its proposed findings, we address the argument it presents there.

The Intervenor first asserts that in promulgating 10 C.F.R. $\$ 74.33$ the Commission noted that the regulation " "was written with full consideration of IAEA agreements. . . ' 56 Fed. Reg. 55,991, 55,992 (October 31, 1991)" and "[t]hus, an MC\&A program which does not comply with IAEA agreements cannot comply with 10 C.F.R. $\$ 74.33$." CANT's Clarifted Proposed Findings

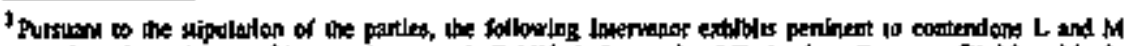

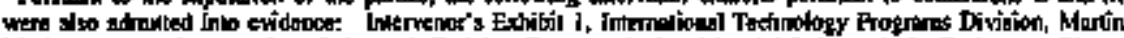

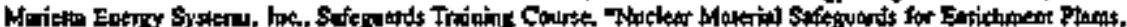

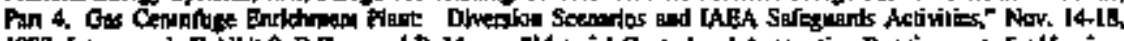

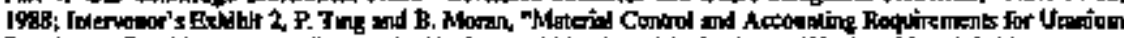

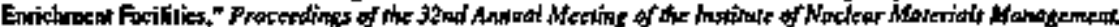

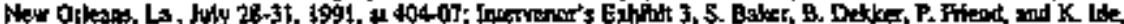

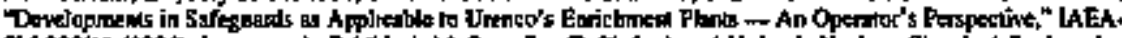

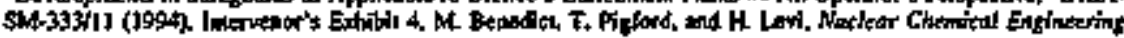

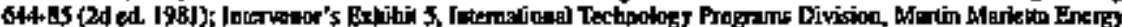

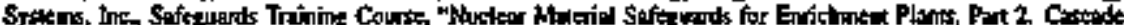

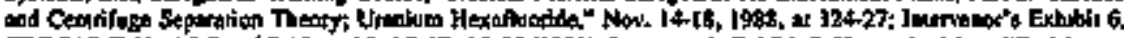

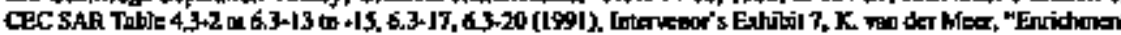

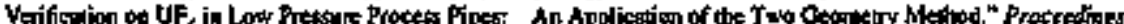

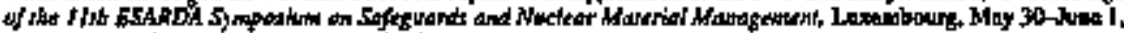

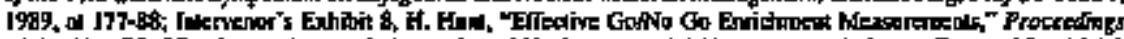

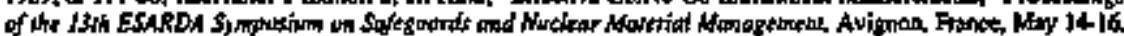

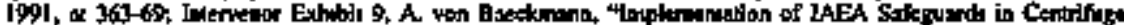

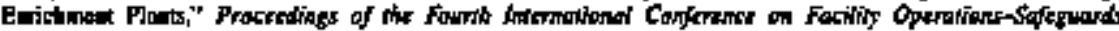

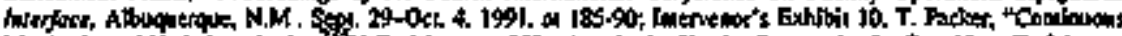

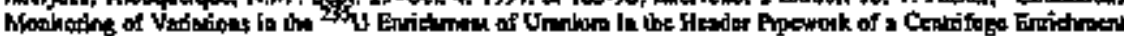

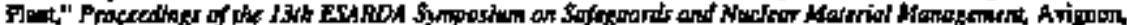

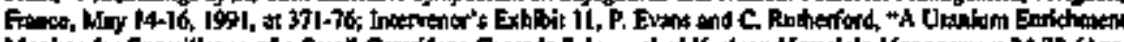

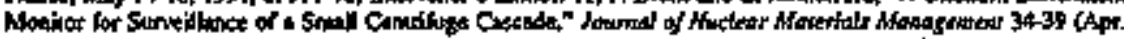

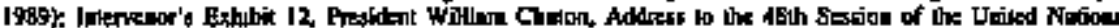

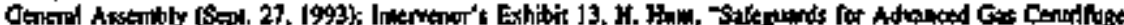

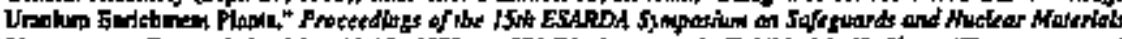

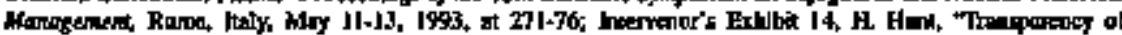

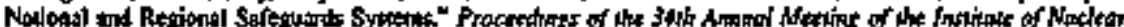

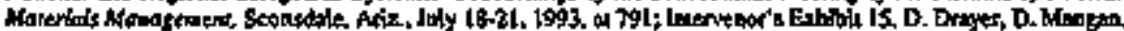

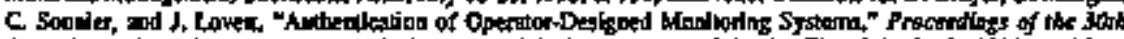

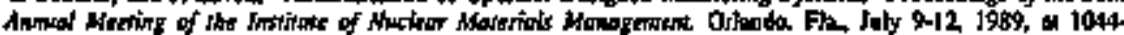

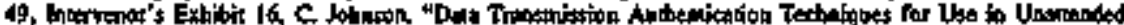

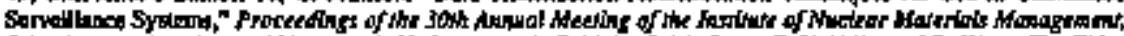

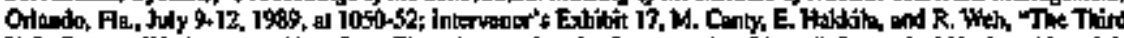

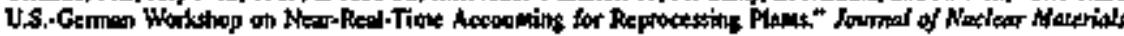

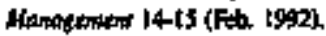
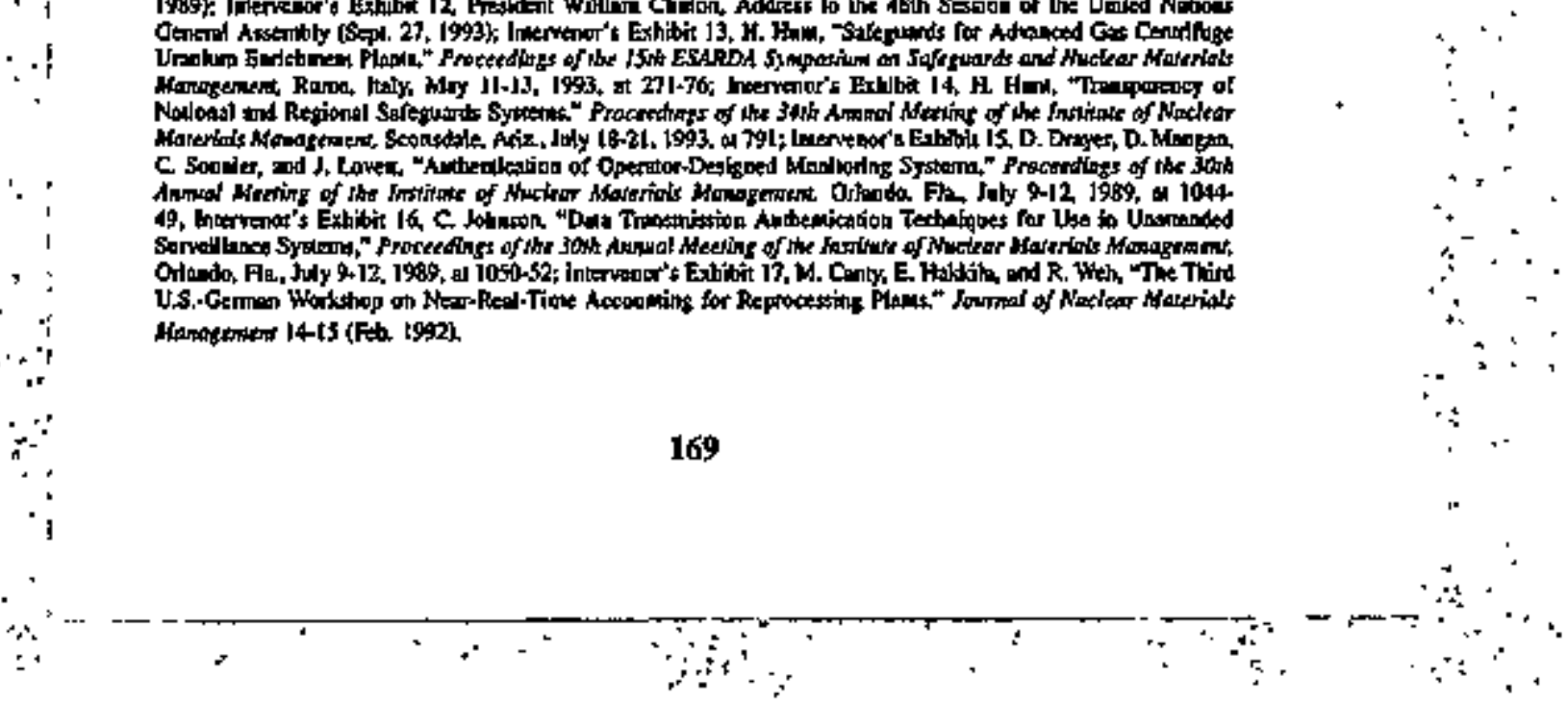
of Fact and Conclusions of Law Pertaining to Contentions $L$ and $M$ (Oct. $24,1994)$ at 2 . Next, the Intervenor asserts that the LES license application is abject to the Agreement Betwees the United States of America and the International Atomic Energy Agency for the Application of Safeguards in the United Stales of America, Nov. 18, 1977, 32 U.S.T. 3062, that took effect in 1980 as pant of the umplententation of the Treaty on the Not-Proliferalion of Nuclear Weapons, July 1, 1968, 21 U.S.T. 483. Citing article 72(b) of the IAEA Agrement, the Intervenor clains that "this treaty provides that the LAEA must be able to "make independent measurement of all nuclear material subject to safeguards. . . " CANT's PF at 2-3 citing 32 U.S.T. at 3082. CANT then argtes that the Applicant's classified information concerring the CEC safeguerds provisions is irelevant to evaluating compliance with LAEA safeguards "because it does not gertain to the LAEA's ability to independently verify the absence of HEU production." Id. at 4-5. Acconding to CANT, only continuous on-line enrichmeat monitoring of each CEC cascade w] II permit "the IAEA to independently verify the absence of HEU production at the CEC." Id at 7. Siciularly, CANT declares that only tamperproof monitors with authenticated transuission to a central computer will permit "the IAEA . . . to be able to independently dedect vanathorized patterns of valve manipulation which would indicale possible HEU production." Id. at 9.

CANT's entire argument fails, however, because it is footed on an erronenous premise. The Intervenor misteads and mistapprehends article 72(b) of the IAEA Agreement, which is the cornerstone of its argument. Contrary to its assertions, that IAEA provision does not, throngh the mechanism of allowing the IAEA to make independent measurements of nuclear material subject to safeguards, mandate that the Applicant employ at its encichment facility any particular design configuration or any specific hardware in order to provide the IAEA with an independent mears of verufying that po HEU has been produced at the factlity.

To make its argument, the Intervebor selectively quotes article 72(b) and adds language to its description of the provision to convey the meaniag that the IAEA Agreement creates a design or hardwane requizensem. In describing article 72(b), CANT states that "[a]nong other things, this treaty provides that the IAEA must be abie to 'make independent measurement of all muckear materjal subject to safeguards . . ' Jd at 3-4 (first emplassis supplied). But the actual language of articte 72 conveys no such meaning. It states:

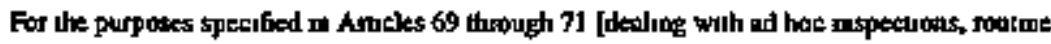

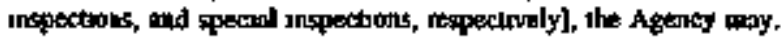

(a) Extamine the reconds kepl purrank to Atucles 49 though $S 6$,

(b) Make independemt metsuar ments of all muctear matenat subject to safeguards under Ihis Agretentew.

$\therefore=2$

$\because \quad \because$

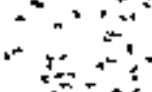
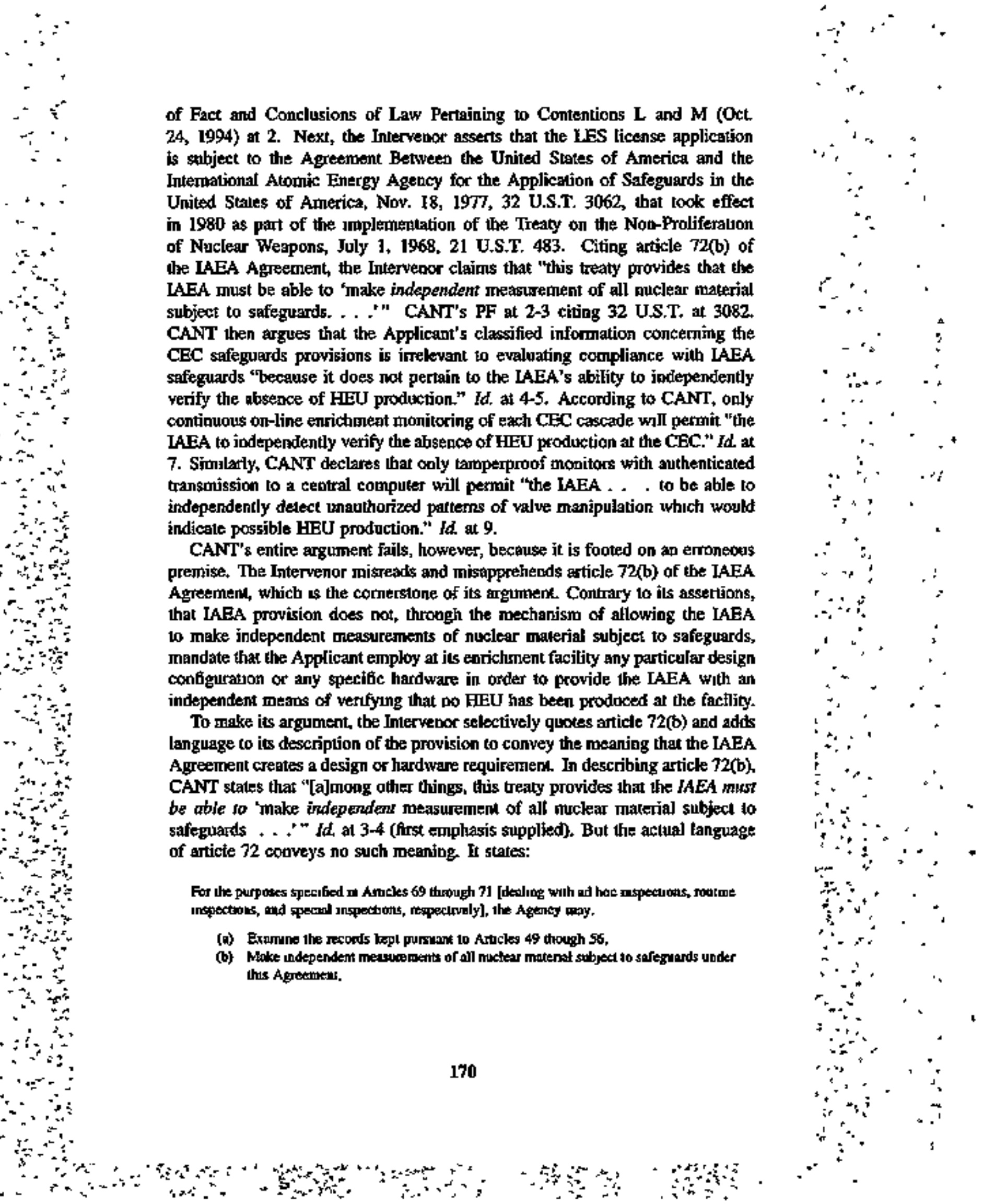
(c) Verfy the tunctioning and calibratiog of Instrumems and other Ineasuring and ontrol equipments

(d) Apply and maks ure of surveillance and conaingunent messures; and

(c) Upe olher objective methods whith have been demonsirated to be techoically fexible.

32 U.S.T. at 3082 . The meaning of article 72 is further delineated by article 73 , which states:

Wilhin the scopte of Article 72, the Agency shat be trathitit:

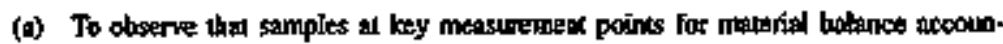
lancy we lekep in accordunce with procedums which pinduce representallve samples, to obserwe the trestmem and andysis of the samples and to obtain duplicates of anch samptes;

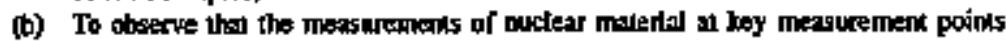

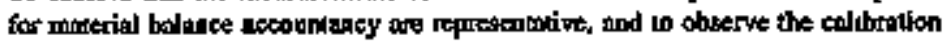
of the instroments and equipment trwolkad;

(c) To make sangements wilh the United Stoles that, if aecensary:

(i) Adtititual mesourements we mode and atditional samples talien foc the Agency's tas;

(ii) The Agency's sumpiand andylyeal samples are analysed;

(iii) Appcopsiale absolute gtandands tro used is ealdmoting insiraments and other equipment;

(iv) Oher caliorutions ane comed oun;

(d) To arming lo use its own tequipment for independent messupenpenl and surveillants. and if so afreed and specified it the Subsidlary Amongements 10 arrogge to install suct equipment;

(c) To atply its seals and other identifylng and tmaper-indianting delices to coalainments, if so agreed and spectiled is the Sobsidiary Arragements; and

(f) To make arrogrencents with the United States for the shipping of samples latken for the Arency's use.

ld. As the Jangutage of these provisions makes clear, the authority of the IAEA pursuant to article 72 (b) to make its own measurements of buckear material subject to safeguards does not translate into a requitement that a facility subject to IAEA inspection must entoloy a particular design or a specific kind of hardware to provide the IAEA an independent and foolproof method of verifying that no HEU has been produced at the facility, as the Intervenor asserts.

Further, the Irtervenor's case ts not advanced by its argument that because the Commission's safeguards nule for enrichment facilities tras tritten "with full consideration of IAEA agreenents," an applicant's MC\&A program compitance with the LAEA Agreentent is central to its compliance with I0 C.F.R. \$74.33. Although CANT is conrect that the Commission issued the safeguaris nule "with foll consideration of IAEA agreements," 56 Fed. Reg. at 55,992, contrary to the Intervenor's claim the 1AEA Agreement does not prescribe any partictlar design configuration or specific hardware for the CEC to provide the IAEA 
an independent method of verifying enrichment production. Because CANT's argumeat is based upon a misreading of the IAEA Agreement, the fact that the Commission issued the safeguards tule with full consideration of the IAEA Agreement provides to support for its position.

Indeod, in promulgating 10 C.F.R. \$ 74.33, the Commission expressly rejected the suggestion of a commenter with close ties to CANT that it should requite that plant hardware be designed to permit and facilitate independent "gofno go" verification of the absence of unauthorized enrichment. See CLI-92-7, 35 NRC 93, J03 n+9 (1992). Similarly, the Cominjssion rejected the suggestion that it should require that an applicant consult with the LAEA on plant basdware design. In the statement of consuterations accompanying the finall ruk, it stated:

The Commission does not believe lhal the suggested hardware design is ellher necessary of

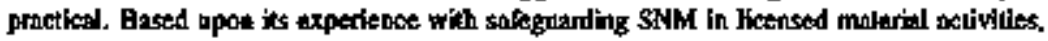

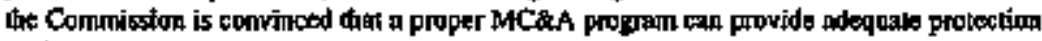
opgotngt unguthorized earichanent, and warance thal strould $k$ occur, it will be delected in a timely manner. Therefoce, the Commission does nol behieve il is nesessary to impose such a

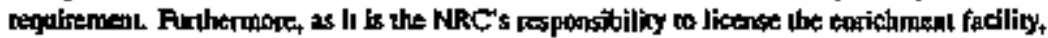

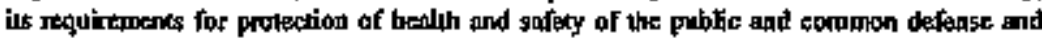
tecourity bice precedence owtr LAEA inspection schenres and profocols. Nonetheless, these MCdA requinements wene developed cognizan of IAEA programs because the U.S. is a member country of LAEA and complies with the LAEA raquinements. Conseguently, the suggestloe of the commenarer is nefused.

56 Fed. Reg. 55,991, 55,995 (1991).

That the Intervenor's reading of the IAEA Agreement is erroneous also is evident from one of the Commission's rulings in this proceeding. In the notice initiating the proceeding, the Commission provided that any subsequently admitted party could seek reconsideration of the special licensing criteria that the Compuission stated would be applicable to the CEC. The Intervenor sought reconsideration and, in its motion, complained of the lack of a safeguards design criterion applicable to the CEC. It requested a destgen criterion for the facility and its bardware conducive to the implementation of effective adranced national and international safeguerds techniques and proctdures. CANT also asked the Conumission to impose licensing standards thet would ensure effective monttoring of the CEC by the IAEA, including online enrichnent monitoring and effective monitoring of all ampling ports, process valves, and flanges the subject of CANT's contentions L and M. CL1-92-7, 35 NRC at 102.

in denying the Intervenor's request for a safeguands design criterion, the Commission stated that it already had adtressed the need for safteguards against unauthorized activities by issuing 10 C.F.R. \$74.33. It also rejecled CANT's call for licensing standards requiring online enrichment monitoring and effective nowitoring of sampling ports, process valves, and flanges. The Commission sudicated that the Intervenor's proposed licensing standards were "prescriptive" 
and explained that, in promulgating the safeguands nule, it had masie a reasoned policy choice to regulate by performante-based standards for MC\&A prograens. It added that "[]]icensees may, of course, choose or need to employ the CANT. suggested means to achieve an appropriate level of safeguards; however, those means are not necessarily the exclusive solutions to meeting the Commission's performance requirements." ld. at 104 .

The Comunission's statements denying CANT's reconsideration motion, taken in conjumction with the statement of considerations accompanying the final safeguands rols, make it clear that the Intervenor's reading of the IAEA Agreemeat is not shared by the Commission. In promulgating the safeguards rule, the Commission remerked that the mle was written with foll consideration of IAEA agreemsnts. Consistent with that statement, is denying CANT's reconsideration motion the Comnission could not have rejected the Intervenor's suggested licensing standards on the ground that such standards were prescriptive, and bence incompatible with the performance-based standards of the safegaards rule, if those very semne proscifptive standards were mandated by the LAEA Agreement.

Thus, as the Commission suggested, $10 \mathrm{C} . F, R . \$ 74.33$ is fally consisted with the IAEA Agreement and the Intervenor's reakting of that Agreement is erroneous. Contrary to CANT's assertions, the IAEA Agretrient, and hence the Commission's safeguards role, simply do not impose on the Applteant a requirement that the CEC must employ a particular design configuration of a specific kind of hardware in order to provide the IAEA an iodependent and foolproof method of verifying that no HEU has been produced at the faciltyWhether the Intervenor's position is viewed as a strictly legal argument that the IAEA Agreement requires, as a matter of taw, continuous online enrichment monitoring and effective monitoring of sampling ports, process valves, and flanges, or whether CANI's position is viewed as a factual argement that these same methods are the only possible way to provide LAEA with an independent method of verifying that no HEU has been produced at the facility, the arguments fail becalse they are entirely based on CANT's incorrect assumption that IAEA safeguards provisions provide the baseline requirements needed to comply with NRC safeguards regulations. CANT"s enoneous reading of the IAEA Agreentent renders its contentions $L$ and $M$ meritless.

As the foregoing oiscussion demonstrates, the adequacy of the Applicant's ssfeguands measures to detect unauthorized praduction of enriched uranium must be detertinimed under the Commission's safeguards roke. Pursuant to 10 C.F.R. $\$ 74.33$ (c)(S), the CEC FNMC Plan nust provide bigh assurance that the Applicant's detection program will detect the unguthorized production of entiched uranium. As previously indicated, the Intervenor's expert chose to forego reviewing of the proprietary and classified information on the Applisant's safeguands program. Additionally, the Intervenor took the position that such tinformation was irrelevant for determining compliance with what it believed (albeil trroneously) 
were the controlling IAEA safeguards requirements. Therefore, in providing her analysis of the Applicant's compliance with 10 C.F.R \$74.33(c)(5) Ms. Hunt lacked complete, aceurate, factual information about the Applicant's safeguards measures and the design and layout of the CEC, including the clessified addendurn to the CEC SAR (App. Exh. I(b)), the CEC FNMC Plan (App. Exh. 1(d)), and the CEC Physical Secuity Plan (App. Exh. 1(f)). As a result, the quality of Ms. Huot's analysis was seriously impaired, For example, Ms. Hunt did not know how the CEC centrifuges are interconected to form cascades, how the cascades are controllect, or how many process valves are on each cascide. Similarly, the Intervenor's expert did not know whether the CEC cascades can be reconfigured and, if $s 0$, by what aness, where the process valves are located, or what measures LES will employ to control personnel access to the centrifuges. (Tr. 231-36.) The poptietary and classified information in the Applicant's Exhibits 1(b), 1(d), and 1(f) are at the herart of the question of the adequacy of the Applicatin's safeguards provisions and indispensable to any determination of whether the Commussion's regulations bave been met. Without knowledge of the relevant facts, CANT's expert did not have a sufficient foundation to reach an informed expert opinion on whether the Applicant's safeguards provisions provide high assurance of detecting the unauthorized production of enriched uraniurr. Hence, we can guve Ms. Hunt's testinnony no weight in considering contentions $\mathrm{L}$ and $\mathrm{M}$.

Turning to the ments of CANT's contention $L$, it asserts that continuous online enrichment monitoning of all cascades, with minimum pipe diameters of 110 millumeters to support it, is necessary to provide ressonable assurance that gas centrifuge equipment is not unlawfully duverted to the production of HEU. In responding to contention $L$, the Applicant's expert witnesses, Mr. LeRoy and Mr. Kraska, stated in their prefiled direct testimony that contenuous online enrichment montering is not necessary to prevent diversion of centrifuge equipment to the production of HEU at the CEC. (LeRoy-Kraska re $\mathrm{L}$ at 4, 12 fol. Tr. 194.) Mr. LeRoy indicated that the classified material in chapter 9 of the CEC FNMC Plan describes the Applicant's clandestine enrichnent prevention program. This program is multifaceled and pcovides a number of means of preventing, detecting, and miligating diversion of ennched uranium. (LeRoyKraska re $L$ at $10-11$ fol. Tr. 194.)

Because the CEC FNMC Plan (App. Exh. 1(d)), the CEC Physical Security Plan (App. Exh. 1(f)), and the classified addendum to the CEC SAR (App. Exh. I(b)) that detail the Applicant's safeguards provisions are comprised of proprietary and classified information, and the Intervenor has chosen not to review this vital information, no purpose would be served by filing separate classified findings on CANT's contentions. It suffices to note generally that the Applicant's safeguards program works through the control of personmel access,

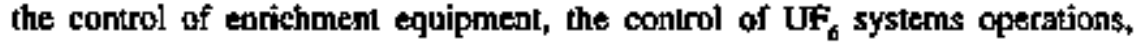

$+\hat{n}^{n}+i$

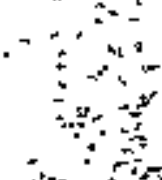

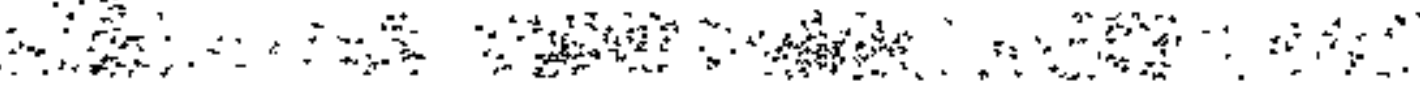

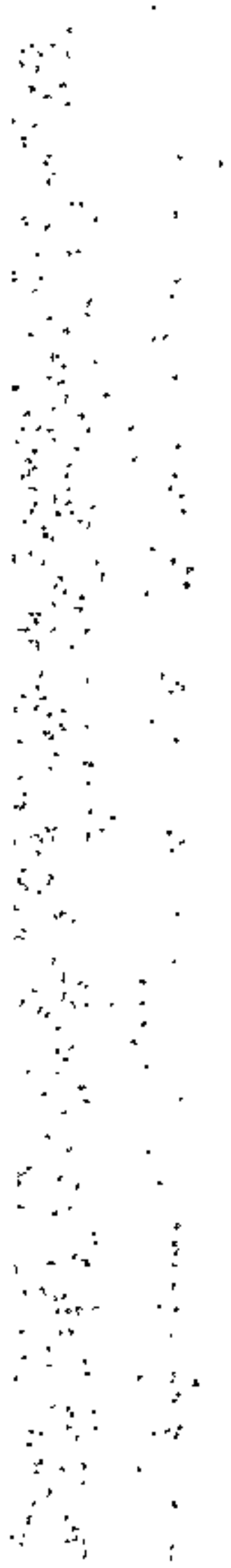


maintenance, testing, and the monitoring and inspection of $\mathrm{UF}_{6}$ systents and $\mathrm{UF}_{6}$ usage and storage areas. Through these methods various clandestine scenarios such as batch recycling will be preverted from occurting at the CEC. (LeRoyKraska re L at 13-14 fol. Tr. 194.) Mr. LeRoy concluded that the Applicant's safeguards nieasures, particularly the CEC design and the CEC FNMC Plan, as well as the proposed procedures, operating practices, and adpinistrative programs for the facility, provide a high degree of assurance that clandestine diversion of enrichment will not occur at the CEC. (LeRoy-Kraska re L at 23 fol. Tr. 194.) Further, the NRC Staff's expert witnesses, Mr. Joy and Mr. Moran, stated in thet prefiled direcl lestimony that continuos as online enrichment monitoring is not necessary to detect unauthorized enrichment. (Joy-Moran re L at 7 fol. Tr. 243.) The Staff cvaluated the Applicant's safeguards provisions and concluded that the CEC FNMC Plan provides the required assurance of detecting the unaustiorized production of HEV at the facility and meets all NRC regulatory Iequirements. (Joy-Moran re L at 6-7 fol. Tr. 243; Tr. 247.)

Based upon the testimony of the expert witnesses for the Applicant and the Staff and the proprietary and classified information contained in Applicant's Exhibits 1(b), I(d), and 1(f), we find that the CEC FNMC Plas meets the regulatory tequirements of the Commission's safegutards regulations, particularly 10 C.F.R. $\$ 74,33(\mathrm{c})(5)$. The Applicant bas met is burden on CANT's contention $L$ and that contention cannot be sustained.

CANT's other safeguards conlention, contention $M$, asserts that in order to effectively preclude and detect production of HEU by batch recycing though the misuse of sampling ports, process valves, and flanges, the CEC FNMC PJan should require effective monitoring by reliable technical means, i.e., tamperproof controls, to track employee access to process connection locations. The Applicant's expert wilnesses, Mr. LeRoy and Mr. Kraskes, both testified that the tamperproof devices called for by CANT in contention $M$ are not necessary to comply with the Commission's safeguards regulations. (LeRoy-Kraska re $M$ at 4 fol. Tr. 194; Tr. 256.) Access to sampling pors, valves, and flanges is controlled at the CEC and the monitoring devices and methods employed by LES for sampling ports, process valves, and flanges will provide the high assurance requited by 10 C.F.R. $\$ 74.33$ (c)(5) for desecting tmauthorized production of enriched uranium. (LeRoy-Kraska se $M$ at 4, $8-9$ fol. Tr. 194.) Chapters 2, 6 , and 9 of the CEC FNMC Plan deseribe the devices, methots, and prograns for controlling sampling ports, valves, and flanges. Specifically, the classitied material in Chapter 9 contains, inter alia, the enrichment scenartos involving sampling ports, valves, and ffanges that will be detected and prevented by the Applicant's program, including batch recycling. (LeRoy-Kraska re M al 8-1 l fol. Tr. 194.) Further, the NRC Staff witnesses, Mr. Joy and Mr. Moran, inclicated in their prefiled direct testimony that the Staff concluded that batch recycling through the use of sampling ports, valves, and flanges has been actequately 
addressed by the Applicant and that compliance with the CEC FNMC Plan will provide adequate detertence to, and detection of, unauthorized production of HEU. (Joy-Moran re M at 6-7 fol. Tr. 243.) Both Mr. Joy and Mr. Moran testified that they were satisfied that the CEC FNMC Flan meets all NRC regulatory requitements and provides the bigh assturance requited by the regulations. (Tr. 247.)

Based on the testimony of the expert witnesses of the Applicant and the Staff and the proputelary and classified information contained in Applicant's Exhlbits 1(b), J(d), and I(f), we find that the CEC FNMC Plan also meets the requirements of 10 C.F.R. \$74.33(c)(5). The Applicant has met its burden on CANT's contention $M$ and that contention cannot be sustained.

IV.

For the foregoing reasons, we conclude that the CEC Emergency Plan and the CEC FNMC Plan comply with the Commission's applicable regulations and that CANT's contentions $\mathrm{H}, \mathrm{L}$, and $\mathrm{M}$ cannot be sustained. Pursuant to 10 C.F.R. $\$ 2.760$ of the Commission's Rules of Practice, this Partial Initial Decision will constitute the final decision of the Commission on these contentions forty (40) days from the date of its issuance unless a petition for review is filed in accordance with 10 C.F.R. \$2.786, or the Commission directs otherwise. Within fifteen (15) days after serviet of this Partial Initial Decision, any party may fife a petition for review with the Commission on the grounds specified in 10 C.F.R. $\$ 2.786(b)(4)$. The filing of a pecition for review is mandatory in order for a party to have exhausted its administrative rentedies before judicial review at the appropriate time. Within ten (10) days after service of a petition for revjew, any party to the proceeding may file an answer supporting

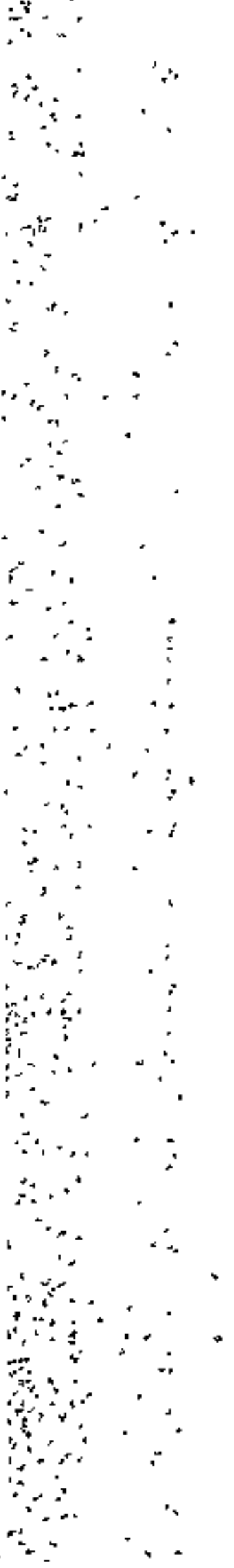


or opposing Commission review. The petition for review and any answers shall conform to the requirements of 10 C.F.R. $\$ 2.786(\mathrm{~b})(2)-(3)$. It is so ORDERED.

THE ATOMIC SAFETY AND LICENSING BOARD

Thornas S. Moore

ADMINISTRATIVE JUDGE

Richard F. Cole

ADMINISTRATIVE JUDGE

Frederick I. Shon

ADMINISTRATTVE JUDGE

Rackville, Maryland

April 26, 1996 


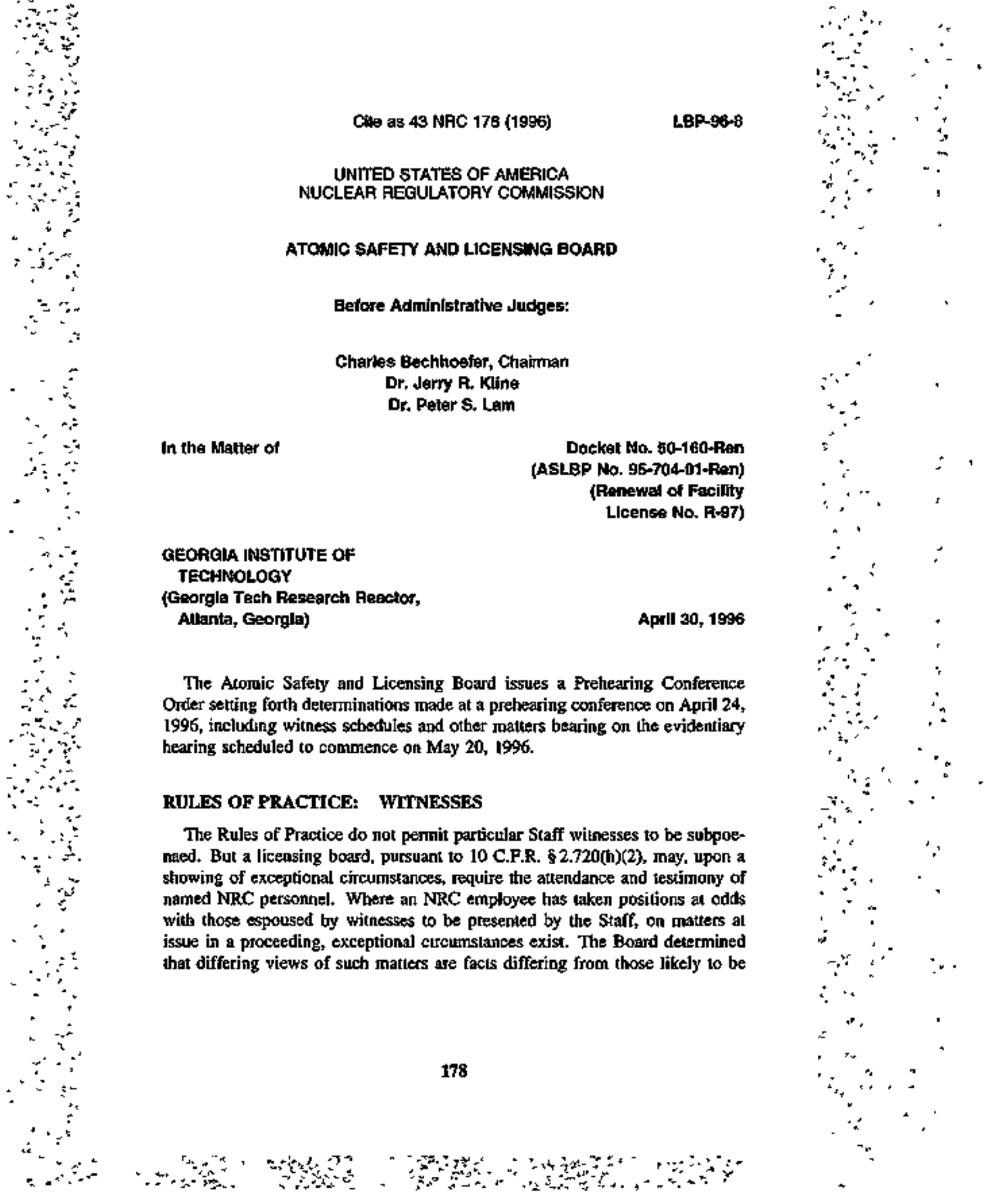


presented by the Staff witnesses and, on that basis, required the attendance and testimeny of the named NRC personnel.

\section{THIRD PREHEARING CONFERENCE ORDER}

On April 24, 1996, the Atomic Safety and Licensing Board conducted a prehearing conference in Aclanta, Georgia (Tt. 834-914).' Parlicipating were representatives of Georgia Institute of Technology (Georgia Tech or Applicant), Georgians Against Nuclear Energy (GANE or Intervenor), and the NRC Staff. This conference served masty of the purposes described in 10 CF.R. \$2.752. Following are the specific matters considered.

\section{A. Witness Schedules}

The Botrd approved schedules for the appearance of particular witnesses at the hearing commeneing on May 20, 1996. Previously, the Board had directed the parties to present the names of all of their witnesses at the prehearing conference. All of them did so. ${ }^{2}$ Because much of Georgia Tech's case is likely to be rebuttal testimony, Ocorgia Tech was given the authority to idenlify additional rebuttal witnesses following the testimony of GANE's witnesses. (Georgia Tech in fact identified not only its direct witnesses but also certain potential rebuttal witnesses.) The sctredules for particular witnesses are as follows:

1. Georgia Tech:
a. Dr. R.A. Karam
b. Dr. Nicholas Tsoulfanidis
c. Dr. Rodney Ice

May 29. 1996, 9:30 am.

Rebuital - atoove witnesses plus:
d. Dr. B.K. Rersin
May $31,1996,9 ; 00$ a.m.
e. Dr. P. Michael O'Banmon
f. Dr. Burnd Kahn
(June 24, 9:30 a.m., if necessary)

2. GANE:
a. R.M. Boyd
b. Glenn Carroll
May 23, 1996, 9.00 a.m.
May 21, 1996, 9:30 a.m.

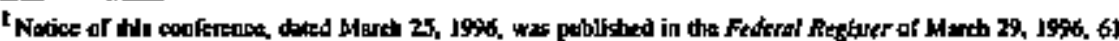
Fed Ret th, I6-4.

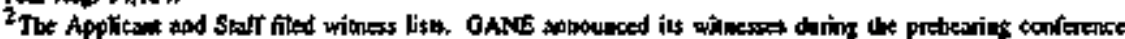
(T. 87,-49).
} 


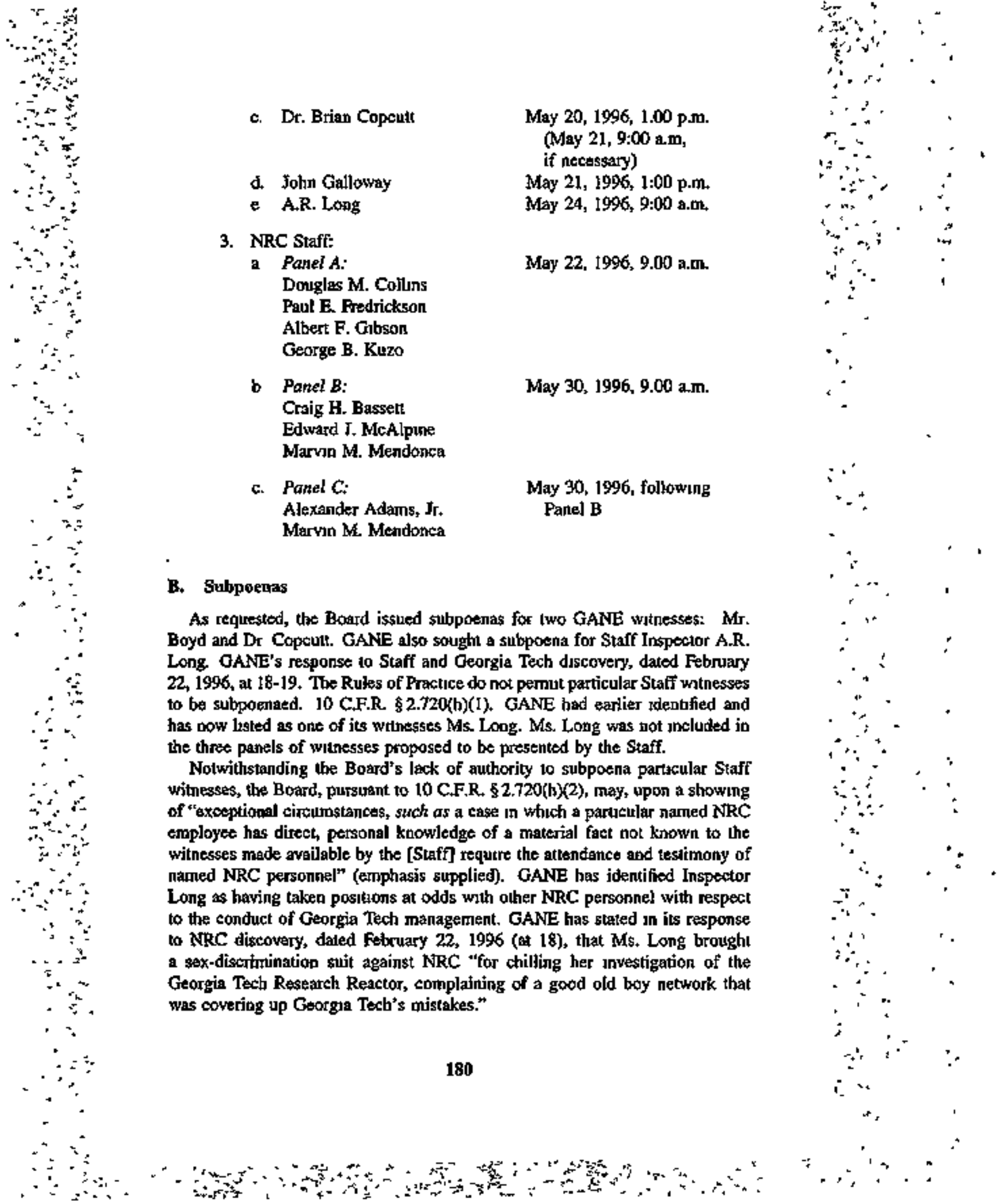


GANE attached two newspaper articles (Autachment 6 of Discovery Response) describing in mowe detail Ms. Long's views. OANE has also filed a motion to compel, dated Marct 8, 1996, seeking Staff documents regarding Inspector Long, and the Board in large part granted that motion.

The Staff taok the position that one of its wilnesses (Albert F, Gibson) was well aware of the events about which Ms. Long would teslify (Tr. 856) and that the Staff's selection of witnesses was adequate. The Board views this situation as comprising the exceptionsl circurnstances referenced by the NRC rule, and it regards differing views of the adequacy of Georgia Tech's management as facts differing from those likely to be presented by the referenced NRC witness.

According to GANE, Ms. Long "still hes some questions about oversight of Georgia Tech [by NRC]." Discovery Response, daled February 22, [996, at 2. Ms. Long's view of the facts thus can reasonably be expected to differ significantly from views likely to be preserted by the inspectors on NRC's witness panels. As set forth in one of the newspaper articles atached to OANE's February 22, 1996 discovery response (Attachment 6, Atlanta JournalConstitution article), Ms. Long's disagreement with other NRC employees concerned an alleged "breakdown in management controls" at Georgia Tech $\rightarrow$ the very ussue raised by GANE in this proceeding. Accordingly, the Board hereby requires the altendance and testinnony of Ms. A.R. Long, on the schedule set forth above.

\section{Local Public Document Raom}

The Board has long urged the establisbment of a Local Public Document Room in the Allanta, Georgia area. Ste, e.g., LBP-95-6, 41 NRC 281, 297-98 (1995). Effective April 25, 1996, such a room was established, at the Decatur Library, 215 Sycamore Street, Decatur, Georgia 30030 (telephone (404) 370 3070). Hours of operation are 9.00 a.rn to $9: 00$ p.m. Monday through Thursday. 9:00 a.m. to 5:00 p.m. Friday and Saturday, and 1:00 p.m. to 5:00 p.m. Sunday. Paper copies of files relevant to this proceetding (from 1985 to date) are present at that localion. (If any of the parties have questions concerning the Local Public Document Room, they may call NRC at J-800-638-8081.)

\section{Limited Appearance Sessions}

The Licensting Board previously announeed that it would hold at least two oral limited appearance sessions - a one-hour session on the opening day of the hearing, from approximately 10:00 a.m. 101 [ $100 \mathrm{am}$. on Monday, May 20, 1996, and a two-how evening session, tentatively set for 7t00-9:00 on Wednesday, May 22, 1996. At the conference, the Board confirmed that the evening session 
would be held on Wednesday, May 22, 1996, from 7:00 to 9:00 p.m., at the Student Center Theatre, Georgia Institute of Technology, Atlanta, Georgia. The Boand also announcto that, if thert appeared to be sufbicient interest or dernand, it would hold a funther session on Wodnesday evening, May 29, 1996, from 7:00 to 9:00 p.m., at a loctation to be announced.

\section{E. Marking of Exhihits}

Exhibits are to be marked, at the time they are first idestitied for the recond, in idmerical sequence for each party sponsoring them - e.g., GT [Georgia Techl Exh. 1, GANE Exh. 1, \$taff Exh. 1. Each party should bring eight copies of each exbibit: three for the court reporter and one for each (other) party and Licensing Board member. Parties are encouraged to distribute copies of all exhibits to other parties at the outset of the initial evidentiary hearing session. The Board also encouraged the parties to stipulate to the authenticity and admission of as many exhibits as possible, as well as 10 past facts, where agreed upon. Such steps could save much bearing time. (Only the Staff, in its list of witnesses, also identified documents it would be presenting in its direct case. The Board had not previously directed the parties to identify documents of this type.)

IT IS SO ORDERED.

FOR THE ATOMIC SAFETY AND LICENSING BOARD

Charles Becthoefer, Chaiman ADMINISTRATIVE JUDGE

Rockvile, Maryland

Aptil 30, 1996 
UNITEO STATES OF AMAEAICA

NUCLEAR FEGULATORY COWHASSION

OFFACE OF NUCLEAR REACTOR REGULATION

Willam T. Russell, Directiok

In the Matter of

\section{ALL REACTOR LICENSEES WITH DSTALLED THERMO-LAG FIRE BARRIER MATERIAL}

April 3, 1996

By pelitions daled September 26, 1994, from the Citizens for Fair Utility Regulation and the Nuclear Information and Resource Service, dated Oetober 6, 1994, from the Maryland Safe Energy Coalition, dated October 21, 1994, from the GE Stockholders' Alliance and Dr. D.K. Cinquernani, dated October 25, 1994, from the Toledo Coalition for Safe Energy, dated October 26, 1994, from R. Betajan, dated November 14, 1994, from B. DeBolt, and dated December 8, 1994, from the Noclear Information and Resource Service and the Oyster Creek Nuclear Watch, Petitioness requested that the U.S. Nuclear Regulalory Commission (NRC) take action with regard to the use of Thermo-Lag material by reactor licensees as fire barriers. Petitioners requested a variety of actions including immediate shutdown of reaciors where Themo-Lag material is used.

In a Director's Decision isstred on April 3, 1996, the Director of Nuclear Reartor Regulation denied the relief sought by Pelitioners. With regard to the requested shusdown of operating facilities using Theimo-Lag material, the Director concluded that fire watches permited by the NRC requirements applicable to the facitities in question provided reasonable assurance of adtequate protection of public health and safety. With regard to the remainieg issues raised by Petitioners, the Director concluded that they are being addressed by licensees in a manner that ensures adequate protection of poblic health and safety. 


\section{INTRODUCTION}

By letter dated September 26, 1994, the Cotizens for Fait Utility Regulation and the Nuclear Information and Resource Service (NIRS), by puss release daled Ottober 6, 1994, the Maryland Safe Energy Coalilion, by separale letuers dated October 21, 1994, the GE \$tockholders' Alliance and Dr. D.K. Cinquemani, by letter dated Octoter 25, 1994, the Toledo Coalition for Safe Energy, by leller daled October 26, 1994, R. Benjan, by letter daled November 14, 1994, B. DeBolt, and by letter dated Deetmber 8, 1994, NIRS and the Oyster Creek Nuclear Watch (the Petitioners) requesied that the U.S. Niclear Regulatory Commission (NRC) take action with regard to the use of Thermo-Lag by reattor licenseses and that their lotters be trealed as petitions pursuant to section 2.206 of Titte 10 of the Code of Federal Regulations (10 C.F.R. \$2.206).

The Citizens for Fair Utility Regulation and NIRS requested that

(1) Texas Utilities Electric Company (TU Electric), licensee of Comanche Peak Steam Electric Station, Unit 1, perform additional destructive analysis for Themo-Lag configurations in proportion to the tolai installed antount of "Therno-Lag to detentine the degree of "dry joint" occurrence;

(2) the licensec perfort fire tests on upgraded "dry joinl" Thermo-Lag configurations for conduit and cable trays to rate the barrier as a tested configuration in compliance with fire protection regulations; and

(3) the NRC inunediately suspend the Comanche Peak Unit 1 license until the abovo corrective aclions are taken.

The Maryland Safe Energy Coaltion requested immediate shutdown of both reactors at the Peach Botlom plant until the risk of fire near eleetrical conirol cables due to combustible insulation is conrected.' Dr. Cinquernani and the Toledo Coalition for Safe Energy requested that the NRC immediately shut down all reactors there Thermo-tas is used until it bas been removed and replaced. The GE Slockholders' Alliance requested shutdown of all reactors where Thermo-Lag is used until it has been removed and replaced with fireretardant material meeting NRC standards. R. Benjan requested immedıate shundown of all reactors where Thermo-Lag is used. B. DeBolk requested shuldown of all reactors in which Thertmo-Lag is used until it has been removed and replaced. NIRS and the Oyster Creek Nitclear Watch requested that NRC immediately suspend GPU Nuclear Corporation's (GPUN's) operating license

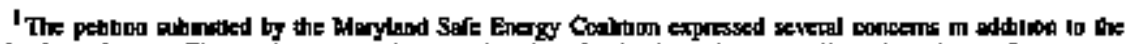

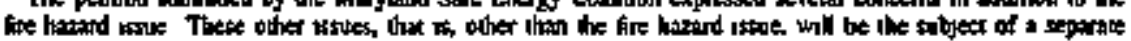
Dartaren's Derian

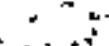

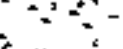

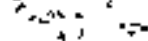

its

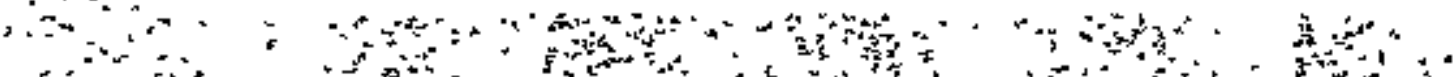
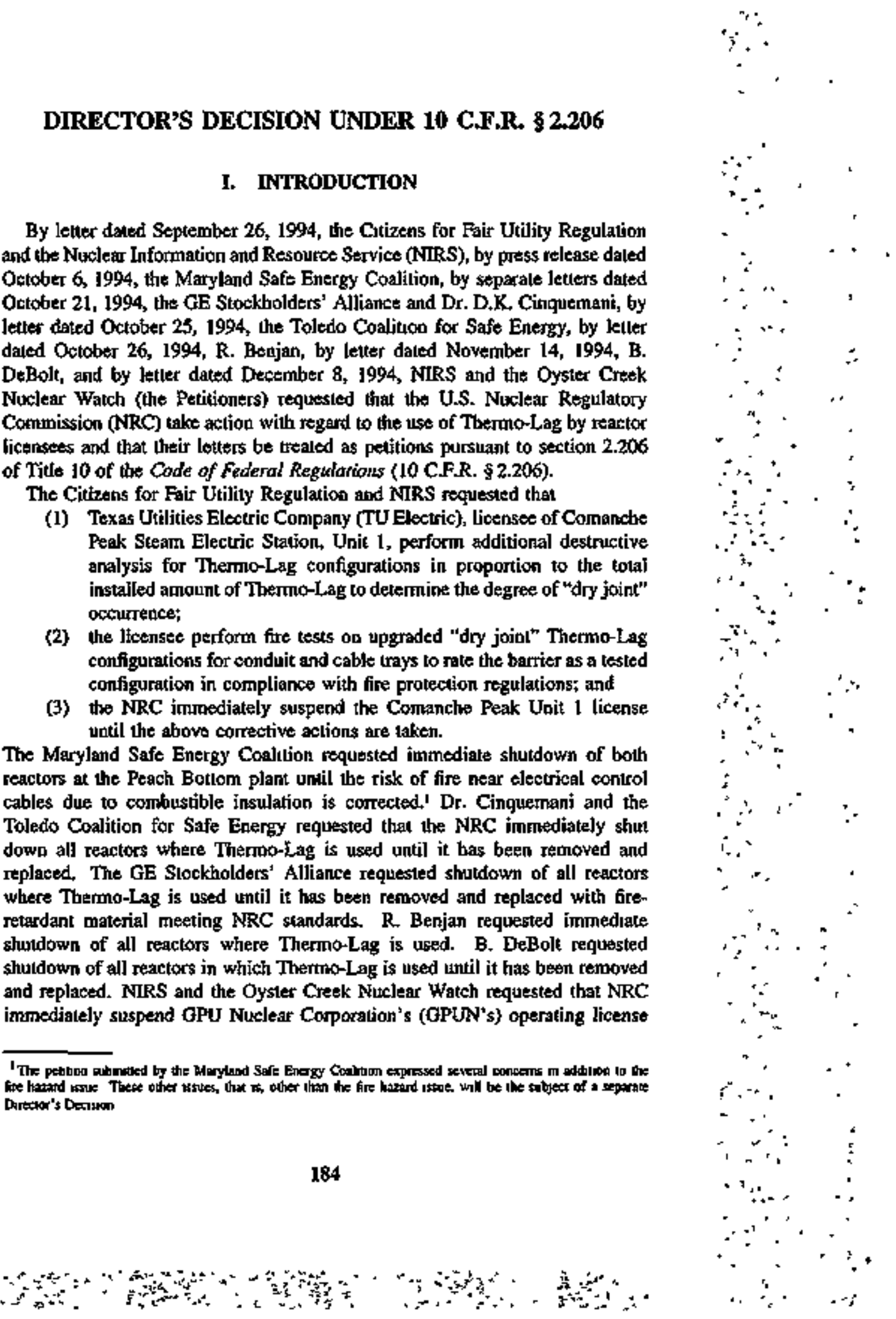
for Oyster Creek Nuclear Generating Station (OCNGS) until GPUN renoves Thermo-Lag fire barrier material and replaces it with a competitive product that meets curtent NRC fire protection regulations.

As a basis for their requests conceming Thermo-Lag 330.1 fire barrier upgrades, the Citizens for Fair Utility Regulation and NIRS Petitioners staled that:

(1) The licensee's records on the original installation of Thermo-Lag fire berriers on conduits and cable trays indicate that its contractor followed specifications for prebuttering all joints.

(2) NRC Inspection Repots $50-455 / 93-42$ and $50-446 / 93-42$ found, besed on destructive analysis documents, that a concern did exist where Themo-Lag conduit joints fell spart easily and did not appesr to bave any residual material of a bottered surface, indicative of a joint that bad not been prebuttered.

(3) The "dry joint" deficiency appeared in Room J15A and other areas of the tunit.

(4) The licensee ditectly contradicts an NRC inspector's findings that were determined in part by destructive analysis.

(5) The "dry joint" or absence of prebuttering of Thermo-Lag panels can be determined only by destructive analysis and cannot be determined by a walkdown visual inspection.

(6) The findings reported in the Comanche Peak Linit 1 Region IV Inspection Reports 50-455/93-42 and 50-446/93-42, based on the limited amount of destructiwe analysis conducted at the unit, constiture a sub. stantial doctrmentation of installation deficiencies found in ThermoLag fire bartiers as documented in NRC Information Notice (IN) 9179, "Deficiencies in the Procedures for Installing Thermo-Lag Fire Barmer Materials," December 6, 1991, and IN 91-79, Supplement 1, "Deficiencies Found in Thermo-Lag Fire Bartier Installation," August $4,1994$.

(7) Neither the NRC nor the industry, by its agent Nuclear Energy Institume (NED, nor a utility, have conducted fire tests on dry-fitted or "dry joint" upgraded configurations of Thermo-Lag 330-1.

(8) The presence of "dry joint" upgraded contlgunations in Comanche Peak Unit I constitutes an untested application of Thermo-Lag fire barriers.

As a basis for the requess concerning Therno-Eag 330-1 fire barrier upgrades, the Maryland Safe Energy Coalition stated that the manufacturer of the flane retardant (Thermo-Lag insulation) was indicted on criminal charges (of falsifying tests of the effectiveness of the instuation as a fire barrier), and fire near the electrical control cables, due to combustible Thermo-Lag insulation. could cause a carastrophic meltdown. 
As the bases for their requests, Dr. Cinquemani, the Toledo Coalition for Safe Energy, the GE Stockholders' Alliance, and R. Benjan stated either individually or collectively that:

(1) The widespreat use of Thermo-Lag in more than sewenty reactors presents a safety critsis.

(2) The NRC has known since 1982 that Thermo-Lag fails NRC performance standards for material that protects vital electrical cables for ampacity rating and fire resistance.

(3) Thermo-Lag has failed tol only NRC tests, but almost all other independent tests.

(4) Thermo-Lag is combustible, contrary to NRC regulations, and is an ineffective fire barrier.

(5) The use of Thermo-Lag could lead to shorts, to failure of the cables in an emergency, and to fire.

(6) Thermo-Lag is faulty in that fraudulent ampacity ratings allowed utulities to smaller cable than pemitted by design requirements, causing the cable to overheat and its insulation to deteriorate.

(7) The NRC bas stated that fire at some muclear power plants can contribute as much as 50 \% of the risk to a core moltodown, and a typical reactor will have three to four signifteant fires during its licensed lifetime.

(8) Thernal Science. Inc. (TSI), the mamufacturer of Thermo-Lag, and its President were indicted by a Federal Grand Jury on seven criminal charges related to conspiracy to defraud the U.S. government in regard to the effectiveness of Thertio-Lag.

(9) The hourly fire watches at the Davis-Besse Nuclear Power Plant operated by Toledo Edison do not replace fire barrier material and do not prevent tires.

As the bases for his requese, B. DeBolt stated that Therno-Lag fails to meet NRC regulations concerning combustibility asd that the mamufacturer of Thermo-Lag was indicted for defrauding the government and the titilities. Among the many bases for their request, NIRS and the Oysler Creek Nuclear Watch stated that:

(1) Southwest Research Instilute (SwRI) conducted fire tests on Thermo. Lag 330-1 specimens for GPUN and reported that all specimens ignited approxintately 2 secconds afier being inserted into the furnace and failed specifled criteria because of foming after the first 30 seconds of testing, an outside temperature rise higher than $30^{\circ} \mathrm{C}$, and a weight loss of $30 \%$.

(2) GPUN's operation of OCNGS with knowledge of the SwRl report is an example of GPUN's reckless disregard for fire protection and public safety.

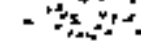

$+2=0$

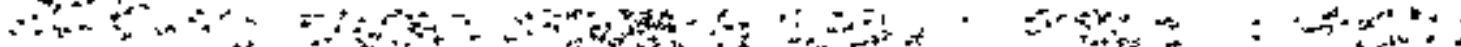

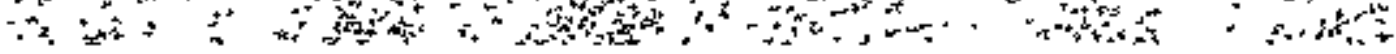

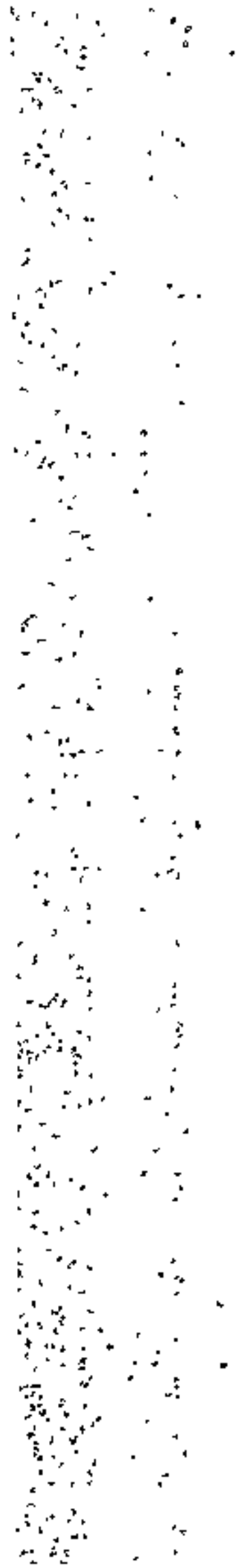


(3) In the event of fire, Therno-Lag is likely to fail its intended function of prolecting vital electrical cables muning from the control room to plant safety systems used to shut down the reactor.

(4) Current installations of Thermo-Lag are likely to fail in less time than I hour (when smoke detectors and automatic sprinkler systems are present) or 3 hours (when there are no fire detection and suppression systens) that NRC regulations requite for fore barriers to withstand fire.

(5) The NRC Inspector General issued a report in August 1992 condemnIng NRC's bandling of the Thermo-Lag issue and documenting the NRC Staff's failure to understand the scope of the problem.

(6) In April 1994, Industrial Testing Laboratories and its President pleaded guilly to five felony counts of aiding and abeuting the distriburion of falsified test data.

(7) On September 29, 1994, the U.S. Department of Justice issued a seven-count indictment against the manufacturer of Thermo-Lag and its Chief Executive Officer for willful violations of the Atomic Energy Act, conspiracy to conceal material facts, and making false slatements to defraud the United States in connection with $\$ 58$ million in fire barrier malerial.

(B) GPUN has known since at least Augusi 11, 1992, that Thermo-Lag 330.1 as a structural base material is combustible and that GPUN was in viojation of Appendices $A$ and $R$ to 10 C.F.R. Part 50 and the NRC Standard Review Plan, NUREG-D800.

(9) GPUN fajled to report the SwRI test results in response to a request for adkitional information regarding Generic Letter (GL) 9208 ("Thermo-Lag 330-1 Fire Barriers") of February 10, 1994, when asked to describe the Therro-Lag 330 -1 fire barriers insfalled as required to meet 10 C.F.R. Part 50, Appendix R.

(10) Continued reliance on fire watches at OCNGS is an unreasconable and unnecessary hazard to the publie health and safety because of an moperable fire protection system for safe stevtriown of the resctor and installed combustible material on the shutdown systems.

On November 7, 1994, I informed the Citizens for Fair Utility Regulation and NIRS that the request for an immediate suspension of the Cornanche Peak Unit I aperating license was denied. On December 2, 1994, I informed the Maryland Safe Energy Coalition that the request for an immediate shutdown of the Peach Bottom plant and for an immediate suspension of the Peach Bottom license was denied. On December 15, 1994, I informed the GE Stockholders Alliance, Dr. D.K. Cinquemani, Lhe Toledo Coalition for Safe Energy, and R. Benjan that the immediate suspension of the operating licenses of all reactors where Thermo-Lag is ased was denied, On January 3, 1995, I informed NIRS and 
the Oyster Creek Nuctear Watch that the immediate suspension of the OCNGS operating license was denied. On January 19, 1995, I informed B. DeBolt that the request for immediate suspension of the operating licenses of all reactors in which Thetmo-Lag is used was denied. The decisions were based on the following:

(1) The Staff is addressing deficiencies in five barriers conseructed with Therno-Lag material as part of a Commission-approved action plant and has issued several bulletins and a generic letter to the nuclear industry to provide information and guidance.

(2) Fire barrier systems construcled with Themmo-Lag bave been idenlified and declated incperable. been instituted.

Additionally in the atbove correspondence, all Petituoners were informed that the petitions were being treated pursuane to section 2.206 and bad been referred to this office for action pursuamt to section 2.206 of the Commission's regulations and that appropriate action would be taken within a seasonable time.

For the reasons stated below, the petitions have been denied.

\section{BACKGROUND}

The picture painted by the Petitioners of inaction by the NRC Staff in responding to the issues presented by the use of Thermo-Lag is at odds with the facts. A review of the chronological developgnent of the issuts shows that the NRC Slaff bas been working diligently to resolve the issues and has consistently sought to ensure that there is adequate protection of the public heatth and safety. It is also inaccurate to contend that Thermo-Lag generic deficiencies have been known since 1982. As can be seen from hie following infornation, the developenent of the Thermo-Lag issue has been evolutionary. Reports of probiens regarding Thermo-Lag began to surface in the lale 1980s when Gulf States Utilities, the licensee for River Bend Station, discovered some cracks and wear darnage due to installation deficiencies (Licensee Event Report 87.005, March 25, 1987) and declared the material inoperable as a fire barrier. The license further discowered that stress skin was missing on all 3-hour ThemoLag fire barriers in the turbine building as a result of an installation enror. In a series of plapt-specific tests performed by Gulf States Utilities in 1989, ThermoLag barriers failed to meet the fire endurance test scceptance criteria. Gulf States Utilites categorized all 1-hour and 3-hour barriers as indeterminate and implemrented compensatory measures in the form of fire watches. Other isolated plant-specific fire procection problems bad been found during NRC inspections at various utilities as early as 1982 and had been acted on by the NRC Staff.

188
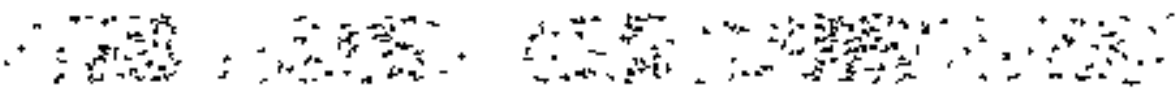

20

$\rightarrow+2, a+1$
(3) Compensatory measures (6te watches) approved by the NRC have

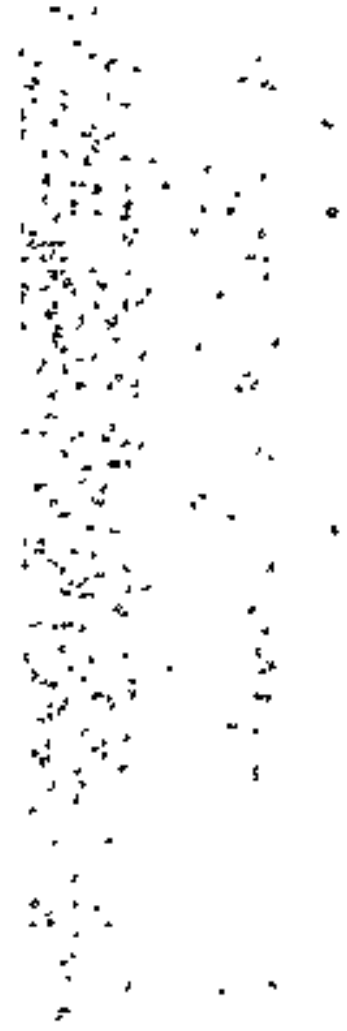

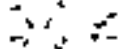

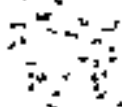

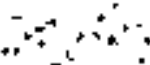

$\because \div$

…

T.

$-v_{k}{ }^{i}$

- r

-

$\because: i^{2}$

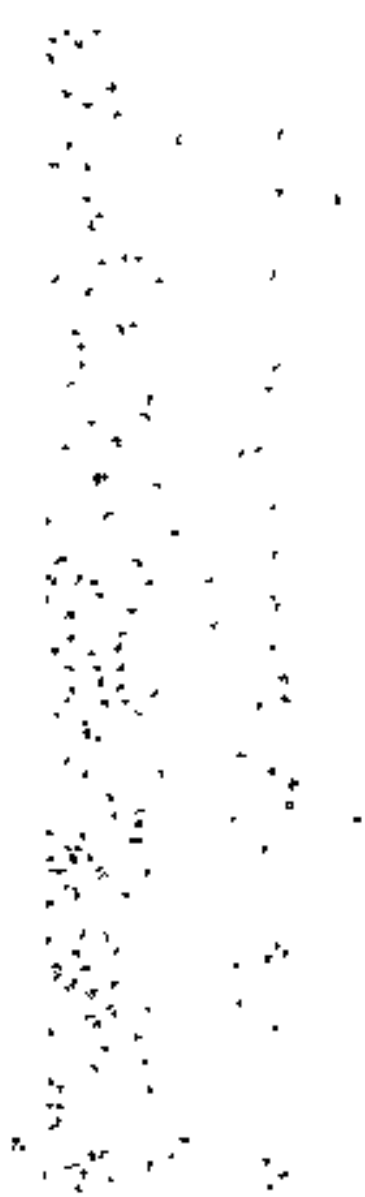


These problems were ireated as plant-specific issues and were not considered as indications of genctic problems.

In February 1991, the NRC received allegations that Theruo-Lag did not provide fire protection for electrical cabies as clained by the vendor. In response, in May 1991, the NRC visited River Bend Station to review the installation procedures and the failed fire endurance tests and concluded that a generic concern existed with 30-inch-swide cable trays. The NRC alerted the industry of the results of the test failures in IN 91-47, "Failure of Thermo-Lag Fire Barrier Material to Pass Fure Endurance Test," August 6, 1991.

In June 1991, the Office of Nuclear Reactor Regulation (NRR) establistied a special review team to investigate the safery significance and generic applicability of technical issues regarding allegations and operating expertence concerting Thermo.Lag fire barriers. In its final report, which was issued with IN 92-46, "Thermo-Lag Fire Barrier Material Special Revisw Team Final Report Findings, Current Fire Endurance Testing and Ampacity Calculation Errors," June 23, 1992, the special review team reached the following conclusions:

- The fire-resistive ratings and the ampacity derating factors for the Thermo-Lag fire barrier systern were indeterninate.

- Some licensees had not reviewed and evahuated the fire endurance test results and the anpacity derating test restlts used as the licensing basis for their Thermo-Lag barriess to determine the validity of the tests and the applicability of the test results to thetr plant designts.

- Some licensees had nol reviewed the Thermo-Lag firo barters installed in their plants to ensure that they met NRC requirements and guidance, such as that provided in GL 86-10, "Implementation of Fire Protection Requirements," April 24, 1986.

- Some licensees used inadequate or incomplete installation procedures duning the consinuction of thetr Thermo-Lag barriers.

After the special review team completed its charter, the NRC \$taff prepared an action plan that provided a process to resolve technical issues identifited with Thermo-Lag fire barier systems. The NEI, formerly the Nuclear Management and Rescurces Council (NUMARC), agreed to coordinate industry efforts to resolwe the issues.

In regard to the Peationers' allegations of NRC's inaction in responding to the issoes presented by the use of Thermo-Lag, the significart progress riade by the NRC Staff and the nuclear reactor licensees in resolving Thermo-Lag issues speaks to the contrary. The NRC Staff has issued a number of gemeric communications related to Thermo-Lag, which include the following:

(1) Two bulletins: BUL 92-01, "Fìilure of Thermo-Lay 330 Fire Barier System to Mainlain Cabling in Wide Cable Trays and Small Conduits Free from Fire Damage," June 24, 1992; and BUL 92-01, 


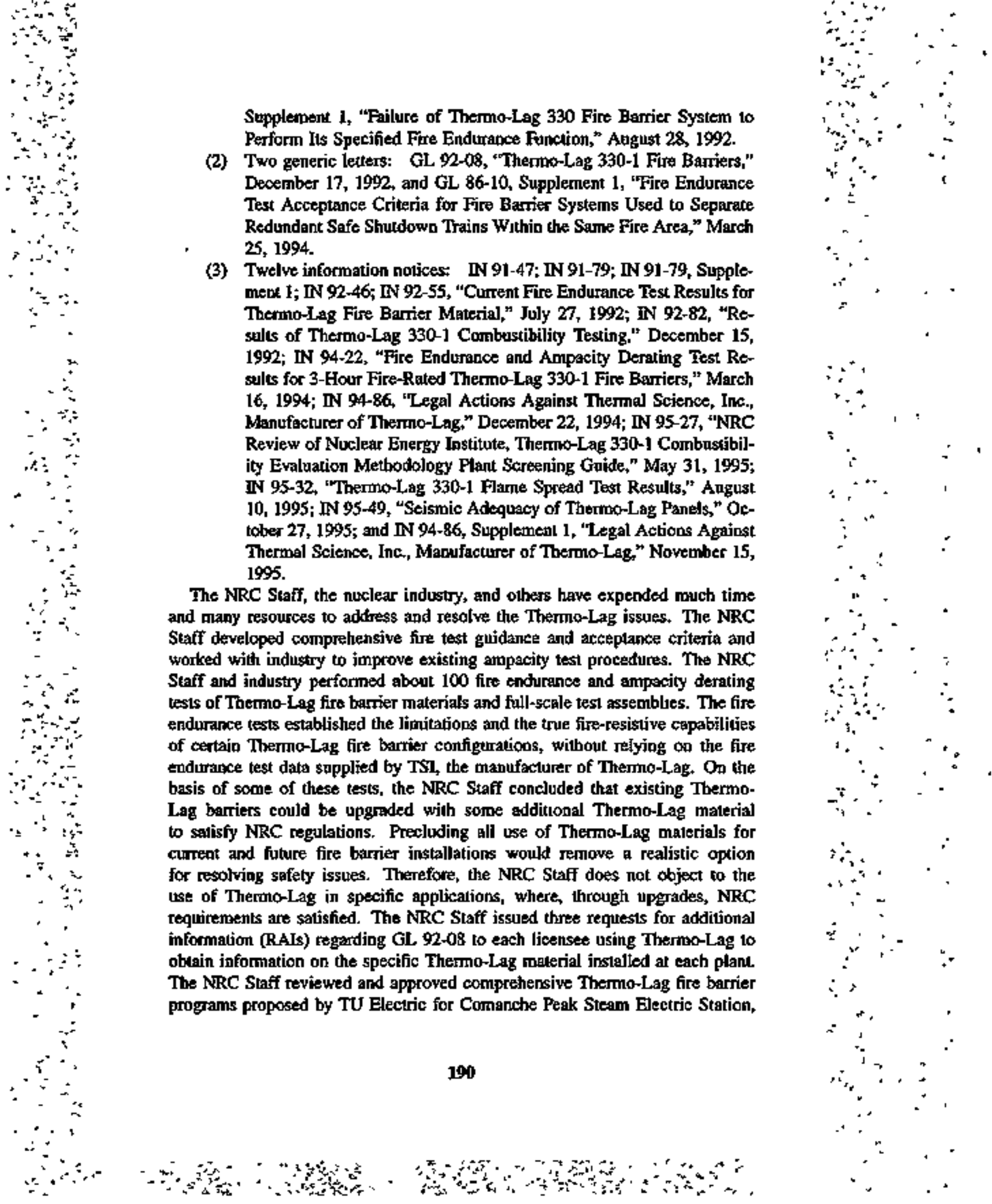


Unit 2, and by Tennese Villey Anthority (TVA) for Watts Bar Nuclear Plant, Unit 1, which attests to the fact thst Thermo-Lag bartiers can meet NRC fire protection guidelines and requirements. The NRC Staff completed toxicity tests of Therroo-Lag matertal. The NRC Staff and the industry completed chenical conposition, combustibility, and flame spread tests of Themo-Lag materials. Finally, the NRC Staff reassessed previous technical conciusions to detesmine the extent to whith the NRC Staff and industry relied on intormation supplied by TSI to reach these conclusions. The Staff had concerns about the reliability of information and data supplied by TSI that have been or could be used to make judgrnents regarding Thermo-Lag materials. The NRC Staff identi6ed and categorized the tssues and previous conclusions and used the results of the industrywide testing program regarding the chenical conposition of ThermoLag, as diseussed below, to determine if the in-plant Thermo-Lag materials were consistent. The results of this reassessmem indicated thas previous technical conclusions were valid independent of the information provided by TSI. The Staff therefore concluded that additional action to reassess the issues or reverify the previons conclusions was not needed.

The NEI testing program on the chemical composition of Thermo-Lag analyzed samples from eighteen utilities representing twonty-five nuclear power plants. The stanples represented Thermo-Lag material manufactured between 1984 and 1995. NEl performed pyrolysts gas chromatography evaluation of 169 samples to assess organic chemical composition and performed energydispersive $x$-ray spectroscopy of 33 samples to assess inorganic chemical composition. On the basis of the tests, NEI conchuded that (1) all of the samples contained the constituents identified by TSI as essential to fire barrier performance; (2) the composition of the samples was consistent; and (3) the test Jesulis provided a basis on which to close NRC questions about themical composition and product consistency and for utility use of generic test data relative to fire endurance ratings, flame spread, heat release, ampacity derating, and other material properties.

The NRC Staff test program on the chemical composition of Thermo-Lag was copducted by the National Institute of Standards and Technology (NIST) during 1992 and 1995. NIST antalyzed twenty-one samples that were either collected by the Slaff during site visits to plants and test laboratories or provided by TVA, Gulf States Utilities, Commonweatet Edison Company, and NEI. The analysis included elemental and ammonia analysis, pyrolysis, gas chromalography, mass spectrometry, and $\mathrm{x}$-ray fluorescence. These analylical tochniques indicated that all of the samples were similar in their bulk chemical composition. These results were consistent with the results of the NEl chemical testing program pertaining to the chemical composition and unifornity of Thermo-Lag.

Industrywide progress bas generaly been commensurate with the complexity of the plart-specific issues and the amounts of Thermo-Lag installed at the 
individual plants. Seweral licensees bave initiated programs to replace ThermoLag and are performing plant-specific tests of other fire barrier materials such as Mecatiss (Ftorida Power \& Light for Crystal River Unit 3) and Darmatt KM+1 (Carolina Power \& Light for Brunswick, IES Utilities for Duane Arnold Energy Center, Commourrealth Edison Company for LaSalle County Station, and Northern States Power Company for Ratairis Island Nurlear Generating Plant). The NRC Staff is reviewing the plant-specific fire endurance test programs and has recently approved the plant-specific application of Darmatt KM-1 fire barrier at the LaSalle plant. The remaining licensees have sobmitled to the NRC Staff detajled plans and schedules for resolving the issues at their plonts. Most licensees are pursuting a combination of such options as upgrading existing Themo-Lag flre barriers to meet NRC fire bartier requirements, teplacing Thenro-Lag fire barriers with another lype of fire barrier, reducing or eliminating reliance on Thermo-Lag fire bartiers by relocating equípunent and cables and by postfire safe-shutdown reanalysis, installing additional fire protection features such as autornatic sprinkler systems, and requesting configuration-specific exemptions when such exemptions are allowed by NRC regulations and are technically justified to provide a level of safety equivalent to that prescnbed by the regulations. The NRC Staff has completed its review of the plans for resolving fire protection issues that were proposed by most of the licensees. As with any issues as technically complex, challenging, and resoucce intensive as those presented by Thermo-Lag barriers, some plant-specific questions remain. However, the number of issues has steadily declined. The NRC Stafi and the litensees will continue to address the residual questions on a case-by-case basis as they arise, and the NRC Staff will continue to follow up with individual licensees on therr corrective actions, as appropriate. Every licensee with Thermo-Lag fire barriers will continue to maintain NRC-approved compensatory measures, such as fire watches, until its permanent corrective actions are implemented. Therefore, the public health and safely are protecled.

The NRC's "defense-in-depth" fire protection concept telies on protecting safe shutdown funetions by achienng a balance among throe echelons or levels of protection, which are (1) fire prevention activities; (2) the ability to rapidly detect, control, and suppress a fire; and (3) physical separation of redundant safe shutdown functions. Weaknesses tound in one area may be dealt with by enhaneing the protetion capabilities of the remaining areas. ${ }^{2}$ The NRC foresaw cases in which fire protection features would be inoperable and reguired licensees, through technical spectications or spproved fire protection plans controlled by license conditions, to provide compensation for the deficient condition. The concept of allowing alternative actions to compensate for an

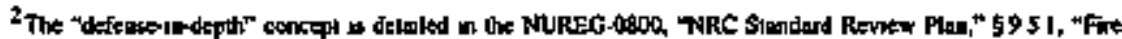
Frotecthos Progran," a 9 S I-10
} 
inoperable condition or component is used in yarious programs assocjated with the operation of nuclear power plants and has long been an integrad part of NRC regulatory requirements. ${ }^{3}$

The fire endurance test results contained in NRC BUL 92-01 and NRC BUL 92-01, Supplement 1, confimsed that certain Thermo-Lay fire barrier configurations compromise one facet of the fire protection defense-in-depth concept. In response to NRC BUL 92-01 and its supplement, the licensees for planis using Thetrio-Lag fire barriters established fire walches in accordance with their technical specifications or license conditions as a cornpensatory measure. Fire watches are personnel trained by the licensees to inspect for the control of ignftion sources, fire hazards, and combustible materials; to look for signs of incipient fires; to provide prompt notification of fire hazands and fires; and to lake appropriate actions to begin fire suppression activities. Generally, therefore, by providing additional fire prevention activities through enhanced detection capabilities to find fire hazards and in the case of a fire, augmented suppression activities before a barrier's ability to endure a fire is chellenged, fire watches compensate for degraded fire barriers.

The NRC Staff has carefully evaluated the issues associaled with continued use of Themo-Lag material, including the use of fire watches to compensate for any degradation in the effectiveness of required fire bariers. Such compensatory actions provide an adequate ievel of fure protection without an indere risk to the health and safety of the public. Liconsees have established fire watches to compensate ior degraded and possibjy inoperable fire barriers. Also, Jicensees rely on a defense-in-depth concept that itcorporates multipte safety measures. i. Automatic fire detection and suppression systems are provided in most areas that have safe shutdown equipment. Trained fire brigades are required 24 hours a day at all plants. All ateas that have safe shutdown equipment have manual fire suppression features. Fuels that can feed a fire and ignition sources to start a fire are conirolled. The combination of fire watches and the defense-int-depth fixe protection features provites an adequate level of fire protection undifl licensees implement permanent corrective actions.

Taken together, these factors represent an adequale means of fire protection at the plants using Thermo-Lag to ensure, with margin, ${ }^{4}$ that operation can be conducled without an undue risk to the bealth and safely of the public. Nevertheless, with these considerations in mind, the NRC Staff addressed below the Petilioners' specific concerns to demonstrate that no substantial health and safety issue has been raised.

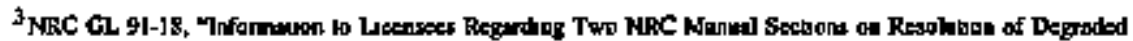

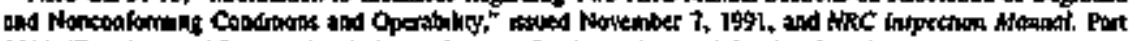

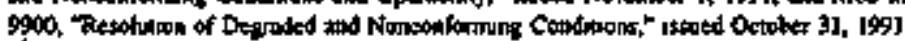

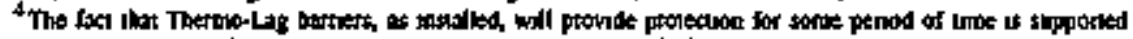

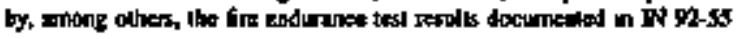




\section{A. Regulatory Compliance}

The NRC Staff acknowledges that certain fire endurance tests have demonstrated that Thermo-Lag barriers may not meel the fitw endurance rating criteria set forth in section III.G of Appendix R to 10 C.F.R. Part 50. This ackmowledgment does nol mean, however, that there no longer is reasonable assurance of procection of the perblic hotalth and safey or that such actions as the shutdown of all reactors using Therstro-Lag and the suspension of Comanche Peat, Peach Bottom, and Oyster Creek operating ficenses are warranted.

It should first be noted that Appendix $R$, which sets forth criteria for specific fre protection features to protect safe shutdown systens, is applicable only to facilities that commenced operation prior to 1979. Facilities commencing operation on or after January I, 1979, although no: bound by Appendix R, generally are bound by licensing commiements to follow the criteria set forth in Appendix R through license conditions."

Even assuming that all of the plants in which Thenno-Lag is installed and that cormenced operation prior to 1979 are not in compliance with Appendix $R$, it does not follow that the failure to comply with a regulation indicates the absence of adequate protection. The Comrisission has explained that

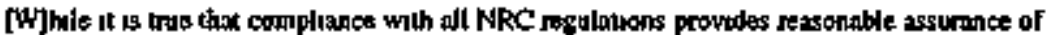
adequate protecion of the public health and safety, the converse is not correct, that falluit to

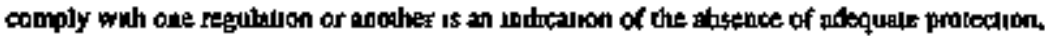

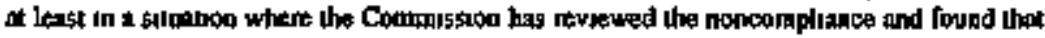
It does not pose an "undne nsk" to the poblic healh and safety.

(Ohio Citizens for Responsible Energy, DPRM-88-4, 28 NRC 411 (1988).)

All the plants using Thermo-Lag bave instiluted fire watches as required by their action statements regarding isoperable barriers contained in their tectunical specifications or fire protection programs subject to license conditions. Generally, action statements provide altemative remedial actions to shuuting down a plant wheo limiting conditions for operation are not met. Compliance with the required remedial actions prowtses reasonab]e assurance that the public bealth and safety is protected notwithstanding the plant's contimued operation and its failure to meet the respective liniting condition for operation. Here, since all of the plants using Thermo-Lag have implemented the reguired fire watches in accordance with plant-specific requirenents, their contibued operation does not pose an undue risk to the public healch and safety.

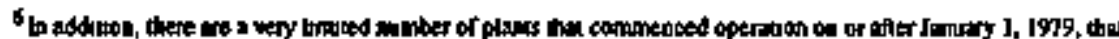

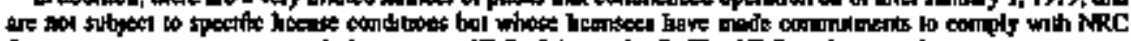

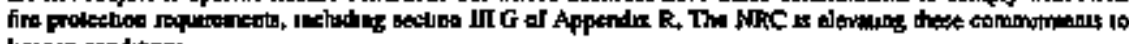
liecose condinges
} 
The Petitioners assert that fire watches do not replace fire bartiers and continued rehiance on fire watches is a hazard to public safety. The NRC Staff acknowledges that fire watches do not replace fire barriers. However, as will be discussed in geater detail later in this Decision, fire watches are judged by the NRC to be acoeptable compensatory measures and are legally sanelioned remedial actions based on 10 C.F.R. \$ 50.36 (c)(2).'

In sum, notwithstanding the failute to have operable fire barriers meeting the fire endurance rating criteria specified by section IIIG of Appendix R, a plant is not necessarily unsafe to continue operation. To the contrary, fire watches are judiged by tie NRC to be adequate remedtial measures that provide reasonable assurance that the public betld and safety is protected. By reason of compliance by all facilities using Thermo-Lag with their technical specifications or fire protection program action stalements requiting the implententalion of fire watches, protection of the pub] ic health and safety is still reasonably ensured for such plants. Because the Commission bas discretion regarding enforcement of its regulations, and given the cireumstances here in which no significam bealth and safety issues have been raised, enforcemest action of the nature requested by the Petitioners is not warranked.

\section{B. Ability of Fire Watches to Compensate for a Degraded Bartier}

One of the Petitioners' allegations is that the measures taken by licensees to compensate for degraded barrier conditions, specifically fire watches, are not adequate to protect the public health and safety. The Pejtioners have questioned the continued reliance on fire watches in the ligh of an inoperable fire protection system for safe plant shutdowrs and the condoustibility of Thermo-Lag. In addition, the Petitioners claim that a fire watch does not replace a fire barrier in that fire watches are not prewentive.

Despite the acknowledged shortcomings identified with certain Therrno-lag fire barriers and after fully considering the arguments presented by the Petitioners regarding the abtlity of fire walches to provide adequate compenststion, the NRC Staff has determined that compensatory measures using bre watches are adequate and acceptable to ensure public health and sajety untit permanent corrective measures are implemented.

The use of fire watches in instances of degraded or inoperable barriers is an integral part of NRC-approved fire prolection prograrns. In general, these NRC Staff-approved compenstatory measures specify the esiablishiment of a contintuous fire watch or an hourly fire watch in cases in which automntic detection systems

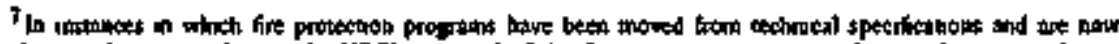

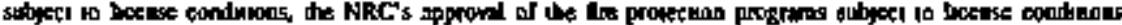

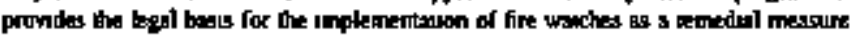


protect the affected components. Although it is true that Thermo-Lag is iriended as a batrier and fire watch personnel cannot at as physical shields, a fire walch provides more than simply a detection function. Personnel assigned to fire watches are trained by the licenses to inspect for the control of ignition sources, fire harards, and combustible materials; to look for signts of incipient fres; to provide prompt notification of fire hazards and fire; and to take appropriate action to bugin fire suppression activilits. Fire watch personnel are capable of detertuining the sizo, the actual location, the source, and the type of fire — valuable information that cannot be provided by an automatic fire detection system.

During a plant fire, compartment tenperatures are likely to be less severe at the early stages. On the basis of enhanced capabilities provided by fire watches and notwithstanding that the level of barrier-type protection may be reduced, the NRC Staff has determined that there is an adequate margin of safecy to ensure protection in cases in which fire watches are approved.

The goal of the NRC Staff's Thermo-Lag Action Plan is directed toward restoring the functional capability of 6re barriers as soon as practicable. There is not a time limit associated with the use of fire watches as a compensatory measure. Oiven the margin of safety a fire watch brings to a fire protection progran, as discussed above, the NRC State has detemined that continuing the use of tire watches while barriers are inoperabte is acceptable. However, the NRC believes that notwitistanding interim reljance on compensatory meqsures, appropriate actions must be taken by licensess to restore operability of Thermo-Lag barriers. Individual licensees have provided schedules for restoring operability and these are being tracked by the NRC Stafi.

The NRC Staff has carefilly evaluated the use of fire watches to compensate for any degradation in the effectiveness of required fire barriers and has concluded that fise watehes contintse to ensure protection of the public bealth and safery. Therefore, the Petitioners' assertion that the measures taken by licensees to compensate for degraded fire bartier conditions, specifically fite watches, are a hazard is without merit.

\section{c. Combustibility}

The Pelitioners alleged that, contrary to NRC tegutations, Thermo-Lag is combustible.

The NRC Staff recognizes that Thermo-Lag is combustible. To assess Thermo-Lag combustibility, the NRC Staff conducted a testing program at NIST based on the American Society for Testing and Materials (ASTM) Standard E136. Under this testing standard, the material is considered to be "combustiblen" if three out of four samples tested exceed the following criteria: (1) the recorded temperalure of the specinen's sarface and interior thermocouples,

,

,

$\because$

.
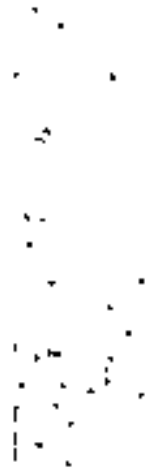
during the test, rises $54^{\circ} \mathrm{F}\left(30^{\circ} \mathrm{C}\right)$ sbove the initial furmace temperature; (2) there is flanting from the specimen after the fitst 30 seconds of iradiance; and (3) the weight loss of the specimen, due to combustion during the testing, exceeds 50\%. Of the four Thermo-Lag specinens tested, all experienced a weight loss of greater than $30 \%$ and flaming continued in excess of 30 seconds. IN 92-82, which provided ticensees with the results of the E-136 tests and conthmed the combustibility of Therno-Lag, restated the NRC fire protection requirengents of section III.G of Appendix R to to C.F.R. Part 50 and asked that licensees review the information for applicability to their facilities.

The NRC's basic fire protection regulation for commercial nuclear power plants is section 50.48 of 10 C.F.R. Part 50 "Fire protection." Section 50.48 references General Design Citerion (GDC) 3 of Appendix A to 10 C.F.R. Part 50, "Fire protection," Appendjx R to 10 C.F.R. Part 50 "Fire Protection Progran for Nuclear Power Facilities Operating Prior to January 1, 1979," and various NRC fire protection guidance documents. Specifically, 10 C.F.R. \$50.48(a) states that each operating muclear power plant must bave a fire protection plan that satisfies GDC 3, and LO C.F.R. \$50.48(b) states that Appendix R to 10 CF.R. Part 50 establishes fire protection features required to satisfy GDC 3 with respect to certain generic issues for nuclear powter plants licensed to operate prior to Janeary I, 1979. These issues ant addressed in section III.G, "Fire protection of safe slyutdown capability," section III.J, "Emergency lighting," and section IILO. "Oil collection system," of Appendix R. Of these three sections of Appendix R, section III.G addresses the use of fire bartiers to protect one train of systents necessary to do hieve and maintsin hot shutdown conditions in the event of a fire and, therefore, is the regulation of inlerest here.

Section $50.48(a)$ notes that fie protection guidance for tonclear powrec plants is contained in two NRC documents. These are (1) Branch Technical Position (BTP) Auxiliary Power Conversion Systems Branch (APCSB) 9.5-1, "Guidelines for Fire Protection for Noclear Power Plants, for new plants docketed after July 1, 1976; and (2) Appendix A to BTP APCSB 9.5-1, "Guitelines for Fire Prokection for Nuclear Power Plants Docketed Prior to July 1, 1976." These two NRC documents specify preferred methods for fire protection program design including the use of fire bestiers to satisfy section IILO of Appendix R. Fire barriers that meet the criteria of section III.G of Appendix R to 10 C.F.R. Part 50 and these NRC guidance docerrients satisfy GDC 3. NUREG-0800, "Standard Review Plan" (SRP) \$ 9.5-1, "Fure Protection Program," iticomporates the guidance of BTP APCSB 9.5-1 and Appendix A to BTP APCSB 9.5-1 and the eriteria of section III.O of Appendix R to 10 C.F.R. Part 50. Therefore,

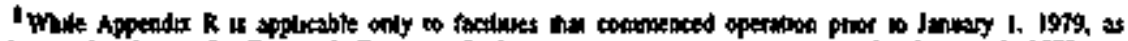

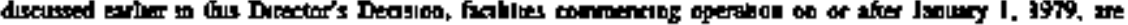

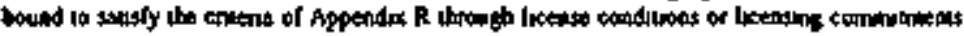


fire batriers that meet the guidelines of SRP section 9S-1 also satisfy 10 C.F.R. $\$ 50.48$ and GDC 3 .

As stated in section 50.48(a), the puspose of the fire protection plan is "to limit fire damage to struclures, systems, or components important to safeby so that the capability to safely shut down the plant is ensured." In general, a fire protection plan consists of administrative controls and procedures, persennel for implementing the plan and for fire prevention and manual fire suppression activibies, fire detection systems, sutomatic and manualiy operated fire suppression systems and equipment, and fire bartiers.

Section III.G of Appendix R to 10 C.F.R. Part 50 is the only part of the fire protection regulations that addreses the tuse of fite barriers. It addrasses the use of fire barriers to protect one train of systemis necessary to achieve and maintain hot shutdown conditions in the event of a fire. Fire barriers ate required to have either a 1-hour or 3-hour rating depending on the specifie regurirement. However, section III.G does not provide acceptance criteria for fire barriers, tor does it address the conbustibility of fire barrier materials. The criteria are set out in BTP APCSB 9.5-1, Appendix A to BTP APCSB 9.5-1, and SRP \& 9.5-1. These NRC documents do not prechude the use of combustible materials for construction of fire barriers jequired to bawe a l-hour or 3-hour rating. On March 25, 1994, the Staff consolidated and clarified in Supplement 1 to Generic Letter (CL) 86-10, the fire barrite critetia specified tn the BTPs and the SRP. This GL supplement provides detailed Staff guidelines for assessing the combustibility of fire barrier materials, but it does not preclude the use of combustible matetials for fire barriers required to satisfy a 1-hour or 3-hour rating. In fact, the fire barrier criteria are appropriately focused on the perfornance of the firs barrier and its ability to achieve its intended design function, that is, its ability to limit temperature rise within the barrier enclosure and to prevent the passage of barne or gases hol enough to adversely affect the functionality of the safe shutdown components (e.g., cables) enclosed within the fire barrier.

Thermo-Lag 330-1 is a sacrificial material. When it is exposed to elevated temperatures, such as those experienced during a fully developed room fire, it sublimes and transitions from a solid to a vapor. The vapors go through an endothermic decomposition process (pyrolysis) that absorbs heat from the fire. As a result of the pyrolysis, the unreacted Thermo-Lag material is replaced by an insulating char layer which is composed of strall interconnecting cells having a large surface area. The char layer reradiates energy and limits beat transfer through the Thermo-Lag material. The low thermal conductivity of the char layer provides additiongl themal insulation. Therefore, even though ThermoLag is ciassified as a combustible material when testing in actordance with the guidance of Supplement 1 to GL 86-10, properly designed, qualified, and installed Thermo-Lag cen yield fire barriers with a l-hour or 3-hour rating that 
As an alternative to the three options discussed above, section III.G.2.f of Appendix R (and the equivalent SRP guidance) provides a fourth option for noninerted containments, that is, the separation of redundant safe shutdown components with noncoubustible radiant energy heat shields. Therno-Lag is classified as a combustible material when tested in accordance with the guidance of Supplement 1 to GL 86-10. Thereforo, it does nol mett the criteria for radiart energy heat shields. Licenses using Thermo-Lag in this fashion will also be required to take corrective action.

To ensure that corrective actions are taken in these cases, the NRC Staff issued IN 95-27. In that IN, the Staff addressed enclosing combustible materials within Thermo-Lag fire bartiers in an atlempt to eliminate the combustible materials as a ftre hazard and using Thermo-Lag to construct radiant energy heat shields inside nouinerted containments. The Staff identified such sohutions for teevaluating the use of Thermo-Lag for these applications as: (1) reanalyzizg postfice safe shutdown circuits inside containmetel and their separation to determine if the Thermo-Lag radiant energy shields are needed, (2) replacing Thermo-Lag barriers installed inside the containment with noncombustible barrier malerials, (3) replacing Thermo-Lag barriers used to creale combustible-fiee zones with noncombustible barrier materials, (4) rerouting cables or relocating other protected components, or (5) requesting plant-specific exemptions where technically justified.

One of the Petitioners also asserted that subsection 5a(3) of section 9.5-1 of the SRP states that fire barrier designs "should utilize only non-combustible matertals." This section of the SRP does not apply to fire barriers that are used to separate sedundant safo shutdown components located within a nucleas power plant fire area. Rather, it applies to fire bartier penelralion seals, which are typically installed in fire area boundaries. Thermo-Lag 330-1 is not used in such applications.

The principal consideration for 1-hour and 3-hour rated fire barriers installed to meet NRC bre protection requiremenls and guidelines is that they can achieve their intended desten function. That $t s$, that they can limit temperature rise within the barrier enclosure and prevent the passage of fiame or gases hot enough to adversely affect the functionality of the safe shutdown compenents enclosed within the fire barriers. The fact that Thermo-Lag material is combustibto does not preclude Themto-Lag fire barriers from achieving the intended function of preventiog fire demage if the fire barriers are properly designed, qualified, and installed. The Petitioners' contention usal Thermo-Lag material should not be used because it is corabustible is withont basis. 


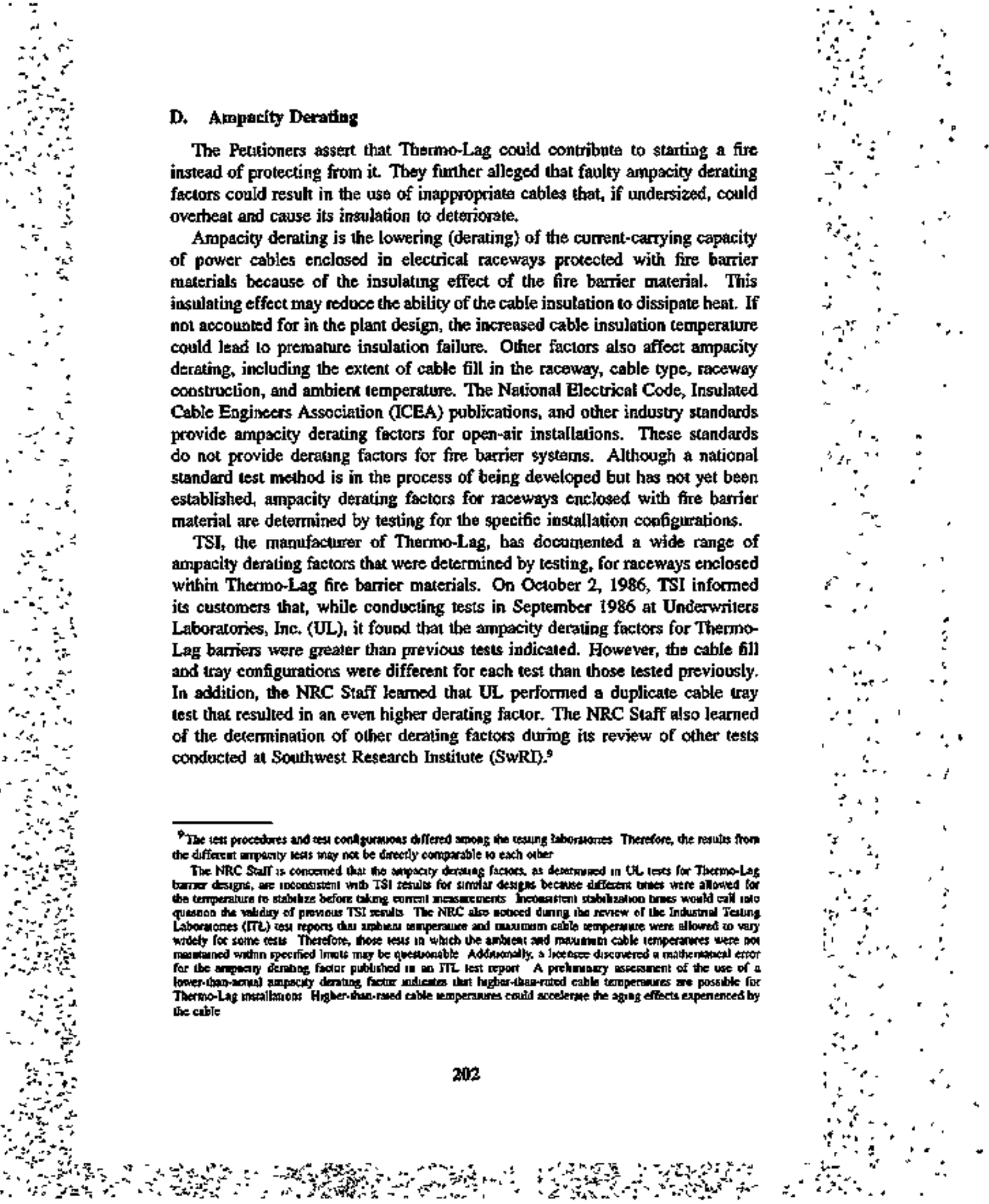


The NRC spectal review team concluded that the amparity derating lest results cormpleted at the time of the review, including the UL test tesults, were indeterminate. This conclusion was based on observed inconsistencies in the derating test tesults of the various testing laboratories. The special review team found that there was no national consensus test standard (e.g.. Institute of Electrical and Electronics Engireers (IEEE) or American National Standards Institute (ANSI)) for conducting these tests, and that some licensees had not adequately reviewed ampacity derating test results to determine the validity of the tests and the applitability of those test results to their plant design. The special review team recognized that, in hypothetical cases, nonconservative ampacity derating factors could have been instrumental in the installation of inoppropriate cables, which as a result, could suffer premature cable jacket and cable insulation failures over a period of time. However, since that time, the NRC Staff has deternibed that in practice the aftpacity derating factor resulting from Thermo-Lag insulating properties represents only one of many variables used in determining the design anpacity for power cable systems and that, as discussed below, sufficient margin exists in this area to preclude any imrnediate safety concerns.

For actual installations, various derating factors ane typically applied to the ICEA ampacity values provided for each cable size. In general, the cables typically used in actual installations bave higher current-carrying capacity than the ICEA ampacity valites. Also, cables are sized based on full-lowd current plus a $25 \%$ margin to account for starting current requirements of the load. Given the short duration of typical equipment starts, this margin is available to compensate for any enrors in ampacity derating. Forther, use of a cable size larger than normal may be required as a result of voltage drop considerations for long circujt kngths. In typical applications this also provides additional currentcarrying capacity. Given these conservalisons inherent in the design ampacity of cable systems and in addition the faet that most power cabtes required for safe shutdown are not nommally energized, but are typically operated duting surveillance testing for short lime periods, the likelihood that cables could ignite as a result of Thermo-Lat anpacity derating ertors has been judiged by the NRC Siaff to be unlikely. In addition, based on these conservatisms and the carrently available information on existing plants, ampacity design, and operating history, the NRC Staff believes that the ampacity derating issue is not an immediate safety issue but rather is an aging issue to be resolved over the long term. ${ }^{\text {th }}$

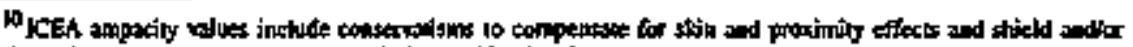

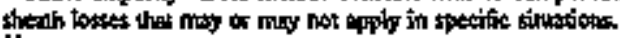

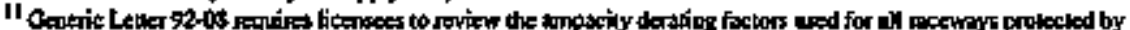

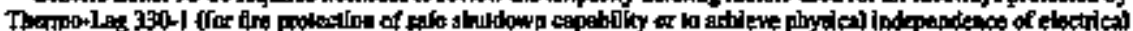
(Covatinown)

$\because \because \cdots$ $\because$ 
E. Oyster Creek Failed to Report Test Results on Combustibility to the NRC

The Petitioners requested that Oyster Creak's license be suspended based on the following:

(1) SwRI conducted fire tests on Thermo-Lag 330-1 specimens for GPUN, the licensee for Oyster Creek, and reported that all specjmens ignited approximately 2 seconds afler they were inserted into the furmace and failed specified criteria beconse of flaming afier the first 30 seconds of testing, on outside temperature tise higher than $300^{\circ} \mathrm{C}$, and a weight loss of $50 \%$.

(2) GPUN's operation of Oyster Creek with knowledge of the SwRI report is an example of OPUN's reckless disregard for fire protection and public safety.

(3) In the event of fire, Thermo-Lag is likely to fail its intended function of protecting vitol electrical cables running from the control room to plant safety systems used to shut down the reactor.

(4) Current instaljations of Thermo-Lag are likely to fail in less time than the 1 hour (when sonoke detectors and automatic sprinkler systems are present) or 3 hours (when there are no fire detection and suppression systems) that NRC rogulations requite for firo barmers to withstand fire.

(5) The NRC Inspector Oeneral isswed a report in August 1992 condemning NRC's handling of the Thermo-Lag issue and documenting the NRC Scaff's failure to understand the scope of the problem.

(6) In April 1994, ITL and jts President pleated guilty to five felony counts of aiding and abetting the distribution of falsified lest data.

(7) On September 29,1994, the U.S. Department of Justice issued a seven-count indictment against the manufacturer of Thermo-Lag and its Chief Executtive Officer for willful violations of the Atoníc Energy Act, conspiracy to conceal material facts, and making false statements to defratud the United States, in connection with $\$ 58$ mitlion in firt barrier material.

(8) GPUN has known since at least August 11, 1992, that Thermo-Lag 330-1 as a structural base material is combustible and that it was in violation of Appendices A and R to Part 50 of Title 10 of the Code of Federal Regulations (10 C.F.R.) and the NRC Standard Review Plan, NUREG-0600.

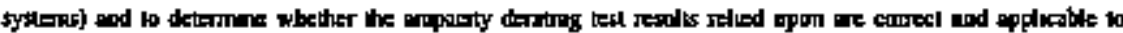

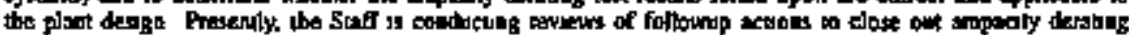

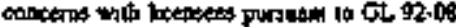

$\therefore \because \because$

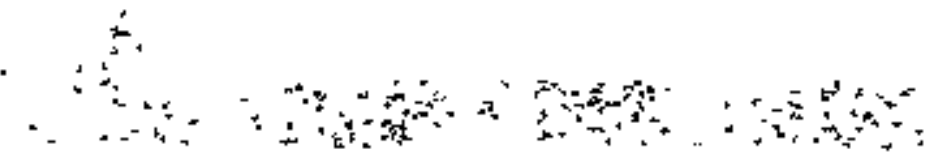

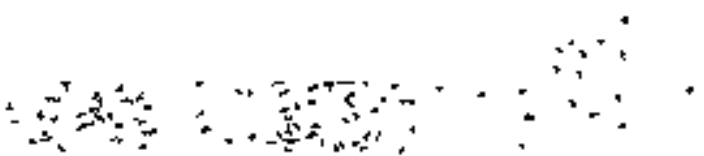


(9) GPUN failed to report the SwRI test results in response to GL 92-08 of Febrvary 10, 1994, when asked to describe the Thermo-L_ag 330-1 fire barriers installed as required to meet 10 C.F.R. Part 50, Appendix $\mathbf{R}$.

(10) Contintued reliance on fire watches at Oyster Creek is an unreasonable and unnecessary hazard to the public health and safety because of an inoperable fire protection system for safe shutdown of the reactor and installed comboustible material on the shiutdown systems.

Several of the issues listed above have been addressed earlier in this decision. Thetefore, the NRC Slaff will ouly address below the rematning plant-specific issues. As discussed eartier in this Decision, the NRC issued IN 92-82 to inform the industry of the results of conbustibility tests performed by NIST in early August 1992. These tests confirmod the combestibility of Thermo-Lag. As a result of discussions with the NRC Staff on the subject of Thermo-Lag conturstibility, GPUN decided to independemly verify the results of the E-136 tests performed by NIST and contracted SwRI to perform the E-136 tests. The results of these tests, as documented by the telecopy transmittal shest submitted with the petition, confirmed the combustibility of Thermo-Lag. Contrary to the Petitioners' allegations, the NRC Staff does not require that licensees report the results of their independent testing. It should be noted here that, prior to the SwRI testing that confinmed conbustibility, the NRC was aware of the combustiblity of Themno-Lag and that the NRC was also well aware of the results of the E-136 tests perfordaed by GPUN through telephone conversations with GPUN personnel, even though there was no requirement for GPUN to report these test results.

The Petitioners also atleged that GPUN did not report to NRC ts findings of the SwRI test results in its "Response to Request for Additional Information Regarding Generic Letter 92-08, "Thermo-Lag Fure Barriers," (RAI) dated February 10, 1994.

The RAI quoted by the Petitioners did not request that GPUN report to NRC its findings of the SwRI tesi results and, in addition, the NRC Slaff does not requite that licensees report the results of thetr independem testing. Therefore, the NRC Slaff has conchuded that, contrary to the Petitioners' allegatton, GPUN did not have to report to the NRC its findings of the SwRI test results.

For the reasons stated above, the suspension of Oyster Creek's license, as requested by the Pettioners, is not warranted.

\section{F. Dry-Joint Issue at Comanche Peak Unit I}

The Petitioners requested that

(a) the Cornanche Peak Unit 1 license be suspended,

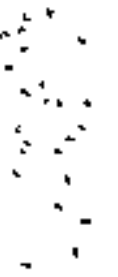


(b) the licensee perform andibonal destruetive analysis for Thermo-Lag configurations, and

(c) the licensee perform fire tests on tppgraded "dry-joint" Therno-Lag configurations based on the following:

(1) The licensee's records on the original installation of ThermoLag fire barriers on conduits and cable trays indicate that its contractor followed specifications for prebuttering all joints.

(2) NRC Inspection Report Nos. 50-445/93-42, 50-446/93-42 found, based on destructive analysis documents, that a concerm did exist where Thermo-Lag conduit joints fell apart easily and did not appear to have any residual material of a butlered surface, indicalive of a joint that had not been prebuttered.

(3) The "dry joint" deficency appeared in Room 115A and other areas of the unit.

(4) The licensee directly contradyets an NRC inspector's findings that were detemined in part by destructive analysis.

(5) The "dry joint" or absence of prebuttering of Thermo-Lag panels can be determined only by destructive analysis and cannoc be determined by a walkdown visual inspection.

(6) The findungs reported in the Comanche Peak Untt 1 Region IV Inspection Reports 50- $445 / 93-42$ and $50-446 / 93-42$, based on the limited amourt of destructuve analysis conducted at the unit, constitute a substantal documentation of installation deficiencies found in Thesmo-Lag fre barriers as documented in NRC IN 91-79 and Supplenent 1.

(7) Nevither the NRC nor the industry, by ils agent NEI, nor a utility. have conducted fire tests on dry fitted or "dry joint" upgraded configurations of Thermo-Lag 330-1.

(8) The presence of "dry jontt" upgraded configurations in Comanche Peak Unit 1 constitules an untested application of Thermio-Lag fire barriers.

These allegations were based on the Pettioners' interpretation of NRC Inspection Report 93-42 issued on Februacy 21, 1994. By leller of November 29, 1994. TU Electric, the liceasee for Comanche Peak Unit 1 , sent a letter to the NRC Staff responding to the Pettion.

The term "joint" refers to the interface between two adjacent Therno-Lag surfaces. Comanche Peak Unit I installation procediures for Thermo-Lag fire barriers specify that, during the mitial installation process, the joints stould be prebultered (or covered) with Thermo-Lag trowel-grade matetial before the mating surfaces are joined to ensure adbesion of the surfaces. The term "dry join" refers to the lack of Thermo-Lag trowel-grade material in a joint. The failure to prebutter a joint wilh trowel-grade Thermo-Lag could result in a

$\therefore \div$

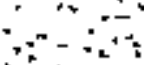

$\because$

$=5$

:

$+7$

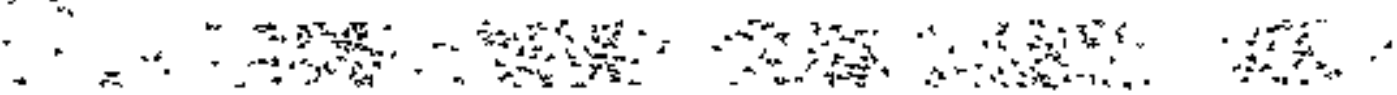

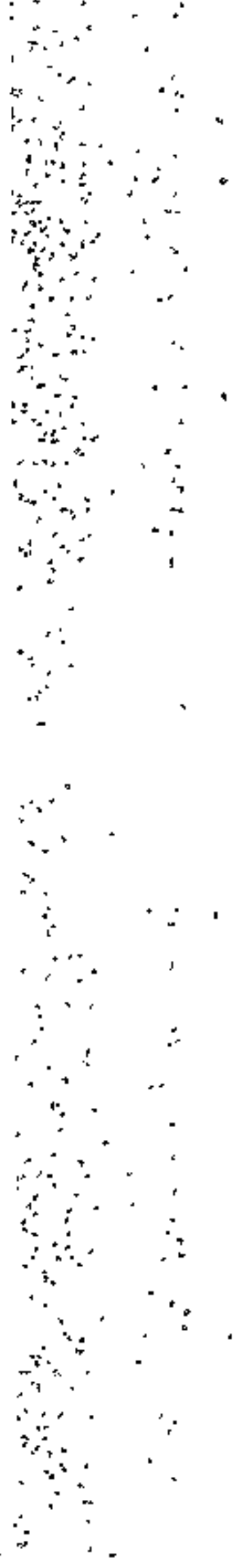


weakening of the joint during a potential fice exposure and could provide an exposure path in the fire barrier envelope. The NRC performed an inspection at Comanche Peak Unit $x$ on November 2-5 and 23-24, 1993, and January 26-28, 1994, to compare the Therno-Lag test specimens with the upgraded ThermoLag configurations on site. The results of this inspection are documented in NRC Inspection Report 93-42. The report stated that there appeared to be a large number of deficiencies with the installed fire batriers and that an example of these deficiencies involved dry joints on conduit overlays installed on pedestal hangers. The NRC inspector did not personally observe the dry joints in question. His statements were based on observations made by TU Electric and documented in an Operations Notification and Evaluation (ONE) form. However, the ONE form in question did not identify a dry joirt. Instead, the ONE form idenlified a condition that was conservatively reported as an apparent dry joint Upon further evaluation of the ONE form, TU Electric delermined that the joint in question bad in fact been prebutiered with trowelgrade Thermo-Lag. These facts are discussed in more detail below.

On November 25, 1992, a speed memo was writen by a TU Electric cottractor identifying "apparent unsatisfactorily conditions on Unit 1 commodities." This memorandum identified "an apparent" dry joint on an oversize coupling section (on top of a pedestal hanger). The speed memo also stated that, "we have decided that the best vehicle to call attention to these apparent deficjencies would be a letter to you attention for further evaluation of the situation. . .." The letter was forwarded to the appropriate TU Electric engineering secion.

The cognizant TU Electric engineer performed a walkitown of the described areas and evaluated the commodities. He conservatively initisied a ONE fom (the process used by TU Electric to report problems and develop resolution for the identified problems). A comprehensive evaluation of this condition determined that the joint had been prebuttered. Therefore, the engineering resolution for this condition was that "this is not a deficient condition, and there aye no generic implications."

The ofiginator of the speed memo initfally believed that the condition in question was a dry joint because of the appasance of the joint. During alignment of Thermo-Lag panels, the leading edge of one panel contacts the outer edge of a preceding panet and forces most of the trowel grade along the initial contact edge toward the inside of the Thermo-Lag envelope. Subsequent strinkage of the trowel grade in the joint can give the appearance of a dry joint because the trowel-grade malerial is not visible. Therefore, contrary to the Petitioners" allegation, there was no "dry joint" deficiency on the pedestal hanger.

The Petitioners also alleged that dry joints appear in other Thermo-Lag installations at Comanche Peak Unit 1 . In response to the petilion, TU Electric performed an electronic search of its ONE-form data base. The search did ldentify additional ONE forms retaled to dry jotnts. However, Themo-Lag 


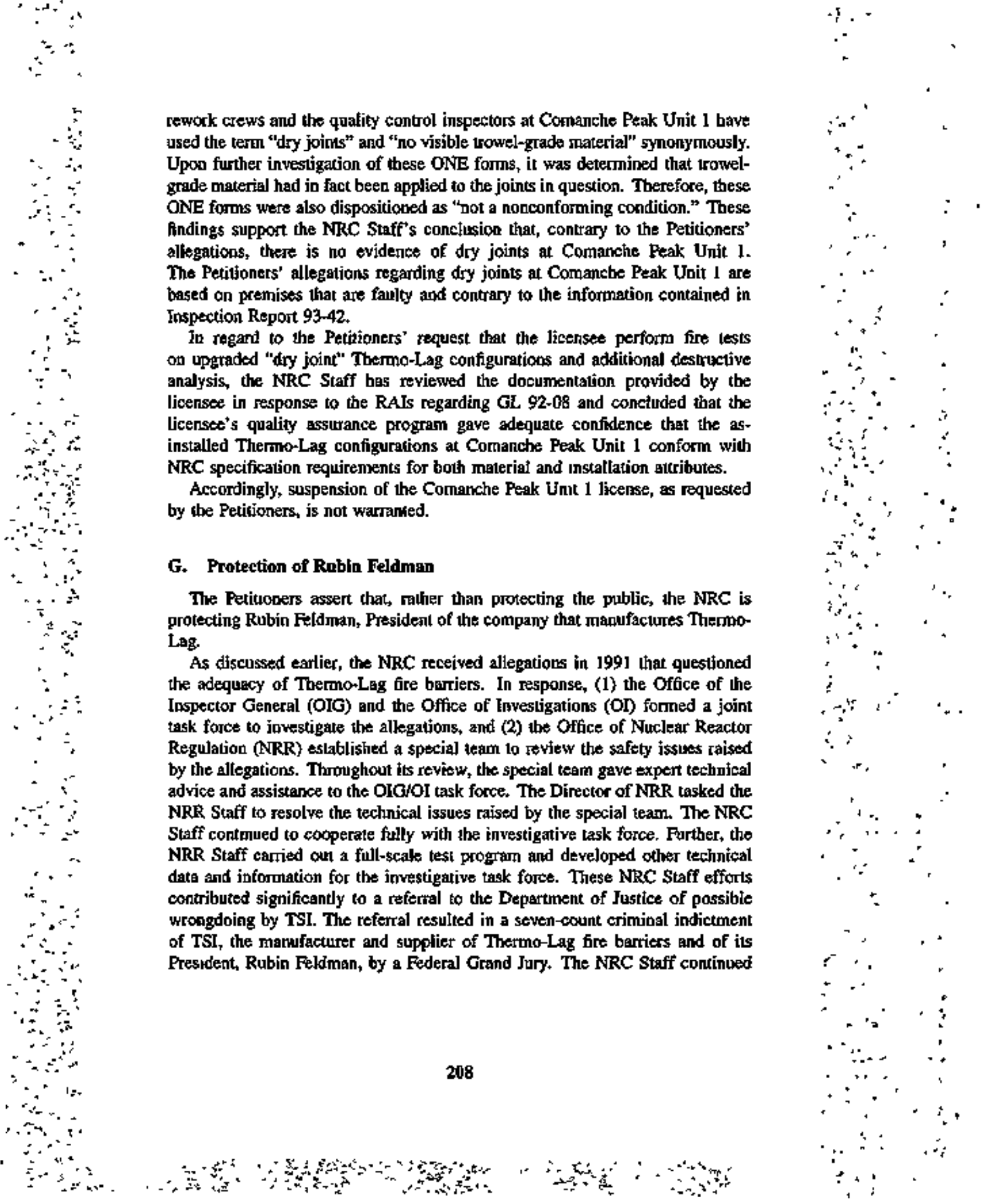


to support the Department of Justice throughout the crimingl case. 12 In addition, throughtout the trial, the NRC Staff continued to pursue corrective actions consistent with its action plan for the resolution of the Thermo-Lag issues. The above facts contradict the Pelitionets' assertion that the NRC was protecting Rubin Feldman.

\section{F. NRC Serming Complitity with Utilities}

The Petitioners also assert that there is seeming conplicity between the NRC and the licensees and that licensees seek to avoid costly replacement of the Therma-Lag.

In May 1991, the NRC Office of the Inspector General perfonmed an inspection of the NRC's Staff performance in regard to Thermo-Lag bartiers and found indications of inadequate performance by the NRC Staff in the aeceptance and review of Thermo-Lag barriers. Subsequently, the NRC Staff initiated an aggressive prograrn of corrective actions to rectify the deficiencies identified in the review and response process, as summarized earlier in this decision.

In addition, the Staff has expended considerable time and effort to address and resolve Thenro-Lag issues to ensure that licensees retum to compliance with existing NRC fire protection regutirements. The NRC Staff issued three requests for additional information regarding GL 92-08 to each licensee using Thermo-Lag to obtain information on the specifte Therno-Lag material installed at each plant, details about the corrective actions each litenste intended to tako to return to compliance with NRC fire protection requirements, and schedules for the implementation of these cortective aetions. The response of each licerise was evaluated by the NRC Staff. As a consequence of this substantial NRC Staff effort, a number of licensees have already retumed to compliance with NRC requirements by a vatiety of means which include replacing, rerouting, or upgrading existung Thermo-Lag bartiers, perfoniting postfire safe shutdown reanalysis, and instailing addtionil fire detection axd suppression features. Al] of these measures involve some burden on licensees. In addition, some licensees have initiated costly programs to perform plant-specific fire endurance tests of other fire barriers with the intention of replacing Thermo-Lag with these barriers. All ficensees who utilize Thermo-Lag will need to expend resources conmensurate with their reliance on Thermo-Lag to come into compliance with NRC fire protection requirements. NRC Staff oversight will ensure that this is the case.

The Petitioners' assertion of seeming complicity with utilities on the part of the NRC Staff is unfounded in the light of the signiticant NRC Staff efforts

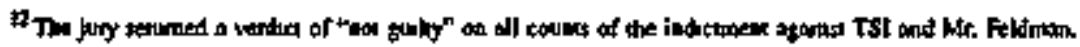


to ensure thet licensees expend the resources necessary to teturn to compliance with NRC requirements.

\section{CONCIUSION}

The Pelitioners request that the NRC order the immediate shuttown of all reactors tusing Thermo-Lag and the suspension of Oyster Creek, Feach Bottom Units 1 and 2, and Cormanche Peak Unit 1 operating licenstes.

For the reasons discussed above, I find no basis for laking sech actions. Rather, on the basis of the revfew efforts by the NRC Staft, $f$ conciude that the issues raised by the Petilioners are being addressed by licensees in a manner that ensures adequate protection of the public bealth and safety. Accordingly, the Petitioners' requesis for action pursuant to section 2,206 are denied.

A copy of this Decision will be placed in the Commission's Public Document Room, Gelman Building, 2120 L Street, NW, Washington, DC, and at the Local Public Document Room for the named facilities. A copy of this Decision will also be filed with the Secretary for the Commisston's review as provided in 10 C.F.R \$2.206(c) of the Conurission's regulations.

As provided by this regulation, the Decision will constitute the final action of the Conimission 25 days after isstance, unless the Combnission, on its own motion, institutes a review of the Decision withnn that time.

\section{FOR THE NUCLEAR REQULATORY COMMISSION}

\section{William T. Russell, Drrector Office of Nuclear Reactor Regulation}

Daled at Rockvilte, Maryland, this 3rd day of April 1996.
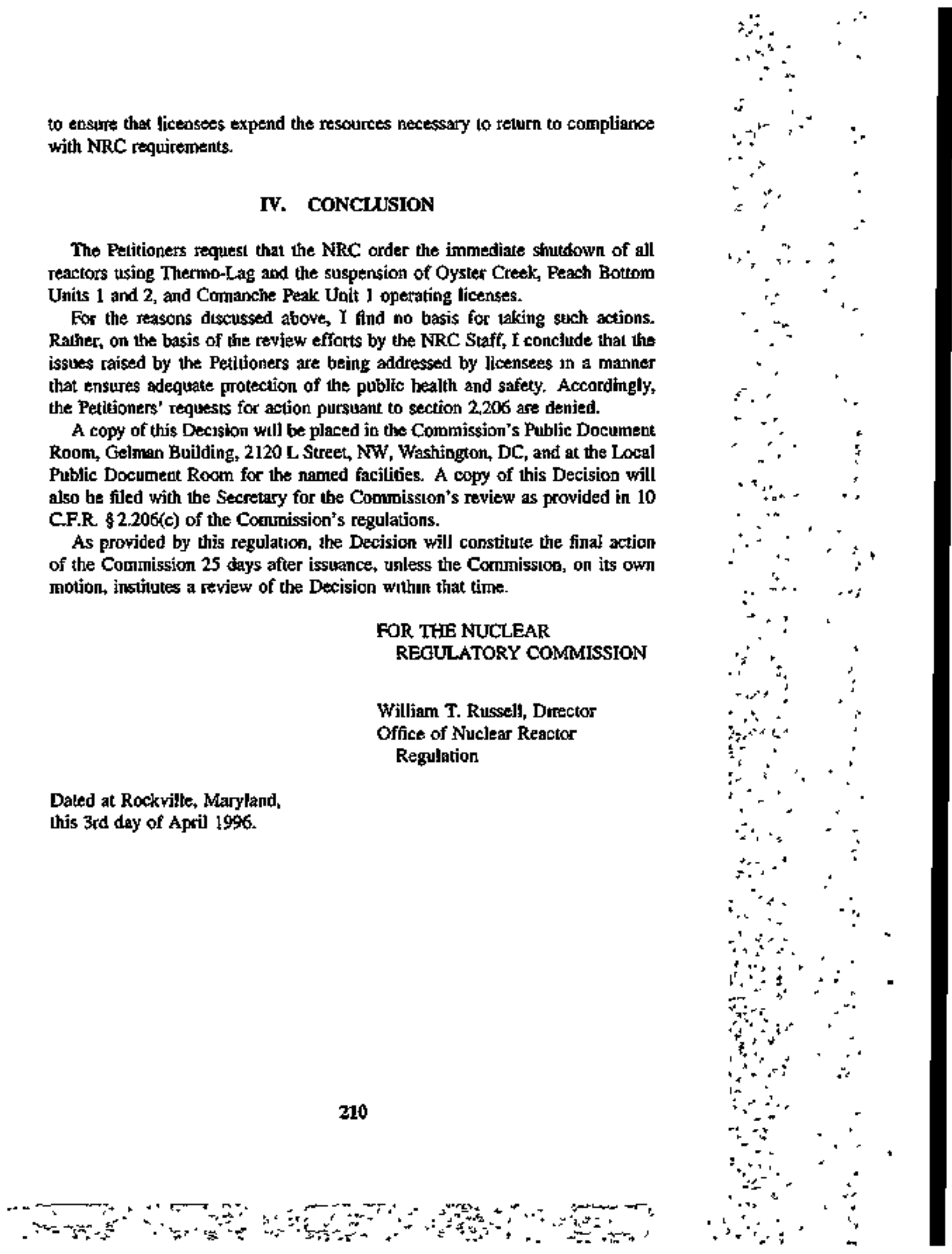
UNITED STATES OF AMERICA NUCLEAR REGULATORY COMMUSSION

ATOAIC SAFETY AND LCENSING BOARD

Before Administrative Judges:

G. Paut Bollwerk, Ill, Chairman

Dr. Charles N. Kelber

Dr. Rlchard F. Foster

In the walter of

Docket No8. 030-05373-EA

0S10-32163-EA

(ASLEP No. 96-714-(62-EA)

(EA 96-085)

(Order Suspending Byproduel

Material License Nos.

29-00814-01 and 29-05814-02)

\section{EASTERN TESTING AND} INSPECTION, INC.

May 10, 1998

Roling on a Licenseo request to rescind an NRC Staff determination to make imumedjately effective an enforcement order suspending two Licensee byproduct materials licensas, the Licentsing Board denies the Licensee's motion, concluding that for certain bases in the order, the Staff had met its burden under 10 C.F.R. $\$ 2.202$ (c)(2)(i) to estiblish by "adequate ovidence" that (1) those charges are not based on "mere suspicion, yofounded allegations, or error," and (2) there is a peed to make the order effoctive immediately.

$\because-$
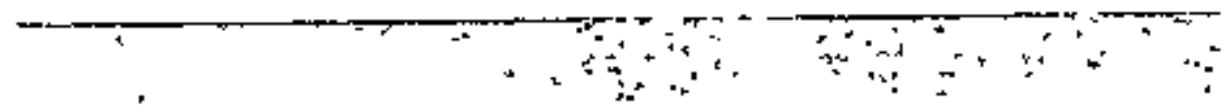


\section{ENFORCEMENT ACTIONS: IMMEDIATE EFFECTIVNESS REVIEW (BURDEN OF GOING FORWARD; BURDEN OF PROOF)

\begin{abstract}
RULES OF PRACTICE: BURDEN OF GOING FORWARD (IMMLDIATE EFFECTIVENESS REVIEW FOR ENFORCEMENT ORDERS); BURDEN OF PROOF (TMMEDIATE EFFECTIVENRSS REVIEW TOR ENGORCGMENT ORDERS); RMMEDLATE EFFECTIVENESS REVIEW FOR ENFORCEMENT ORDERS (BURDEN OF GOING FORWARD; BURDEN OF PROOF)
\end{abstract}

The movart challenging a Staff detenutination to make an enforcemsent order immediately effective bears the burden of going fortard to demonstrate that the order, and the Staff's determination that it is necessary to make the onder immediately effective, are not supported by "adeguate evidence" withim the meaning of 10 C.FR. 82.202 (c)(2)(i), but the Slaff has the ultimate butden of persuasion on whether this standard bas been met. See 55 Fed Reg. 27,645, 27,646 (1990). See also St. Joseph Radiology Associates, Inc. (d.b.a. St. Joseph Radiology Associales, Inc., and Fisher Radiological Clinic), LBP-92-34, $36 \mathrm{NRC} 317,321-22$ (1992).

\section{ENFORCEMENT ACTIONS: IMMIEDIATE RFEECTIVENESS REVIEW (CORROBORATING ALLEGATIONS OF UNRELIABLE SOURCE)}

\section{RULAS OF PRACTICE: IMMEDLATE EFEECTIVENESS REVIEW FOR ENFORCEMENT ORDERS (CORROBORATING ALLEGATIONS OF UNRELIABLE SOURCE)}

When the character and veracily of the source for a Staff allegation are in doubt, a presiding officer will be unable to credit the source's information as sufficiently reliable to provide "adequate evidence" for thal allegation absent sufficient independent corsoborating trformation.

\section{ENFORCEMENT ACTIONS: IMMEDIATE ERFECTTVENESS REVIEW (CORROBORATING ALLEGATTONS OF UNRELIABLE SOURCE)}

\section{RULES OF PRACTICE: IMMEDIATE EFFECTIVENESS REVIEW FOR ENFORCEMENT ORDERS (CORROBORATING ALLEGATIONS OF UNRELLABLE SOURCE)}

In constidering whether there is probable cause for an atrest, courts have held that information supplied by an joentified ordinary citizen witness may 
be presusted reliable. See, e.g., McKitmey v. George, 556 F. Sapp. 645, 648 (N.D. Ill. 1983) (citing cases), aff'd, 726 F.2d 1183 (7th Cir. 1984). In determining whether there is "adequate evidence" within the meaning of 10 C.F.R. $\$ 2.202(c)(2)$ (i) to sappoit the immediate effiectiveness of an enforcennent order, applying this presumption to a witoess who is corroborating a family member's allegations may be inappropriate becalse that rejationship creates a possible bias that also brings the comoborating witness' reliability into substantial question.

\section{REGULATIONS: INTERPRETATION (10 C.F.R. § 30.10(a), (c))}

Under 10 C.F.R. $\$ 30.10$ (c)(2), an intentional act that a person knows causes a violation of a licensete procedure is considered "deliberate muscondact" actionable under section $30.10(a)(1)$. As a consequence, an assertion that a person who created a document containing false information did not intend to mislead the agency (or did not actually mislead the agency) appears irrelevant. Instead, the focus is on whether the person's action was a knowing violation of a licensee procedure that could have resulted in a regulatory violation by the submission to the agency of materially inconplete or inaccurate information. See 56 Fed. Reg. 40,664, 40,670 (1991) (stating that "[f]or situations that do not actually result in a violation by a licensee, anyone with the requisite krowledge who entages in deliberate misconduct as defined in the rule has the requisite intent to act in a manner that falls within the NRC's area of Iegulatory concern. The fact that the action may bave been intercepted or coirected prior to the oceurrence of an actual violation has no bearing on whether, from a health and safecy standpoint, that person should be involved in nuclear actrvities,").

\section{ENFORCEMENT ACTIONS: IMMEDIATE EFFECTIVENESS REVIEW (RELIABILITY OF AGENCY INSPECTOR'S OBSERVATIONS)}

\section{RULES OF PRACTICE: IMMEDIATE EFFECTIVENESS REVIEW FOR ENFORCEMENT ORDERS (RELIABIIIY OF AGENCY INSPECTOR'S OBSERVATIONS)}

Absent a showing that provides some reasonable cause to believe that, because of bias or mistake, an agency inspector cannot be considered a ciedible observer, inspector's direct personal observations should be credited in considering whether allegations based on those observations are supported by "adequate evidence" within the meaning of 10 C.F.R. $\$ 2.202$ (c)(2)(i). This is bastit on the accepted presumption that a government officer can be expected faitifully to execute his or her official duties. See Untted States v. Chemical Foundation, Inc, 272 U.S. 1, 14-15 (1926). 


\section{ENFORCEMENT ACTIONS: IMMEDLATE EFEECTIVENESS REVIEW (NEED FOR IMMEDLATE EFFECTIYENESS) \\ RULES OF PRACTICE: IMMEDIATE EFFECTIVENESS REVIEW FOR ENFORCEMENT ORDERS (NFED FOR MMEDLATE EFFECTIVENESS)}

Under 10 C.F.R. $\$ 2.202$ (c)(2)(i), to support an immiediate effectiveness detennination for an enforcement order, besides showing that the bases for the order are supported by "adequate evidence," the Staff nust show thene is a need for immediate effectiveness that is supported by "adequate evidence." That need can be established by showing either that the alleged violations or the conduct supporting the violations is wilfful or that the public health, safety, or interest requires imanediate effectiveness.

\section{MEMORANDUM AND ORDER \\ (Denging Licensee Motion to Set Astde Immediafe Eifectiventess)}

By a March 29, 1996 enforcemem order effective on the date of issuance, the NRC Staff suspended two byproduct material licenses held by Eastern Testing and Inspection, Inc. (ETI). See 6] Fed. Reg. 15,836 (1996), In a Jetter dated April 1, 1996, as suppleinented on April 19, 1996, ETI requests that we set astide the Staff's immediate effectiveness detemnination." See Letter from H. Soni, ETT President, and J. Badiali, ETI Radiation SaFocy Officer (RSO), to J. Lieberman, Director, NRC Offoe of Enforcement (Apr. 1, 1996); Lelter from Damiel F. Stenger and Robert E. Helfich, Winston and Strawn, to the Licensing Board (Apr. 19, 1996) (hereinafter ETI \$upplentent]. In responsive filings dated April 8, 1996, and April 25, 1996, the Staff opposes ETI's inmediate effetiveness recision motion. See NRC Staff's Response to Request to Set Astide immediate Effoctiveness of Order Suspending Licenses (Apr. 8, 1996) [htreinafter Staff Response]; NRC Staff's Response to Supplemental Information in Support of License's Request to Set Aside Innediate Effectiveness of Order Suspending Licenses (Apr. 25, 1996) [hereinafter Staff Supplentent Response]. Thereafter. on April 30, 1996, the Board contincted an oral argument to provide an opportunity for the parties to further explain their positions on ETT's request

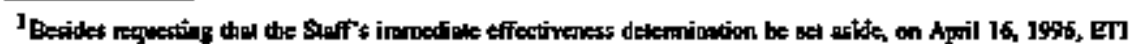

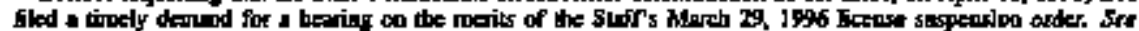

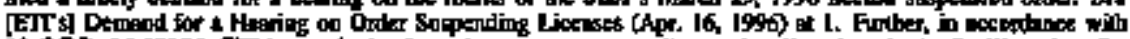

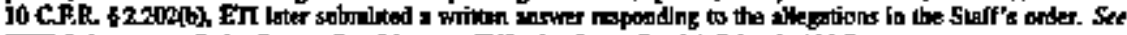

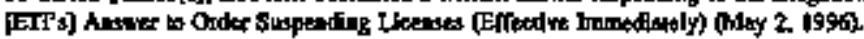


and for the Board to abtain clarification regarding the information submitted by the parties. See Tr. at 1-127.

For the reasons set forth below, we deay ETI's request to set aside the innmediate effectiveness of the Staff's suspension ordect.

\section{BACKGROUND}

\section{A. Regalatory Scheme for Immediately Eftective Enforcement Orders}

Section 2.202(a)(S) of 10 C.F,R. dectares that an enforcement order instituting a proceeding to modify, suspend, or rewoke a license will state "the effective date of the order." That subsection also provides that if there is a finding, with stated reasons, that "the public health, salety, or interest so requites" or if the regulatory vitolation or conduct that causes the enforcement order to be issued is "willful," the order may be made immediately effective. Futher, if an enforcement order is made immediately offective, under section 2.202 (c)(2)(i) the ticensee or other person to whom the order was issued may move to set aside the immedlate effectiveness on the ground that the order, including the need for immediate effectiweness, "is not based on adequate evidence but on mere suspicion, unfounded aflegations, or error." Section 2.202(c)(2)(i) also provides tiat a motion challenging an immediate effectiveness delermination must "state with particularity the reasons why the arder is not based on adequate evidence and must be accompanied by affidavits or other evidence relled on.'

The Commission adopted the immediate effoctiveness provisions of seclion 2.202 in their present form in a 1992 rulemaking. See 57 Fed. Reg. 20,194 (1992). In adopting the "adequate cridence" test - as opposed to a "preponderance of the evidence" standard suggested by some commenters on the rule - the Commission described the adequate evidence test as follows:

\footnotetext{
The test may be tukened to the probalite canse necessary for an arest, a seanch wartant,

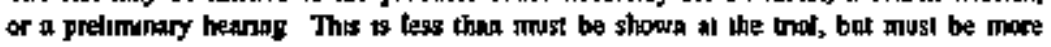
ltan unconroborated suspcion of accusation "Probable conse is deemed to exist where

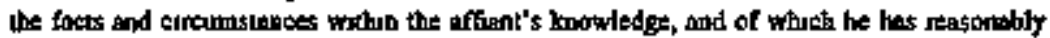

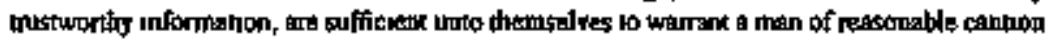
o beheve that an offense has beep or s beng conmunted ${ }^{n}$ Thos, 기 the context of the rule,

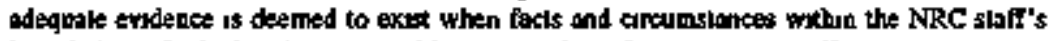
knowledge, of winch it has reasonsbly trustuorthy informallon, ane stefhetent to tramen a

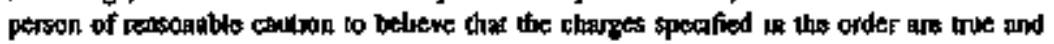
that the order is necessary to protect the publsc heallh, safety, of unterest
}

57 Fed. Reg. at 20,196 (guoting United States v. Hilt, 500 F.2d 315, 317 (5th Cir. 1974)) (citation omitted), 
(5) In violation of 10 CF. \$ $\$ 427$, ETT perronnel Eriled 10 compleke willization records on minety-gevent axcolions benween Jankary 1, 1994, and August 31, 1995; and

(6) On September 29, 1995. ET] phesideat Himat Soni litentened Mr. Bhalt will physied harm becuose he belleved Mr. Bhatt may hare coopersied witth an NRC inrestifation andfor inspection of ETt.

See 61 Fed. Reg. at 15,836. Further, based on May 1994 and July and August 1995 mispections at ETI's Thorofare, New Jersey facility and at a temporary job site in Deepwater, New Jersey, the Staff maintains that the following additional violations of the radiography license were identified (which we will refer to as Basis B):

(1) In violation of 10 CF.R. \$ 343I(b) and RSP No. RS-I, Revision 4. incorporated by Fof forty hours of formal elagoroan ingurnction to Mr. Bhalt, who acted as a fodiographer's assirtant during June and Jody 19g5;

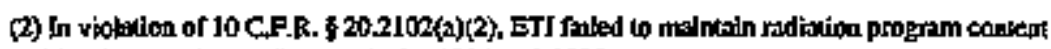

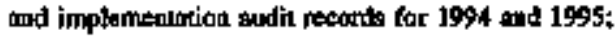

(3) In violation of 10 C.FR \$34,33(a) and RSP No. ETI-1. Retition G, intopparaled by reference In Condution 17 of the cadiography license, E[] falted wo "rezero" pocket dosimeters

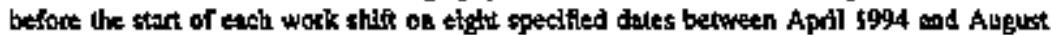
1995;

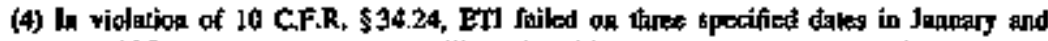
Ausust 1995 to use gurwey meters catibrated within these months and to maintain survey meter calsbration reconds;

(5) in vidation of 10 C.F.R. 320.2106(c), during June and July I995 ETI tarted to mainaik complete dosimetry records that included the names, soctal security numbat, and binth dales or inditiduals;

(6) In violation of RSP No. ETJ-1, Revigion G, incerporated by xeforence in Condition if of the radiography license, between Jowe 1994 and Aogust 1995, ETI persopnel falled to complete ullization logs and retum completed utillzathon Jogs to the RSO;

(T) In vialotion of RSP No. ETI-1, Revision G, tncomprated by tererence in Condition 17 af the radiography beterte, on August 23, 1995. ETI persounol failed to perform physical radiation sarveys to ensure reactaps to roped-aft boondaries did not exceed two millirem in an havr;

(8) In violetion of J0 C.F.R. \$34.43(b), on August 23, 1995, while making madiographic

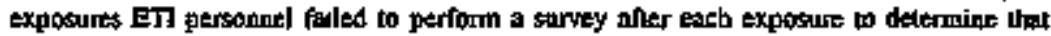

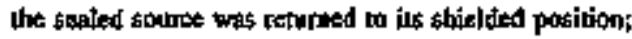

(9) In violation of 10 C.F.R. \$71.5(a) and 49 C.F.R. \& IT7.817(a), on Joly l2, 5995, ET persannel fot'ed to complete a shlpping paper pstoc to innsporling lloensed moderial outside the lieenset's ficility;

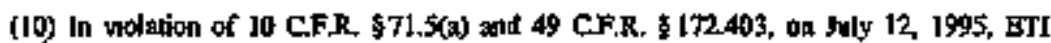
personnel failed to idendfy the activity or transport index on the "RADPHOACTIVE" Isbel 


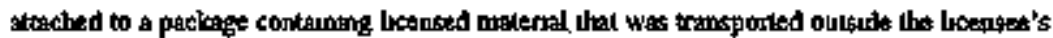
faxility, and

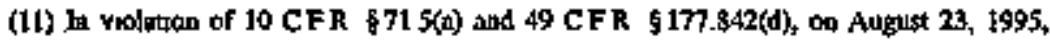

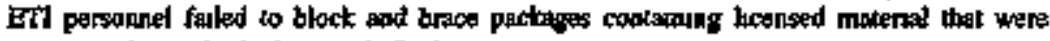
transported ontside the heensee's facclity

See id at $15,836-37$.

A third basis for the Staff's order (which we will refer to as Basis C) purportedly flows from a March 14, 1996 safely reguirement coutpliance foltowip inspection regarding the radiography license. The Staff declares that this inspection revealed a deliberate Licensee falsification of radiographer examination documents. As evidence of such falsification, the Staff alleges that (I) a radiogapher's purported responses to the twenty-two questions on the January 16, 1996 examination given during an eight-hour annual refresher training course at the ETI facility were identical to those of ETI's President, while other individual's responses were markedly different, and (2) an ETI inwoice and work order for that date indicated the Jadiographer worked from 6:00 $\mathrm{am}$. to 2:00 p.m. at a job site some 3 hours drive from the ETI facility where the course and test were given. See it, at 15,837 .

Finally, as a basis for the March 29 order (which we will refer to as Basis D) the Staff references the Licensee's supposedly poor enforcentent history. This includes (1) civil penalties of $\$ 6500$ and $\$ 5000$ in 1987 and 1992, respectively, the latter of which was based on some admitted violations that were found to be 却 a careless disregard for NRC requiremenis, and thos willfuj; and (2) a 1994 motice of violation that is repetituve of the current allegation in Basss $A(4)$ that an unqualified employec was directed to perform radiography. $\$$ ee id. at 15,837 \& nn.1-4.

In its March 29 order, after oulining these bases, the Staff declares that ETI "Thas violated numerous NRC jegunements, some willsully, and has failed to take appopiate actions to prevent the recurrence of past viojations." Id.

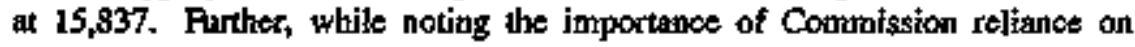
licensees to provide complete and accurate licensee information, to comply with NRC requirements, and to refrain from conduct that could impede agency safety inspections or investigations, the Staff further sfates that ETI President Soni and RSO Badtalt have demonstrated "an unwillugness to tomply with NRC requirements" and thet the actions of ETI and its senior errployes "have raised serious doubts as to whether the Licensee and its employees can be relred upon in the future to comply with NRC requirements and to mainiain complete and accurate records of licensed activities." Id The Staff thus concludes that it lacks the requisite reasonable assurance that ETI's current operations onder both its radtography and portable gauge licenses can be conducted in compliance with agency requirements and that health and safety of the public,

218 
including ETI's employees, tan be proteted. This, the Staff asserts, requires that ETI's radiography and portable gauge licenses be suspended, pending further investigation, and that the significance of the alleged violations and wilfumess of the purported conduct requite that the suspension (and the accompanying terms) be made effective immediately. See id at $15,837-38$.

\section{ANALYSIS}

The parties have placed a greal deal of information and a variety of factual and legal dispules before the Board relative to ETI's April 1, 1996 request to sel asjite the immediale effectiveness of the Staff's March 29, 1996 license suspension order. Nonetheless, the resolution of ETI's request does not require that we delve into most of that information or definitively resolve all those controversies. During the April 30 oral argument, in response to a Board question sbout the "crux" of the Slaff's concents about ETI that led the Staff to suspend ETT's radiography and portable gauge lteenses, counsel indicated that the \$taff's central concern was with the willful violations regarding the training of individuals who will be going out into the public, and performing radiography with sources." Tr. at 99 . Also mentioned by counsel as important to the Staff's immediate effectiveness determination was the purported physical threat to Mr. Bhat because of his coroperation with NRC investigators and the "failure [of ETI enployees] to sorvey certain boundary areas." Tr. at 99-100.

After reviewing the comresponding bases set forth in the March 29 order relating to (I) deliberate, training-related violations - Bases $A(1)-(4)$ and $C_{;}$ (2) the threat to Mr. Bhatt - Basis A(6); and (3) the failure to perform job sile surweys - Bases $B(7)-(8)$, we conclude we are unable to sustain a "probable cause" finding relative to Bases A(2)-(4) and A(6). We do find, however, with respect to Bases $A(1),(B)(7)-(8)$, and $C$, that the Staff has provided "adequate evidence" to support its allegations and the need for immed fate effectiveness of its suspension order relative to those allegalions.

\section{A. Buses $A(2)-(4)$, (6)}

Regarding the allegations of delaberale misconduct set foth in Bases $A(2)-(4)$ and (6), ETI has denied that any wrongdoing took place. See ETI Supplemient, Affidavit of Himat J. Soni in Support of [ETI's] Request of April 1, 1996 to Set Aside Immediate Effectiveness of Order Suspending Licenses (Apc. 18, 1996) at 6, 8 [hereinafter Soni Affidavit]; id. Affidavit of Joseph Badiali in Support of [ETI's] Request of April 1, 1996 to Set Aside Immediate Effectiveness of Order Suspending Licenses (Apr. 18, 1996) at 2-3 [hereinafter Badjali Affidavit]. As 


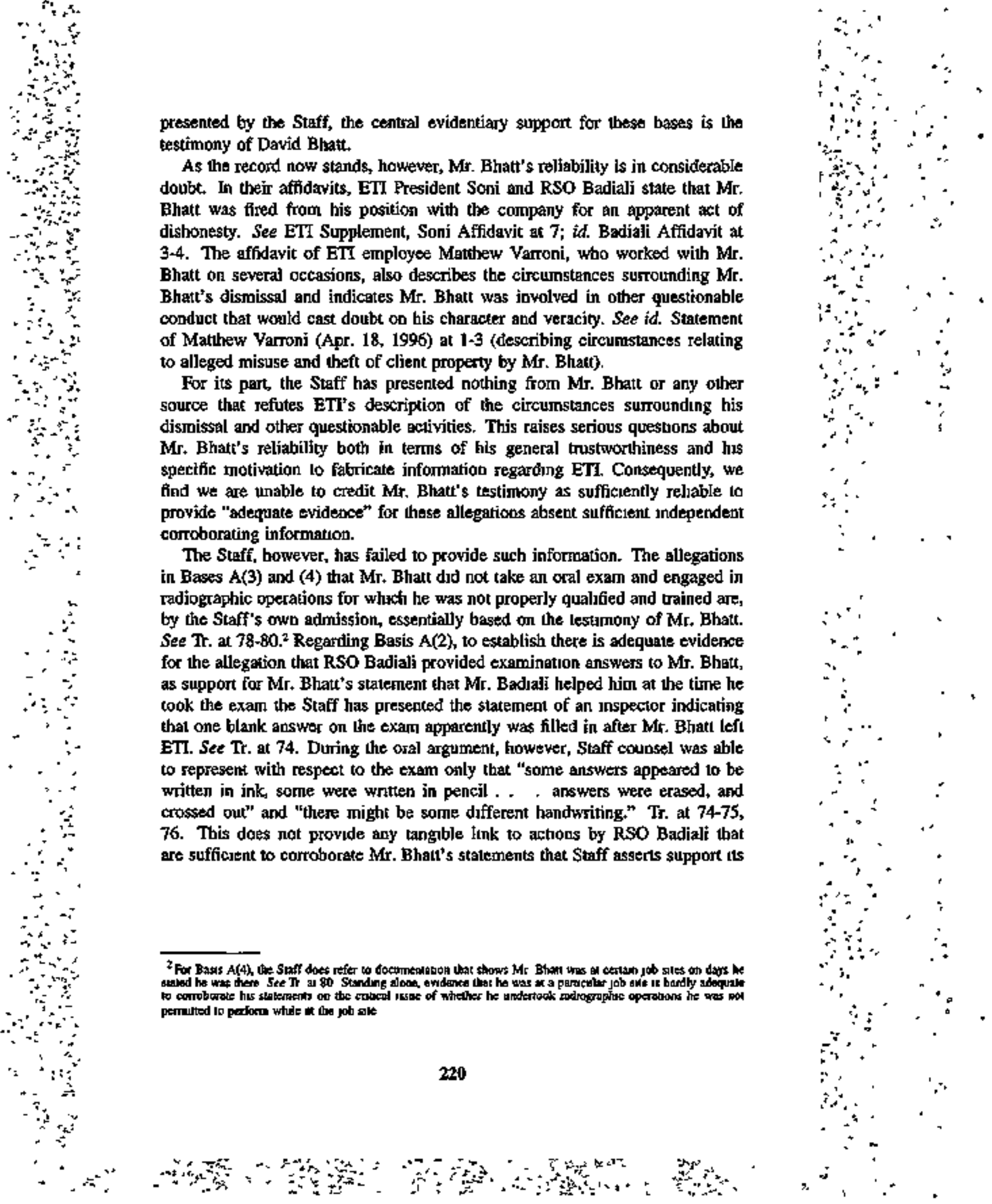


allegation regarding Mr. Badjali's purported improper activities while Mr. Bhatt was taking the exam. ${ }^{3}$

Concerning Basis $A(6)$, the testimony of other witnesses could provide sufficient corroboration to Mr. Bhatt's account of the evems on Septerber 29. 1995, when during a community cultural function Mr. Soni allegedly threatened hìm for conperating with NRC investigators. The Staff does proffer additional witnesses - whom Staff counsel jdentified as Mr. Bhatt's wife and cousin - albeit without providing any detail regarding the nature or extent of their knowledge about the alleged incident. See Tr. at 88; Staff Response, Exb. 3, at 4 [bereinafter Teator Affidavit].

Courts have recognized in the context of considering whether there is probable cause for an arrest that infornation supplied by an jdentified ordinary citizen witness may be presumed reliable. See, e.g., McKinney v. George, 556 F. Supp. 645, 648 (N.D. IlL 1983) (citing casts), aff'd, 726 F.2d 1[83 (7th Cir. 1984). The cocroborating witnesses offered by Staff to not fall into this caregory, however. Because they are members of Mr. Bhatt's family, by reason of that relationship they also have a possible bias that brings their reliability into stbstantial question as well.4 Therefore, based on the informalion now before us, we find that those witnesses are not sufficient to corroborate Mr. Bhatt's account of events on September 29, 1995.

Because the record in its current state fails to provide sufficient information for us to conclude that the testionony of Mr. Bhatc has the degree of reliability the Commission has decreed axust be present, see 57 Fed. Reg. at 20,197 (section 2.202 (c)(2)(i) review process is designed to safeguard against Staff immediate effectiweness decisions based on "unreliable evidence"), we also are unable to find that Bases $A(2)-(4)$ and (6) are supported by "adequate evidence" so as to support immediate effectiveness.

\section{B. Basis (A)(I)}

We tem next to Basis $A(1)$, which is the Staff allegation that ETI violated 10 C.E.R. \$\$30.9, 30.10, when ETI president Soni gave Mr. Bbatt a card

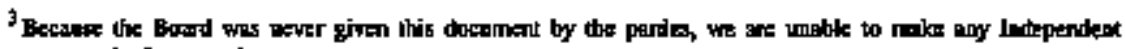
ussersoment in flut rogard.

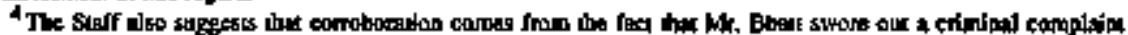

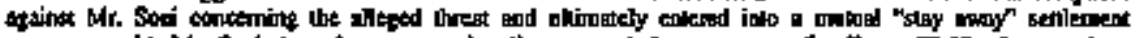

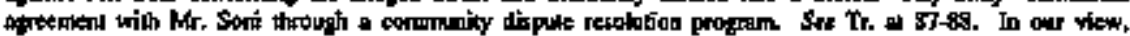

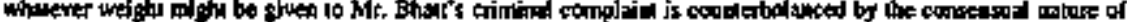

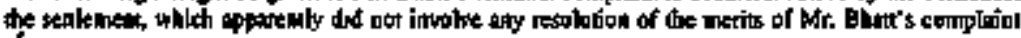

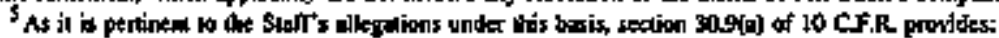

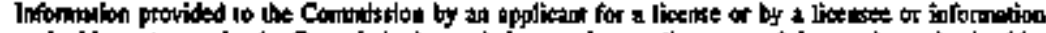

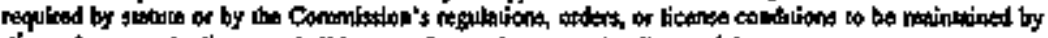

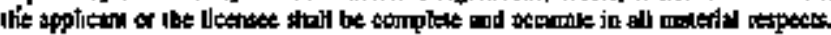


identifying him as a Radiographer Level I. As descnbed in the affidavits that accompanied the Staff's April 8, 1996 response and other supporting information supplied by counsel, ${ }^{6}$ the card was issued to Mr. Bhatt on June 16, 1995, the day after be began work al ETL. On the card, which was signed by Mr. Soni, is a handwritten inseription certifying that Mrr. Bhall is a Radiographer Level I per ETI procedures and meels the applicable American Socjety for Nondestructive Tesung SNT-TC-1A rexuirenents. See Staff Response, Teator Affedavit at 2;

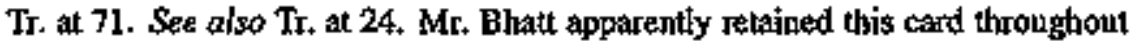
his six-week employment with ETI, which ended on Juty 27, 1995, and was expected by ETI to provide it as identification. See Tr. at 19, 21 .

Conterning Basis A(1), in his affidavit, ETI presidery Soni indicates that Mr. Bhatt was hired mainly to work at a Brooklyn, Now York job site. Mr. Sons admits that Mr. Bhalt was stpplied with a tard, but declares the card was intended only to give hum job site identification, as is requited by the New York State Department of Labor. According to Mr. \$on, the card was not a deliberale attempt to qualify or authorize Mr. Bhatt to perform radiography before he was properly trained. The only thing the eard may have shown, Mr. Soni declares, is that Mr. Bhalt would perform the duties of a trainee or radiographer's assistant, although under approproate supervision. See ETI Supplennent, Soni Affidavit at 4-5. In addition, at the oral argument ETI counsel suggested that any problem with the card may have arisen beeasse RSO Badiali was not present at the time the card was issued because of the recent death of bis son. See Tr. at 20.

In support of its allegations $m$ this basts, the Staff reties on the affidavit of OI Investgator Jeffrey A. Teator supplied with its April 8, 1996 response. Mr. Teator states that this charge is based on (1) intervews with Mr. Bhalt, who staled that be did not receive 40 hours of classrobm training and told ETI presiders Soni of this fact; (2) an NRC inspector's determination, based on an tnterview with Mr. Bhatt, that he was not knowledgeable about radiation safety or ETT's operathng or emengency procedures; and (3) statements by Mr. Soni

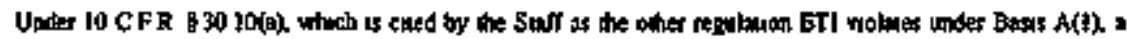

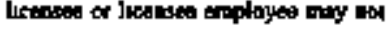

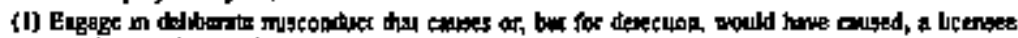

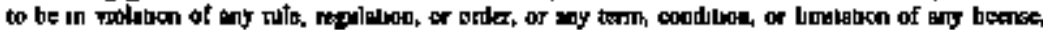
sabed by the Conmosess, of

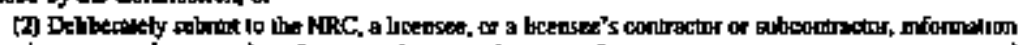

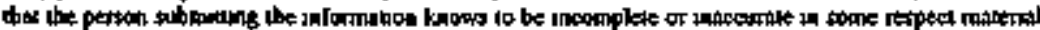
to the NRC

Finther, subection (c) of Uns toctun provides

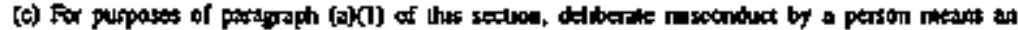

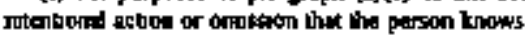

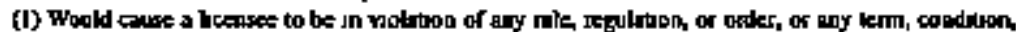

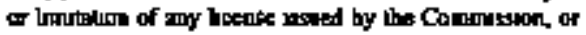

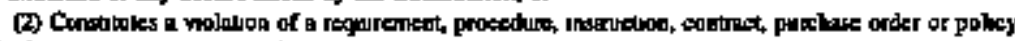

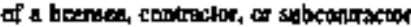

Thelhe porty seppled the Boand web a eopy of the eard

$\because+\frac{1}{3}$

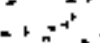

in.

$\therefore \cdots$

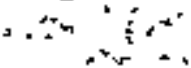

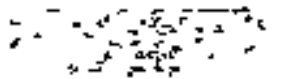
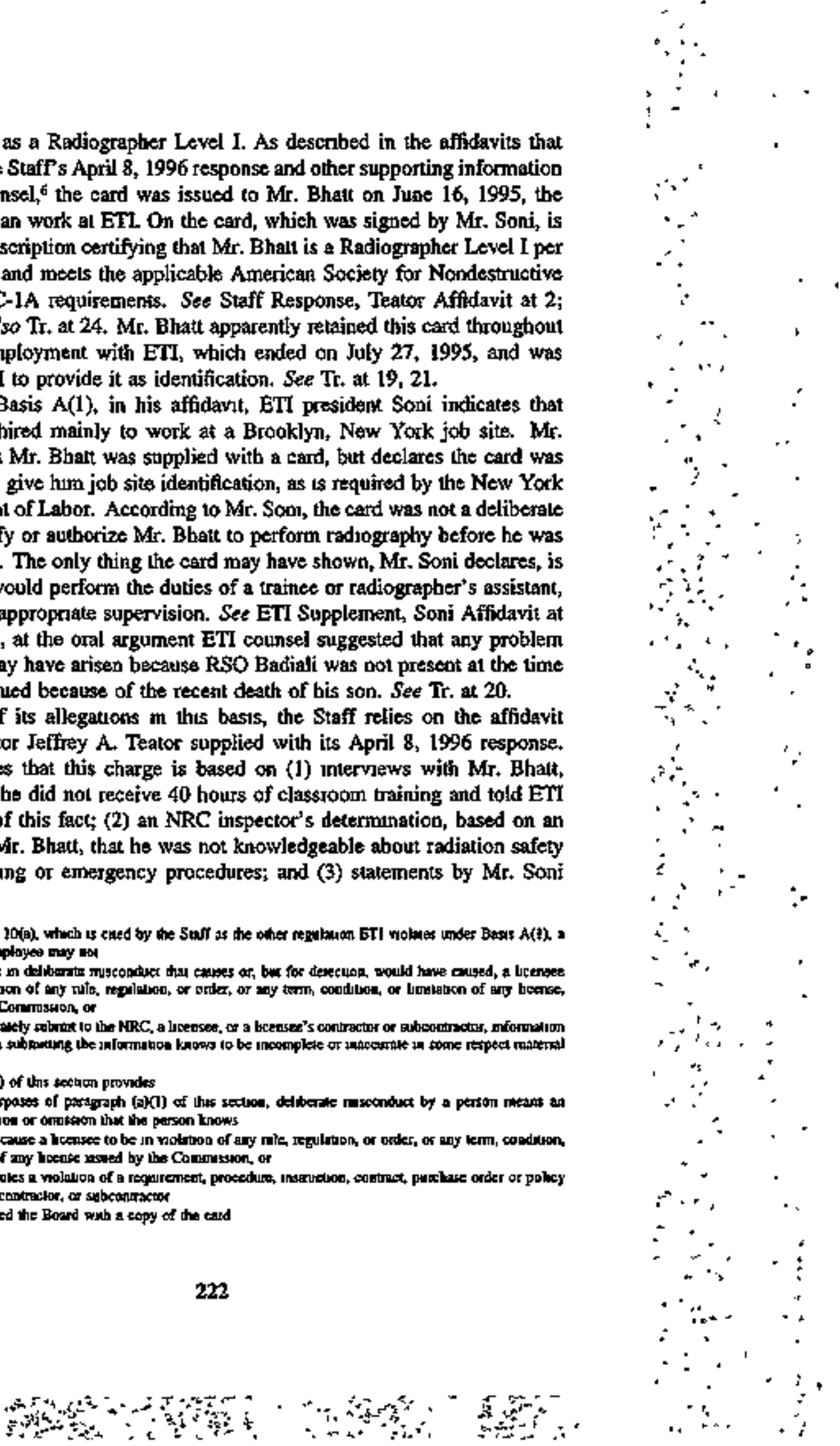
and RSO Badiali that the employee was a trainee who never used radiography equipment. See Staff Response, Teator Affidavit at 2.

ETI procedures make it clear that a certification card is to be issued only after an individual has fulfilled the applicable training and experienct requiroments. See Board Memorandum (Party Submissions in Response to Board Request at Oral Asgument) (May 1, 1996), Altach. 2, at 8 (ETI Procedure No. CP-101, Rev. 9 (Mar. 12, 1990)) [hereinafter Board Menorandum]. To be a Rediographer's Assistant, cme Inust have a mininum of $\mathbf{4 0}$ hours of "fornsal classroom training" and 3 months of "on-the-job training," while the higher-level Radtographer must hawe a minimum of 40 hours of "fomal ctassroom trajning" and 9 months of "on-the-job training" as a Radiographer's Assistant. Id. Atlach. 3, at 50-51 (ETI RSP No. RS-1, Rev، 4 (Mar. 14, 1994)). See aiso id. Attach. 2, at 11-12. Under these provisions, it seems apparent that Mr. Bhalt did not have surficient training or experience to qualify as a Radiographer or even a lower-level Radiographer's Assistant at the time the card was isssued or, apparently, anytime thereafter.'

Pointing to this deficiency, the Staff maintains thal issuance of the card to Mr. Bhat violated sections 30.9 and 30.10 because (I) the information in the card is incomplete or inaccurale by reason of the fact that a person who examined the card at any time during Mr. Bhatt's employment, including an NRC or agreement state official, clearly could have misapprehended his level of training and experience; and (2) such incorrect information about an individual's training and experience level would be information that (a) is incomplete or inaccurate in some respect malerial to the agency within the meaning of section 30.10(a)(2) and (b) would not be complete in all material respects as is required by section 30.9(a). See Tr. at 72-74. EN, on the other hand, maintains all this is irrelevant because there was no NRC regulatory requirement that ETI employees carry such a card and, in any cvent, there has been no showing of "scienter" by establishing any delibetale attempe by ETh to viotate any regulatory requirement. See Tr. $14-15,21-22$.

EII is correct that there apparently is no NRC regulation that requites ETI to prepare certífication cards for its employees. Yet, as we have noled above,

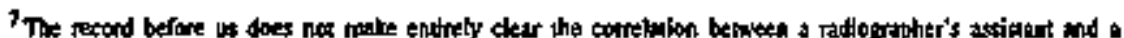

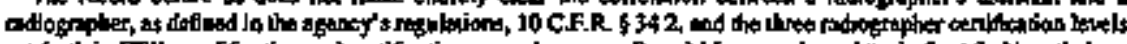

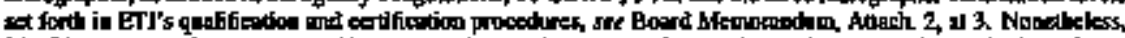

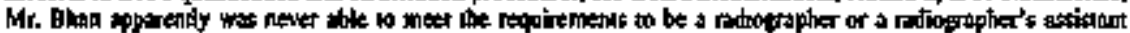

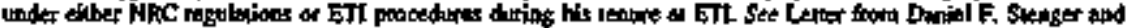

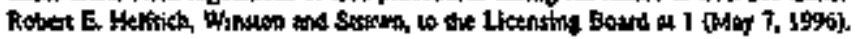

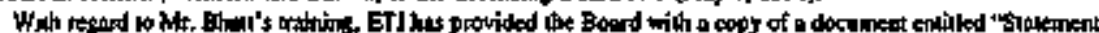

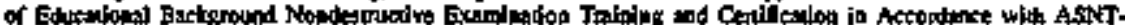

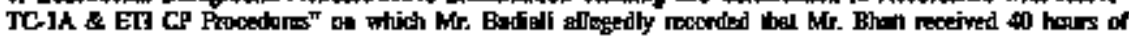

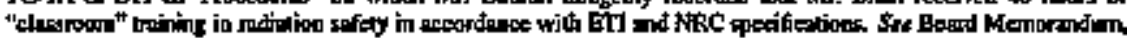

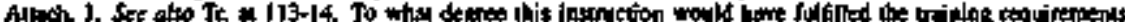

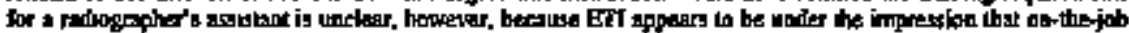

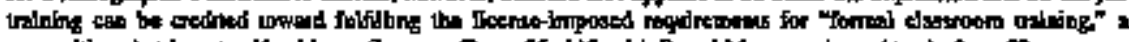

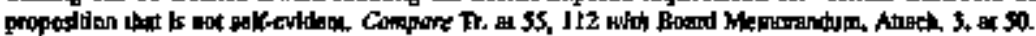


ETI's own procedures indicate that radjographer certification cards are to be issued only to those who have fuliflled the applicable requirements. Under section 30.10(c)(2) an imtentiona' act that the person knows causes a violation of a licensee procedure is considered "deliberate misconduct" actionable under section 30.10(a) (1). As a consequence, ETI's contention that Mr. Sonj did not intent to mislead the agency (or did not aculally mislead the agency) appears inelevant, Instead, the focus is on whether bis aetion was a knowing violation of ETI's procedure that could have resulted in a regulatory violation by the submission to the agency of matejially inconglete or inaceurate information. See 56 Fed. Reg. 40,664, 40,670 (1991) (stating that "[f]) situations that do not actually result in a violation by a licensee, anyone with the requisite knowledge twlo engages in deliberate misconcuct as defined in the rule has the requisite intert to act in a manner that falls within the NRC's area of regulatory concem. The fact that the action may bave been intereepted or conrected prior to the occurrente of an actual violation has no bearing on whether, from a health and safety standpoint, that person should be involved in nuclear activities.').

Because ETI has not presented any evidence suggesting that Mr. Soni was not aware of ETI's own procedures regarding such certifications, it appears that his action in siésing and issuing the cerd would, in fact, amount to a detiberate contravention of one or both of the regolations cited. Thus, based on the record and the arguments before us, we find the Staff's position relative to Basis $(A)(I)$ is supported by "adequate evidence."

\section{Bases (B)(7)-(8)}

Bases B(7)-(8) involve allegations of a fajlure of ETI personnel on August 23, 1995, to conduct proper surveys ouring radiographic operations to ensure that (1) readings at roped-off boundaries did not oxceed levels mandated by ETI procedures, and (2) a sealed source bad been returned to its shielded position as required by 10 C.F.R. $\$ 34.43$ (b). The support for these purported violations is the personal observations of an NRC inspector. See Staff Response, Exh. 4, at 3 [hereinafter Costello Afidavit]; Tr. at 105. ETI responds that ils own investigation indicates there were no such violations by the team involved, which included ETI president Sont and ETI employee Mathew Vartoot. See ETI Supplement, Badiali Affidavit at 5-6. Indeed, ETI asserts its employees at the site were aware that NRC inspectors were watching them. See $\mathrm{Tr}_{\text {. }}$ at 106.

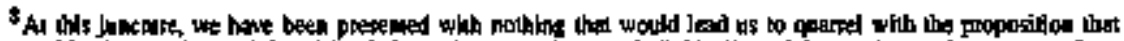
a certifiction

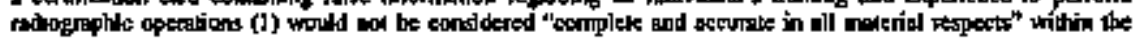

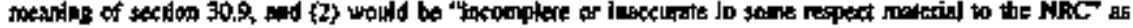
defined in section $30.10(0)(2)$.
} 
For present purposes, the resolution of this dispute over what occurred on August 23, 1995, turns on an assessment of whether the Staff's evidence is "vureliable." 57 Fed. Reg, at 20,197. The allegations are based on the direct personal observations of an NRC inspection official. Other than a declaration flatly denying the altegations, which clearly would serve ETI's interests, ETI has not provided us with any reasonable cause to believe that, because of bias or mistake, the goverament official involved cannot be considered a credible observer. ${ }^{9}$ Absent such a showing we conclude that Bases $A(7)-(8)$ are supported by "adequate ovidence."

\section{Basis C}

We come finally to Basis C, which concerns the test given to ETI Radiographer's Assistant Ram Lubhaya on January 16, 1996, as part of a course being condueted that same day by RSO Badiali. Based on the parties' submissions, it appears that their dispute over this allegation is rot so muxh what happened as the significance of the events that transpired.

After performing soil compaction testing in Queens, New York, under ETI's portable gavge license during the morning of January 16 , that afternoon Mr. Lubhaya relumed to ETI's New Jersey facility to attend the refiesher course being corducted by RSO Badiall Ste ETI Supplement, Afftavit of Ram Lubhaya (Apr. 12, 1996); in. at 48. He also took a twenty-two-question examination. His answers, the Staff atleges and the Licenses apparently admits, are essentially identical to those found on the exsmination of ETI president Soni. See Staff Response, Costello Affidavit at 6; ETI Supplement, Soni Affidavit at 10. See also Tr. at 49.

Under appticable ETI procedtues, annually all radiographers and radiographer's assistants must "receive an eight (8) how refiesher course in Radjation Safety Training from the [RSO] or his designated representative" and "[u]pon completion of this training all personnel will be administered a written examination with a minimum passing grade of $80 \%$ seguired." Board Mexnorandurn,

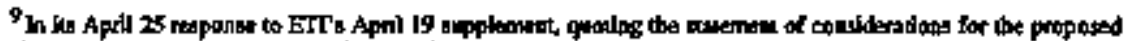

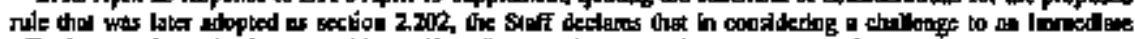

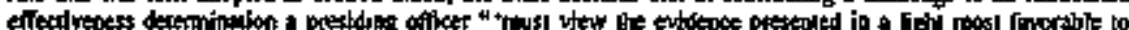

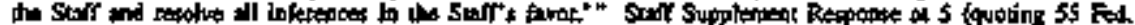

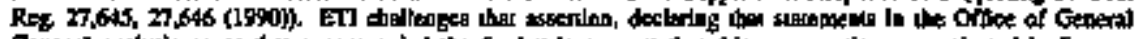

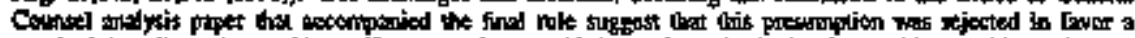

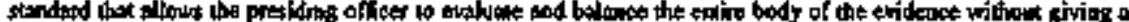

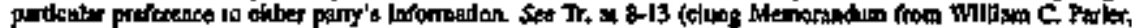

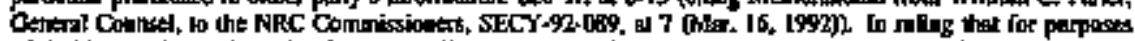

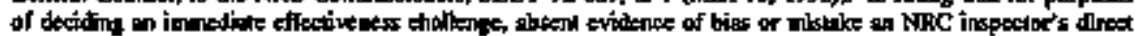

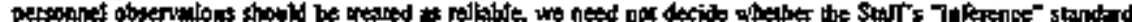

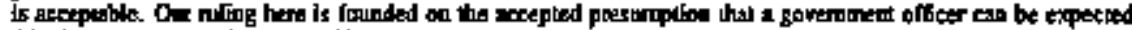

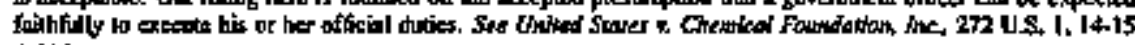
(1926).
} 


\section{E. Need for Immediate Effectiveness of the Radiography and Portable}

Gauge License Suspensions

As was noted earlier, to support an immediate effectiveness determination, besides showing that bases for the order are supported by adequate evidence, the Staff must show there is a need for immediate effectiveness that is supported by adequate evidence. That need can be established by showing either that the alleged violations or the conduct supporting the violations is willful or that the public health, satety, or interest, requires immediate effectiveness.

Regarding the suspension of ETI's radiography license, taken together the Staff's "crux" allegations that we have found are supported by adequate evidence also demonstrale a need for immediale effecliveness in accordapce with this standard. As we have already explained, there is adequate evidence to support Staff's claim that Bases $A(1)$ and $C$ involve deliberate, i.en, willful, regulatory violations within the mearing of section 2.202(a)(5). As to Bases B(7)-(8), while the Staff had not sought to label these violations as willful, they have asserted that they involve a potential for serious injury to the public health and safety. As was noted in several of the affidavias accompanying the Staff's response, industrial radiography jowolves the we of high-activity sources that can cause high radiation doses if mishandled. Further, the failure to perform a survey after each exposure to ensure that a sealed source has been retumed to its shielded position, as is alleged in Basis $\mathbf{B}(\mathbf{8})$, has the potential for causing a significant radiation exposure to individuals using the exposure device and to members of the public. See Slaff Response, Costello Affidavit at 7; id. Exh. 5 , at 2 (Affidavit of James Lieberman in Support of NRC Staff's Response to Request to Sex Aside Immediate Effectiveness of Order Suspending Licenses). We find this suffictent to meet the Staff's buriten relative to ETI's radiography Iicense.

With respect to ETI's portable gatge license, ETI asserts that the weak sources used in the gauges create only a very minor possibility that activities under this license will have any inpact on the public health and safect, thereby establishing there is no effective support for immediate suspension of this licenst, See EII Supplement at 2; $\mathbf{T}_{+}$at 62-64. During the oral argumeat, Staff counsel disagreed, conleading that the nature of the training violations in this instance support the need for immediale effectiveness. See Tr. at $\$ 4-95$.

Bases $C$ and $A(1)$ are sufficient to establish the need for immentiate effectiveness of the suspension of ETI's portable gauge license. Basis C questions the adequacy of training for Mr. Lubhaya, who just before taking the January 16, 1996 refresher course and exam was doing soil compaction gauge work under ETI's portable gauge license. Basis A(I) raises concerns about the circunstances under which Mr. Bhatt was being trained. As the Staff observed, there is a greater possibility that untrained or improperly trajned personnel will 
lose such a source, which then could result in exposures in excess of 10 C.F.R. Part 20 likilations and an increased likelibood of cancer development. See Staff Response, Costello Affidavit at 2; Tr. at 94-95.

Thus, we find that considering Bases A(1) and (C) together, the Staff has provided sufficient reliable information to establish "adequate evidence" to suppore the public health and safety need for 1mtmediale suspension of ETI's portable gauge licenso.

\section{CONCLUSION}

Under 10 C.F.R. \$2.202(c)(2)(1), in the face of a hoensee challenge we are to uphold a Staff immediate effectiveness determination if the order, and the Staff's determination that it should be made inmeduately effective, are supported by "adequate evidence." In this instance, looking to those allegations ddentified by the Statf as central to immediate effectiveness for its Marth 29, 1996 license suspension order, we find that wath respect to Bases $A(1), B(7)-(8)$, and C, the Slaff has met its burden to establish by "adequate evidence" that (I) those charges are not based on "mere suspieion, unfounded allegations, or enor," and (2) there is a need to make the order effective imunediately.

For the foregoing reasons, it is, this tenth day of May 1996, ORDERED that:

1. ETI's April 1, 1996 request 10 set aside the jumediate effectiveness of the Staff's March 29, 1996 order suspending ETI Byproduct Material License Nos. 29-09814-01 and 29-09814-02 is denied.

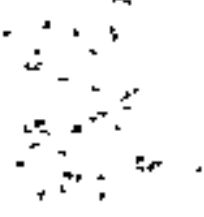

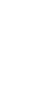$$
\text { : }
$$$$
\therefore
$$ 
2. In accordance with 10 C.F.R. $\$ 2.202$ (c)(2)(i), this order upholding inmediats effectiveness is final agency action."

\section{THE ATOMIC SAFETY AND LICENSING BOARD}

G. Paul Boliwerk, III, Chairman ADMINISTRATIVE JUDGE

Charles N. Kelber

ADMINISTRATIVE JUDGE

Richard F. Foster

ADMINISTRATTVE JUDGE

Rockville, Maryland

May 10, 1996

\section{ADDITIONAL VIEWS OF BOLLWERK, J.}

I write separately to express my concern about an apparent procedural limitation that exists under ctrrent regulations on a presiding officer's ability to clarify the information supplied by the parties during a challenge to an NRC Staff immediate effectivenes determination. Based on my experience in this procedijog, that limitation does not appear to serve the immediale effectiveness review process particularly well.

The statement of considerations supporting the final rule adopting 10 C.F.R. $\$ 2.202$ with its imrtedjate effectiveness provisions indicates that after recejing the parties' written subrnissions the Board atay conduct an "oral argument" if it wishes to gain additional insight or information regarding the parties' positions supporting or opposing an immediate effectiventess challenge. 57 Fed. Reg. $20,194,20,196$ (1992). Nonelbeless, as with a criminal preliminary hearing, which is cited in the final rule in conjunction with the proper application of the "adequate evidence" standaru, or a civil temporary restraining order or preliminary injunction proceeding, there undoubtedly are instances when convening a limited evidentiary hearing to ensure that the record is fully

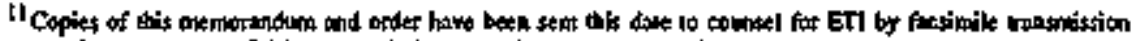

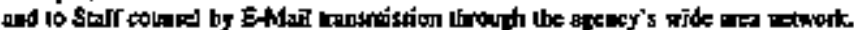


developed is useful. Arguably one of those instances would be when, as beer, there are significant questions regarding the reliability of a centrai witness.

Through the ongoing National Performance Review and other agency initjatives, the adjudicalory procedures in 10 C.F.R. Part 2 are likely to come under scrutiny in the near future. I would urge that as part of any such review, consideration bo given to clarifying the atthority of a presiding officer to hold an evidenliary hearing when a licensec or other person subjecl to an enforcement order challenges a Staff immediate effectìveness decision.

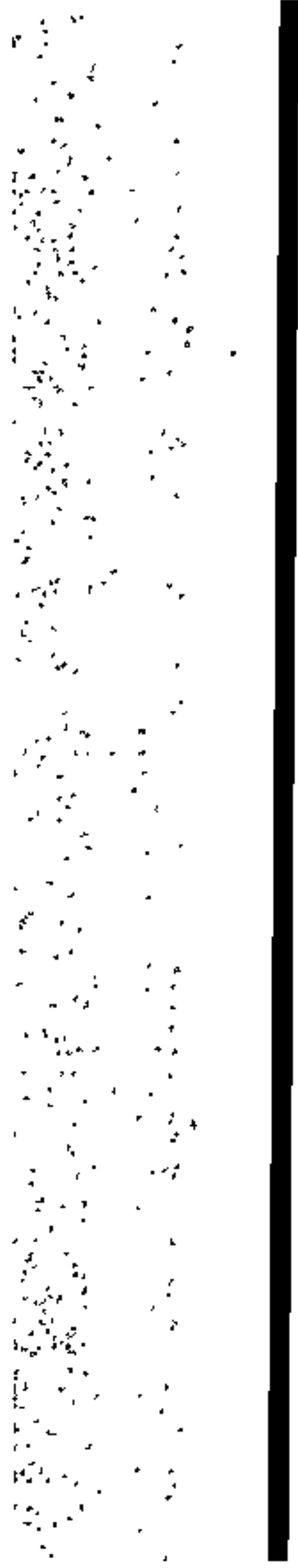


UNITED STATES OF AMERICA

NUCLEAR REGULATORY COMMISSION

ATOAIC SAFETY AND LCENSANG BOARD

Bofore Administrative Judges:

Charles Bechthoefer, Chairrian

Dr. Jerry R. KIIne

Dr. Peter \$. Lam

in the Matter of

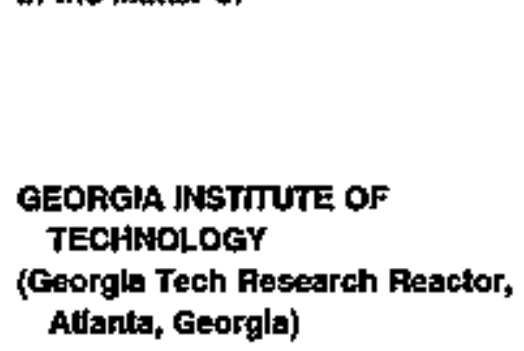

May th, 1998

Docket No. 50-160-Aen

(ASLEP No. 95-704-01-Ren)

(Rinewal of Facillty

Litense No. R-97)

In a Menorandum and Order setting forth ralings of the Atomic Safety and Licensirig Board during a telephone conference calt on May 15, 1996, the Licensing Board granted (with one liotited exception) the NRC Staff's motion to exclude the prepared testimony of Ms. Glent Carroll, the Intervenor's representative. The Board determined that Ms. Carroll lecked personal knowledge of the malters in the testimony (with one exception), as well as expertise to discuss matters in her testimony (which for the arost part had been derived from documentary evidence). The Board conclided in this regard that the underlying documents themselves were the "best evidence" of what they stated. The Board ruled that the Intervenor could seek to introduce the underlying documents to the extent relevant and that the testinony conld be entered into the record as an opening statement of position.

The Lifensing Board also deniet Georgia Tech's mation to bar Ms. Cinroll as a wituess for any purpose bet granted Georgia Tach's motion to exclede Ms. 
Carroll's prepared testinony to the same extent as it had excluded this testimnony in response to the Staff motion.

\section{RULES OF PRACTICE: PREPARED TESTMMONY}

Prepared testimony may be struck where the witness lacks personal know]edge of the matters in the testimony and lacks expertise to interpret facts contrined therein.

\section{MEMORANDUM AND ORDER (Telephone Conference Call, 5/15/96)}

On Wednesday aftemoon, May 15, 1996, the Atornic Safety and Licensing Board conducted a telephone conference call with the parties to this proceeding. The call was transcritbed (Tr. 915-62). Partictpatung, in addition to the Licensing Board members, were Alfred Evans, $\mathbf{I}$., Esq., for Georgia Institute of Technology (Georgia Tech), Ms. Glenn Caroll, for Georgions Against Nuclear Energy (GANE), and Sherwin E. Turk, Esq. and Colleen Woodhead, Esq., for the NRC Staff.

Primary topic of the call was the Staff's Motion In Limine to Exclusde the Testimany of Glent Cartoll, dated May 10, 1996. The Board and alt partites had received this motion. Georgia Tech advised that it was in the process of preparing and would file by fax (later that afteruoon) a motion to bar the appersance and to strike the testimony of Ms. Glenn Caroll. (The motion was in fact filed by fax and received by the Board today, May 16, 1996.) The primary basis of Georgia Tech's motion was the alleged failure of Ms. Cartoll to comply with previous Board orders conceringing the filing of prepared lestinony, as well as the lack of expertise of Ms. Carroll to sponsor the testimony in question.

After some discussion, the Board determined that it would excluce the prepared restimony of Ms. Carroll (with the limited exception of the statements concerming a videotape of a prograrn on FOX-TV (see p. 233) GANE wishes to inlroduce into evidence). The Board stated that it was prepared to grant the Staff's motion (with the one limited exception) but woukd pernil Ms. Carroll to read the festimony into late record as an opening statement. Although ber opening statement would not have evidentiary status, it would be useful to alent the Board and parties to the points GANE wishes to raist.

The basis for this ruling was Ms. Carroll's lack of expertise together with her lack of personal knowledge of the events relied on (except with respect to GANE's preparation of a copy of the FOX-TV tape). Most of the testimnay (which hat mitially been prepared as a discovery response) consisted of a

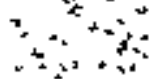

$\therefore+40$

$+i$

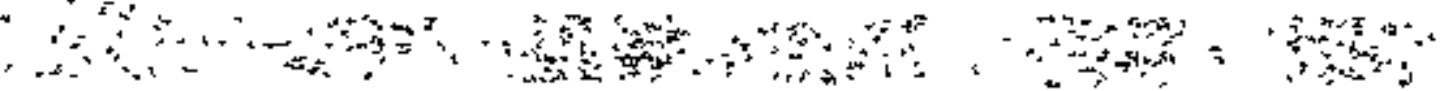

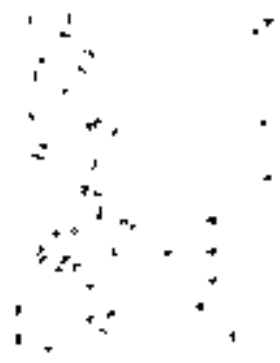

$\because$ 窨

a

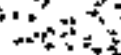

$-\because x^{2}$

$\therefore$

ה"ה

, ?

: : i .

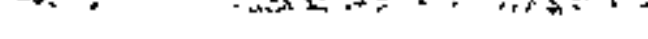


recitation of historical events, derived from specified reports. The Board believes the "best evidence" of what the reports say is the reports themselves, and we indicated that Ms. Cirroll could seek to introduce the docements on which she was relying for her testimony through other witnesses - appearing either on behalf of GANE or through the other parties.

The single exception to our overall rulsng was our deterninalion that Ms. Carroll could testify as a witness concerning a videocope she had prtpared and was seeking to introduce. The Bosrd rejected the Slaff's clain of lack of relevance of the tape. The Boand also indicated it woutd consider issning a subpoena for a FOX-TV represenuative if questions were raised as to the manner of preparation, conlenls, completerness, of authenticity of such tape.

The Board notes that, in suppoft of its motion to bar the appearance of Ms. Carroll as a witness, Ceorgia Tech asserts that the "most appropriate" formitit for prefiled writlen testimony is "manifestly the traditional queslion and answer approach which courts routinely require." No such requirement appears tither in NRC nules or in orders that we have issued. Those rules instead require only that testimony be "relevant, material, and reliable." 10 C.F.R. \$2.743(c).

Mis. Carroll raised a question as to the possibte modibication of the hearing schedule that we previously had approved (see Third Prehearing Conference Order, LBP-96-8, 43 NRC 178 (1990). Ms. A.R. Long, the Stoff menter who is to testify for GANE, bad travel plaps that would make ber unavailable on May 24, 1996, the date for which she previously was scheduled. The Board indicated that, at the outset of the bearing on May 20, 1996, the Board would revisit the witness schedule to the extent necessary. (The Board had no objection to the suggested atternate date for Ms. Long, Tuesday, May 21, 1996.)

Accordingly, for the foregoing reasons, the Staff's motion to exclucte the testiniony of Ms. Glepn Carroll is granted. Georgia Tech's motion to bar Ms. Glenn Carroll's appearance as a whthess is denied. To the extent that Georgia Tech seeks to exclude GANE's testimony for lack of expertise (parallel to the Staff's molion), Georgia Tech's motion is likewise granded GANE will be permitted to read the substance of its testimony (except for portions not retevant 
to the proceeding, such as claims with respect to Cobalt-60 and $x$-ray machipes) into the record as an opening statement.

IT IS SO ORDERED.

FOR THE ATOMIC SAFETY AND LICENSING BOARD

Charks Bechboefer, Chaiman ADMINISTRATIVE JUDGE

Rockville, MD

May 16,1996 


\section{UNITED STATES OF AMERICA \\ NUCLEAR REGULATORY COMMISSHON}

COMMISSIONERS:

\section{Shirley Ann Jackson, Chaimman} Kenneth C. Rogers

Greta d. Dicus

In the Watter of

Docket No. 50-029-DCOH

(Decommissioning Flan)

\section{YANKEE ATOMIC ELECTRIC COWPANY \\ (Yanked Nuclear Power Station)}

June 18, 1996

In LBP-96-2, 43 NRC 61 (1996), the Board granted standing to two Petitioners but dectined to admit any of their contentions, denied their request for an administrative hearing, and terminated the instant proceeding. Petitioners appealed, and sought reversal of the Board's rejection of their contentions, and also challenged for a third tíne certain goidance given by the Commission in CLI-96-1, 43 NRC 1 (1996), earlier in this proceding. YAEC and the NRC Staff opposed Petitioners' arguments on appeiel and urged affirmance of LBP96-2. Altematively. YAEC challenged Petitioners' standing to seek a hearing. The Cornmission grants in part and denies in part Petitioners' appeal, rejects YAEC's arguments regarding standing, and rentands the case to the Licensing Board for further proceedings consistent with this opinion.

\section{RULES OF PRACTICE: STANDMNG TO INTERYENE; INTERVENTION (STANDING)}

Once a party demonstrales that it has standing to intervene on its owa accord, that party may then raise any contention that, if prowed, will afford the party relief from the injury it relies upon for standing. 


\section{RUEES OF PRACTICE: STANDING TO INTERVENE; INTERVENTION (STANDING)}

Ueder Commission jurisprudence, proximity alone normally does not estabfish standing (outside the nuclear power reactor construction permit or operating jicense contexk) absent an obvious potential for offsite consequences.

\section{RULES OP PRACTICB: STANDING TO INTERVENE; INTERVENTION (STANDING)}

Where the Licensing Board rests its finding of standing on a combination of (a) the petitioners' proximity to the licensed facility, (b) petitioners' everyday use of the area near the reactor, and (c) the decommissioning effects described in the Commission's 1988 GEIS, the Commission defers to the Board's finding "that some, even if minor, public exposures can be anticipated" and "will be visited" on petitioness" members.

\section{RULRS OE PRACTICE: ADMISSIBII,ITY OF CONTENTIONS; CONTENTIONS (ADMISSIBILITX, SPECIFICITY AND BASIS)}

Under the Commission's "Contention Rule," 10 C.F.R. \$2.714, a petitioner pof only must demonstrate standung but also must proffer with specificity at least one admissible contention. For a contention to be admissible, a petitioner must refer to the specific portion of the license application being challenged, state the issue of fact or law assoctated with that portion, and provide a "basis" of alleged facts or expert opinions, together with references to specific sources and documents that establsh those facts or expert opinions. The basis must be sufficient to show that a genuine dispute exists on a materıal ussue of fact of law.

\section{RULES OF PRACTICE: BURDEN OF PROOF; BURDEN OF GOING FORWARD}

Although 10 C.F.R. $\$ 2.714$ imposes on a petitioner the burden of going forward with a sufficient facsual basis, it does not shift the ultimate burden of proof from the applicant to the pehtioner.

$\therefore 4$

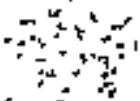

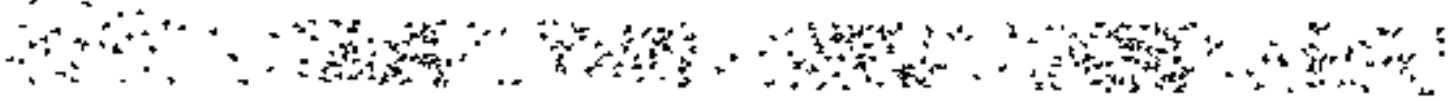

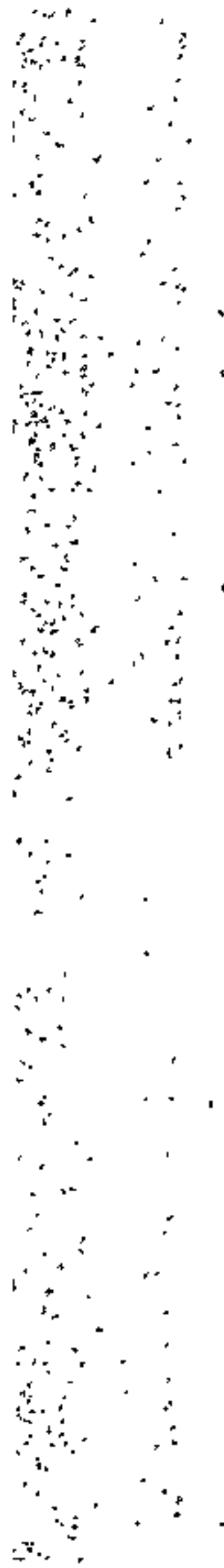




\section{REGULATIONS: DECOMAISSIONING; INTERPRETATION (10 C.F.R. \$ 50.82); RADLATION PROTECTION STANDAROS (ALARA)}

Section 50.82(e) of 10 C.F.R. expressly requires that decommissioning be performed in accortance with the regulations, including the ALARA nule in 10 C.F.R. $\$ 20.1101$.

\section{REGULATIONS: DECOMNISSIONING; RADIATION PROTECTION STANDARDS (ALARA)}

ALARA thay pot be invoked to restrict licensee decisions on, for example, whether to decommission an operatting nurclear power reactor or whether to build one in the first place (as opposed, say, to a coal plant). ALARA comes into play only after such basic choices are made and reqpities a licensee to carry out its activtly in a mantrer calculated to minituize radiation exposures as much as is practical consistent with the purpose for which the licensed activity is undertaken.

\section{REGULATIONS: DECOMMISSIONING; RADLATION PROTECTION STANDARDS (ALARA)}

A licenses's choict between DECON and SAFSTOR (or their variants) is presumptively reasonable under the ALARA principle.

\section{RULEMAKTIG: EFFECT ON ADJUDICATION}

\section{NEPA: RIQUIREMENT FOR HEARING; GENERIC ISSUES}

It would be unreasonable to require the Commission continually to relitigate tasures that may be establistur fairly and efficiently in a single mennaking procecding. This principle applies also to environmental issues raised unter the National Environmental Policy Act.

\section{REGULATIONS: DECOMMISSTONING}

The fact that a very small portion of a site may not be releasable does not preclude the release of the overwheloning temainder of the site. 


\section{RULES OF PRACTICE: HURDEN OF PROOF}

\section{REGULATIONS: DECOMMUSSIONNG; RADIATION PROTECTYON STANDARDS (ALARA)}

Petitioners are not absolutely barred from litigating the DECON-SAFSTOR choice on ALARA gropods. It is, however, petitioners" burden to show "extraordinary circumstances" rebuting the presumption that the licensee's choice is reasonable.

\section{RULES OR PRACTICE: CONTENTIONS (NEW INFORMATION, UNTIMELY FLING); NEW MATERLAL; NONTIMELY SUBMISSION OF CONTENTIONS}

The fact that petitioners raise an argument for the first time lale in a proceeding is not necessarily fatal where the argument rests significantly on a document prepared only sbortly before the argament is proffered and whese petitioners promptly bring it to the adjudicator's attention.

\section{ADMINISTRATIVE TRIBUNALS}

\section{ADJUDICATORY BOARDS: ROLE}

\section{ADJUDICATORY HEARINGS: RESOLUMON OF FACTUAL ISSUES}

\section{NRC: ADJUDICATORY RESPONSLBTLITIES}

\section{LICENSING BOARD: RESPONSIBILITIES (DEVELOPMENT OF RECORD)}

The Licensing Board, rather than the Commission itself, traditionally develops the facwal record in the first instance.

\section{REGULATIONS: DECOMMISSIONING PLAN}

A decommissioning plan by its very nature deals with a myriad of uncertaitties, and the Commission's regulations cannot be construed to require the pian to predict the fulure with precision.

\section{REGULATIONS: DECOMMISSIONING PLAN}

The Commission's regulations do not require a licensee, at the time it seeks approval of its decommissioning plan, to decide whether it will move spent fuel into dry cask storage. 


\section{REGULATIONS: DECOMMISSIONING FUNDING}

A contention challenging the reasonableness of a decommissioning plan's cost estimate is not litigabje if teasonable assurance of decommissioning costs is not in serious doubt and if the only avilable relief would be a formalistic redraft of the plan with a new estimate.

\section{RULES OF PRACTICE: HEARIG ON CONTENTIONS}

To obtain a bearing on the adequacy of the decommissioning plan, petitioners must show some specific, tangible link between the alleged exrors in the plan and the health and safecy impacts they invoke.

\section{REGULATIONS: DECOMMISSIONING FUNDING}

The standard for determining that the furds for decommissioning the plant will be forthcoming is whether there is "reasonable assurance" of adequate funding, not whelher that assurance is "ironclad."

\section{REGULATIONS: DECOMMYSSIONING FUNDING}

A decommissioning funding mechanism is external in nature where its collections are made through Power Contracts and are deposited in at independent and irrevocable trust at a commercial bank and where the trust is executed in compliance with 10 C.F.R. $\$ 50.75$ (e)(I)(ii).

\section{RULES OF PRACTICE: CONTENTIONS (ADMISSIBILITY, SPECIFICITY AND BASIS); ADMISSIBILITY OF CONTENTIONS}

Petitioners must submit more than speculation in order for a contention to be admitted for litigation.

\section{COMMISSION PROCEEDING: CLAIMS FOR DAMAGBS REMEDY}

Although the Commission has a general responsibjity to ensure that decommissioning operations do not jeopardize public health and safety, no stahte or regulation grants the Comnission authority to require the licensee to pay (in effect) corcopensatory damages to private individuals. 


\section{RULES OR PRACTICE: SCOPE AND TYPE OF PROCEEDING}

Completed deconmmssioning activitites are beyond the scope of a decommissioning prockeding that deals solely with the propriety of a decontruissioning plan and future decommissioning activties.

\section{NEPA: SUPPLEMENTAL ENVIRONMENTAL IMPACT STATEMENT}

\section{ADJUDICATION: SUPPLEMENTAL ENVIRONMENTAL IMPACT STATEMENT}

The standard for issuing an SEIS is set forth in 10 CF.R. \$51.92: There must be either substantial changes in the proposed action that are relevant to environmental concerns, or significant new circumstances or infornatson relevant to environmental concerss and bearing on the proposed action or its impacts.

\section{RULAS OF PRACTICE: CHALLENGE TO COMMISSION'S REGULATIONS; CONTENTIONS (CHALLENGE OF COMMISSION RULE); GENERIC ISSUES; LITIGABILITY OF ISSUES (GENERIC ISSUE); RULEMAKING (EFEECT ON ADJUDICATION)}

If parties believe that the agency's prior generıc revew reached the wrong conclusions, the proper remedy is a petition for rulemakıng. not a litigation contention challenging the basis for a Commission rute.

\section{RULES OF PRACTICE: OFFICIAL NOTICE}

Pursuant to 10 C.F.R. $\$ 2.743$ (i), the Commission may take official notice of publicly available documents filed in the docket of a Eederal Entergy Regulatory Comníssion proceeding.

\section{TECHNICAL ISSUES}

The following technical tssues are discussed: Decommissioning; ALARA.

\section{MEMORANDUM AND ORDER}

\section{INTRODUCTION}

On Marth 1, 1996, the Atomic Safety and Licensing Board ("Liteensing Board" or "Board" issued LBP-96-2, 43 NRC 61, in this proceeding involving

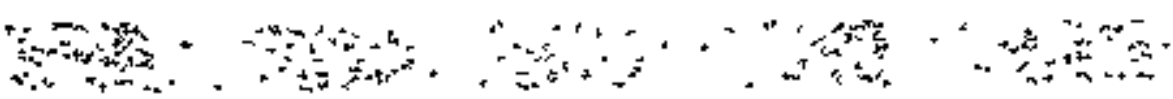


the decommissioning of the Yanke Nuclear Power Station aear Rowe, Massachusetts ("Yankee Rowe facility" or "Yankee Rowe"). The Yankee Rowe facility was a I85-MWe muclear power plant owned and operated by Yankee Atomic Electric Company ("YAEC" or "Licenste"). It is the Licensee's only power plant and its principal asset YABC is in twr owned by ten New England utilities ("Purchaser/Co-owners") which purchased electricity from the facility pursuant to ten identical "Power Contracts." Despite the stutdown of the Yankee Rowe facility, these condracts remain in full force and effect.

In LBP-96-2, the Board granted standing to the New England Coalition on Nutkar Pollution and the Citizens Awareness Network collectively "Petitioners"), but dectined to admit any of their contentions, denied their request for an administrative hearing. and terminated the instant proceeding. Petitioners appeal, and seek reversal of the Board's rejection of their contentions, and also chalkenge for a third time cetain guidance given by the Comurission ia CLI96-1, 43 NRC I (1996), earlier in this proceeding. (Pelitioners had previousty sought reconsideration and partial rescission of CLI-96-1 on Jantuary 26 and March 7, 1996.) YAEC and the NRC Staff oppose Petitioners" argontents on appeal and urge affirmance of LBP-96-2. Altemattvely, YAEC challenges Petitioners' standing to seck a hearing.

For the reasons set forth below, the Commission grants in part and denies in part Petitioners' appeal, rejects YAEC's arguments regarding standing, and remands the case to the Licensing Board for furcher proceedtings consistent with this opinion.

\section{BACKGROUND}

\section{A. First Circuit's Decision and Comntisshon Response}

On Oetcober 1, 1991, YAEC ceased operation of its Yankee Rowe facility. In February 1992, the Licensee removed all fuel from the reactor vessel at that facility; notitied the Commission that the plant was permantently shut down and that decommissioning would comoxence; and applied for a possession-only license ("POL") from the Commission. On August 5, 1992, the Commission granted the POL, but stated that the NRC must approve any major structural changes to the radioactive components of the Yankes Rowe facility. This statement was consistent with the Commission's then-effective interpretation of 10 C.F.R. \$50.82, that a power jeactor licenses was prohibited from conducting major decommissioning activities prior to final Commission approval of a decommissioning plant.

In early 1993, bowever, the Commission announced a new policy interpreting its decommissioning nuie to allow NRC licensees to intitiate substantial docommissioning of their facilities prior to plan approval if they met certain conditions. 
Having met those conditions, YAEC injitiated a "Component Removal Project" or "CRP," during which many radioactive components of the Yankee Rowe facility, including large components tike the reactor's steam gentrators and pessicurizer, were removed and sent to a low-level radioactive waste ("LLRW") disposal facility in Barnwelt, South Carolina. The Citizens Awareness Network ("CAN'), one of the Petitioners in this proceeding, asked the Commission to provide an opportunity for a hearing regarding the CRP. The Commission refused and CAN filed a petition for review of that decision in the United States Court of Appeals for the First Ciecuit.

On July 20, 1995, the First Circuit ruled that: (1) the Comouission hat smproperly changed its regulatory interpretation, (2) it should have offered a hearing on the CRP, and ( 3 ) it should have performed a NEPA evaluation of the CRP. See CAN v. NRC, 59 F.3d 284 (1st Cir. 1995), referring to National Environmental Policy Act ("NEPA"), 42 U.S.C. \$4321 ef seq. The First Circuit beld that CAN was entitled to a hearing opportunity because the original Comuisston policy "required NRC approval of a decontmissioning plan before a licensee undertook any major structural changes to a facility" and could not be altered "without complying with [the Atomic Energy Act's] notice and hearing provisions." 59 F.3d at 291-92. Sirrilarty, the First Circuit held that "YAEC's onginal Jicense did not authorize it to implement major-component disassenobly . . . ," without a hearing opportunity. 59 F.3d at 294.

The Comunission subsequently announced in the Federal Register that it would not seck further review of the First Circuit's decision, and requested publie comment on what sort of hearing the Commission should offer on remand. See 60 Fed. Reg. 46,317 (Sept. 6, 1995). After reviewjng the publik comments, the Commission on October 12,1995, issued an Order announcing its deciston, Yankee Atomic Electric Co. (Yankee Nuclear Power Station), CLI-95-14, 42 NRC 130 (1995). The Conmission decided, over YAEC's vigorous objection, that it must offer a hearing on YAEC's decommissioning plan and order a halt to major YAEC decommissioning activities in the meantime. ${ }^{1}$

\section{B. The Hearing Opportumity}

In February 1995, during the pendency of the First Circuit litigation, the NRC Staff approved YAEC's decommissioning plan, which became part of the Licensee's Final Safety Analysis Report ("FSAR"). See 60 Fed. Reg, 9870

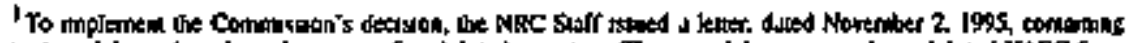

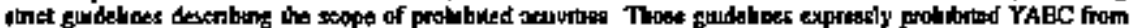

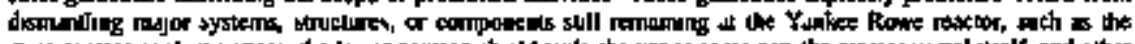

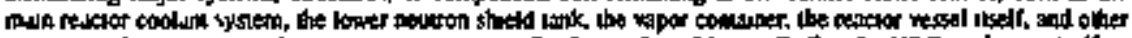

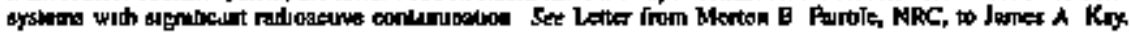
YAEC, dned Hov 2 , 5995 , al 3
}
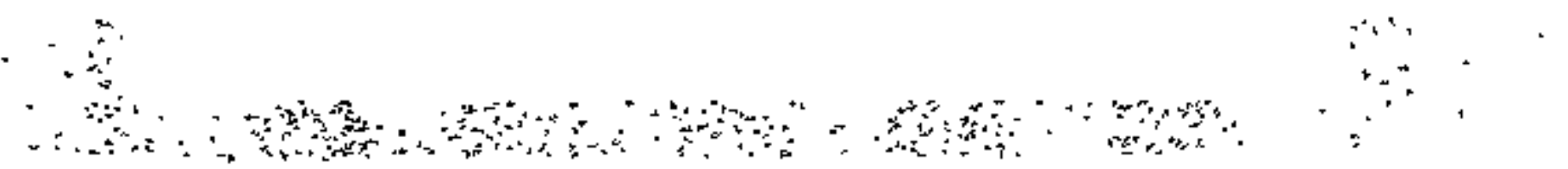
(Ftb. 22, 1995). The Staff also approved both an Environmental Assessinent ("EA") and a Finding of No Significant Impact ("FONSI"). Id. But in October 1995. when the Comumission decided that CAN v. NRC necessitated an offer of a hearing on the Yankee decomnitssioning plan, the Commission indicated that the prior Staff approval of the plan "cannot be accorded further Itgal effect, pending a hearíng opportunity." See CLI-95-14, 42 NRC at 134.

YAEC's plan, first submitted in late 1993, proposed an approech that wond enabte YAEC to complete its decommissioning of the Yankec Rowe facility more slowly than under the pure DECON alternative but more quickly than under the ocher decommissioning altemative, SAFSTOR. ${ }^{2}$ More specifically, the plan provided that YAEC would dismantle the plant (except for those systems that are reguired for safe mainienance of the spent furel pool), dismantle the spent fuel pool when other options for fuel and higl-leves radioactive waste ("FLRW") storage and/or removal becomo available, ship contaninated radionctive materials to an LLRW facility, and decontaminate the site to a sufficiently low nofioactive level that it can be released for unrestricted use. See 60 Fed. Reg. 55,069 (Oct. 27, 1995).

On October 23, 1995, the Commission issued the notice of hearing opportunity promised in CLI-95-14, stating that the NRC was considering the issuance of an order under 10 C.F.R. $\$$ 50.82(e) to YAEC approving is decommissioning plan as it related to the decommissioning of the remaining portions of the Yankee Rowe facility. Also, the Commission in its October 23rd notice required any petitioners to submit all their contentions sirmultaneously with their petitions to interwene. 60 Fed. Reg. 55,069 (Oct. 27, 1995).

On Noventer 30, 1995, Petitionters soughit to intervene in this proceeding. In that pleading, they argered that they bad standing to partictipate in this procteding and proffered five conteptions:

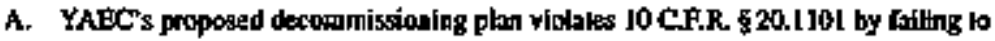

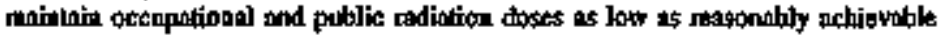
("ALARA")

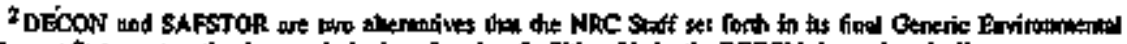

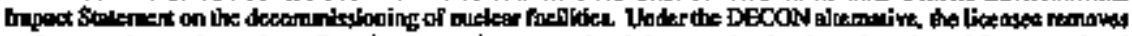

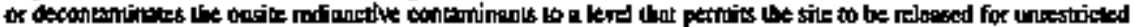

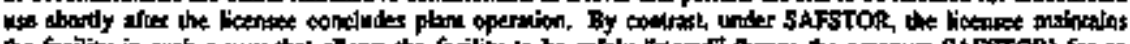

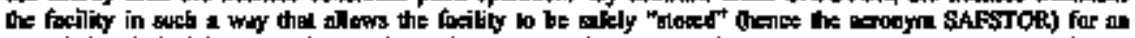

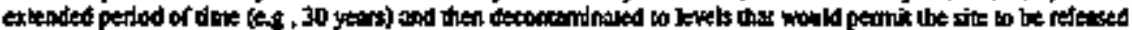

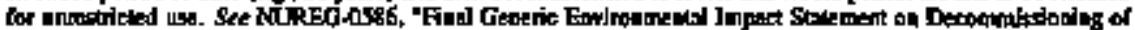

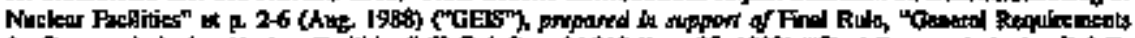

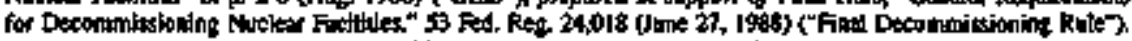
Like the Bound, wh will retar to the YAEC"a modfied DECON appooed streply as DECON"
} 
some "extraordinary aspect to the case not apparent to us from the pleadings" $43 \mathrm{NRC}$ at $8-9$.

Third, regarding Contention C, we considered Petitioners" argtinent that YAEC's upciated cost estimate was not reasonable. We found that the "essential purpose" of the estimate requirement "is to provide "reasonable assurance" of adequate funding for decorismissioning." 43 NRC at 9 . We therefore conchuded that, to receive relief, Petitioners would need to demonstrate "not only that the estimate is in error but that there is not reasonable assurance that the amount will be paid." Id. "Thus, a contention that a licensee's estimate is not 'reasonable,' standing atone, would not be sufficient in and of itself because the potential relief would be the formalistic redraft of the plan with a new estimate." Id.

Fourth, regarding Contention D, we ruled that Petitioners' allegations of "illegal" past conduct by YAEC were not relevant in a decommissioning proceeding where the "foces . . is prospective only." 43 NRC at 9. The Commission viewed Petitioners' "past conduct" alkegations as "more properly the subject of separate enforcement action. ${ }^{n}, d^{3}$

\section{The Licensing Board Dectsion}

On February 21, 1996, the Licensing Board held a prehearing conference at which the Board heard oral argument on the issues of standing and contentions. At the conclusion of this hearing, the Board indicated that it intended to issue an order by March 1 concluding that Petitioners had standing to particigate in this proceeding, that they had failed to raise any admissible contentions, and that the proceeding would therefore be dismissed. In anticipation of the Board's promised order, the Commission on February 27, 1996, issued an unpublisbed order staying the effectiveness of any Licensing Board orter dismissing this case.

On March 1, 1996, the Licensing Board issued LBP-96-2. In that order, the Board first concluded that the two intervenor organizations had established standing to intervene and seek relief regarding alleged health and safety or

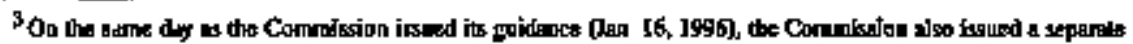

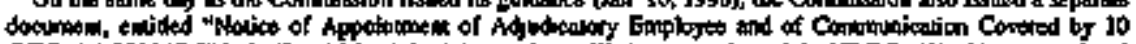

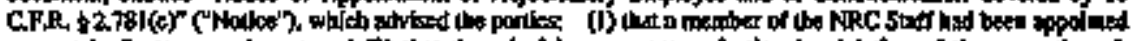

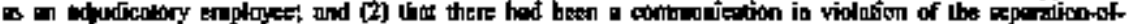

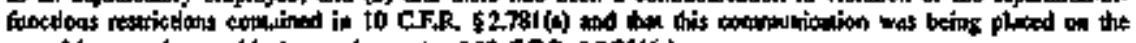

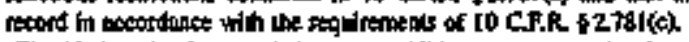

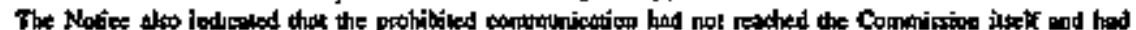

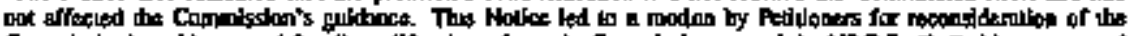

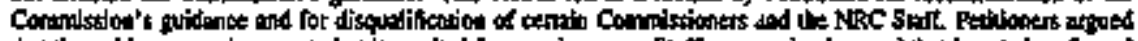

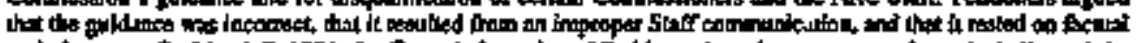

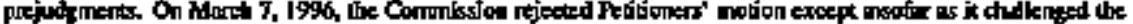

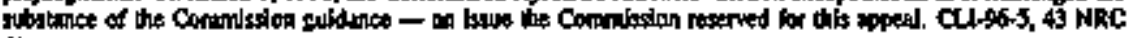
53.
}

1
$\therefore !$
$\therefore !$ 


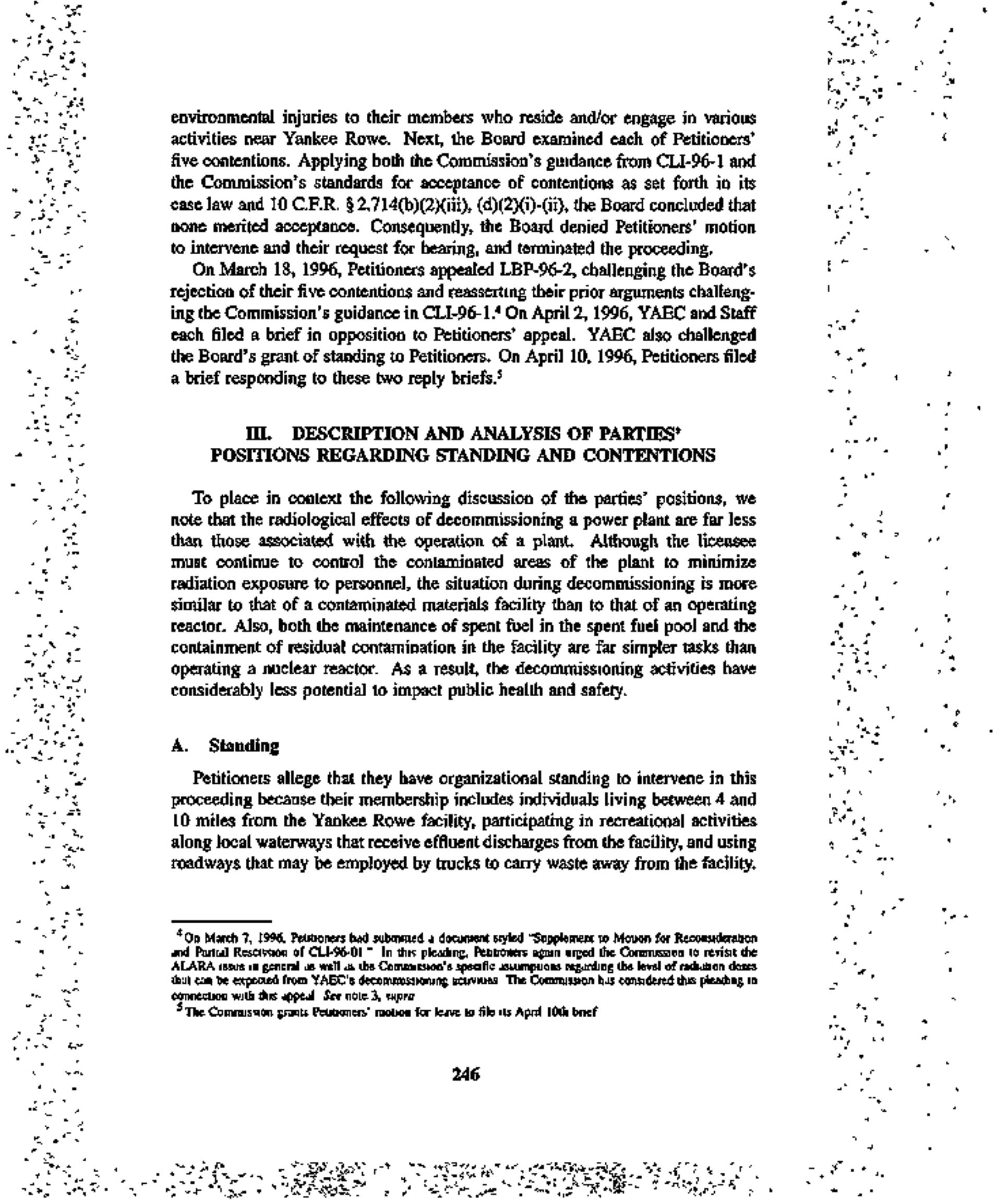


These individuals have expressed concen about the impact of the Yankee Rowe decommissioning upon their heatth and safety and upon the local environment, and bave authorized Petitioners to represent them in this procecting.

Although neither YAEC aor the Staff contested Petitioners' standing to raise public bealth, safety, and chvironmental chalilenges to the deconumistionitg plan, both of these parties initially objected to Petitioners' standing to raise argumenta based on the health and safety of workers at the plant. As noted above, the Commission in CLI-96-1 took the position that "once a party demonstrates that it has standing to intervene on its own accord, that party may then raise any contention that, if proved, will afford the panty relief from the injory it relies upon for standing," CLE-96-1, 43 NRC at 6.

Interpreting this ruling in CLI-96-1, YAEC angued to the Board that Petitioners' reliance on public exposure dases (which were substantially less than occupational doses) is insofficient to give then standing to intervene as to any aspect of their contentions, including radiological impacts on workers at the facility. By contrast, Petitioners and Staff interpreled CLI-96-I to support Petittoners' standing to pursue all their contentions, including those related to occupationai impacts.

The Board in LBP-96-2 raked that Petitioners had standing to intervene in this proceeding. The Board reasoned that "some, ewen if minor, public exposure can be anlicipated from the decommissioning process" (citing the GEIS) and the Board was therefore not

"in a position al this lheshold slage to fule out as a mater of certainty the existence of a

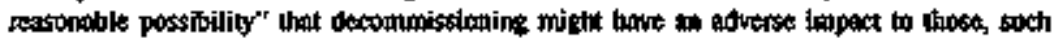
a Pelfioners' members, who live or recreate in sueh close proximty to the facility, or use local waste imatiportation motes.

LBP-96-2, 43 NRC at 70, quoting Virginia Electric and Power Co. (North Anna Power Station, Units 1 and 2), ALAB-522, 9 NRC 54, 56 (1979).

YAEC, in its Brief opposing Petitioners' appeal ("YAEC"s Britf'), argues that Petitioners' mete proximity to the Yankee Rowe reactor does not give them standing to challenge YAEC's decommissioning plan. ${ }^{6}$ YAEC is correct that, under Commission jurisprudence, proximity alone uxmally does not establish standing (outside the muclear power reactor construction permit or operating license context) absent an "obvious potential for offsite consequences." See Florida Power and Light Co. (St. Lucie Nuclear Power Plant, Units 1 and 2),

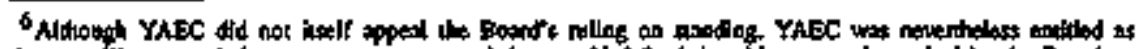

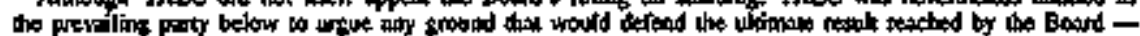

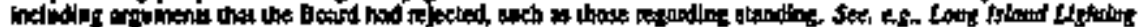

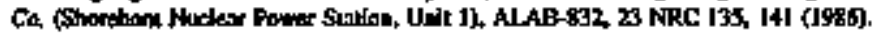


CLI-89-21, 30 NRC 325, 329-30 (1989); of. Georgin Institute of Technology (Georgia Tech Reseatch Resctor), CLI-95-12, 42 NRC 111, 116-17 (1995).

Here, however, the Licensing Baard did not rest its finding of standing on proximity alone. Pointing to Petitioners' description of their everyday use of the area near the reactor and to the decomunissioning effects described in the Commission's 1988 GEIS, the Board reasonably found "that some, even if minor, public exposures can be anticipated" and "will be visited" on Petitioners" members. LBP-96-2, $43 \mathrm{NRC}$ at 69-70. We defer to the Board's resolution of the standing issue. See Georgia Tech Research Reactor, $42 \mathrm{NRC}$ at 116.

\section{B. Contentions}

In 1989, the Commission issued a new "rule heightemng the specificity requirements for pleadings filed by parties seeking to intervene in [formal] licensing proceedings." Unton of Concemed Scientists v. NRC, 920 F.2d 50, 51-52 (D.C. Cir. 1990). Ueder this "Contention Rule," 10 C.F.R. \$ 2.714,' a petitioner must not only demorstrate standing but also must proffer with spectficity at least one admissible contention. For a contention to be admissible, a petitioner must refer to the specific portion of the license application being challenged, state the issue of fact or law associated with that portion, and provide a "basis" of alleged facts or expert opinions, together with references to specific sources and documents that estabitish those facts or expert opinions. 10 C.F.R. $\$ 2.714(b)(2)$, (d)(2). The basis must be suffeient to shiow that a genuine

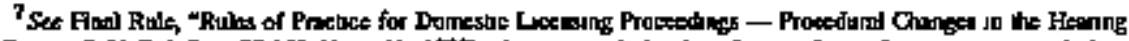
Proces;" 4 Fod Res 33,368 (Mug II, IG

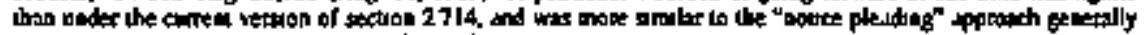

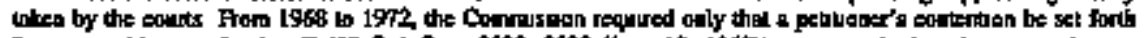

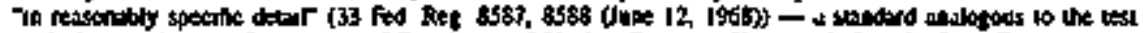

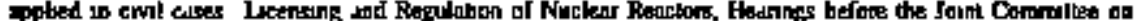

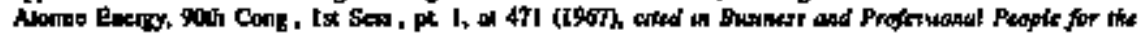

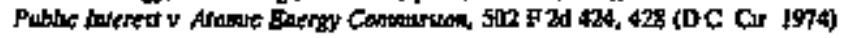

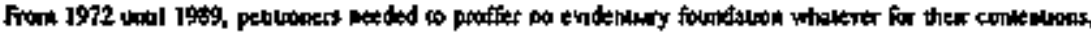

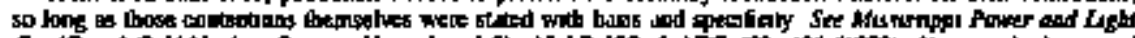

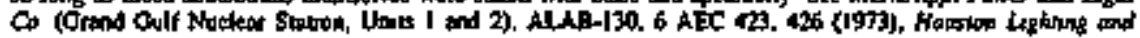

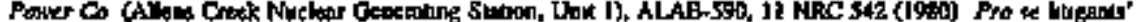

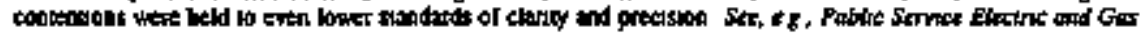

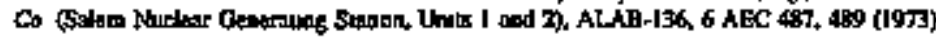

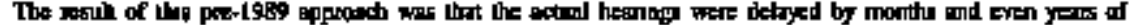

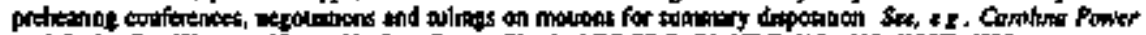

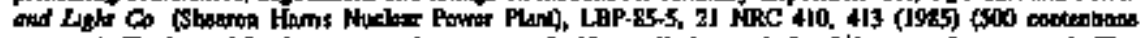

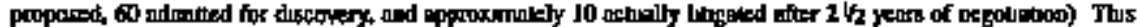

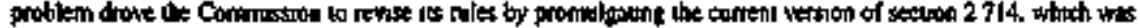

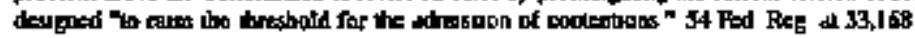


dispute exists on a material issure of fact or law. 10 C.F.R. \$2.714(b)(2). "A contention may be refused if it does not meet the requirenents of section 2.714(b) or if the contention, even if proven, would "be of no consequence in the proceeding because it would not entitle the pecitioner to relief.' to C.F,R. \$2.714(d)(2)(ii)." Sacramento Muntcipal Utilty District (Rancho Seco Nuclear Generating Station), CLI-93-3, 37 NRC 135, 142 (1993).

Although section 2.714 imposes on a petilioner the buiden of going forward with a stufacient factual basis, it does not shift the ultimate butien of proof from the applicant to the petitioner. Final Ruke, skpra note 7, 54 Fed. Reg. at 33,171. Nor does section 2.714 require a petitioner to prove its case at the contention stage, For factural disputes, a petitioner need not proffer facts in "formal affidavit or evidentiary form," sufficient "to withstand a summary disposition motion," Georgia Tech Research Reactor, 42 NRC at 118. On the other hand, a petitioner "must present sufficient information to show a genuine dispute" and reasonably "jipdicating that a further inquiry is appopriate." Id."

We assess Petitioners" contentions onder these standards.

1. Contention A: YAEC's Decomaissioning Plan Violates IO C.F.R. $\$ 20.1101$ by Failing to Maintain Occupational and Public Radiation Doses as Low as Reasonably Achievable

\section{a. Background}

In Contention A, Petitioners asserted that the Licensee is required under 10 C.F.R. \& 20.1101(b) to maintain rbdjation doses as low as reasonably achievable. That section provides that each licensee

shall use, to the extent procticable, procedures and engineertag coumols based upon sound

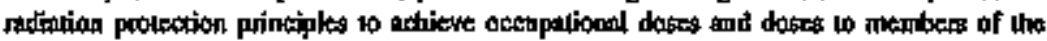
public lhat are as low is is ressonably achierdble (ALARA).

"ALARA" is in turn defined in 10 C.F.R. § 20.1003 as

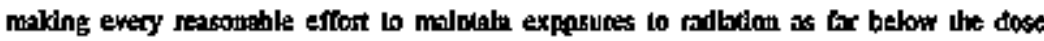

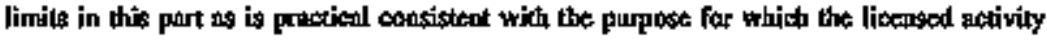
is ondertaken, lahing isto account the state of tectnology, the economiks of improventents It relintion to siote of technology, the economies of improvemeats in relation to benedis to

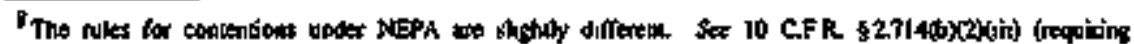

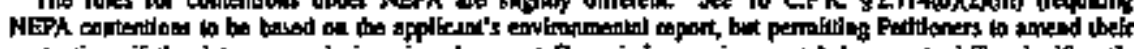

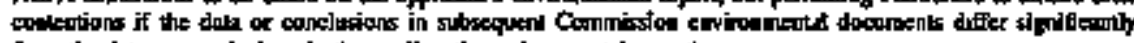

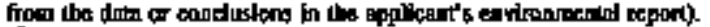

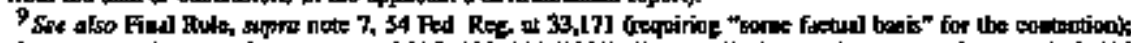

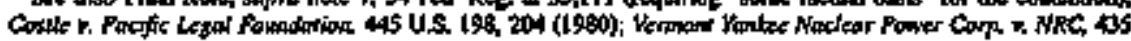
US. 519. 554 (1978).
} 
the pabhe tealth and safety, and other sacketal and sockoeconomuc consideratuons, and at relation to ublization of muclesr energy and heensed maleriali in the publite tinterest

According to Petitioners, if an alternative is available that reduces radiation exposere and lowers cost, then 10 C.E.R. \$20.1101(b) requires the licensee to use that altenative. They further argued that, even where a dose-saving alternative costs more than the other altematives, the Licensee must still determine whether the health and safery benefits associated with the retuction in exposure outweigh the additional cost. Petitioners asserted that YAEC's selection of a DECON approach violates these principles by ignoring SAFSTOR's capability of achieving significant dose reductions in a cost-effective manner.

In CLI-96-I, the Commission ruled that a challenge to YAEC's choice of the DECON rather than the SAFSTOR option for Yankes Rowe cannot be based solely on dose differences on the order of 900 person-rem - barting some "extraordinary aspect to the case not apparent to us from the pleadings." Id. at 8-9. We reasoned that our 1988 decommissioning rule, and its supporting GEIS, had already found both DECON and SAFSTOR acceptable, despite the recognized potential for a 900 person-rem differential in occupational dose. $/ d$. The Comnission concluded that its approach was "entirely consistent with the ALARA concept," which focuses not only on radiation exposure but also on costs and "other societal and socioeconomic considerations." Id.

Given the Board's nearly exclusive reliance on CLI-96-1 regarding Contention A, Petitioners' Appeal Brief focuses on the Commission's rather than the Board's ordex and, in mary respects, repeats the arguments previcusly proffered in their January 26th and March 7th pleadings seeking Commission recomsideration of its guidance. In these three pleadings, Petitioners claim that the Commission, in dtscussing the relative merits of DECON and SAFSFOR, improperly prejlidged the facts, relied on communications prahibited by the Commission's separation-of-tonctions regulation, misperceived the meaning of Petitioners' Contention A, and provided erroneous guidance.

\section{b. YAEC's Thrtshold ALARA Argthemt}

At the outset, to clear away a preliminary matter, we deal with a fresh proposition urged by YAEC as a ground for affirming the dismissal of Petitioners' ALARA contention. YAEC asserts that, in this proceeting, it is a license applicant rather than a licensee and that section 20.1101 (the ALARA regulation), "[b]y its terms, . . . only applies to licensees, not applicants for licenses." YAEC Bricf at 5. The simple answer to YAEC's argument is found in 10 C.F.R. $\$ 50.82(\mathrm{e})$ - which expressly requires decommissioning to the performed in 
accordance with the regulations in this chapter," These regulations include, of course, the ALARA nue in 10 C.F.R. Part $200^{10}$

\section{c. Soundness of Comntission Gutdance}

In our view, the Commission guidance on Contention A Jemains sound. The guidance means, in essence, that a licensee's choice between DECON and SAFSTOR (or their variants) is presumptively reasonable under the ALARA principle. This presumption does no more than restate what the Commission found in its 1988 decommissioning rulemaking: that no likely cost or dose differential between DECON or SAFSTOR made one or the other option preferable from a stafety or environmental perspective. See 1988 GEIS \$4.5. at 4-17 through 4-20. Notably, the 1988 ntle forces no choice on licensets, stating only that a licensee-chosen "alternative is acceptable if it provides for completion of decommissioning within 60 years." 10 CF.R. \$ 50.82(b)(1)(1).

Despite the NRC's 1988 generic review of the DECON-SAFSTOR choice, Petitioners seek to revisit that choice case-by-case, basing their objections on essentially the same factors that the Commission weighed when coneluding that either SAFSTOR or DECON was a ressonable decommissioning choice."1 But Petitioners" approach unreasonably "would require the agency continually to relitigate issues that may be extrblished fairly and efficiently in a single rulemaking proceeding." Heckler v. Campbell, 461 U.S. 458, 467 ([983). Accord Nuclear Information and Resource Service v. NRC, 969 F.2d 1169 , 1174-77 (D,C. Cir, 1992) (en banc). "Significantly, the Supreme Court has found agency reliance on prior determinations to be perfectly acceptable, even when the statute before it plainly calls for individualized hearings and findings." Id at 1175 (citing cases). See Kelley v. Selin, 42 F.3d 1501, 1513, 1518-20 (6th Cir.), cert. denied, 115 S. Ct. 2611 (1995).

Petitioners argue that the likely unavailability of spent fuel disposal facilities in the near funure renders iilusory the early site release advantage of DECON (which woutd offset the disadvantage of DECON's somewhat higher radiation doses). This argument, however, raises a generic issue affecting the decomunissioning plans for all reactors in this country. Pelitioners" position amounts to en argurmen that SAFSTOR is always preferable to DECON, especially until

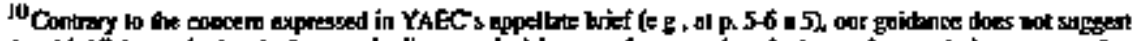

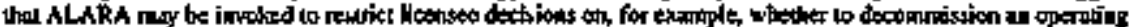

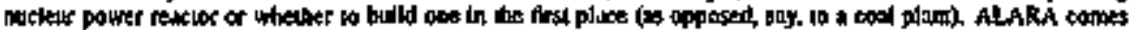

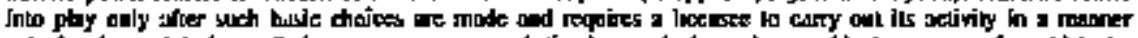

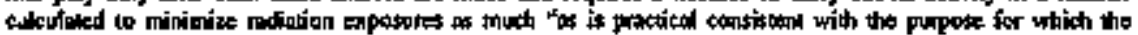
licensed aftivity is undipninten" IOF C.F.R. 820.1003.

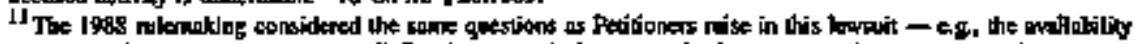

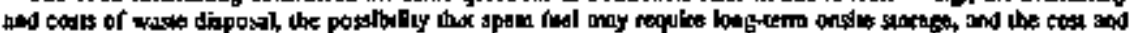

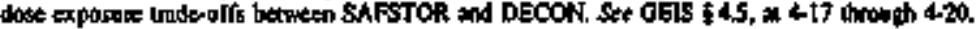


the completion of an HLRW repository - an argument that fies in the face of what the Comunission concluded in its I988 tule and GEIS. An adjutication of a single case is not the place to consider Petitioners' teross-the-board challenge to the Commission's 1988 decision generically approving both SAFSTOR and DECON.

Petitioners' argument fails for two other reasons as well. The fact that a very small portion of the 2000 -acre site may not be releasable does not pretitude the release of the overwhelming romainder of the site. In addition, early site rolease was only one of a number of benefts to DECON cited in the GEIS. See Pp. 275-76, supra.

This is not to say that Petitioners are absolutely barred from litigating the DECON-SAFSTOR choice at Yankee Rowe on ALARA grounds. But, as the Comnission's guidance suggests, it is Petitioners' burden to show "extraordinary circumstances" rebutting the presumption established in the 1988 rulemaking that the Licensee's choice is reasonable. With one exception - the claim that occupational exposures during the Yankee Rowe reactor's decommissioning have been muxh higher than what the 1988 GEIS anticipated - Petitioners' various argutments on appeal do not pessuade us that further ALARA litigation is necessary in this case. Petitioners also advance no good reason for the Comrrission to reconsidet its guidance.

Petitioners first assert that the $\mathbf{9 0 0}$ person-rem dose savings ciscussed in the GEIS equates to the avoidance of between 0.6 and 2.4 deaths, plus the same number of other health and genetic effects. According to Petitioners, the Commissiton errs in considering this level "trivial," and the ALARA regulation (10 C.F.R \&20.1101) therefore requires YABC to take reasonable mitigation measures - i.e., to shift to the SAFSTOR option. Appeal at 16-17. But the Commission and its Licensing Board nowhere suggested that the health effects of 900 persot-rem were "trivial." The Commission's guidance means only that it would bot permit case-by-case litigation over health effects already considered acceptable in the 1988 decommissioning rulemaking. This deference to prior generic findings reflects a sensible allocation of the Commission's decisional resources.

Petitioners also claim to have demonstrated (with sufficient specificity to rocuitre a hearing) that significant dose savings can be actomplished at a lower cost under SAFSTOR than under DECON. Petitioners point to evidence, based on the GEIS, that the use of SAFSTOR over a 50-year period will result in a Soss reduction of LLRW volumes. Appeal at 17 .

This argument fails for two reasons. First, Petitioners point essentially to the same facts and policy choices already considered in the Commisston's I988 decommissioning rulemaking. This conclusion is supported by the very fact that the infomation on which Petitioners rely for their argument comes from the Commission's own GEIS. Second, atthough Petitioners are correct that, due

$=\therefore$
$\because \because$
$\because$ 
to radioactive decay, the volume of LLRW at Yanket Rowre witl be less in 50 years than now, this does noc necessarily or logically require the conclusion that decommissioning costs will be lower. It is just as likely that site availability or pricing concerns will raise costs substantially, even for lower volures. Petitioners' argument also ignores expenses associated with maintenance of the site during the 50-year waiting period, Pelitioners' contention, therefore, shows no such obvilous cost advantage to SAFSTOR over DECON that the Commission's generic approval of both options in 1988 is seriously brought into question.

\section{d. Alisged Prejudgment of Facts}

Petitioners focus most of their appellate arguments regarding Contention $A$ on several instances is which, according to Petitioners, the Commission's guidance prejudged the facts regarding the comparative doses atd costs associated with DECON and SAFSTOR. We already have juled that the Commission statements to which Petitioners refer are not prejodgments of the facts but ane instead "regulatory interpretations and policy judponents, and tentative observations about dose estimates that are derived from the public record" CLI-96-5, 43 NRC at 59. We will reiterate briefly why Petitioners' charge of intproper "prejudgment" cannot be sustained and does not require further Licensing Board litigation. ${ }^{12}$

Petitioners' reargument of the "prejudgnent" issue overlooks two key points. First, as the Commission stressed in CLL-96-5, the Commission statements singled out by Petitioners resolved no facts and simply pointed to a number of salient features in the record and in Commission policy that might bear on Contention A. Second, none of the alleged factual prejudgments was necessary to the Commission's guldarce, which rested on the Commission's generic inquiry into the DECON vs. SAFSTOR question in its 1988 decommissioning rulemaking.

Petitioners question in particular the Commission's comment that, uoder its current policy, the "value" of awoiding 900 person-rem is relatively low about $\$ 2000$ per person-iern or $\$ 2$ million - particularly in relation to a project costing handreds of millions of dollars over many years. Petitioners are quite correct that the $\$ 2000$ figure does not reflect a binding legal rule, but simply ant NRC policy judgment, albeit a recent and well-coosidered one. See SECY-95028 (Feb. 7, 1995); SRM 95.028 (June 30, 1995). The "valus" of an avoided

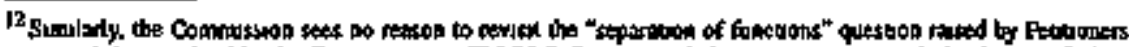

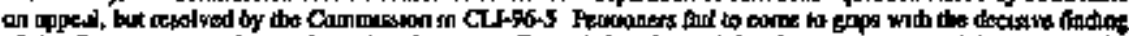

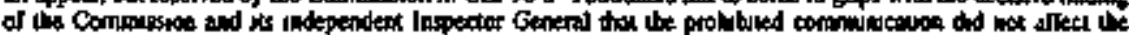

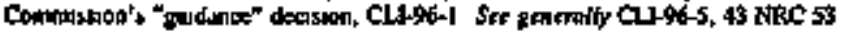


person-rem, of course, is by nattre a faitly subjective judgment and Petitioners themselves have not proffered or justified any specific alternative value. We need not, in any ovent, deffutively resolve the value of avoided person-rem in this adjudication.

\section{e. New Dose Information}

Petitioners, in their pleadings pending before us, bring to our attention the following two new pieces of information relewant to the level of radiatton doses that can be expected from YAEC's decommissioning activities. First, YAEC wroto the Commission staff on February 28, 1996, proposing to conduct eleven "minor" decommissioning activities which the Licensee expects to result (at least according to Petitioners) in 82 person-sern of occupational dose. ${ }^{13}$ Pentioners note that this is folly half of the dose (160 person-ren) that YAEC predicted from the entire CRP, and more than $10 \%$ of the total reminining ratiation dose projested for the rest of XAEC's decommissioning activities. Second, according to Pelitioners, NRC Inspection Reports reveal that in 1994 alone, the occupational doses for the CRP (197 person-rem) exceeded the tocal CRP dose estimate (160 person-rem) in the FSAR and that, as of October 10/11, 1995, workers at Yenkee Rowe had received additional doses of between 21 and 57 person-rem ${ }^{\text {H4 }}$

Based on these two pieces of information, Petitioners assert that the total occupational radiation dosage from the CRP is hundreds of rems higher than the Licensee's latest (1995 FSAR) estimated level of 160 person-rem for the CRP, drawung into question the accuracy of not only the CRP dose estimate but also YAEC's dose astimates for all decommissioning activity at the Yankes Rowe facilty. See Petitioness' Supplement to Motion for Reconsideration at 4-11; Appeal at 11, 17-18; Reply Brief at 3-5.

In addition, Petitioners have raised the following argument: According to YAEC, 99\% of tie plant's remaining nonfuet and non-Greater-Than-Class-C radioactivity is in the reactor vessel and lower neutron shiteld. Consequently, according to Petitioners, the radiogenvity in all of the components found in the eleven actuvtlies discussed in YAFC's February 28th letter (none of which involves the vessel or shuld) necessarly totals tess than $1 \%$ of the plant's remaining radioactivity. Pebtuoners go on to argue that, assurning some

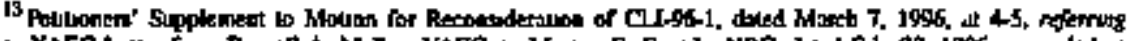

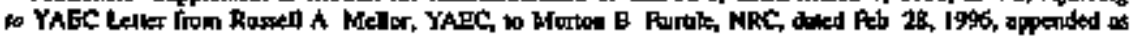

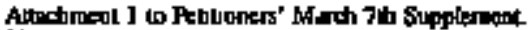

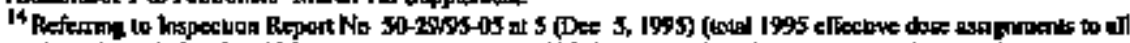

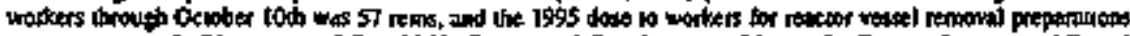

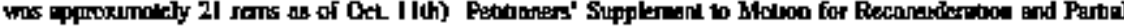

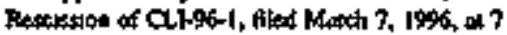

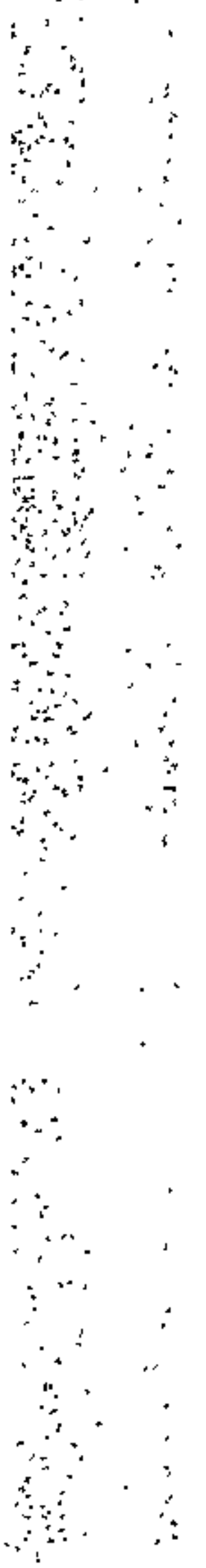


proportionality between the level of radioactivity in these conponents and the radiation dose to workers involved in decommissioning these components, then 82 person-tem is a very small proportion of the total occupational dose that workers will receive from the decommissioning of Yankee Rowe, and the total DECON dose would be far above the 1215 person-ren postulated in Table 4.3-2 of the GEIS for the decomplnissioning of a 1175-MWe pressurized water reactor. GEIS at 4-1 aod 4-5 to 4-6. Conseguently, Petitioners' theory goes, the dose differential between DECON and SAFSTOR is likely to exceed greally the 900 person-rem assurned by the Conmission in CLI-96-1. See Petitionets ${ }^{*}$ Supplement to Motion for Reconsideration and Partial Rescission of CLI-96-01, dated March 7, 1996, at 9-10.

This recently proffered jntomation and new argument, if substantiated, may constitute "extraordinary corcturmstances" justifying further litigation on whether YAEC's DECON approach meels the ALARA stanciard. The NRC Staff and YAEC do not counter Petitioners' argument on its merits, but contend only that the argument comes too late and should not bo considered for the first time on appeal. Statf Brief at 11; YAEC Brite at 10-11. Howtever, on the current record, we cannot say that Petilioners' lateness is fatal, as thair argument rests significantly on a documeal dated February 28, 1996, and Petitioners promptly (on March 7) brought tt to the Commission's attention.

The current record does not provide enough information for us to assess whether Petitioners meet the standard for late-filed conteritions set forth in I0 C.F.R. $\$ 2.714(a)(1)^{15}$ or to evaluate fully the substance of their new dose argument. "In Commission practice the Licensing Board, rather than the Commission itsclf, traditionally develops the fachal record in the first instance." Georgia institute of Techtology (Georgia Tech Research Reactor), CLL-95-10, 42 NRC I, 2 (1995). We therefore remand to the Board the questions whether Petitioners' new dose argument satisfies the "late-filed contention" standards set forth in 10 C.F.R. \$2.714(a)(1) and, if so, whether tt provides a sufficient basis for the ALARA challenge to YAEC's choice of a decommissioning alternative. The Board may well be able to resolve these questions by our original anticipated mits-Juty endpoint to the Board proceeding. See CI.I-96-1, 43 NRC at 10. But if the remanded questions prove too complex for final resolution by July $\mathbf{3 1}$, 1996, we ask the Board to establish a fresh expedited schedule and to refer it to the Commission for approval.

\footnotetext{
75 It Ge

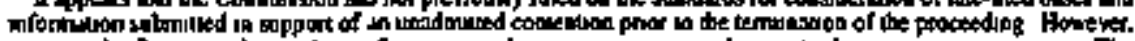

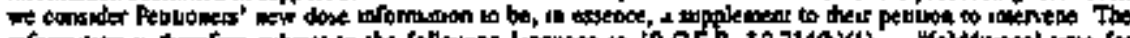

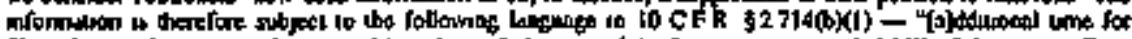

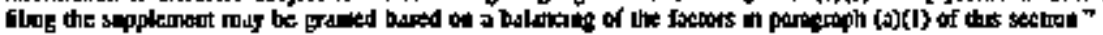




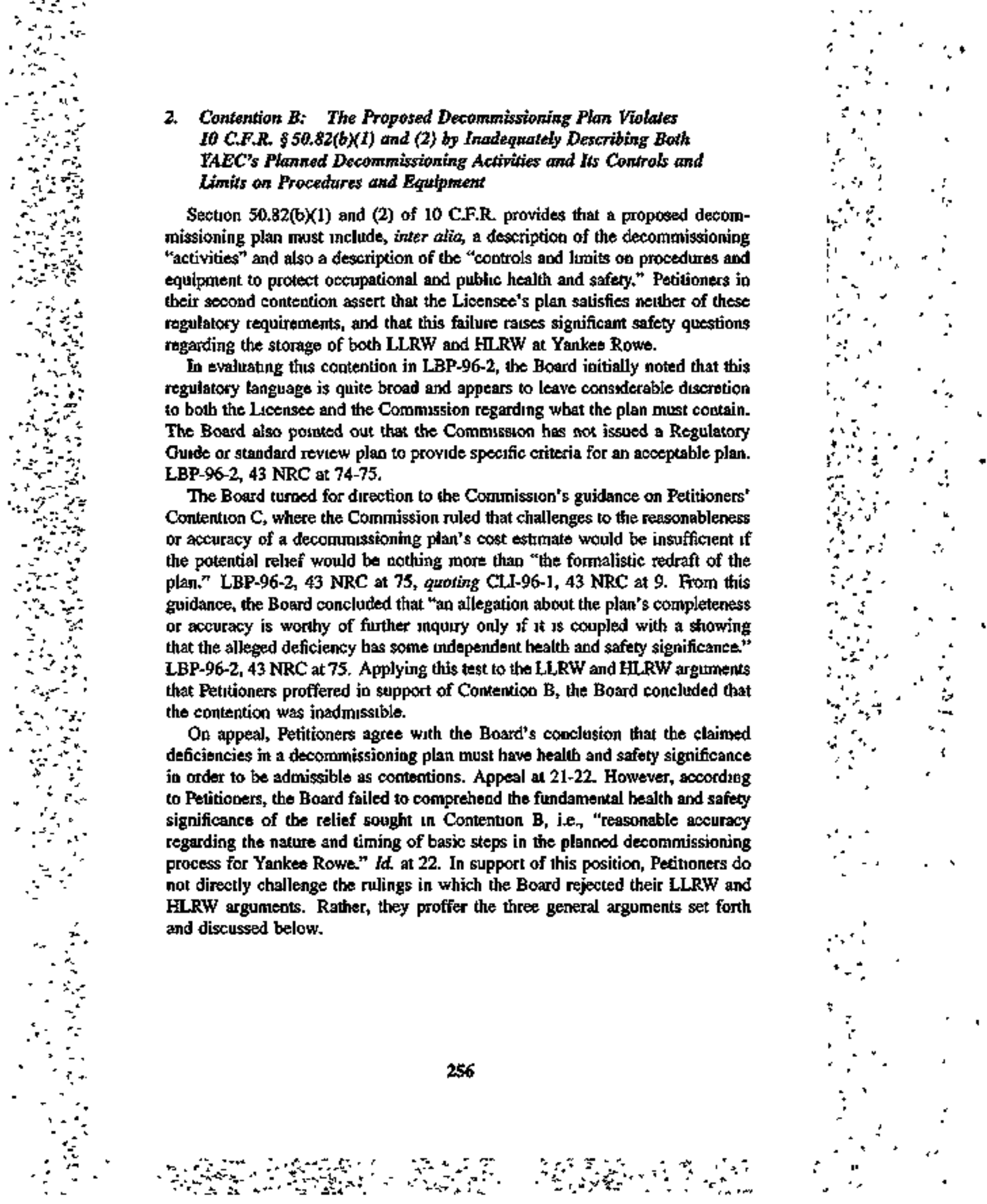




\section{a. Distortion of Cost-Benefit Anatysis}

Petitioners assert that YAEC's decormmissioning plan fails to provide a reasonably accurate description of the mature and timing of waste disposal and therefore distorts the ALARA cost-betefit calculation. As an example, Petitioners point to YAEC's claim that DECON is preferable because "the site is remediated as soon as possible after eessation of power operations, allowing unrestricted use of the site." According to Petittoners, this assertion is based on the tureesonable assumptions that HLRW will be Jemowed from the site by the year 2025 and that, by transferring spent fuel from the spent fuel pit to dry casks by the year 2000, YAEC can compleate decominissioning activities that cannot otherwise precede closure of the pit. Appeal at 22-23, referring to FSAR at 4.

We cannot agree with this argument. The factors cited by Petitioners, of course, represent uncertininties. However, that fact does oot, without more, make the plan unsound. A decommissioning plan by its wery nature deals with a myriad of uncertainties, and otr regulations cannot be construed to requite the plan to do the impossible, i.e., predict the future with precision.

Also, Petitioners inappropriately assume that YAEC plans to move the spent fuel fiom the pool into dry cask storage. The Commission has not approved any license amendment authorizing YAEC to do so, nor bas the Licensee submitted an application for such an amendment. Indeed, YAEC has indicated several times in this proceeding that it has not yet made any decision whether to seek such an amendment. ${ }^{16}$ Our regulations do not require YAEC at the time it seeks approval of its decommissioning plan to decide whether it will move spent fuel into dry cask storage. Again, YAEC is dealing with uncertainties, and YAEC's inclination to defer this decision is hardly upreasonable.

\section{b. Effect on Basis for Cost Estinate}

Petitioners next contend that the absence of reasonably accurate and reliable strategies and sthedules in YAEC's decommissioning plan deprives the Litensee of an adequate basis for a rtasonably Appeal at 23-24.

This argument runs afoul of the Commission's ruling in CLI-96-1 that a contention challenging the reasonableness of a decommissioning plan's cost estimate shoutd not be deemed litigable if reasonable assurance of decommissionjing costs is not in seriouss doutt and the only available relief would be a "fornalistic redraft of the plan with a new estimate." CLI-96-1, 43 NRC at 9. We discuss

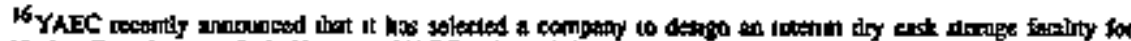

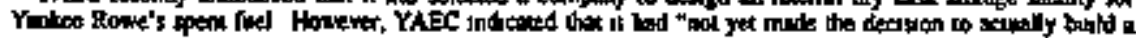

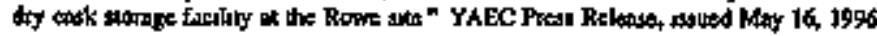


the cost estimate issue at length in cosnection with our analysis of Petitioners' Contention C, infro.

\section{c. Publtc Accountabiluty}

According to Petitioners, the Licensing Board improperly discounts the importance of requiring a reasonably accurate and reliable decommissioning plan so as to maintain Licensee accountability to the pubtic regarding both the impacts of decommissioning on their health and safety and the nature of Licensee's and Conmsission's cost-benefit judgments. Petitioners also argue in the abstract that Commission approval of a flawed plan would somehow implicate the govemment in a deception of the poblic that directly affects theis healiti and safety. Appeal at 24-25.

We find this arguntent unpersuasive. Petitioners appear to believe that an allegation of ecrors in a decommissioning plan should be sufficient in and of itself to entitle them to a hearing on the plan. The NRC adjudicatory process requires mote than that To obtain a hearjag, Petitioners must show some specific, tangible link between the alleged emors in the plan and the heatth and safety impacts they invoke. (Elsowhere in their appeal, e.g., at 22, they appear to acknowledge this.) For all their heated thetoric, Pelitioners have not sttempted to make stch a stowing.

\section{Contention C: The Decommissioning Plen Does Not Contply with the Decominisstoning Funding Requirements of It C.F.R. $\$ 50.82(b)(d)$ or (c)}

Section $50.82(b)(4)$ requires that a decommissionipg plan contain

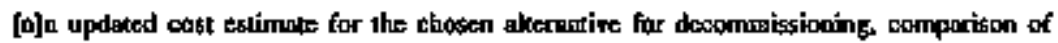
that extimnte with present funds set aside for decommisginaing, and a plan for assuring the awilablilty of adequate funds for completten of diecommisstioning.

Section 50.82(c)(I) provides that plans that "propose an alternative that delays completion of decommissioning by including a period of storage or long-term surveillance" must either provide that the decommissioning funds are placed "Into an aocount segregated from licensee assets and outside the licensee's administrative control duriag the storage or surveillance period" or maintajn "a surety method or fund statement of intent" in accordance with the criteria in 10 C.F.R. \$50.75(e). Finally, pursuant to section 50.85(c)(2), the decommissioning plan must include means for "adjusting cost estimates and associated funding levels over the storage or survetlance period." Petitioners argued in Contention $C$ that YAEC bat satisfied none of these requirements.

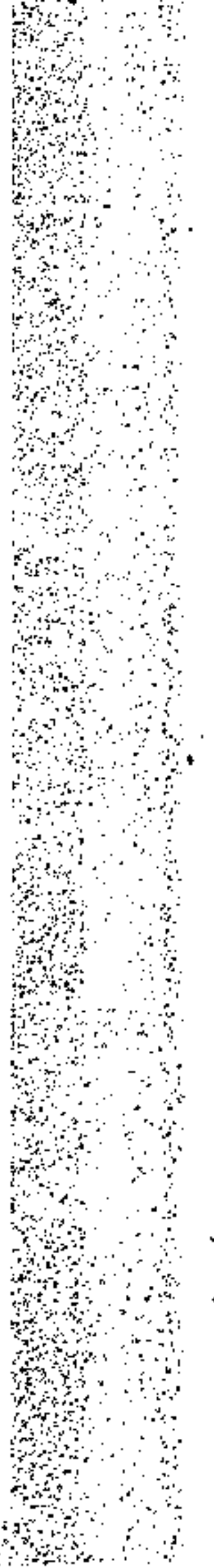


The Commission roled in CLI-96-I that to prevail on this contention, Petitioners would need to demonstrate not oniy that YAEC's decommissioning cost estimate was incorrect, but also that there was no reasonable assuranter that the decommissioning costs would be paid. The Commission explained that a contention challenging the reasonableness of a decommissioning plan's cost estimate provisions should not be litigable if the only relief available would be a "formalistic redraft of the plan with a new estimate." CLI-96-1, 43 NRC at 9. Petitioners responded at the prebearing conference that they were entitled under section 50.85(b)(4) to have the decommissioning plan changed to include a "reasonsble number" for the decommissioning costs. Transcript of Preheating Conference, Fub. 21, 1996 ("Tr."), at 128.

The Board applied the gutdance from CLI-96-1 to Contention C and found that Petitioners had failed to make the required showing. LBP-96-2,43 NRC at 83+84.

On appeal, Petitioners question the legality of the Commission's ruling in CLI-96-1 and argue that their challenge to YAEC's abitity to pay the decommisstoning expenses is sufficiently strong to merit a hearing.

They claim that the ruling was an effort to "amend by fiat the unconditional lenguage of the 1988 deconunissioning funding role which requires decommissioning plans to include an 'updated cost estimate for the chosen [decomunissioning] alternative." "Appeal at 28, quoting 10 C.F.R. \$ 50.82(b)(4). Petitioners describe this as an improper rule change, accomplished without notice and the opportunity for comment guaranteed by the Administrative Procedure Act, 5 U.S.C. \& 553, and the Atonic Energy Act, 42 U.S.C. 82239(a). Appeal at 28. According to Petitioners, the guidance means that the Licensee need not protuce an updated cost estimate for the chosen alternative unless Petitioners can demorsirate that the Licensee lacks reasonable assurance of its ability to pay the decommissioning costs; this, Petitioners say, shifts to them the burden of proving compliance with the decommissioning funding regulations. Appeal at 28 , citing 10 C.F.R. $\$ 2.732$.

Petitioners have misconstrued the Commission's guidance, which was intended neither to rewrite the decommissioning role nor to add new and higher hurdles for Pecitioners to meet. Rather, its purpose was to make clear that the decommissioning rule, like all other NRC rules, does not stand in a vacuum, but needs to be read in conjunction with other pertinent regtlations, including, in this case, the contention sule. For it should be evident that not alt actual or alleged errors in a decommissioning plan are of equal significance; to be significant enough to be "material," within the meaning of the contention rule, there needs to be some indication that an alleged flaw in a plan will result in a shortfall of the fonds aciually needed for decomnissioning.

In the present case, however, Petitioners have made only a perfunctory effort, relying heavily on speculation, to show why the alteged flaws could lead to an 
eration for the Final Decommissioning Rule, "[i]n an internal reserve, funds are placed into an account or reserve which is not segregated from Licensee assets and is within the licensee's administrative control." 53 Fed. Reg. at 24,03I. By contrast, YAEC's mechanism is external in nature. As described in the decommissioning plan, "[e] he decommissioning collections are made through YAEC's Power Contracts and are deposited in an independent and irrevocabie trust at a commercial bank" and the trust is executed in compliance with 10 C.F.R. $\$ 50.75(e)(1)(j i)$. The Licensee provided the Conmission with copies of those trust docotments (see id.) and they have also been publicly avaitlable at the Federal Energy Regulatory Commission ("FERC") since at least March 31, 1995.21 Petitioners provide an ovidence that would call into question the external nature of the trust fund.

In their Reply Brief on appeal, Pesitioners belatedly contend for the first time that YAEC's failure to collect all the necessary funds renders the tacollected funds a de facto intemal sirking fumd that is both subject to Purchasetr/Coowners' rewocation and vuleterable to their creditors in the ovent of bankruptcy. Petitioners' Reply Brief on Appeal, dated Aptil 10, 1996, at 14-15. This argument (like Petitioners' other "internal reserves" argument) comes too late in the day to save Pelitioners' Contention C. See cases cited in note 19, supra. Moreover, the argument is based on pure speculation; Petitioners offer no evidence whatever suggesting that a Phichaster/Co-owner will either default on its obligations under the Purchase Contract or go bankrupt. Petitioners must submit mote than this in order for a contention to be admitted for litigation. ${ }^{2}$

\section{b. Alleged Lack of Reasonable Assuraste}

Petitioners argue that, even accepting the Cotnutission's guidance that cost estimates are litigable only to the extent Petitioners can show a lack of reasonable assurance of payment, Petitioners have still raised a sufficient challenge to YAEC's ability to pay the decommissioning expenses. Petitioners claim to have demonstrated that (i) YADC's PurchaserkCo-owners' ability to pay decommis-

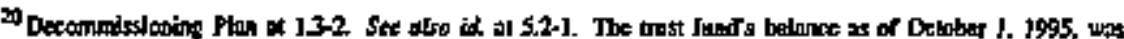

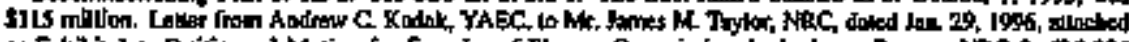

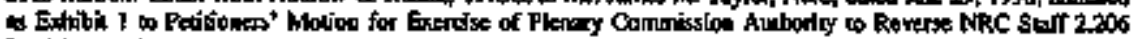

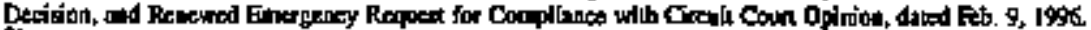

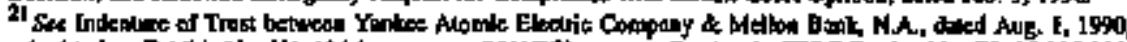

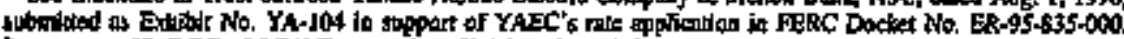

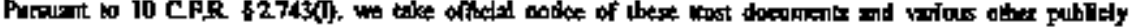

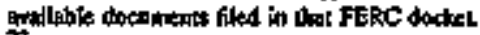

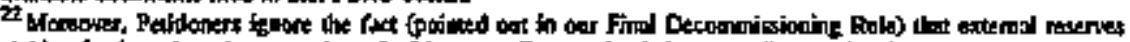

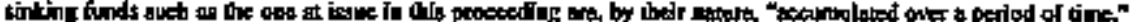

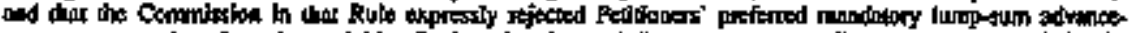

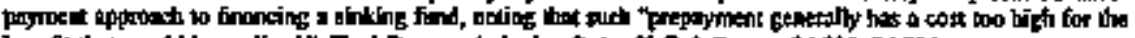

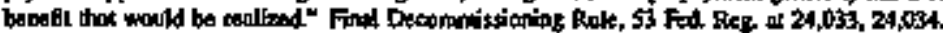

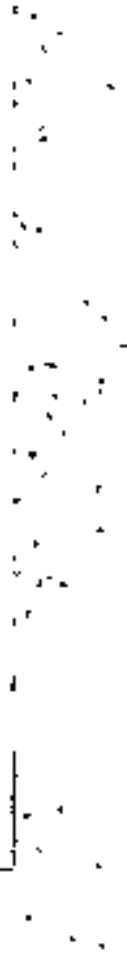




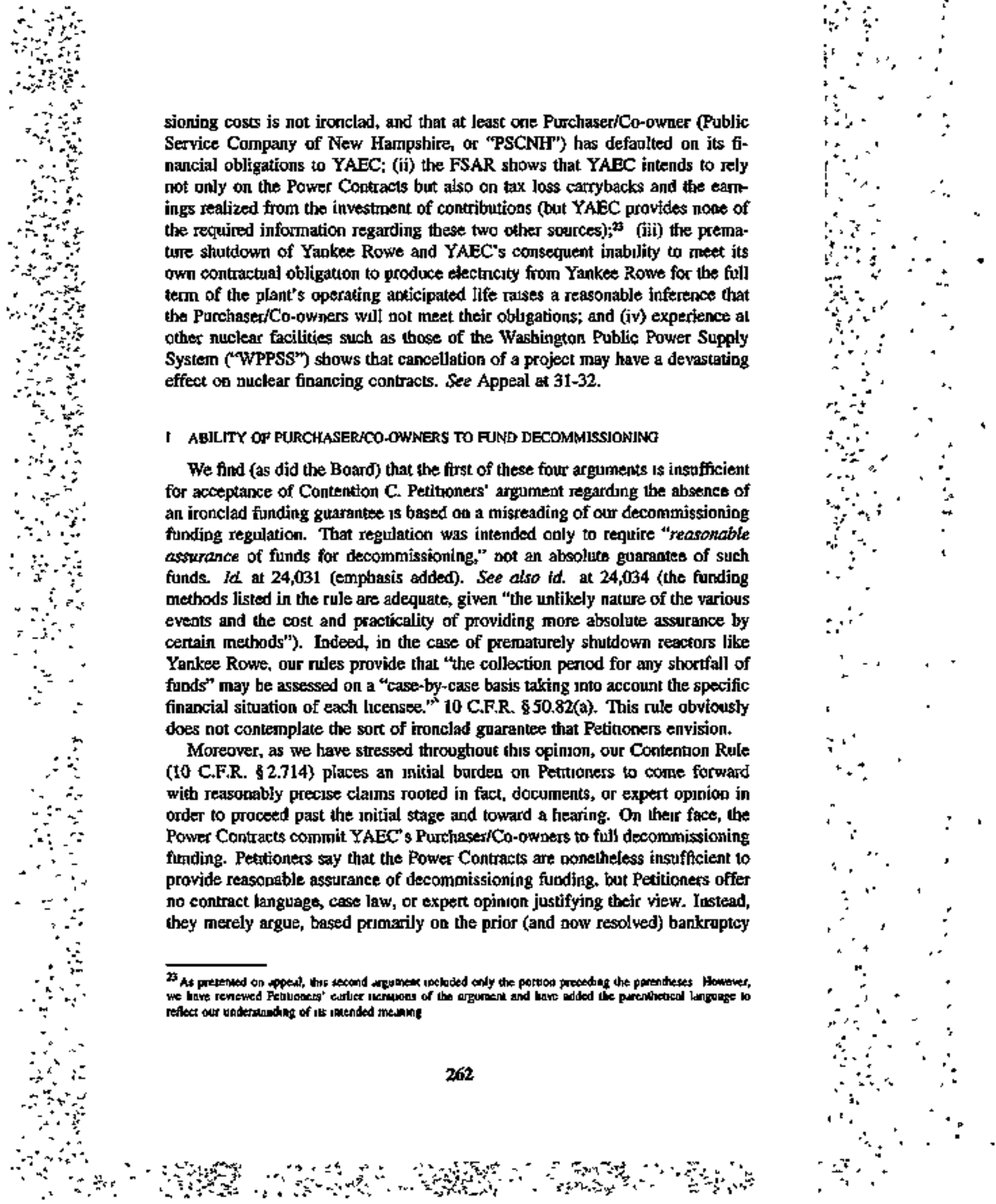


of PSCNH, that the YAEC plan moy not be fully funded because of possible contract breaches. Petitioners not only offer no supporting evidence for their conjectute, but they also ignore the fact that PSCNH continued payments to Yanke while under bankruptcy protection. See Yankee Atomic Electric Co., Op. No. 390, 67 FERC 161,318, 1994 WL 270437 (FE.R.C) at *17 (1994).

We conclude that Petitioners' concluspry fears of contract breach do not justify a challenge to the reasonable assurance provided in the Power Contracts. Our conclusion is reinforced by a look at rate proceedings conducted by our sister federal agency, the FERC, which recently studied the decommisstoning funding issise at Yankee Rowe in sone depth. The FERC concluded that the Yankee Rowe decommissioning contracts were binding and would require full decommissioning funding. An understanding of the FERC conclusions requires a digression of some length.

The FERC has repeatedly found that the Purchaser/C0-0woers of YAEC are obligated under their Power Contracts to pay for the entire costs of decommisstoning Yanke Rowe. 2t We bave reviewed the Power Contracts and agree with the FERC's reading of their language. We rely specifically on sections 2 and 6 of the Power Contracts' composite conformed version, which state, respectively, that

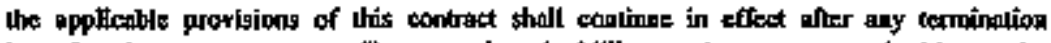
hereof to the extent necessary (i) to camplete the billings and payments required hereunder wilh respect o the Cusiomer's obligrikn to pay its powze percenlage of the fall cost of decornmissioning the plant . . . .

[T] costorper will pary Yankee on anount equal to the Cutiomer's power pertentige of the totol cost of service. . . . The "kotnl cosl of service" . . . shall [inctude] Yonkee's operning expeuses . . . . [O]peruting expenses sholl include . . . (1v) costs tnecurted in connection with decommissioming the plant, including (a) the direct and indtrect costs of optrating.

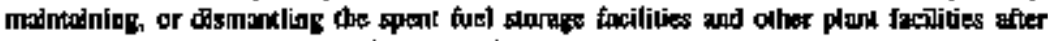
the cessulioc of electricly production and (b) the accruals to any reserve extablisted by Yinkes's bourd of dintelors to provide for physical decommissioning of the plant over the estimated remaibing useful life of the plant, provided, lowever, thox if a decision is made to ceose elecirisity ptoduction * the planl prior to July 9,2000, then the accorals to the teserve reforred to in elanse (b) sholl be made over a period extetiding io July 9. 2000. 35

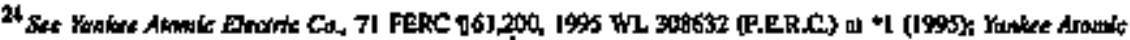

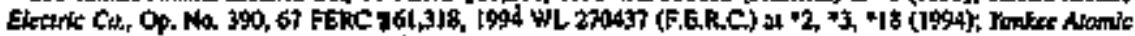

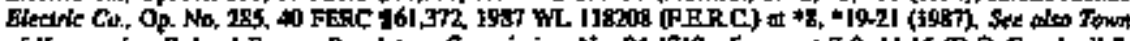

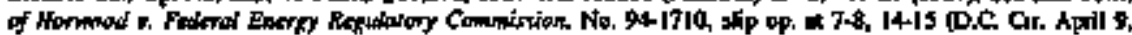

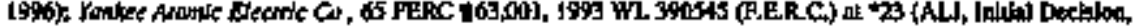
(1993).

${ }^{15}$ Componik Canfnrmed Copy of Poner Contrach, sobmited as YAEC's Estobit No. YA-l02 in support of YABC": 1/3495 nut appliculion in FERC Dodket Ho. BR-95-835-000, at 3, 36.
} 


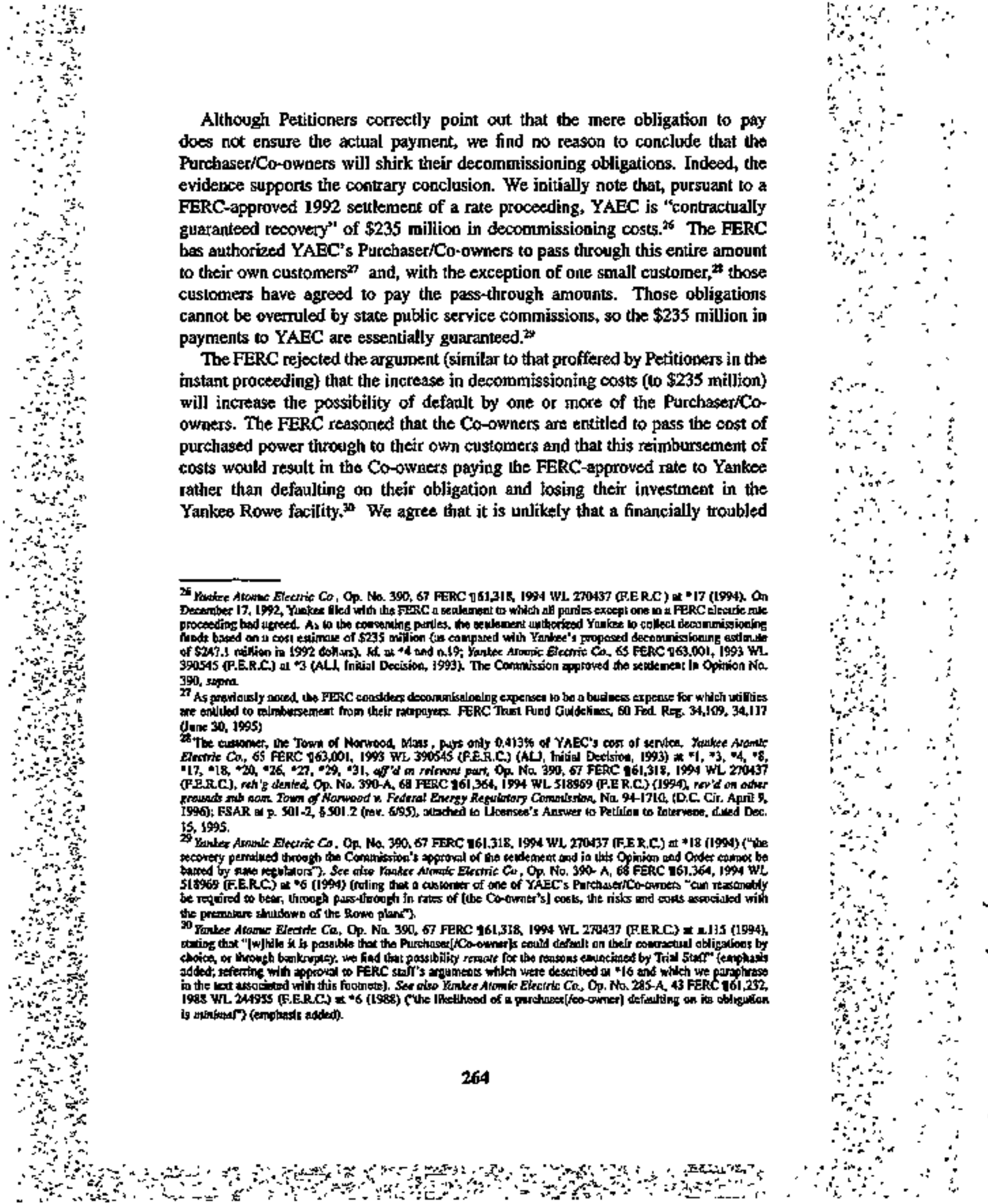


Purchaser/Co-owner would default and thereby lose the opportunity to pass through to its own customers so large a debt.

Regarding the decommissioning costs in excess of \$235 million, the Power Contract imposes a general obligation on each Purchaser/Co-owner to pay its pro rata percentage of the plank's fotl decommissioning costs. ${ }^{31}$ Petitioners have offered us no reason to concludie that any of the Purchaset/Co-owners will default on this pro rata payment obligation. Indeed, as indicated below, all indications point to a contrary conclusion.

In the following discussion, the FERC further determined that YAEC's overall business and financial risks (including the risk of Purchaser/Co-owner default) have decreased as a result of siluting down the Yankes Rowe facility:

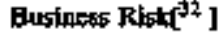

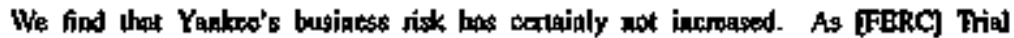

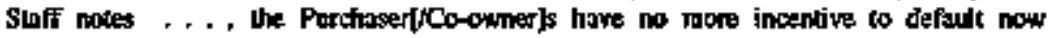
then they did vefone. The Purchiserfico-owner]s woule, In hel, be berter senved by mestiag cheir contructual ofligalions and passing the cost throngh to their custorters, thereby malntesining Iheir invegiment in Yankee, ruther than defouking and 3osigg their invesiment.

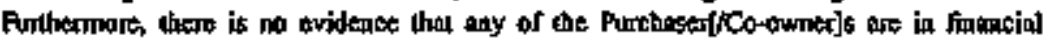

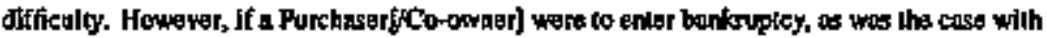

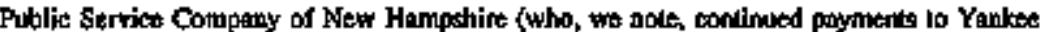

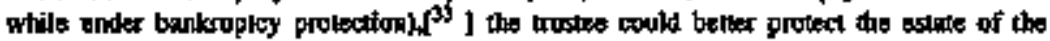

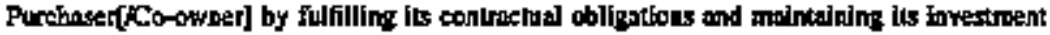
in Yankes, fallher then defaulting and losing the bankrupt Purchiser[/Co-owaer]'s imvesimenl.

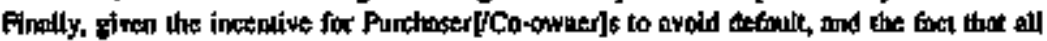

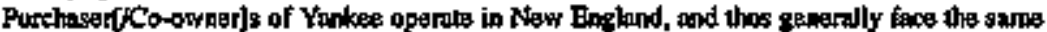
competilive pessores, we are unconricced lhat competitive pressoes would induce any

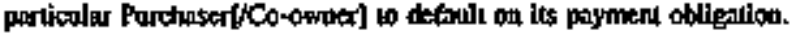

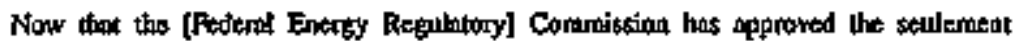
and tseved th's Opinion and Onder, regulotory and competitive pressures become non-

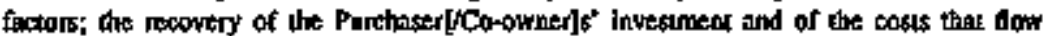
from main'siging the Rowe plank untit docommissioning oecturs, and also of the costs of decommissioning the Rowe plant, are now lorgely issured. $\left.{ }^{34}\right]$ Wloreover, the recovery

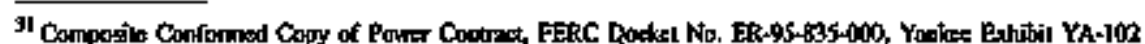

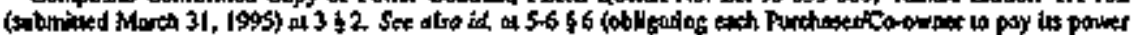

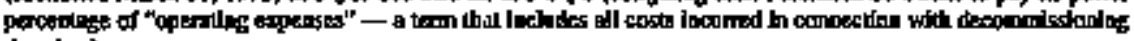
he planin).

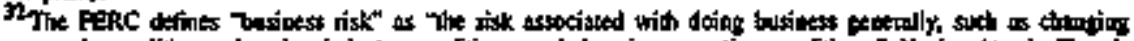

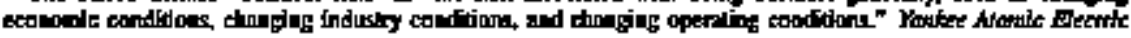

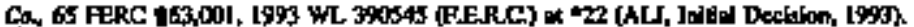

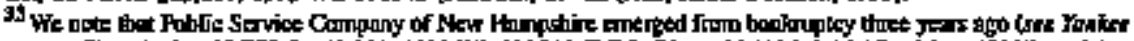

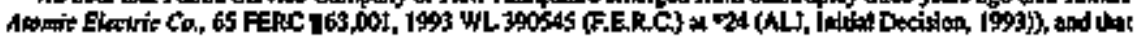

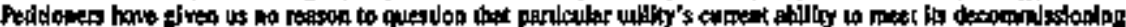
cost oblioptions undet is Power Conersa

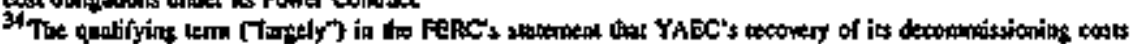

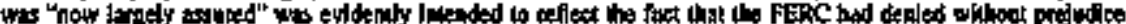
(Cotulinued) 
permilued through lte Commistion's approval of the setllement and in this Opinion and

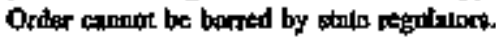

Thus, the risk assotiaved with the Ront plnat, and in particular the regulntery rist of mits approval for the collection of adequons funds for decommissioning and the risk of aclugly

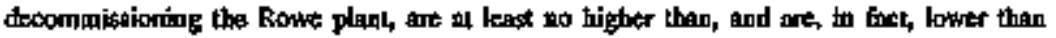
betore the shuidown.

\section{Financind Rksk[35 ]}

Whits Yankee wis subject to financial risk as a trall of the shuldown of the Rowe ptant,

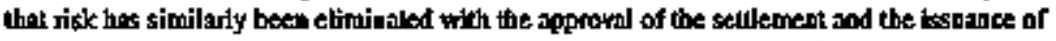
this Opinton and Order. In sddition, Yapkes wilnass Tracy tartified that Moody's virmed the

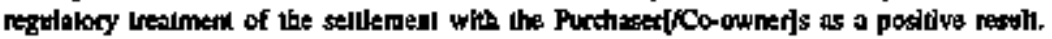

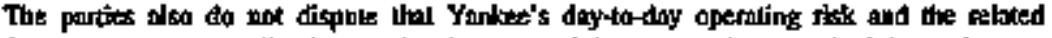
financial risk have dectined sincs the shutdown of the plont arti approval of the sethemeal, respecthety. Nor are we convinced that Yankes's decommissioniags riak has soptuced ils dryto-dny aperallng fisk; in the past, Yontsee foced both decommisslonlag risk and doy-to-day

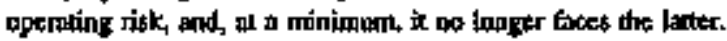

Op. No. 390 at $\neq 17-18$ (footnotes omitted).

Notably the FERC, in issting the tuling quoted above, expressly reversed an ALJ conclision that YAEC's sbutdown of Yankee Rowe increased YAEC's business and financial risks due to such factors as the risk of further increases in decommissioning costs, the risk of default by one or more Purchaser/Co-owners due either to bankruptcy or to the fact that Yankee Rowe is to longer praviding power, doubts as to DOE's ability to accept spent foel in 1998, and doubts as to the availability of an LLRW disposal site - all factors cited by Petitioners in our own protetefing. See Yankete Atamic Electric Co, 65 FERC 1863,001, 1993 WL 390545 (F.E.R.C.) at *23-25 (ALJ, Initial Decision, 1993).

Moreover, the FERC, by recently approving YAEC's Decenter 29, 1995 settlement, has authortzed YAEC to colleet from the Purchaser/Co-owners all estimated decommissioning costs (including site restoration expenses, see note 34, supra), up to $\$ 306.4$ mitlion ${ }^{36}$ Uxder Supreme Court precedient, those Purchaser/Co-owners would appear to have a sirnilar right to pass through thos:

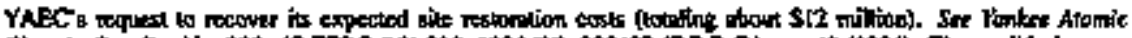

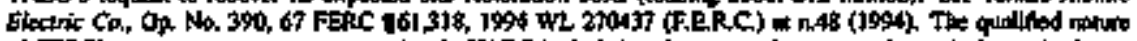

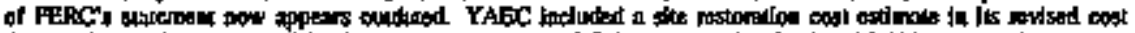

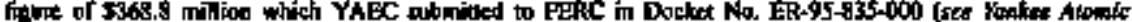

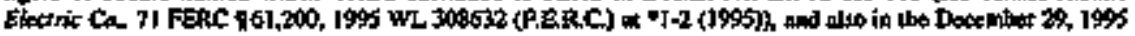

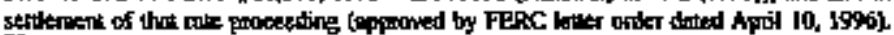

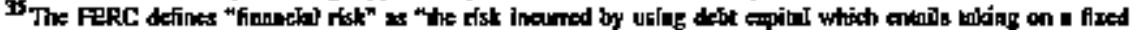

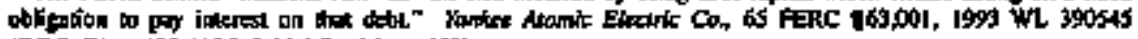

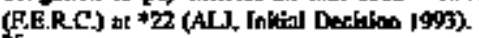

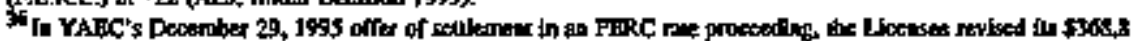

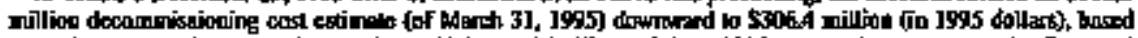

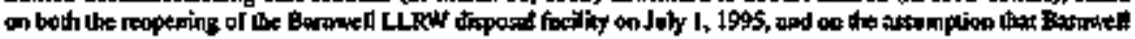

\{Coninaces\} 
costs to their own customers. See Mtsstsstppt Power and Light Co. v. Mississippl, 487 U.S. 354, 370.74 (1988) (ruling that states may not bar regulated utilities from passing through to retail customers FERC-mandated wholesale rates and that the Supremacy Clause cormpels the states to pentit such utilities to recover as a reasonable operating expense any costs incuned as a result of paying a FERC-determined wholessle rate for a FERC-mandated allocation of power). Mississippt Power and Light Co. suggests that YAEC's Purchases/Co-owners are entitled to pass through to their own customers the cost of purchased power - including decommissioning costs. Such a sitation would remove virtually all remaining risk that a Purchaser/Co-owner would default on its obligation to pay its pro rata share of decommissioning expenses.

\section{DTHER ARGUMENTS}

Petitioners' second argument complains that YAEC has failed to provide informalion on any funding sources other than the Power Coutracts - specifically, the ax loss carrybacks and the earnings realized from investment of the Purchaser/Co-owbers' contributions to the trust fund. However, given that YAEC has provided sufficient proof that its Purchaser/Co-owners are cbligated under the Power Contracts to pay all decommissioning costs, and given Petitoners' failure to demonstrate any likelihood that any Purchased/Co-owner will default on that obligation, we need not rely on these other two sources of incone in rejecting Petitioners' Contention C, and the Licensee's alleged onission of specific details as to these two sources of income is consequently of no moment.

We reject Petitioners' third argument (that the Purchaser/Co-owners will not meat their obligations) on the same grounds upon which we retied in rejecting Petitôners' first argument. Moreover, the third sagument is mere speculation. and therefore insufficient to merit further consideration. See genterally Rancho Seco, CLI-93-3, 37 NRC at 145-46 (rejecting contentions in a decommissioning proceeding as too speculative).

Finally, we reject Petitioners' fourth argument (regarding WPPSS) on the grounds that they have shown no logical relationship between the WPPSS situation and that at Yankee Rowre and have therefore failed to demonstrate the relevance of their argument to this case. $I d$.

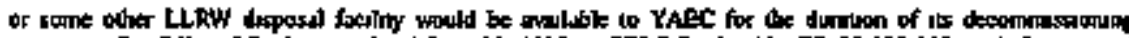

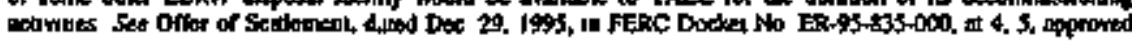
by FERC keat odder ouned Apol 10, 19\% 


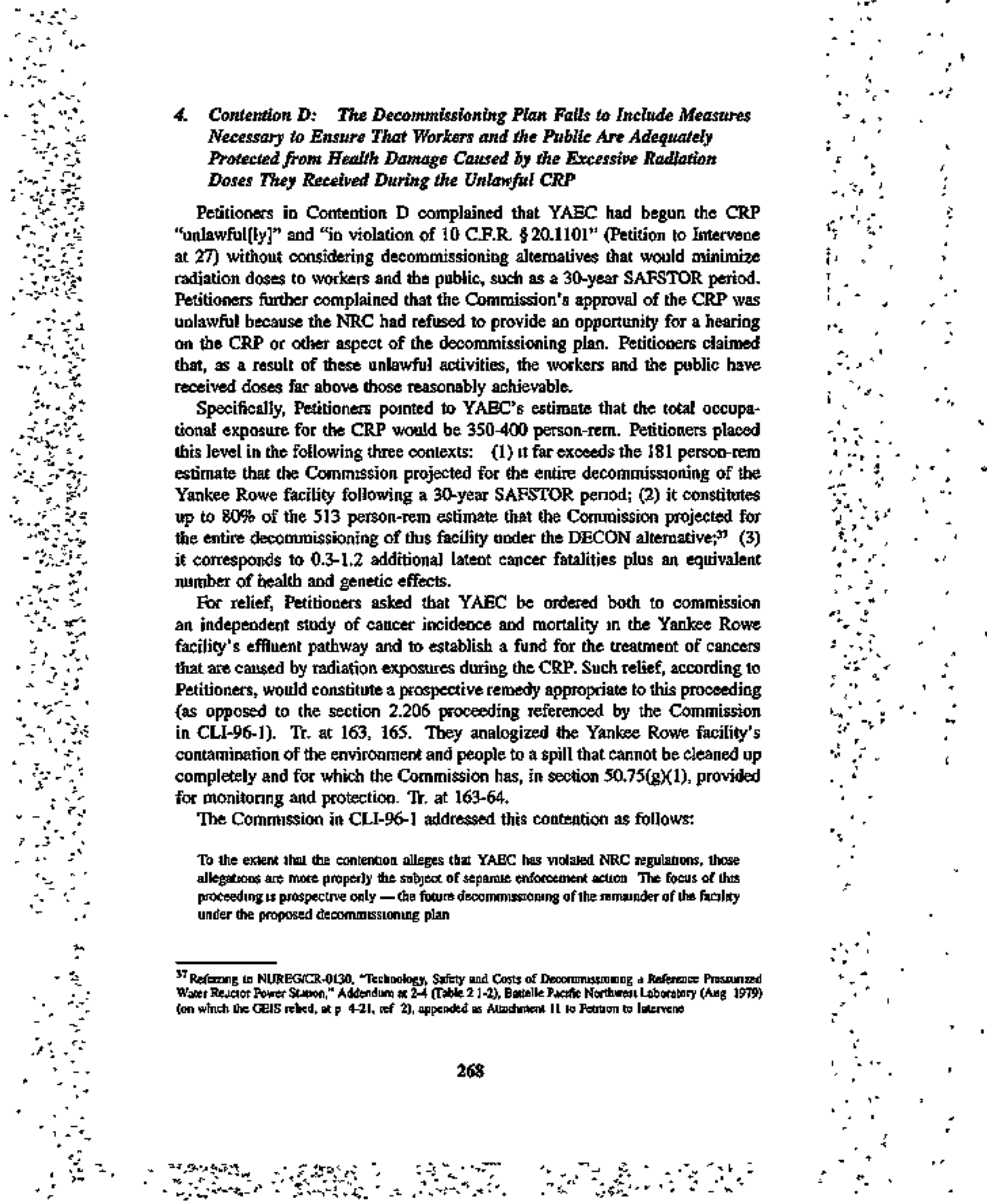


43 NRC at 9. The Broard cousidered this gridance dispositive of Contention D and, accordingly, rejected it. LBP-96-2, 43 NRC at 85.

On appeal, Petitioners rejterate their arguments, and contend again that they seck prospective rather than retrospective relief. Appeal at 32-33. We reject Petitioners' arguments for two reasons.

Fist, they cite no authority supporting their povel prayer for relief. Although the Commission bas a general responsibility to ensure that decomatissioning operations do not jeopardize poblic bealch and safely, no statute or regutation grants the Commission authority to requite the Lisenser to pay (in effect) compensatory damages to private individuals.

Second, the activities completed under the now-concluded CRP are beyond the scope of this proceeding, which deals solely with the propriety of YAEC's deconmissioning plan and its future deconunissioning activities. Insofar as Petitioners contend that YAEC's alleged regulatory violations call for NRC enforcement action, agercy rules provide a procedural mechantism for requesting such Jelief. See, e.g.. J0 C.F.R. \$2.206.

\section{Contention E: The NRC Staff Violated NEPA by Failing to Prepare a Supplementol EIS for the Decommissioning of Yankes Rowe}

In Contention E, Petitioners argued that NEPA requires the Commission to prepare a Supplemental EIS ("SEIS") to address the significant environmental impacts that are specific to Yankee Rowe and were not addressed in the GEJS that the Commission prepared in 1988 in support of its Final Decontrissioning Rule," and to address assumptions that were relied on in the GEIS but are invalid for the Yankee Rowe facility. According to Petitioners, this requirenoent is applicable because the Comntission's approval of the Yankee Rowe decommissioning plan constitutes a "major federal action signuticantly affecting the quality of the human environment." NEPA $\$ 102(2)(C), 42$ U.S.C. $\$ 4332(2)(C)$.

The scandard for issuing an SEIS is set forth in 10 C.F.R. § 51.92: There must be eitter substantial chantges in the proposed action that are retevant to environmental concerns, or signiffcant new circumstances or information relevant to environmental concerns and bearing on the proposed action or its impacts. Petitioners proffered five bases in support of this contedtion, the following four of which are still at issue in this appeal."

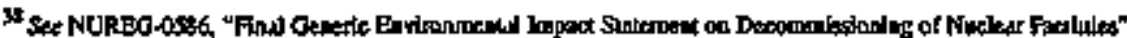

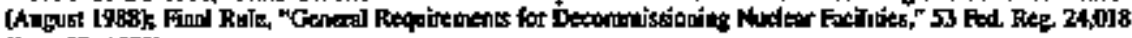
(Jun 27, 1958),

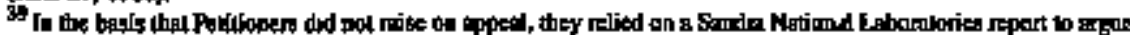

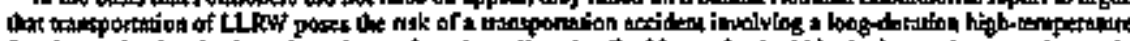

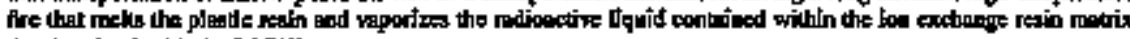
Itat is mixed wh lie LLRW.
} 


\section{a. Decommissionting Financing}

Petitioners claim that the GEIS failed to consider the environmental impacts of potentially inadequate decommissioning financing for prematurely shuldown reactors such Yanke Rowe. The Board in LBP-96-2 rejected this basis, noting that the GEIS did in fact include a discussion of the problem of tnsdequate funding (citing GEIS at pp. 2-14 to 2-20). The Board also concluded that, under the guidance offered by the Commission regarding Contention C. Petitioners have not provided a sufficient basis to question the sdequacy of funding for Yankee Rowe's decomnissioning and therefore thave not provided any material factural or legal dispute regarding the need for additional discussion on this topic in an SEIS for Yankee Rowe." LBP-96-2, 43 NRC at 83-84.

The Board niled contelly. The GEIS did in fact consider the situation of a plant being decommissioned prior to the full funding of its decomnissioning accosnt. GEIS at p. 2-15, 13:

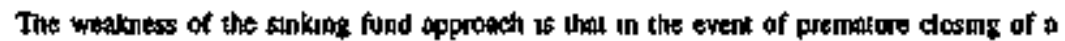
fecility the decommassioning fund wotld be insufficeal Therelore the siaking fund woukd

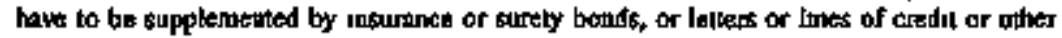
suarsatee methods

Petitioners have pointed to no factors that were not already considered in the GEIS and that are peculiar to the Yankee Rowe facility (other than Petitioners" concerns about the Power Contracts, discussect and dismussed above). Finally, we reject Petitioners' argument on the same grounds as we rejected their Contention C (see pp. 258 67, supra).

\section{b. Occupational Dose Estimate}

According to Petitioners, the NRC Staff erroneously asserted in the EA that YAEC's ocsupational dose estimate is within the range that the GEIS evaluated and found acceptable. Petitioners argued to the Licensing Board that this claim is flawed because Staff failed to "scale" the acceptable dose level downward to refleat the small size of the Yankee Rowe plant (I85 MWe) as compared to the size of the model plant considered in the GEIS (1175 MWe). According to Petitioners, the projected occupational doses for Yankee Rowe exceed the decomnissioning doses that were anticipated for Yankee Rowe in an NRC study on which the GEIS relied. 
In support of this basis, Petitioners proffered tus arguntents: They pointed out the discrepancies in YAEC's various occupational dose estintates (755, * $744,{ }^{41}$ and $350-400^{\circ}$ person-rem), and they clained that the EA erroneously compared YAEC's estimate of 755 person-rem with the GEIS's cestimated dose level of 1215 person-rem for the DECON decommissioning of a generic 1175MWe pressurized water reactor. According to Petitioners, Staff should have instead compared YAEC's estimate with the 513 person-rem estimate that had been calculated specifically for the decommissioning of Yankee Rowe in a 1979 NUREG docement on which the GEIS relied, ${ }^{43}$ Petitioners concluded that an SEIS is required to evaluate these previously unexamined impacts.

The Board rejected the first of Petitioners' two arguments on the grounds that the $350-400$ persoo-rem estimate fiom Iune 1993 has been superseded by a more-recent (1995) estimate of 160 person-tem (FSAR at pp. 507-4 and 507-15) and that Petitioners have presented no evidence to show that this latter estimate is incortset. Consequently, the Board reasoned, Petitioners have failed to estabtish any disputed material issue warranting futher litigation. LBP-96-2, 43 NRC at 87.

The Board, in rejocting Petitioners' second argument, determined that the GEIS's assessment of the impacts of oceupational exposure was based on a comparison of the impacts of exposure during docommissioning with the impact of exposure during operation of the facility and that the GEIS concluded that the former inpacts were aceeplable. The Board concluded that Petitioners hat neither challenged the substance of the GEIS's conclusion in this regard nor attempted to show that suck a comparison for Yankee Rowe would yitld a different result, LBP-96-2, 43 NRC at 88.4

On appeal, Petitioners interpret the Board's response to their first argument as a finding that the difference between the 1993 dose eslimate of $350-400$ personrem for the CRP and the decommissioning plan's more recent CRP estimate

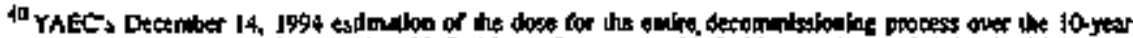

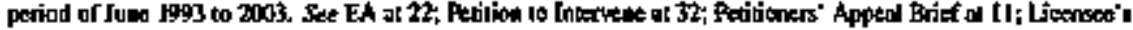

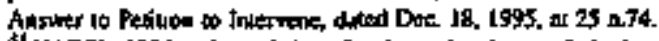

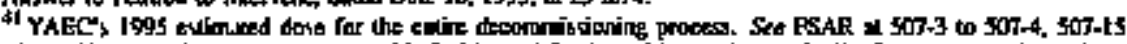

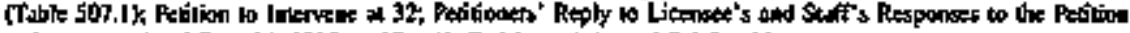
is Inerwose, dured Dee, 24, 1995, at IB n4I; Febiliowerr' Apged Brief al II.

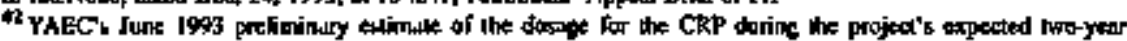

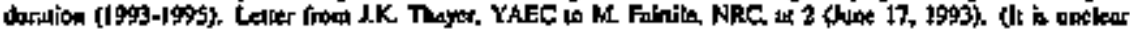

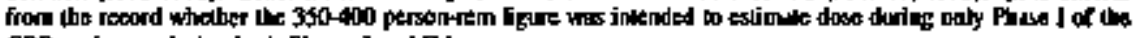

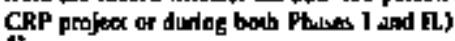

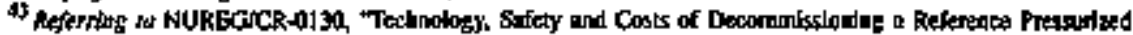

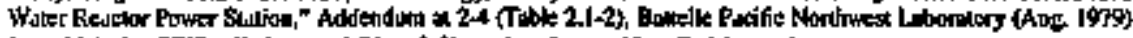

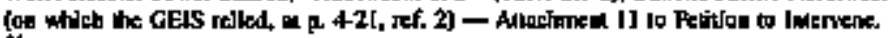

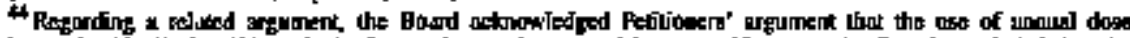

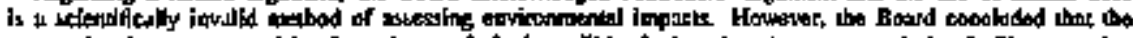

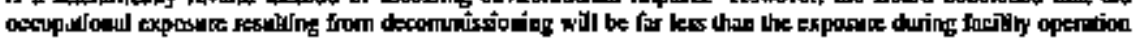

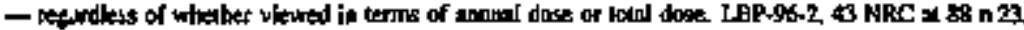


of 160 person-rem is "Inconsequential." Petitioners assert that "such a large discrepancy cannoc be explained away by merely claiming to correct it." Appeal at 36. Petitioners also argure on appeal that "dose records submitted by YAEC and the NRC Staff for the CRP and YAEC's current activities show that, in fact, the radiation doses caused [by] YAEC's decommissioning activities thes far ars far in excess of the doses represented in the deconumissioning plan" According to Petitioners, these showings raise a sufficient factual and legal basis to juslify admission of Contention $\mathrm{E}$.

We fall to see the significance of Pebitoners' cursory assertion that Staff and YAEC have proffered inconsistent representations about decommissioning dose levels. Petitioners on appeal fail both to ideatify the inconsistent representations about which they are conceroed and to deseribe those concems. See Curators of the University of Missouri, CLI-95-1, 41 NRC 71, 132 n.81 (1995); Public Service Co. of Oklahoma (Black Fox Station, Units 1 and 2), ALAB-573, 10 NRC 775, 786-87 (1979). We already have found the remainder of Petitioners' argurment - that "new" dose information raises a question whether excessive occupational dose will be incurred at Yankee Rowe - worthy of further serutiny by the Board. See pp. 254-55, supra. If Petitioness can substantiate that argument on temand, they are free to purste it on NEPA, as well as ALARA, proutats.

Petitioners also chatlenge the Board's sejection of their "scaling" argumeot. They characterize the Board's decision as "appear[ing] to concefte" the appropritaleness of scaling but then finding that doses are acceptable because they fall within the range of doses experienced during plant operation. Petitioners respood that the actual deeommissioning dose amount is unknown and that the record is filled with ineonsistent representations by YAEC and the Staff. According to Petitioners, these factors underinine the Board's dismissal of Contention E. Appeal at 37 n.11.

We reject these arguments for two reasons. First, Petitioners' argument that Staff improperly failed to "scale down" the occupational dose estumales to reflect the smalier stze (185 MWe) of the Yankee Rowe plant fails to take into account the reason why the GEIS found acceptable a 1215 person-rem total estimated dose for decommissionang a 1175-MWe pressurized water reactor. This acceptability was not based on dose per megawatt of capacity, as Petitioners apparencly suppose. but was premised instead on the fact that the 1215 person. ren dose est!mate compared favorably on an annual basis (279 person-rem/year for the 4-year DECON penod in the case of the GEIS's reference 1t75-MWe phant) with the annual occupational radiation doses (between 550 and 1101 person-rem) seen over the period 1974-1980 from operation, maintenunce, and refueting of PWRs. See GEIS at p. 15-1, See also LBP-96-2, 43 NRC at 87 n.21. 
Seeond, Petitioners have not alleged any facts supporting their assumption that size has any effect on the decommissioning dose estimates, aor have they shown why the dose from decommissioning a smalter power plant must be less than the dose from decommissioning a large plant in order to be acceptable. We see no necessary correlation between the size of a plant and the dose from decommissioning that plant. The decommissioning of a larger ptant might even result in less dose than the decommissioning of a smaller plant, depepding on such factors as the difference in the two plants' designs, operating prattices, fuel failtres, and contamination levels. Also, Petitioners admit that there is ne specifie language in the regulations or the GEIS thet would support their position regarding scaling the dose to fit the size of the plant. Tr. at 61 .

\section{c. Cask Droppage Accident}

Petitioners clatm that the GEIS fails to consider the potential for an accident involving the dropping of a cask into the spent fuel pit.

The Board tesponded that this matter is most directly relevant to a possible futwre application from YAEC to change Yankes Rowe's Technical Specification 3.2 (which effectively precludes the Licensee from moving larger multipurpose canisters over the pool), that any agency action on such an application would have to be accompanied by an appropriate safely and environmental anslysis, and that such an analysis would then be subject to challenge at an acjoudicatory hearing. The Board concluded that Petitioners had faited to show that current rather than future analysis of such a change in the technical specification has any relevant impact on the approval of YAEC's decommissioning plan, and that Petitioners have therefore failed to demonstrate any violation of the Commission's NEPA responsibilities. LBP-96-2, 43 NRC at 90.

Petitioners respond in their appeal that the Commission has an obligation under NEPA to mitigate significant environmental impacts of proposed licensing actions; that the health and enviroumental impacts of decommissioning Yankee Rowe can be mitigated by selecting the SAFSTOR altenative; and that the cask drop accident scenario is relevant to any analysis of whether SAFSTOR must be employed as such a mitigating measure because the scenario retates to YAEC's ciaim that the benefits of speedy decommissioning under DECON outweigh any benefits under SAFSTOR.

Petitioners go on to argue that YAEC's assumption that it will be able to complete its decommissioning rests on the feasibility and cost-effectiveness of its plan to place spent fuel in dry casks for long-tern storage, thereby enabling YAEC to close the spent fuel pit and obtain access to the as-yelundecommissioned remainder of the plant Petitioners conclude from this line of reasoning that, to compare DECON and SAFSTOR adequaley under NEPA, the Commission must evaluate the risks and feasibility of the Licensee's proposal 
to use dry cask storage - including the nisk of a cask trop aceident. Appeal at 38 .

We reject Petitioners' arguments for two reasons. First, Peltioners fail to demonstrate that nsks of exposure from a cask dcoppage accident (or even the use of casks) are affected by the Licensee's selection of DECON over SAFSTOR. Such an accident could oceur under ether of these decommissiontng options. Second, we agree with the Board that the issue of the risk of a cask droppage accident is not now ripe, and will not be ripe unkess and untul YAEC seeks a license amendment to permit it to remove fuel from the spent fuel pit. YAEC at this point disclaums any decision to use dry storage casks. ${ }^{45}$ As previously noted, if YAEC uitimately adopts the dry cask storage optıon, it will bave to foltow the proper licensing procedure.

\section{d. Improper Consideration of Etrly Site Release}

Petitioners point out that NEPA requires the agency to consider aliernatives that could mitugate the adverse impacts of a proposed actron, and that the Commission's implementing regulations require a draft EIS that includes an analysis that

\footnotetext{
conswers and bandes the envirommental and other effects of the proposed action and the

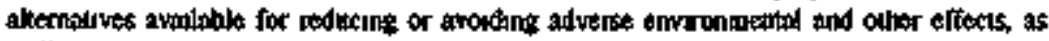
weill as the envinonarentol, economic, techneed and other benefils of the proposed action
}

10 C.F.R. $\$ \$ 1.71(d)$,

Accordung to Pettuners, the GEIS's balancing of the advantages of DECON and SAFSTOR for plants in general fails to reflect the advantages of DECON and SAFSTOR for Yankee Rowe in particular. Petitioners refer back to their earlier contentions $A(1)$ and $B(2)$ (a) that the tuse of the DECON alternative will not resule in an early release of the faciluty for unrestricted use. Petitioners estimate that Yankee Rowe's spent fuel will remain on site for at least $\mathbf{3 0}$ more years. They conclude that the conseguent absence of sny early release under DECON swings the balance in favor of SAFSTOR. According to Petitoners, this swing in the balance necessitates the preparauon of an SEIS.

The Board rejected this basss on the ground that Petitioners have falted to satısfy the requirement of 10 C.F.R. \$ 5192(a)(2) to show "significant new circumstances or joformathon relevart to environmental concerns and bearing on the proposed action or jts unpacts." The Board pointed out that the GEIS already contains an analysis of the envimonimental Imipacts of the SAFSTOR

\footnotetext{
45 Sec p 257 \& wote 16, enthr
} 
option in the event that a longer storage period for HLRW becondes necessary."6 The Board also noted that, although the argunent is couched in terms of NEPA compliance, it is essentially just another challenge to the Licensece's choice of DECON instead of SAFSTOR. The Board concluded that such a diallenge doss not produce a litigable NEPA issue, absent a showing grounded it dose estimates or other information outside the analytical framework of the GEIS. LBP-96-2, $43 \mathrm{NRC}$ at 91.

Patitioners in their appeal reilterate their argament that the GEIS approved both DECON and SAFSTOR because each option balanced the level of exposure with the speed with which the site would be relessed, but that this balance is inopplicable to Yanke Rowe. According to Petitioners, this is dite to DOE's apparent inability to open a HLRW repository in the near future and the consequent need for YAEC to retain the spent fuel on site for at least 30 more years. Petitioners assert that such retention will preclude the early releass of the site and thereby alters drastically DECON's expected "balance" of greater dose with early site release. Accordingly, argue Petitioners, an SEIS is nesessary to examine both this change in balance and the health and environmental advantages of SAFSTOR. Appeal at 38-39.

Petitioners essentially construct their argument around the following syllogism: (1) the OEIS found DECON acceptable only because the site would be available for unrestricted use sooner rather thant laler; (2) a licensec must remove the spent fuel from the site before releasing a site for unrestricted ust; (3) as YAEC does not propose, or cannot accomplish, an early removal of spent fuel, DECON is inappropriate as to the Yankee Rowe site. We find problems with both the first and second prong of this syllogisn.

Regarding the first prong, the GEIS's approval of DECON was not premised solely on the early availability of the site. The first prong ignores the following other benefits of DECON cited in the GEIS:

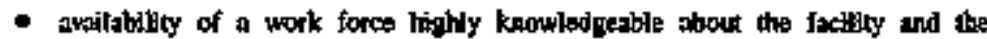
elirtinalion of the need for long-term security, mintenanes and survaillaboe of the

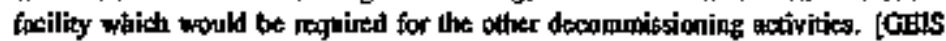
at p. 2-9, see utso id. at p. 2-I [.]

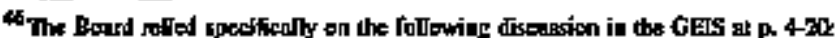

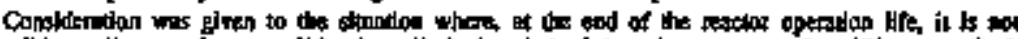

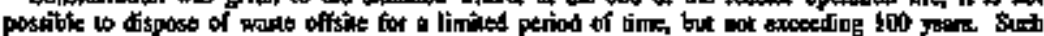

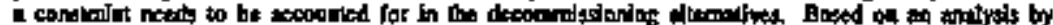

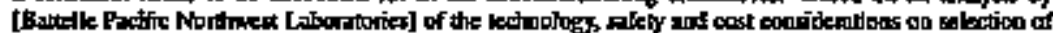

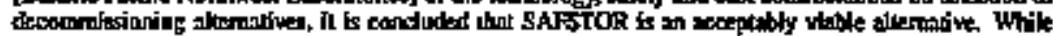

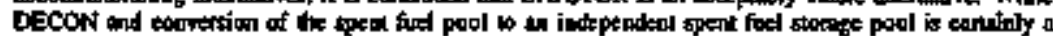

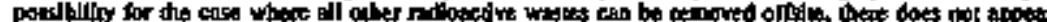

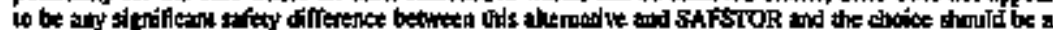
livenues declsion. LBP-96-2,43 NRC at 91.
} 


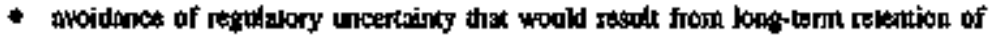
the sile. [Jd. at p. 2-11.]

- Iowes cost thar SAFSTOR. [Id. al p. 4-17.]

Moreover, as already noted, the GEilS also focused on the fact that neither DECON nor SAFSTOR was expected to result in more than a minor fraction of the dose from a typical operatints plant. NEPA does not require preparation of an EIS for governmental actions having such a minimal impact.

The second point of the syllogism is also flaped in that it erroneously treats the enlire site as indivisible, assuming that if one square foot bad enough residual activity to preclude its release to the public, then none of the site would be releasable. According to YAEC, the builoings on the Yankee Rowe site take up only 10 of the site's 2000 acres, and the spent furel area takes up only about one-tenth of an acre. Petitioness have offered no season why 1990 or 1999.9 acres stiould be essentially "held hostage" by the 10 or 0.1 acres with residual activity, 47

In addition to their syllogistic argoment, Petitioners also disagree with the Board's statement that the GEIS actually assessed the potential impact of longerterm onsite storage of spent fuel. Pointing to the startement in the GEIS that "consideration was given" to situtations "where, at the end of the reactor operation life, it is not possible to dispose of waste offsite for a limited period of time, but not exceeding 100 years," Petitioners assert that "it is toot at all clear what that "consideration' amounted to." They sirnilarly point to the use of the word "appear" in the GEIS's following statement:

White DECON and conversion of the spent fuef pool to an independent spent fol storpge pool is cectininly a possibility for the cose where all athex rodiooctivs wastes can be removed offiste, there does not appear to be any significan snlety ditrerence between this alterantire and SAFSTOR and the theice shopld be a licanses decision.

They say that this passage reflects the "sopenficial[ity]" of the GEIS's conclusion that the differeace between SAFSTOR and DECON under such cireumstances is insignificant. Appeal at 39-40, quoting GEIS at p. 4-20. For these reasons, Petitioners claim that the Compuission must take a hard look at eaviroumental impacts that it had previously considered ublikely.

We cannot accepe Petitioners' second argument. Regardless of their efforts to find "tentative" words in the GEIS's discussion of prolonged onsite storage of spent fuel, Petitioners cannol (and do not) gainsay the critical fact that the GEIS does address that very issue. Consequently, as the Board correctly

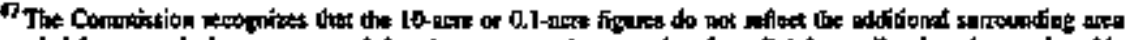

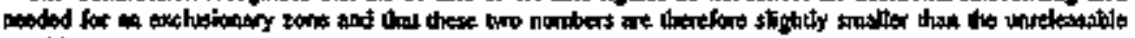
atsists) 
pointed out, Petitioners have fajled to demonstrate the necessary "significant new circumstances or ifformation relevant to envirosmental concerns and bearing on the proposed action or its impacts." LBP-96-2, 43 NRC at 90 (emphasis added).

As we explained earlier in this opinion (at pp. 251.52), the Commission need not revisit in case-by-case jitigation matters resolved generically in prior rulemakings, including NEPA matters. See Kelley v. Selin, 42 F.3d at 151920. If parties beliewe that the agency's prior generic teview reached the wrong conclusions, the proper remedy is a petition for rulemaking, not a litigation contention challenging the basis for a Comnission nule.

\section{CONCLUSION}

For the reasons set forth above, the Commission grants in part and denies in part Petitioners' appeal, rejects YAEC's argurnents regarding standing, and remands for the Board's further consideration the questions whether Petitioners' new dose argument satisfies the "late-filing" standards in 10 C.F.R. \$2.714(a) and whether it provides a sufficient basis for an ALARA or NEPA challenge to YAEC's choice of a decommissioning altemative. Ste pp. 254-55, 271-72, supra. If a final decision on remand cannot be reached by July 31,1996 , the Board shall establish a fiesh expedited schedule and refer tit to the Comurission for approval.

It is so ORDERED.

For the Comunission

JOHN C. HOYEE

Secretary of the Commission

Dated at Rockville, Maryland, this 18th tay of June 1996. 


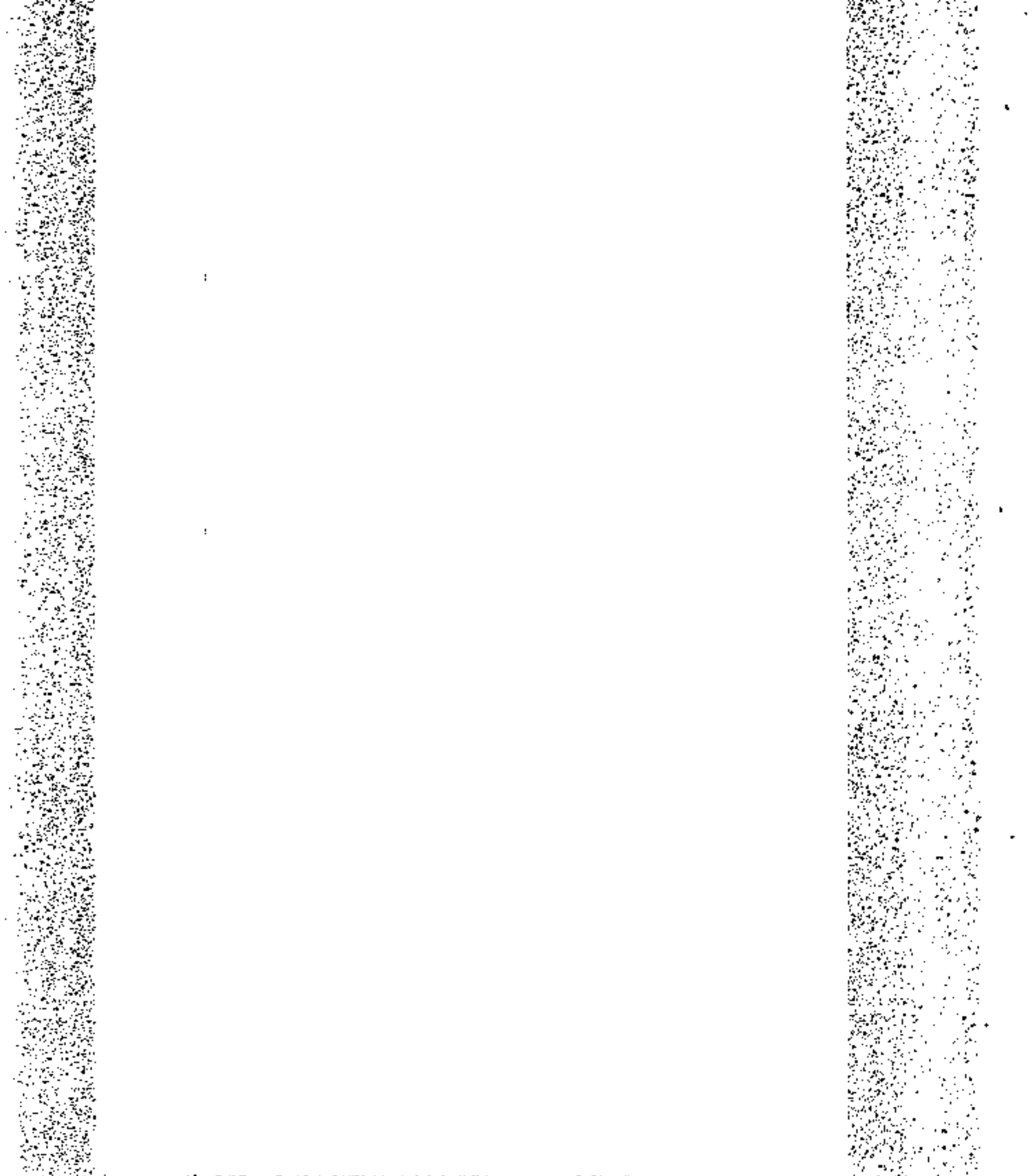

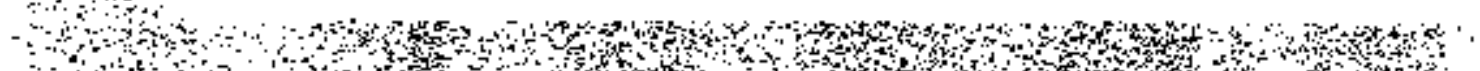
and 
UNITED STATES OF AMERIGA

NUCLEAR REGULATORY COHMISSION

\section{ATONGC SAFETY AND LICENSANG BOARD}

Before Adminlatrelive Judges:

G. Path Bollwork, Ul, Chairmatn

Dr. Charles N. Kolber

Dr. Richard F. Foster

In the Matter of

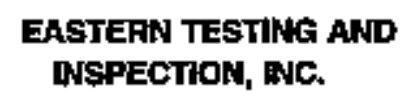

\section{EASTERN TESTING AND} DNSPECTRON, NC.

Docket Nos. 030-05373-EA 090-32163-EA

(ASLEP No. 96-714-02-EA)

(EA 98-495)

(OFder Suspending Byproduct Material License Nos. 29-09814-0t and 29-09814-02)

June 11, 1996

Ruling on a joint request by Licensee Eastero Testing and Inspection, Inte, and the NRC Staff to approve an agreement settling this ticense suspension enforcentent proceeding, the Licensing Board approves the parties' accord and dismisses the case.

\section{RULES OF PRACTICE: SETTLEMENT OF CONTESTED PROCEEDINGS}

As is true with court proceedings requiring juxicial approval of settlements, see, e.8., Evans v. Jeff D., 475 U.S. 717, 727 (1986); Jeff D. v. Andrus, 899 F.2d 753, 758 (9th Cir. 1989); in re Wamer Communications Sec. Litig., 798 F.2d 35, 37 (2d Cir. 1986), a presicing officer does not have the authority to revise the parties' settlement agreement without their consent. A presiding officer thus must accept or reject the settlentent with the provisions proposed by the parties. 


\section{ENFORCEMIENT ACTIONS: SETTLEMENT OF CONTESTED PROCEETINGS (LICENSING BOARD JURISDICTION)}

\section{LICENSING BOARDS: JURISDICTION (SETTLEMENT OF CONTESTED PROCEEDINGS)}

\section{RULES OF PRACTICE: SETTLEMENT OF CONTESTED PROCEETINGS (LICENSING BOARD JURISDICTION)}

When the partes agree to settle an enforcement procededing, the Licensing Board loses jurisdiction over the settiement agreenent once the Board's approval under 10 C.F.R. $\$ 2.203$ becomes final agency action. See Carolina Power and Light Co. (Shearon Harts Nuclear Fower Plant, Ueits 1, 2, 3, and 4), CLI-80. 12. 11 NRC 514, 517 (1980); Philadelphia Electric Co. (Limerick Generating Station, Units 1 and 2), ALAB-726, 17 NRC 755, 757-58 (1983). Thereafter. supervisory authority over such an agreement rests with the Cormmission.

\section{MEMORANDUM AND ORDER \\ (Approving Settlement Agreement and Dismissing Proceeding)}

Pending before the Board is a joint request by Licensee Eastern Texting and Inspection, Inc. (ETI), and the NRC Staff to approye an agreement settling this case. Because we find the settlement agreement consistent with the poublic interest, we approve their accord and terminate this rause.

At issue in this proceeding is the validity of a March 29 , $1996 \mathrm{NRC}$ Staff order that suspended, effecture immediately, two byproduct material licenses held by ETI. See 6I Fed. Reg, 15,836 (1996). The suspended licenses authorized ETI to possess and use iridium-192 and cobalt-60 in a compatuble radiographic exposuse device for pefforming industriat radtography, and cesium-137 and americium241 in specified portable gauges. Is its March 1996 order, the Staff asserted that an immediately effective suspension was necessary because of problems identified during agency inspections and an NRC Office of Invesugations investigation. Cited by Staff in support of the order were purported violations of NRC requirements, some categonzed as delıberate, conceming matters such as training, reconds accuracy, and alleged Licensee threats against a former enployee because of his cooperation with agency inquities.

In filings dated April 1 and 16, 1996, in accordance with 10 C.F.R. \$2.202(b), (c)(2)(i), EII both requested a hearing to contest the Staff's March 1996 order and challenged the Staff's determination to make the license suspensions inuredjately effective. After receiving responses from the Staff, on April 30 , 1996, the Board beld an oral argundent concenning ETT ismediate effectiventess recision request. Thereafter, the Board denied ETT's notion, concluding that

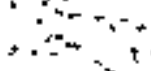

Ex

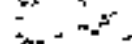

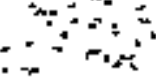

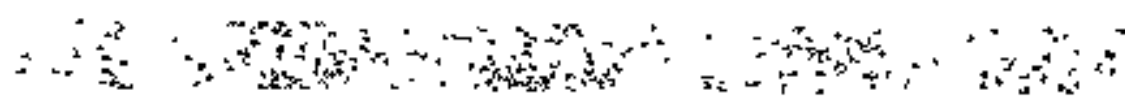

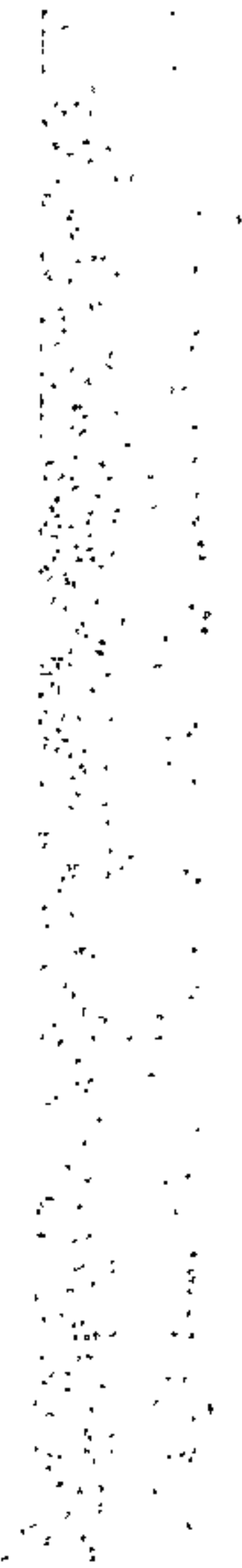


the requisite "adequate evidente" existed for some of Staff's charges and its immedlate effectiveness detersnination. See LBP-96-9, 43 NRC 211 (1996).

Following the April $\mathbf{3 0}$ oral argument, ETI and the Staff began settlement negotiations. To permit negotiations to contime, on May 22 and again on May 28,1996 , the parties requested, and subsequently were granted, extensions to file a Board-ondered joint prehearing report, On June 3, 1996, the parties submitted the joint motion uow pending with the Board. After teviewing the proposed settlement agreement, on June 5, 1996, the Board held a telephone conference with counsel to discuss several points the Board felt needed clarifying. As a result of that conference, on June 6, 1996, the parties submitted a revised settlement agreement.

Under the terms of the revised settlement agreement, prior to resuming NRC-licensed activities ETI must (1) have Staff approve ETT's choice of an experienced, outside, independent anditor who will then be retained as ETr's Radiation Safety Officer (RSO), and (2) have the auditor/RSO make various certifications to the Staff concerning employee qualifications and training as well as the auditor/RSO's knowledge of applicable regalatory requirements and agency concerns relating to ETr's operations. The agreement also provides that the alditor/RSO has the authority and Iesponsibility to stop tnsafe work, make reports to the NRC regardjog any concerns about safety or regulatory compliance and "Whistleblower" harassment, and conduct EIT's training and radiagrapher certification program. In addition, the auditor/RSO is to plan and implement an audit program that will review and suggest improwements in various ETI headquarters and field activities, including training and radiographic operations. Although the various requirements in the agreement could remain in effect as long as the two ETT licenses are extant, the agreement prowides that one year after Board agproval of the agreement the NRC Region I Regional Administrator may grant any ETI request to rescind any of the agretement's provisions. Such recision, which would require a showing of good cause, would be in the sole discretion of the Regional Administrator.

Pursuant to section 81 and subsections (b) and (0) of section 161 of the Atomic Energy Act of 1954, 42 U.S.C. $\$ \$ 211$ \%, 2201(b), (o), and 10 C.F.R. $\$ 2.203$. we have reviewed the parties' revjsed joint settlement accord to determine whether approval of the revised agreement and temination of this procesoling is in the public interest. Based on that review, and acconding due weight to the position of the Staff, we have conciuded that both actions are consonant with 
the public interest. ${ }^{1}$ Accordingly, wh grant the parties' joint motion to approwe the strttlenept agreenent, as revised, and dismiss this procoeding.

For the forogoing reasons, it is, this eleventh day of June 1996, ORDERED that:

1. The June 3, 1996 joint motion of the parties is granted and we approve their June 6, 1996 "Settlement Agreement," which is attached to and incorporated by reference in this Memorandum and Order.

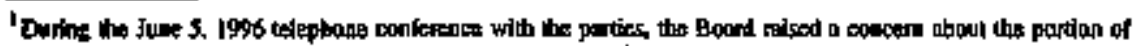

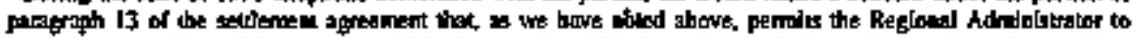

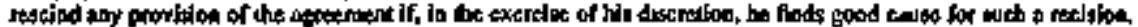

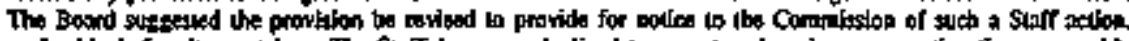

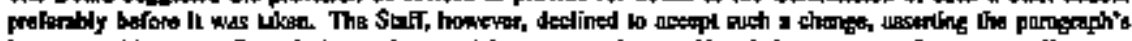

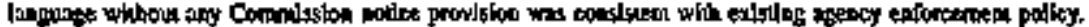

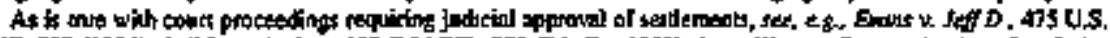

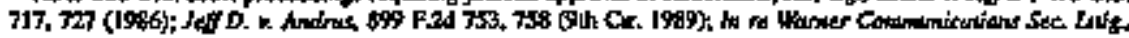

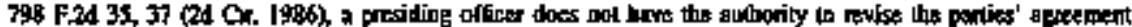

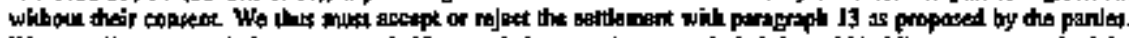

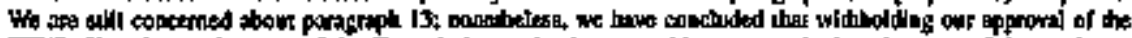

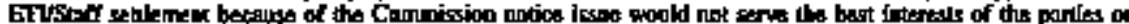

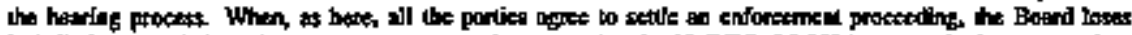

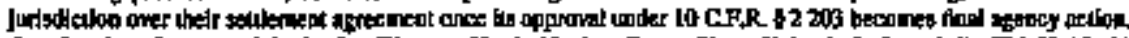

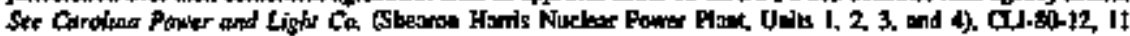

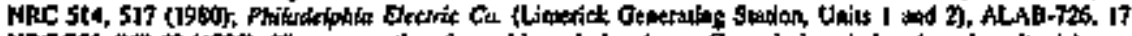

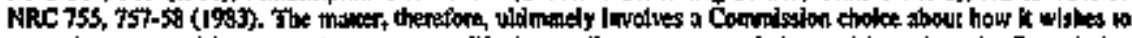

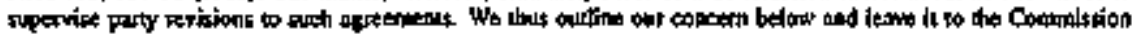

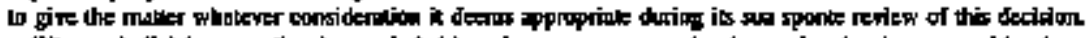

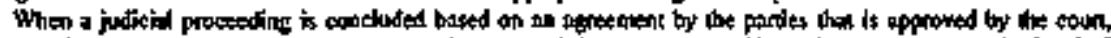

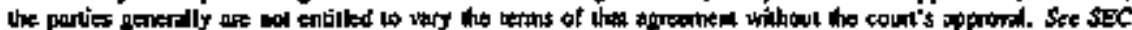

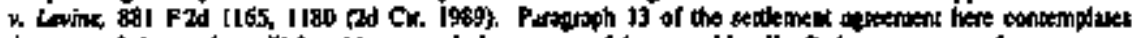

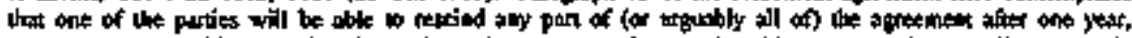

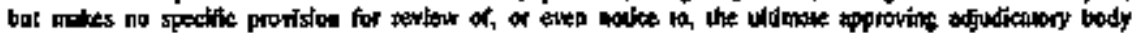

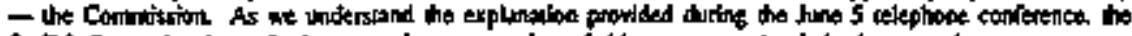

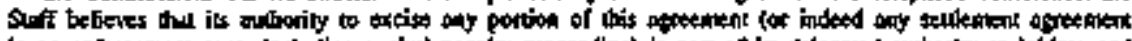

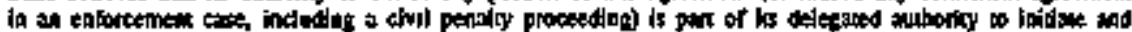

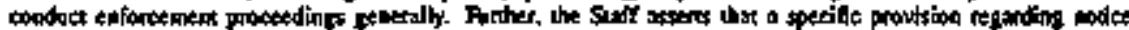

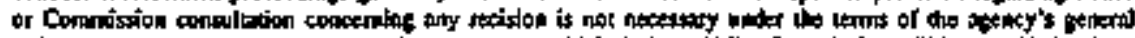

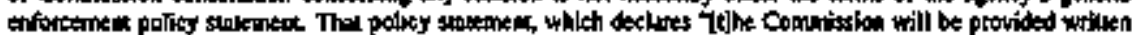

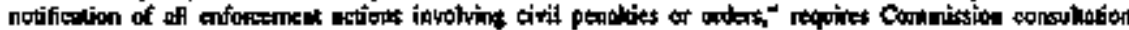

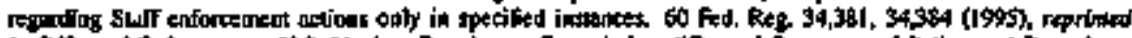

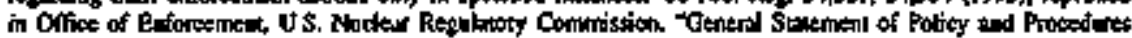

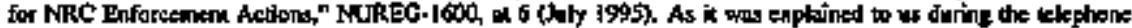

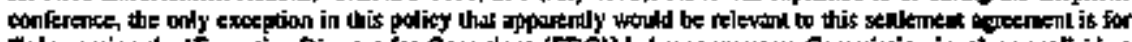

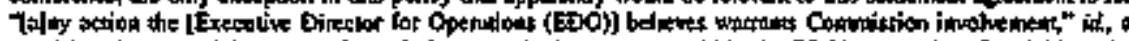

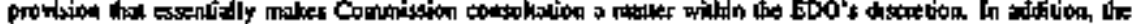

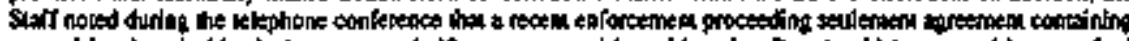

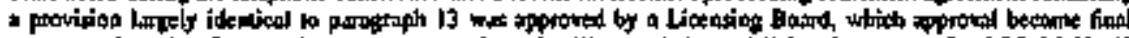

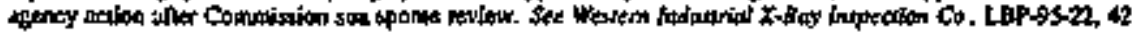
NRC 201, 212-13 (1995) (partopoli 5(k))

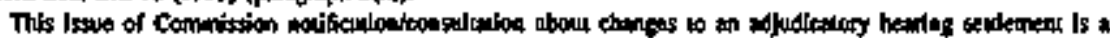

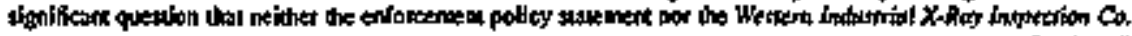
(Conltioded) 
2. This proceeding is dismissed ${ }^{2}$ THE ATOMIC SAFETY AND
LICENSING BOARD

G. Paul Bollwerk, III, Chairman ADMINISTRATIVE JUDGE

Charles N. Kelber

ADMINISTRATTVE JUDGE

Richard F. Foster

ADMINSTRATTVE JUDGE

Rockville, Maryland

June 11, 1996

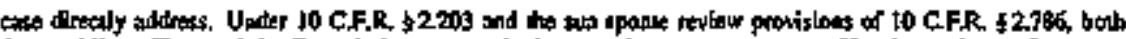

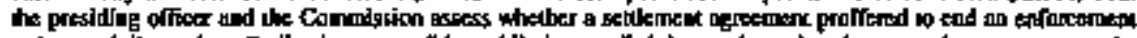

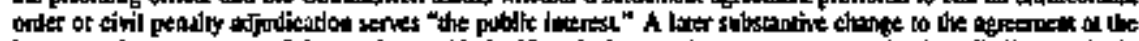

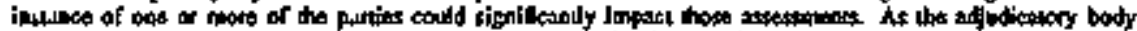

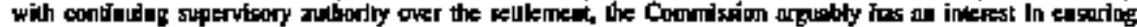

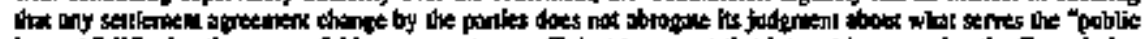

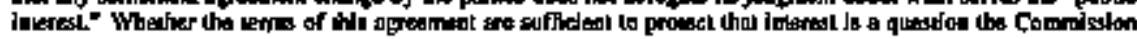
may now trith to copolite.

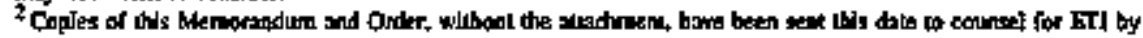

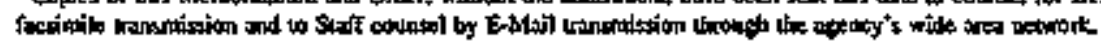




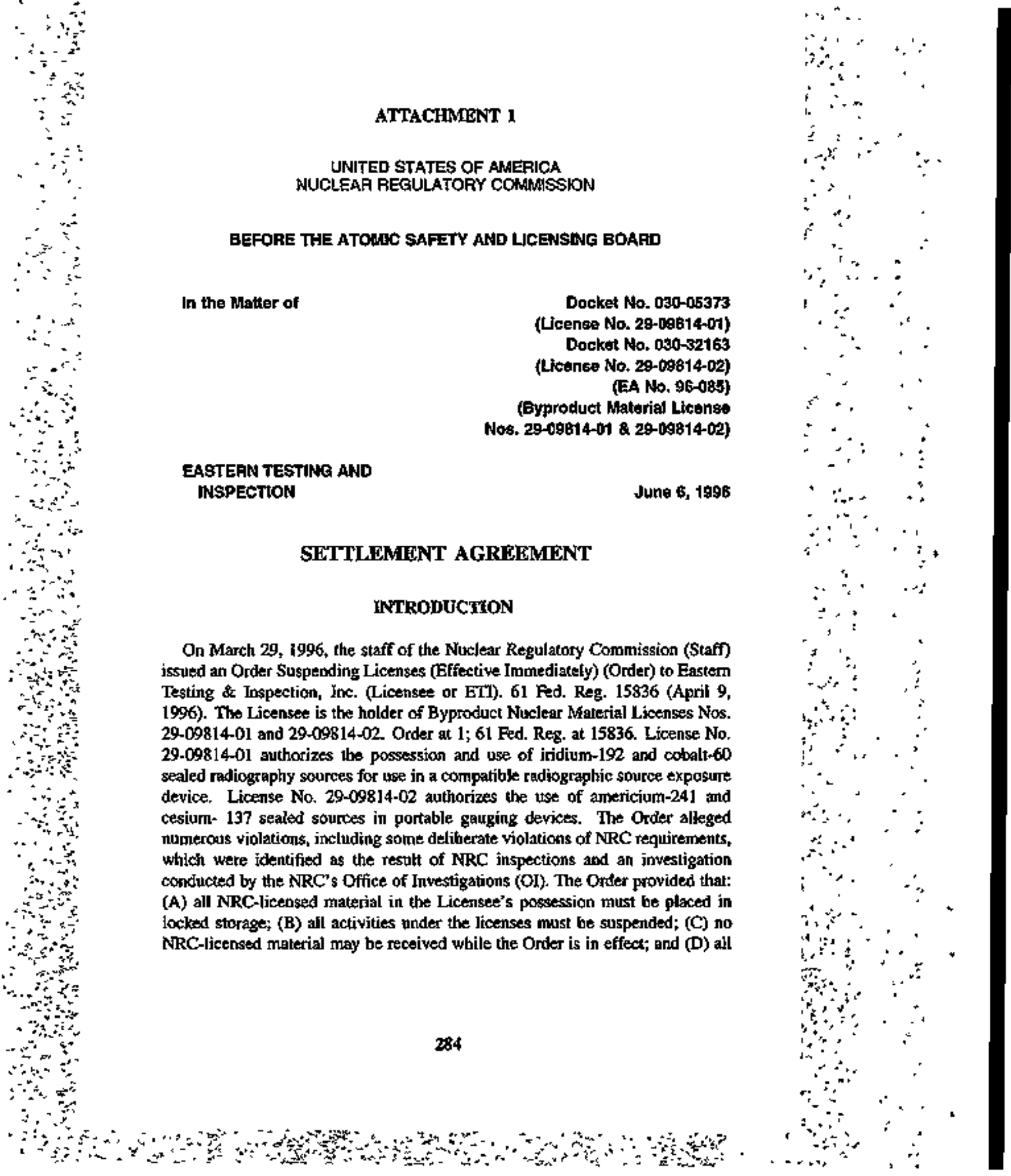


records related to licensed activities must be maistained in their original form and not be tomowed or altered in any way. Order at 8-9, 61 Fed. Reg. at 15838.

By letter dated April 1, 1996, the Licensee requested that the immediate effectiveness of the order be set aside. On April 10, 1996, an Atomic Safety and Licensing Board was established to preside over the proceeding. Eastern Testing and Inspection, Inc,; Establishment of Atanic Safety and Licensing Board, 61 Fed. Reg. 16654 (Apit! 16, 1996). On May 10, 1996, following oral argument, the Board denied the Licensee's request. "Menrorandum and Order (Denying Licensee Motion to Set Aside Immediate Effectiveness), LAP-96-9, May 10, 1996.

On April 16, 1996, the Licensee reyuested a hearing on the Order. "Eastern Testing and Inspection, Inc.'s Demand for a Hearing on Order Suspending Licenses." On May 2, 1996, the Licensee submitted its answer to the Order (Answer). "Eastern Testing and Inspection, Inc.'s Answer to Order Suspending Licenses (Effective Immediately)." In its Answer, the Licensee adinitted certain of the allegations in the Order and denied the remainder. Specifically, the Licensee deried any deliberate misconduct by its President and Radiation Safely Officer (RSO) as alleged in the Order.

The Staff and the Licensee agree that it is in their respective inleresis and in the public interest to settle this enforcement action without further litigation and agree to the following terms and conoitions:

1. Prior to resumption of NRC-licensed activities:

a) In addition to implementing the correclive actions identfied in its Answer dated May 2, 1996 to the March 29, 1996 Order, ETI agrees wo submit to the NRC for approval, the name of an experienced outside independent auditor who also can qualify as the Corporate Radistion Safety Officer. The NRC staff will review and approve the auditor based on the auditor's qualifications. Upon NRC approval of the auditor, ETI will retain that individual.

b) The auditor will (1) review the qualifications of all employees who perform NRC-licensed activities for ET, (2) contuct or supervise any additional training needed, and (3) test, in the area of radiation safety, each employee who performs NRC-licensed activities $t o$ assure that the employee is qualified, consistent with the training provisions of $t$ ( C.F.R. Part 34 and the license, to act as a radiograplber, radiographer's assistant, or gauge operator. The auditor will certify to the NRC completion of this step before each individual may resume performance of NRC-licensed activities.

c) The independent auditor will certify to the NRC that he or she has read and understands the concerns of the NRC expressed in the Order of March 29, 1996, the Inspection Reports issued April 22, 1996, the terms and conditions of this Settlement Agreernent, the applicable NRC regulations, and ETI's license requirements, and understands that he or ste unay be held personally accountable 
for any violations of NRC regulations or ETI ticenses pursuant to 10 C.F.R. $\$ 30.10$.

2. The auditor will make findings and recontmendations based upon his or her own discretion and professional judgment in any area of ETI licensed operations, including, bat pot limited to: ETI management oversight, procedures, radiographer training, testing, and qualífications, recordkeeping, field operations and audits.

3. The auditor has the authority and obligation under this Settlement Agreement w:

a) stop work on any opecation that is unsafe or which either violates ETT's licenses, applicable NRC regulations, or the provisions of this Settlement Agreernent;

b) Inake requited reports to the NRC and report to NRC any concens relating to safety or compliance with NRC requirements, ET1's licenses, or this Setrlentent Agreemenh, if ETI is not taking prompt and appropriate corrective action as required; and

c) report to the NRC any interference by ETI management or employees with his or ber duties and obligations pursuant to this Settlement Agreement or the proper conduet of NRC-licensed activities by any ETI employee.

4. The auditor shall implement the following audit program:

a) Phase One. The auditor will subnit an audit plan for NRC approval trithin 30 days of approval of this agrement by the Atomic Safely and Liceasing Board, describing the audit scope and methodology, including but not limited to performing a check on equipment and storage practices, including radiationproduction devices and monitoring devices, qualifications of staff, training, field audits of radiographers' performanto, and reviewing selected ETI recorits to verify compliance with ETI's radiation safety program. Within 30 days of approval of the audit plan, the auditor will commence the audit. The auditor thereafter will prepare a report on these activities, which he or ste will provide to the NRC Staff and to ETI in a timely manner, but within 30 days of the completion of the audit. Within 30 days of receipt of the auditor's report, or at some other mutually agreeable timte, ETI will notify the NRC \$taff in writing concerning the status of any corrective actions as a result of the auditor's findings, including an explanation of and justification for any recommendations by the auditor that will not be addressed in ETI's corrective actions.

b) Phase Two: Within three months after completion of Phase One activities and at quarterly intervals thereafter, the anditor will perform unannounced field andits of radiographic operations and each radiographer $\alpha$ radiographer"s assistant, at various ETI job sites consistent with the NRC-approved audit plan. Within $\mathbf{3 0}$ days of completion of these audits, the auditor will report his or her findings to ETI and the NRC Staff. Within thrty days following receipt of the auditor's report, or at some other mutually agreeable time, EII will notify the

$\therefore \therefore$

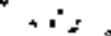

$\overline{-1}-a^{2}$

$\therefore$ 手,

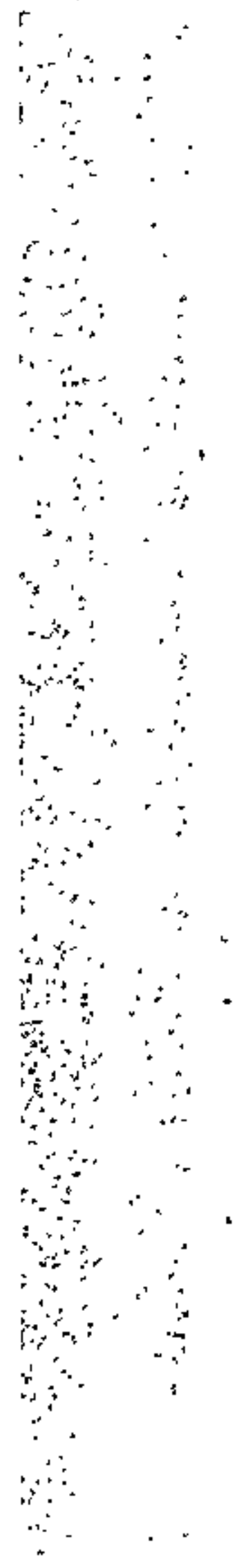


NRC Staff in writing concerning the status of any comective actions as a result of the auditor's findings.

5. The auditor will act as the "Corporate Radiation Safety Officer," on NRC license 29-09814-01, with the following dulits and obligations:

a) be responsible, at all bimes, for the training, qualification, and testing of all individuals performing NRC-licensed activities, including, but not lintred to, radiographers and radiographer's assistants;

b) will certify to the NRC Staff that he or she has personally attended any and all training sessions and that the required subject matter was adequately covered, that any tests giwen at the training session were appropriately monitored and graded, that the individuals attending the training were present during the entite time of training, and that the individuals who attended the training were approprialely trained for his or her daties in accordance with NRC regulations and license requirements;

c) will verify and certify to the NRC, on a quarterly basis, that all utilization logs are accurate and complete; and

d) oot take direction on any compliance issue or radiation safety matter from any officer or employee of ETI.

6. In addition to the Corporate Radiation Safety Officer, prior to the cortmencement of NRC-licensed activities, ETI will propose an assistant Radiation Safety Officer, who must also be approved by the NRC Staff. The assistant Radiation Safety Officer shall:

a) be responsible for the day-to-day performance of the duties of a radiation safery officer as described in ETI's License No. 29-09814-0I procedures;

b) have the authority to stop work on any operstions that are unsafe and or which will violate ETI's licenses. NRC regulations, or this Setelement Agreement;

c) report to the NRC any interference by ETI management or employess with his or her duties and obligations pursuant to this Settlement Agreement or the proper conduct of NRC-licensed activities by any ETI employee;

d) report directly to the Corporate Radiation Safety Officer; and

e) not take direction on any compliance issue or radjation safety matter from any supervisor at ETI other than the Corporate Radiation Safety Officer.

7. ETI also agrees to inform all employees, including radiographers and radiographer's assistants, of the terms and conditions of this Settlement Agreement, the terms and conditions of ETI's licenses, and the applicable NRC Regvlations. ETT specifically agrees to inform, in writing, its employees of the requirements of 10 C.F.R \$34.44. "Supervision of radiographer's assistants" and to require employees to certify that they have read these requinentents and provide to the NRC Staff each employes's certification.

8. ETI agrees to ensure the cooperation of tis officers and employees with the anditor, the Corporate Radiation Safecy Officer, and the assistant Radtalion 
Safety Officer, and will provide these individuals upon request with access to

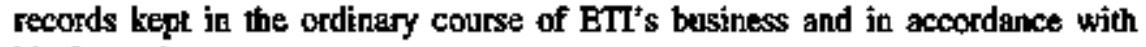
NRC requirements.

9. To ensure his or her independence from ETI, the auditor will not be an employe of ETI and will bave no financial interest in ETI. Except as provided in this Settlement Agreement, nothing in this Settlement Agreement will be construed to provide the auditor with any tegal anthority to bind ETI with respect to any matter relating to ETI's NRC-licensed activities, and forther, the auditor will not tepresent ETT's interest to the NRC or other authority.

10. ETI will also propose and obtain approval of a new Radiation Safery Officer for License No. 29-09814-02 prior to conducting activities under that license. The new Radiation Safety Officer may be the same individual named on License No. 29-09814-01 as the assistant Radiation Safety Officer.

11. Upon the resumption of NRC-licensed activities, ETI will, at the start of each work week, provide, in writing, the NRC Region I Staff and the auditor, with its work schedule for the week. The notification shall include the name of the customer, the schedule of work hours and location of the work. If there are any changes to this schedule. ETI will make its best effort to inform NRC Region I stoff and the auditor at least 24 hours in advance, if possible. These submissions may be made by facsinile. Notification to the NRC shall be made to Frank Costello, Region I, 610-337-5275; FAX: 610-337-5269.

12. ETI agress that its President, Himat J. Sonj and the current Rakiation Safety Officer named on License No. 29-09814-01, Joseph Radtali, will not be involved in the supervision of NRC-licensed artivities or ETT's radiation safety program. However, Messrs. Soni and Badiati may perform the duties of radiographer and supervise radiographers' assistants as part of those duties. In atdition, Messrs. Soni and badiali may be involved in other business activities of ETI, including marketing, record keeping and technical training exciusive of radiation safety.

13. For good cause shown, the Staff may, in writing, extend the time to complete any action set forth in any provision of this Setlement Agreement. No earlier than one year from the date this Settlement Agreement is approved by the Acomic Safety and Licensing Board, ETI may request that the NRC Regional Administrator, Region I, rescind any of the provisions of this Settlement Agreenent upon a demonstration of good cause. The decision as to good cause is in the sole discretion of the NRC Regional Adminissator, Region I.

14. The NRC Staff agrees to withdraw the Onder dated March 29, 1996. ETI agrees that a failvre on its part to conlyly with the terms of this Setterment Agreement will constitute a material breach of this Agreenent, and that any such breach may result in the revocation or suspension of the linensse, effectivo inmmodiately, if the NRC Staff, to its sole discretion, determines such action 
to be appropriate, and may result in further enforcement $\alpha$ other action as the NRC Staff may determine, in its sole discretion, to be appropriate.

15. ETI agres to withdraw its demand for a hearing dated April 16, 1996. The Staff expects that good fatth implementation of this Settlement Agreement should resolve the concerns stated in the March 29, 1996 Order. Nothing in this Settlement Agreenent pretudes the NRC Staff from taking additional regulatory action if warranted. The Staff and ETI agree and understand that this Settlement Agreement is only binding on the NRC and ETI and only relates to NRC's March 29, 1996 Order. This Settlement Agreement shall not be relied upon by any person or other entity as proof or evideace of any of the matiers set forth in the Order.

16. This Settlement Agrcement shall be binding upon the legat representatives, successors and assigns of each of the parties hereto.

17. The Staff and EII shall jointly move the Atomic Safety and Licensing Board designated in the above-captioned proceeding for an order approving this Settlentent Agreement and terminating this proceeding.

In Witness Whereof, the parties have caused this Settlement Agreement to be executed by their avthorized representatives.

\section{FOR EASTERN TESTING AND INSPECTION FOR THE NRC STAFP}

Himat J. Soni

Presiden

Eastern Testıng and Inspection, Inc.
Marian L. Zobler

Richard G. Bachmana

Counsel for NRC Staff

Daniel F. Stenger

Robert E. Helfrich

Counsel for Eastern Testing

and Inspection, Inc.

Dated at Rockville, Maryland, this 6th day of June 1996. 


\title{
UNITED STATES OF AMERICA \\ NUCLEAR AEGULATORY COMMISSION
}

\section{ATONIC SAFETY AND LKENSWNG BOAAD}

Belore Administrative Judges;

\author{
James P. Gleason, Presicling Ofticer \\ Jerry R. Kilne, Special Asslsiant
}

In the Melter of

Docket No. 10-8027-MLA-3

(ASLEP No. 94-700-04-HLA-3)

(Source Materlals LIcense

No. SUe-1010)

\section{SEQUOYAH FUELS CORPORATION}

June 21, 1996

In this Dectision, the Presiding Officer finds that Intervenors fail to prove deficiencies in a management reorganization and sustains a \$taft issuance of a license anendment for that punpose.

\section{INITIAL DECISION \\ (License Amendment Appliention)}

This opinion concerns challenges to a materials license amendment application of the Sequoyah Fuels Corporation (SFC), a Neclear Regulatory Commission (NRC) Licenses. Pursuant to NRC's regolations, the applicant is involved in the development of a decommissioning program at its facility in Gore, Oklahoma

For reasons set forth below, the Presiding Officer finds no justitication for determining that Licensee's proposed amendment should be disapproved. 


\section{BACKGROUND}

On May 6, 1994, the License submitted an application for amending its materials license to effect administrative organizational changes. Allegedly, the changes are designed to reassign management responsibility for SFC's reduced and limited decommissioning activities. Native Americans for a Clean Enviromment and the Cheroke Nation (Intervenors) petitioned the NRC for a hearing which was granted under the agency's Subpart $\mathbf{L}$ informal hearing procedures.' The NRC Staft elected not to participate in the case, and as required by 10 C.F.R. \$ 2.1231, submitted a hearing file, with updates, of relevant documents in the proceeding. ${ }^{2}$ The Licensee revised its amendunent application on November 23, 1994, and March 3, 1995. ${ }^{3}$ It several pleadings, Intervenors submitted a number of areas of concern of the proposed organizational changes. and the Presiding Officer recognized six as germane to the subject matter of the proceeding." The Intervenors contend that these concerns or issues demonstrate that the proposed amendment is deficient in the following areas:

1. Management and supervision of contractors.

2. Oversight of reporting requirements on safezy and environmental work.

3. Qualifications of bealth and environmental protection positions.

4. Description of critical safety and environnatental functions.

5. Compliance with regulatory timing requirements in decommissioning.

6. Quality assurance program.

In addition to the issues above, Intervenors presented legal argoments that SFC has violated provisions of the Atomic Energy Act (Act) and NRC's regolations. It contends that these violations resulted from SFC implementing the changes requested in its licconse amendment applicalion prior to filing the amtendment itself.

\section{LEGAL STANDARDS}

There are general zules applicatile to informal sdjudications under the Conmission's Subpart L regulations. These regulations govern the proceduse intitated by a request for a bearing in a proceeding for the grant, transfer, renewal, or amendment of a materials license subject to Parts 30, 32 through 35, 39, 40, or 70. See 10 C.F.R. \$2.1201(a).

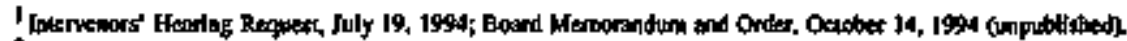

${ }^{2}$ Letiess, Hon to Geasen, Seporiber 6, 1994, Novernber 10, 1994, and Febniry 24. 1996

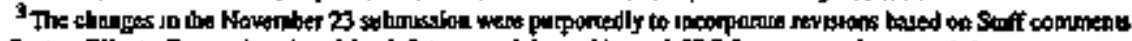

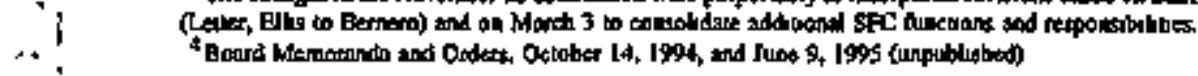

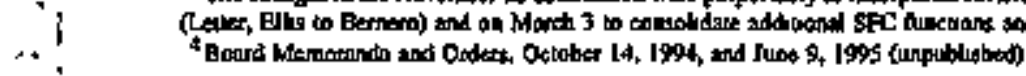
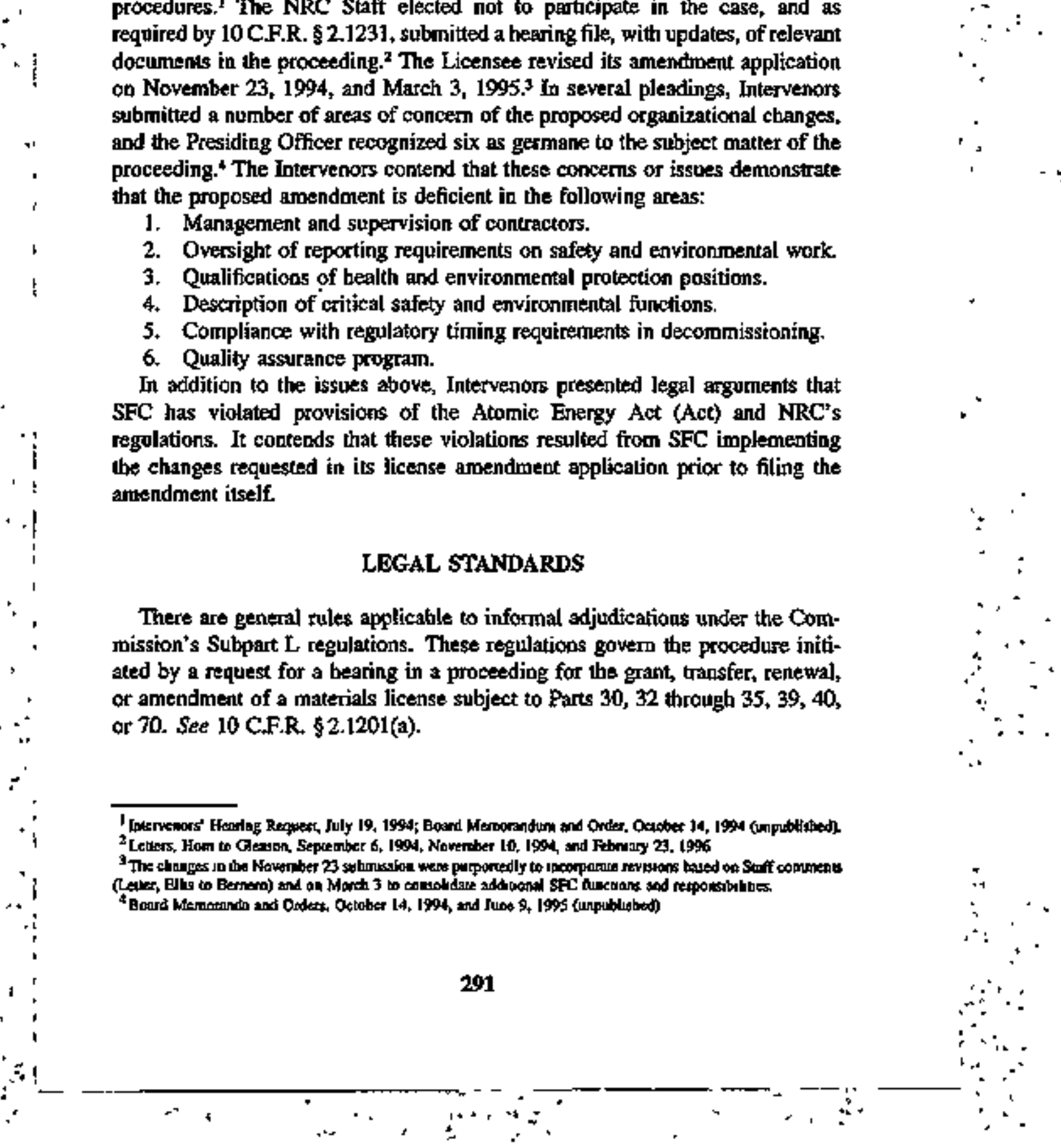
Any person whose interest may be affected by a proceeding under Subpart L may file a request for bearing. 10 C.F.R. \& 2.1205 \{a). However, a reguest for a hearing filed by a person other than the licensee must describe in detail " $[t]$ he requester's areas of concem about the licensing activity that is the subject matter of the proceeding." 10 C.F.R. \& 2.120S(d)(3). In ruling on a request for a hearing, the Presiding Officer "shall determine that the specified areas of concern are germane to the subject matter of the proceeding." 10 C.F.R. $\$ 2.1205(\mathrm{~g})$. The petition to intervene must be ruled upon, taking into account matters set forth in section 2.1205(g). 10 C.F.R \$2.1203(j)(3). An order granting a request for a hearing or petition for leave to intervene may condition or limit participation in the interest of avoiding repetitiwe factual presentations and argunent. 10 C.F.R. 8 2.1205(m). The Presiding Officer has the duty to conduct a fair and impartial hearing according to law and has all powers necessary to regulate the course of the hearing and the conduct of the participants. 10 C.F.R. \$2.1209(a).

In the Order of Oetober 14, 1994, which granted Intervenors' hearing request, and the Order of June 9, 1995, the Presiding Officer limited the seope of the heariog and specifically set forth the areas of concem which the parties subsequensiy supported or opposed in written presentations. ${ }^{5}$

On February 23 of this year, the Staff accepted the license annendmeat, and the organizational changes proposed by SFC were authorized. See \$taff Letter updating file, February 23, 1996.

The relevant arguments in support of the parties' postions, and the decisions by the Prestding Officer with respect to them, are set forth below. ${ }^{6}$

\section{DISCUSSION}

\section{Management and Sopervision of Contractors}

Interwenors contend that SFC's prelımınary plan for conpletion of deconmissioning (PPCD), as submitted to the NRC, reflects that private contractors would be utilized for major decommissioning projects. However, no information was presented in either the PPCD or the current amendment application on the nature of the work to be performed or the management systemss required to provide information on contractor performance. A reduction in SFC personnel

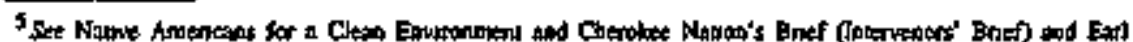

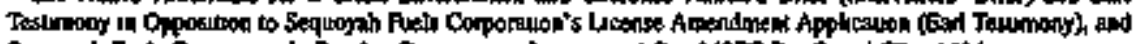

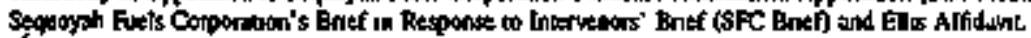

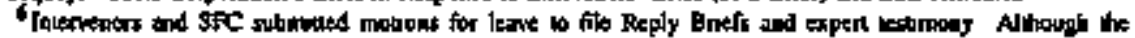

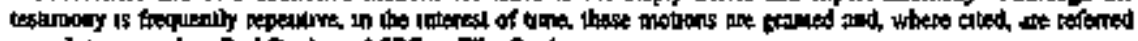

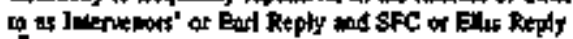

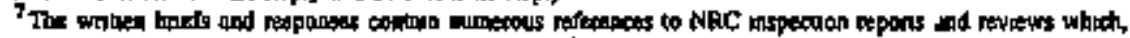

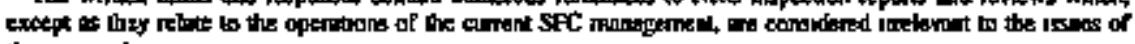
thes proseding
} 
and the magnitude of the work to be undertaken suggest, in Intervenors' view, that SFC will rely beavily on contractors in decommissioning. See Intervenors' Brief at 17; Ear Testimony at 29-32.

The Licenset responds that SFC is not relying extensively on contractors, with their use being Iimited to activities customarily performed at the facility, such as cousulting, land surveying, well drilling, and fertilizer distribution, See SFC Brief at 18; Ellis Afbidsvit at 8, 14-15.

Intervenors argue, in reply, that SFC provides no evidence that its management structure is adequats to supervise existing levels of contractors, let alone any increase, and that its PPCD provites illustrations of "weak" project planning capabilities, such as not providing a breakdown of contractor tasks, number of contractors required, and supervistion information. They also conteod that prior inspection Jeports show a lack of strong project planning tfforts. See Earl Reply at 16-17.

\section{Decision}

SFC's application makes no reference to the utilization, supervision, or responsibilities of private contractors. See License Application, Hearing Fila. No judgenent can be made on the basis of the facts in evidence that the anendment raises a deficiency at this point in SFC's decombissioning mode. The proposed amendment is intended to reassign basic responsibilities among a fewer number of employees for performing a diminjshing mumber of activities pending the subrnission of the Licensee's final deconrmissioning completion plan. The allegations of Interventors conceming the responsibijity of managenent in monitoring private contractor work at the site nay be validated during future decommissioning operations at the facility. However, no conclusion may be reached now concerning such a happenstance. The Licensee has testified, without challenge, that the role of contractors at the present time is linsted to routine activities. Not demonstrating a regulatory necessity for referencing the utilization of private contractors in SFC's ongoing work, the issue misust be resolved in the Licensee's favor.

\section{Oversight of Reparting Reguirements on Safety and Euvironmental Work}

Intervenots allege that, in the proposed amendment, SFC's Director of Regulatory Affairs assumes responsibility for the quality assurance ( $Q A)$ furction over the Heatth, Safety, and Environmental deparonents. This, it contends, presents a conflict of interest with the Director having audit duties over operations in departments he regularly supervises. See Earl Testimony at 50-51.
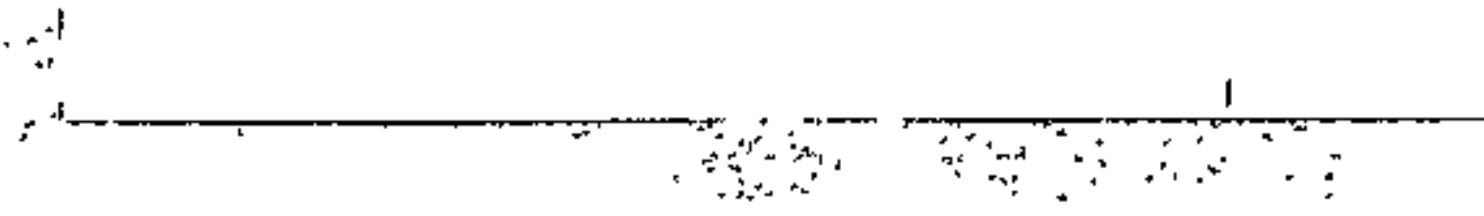
SFC answers that the Director of Regulatory Affairs has been responsible for the auditing function prior to the amendmen under consideration. It contends that section 2.8 of the proposed changes protects aganst any conflict by having General Atomics (GA) perfomm audits of operations under the Director's jurisdiction. And to provide further protection against conflicts, the Director is enthorized to provide additional audits by independent sources if needed. See Ellis Affidavit at 22-23. Intervenors argue, in rebuttal, that a conflict is presented by the Director having authonty to decide whether an audut will, in fact, take place and to determine the areas to be audited. See Earl Reply at 27-28.

\section{Deciston}

The Licensee has instituted an audit procedure that insulates the Director, Regulatory Affairs, against conflicts by providing a penodic audit by $G$ A with additional audits to be performed by ontside soprces as requested. It is evident that when such audits occur, they will not be perforated by individuals supervised by the Director. That is the dividing line that immunizes against the type of contict envisioned by the Intervenors' concem. No grounds exist here to justify disapproval of the license amendment.

\section{Qualificitions of Fealth and Envirommental Protection Positions}

Intervenors allege that a "high twrover" in SFC personnel and inereased "celiance" on contractors cals for a premium to be placed on training requirements but that the positon responsible for managing and certufyong training, the Technical Traning Coordinator, is beng elintinated by the proposed amentment. Further, the sole duty of the Manager, Health and Safety, to whom training duties are being transferred, appears to be one of meroly documenting that adequate training bas been conducted. Additionilly, Intervenors claum, the Managet's predecessor had to have 3 years of experience in tranoing and development but none is required of the Manager. See Earl Testimony at 51-52.

The Lrcensee avers that training requirements at its facility have been redaced with fewer staff on board and also somplified with fewer casks, with training basically linited to radiation protection and indistrial safery. On the question of experience, the Manager, Health and Safety, has helped develop the current training program - rated a "programmatic strength" by the NRC in 1994 - and conducted several traning courses at the facility. Also, Licensee asserts, the Mansger has a Masters degree in health physics with 8 years of industrial experience in the field. Finally, it notes, the training program is the Manager's responsibility, and his documentation of course completion is adequate certufication that it has been conducted, See Ellis Affidavit at 23-24.
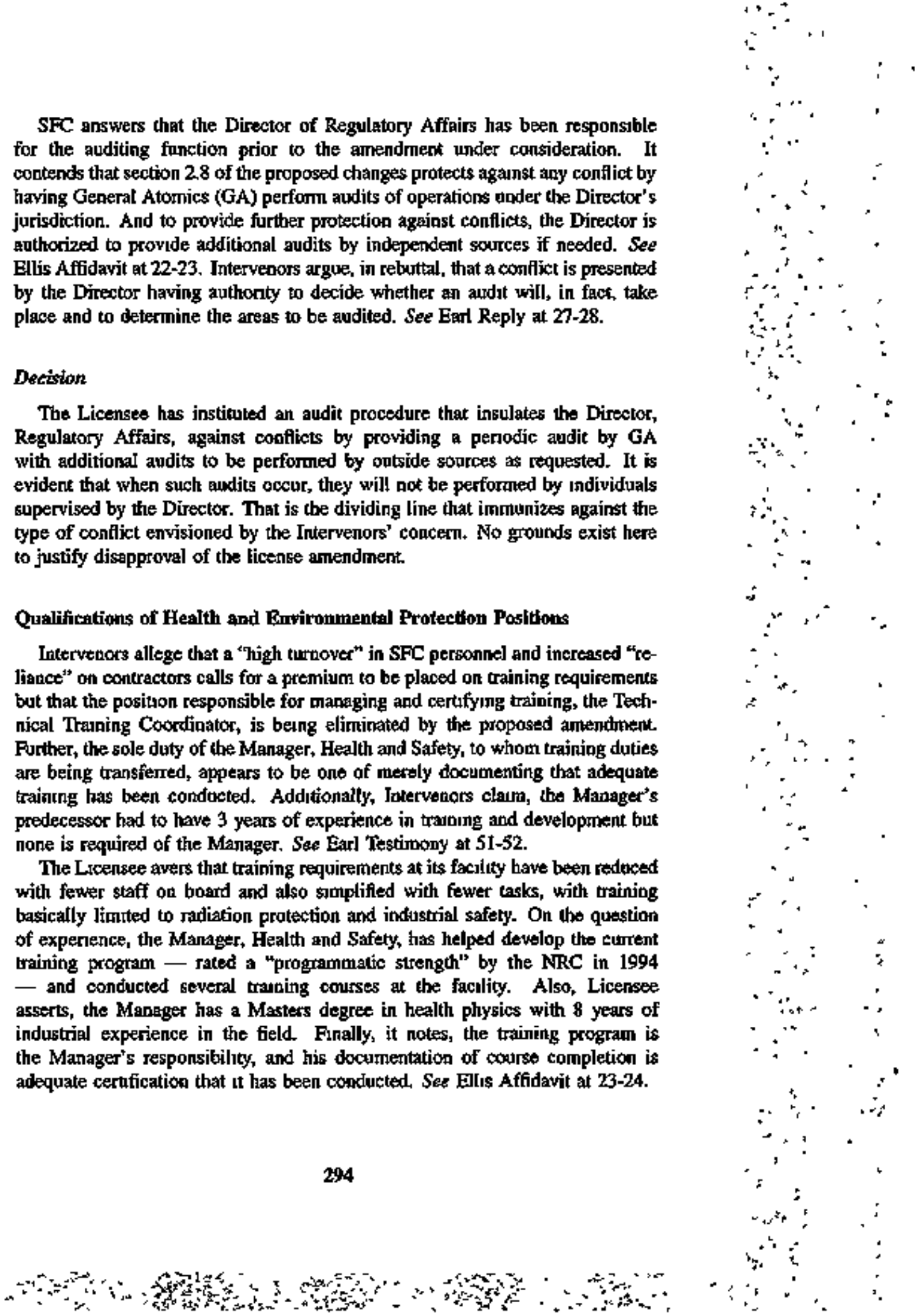
Intervepors contend that havicg fewer enployees does not require less of a training effort and, although no obligation exists that a certificate of training completion be issued, SFC's license does require that the training be certified. See Earl Reply at 14-15, 28-29.

\section{Decision}

With respect to an alleged intappropriate reduction in the quallfications of these positions, the facts verify that the position of Tratning Coordinator has been abolished in the proposed license amendment and the responsibilities of that position transferred to the Managet, Healtin and Safety. It is uncontested that the incumbent of that position has an exceptional training background and has previously conducted training courses. We do not subscribe to the Intervenors" proposition that, even with substantiatly fewer employees, the same level of training resources are required, nor do we, in light of the limited activities to be performed, evaluate the training requirements to be imposed here as burdensome or complicated. Certainly, they are far less than the period when SFC was in an operating mode. Accordingly, it cant ot be said on the basis of the evidence, that there is a deficiency in training requirements called for by the license anendment or that the Intervenors have successfully carried the argument on an inappropriste reduction in qualifications bere. The Presiding Officer finds that the Licensee has carried its burden of proof on this issue.

\section{Description of Critical Salety and Environmental Functions}

Interweroms allege that a number of safery and environmental functions have incomplete and unclear descriptions in the proposed amendment. These involve staff positions responsible for audits, a mumber of unlisted manager positions under the Director, Decontamination and Decommissioning (Director, D\&D), unauthorized positions on the Plant Safety Review Commiltee (PRC), and designee to act as Chairman of that committee, and a Project Supervisor, a safery-related position, whose description, qualifications, and line of support are unspecified. The testimony cites Regulatory Guide $3.55, \$ 2.2$, as requiring license applicants to describe minimura requirements for safety-related positions. See Inter venors' Brief at 15, 17-18; Earl Testimony at 52-56.

The Licensee claims that, in view of the limited nature of authorized decommissioning activitits under the license, only the Director, D\&D, is requited to handle that position's responsibilities, and no plan is contemplated to employ additional managers. SFC states that the PRC is composed of senior facility managers with safety roles, but the President, who has overall responsibility for the plant's safe operation, is being provided the authority to 
make additional assignmients if assistance is required by the Combrittet. The license assigns autionty to the President to fill safety-related positions. The word "designee" was added by the arnendment to provide someone to fill the role of Chairman in the President's absence. And the Project Supervisor is a position canrying no safety responsibitities. See Ellis Affidavit at 24-26. Funally, SFC states that Regulatory Guide $\mathbf{3 . 5 5}$ is guidance only, and is written for operating facilities seeking license renewal.

Intervenors argee that the workdoad of the Director, $D \& D$, is too heavy for a single person and the Licensee has fatiled to provide enough information tegarding the respensibjititits of that office and bow its duties woold be distrituted among subordinates. Also, SFC provides no justiflcation for the President's proposed atthority to appoint additional members to the PRC even though they bold no safety-rejated position. Additionally, the current license does not permit the President to appoint some nonmeraber of the PRC to serve in bis place as Chairman. And finally, it is stated that, since the SFC testimony lists for the first time the Chief Executive Officer as part of SFC's management organizalion, the responsibilities and reiationship of that office to otber positions should be described in the application. See Earl Reply at 30-31; also, Ellis Afadavit at 5:

In reply, SFC states that the purpose for referring to the Chief Executive Officer was to identify the number of employees on SFC's payroll and not to indicate that the position has safety-rejated responsibilities, which it does not. By providing for a "designee" to be appointed to the PRC, the amendment was merely attempting to clarify the wording on the license, which is silent on who may serve as Chairman in the President's absence. The Licensee argues that the President, who is responsible for the overall safety of the plant, should have the authority to select additional members for the PRC as well as designate soneone to act as Chairman in his absence. See Ellis Affidarit at 6.

\section{Deciston}

Intervenors' allegations challenging the descriphion of critical safety and environmental functsons embrace a number of assumptions, the validity of which has been vitiated by SFC's responses. No subordinate employees are intended to belp canry out the responsibilittes of the Ditector, $D \& D$; the Chief Executive Officer position is not safety-related; the necessity of having someone preside as Chatratan of the PRC in the President's absence requires some indication of that intention in the license; and finally, it cannot be stccessfully averred that the Presideat of the corporation who earries ultimate responsibility for the safety

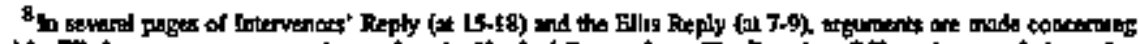

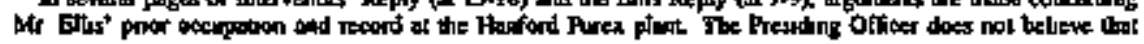

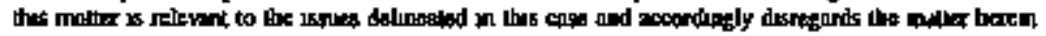

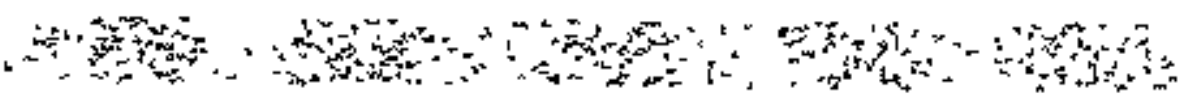


of the facility should be unable to make additional appoinuments whenever the PRC - which serves an important function - may need specialized assistance. The Licensee prevails on this issue.

\section{Compliance with Regulatory Tining Requirements in Decommissioning}

Intervenors state that Commission rules require the submittal of the Licensee's final decomenissioning plan by September 15, 1995, and, unless a schedule change is requested and approved, the contpletion of decomntissioning within 2 years of approval of the decontnissioning plan. The contention is that SFC neither requested nor had approved a decomnissioning schedole extension. As a conseguence, Licensee's proposed management and organizational structure will be inadeguate to meet decommissioning deadlines and the schedule for completion of decommissioning will be delayed.

According to Intervenors, the Timeliness-in-Decommissioning Rule (10 C.F.R. \$ 40,42) injects considerations of titise and efficiency into the agency's evaluation process. Except for NRC appoval of SFC submitting its site characterization plan (SCP) late to conforn to an Envitonmental Protection Agency (EPA) schedule date, the argument is that there has been no approval of any other time change in the decommissioning schedple. Intervenors argue that SFC is already 2 years behiod the Timeliness-in-Decommissioning Rule date.

Related to this conteution, Intervenors assert that an efficient and effective ofganization requires full-time directors and managers in key positions. However, SFC's application does not provide essential information for the assessment of time buritens imposed on key safety positions. Instead, it appears that SFC is assigning one of its most critical positions, Director, D\&D, to part-time stalus.' Due to the large workload and responsibilities of that position, where four positions with substantial duties have been combinsd into one, it is inappropriate, in Intervenors' vjew, to treat that position as part-time. Its employouent status, whether full- $\alpha$ part-time, should be set forth explicitly in the license application.

Intervenors also contend that substantial responsibilities of several other functions have been consolidated in the new pastion of Manager, Health and Safety. This, withont apparene consideration of whether the worklosd can be handled in a timely manner. This position, among other duties, they assert, carries training program responsibilities, the effective performance of which is nhelear dise to the lack of demonstrated training experience. Consequently, Intervenors conclude, the Licensee's amendment fails to demonstrate that its

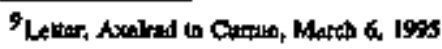


Licensee's Reply restales that, despile Intervenors' claim to the contrary, NRC bas approved a change in its decommissioning schedule. The brief argues that po regulatory requirement exists on specifying full- versus parttime employment, but the performance of functions of safecy-related positions by qualified individuals is required, and that satisfyitg such a requitement can only be confirtned by NRC utspections. See Licensee Reply Brtef at 3-4; Ellis Reply Afficavit at 14, 5 .

\section{Decision}

The arguments alleging noncompliance with regulatory decommissionting timing requirements are confusing and seemingly disparate. Summarized, they can be stated as follows:

1. SFC has not had an NRC officially approved schedule extension change to complete decommissioning although the agency, in fact, endorsed a change by not tinely approving an SFC draft SCP.

2. SFC violates 10 C.F.R. $\$ 40.42(f)(4)(j v)^{\text {to }}$ in its proposed deadline of 2004 for decommissioning completion as it has not obtained a schedule extension approval.

3. In order to comply with regulatory timing requirements for decommissioning and the protection of health and to mininize danger to life or property, it is essential for SFC to designate which of its positions are part-time. Its failure to do so makes it unpossible to evaluate whether SFC's proposed organization can handle its work responsibilities to meet timing requirements.

Although the parties have a confilict on the current approved schedule for decomnissioning, it is not clear bow that schedule is relevant to the evaluation of a proposed aruendment dealing with organizational changes. The issue of concern raised by the Intervenors and relevant to the subject matter of this proceeding is whether the Licensee's proposed organization violates regulatory requirements. The regulations cited by Intervenors (I0 C.F, R. \$\$ 40,4I and 40,42(g)(4) and (h)) deal with the terms and conditions of materials licenses; the expiration and termination of those licensts; and the decommissioning of sites, bujldings, and outidoor areas. Although provisions of section $\mathbf{4 0 . 4 2}$ are concerned with the submisstion and completion of decomnissiorang plans, it is silent with respect to questions concenuing the capabtity of personsel to inpiement and complete decommitssioning, the enployment of full-time or part-time persongel, or requirements to maintain an organtzational structure and staffing levels to meat specific time periods for completion of decommissioning. In connection with

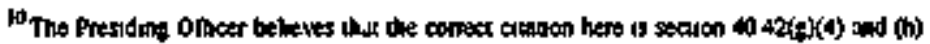


decommissoning schedule deadlines, the regulations provide for changing timing schedules for the submittal-and completion of decommissioning A tecent Staff status report reflects an agency determination that the subntittal of the PCD will not oxcur prior to Iate 1997 rather thar 1996 .I Based on this infortmation and the evidence subritted, no signiiticant challenge has beten raised to regulatory timing requirements concerting decommissioning, and this issue is accordingly ruled on in the Licensee's favor.

\section{Quality Assurance Program}

Intervemors assert that an adequate and effective quality assurance (QA) program is jeopardized by the proposed license amendment at the Licensee's facility. It claims that the changes in SFC's operation will not ensure the safe handling of existing radioactive and toxic materials or avoid contaminating the environment. Through deleting a requirement for an internal audit function and assigning the primary $Q A$ function to SFC's parent organization, $G A$, Intervenors contend that the proposed application undermines the QA system's checks and balances and the comprehensiveness and independence of the program. Additionally, Intervenor assert that witten procedires are not available that limit SFC's ability to conduct additional atedits on an "as needed basis." The brief cites these changes as violating a "principle" from NRC"s Timeliness-inDeconmissioning Rule (59 Fed. Reg. at 36,032) that QA programs govening operations equally apply to decommissioning. Intervenots contend that the texthical precision requined for preparing SFC's site characterization report and the ongoing work at the facility, although reduced in scope, calls for an adequate and effective QA program to ensure that employees are following health and safety requirements.

Basically, Intervenors assert that the independence of SFC's atditing processes is undermined by placing responsibility for the QA function with the Diretor, Regulatory Affairs, who has opesating responsibilities, and GA, which has operational and conflicting responsibilities of its own. The elimination of internal audits dispenses, Intervenors contend, with a system of checks and balances for a review of $\mathrm{GA}^{\prime}$ 's auditing work. Having GA perform its auditing function on a guarterly basis demonstrates a substantial downgrading of SFC's QA program. Finally, Intervenors argue that GA is engaged in another litigation jnolving the $\mathrm{NRC}$ and is attempting to distance itself from $\mathrm{SFC}$ in that proceeding. This creates a conflict with GA sintultaneously having responsibulity for

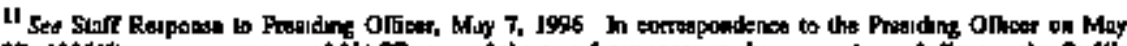

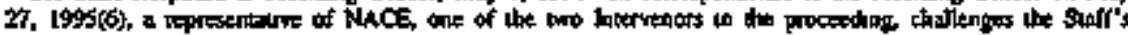

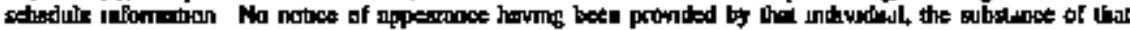

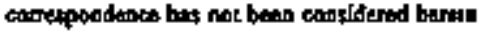

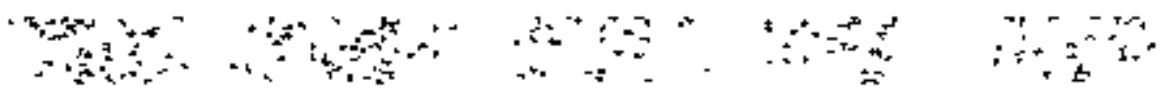


auditing under the proposed SFC amendment. See Intervenors' Brief at 13-15; Earl Testimony at $\mathbf{3 2 - 5 0}$.

The Licensec asserts that, for $\mathrm{QA}$ purposes, no large quantities of raficactive or hazardous materials exist at the site, as Intervencrs contend, and even the emptying of the site's pools has been deferred untit the final PCD is approved. Although SFC claims that there are no regulatory requirements or guidance on $Q A$ for a site in a decommissioning mode, nevertheless, the provision for $G \mathrm{~A}$ and additional independent audits, if needed, meets the regulatory criteria of Regulatory Guide 3.55. The Guide merely provides guidance and calls for the performance of audits and inspections pursuant to a written plan by people not responsible for production activities. SFC contends that GA's audits satisfy this requicement, that $\mathrm{SFC}$ is implenenting an effective $\mathrm{QA}$ program tailored to the company's ongoing activities, and that no inspector's reports have cited its QA program for any deficiencies.

In regard to the independence issue, the Licensee asserts that there is no regulatory requirement that internal-andexiernal audits must be conducted during decommissioning and the corrent level of activity at the site does not warrank an internal audit function. The audit function performed by $G A$ under the 1tcense has beep retained in the ameadment and, again, GA bas been directed to perform audits of areas and departments responsible and reporting to the Director of Regulatory Affairs. If additional audits are needed, the Director of Regulatory Affairs will arrange to have them performed by an independent auditor. Referring to a recent inspection report on Angust 9, 1995, the Licensee claims that the NRC Staff characterized the oversight of the SFC as evidenced by audits as adequate. SFC regards the argument questioning GA's independence within its own organization an írelevant concem.

On the challenges asserted to comprehensiveness and downgrading of the QA program by quarterly audits, SFC contends that no mecessity exists for GA to be available on a daily basis. SFC's ocher resources, it claims, routinely handle daily inspections. It states that an NRC 1994 inspection report cited the audit plan and audits at the site as appearing to be very comprehensive. Admitting that there had been some previous confusion regarding lines of reporting due to changes in personnel, the present functions and responsibilities, SFC contends, remain basically unchanged and all activities and responsibilities are assigned to SFC personnel who meet license qualifications. It states that the fact that GA is continuing tie audit fonction that it holds in the current license evidences the fact that $\mathrm{GA}$ 's position in another proceeding is unrelated to its audit responsibilities for the SFC.

The Licensee contends that the workload associated with audits and the QA function is not heavy for the limited activities currently taking place. It asserts further that the nonconpletion of written procedunes referred to by Intervenors involved SFC in an operating mode, not its carrent decommissioning one. SFC 
decided not to complete those procedures and has not been ciled by the NRC for a failure or lack of appropriate procedures in its QA. SFC ciles seelion 2.8 of the license applitation as requiring GA to audit the Director, Regulatory Affairs, and as also authosizing the Director to direct the performance of addtional alrdits of functions under his responsibility. See SFC Brief at 14-16; Ellis Affidavit at 15-23.

Despite the lack of a regulatory requirement on audits, Intervenors contend that the Board ["Presiding Offices"] can impose conditions when health and safety protection concerns require it. Alleging that there still may be activities involving radioactive materials. Intervenors contend that the spotty operating histary of SFC requires frequent $\mathrm{QA}$ oversight.

They allege that the EPA has imposed stringent $\mathrm{QA}$ requirements on SFC, and Intervenors find it difficult to understand, therefore, how the Licensee would not need internal audits. The Intervenors claim that GA's auditing role is not clearly outlined by the License amendment and insıst that the Durector of Regulatory Affairs has a conflict in being able to decide on additional audits over areas in which he has program responsibility. See Intervenors' Reply at 11-14; Earl Reply at $18-27$.

In the Licensee's view, a quarterly audit program conducted by GA and backed by selected independent audits is sufficient for the curremt level of limited activities at SFC. The QA program is not being degraded and it satisfies EPA and NRC requitements. SFC argues that other proceedings that GA is sovolved in are irrelevant to this proceeding and no one has previously challenged GA handling the QA function under SFC's current license.

Accorting to the Licensee, the Intervenors are seemingly confused and are mistaken in referring to SFC as discontinuing its internal QA program. Internal inspections, SFC states, are sull being performed on quality control functions and only internal $Q A$ audits have been eliminated. NRC's inspection program has not idenufied any of the problems cited by Intervenors. Finaly, the Licensee asserts that the authority of the Charrman, who has overall responsibility for the plant's safety, is not limuted by the license fiom designating someone to serve in his place or to appoint additional menbers to the PRC. See Licensee Reply Brief at 5-6; Ellis Reply Affidavit at 4.

\section{Decision}

Interwenors challenge the amendment application as undesminning the checks and balances of the Licensee's QA program as well as its qualty and independence. It argues that making $\mathrm{GA}^{+}$s audit function the responsibility of the Director of Regulatory Affairs, who has operating superviscry authority, and eliminating internal audits presents a confict of interest, dispenses with a check-

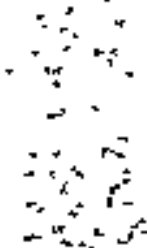

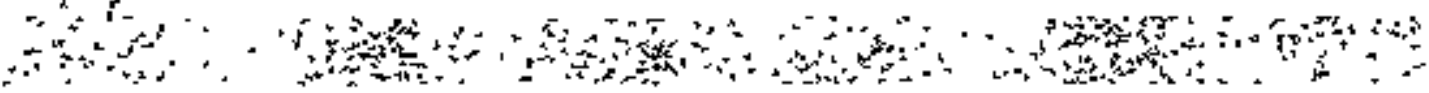


and-balance system, and removes any method of validating GA's auditing performlance.

It cannot be demonstrated that a licensee in a deconirissioning posture where its activities are greatly decreased requires the same level of resources as in an operating mode. That is the case here where unchallenged testimony shows an overall personnel reduction from 350 ar the peak of SFC's optrations to less than 30 currently." As Jesoutces and activities decitne, similarly will the QA effort to which it applies. Since GA has been performing its andit responsibilities while in a decommissioning stance and no one has produced evidence of current $Q A$ deficiencies being cited by NRC inspectors, it is impossible to conclucte that SFC'S QA audit procedure has any basic flaws at this point in time.

In view of its decreased activities, a stccessful challenge cannot be made that NRC has a requirement for an internal audit function at present. We need rot debate the issure of a regulatory requirement for $\mathrm{QA}$ during decommissioning since the $Q A$ function, although lessened, is being performed here. No substantial challenge has been made to SFC's arrangement to have GA contimue the QA function it has performed previously or the additional independent audits whenever needed to review GA's work or other activity. The fact that the anthority to request such additional audits rests with a person who has authority over the areas to be audited toes not, in and of itself, represent a conflict of interest. Nor is the independence of SFC's QA program threatened by the utilization of $\mathrm{GA}$ as an outside auditor. That company has been exercising the same responsibility for years without any regulatory challengo to its independent performance.

In light of the present level of activity, Licensee's $Q A$ effort appears at this stage as adequate. And lack of independence or conflict of interest cannot be successfulty claimed where GA's QA work is deliberately interposed between the Director, Regulatory Affairs, and the departments supervised. Further, it cannot be maintained that the question of $\mathrm{GA}$ 's independence within its own organization is relevant to this proceeding. If the Inlervenors' argument that GA is Irying to distance itself in another proceeding from SFC is correct, one can only conclude that a willingesess to continue an audit function with the same company is an odd way to demonstrate that fact. It is difficult to understand how SFC's QA effort, at this límited stage of its decommissioning activity, can be reviewed as deficient. At a time when the PCP is forwarded for approval to the agency and the effort to dispose of contaminated materials is clarifed, the QA program can be screened with more pertirency than it can under the present state of affairs. It should be noted that the Staff now requires SFC to review its staffing levels and qualifications whenever there is a change of activities at

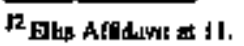


the facility, and there is a requirement that such reviews will be made available. See Amendment of SFC License, Weber to Ellis (Feb. 21, 1996).

\section{Legal Argument}

The Intervenors claim that section 103 of the Atomic Energy Act (Act) and 10 C.F.R. $\$ 40.3$ of the Commission's regulalions control the issuances of licenses to conduct activities with radionctive materials. The Staff ordtnarily issues requested licenses, but in this case, it is asserted "becanse a hearing was requested by the Intervenors, the authonty to issue a license resis with the Licensing Bourd." fotervenors' Brief at 2-3. Intervenors cite 10 CF.R. $\$ 2.104$ (d)(3) as support for this proposition. $l d$. at 3 .

Intervenors argue that NRC Staff inspectors, acting on befialf of the agency, acquiesced in the unilateral organizational changes made by SFC prior to obtaining licensing autherity to do so. Thus violated section 189a of the Act and abrogated Intervenors' hearing rights. From this argument, Interwenors conclude, the Presiding Officer stoold decline to exercise his authonty to constider a license amendment application as a "fait accomplis." Instead, SFC's license application should be denied; the PTesiding Officer should order SFC to restore the staffing and management organization as they existed prior to April 1993; and the Presiding Officer should refuse any further license amendments "implemented prior to receiving approval from the NRC Staff or the Board [sic], as appropnate." IA, at 5.

In ìts Reply Brief, SFC counters that Intervenors have relied upon the wrong provistions of both the AEA and NRC regulations. SFC claims that the provisions cited for support refer exclusively to the licensing of atulear reactors and fuel reprocessing facilities. Accordang to $\mathrm{SFC}$, section 103 of the Act is noe retevant to a source materuals licenses "which is subject to NRC jurisdiction under Section 62 of the AEA (42 U.S.C. \$2092) and licensed under t0 C.F.R. Part 40." SFC Brief at 3. SFC argues that 10 C.F.R. 8 2,104(d), upon which Intervenors rely, is applicable to production and utlization facilites under Part $\mathbf{5 0}$ and only to antitrust questions, neither of which is a concern in this proceeding. The Interwenors, SFC contends, ignore the provisnons of 10 C.P.R. $\$ 2.1205(l)$ where "the staff rebatrs its authority to $a c k$ upon the pending application notwithstanding the granting of Intervenors' hearng request" Id. at 4.

As to the substance of Intervenors' argument that many of the administrative changes requested by the Licensee's amendment request are aiready a fait accompli, SFC answers that all the individuats assigned to decomnissioning responsibilities are fully qualified for those positions under the current SFC license, and therefort, SFC is meeting its regullatory responsibilities. SFC stattes that Intervenors have failed to identy any regutatory requirements concenning the assigning of moce than onts position to a single individual, Id. at 5. SFC
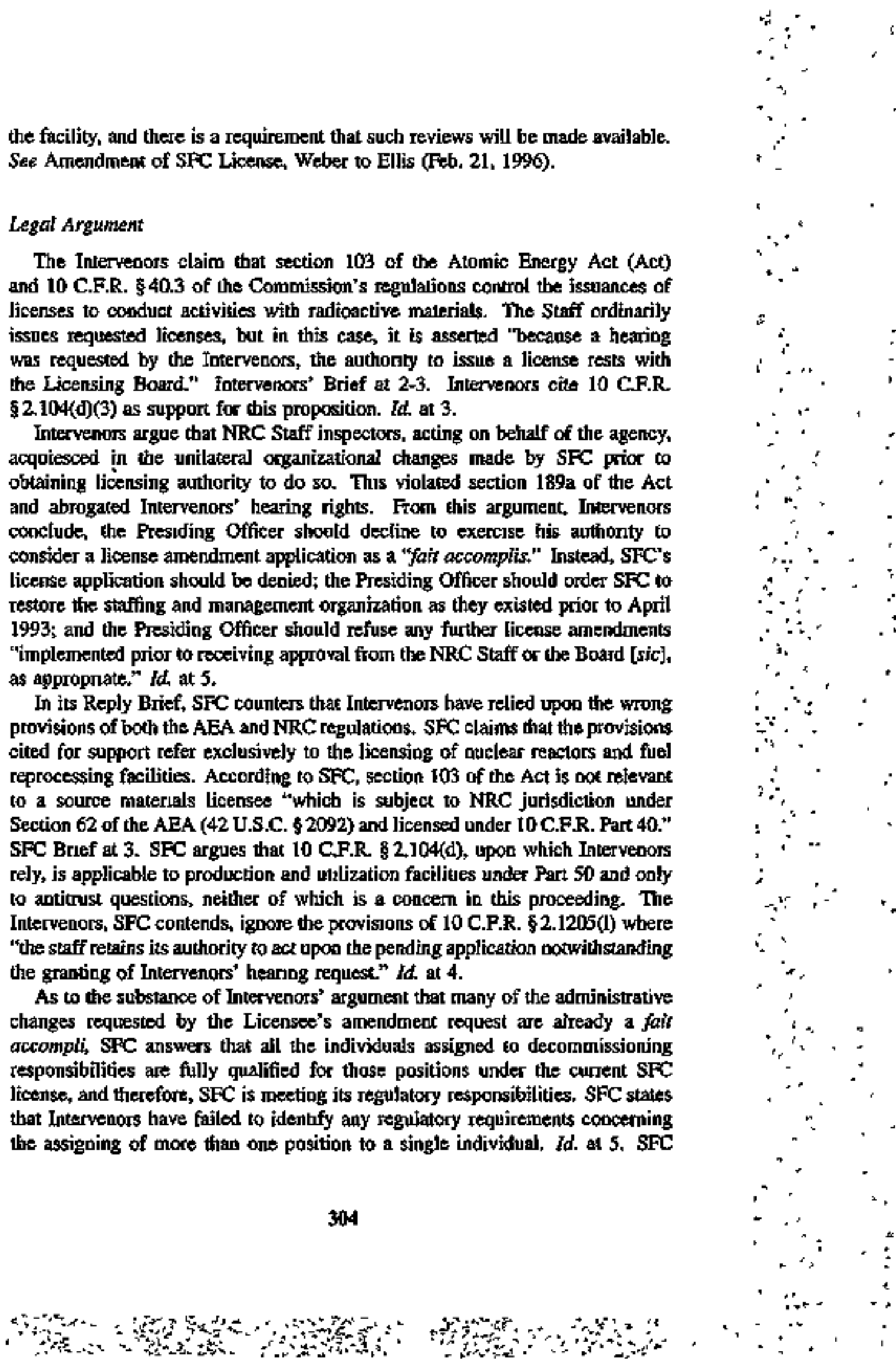
further argess that Intervenors' requests - that the Presiding Officer declins to consider the amendment application, that the application be denied, and that the staffing levels be returned to the April 1993 level - are, except for denying the application, beyond the scope of the Presiding Officer's authority. According to SFC, that authority is liznited to the resolution of the admitted areas of crncem in determining whether the pendiag application showid be granied, denied, or conditioned, $l d$, at 6.

SFC also argues that Intervenors have not been denied their hearing tights under the AEA. It states that under the provisions of 10 C.F.R. Part Z, Subpart $L$, a bearing on a materials license cap be held before or after the issuarce of the license, depending upon the circunstances of the hearing request. SFC cites, for an example, if the Federal Register notice of a licensing action has not been published, a hearing on the issuance of a license or license andendnent can be jequested until the earlier of 30 days after the requester teceives actual notice of the NRC action gronting an application or 180 days after such action. Id at 7, clting 10 C.F.R. \$ 2.120 S(c)(2).

In their Reply Brief, Intervenors agree that they insppropriately relied on section 103 of the AEA in their earlier written presentation. See Interwenors' Reply. However, they point to language in section 62, cited by SFC, that carries "even moce explicit prohibition than 103 against the conduct of unlicensed activities." Id at 1. Again Intervenors argute that changes in the management structure at the SFC facility "in the absence of priot staff approvat, requited SFC to wait for the Board's nuling that the amendment was Jawful and reasonable before it could implement the proposed license amendment." Id at 3. Intervenors question the validity of 10 C.F.R. \& 2.1205(a)(1) under section 189(a) of the Act. Intervepors state that section 189(a)(2)(A) of the AEA (which clearly enunciates "construction and operating licenses") "applies to all licenses issued under Chapter 23 of the U.S. Code" and further presumbes "all hearings on license amendments which are offered under 8189 (a) of the AEA will be held prior to the issuance of the license amendment unless they are subject to a no significant hazarojs determination." Id at 3-4. The Board has an interest in seeing that the integrity of its adjudicatory process is respected, Intervenors say, and in the absence of formal licensing approval from the NRC staff, SFC Is requited to wait for the Board's resolution of the pending hearing request before implementing those changes. $I d$. at $\mathbf{S}$. The Licensee's Reply alleges the inapplicabtlity of the "no significant bazards" determination of section 189(a) to materials licensees. 


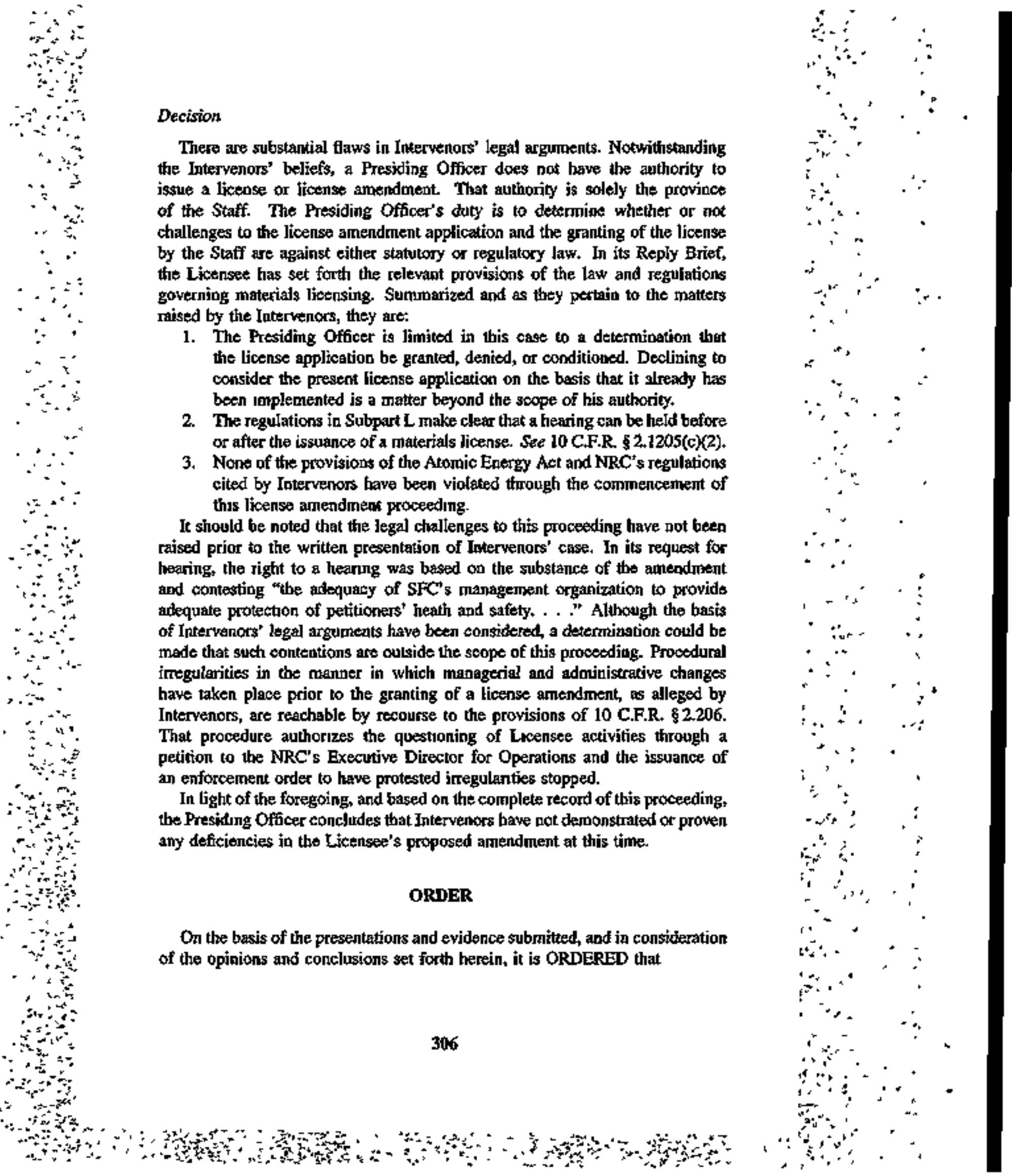


1. The issuance of an Amendment dated February 21, 1996, to Skgpuoyah Fuels Corporation Materials License SUB-1010 is sustained.

2. In accordance with 10 C.F.R. \$2.1251, this Initial Decision will constitute the final action of the Commission within thirty (30) days after the date of issuance, unless any party petitions for Commission review in aceordance with 10 C.F.R. $\$ 2.786$, or the Commission takes review ster sponte. Any other party to the proceeding may file within ten (10) days after service of a petition for review, an answer supporting or opposing Commission seview.

James P. Gleason, Presiding

Officer

1

ADMINISTRATTVE JUDGE

Rockvilke, Maryland

$\therefore \quad$ June 21, 1996.

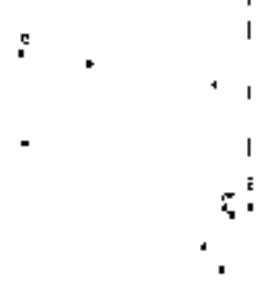

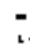

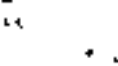

$\therefore$

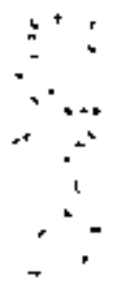

j 
UNTTED STATES OF ANERICA

NUCLEAR REGULATORY COMMISSION

OFFICE OF ENFORCENENT

Jamess Lioberman, Ditector

In the Matter of

Dookst Nos. 50-528

80-529

$50-5030$

\author{
ARIZONA PUBLIC SERVICE \\ CONPANY \\ (Palo Verde Nucloer Cenerating \\ Stalion, Unils 1, 2, and 3)
}

June 3, 1996

With the exception of granting the request that the Nucjoar Regulatory Commission (NRC) lake escalated enforcement action against the Licensec, Arizona Public Service (APS) Company, the Director of the Offee of Enforcement de. nies the requests set forth in the petitions dated May 12, 1993 (as supplemented on May 28, 1993, October 26, 1993, and Janvary 15, 1994), May 27, 1994 (as supplemented on July 8, 1994), and November 14, 1994, filed by Thonas J. Saporito, Jr+, Flontda Energy Consultants, and Linda Mitchell (Petitioners). The Petitioners requested that the NRC (1) initiate a proceeding pursuant to 10 C.F.R. \$2.202 to modify, suspend, of revoke the Palo Verde operating licenses; (2) intitiate actions to immediately shut down Paio Verde; (3) issus escralated en forcement action against the Licensec and/or Licensee management personnel; (4) take immediate actions to survey Palo Verde employees to ascertain any chilling effect and discover any management actions effective in limiting the chilling effect; (5) issue a notice of violation to APS for continuing to employ The Atlantic Group (TAG) as a labor contractor at Palo Verde; (0) investigate alleged material false statements made by William F. Conway and require thet he be relieved of his duties; (7) investigate comments about Mr. Saporito appearing in an APS letter dated August 10, 1993; (8) investigate the termination of Joseph Straub; (9) initiate a "chilling-effect letter" to APS regaroing Mr. Straub's temination; (10) issue an order requiring APS to bring the 
Palo Verde units to 0\% power until APS can demonstrate that comrective actions have been taken to obviate any inference of a hostile work environment at Palo Verde; (11) issue a demary for information requesting specified information from APS conceming the work environment at Palo Verde and the effect that the enployment of cerain named individuals has on the work environment and why the NRC should have confidence that the named indincuals will comply with NRC regulations; (12) take escalated enforcement action against TAG and any of its etoployes found to have engaged in wrongioing: (13) regujre APS to provide Mr. Saponito a make-whole remedy for terminatıng hing and failung to rehite him; and (14) requine actions by APS to abate and obviate the chilling effect caused by the failure to provide employes protectuon for Mt. Saporito. The Director has reviewed the Petitioners' requests and concerns and concluded that the need for further action has not been substantrated. The reasons for the partial dential are fully set forth in the Director's Destsion.

\section{DIRECTOR'S DECISION UNDER 10 C.F.R. \$2.206}

\section{INTRODUCTION}

A petition was filed by Thomas J. Saporto, Jr. (Petstioner) in accordance with 10 C.P.R. $\$ 2.206$ on May 12,1993 . The petition requested that the NRC. (1) instutute a show-cause proceding putsuant to 10 C.F.R. \$2.202 to modify, stspend, or revoke Anzona Pubjic Service (APS) Company's operating Itcenses for Palo Verde Nuclear Generating Staton (Palo Verde); (2) intiate actions to shut down Palo Verde (3) take escalated enforcement action against APS, including the issuance of cyl penaitbes against APS and/or Licensee management personnel at Palo Verde; and (4) survey Palo Verde employees to gauge the chilling effect that may exust and whether the Licensee's actions were effective in limiting the chilting effect. On May 28, 1993, Petitioner forwarded a New Ttmes article (May 26-Iune 1, 1993) to the NRC as a supplement to this petition.' On Oetober 26, 1993, Petitionter supplemented the May 12. 1993 Petition to include a copy of an October 23, 1993 discrımınation complaunt filed by the Petitioner with the Department of Labor against APS and The Attantic Group (TAG). In the October 26, 1993 supplement, Pettsoner retterated his earlier request for action and additionally requested escalated enforcement action against TAG and agannst any of ts employees who are fonthd to have engaged in wrongdoing.

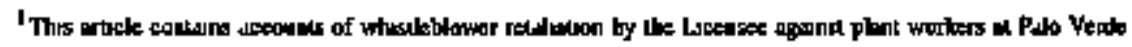

$\because ;:$

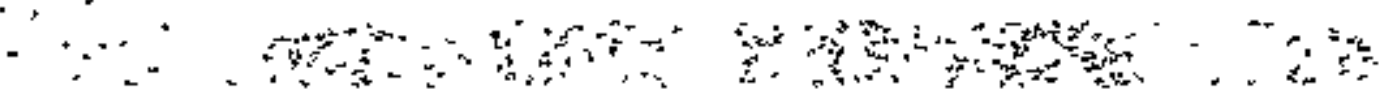


Another petition was filed by Petitionet on Jamary 15, 1994. This petition, which has been treated as a supplenent to the May 12, 1993 Petition: (1) reiterated the requests for escalated enforcentent action against APS that were made in the May 12, 1993 Petition; (2) requested that APS be requiced to ptovide a make-whole renedy for Petitioner for terminating Petitioner and failing to rehire him as a result of Petitioner's engaging in protected activities; and (3) requested that APS be regivired to abate and obviate the chilling effect at APS arising from the failure to provide the Petitioner with employes protections afforded under 10 C.F.R. $\$ 50.7$.

As the bases for the May 12, 1993 request, Pelitioner asserted that: (1) a Department of Labor (DOL) Administrative Law Judge (ALJ) ruled that APS discriminsted against Petitioner (ERA Case No. 92-ERA-030); (2) the DOL case is evidence that "the Licensee appears to have violated numerous NRC requisements regarding operation of the Palo Vesde nuclear station; and (3) Ljeensee managers have made questionable if not false statements to the NRC regarding the emergency lighting at Palo Verte. Petitioner's October 26, 1993 supplement to the original petition bases the request for action on Pefitioner's October 23, 1993 complaint filed with DOL and the nuling in favor of Ms. Sarah C. Thomas against APȘ. Petitioner's Jamuary 15, 1994 supplement to the original petition bases the requesc for action on the admission by one of the witnesses at the Patitioner's DOL hearing that the wimess lied under oath, as evidence of APS' intent to discrimingte against Petitioner and that the discriminatory treatment of Pexitioner has caused a chilling effect on other employees at Pato Verde.

Anocher petition was filed by Petitioner and Florida Exergy Consultants (Fetitioners) on May 27, 1994. This petition (I) reiterated the request for a show-cause proceeding, and further requested that the NRC: (2) issue a notice of violation against the Licensee for contiaving to employ TAG as a labor contractor at Palo Verde: (3) investigate alkeged material false statements made by Willian F. Conway, Executive Vice President at Palo Verde, during his testimony at Pelitioner's DOL hearing (ERA Case No. 92-ERA-030) and that, in the interim, the NRC require that Mr. Conway be relieved of any authoity over operations at Palo Verde; (4) investigate the Licensee's statennents regarding Petitioner Saporito in an Aogust 10, 1993 letter from Mr. Conway to NRC Adrifnistrator, Mr. Bobby H. Faulkenberry, in which the Licensee said that Mr. Saporito gave materially false, inaccurate, and incomplete information on his application for unescorted access to Palo Verde so that, as a result of that event, Petitioner Saporito lacks trustworthiness and reliability for access to Palo Verde; (5) investigate the circunstances sorroundigg the Feturoary 1994 termination of

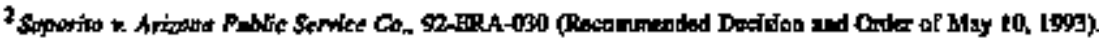


are being addressed in the above-noted Director's Decision by Mr. Russell and will not be addressed here.

Another petition was filed by Thomas J. Saporito, Js. Florida Energy Consultants, and Linda Mitctiell (Pettioners) on Nowember 14, 1994. The petition regnested that NRC: (1) issue a confirmatory order requiring APS to reduce power at all Palo Verde units to $0 \%$ until APS can demponstrate corrective actions for the alleged hosile work environment at Palo Verde: (2) issue a demand for tnformation to APS asking (a) why NRC should have confidence that APS can operate Palo Verde in an environment free of harassment, intimidation, and discrimination; (b) about the current duties and responsibilities of certain listed employees, including whether any of those employees is currently involved in NRC-licensed activities: (c) why the Commission should have confidence that these employes will eomply with NRC reguirements: and (d) why the NRC stould not take artion to prohibit the involvemert of these employees is NRClicensed activities.

As the bases for these requests, Petitioners assert that: (1) DOL found that Sarah Thomas was diserininated against by APS; (2) DOL found that Linda Mitchell was discriminated against by APS; (3) DOL found that Thomas $I$. Saporito, $F_{r}$, was discriminated against by APS; (4) these matters could have been sertled before adjudication by DOL; (5) other recent DOL complaints by Straub and Irick are indicators that discrimination is the nomal course of business at Palo Verde; (6) Petitioner Linda Mitchell lives within 2 air miles of Palo Vetde and, therefore, has standing to intervene in a bearing before an NRC Atomic Safety and Licensing Board (Board): (7) Peticioners Saporito and Florida Energy Consultants have the requisite standing to intervente in a hearing before a Licensing Board through Ms. Mitchell; (8) Petitioners are subject to physical harm and loss of personal property in the event of a nuclear accident at Palo Verde as a direct or indirect result of the hostile work envirominent fostered at Palo Verde; and (9) a hostile work environment exists and is pervasiwe at Palo Verde and is condoned and fostered by Licensee management.

\section{DISCUSSION}

Due to the numerous requests and interrelated nature of the issues raised and the bases provided by Petitioners, the items raised in each of the petitions and their supplements described above have been considered together and are described in one composite list below. The discussion that follows the list is keyed to the numbers used to identify each request. The petitions and supplements noted above reguest that the NRC:

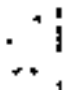




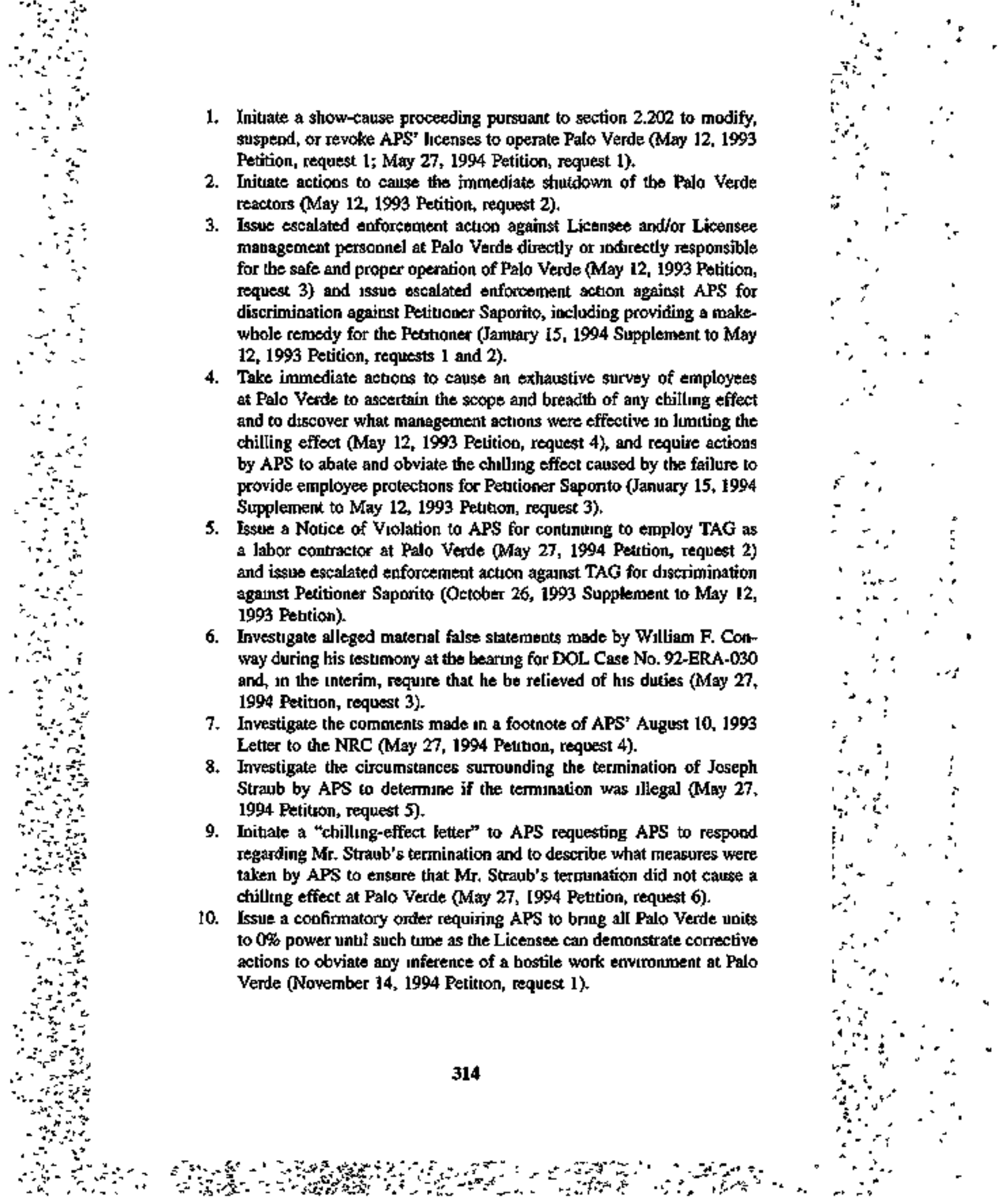


11. Issue a demand for information regaesting that APS:

a. explatn why NRC can have confidence that the environment at Palo Verde is free of harassment, intimidation, and discrimination, both in general and with respect to certain individuals.

b. describe the current employment duties and responsibilities of certatn named License employess, including whether any of those employees is now involved in NRC-licensed or -regulated activitites.

c. explsin why NRC can have confidence that the named employees witl comply with $\mathrm{NRC}$ requizements.

d. provide information as to why the Commission should not prohibit the named employees from involvement in NRC-licensed activities.

(November 14, 1994 Petítion, request 2).

\section{Requests for Action for Discrimination Agalmst Petitioner Saporito - Items 3 and 5}

With respect to the portion of item 3 that requests enforcernent action against APS, Petitioner has based the request for civil penalties against APS and/or its managers on violations of section $\mathbf{5 0 . 7}$ for denying Petitioner Saporito employment at Palo Verde Unit 1 in 1992 based on his earlier tivolvement in protected activities at Palo Verde. In fact, in a lelter to NRC, dated August I0, 1993, APS slated that, following a heariog before a DOL ALJ concerning whether APS had violated section 210 (now section 211) of the Energy Recrganization Act of 1974 (ERA) in denying the Petitioner employment at Palo Verde (DOL Case No. 92-ERA-030), an APS supervisor admitted that he discriminated against the Petitioner in denying him employment at Palo Verde and falsely testifed in the ALJ proceeding. The NRC Office of Investigations conducted an investigation into the matter and concluded that the APS supervisor discrittinated against the Petitioner (OI 5-93-023R). OI referred its findings to the Department of Justice (DOJ) for criminal prosecution. DOI pursued and obtained a criminal conviction of the APS supervisor for discrimination in this case. On March 7, 1996, the NRC issued a civil penalty in the amoumt of $\$ 100,000$ to APS (EA 93-159) and a Notice of Violation to the APS supervisor (IA 96-0l5) iavolved in the violation of section 50.7 for failure to hise Petilioner due to his earlier involvement in protected activities. Therefore, Petitioner's request in item 3 for enforcement action has been granted.

With respect to the portion of item 3 that requests a make-whole remedy for Petitioner, section 210 (now 215) of the BRA gives the Department of Labot the authority to effect remedies for the complainant. The NRC has no such authority. Therefore, this portion of the request in iten 3 is denied. 
Item 5 requests escalated enforcement action against TAG for TAG's ajleged discrimination against Pettioner Saporito and further teguests that a Notice of Violation be issued against APS for continuing to enploy TAG as a contractor at Palo Verde. Petituoners based this request for enforcernent action agaunst TAG on its alleged discrimination against Petitioner Saporito and based the request for enforcement action against APS on the fact that past practices by TAO demonstrate that entployees of TAO were retaliated against for having raised safety concerns while employed by TAG at Palo Verde.

Of the five complaints filed with the DOL against TAG for alleged violations of employee protection reguirenrents at Palo Verde, four were filed by Pettioner Saporito and were ultumately settled without the DOL finding any discrimination. ${ }^{3}$ On January 14, 1994, the NRC's Office of Investigations (OI) initiated an investigation of multiple allegations of Petitioner Saporito that TAG had discriminated against Petitioner by refusing to hire him for addutional enployment and "blacklisting" him and that a TAG employee lied in testíniony in a DOL hearing. Following its investigation, OI issued a report on November 8 , 1995 (OI Case No. 2-94-003) in which it found that these allegations were not substantuated. Accordingly, Petitioners" allegations of dusenmination, "blacklisting," and false testumony by TAG with regard to Pebtower Saporito do not appear to have merit and do not provide a basis for the NRC action against APS and TAG that Petitioners request.

The complaint filed by another TAG employee involved a claim that TAG violated its internal policy when a TAG supervisor divulged derogatory informat tion about the complainent to a prospectuve employer. The DOL ALJ concluded that discrimination occurred in that case (DOL Case No, 94-ERA-009) and the NRC issued a Notıce of Violation to TAG on January 8, 1996, for a Sewerity Level III violation (EA 95-192).

While cisputing the violation, TAG's February 6, 1996 response advised the NRC that it was going to comply wtith the Secretary of Labor's order requiting TAG to pay compensatory damages and attomey's fees. The response also described the corrective sleps taken by TAG, including: (1) the requirement for a signed release from an employee bofore any information about bis/her personnel file can be given our; (2) a new limitation on types of personnel information that can be given out; (3) training of company employes on the requirements of section 211 of the Energy Reorganization Act; (4) training of supervisors to enphasize the nght and obligation of employees to maintain an environment in which employees are encouraged to raise safety concems;

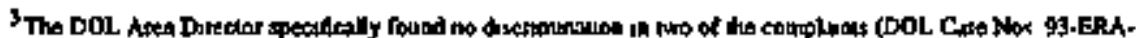

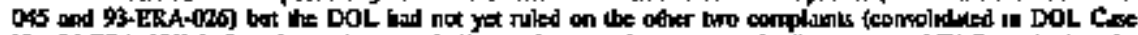

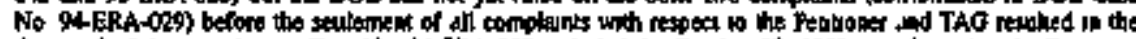

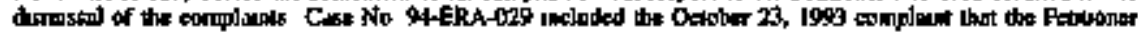

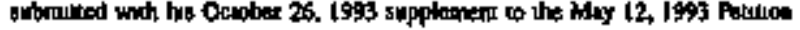


(5) specific training for the supervisor involved in the case; (6) additiontal correspondence from the President of TAG to its employees reminding them of the company's commitment to a proper work envinonment; and (7) the hiring of an individual as TAG's Marager of Quality Assurarce who had won a section 211 whistleblower complaint against another employer. The Staff has concluded that Petitioners bave failed to provide information that would show that TAG retaliated against its employees and that, with regard to the one violation of employee protection requirements that was substantiated against TAO, considerable improvernent and corrective actions have been implemented by TAG. Moroover, it is not a violation to utilize a contractor that has been involved in past violations. In short, there is no basis to justify further action against TAG at this time and no basis to take actiont against APS for employing TAG.' Petitioners' request for additional enforcenent action beyond that described above is, therefore, denied.

\section{Requests tor Action for Dkerimination Against Joseph Straub - Item 8}

With respect to jtem 8, which concerns the Petitioners' request for an investigation of the circornsances conceming the termination of Joseph $R$. Straub by APS, I note that of the two complaints filed by Mr. Straub with the DOL cancerning his termination by APS, the DOL ALJ dismissed Case No. 95-ERA-0105 on February 23, 1995 without action, finding that is issues were inexiricably intertwined with those of Case No. 94-ERA.037 and, in 94-ERA037, the ALJ concluded on October 6, 1995, that Mr. Straub had not established a prima facie case of discrimination. ${ }^{6}$ In fact, the DOL ALJ found that Mr. Straub was not credible in his assertions of discrimination or the presence of a bostile work environment at Palo Verde. The ALJ recommended that the complaint be dismissed and, in an order issued on April 15, 1996, the Secretary of Labor concurred, dismissing Mr. Straub's complaint. Considering the Secretary of Labor's finding regarding Mr. Straub's complaints, and the fact that there has not been any other evidence of diserintination presented by the Petítioner that would establish that Mr. Straub was the subject of discrimination, an investigation into Mr. Straub's claims of discrimination is not wartanted and, therefore, the request is denied.

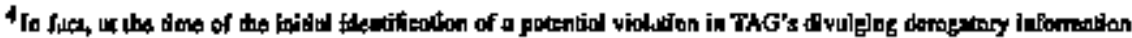

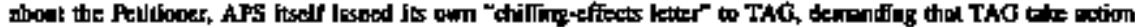

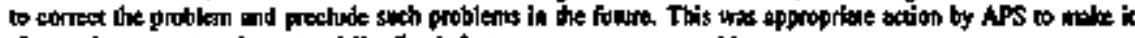

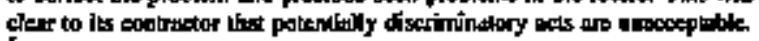

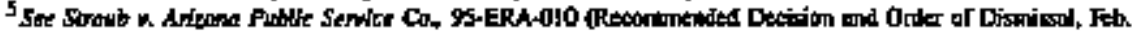
20. tosis.

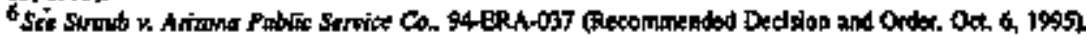




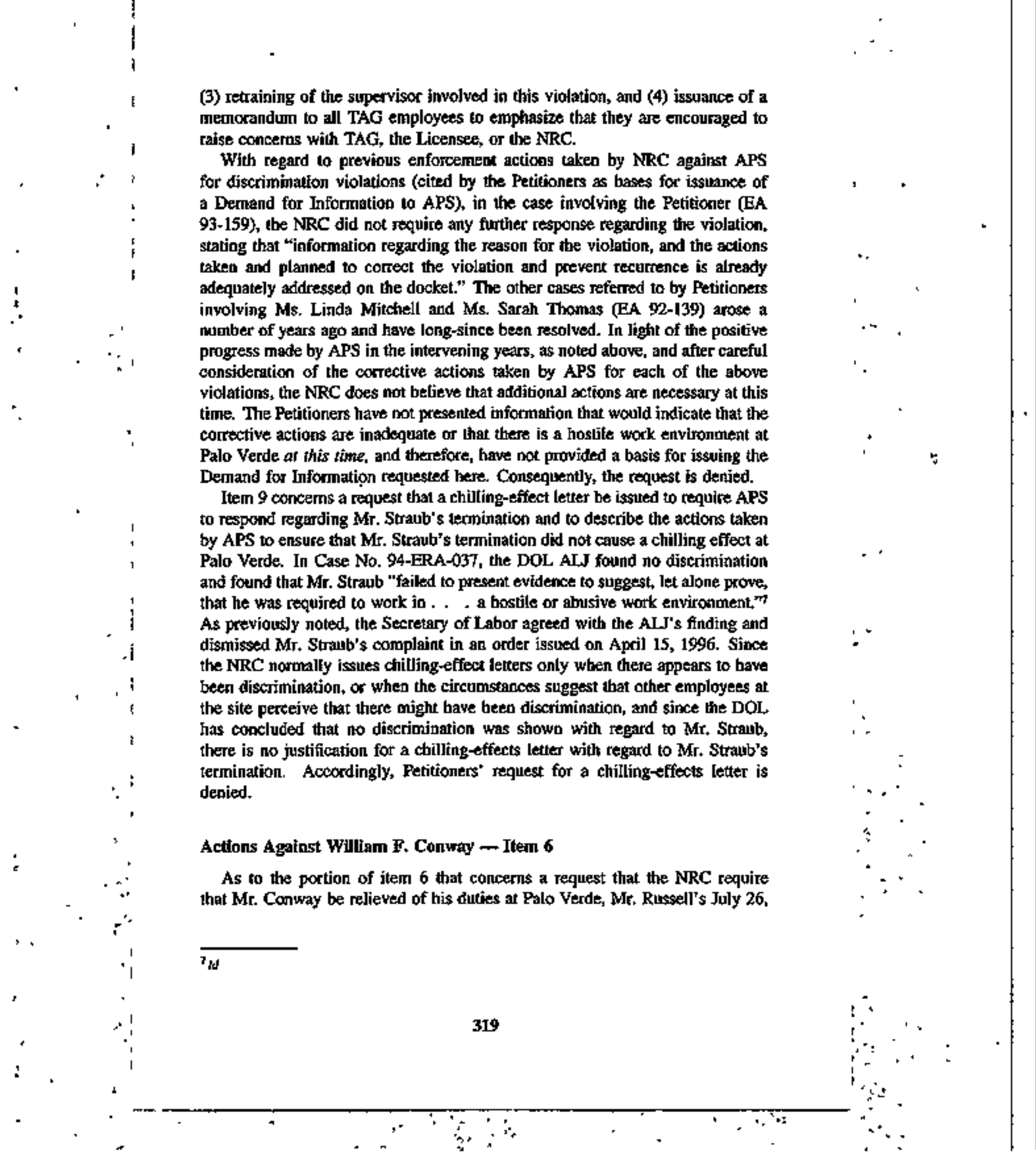




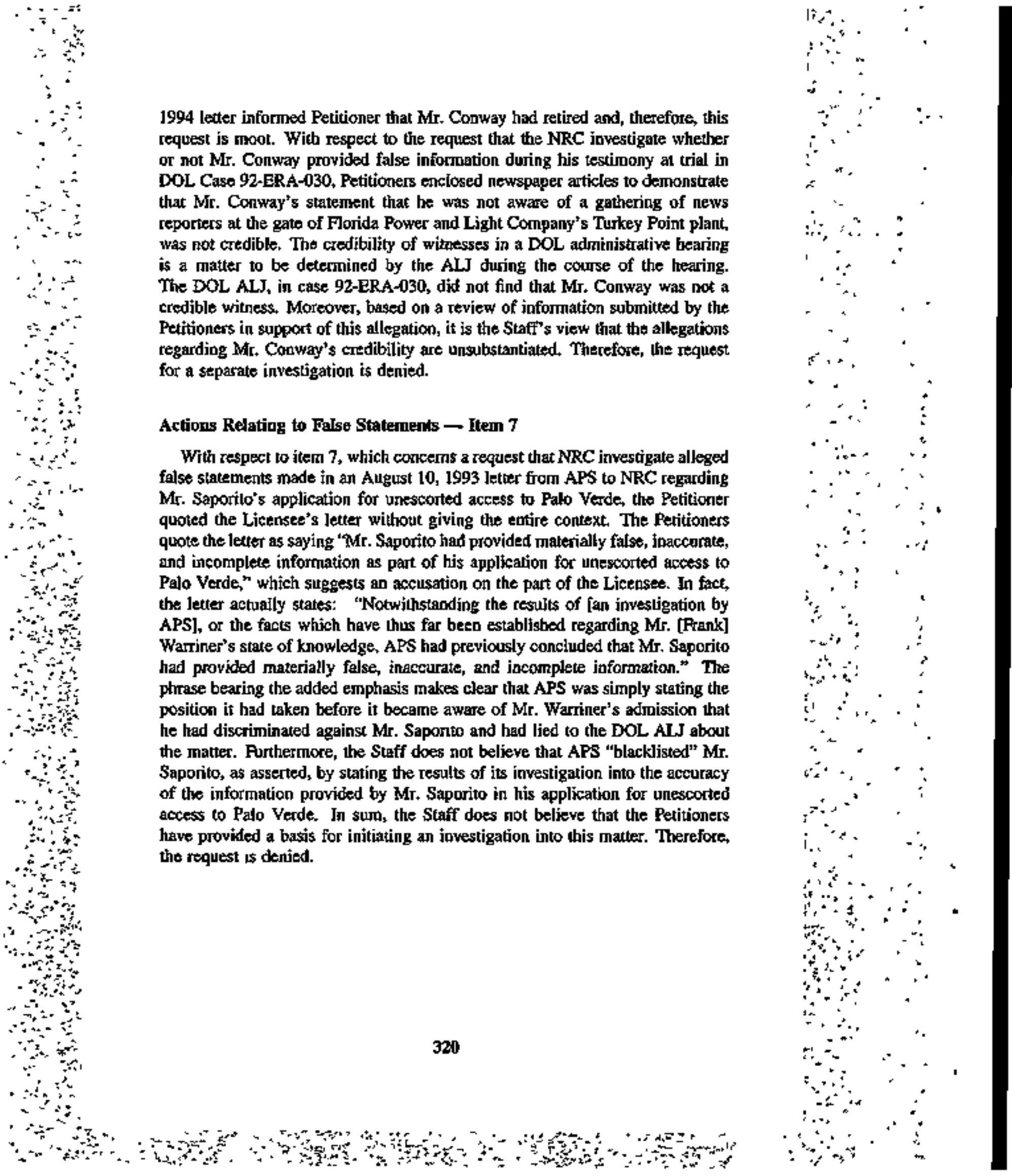


Actions to Shut Down Palo Verde or Bring It to 0\%

Power - Items 1, 2, and 10

Items 1 and 2 concern requests for actions to styut down the Palo Verde ro actors and item 10 concerns a request for a confitmatory order requiring APS to bring all Palo Verde units to $0 \%$ power until such time as the Licensee can demonstrate conective actions obviating any inference of a hostile work environment at Palo Verde. Basted on the information discussed above, Petitioners have not provided information that would establish that a hostile work environment exists at Palo Verde. Therefore, Petitioners have not provided a basis to support the requested action. These requests are hereby denied.

\section{CONCLUSION}

As explained above, the request for euforcement action against APS (see item 3, above) has been granted. For the reasons given in the discussion of items relating to continued employmeak of TAG by APS, discrimination against Mr. Siraub, the alleged chilling effect at Palo Verde, actions against Mr. Conway, false statements, and the shutdown of Palo Verde, the remainting requests, olher than chose to be addressed by Mr. Russell in a separate Director's Decision, have been denied.

A copy of this Decision will be filed with the Secretary of the Commission for the Commission to review in accordance with 10 C.F.R. \$2.206(c). As provided by that regulation, the Decision will constitate final action of the Commission on the issues discussed herein $\mathbf{2 5}$ days after issuance, unless the Commission, on its own motion, institutes a review of the Decision within that time.

James Lieberman, Director

Office of Enforcement

Dated at Rockville, Maryland, this $3 d$ day of June 1996 . 


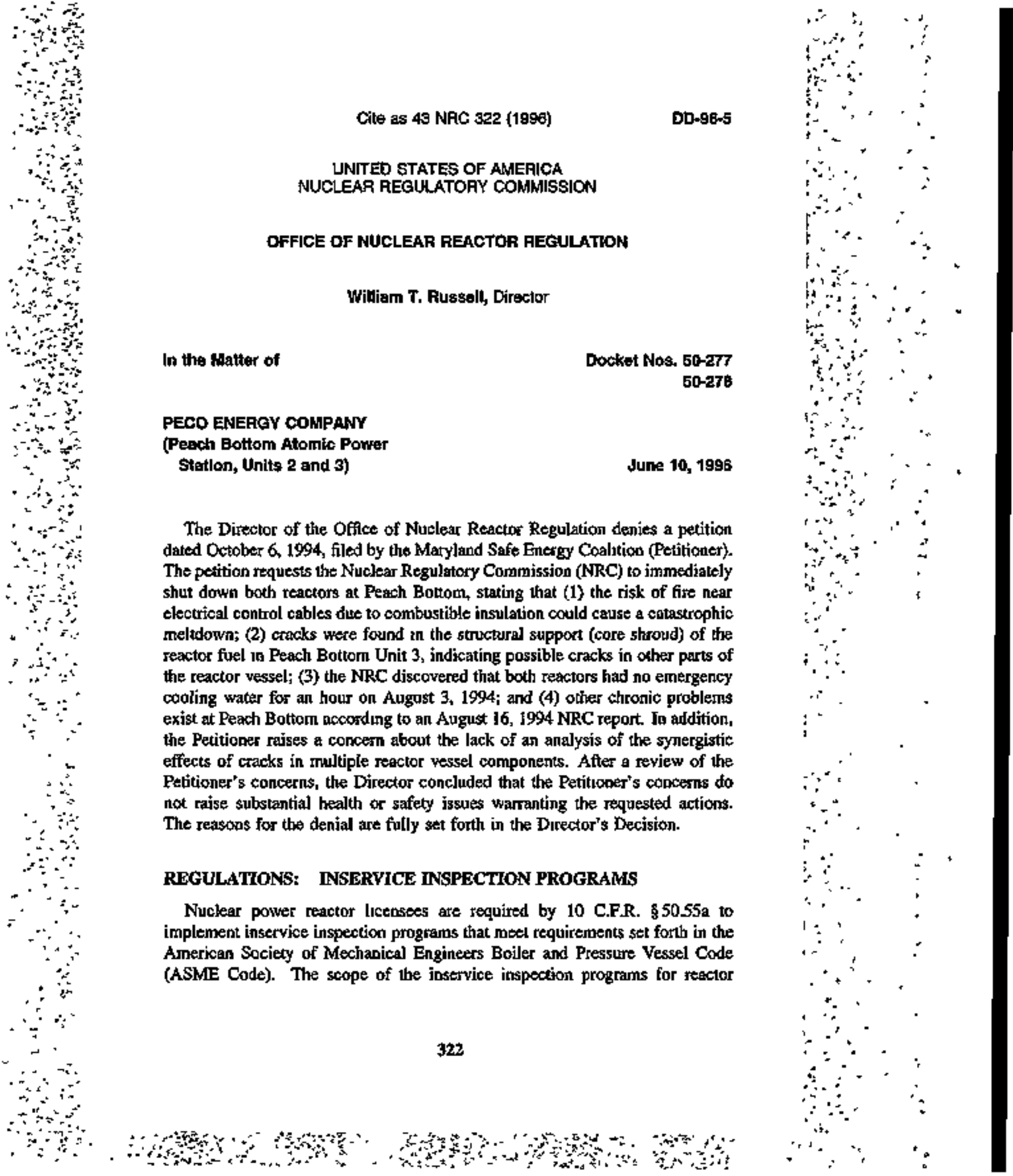


pressure vessels and their intemal components is prescribed by ASME Code $\$ \mathrm{XI}$, Division 1, subsections IWA and IWB. Licensees ase required by the ASME Code $\S \mathrm{XI}$, art. IWA- 6000 , to submit the results of the inspections to the NRC within 90 days of completion.

\section{FINAL DIRECTOR'S DECISION UNDER 10 C.F.R. \$2.206}

\section{INTRODUCTION}

On October 6, 1994, the Maryland Safe Energy Coelition (Petitionec) issued a press release describing tis concerns with the operation of PECO Energy Company's Peach Bottom Atomic Power Station (PBAPS). In the press release, the Petitioner tequested that the U.S. Nuclear Regulatory Comuntission (NRC) take action to address those concerns. The Petitioner requested the NRC, among other things, to immediately stut down both reactors at Peach Bottom and keep then shut down until certain conditions are comected. Specifically, the Petilioner stated that ( 1 ) the risk" of fire near electrical control cables due to combustible insulation could cause a catastrophic meltdown; (2) cracks were discovered in the siructural support (core shroud) of the reactor fuel in Peach Bottom Unit 3 , indicating possible cracks in other parts of the reactor vessel; (3) the NRC discovered that both reactors had no emergency cooling water for an bour on Attgust 3, 1994; and (4) other chronic problems exist at Peach Bottom according to an August 16, 1994 NRC report.

The Petittoner secks relief from the risk of fire (Request 1) duse to cabje insulation on the basis of a September 30, 1994 article in the Bathimore Sun that described the indictment of Thermal Sciences, Inc., on charges of falsifying laboratory records related to Thermo-Eag. Thernto-Lag is a material used to insulate electrical cables and other equipment from fire darnage. The petition states that a fire in combustible insulation near electrical control cables could cause a catastrophic meltdown.

The petition also seeks the conection of cracks that were discovered in the structural support (core shroud) of the reactor fuel in Peach Bottom Unit 3, indicating possible cracks in olher parts of the reactor vessel (Request 2). In support of this request, the Petitioner also references an eartier demand by the Nuclear Information and Resource Service (NIRS)' that all safety-class

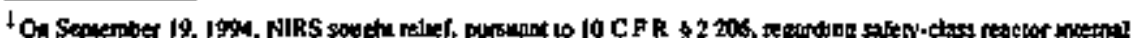

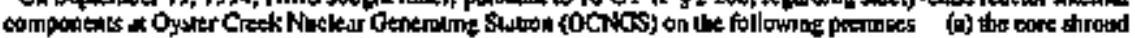
(cominint) 
Director's Decision with regard to Requests 2, 3, and 4. A discussion of the Final Director's Decision follows.

\section{DISCUSSION}

\section{A. Correction of Cracks in the Core Shroud and Assertion of Possible Cracks in Other Parts of the Reactor Vessel (Request 2)}

Nuclear power reactor licensees, including PECO, are required by t0 C.F.R. $\$ 50.55$ a to implement inservice inspection programs that meet the requirements set forth in the American Sociery of Mectanical Enginets Boiler and PJessure Vessel Code (ASME Code). The scope of the inservice inspection prograns for reactor pressure vessels and their intermal components is preseribed by ASME Code $\S \mathrm{XI}$, Division 1, subsections IWA and IWB. Licensees are also required by ASME Code $\$$ XI, art. IWA-6000, to submit the resulls of these inspections to the NRC within 90 days of completion. The NRC Staff performs periodic audits of licensee.implemented inservice inspection prograns to determine compliance with applicable codes ard regulations. These audits are documented in NRC inspection reparts, which are publicly available at the NRC Public Document Roorn, the Gelman Building, 2120 L Street, NW, Washington, DC. Inspection reports related to PBAPS are also available at the loctal public document room for PBAPS focated at the State Library of Pennsylvania (Regional Depository), Govemment Publications Section, Eductation Building, Walnut Street and Commonwealth Avenue, Box 1601, Harrisburg, PA 17105.

The Licenste's inservice inspection program contains provisions for the periodic inspection of the PBAPS reactor vessel internal components, inciuding such components as the top guides, core shroud welds, shroud support plate access bole covers, incore instrament tubes, steam dryer drain channels, core spray piping, and jet punp assemblies. By letter dated April 8, 1986, the NRC found the Inservice Inspection Program for the Second Ten-Year Interval at PBAPS Units 2 and 3 to be satisfactory (September 1986-Novenber 1997 and December 1985-August 1997, for Units 2 and 3, respectively).

In addition to the ASME Code design and inservice inspection program requirements, the NRC provides information to the muclear power industry on various enterging phenomena that may potentially affect the safe operation of nuclear power plants. For exarnple, integranular stress comosion cracking (IGSCC) of BWR internal components hes been identified as a terhnical issue of concern by both the NRC Staff and the nuclear indusiry. The core shroud is anong the internal reactor components susceptible to JGSCC. Identification of cracking at the circumferential beltine region welds in several plants during 1993 led to the publication of NRC Information Notice (IN) 93-79, "Core Shroud Cracking at Beltline Region Welds in Boiling-Water Reactors," issuled 
on Seplember 30, 1993. Several licensees inspected their core shrouds during planned outages in the spring of 1994 and found cracking at the circumferential welds. To disseminate this information to nuclear power plant licensees, the NRC issued IN 94-42, "Cracking tin the Lower Region of the Core Shroud in Boiling-Water Reactors," on June 7, 1994, and Supplement 1 to IN 94-42, on July 19, 1994, concerning cracking found in the core shrouds at Dresden Lnit 3 and Quad Cities Unit t. On July 25, 1994, the NRC issued GL 94-03, "Intergranmular Stress Comosion Cracking of Core Shrouds in Boiling Water Reactors," requesting that BWR licensees inspect their core strouds by the next refueling ontage and justify continued operation until inspections could be completed. The NRC has been closely monitoring these inspection activities. Additional examples of NRC action regarding reactor vessel internal component reliability issues are the issuance of Bultetio 80-13, "Cracking in Core Spray \$pargers," on May 12, 1980, after the deteclion of cracks in core spray system sparger piping at several operating BWRs and the issuance of IN 95-17, "Reactor Vessel Top Guide and Core Plate Cracking," issued on March 10, 1995, that concerned reactor vessel top guide and core plate cracking.

\section{Core Shroud Cracks}

The Licensee submitted letters dated March 14, 1994, Nowember 7, 1994, and Novenber 3, 1995, regarding the resutis of its inspections of the PBAPS Unit 2 and 3 core shroults. The inspections revealed a moderate amound of crack indications in the Unt 2 and Unit 3 core shrouds, totaling $5 \%$ of the weld length examtived in Unit 2 and $12 \%$ of the weld length examined in Unit 3 . Along with the inspection results, the Licensee presented an analysis of the impact of the crack indications on the structural strength of the core shrouks for Unit 2 and Unit 3. For both the Unit 2 and Unit 3 core shroud, the Staff reviewted the Licensee's analysis of structural loading of the as-found shroand weld which showed that the loadings were less than ASME Code-allowable values. In a letter dated February 6, 1995, the NRC Staff issued a safety evaluation of the 1994 Unit 2 core shroud inspection concluding that sufficient structural margin remained in the Unit 2 shroud to justify operation of PBAPS 2 for another operatiog cyclo (current operating cycle 11 that ends in September 1996) without modification to the shroud. In a letter dated January 29, 1996, the NRC Staff issued a safety vvaluation of the 1995 Unit 3 cors shroud inspection concluding that sufficiest structural margin remained in the Unit 3 shroud to justify operalion of PBAPS 3 for another operating cycle (curremt operating cycle 11 that ends in September $1997)$ without modification to the shroud. 


\section{Reatar Vestel Internals Cracking}

In addition to the inspection of core shrouds, PECO performs inspections of the PBAPS Unit 2 and 3 reactor vessel internals and other internal safety-related components in accordance with the PBAPS inservice inspection program, as set forth in section 50.55a and ASME Code \$ XI. By letter dated Janvary 17, 1995 , PECO submitted, in accordance with 10 C.F.R. \$50.55a(g)(3), a report on its inservice inspection activities conducted during the September 1994 Unit2 refireling outage. In the report, PECO lisited the inspections ptrformed and discusssed the disposition of jodications in centain components. In addition to the core stmotd flaws described above, the Licenste discovered some minor defects, sukh as a crack in a jet pump assembly restrainer adjustment screw tock welch, and performed an engineering evaluation to determine if a repair was needet. In the case of the jot pump restrainer adjustment screw tack weld crack, a second existing weld was found intact and no repair was necessary. The NRC Staff conducted an inspection of the Licensee's inservice inspection activities during the PBAPS Unit 2 refueling outage. The results of that inspection are documented in Inspection Report 50-27//94-28 and S0-278/94. 28 (IR 94-28). The Stoff concluded that PBAPS inservice inspection programs atnd nopdestructive examination programs were well planned, controfled, and exectted for both PBAPS 2 and PBAPS 3. Therefore, the requirements of section 50.55a and the ASME Code have been met in this aree, and the results confitm that satisfactory material condutions exist for the safe operation of both unils.

The NRC Staff has reviewet the content and results of other Licensee inspection activities, as discussed below.

NRC Bulletin 80-13, issued on May 12, 1980, requested that BWR licensees visually inspect core spray piping inside the reactor vessel at each subsequent refueling outage. During inspections conducted as requested by the Staff in Bulletin 80-13, PECO detected cracks in core spray piping inside the reactor ressel in Unit 2 and Unt 3 in 1982 and 1985, respectively. In both instances, the Licensee installed clamps on the affected piping to mitigate the consequences of the cracks. In letters dated June 10,1982, and November 21, 1985, the NRC Staff reviewed the Licensee's analysis of the crack consequences and repair plans ${ }^{4}$ and found them acceptable for PBAPS Units 2 and 3, respectively.

In Novenber 1993, during subsequent inspections, PECO identified cracking in the downcomer portion of the Unit 3 core spray piping. By letters dated Nowember 5 and November 10, 1993, the Licensee provided an analysis that demonstrated that this downcomer piping had sufficient structural integnity

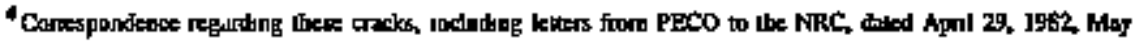

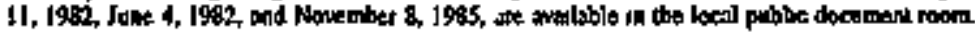


to justify operation without Iepair for the subsequent operating cycle. In a letter dated Noventer 16, 1993, the NRC foumd PECO's proposal to operate for one operating eycle without repaining the core spray downtomer cratks acceptable. During the September 1995 refueling outage for PBAPS Unit 3, PECO performod additional inspections of the cors spray piping within the reactor vesel. As documented in its Jetter dated October 9, 1995, PECO stated that this inspection revealed additional cracking. In its letter of October 9, 1995 , as supplemented by a letter dated Oetober 12, 1995, PECO proposed to repait the core spray piping by instalting mechanical clamps over the affected crackesd welds. The NRC Staff reviewed the design of the proposed clamps and foend that the clamps provided the required structural jotegrity for the piping. The NRC Staff also approved restart of the Peach Bottom Unit 3 tased on PECO's installation of the clamps.

Although eracking of the top guide has not been detected at PBAPS, the Licensee has implecnented a program to inspect the top guide and has included the top guide inspection into the PBAPS inservice inspection program.

\section{Analysis Regarding Synergistic Effects of Cracking of Multiple Components}

The Pelitioner raises a concern about the lack of an analysis of the synergistic effects of cracks in multiple reactor vessel components.

Most reactor internals are fabricated from high-toughress materials such as stainless steel and were designed with significant margins on allowable stresses. Cracking must be severe to adversely impact plant safety. It is untikely that Eicensee inspections would not find such severe degradation. In fact, the PECO inspections, usijg qualitied inspectors and proceriures, have been effective in identifying and sizing of the cracks in the Peach Bottom Unit 2 and Unit 3 core shrouds. In addition, after evaluating the resuts from internals insptections performed to date at PBAPS, the NRC Staft has concluded that ASME Code structural margos have been mantanted to mets ASME design requirements. Thus, these components will perform their function in the safe operation of the plants.

Implententation of an tffective inservice inspection progan serves to detect cracking. Upon detection of cracking, proper actions by the Licenset to maintain component integrity will prevent cracks large enough to affect operabulity from existing in mult'tple components at the same time. Neverthejess, the NRC has asked the BWR Yessel Internals Project (BWRVIP), an industry group, to develop an assessment to address this unlikely situation. A repart from the

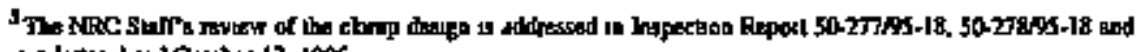
IA a loter deted October 13, 1996

0
0
0
0

$\therefore$

.
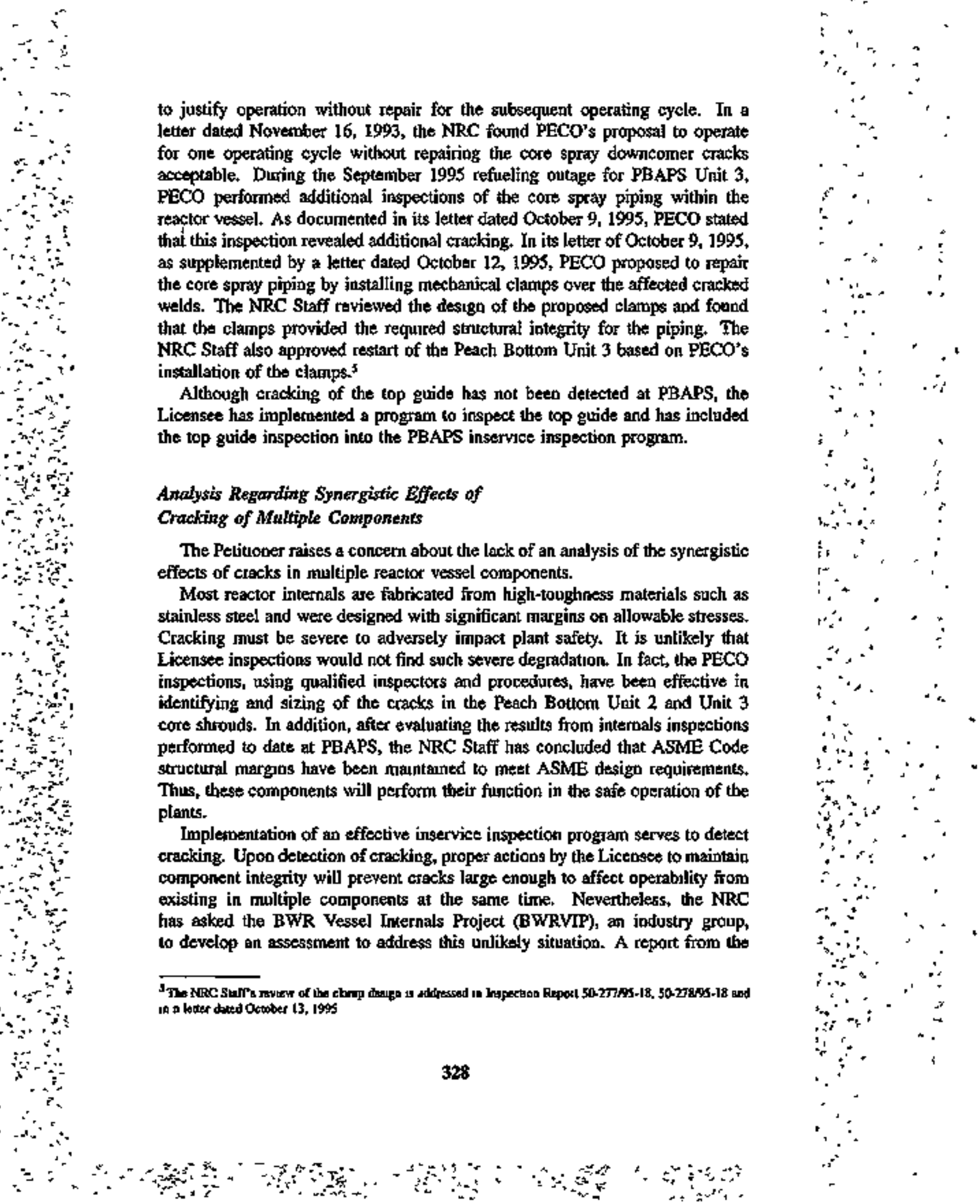
BWRVIP on this issue, "Reactor Pressure Vessel and Interaals Examination Guidelines (BWRVIP-03, EPRI Repont TR-105666," dated Nowentuer 10, 1995. is currently under NRC Staff review. In addition, the NRC has undertaken a longex-term evaluation of the effects of cracking in multiple internal components. This evaluation will involve approprate probabilistic treatment of the key variables (such as material susceptibility, loading, and envíonment).

Moreover, the Licenusee is not required by section $50.55 \mathrm{a}$ or the ASME Code to perform an analysis that addresses the synergistic effects of cracking in multipte safety-class eomponents. Since the KRC Staff has fourd duning reviews of the initial plant design and reviews of the Licensee's response to subsequently identified cracks, as described above, that each affected component has been shown to meet the ASME design margins, the NRC Staff is satisfied that these components will perform their intended function in the safe operation of the facilities. Because of this and the inspection requirements that pertain to reactor internals and the results of the inspections performed to date, the NRC Statf does not consider the lack of an analysis of the sypergistic effects of cracks in multiple teactor components for PBAPS to be a substantial safety concern.

In summary, on the basis of the NRC inspections and the evaluations of the Licensee inspections required by section 50.55a and the ASME Code, the NRC Staff has concluded that the Licensee has taken appropriate actions to enseme the structural integrily of the PBAPS reaclor vessel intemal components. The NRC Staff, however, continues to overview PECO's inspections, evaluations, and repairs as necessary to meet these requirements. At this time, the NRC Staff has not fousd any reason to guestion the safe operation of PBAPS. Therefore, the NRC Staff has concledied that the Petitioner has not presented a substartial health or safety issue to warrant taking the actions requested in the petition.

\section{B. Correction of Eqquipment Problems Identified in Recent NRC Inspection Reports (Requests 3 and 4 )}

\section{Energency Core Cooling}

The petition referred to a situation on August 3, 1994, wherein the PBAPS entergency service water (ESW) system was placed in a degraded condition. The Petitioner asserted that both reactors at PBAPS had no energency cooling water for about 1 hour. The NRC resident inspectors at the Peach Hottom site conducted an inspection of this event and documented their findings in Inspection Report 50-277/94-24 and 50-278/94-24, dated September 29, 1994 (IR 94-24). In the report the NRC inspectors concluded that the discharge valve from the ESW system back to the Susquehanna River was shat and left unattended for approximately 50 minutes after maintenance and testing on the valve. In the report, the NRC Staff conchuded that, if an axcident requiring the tuse of safety 
equipunent (including emergency diesel generators and emergency core cooling

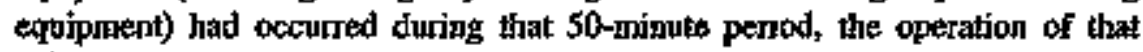
safety equipment could have been jeopardized.

By letter dated Noventeer 21, 1994, the NRC issued a Notice of Violation and Proposed Imposition of Civil Penalty (EA-94-197) to PECO Energy Company regarding the circumstances sucrounding the August 3, 1994 event The NRC Staff cited the Licensee for fatture to implement maintenance and testing procedares that were adequate to ensure that the ESW system could perform its intended function while maintenance activities were being performed. The Staff noted that since the August 3, 1994 event, the Licensec had restored the ESW to its intended configuration and had intiated steps to ensure that fuhure maintenance activities would not lead to a degraded ESW system. Notwithstanding the specific conective actions implemented by the Licensee, the \$taff imposed a civil penalty in the amount of $\$ 87,500$. On December 21, 1994, PECO Energy paid the civil penally.

Because appropiate NRC action bas beto taken and the Licensee has restored the ESW system to its intended configuration and has implemented conective actions to prevent recurrence of the deficiencies that occurred on August 3, 1994, no specific concern about the ability of the ESW system to perform its jotended function currently exists.

\section{Chronic Equipment Problems}

The petition also referenced a list of chronic equipment problems at PBAPS. 6 The petition referenced an NRC report dated August 16, 1994 (NRC Inspection Report 50-277/94-17, 50-278/94-17 (IR 94-17)), as the source of the chronic problems.

In this inspection report the NRC assessed the perfornance of the Licensee's engineering and lechnical support organizstion at Peach Bottom. The NRC inspector reviewed various facets of PECO's engineering department's performance in order to identify potential organizational weakeesses and defeciencies. The NRC uses the inspection findings to matntain a close understantiting of the Licensece's performance in areas that can affect safe plant operation. As such, the NRC reviews the Liensece's program for identfying, addnossing, and resolving recentring of "chropic" equipunent probtems. Al the time that IR 94,17 was issued, the bassis document for the Licensee's program was the "Chronic Expipment/System Problems" list. This was a list of recuming problems for whith the Licensee had ejther identified the oced for engineering depantmen

Gee nole 2 nypry
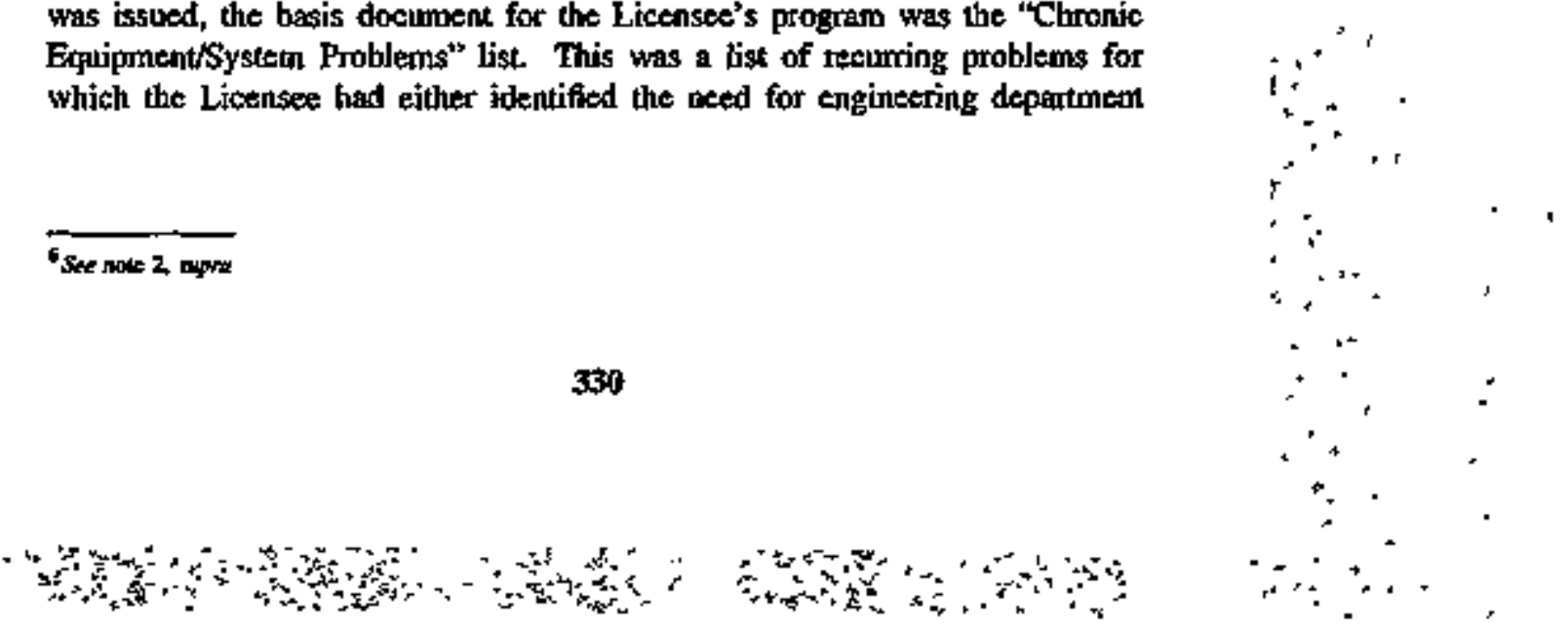
review and action or had determined a method for resolving the problem but had not yet implentented the solubion.

The "Chromic Equjpment/System Prablents" list included equipnent problems with potential safety impact as well as obvious non-safety-related problems. In assessing the management of recurring problems, the NRC evaluates the Licensee's ability to address and resolve problems in a imely manner and the Licensee's ability to ovaluate the safety significance of each problent. The existence of a list of issues does not in itself iadicate poor engineering department performance. As noted in IR 94-17, the Licensec bad developted solutions for a number of the problems on the list and had developed plans to implement thest solutions. Further, the NRC Staff assessed the PBAPS Chronic EgupmendSystem Problem list as a positive managernent feature and a commitment on the part of the Licensee to improve overall plant perfonnasce.

The NRC Staff, including the resident inspectors and the Region I inspection staff, periodically reevaluate the performance of the Licensee's engineering department. In addition, NRC inspectors continue to review the Licensee's action on many of the individual probłems on the PBAPS Chronic Equiprnentosystem Problem list. Accordingly, the NRC performed a followup inspection to IR 9417. In the followup inspection, docunented in Inspection Report 50-277/94-21, 50-278/94-21 (IR 94-21), tated Novembur 4, 1994, the NRC Staff examtued the safety stigniticance of those items that were on the Chronic EgujprontSystem Probjem List as of September 13, 1994. The Staff concluded that none of the items on the list was a significant curremt safery concern. The inspectors concluded that the Licensec had initiated appropriate action to evaluate and correct those items detailed in IR 94-21. The Staff coneluded that the Licensec nsed the Chropic Equipment/System Problem list to appropitately focus long-term engineering and management attention to known reliability problems.

In sumnary, the Staff considers proper managentent of recurring equipgnent problems important to the contipued safe operation of a nucless power plant. Accordingly, the NRC Staff views positively the Licensee's activities such as the formulation of the Chronjc Equipment/Systems Problem list, which was cited in the petition, On the basis of the review efforts by the NRC Staff, I conclude that no substantial health or safecy issues have been raised by the Petitioner.

\section{CONCLUSION}

The institotion of proceedings in response to a request pursant to section 2.206 is appropriate only when substantial health or safety issues have been raised. See Consolddated Edison Co. of New York (Indian Point, Units 1, 2, and 3), CLI-75-8, 2 NRC 173, 176 (1975), and Washington Public Power Supply System (WPPSS Nuclear Project No. 2), DD-84-7, 19 NRC 899, 923 
(1984). This standard bas been applied to the concens raised by the Petitioner to detenmine whecher the action requested by the Petitioner is wartanted. With regard to the specific requests made by the Pettioner discussed herein, the NRC Staff finds no basis for taking any additional actoons. Rather, as explainted above, the NRC Staff considers that no substantial health or safety issues bave been rassed by the Petitoner. Accordingly, the Pettuoner's requests for additional action pursuant to section 2.206, specifically requests 2,3 , and 4 , are denied. Accordingly, po action pursuant to section 2.206 is being taken un this matter.

A copy of this Final Director's Decision will be filed with the Secretary of the Commisston for review is accordance with 10 C.F.R. 2,206(c). This Dexision will become the final action of the Commission 25 days after issoance unless the Commission, on its own motion, institotes reviow of the Decision within that time.

FOR THE NUCLEAR REGULATORY COMMISSION

\section{Willian T. Russell, Directior Office of Nixclear Reactor Regulation}

Dated at Rockville, Maryland, this loth day of June 1996.

Attachnent: DD-96-3

[The attachment, DD-96-3, has been omitted from this publication but can be found at 43 NRC 183 (1996) or in the NRC Public Document Roon, $2120 \mathrm{~L}$ Street, NW, Washington, DC.] 
UNITED STATES OF AMERICA

NUCLEAR REGULATORY COMAISSION

OFFICE OF NUCLEAP REACTOR REGULATION

Willam T. Fussell, Director

In the Malter of

Docket Hos. 80-247

50-286

(LIcensp Nos. DPR-28

DPR-64)

\section{CONSOLDDATE EDISON COMPANY \\ OF NEW YORK}

(indlan Polnt, Units 2 and 3)

June 10, 1996

The Director of the Office of Nuclear Reactor Regulation denies a petition filed on May 18, 1995, requesting that the operating license for Indian Point Units 2 and 3 be suspended until the Licensees have completed the actions requested by Generic Letter 95-03, "Circumferental Cracking of \$team Generator Tubes" The Petitioner also requested that the NRC bold a public meeting to explain its response to this request.

\section{DIRECTOR'S DECISION UNDER 10 C.F.R. \$2.206}

\section{INTRODUCTION}

On May 18, 1995, Ms. Connie Hogarth (Petitioner) Gled a petition with the U.S. Nuelear Regulatory Commission (NRC) pursuant to 10 C.F.R. \$2.206. The Pelittonter regitested that the operating licenses for Indian Point Units 2 and 3 be suspended until the Licensees have conpleted the actions requested by Generic Letter (OL) 95-03, "CircumferentiaI Cracking of Steam Generator Tubes." The Petitioner also requested that the NRC hold a public neeting to explain its response to the suspension request. 
The Patitioner stated that the impetus for GL 95-03 was the duscovery at the Maine Yankee plant of stearn generator tube cracks that had previously gone undetected due to inadequate jnspection procedures. The Petitioner also stated that while GL 95-03 calls for comprehensive exantination of steam generator tubes, it appears to allow licenseces to postpone their evaluations until the next scheduled inspection.

On June 16, 1995, I informed the Petitioner that the pelition bad been referred to ny office for preperation of a Director's Decision. I informed the Pettioner that her request for inntediate suspension of the operating licenses of Indian Point Units 2 and 3 was denied because the continued operation of these units posed no undue risk to public bealth and safety. I further informed the Peutitioner that ber request for a public meeting to explain the denial of her request for license suspension was denied, primarily because the NRC assessment of risk associated with steam generator tube rupture events has already been articulated in public documents.

\section{DISCUSSION}

The Petitioner requested that the operating licenses for Indian Point Units 2 and 3 be suspended until the Licensees have completed the actions required by GL 95-03. The Petitioner's request appears to be based on her belief that without the immediate completion of the requested actions of GL 95-03, the steam generators in Indian Point Units 2 and 3 could be susceptible to one or more steam generator tube nptures brought about by existing circumferentiał cracks.

Generic Leter 95-03 was issued on April 28, 1995, after Maine Yankee shut down due to primary-to-secondary leakage through theretofore undetected circumferential steam generator tube cracks. The generic letter was intended to alert lieensees to the importance of performing steam generator inspections with equipment capable of detecting degeneration to which the steam gentrator tubes are suscepibla. GL 95-03 requested three actions of licensees of pressurized water teactors. It requested (1) that they evaluate their operating experience to determine whether or not they could have a cireumferential cracking problem, (2) that based on this evaluation they develop a safety assessment justifying continued operation until the next scheduled steam generator tube inspection, and (3) that they develop a plan for inspecting for circumferential cracking during the next steam generator tube inspection.

Stress corrosion cracking of the Indian Poirk Unit 2 steam generator tubes was first detected during the 1993 refueling outage. During the 1995 refueling outage, Unit 2 condscted a stean generator inspection as required by their technical specifications; this jnspection iraciuded a complete examination of all

(1)

$x_{x \rightarrow 0}$

$\therefore x+3$

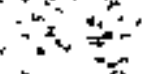

$\therefore$, A ${ }^{2}$

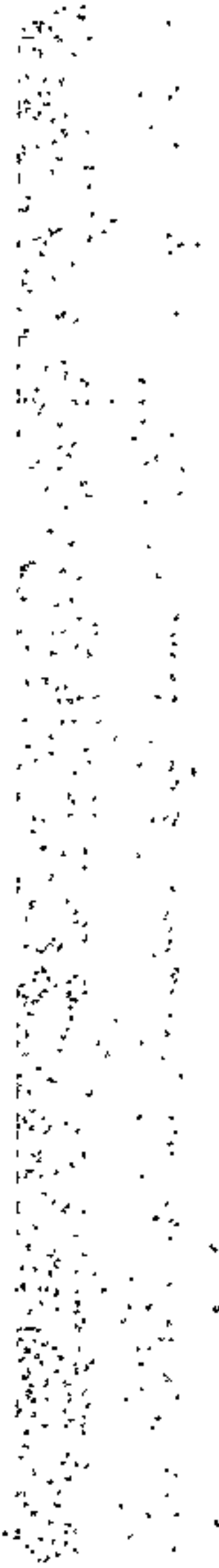


ayeas deemed most susceptible to circumferential cracking. This inspection, which used enhanced techniques and eddy-current probes sensitive to indications of cireumferential cracking, identified 114 tubes with potential cincumferential crack jodications; bowever, these may actually have been closely spaced axial indications. Since the Licensee could not conclusively determine that these 114 tubes did not contain indications of circumferential cracks, the worst case was assumed, that is, that the indications were in fact circunferential. The indications were logged as circumferential and all of these tubes were removed from service before the unit was restarted. All of the logged circumferential indications were deep within the tubesheet. The fact that the indications were all within the tubesheet is significant since, if a citcumferential faiture were to occur at this location, the structural strength lent to the tubes by the turbeshest would reduce the anount of primary-to-secontary leakage. The Licensee for Indian Point Unit 2 will contipule to use inspection techaiques capable of detecting eiscumferentially oriented tube degradation.

Because pitting corrasion bad caused deterioration of the Indian Poith Unit 3 steam generators, they were replaced in 1989 with steam generators designed and fabricated to reduce the possibility of corrosion-nelated problems; specifically, the new generators have tubes made of thermally treated Alloy 690 . Four other nuclear plants tn the United States have thernally treated Alloy 690 ubes and to date neither Indian Point Unit 3 nor any of the other four units bas experienced twbe cracks.

Circumferential cracking of steam generator tubes is accompanied by other forms of twhe degradation that are readily detected by bobbin coil inspections. Since the botbin coil inspections at Indian Point Unit 3 have detected no serviceinduced twbe degradation, the Staff has concluded that Indian Point Unit 3 does not have a circumferential tube cracking problem. Indian Point Unit 3 has not yet experiented steam generator tube degradation; nevertheless, the Licensee has committed to performing an augmented inspection for indications of circumferential cracking during the next scheduled steam generator inspection. Unit 3 is curtently operating and this inspection is required by May 1997.

The requitements placed on licensees to ensure steam generator tube integrity go beyond the requested actions of GL 95-03. Stearn generator tube degradation is desls with through a conbination of inservice inspection, tube plugging and repair criteria, primary-to-secondary leak rate monitoring, and water chemistry analysis. In addition to the stean generator inspections required by their techpical specticacions, boch Inctian Point Units 2 and 3 are required to monitor primary-to-secondary leakage to ensure that, in the event that steam generator uubes begin to leak, operators will be able to bring the plant to a depressutized condition before a tube ruptures. In addition, both units are required to implement secondary water chemistry management programs that are designed to minimize steam generator tube corrosion. 
The layers of protection that licensees are recinired to implement make multiple steam genterator tube raphures uolikely events. The NRC issued the results of its study of the risk and posental cansequences of a range of steam generator tube nupture events in NUREG-0844, "NRC Integrated Program for the Resolution of Unresolved Safety Issues A-3, A-4, and A-5 Regarding Steam Gentrator Thbe Integrity" dated September 1988. The Staff estimated the risk contribution due to the poitential for multiple steam generator tube ruphires. A combination of citcumstances is required to produce such fallures, specifically: (1) a main steam line break or other loss of secondary system integrity, (2) the existence of a layge number of tubes susceptible to ruplure in a particular steam gentrator, (3) the fafiure of operators to take action to avoid high differential pressure, and (4) the actual simultaneous nupture of a large number of tubes. In the NUREG-0844 assessment, the Staff concluded that the probability of simultaneous multiple tube failure was surall (approximately $10^{-5}$ ), and the risk resulting from releases during stean genterator tube nupeures with loss of secondary system integricy was also smafl.

\section{CONCLUSION}

Based on the facts that (1) adequate steam generator tube inspections bave been performed at both Indian Point Uaits 2 and 3. (2) Unt 2 steam generator tubes that showed signs of circumferential cracking have been removed from service, (3) Unit 3 stean generator tubes show to sign of service-indoced comosion, (4) Items (1). (2), and (3), above, collectively constitute an acceptable response to the requested actions of GL 95-03 for both tanits, (5) operational limits are placed on primary-to-secondary leakage, (6) the risk of multiple steam generator tube rupture events is statil, and (7) the NRC assessment of nisk associated with stean generator tube rupture events bas already been artiellated in poblic documents (NUREG-0844 and GL 95-03), I have concluded that neither the saspension of the licenses of Indian Roint Units 2 and 3 nor the holding of a public meeting to explain this Deciston is wartanted.

The Petitioner's request for action porsuant to l0 C.F.R. 82.206 is denied. As provited in 10 C.F.R. $\$ 2.206$ (c), a copy of the Decision will be filed with the Secretary of the Commission for the Commission's review. This Decision will constitute the final action of the Commission 25 days after issuance unless 
the Commussion, on its own motton, institutes a revitew of the Dectision within that time.

\section{FOR THE NUCLEAR \\ REGULATORY COMMISSION}

William T. Russell, Director

Oftice of Naclear Reactor

Regulation

Dated at Rockville, Maryland, this 10th day of June 1996. 
UNITED STATES OF AWERICA

NUICLEAR REQULATORY COMANSSION

OFFACE OF NUCLEAR REACTOR REGULATION

Frank J. Miragile, Acting Drector

In the Matter of

YANKEE ATOMIC ELECTRIC COMPANY

(Yankee Nuclear Power Stallon)

Docket No, 50-028

(License No. DPR-3)

SACRAMENTO NUNICIPAL UTILITY

Docket No. 50-312

DISTRICT

(Ucense No, DPR-54)

(Pancho Stco Nuclear Generating

Station)

POATLAND GENERAL ELECTRIC

CONPANY

(Trojan Nuclear Plant)

Docket No. B0-344

(License No. NPF.1)

SOUTHERN CALIFORANIA EDISON

Docket No. 50-206

COMPANY

(San Onofre Nuolegar Gemarating Station, Unit 1)

(License No. DPR-13)

June 14, 1996

The Durector of the Office of Nuclear Reactor Regulation dentes a petution dated April 1, 1996, submitted to the Naclear Regulatory Connosssion by Citrzens Awareness Network, Nuclear Information and Resource Service, and nume other organizations. The petton requests that the NRC; (I) suspend the current plan by Yankee Atomtc Electric Company to remove, transport, and bury the Yaukee Nuclear Power Station (or Yankee Rowe) reactor pressure vessel (RPV); (2) requice luenses of Yankes Rowe, Rancho Seco Nuclear Generating Statıon, Trojan Nuclear Plant, and San Onofice Nuclear Generating Station, Unut 1 , who are now developing plans to remove, transport, and bury their respective

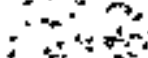

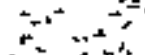

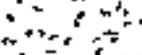

$\therefore x=2$

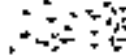

i.

$\therefore \quad 2=0$
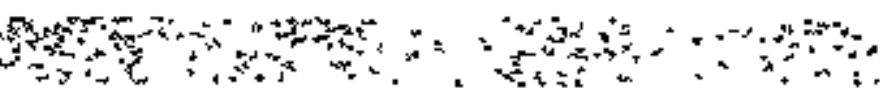
RPV', to suspend such operations; and (3) requite the owners of the four muclear poper plants to present substantial metal and weld specinens from their respective RPVs to the NRC for analysis in order to study and materially archive the radiation embrittiement phenomenon.

The Director denies the perition becsuse the Petitioners did not provide sufficient bases to warrant the suspension of deconmissioning glans or activities at the four melear power plants, and because sufficient information is aratlable to the Staff to address such radjation enbrittlement phenomenon in a manner that protects public bealth and safery without the issuance of ant order.

\section{DIRECTOR'S DECISION UNDER 10 C.F.R. \$ 2.206}

\section{INTRODUCTION}

Cítizens Awareness Network, Nuclear Infornation and Resource Service, and nine other organizations' (Petitoners) subnitted a petition dated April 1, 1996, pursuant to extion 2.206 of Title 10 of the Code of Federal Regulations (10 C.F.R.), requesting that the U.S. Noclear Regulatory Commission (NRC) take action with regard to the Yanke Nuclear Power Station (or Yankee Rowe, licensed to the Yankee Atanic Electric Company), Rancho Seco Nuclear Generating Station (ticensed to the Sacramento Municipal Utility District), Trojan Noclear Plant (Jicensed to the Portiand General Electic Company), and San Onofre Nuclear Generating Station, Unit 1 (jicensed to the Sonthern California Edison Company). These four power resctors have permanently ceased operation and are in various stages of decommissioning.

Febitioners request that the NRC take emergency action to require a collaborative effort by the Licensess of the four power reactors to document and research radiation embittlement of RPVs (RPVs) is an age-retated deterioration phenomenon because an archive is essential in understanding the issues surrounding embritukement of reactor vessels. Specifically, the Pebitioners request that the NRC (1) suspend the cutrent ptan by Yankee Atoutic Electric Corporation (YAEC) for the removal, transport, and butial of the Yankee Rowe RPV; (2) require Licensees of the four perminnextly closed reactors, who ane now developing plans to remove, transport, and bury their respective RPVs, to suspend such operations; and (3) require the owners of the four nuclear power plants to present substantial metal and weld specimens from their respective

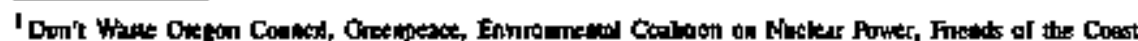

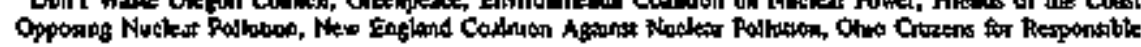

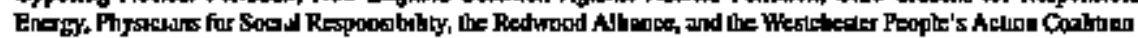
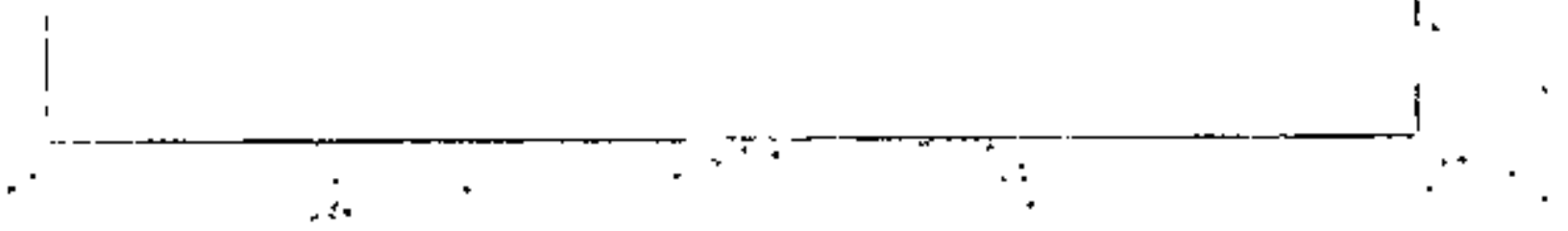
RPVs to the NRC for analysis in order to study and materially archive the radjation embrittlement phenomenon.

As bases for their requests, Petitioners state that (1) the four permanently closed reactors constitute a valuable asset for evaluating RPV embrittlement, (2) "boat" or scoop samples from the RPV could be retrieved with minimal occupational radjation exposure, (3) data from boal sampies could be used to verify the veracity of simblated embrittlement in research reactors, and (4) boat samples could be subjected to annealing or rebeating processes to analyze the results for restoning ductility of the material and for determining the durabitity of an annealing process.

For the reasons explained below, Felitioners' request is denied.

\section{II}

Irradiation of the RPV materials adjacent to the reactor core (the beltline materials) by netrons escaping from the reactor core leacs to embrittlement of those materials. This embrittemert phenomenon causes the RPV to be more susceptible to fracture when subjected to operattonal or accident transients that cause overcoolting (thermal shock) concurrent with or followed by significant pressure in the reactor vessel. Concern over this phenomenon has resulted in the NRC developing regulations to closely monitor embrittement of reactor vessels. Additionally, to better understand and qualify the embrittement process, the NRC Office of Research has an RPV safety research program that addresses the embrittlement phenomenon on a broad basis.

III.

The NRC Staff has concluded that sufficient information aljeady is and will be avalable to the Staff in order to address the radiation embrittlement phenomenon in a manner that protects putblic health and safety, without ordering any of the four Licensetes to suspend decommissioning plans or decommissioning activilies to supply metal and weld RPV samples for study. In addition to studying monttoring dats which all licensees are required to staply, the Staff has lested and will contine to test material from several sources as part of its confirntatory reseanch program. Samples obtained from decommisswoned RPVs already do and will continue to supplement other enbrittlement dats.

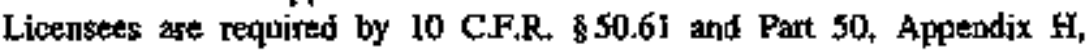
"Reactor Vessel Material Surveillance Program Requirements," to monitor RPV embsitternent. Appendix $\mathbf{H}$ specinies requirements for matterial surveillance progranis to monitor changes in the fracture toughness of ferritic mattrials in the

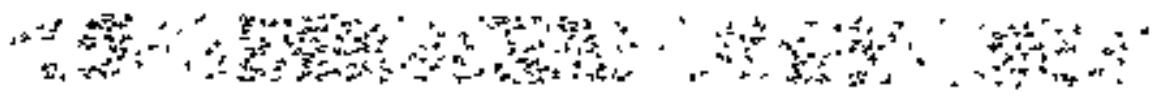


RPV beltitue region from exposure of these materials to neutron radiation. This regulation requires each licensec to monitor neutron iradiation embrittlement by placing wold andiox base materials (either plate or forging) that are representstive of its bettline materials in capsules that are placed inside the RPV. Most plants have plant-specific surveillance progrants under which the capsules are irradiated in the licensee's RPV. Sorne licentsees are participating in integrated surveillance programs under which the capsujes are irrodiated in a vessel that has an irradiation and thermal environment equivalent to that of the Licenseet's RPV. The capsules are periodically withdrawn from the RPV and the materials cested to monitor the effect of neutron radiation on the fracture toughness of the vesset beftline materials. These programs have been reviewed by the Staff and are sufficient for monitoring the effect of pentron radiation at all operating light-water reactors.

In addition to licensec programs, the NRC is sponsoring a number of other programs. NRC confirmatory research prograns in which materials are irradiated in test reactors, and the effect of neuteron radiation on the fracture toughness of beldine materials is analyzed, are the Heavy Section Steel Irradiation Program, the Radiation Embritlement and Predietion Program, the Improved Radiation Embritulement Correlation Program, and the Embrittlement Database and Dosimetry Evaluation Program, In the Improved Radiation Enbbrittlement Correlation and the Extbrittlement Database and Dosimetry Evaluation Programs, the Staff acempulates and evaluates data from power reactor licensee and test reactor programs and determines the effect of neutron radiation on the fracture. toughness of beltline welds, forgings, and plates. In connection with these issues, the Staff has documented in Regulatory Gutide 1.99, Revision 2, "Radiation Embrittlement of Resctor Vessel Materials," a methodology for determining the effect of neutron radiation on reactor vessel welds, forgings, ard plates. The methodology in Regolatory Guide 1.99 includes a margin term to account for the uncertainties in the material properties and the radiation envirchament. As the NRC Staff accumulates more surveillance data from licensees, it periodically evaluates the data to determine whether the Regufatory Guide 1.99 methodology needs revision. The licensee surveiliance database consists of data from several hurdred licensee capsules.

The Heavy Section Steel Irradiation Program provides experimental evaluation of the effects of chenistry and radiation environment on the irradiation embrittement of RPV steels, including the effects of thermal aging, recovery of fracture toughness by thermal annealing, and reenbrittlement trends on annealed reactor vessel materials. This program, in conjoction with the Radiation Embritternent and Prediction Progran, is developing improved methods for predicting irradiation embrittlement. Both prograns are evaluating, experimentally and analytically, the mechanisms that control tradiation embrittlement to justify extrapolation of the empirical model to predict plant-specific irratiation trm-

$\cdot$ 


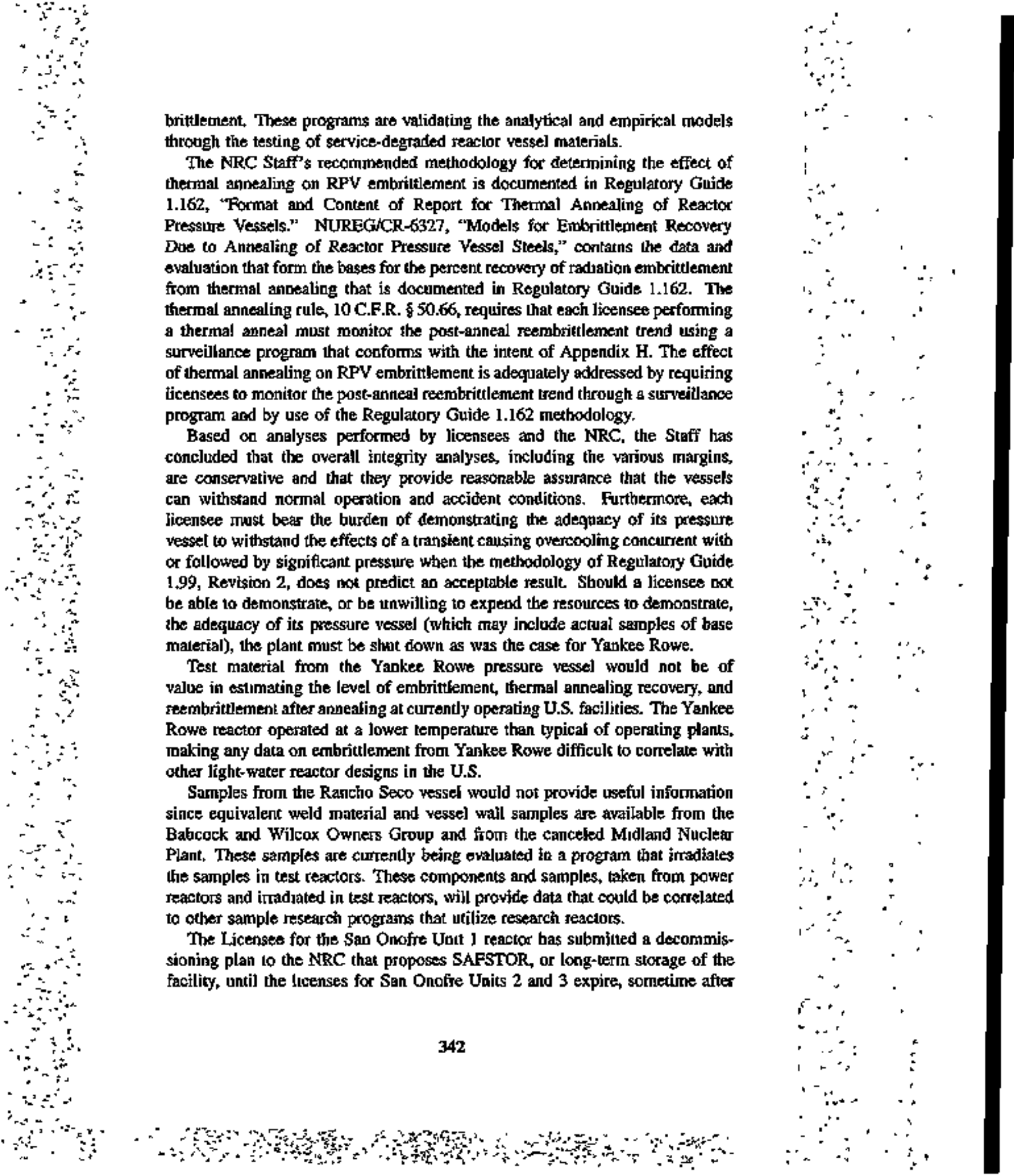


2013. Therefore, the Unie 1 vessel will remain on site and in a condition that would allow samples of test material to be obtained for a substantial pertiod of tirie, should it be deternined that such samples would be useful for study.

The Trojan Nuclear Plant is currently undergoing active dismantlement. Portland General Electric, the Licensee, is planning to remove the reactor vesset and dispose of it at the Hanford. Washington low-jevel burial site no earlier than 1998. The \$taff currently is pursuing the possibility of obtaining samples from the reactor vessel once the reactor vessel reaches the burial site.

For the above reasons, the Staff concludes that sufficient information is already and will be available to approprialely and timely address the radiation embrittlement phenomenon.

\section{CONCLUSION}

The Petitioners have not provided sufficient bases to warrant the suspension of decommissioning plans or activities at the four nuclear power plants in order to take specimens of reactor vessels for the purpose of studying the nuclear power RPV radiation embrittlement phenomenon. Moreover, as explained above, sufficient information is available to the Staff to adGress such radiation embrittlement phenomenon in a manner that protects public health and safety without the issuance of an onder. Accordingly, for the reasons discussed above, the petition, including the request to take emergency action, is denied.

A copy of this Director's Decision will be filed with the Office of the Secretary for the Commission to review in accordance with 10 C.F.R. \$2.206(c). As provided by section $2.206(\mathrm{c})$, this Decision will constitute the final action of the Commission 25 days after issuance, onless the Commission, on its own motion, institates a review of the decision within that time.

\section{FOR THE NUCLEAR REGULATORY COMMISSION}

Frank J. Miraglia, Acting Director

Office of Nuclear Reactor Regulation

Dated at Rockville, Maryland, this 14 th day of June 1996.

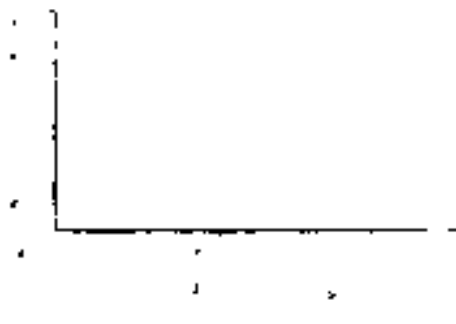


UNITED STATES OF AMERICA

NUCLEAR REGULATORY COMMSSION

\title{
OFFICE OF NUCLEAR AEAGTOR REQULATION
}

William T. Russell, Director

In the Matler of

Docket Nos, 50-528

$50-529$

$50-530$

\author{
ARIZONA PUBLIC SERVICE \\ COMPANY \\ (Pala Verde Nuclear Generation \\ Station, Uniks 1, 2, and \$)
}

June 25, 1998

The Director of the Office of Nucieas Reactor Regulation partially denies a petition dated May 27, 1994, as supplemented on July 8, 1994, 6led by Thomas J. Saporito, Jr., for bimself and on behalf of Florida Energy Consuttants, Inc. (Petitioners). Specifically, Petitioners' requests $1,2,3,5$, and 6, subnitted in the July 8, 1994 Stupplement, were addressed and denied on the basis that the concesns raised have been satisfactorily addressed and do not raise substantial health and safety concerns warraning the requested action. The Petitioners requested that the Nuclear Regulatory Commussion (1) institute a proceeding pursuant to 10 C.F.R. $\$ 2.206$ for the modification, suspension, or revocation of the Palo Verde operating licenses for Units 1, 2, and 3; (2) modify the Palo Verde operating licenses to require operation at $86 \%$ power or less; (3) require the Licensee to submit a no significant hazards safety analysis to justify operation above $86 \%$ power, (5) require the Licensee to analyze a design-basis steam geperator tube gupture event to show that the offsite radiological consequences do not exceed the Iimits of 10 C.F.R. Part 100; and (6) require the Licenses to denonstrate that ats energency operating poucedures for steant gencrator tube ruptare events are adequate and that the plant operators are sufficiently trained in the procedures. The remenning issues were addressed th the Director's letter dated July 26, 1994, acknowledging receipt of the petition and in a Director's 
Decision (DD-96-4, 43 NRC 309), issued on June 3, 1996. The reasons for the partial denial are fully set forth in the Director's Decision.

\section{DIRECTOR'S DECISION UNDER 10 C.F.R. \$2.206}

\section{INTRODUCTION}

On May 27, 1994, Florida Energy Consultants, Itce. (FEC), by and through Thomas J. Saporito, Jr. (Petitioners), submitted a petition parsuant to 10 C.F.R. \$2.206 to the U.S. Nuclear Regulatory Commission (NRC). The petition requested that the NRC (1) instinte a show-cause proceeding purstrant to 10 C.F.R. $\$ 2.202$ to modify, suspend, or revoke the operating licenses of Arizons Public Service Comapany (Licensee or APS) for Pato Verde Nuclear Generating Station (PVNGS or Palo Verde); (2) issue a notice of violation against the Licensee for contimuing to employ The Atlantic Group (TAG) as a labor contractor at Palo Verde; (3) investigate alleged material false statements made by William F. Consway, Executive Vice President at Pajo Verde, during his testimony at a Department of Labor bearing (BRA Case No. 92-ERA-030) and, in the interim, require that he be relieved of any authority over operations at Palo Verde; (4) investigate the Licensee's statements in a lelter dated August 10, 1993, from Mr. Conway to the former NRC regional administrator, Mr. Bobby H. Faulkenberry, that Mr. Saporito gave materially false, inaccurate, and incomplete information on his application for unescorted access to Palo Verde and that, as a ressult, Mr. Saporito lacks trustworthiness and reliability for access to Palo Verde: (5) investigate the circumstantes surrounding the February 1994 termination of Licensee employee Joseph Straub, a formex rodiation protection technician at Palo Verde, to determine if his employment was illegally terminated by the Licensee because he engaged in "protected activity" during the course of his employment; (6) require the Licensee to respond to a "chilling-effect" letter regarding the circurnstances surrounding Mr. Straub's termination frorn Palo Verde and specify whether any measures were taken to ensure that his termination did not have a chilling effect at Palo Verde; and (7) initiate appropriste actions to require the Llcensee to immedjatedy conduct oddy-cisrent testing (ECT) on all steam generators (SGs) at Palo Verde because the SG tubes were recently found to be subject to cracking.

As the basts for these requests, the Petitioners allege that (1) a showcause proceeding is becessary (a) because the public health and safecy concerns alleged ane significant and (b) to permit public participation to provide NRC with new and relevant information; (2) past practices of TAG demonstrate that employees of TAG were retaliated against for having raised safery concerns 
whike employed at Palo Verde; (3) citations to testimony from transcripts and newspaper articies (appended as cxhbits to the petition) demonstrate that $\mathrm{Mr}$. Conway's testimony is not credible; (4) statements in the letter of Augutst 10 , 1993, are inaceurate and mattrially falso and characterize Mr. Saporito as an individual lacking toustworthiness and reliability for acosss to Palo Verds, and that such ntgative characterizations have caused the nuclear intostry to blacklist him from continued employment, all in retaliation for his raising safery concerns about optrations at Palo Verde; thus, the Petitioners ask that thase statements be rescinded; (5) an investigation into the tentuination of Mr. Straub is warranted in view of the fact that the Licenset has engaged in sumilar illegal conduct in the past for which the NRC has required the Licensee to pay fines; (6) Mr. Straub is entided to reinstatement with pay and benefits pending the NRC's investigation into his termination to offset the chilling effect his termination had on the Palo Verde workforce; and (7) in addition to cooling tower problems, the stress-corrosion and cracking in the SGs is a recurning problems of which the Licensee is aware and has failed to properly conect, so that the NRC should be conterned about proper mantenabce of safecy systems and equipment at Palo Verde.

On July 8, 1994, the Petitioners filed a supplemental petition (Potition Supplement) raising six additional issues. The Pebitioners requested that the NRC (1) instibute a show-cause proceeding pursuant to section 2.202 for the modification, suspension, or revocation of the Palo Verde operating licenses for Units 1, 2, and 3; (2) modify the Palo Verde operating licenses to require operation at $86 \%$ power or less; (3) require the Licensec to submit a No Significant Hazards safety analysis' to justify operatuon of those units above $86 \%$ power, (4) take immediate action (e.g-t by confirnatory order) to require the Licensee to reduce operation to $86 \%$ power or Jess; (5) require the Licensee to analyze a design-basss steam generator tube rupture (SGTR) event to show that the offsite radological consequences do not exceed a small fraction of the limits of 10 C.F.R. Part 100; and (6) require the License to dentonstrate that its emergency operating prócedures (EOPs) for SGTR events are adequate and the plant operators are sufficiently traned in EOPs.

As bases for these requests, the Petioners allege that (1) the Licensee experiented an SGTR in the freespan area on Unit 2 on March 14, 1993; (2) during a Japuiry 1994 inspection on Unit 2, 85 axial indications were identified, the longest indication being 7.5 inches; (3) as of May 1994, 28 axial indications were found at Unit 2, and 9 axial indications were found at Unit 1 (more extensive testing will confirm the existence of circumferential crack indications

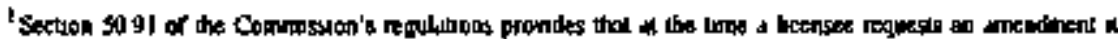

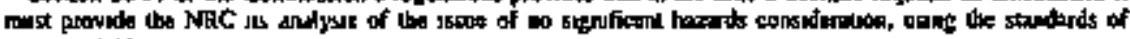
socton 5092
}

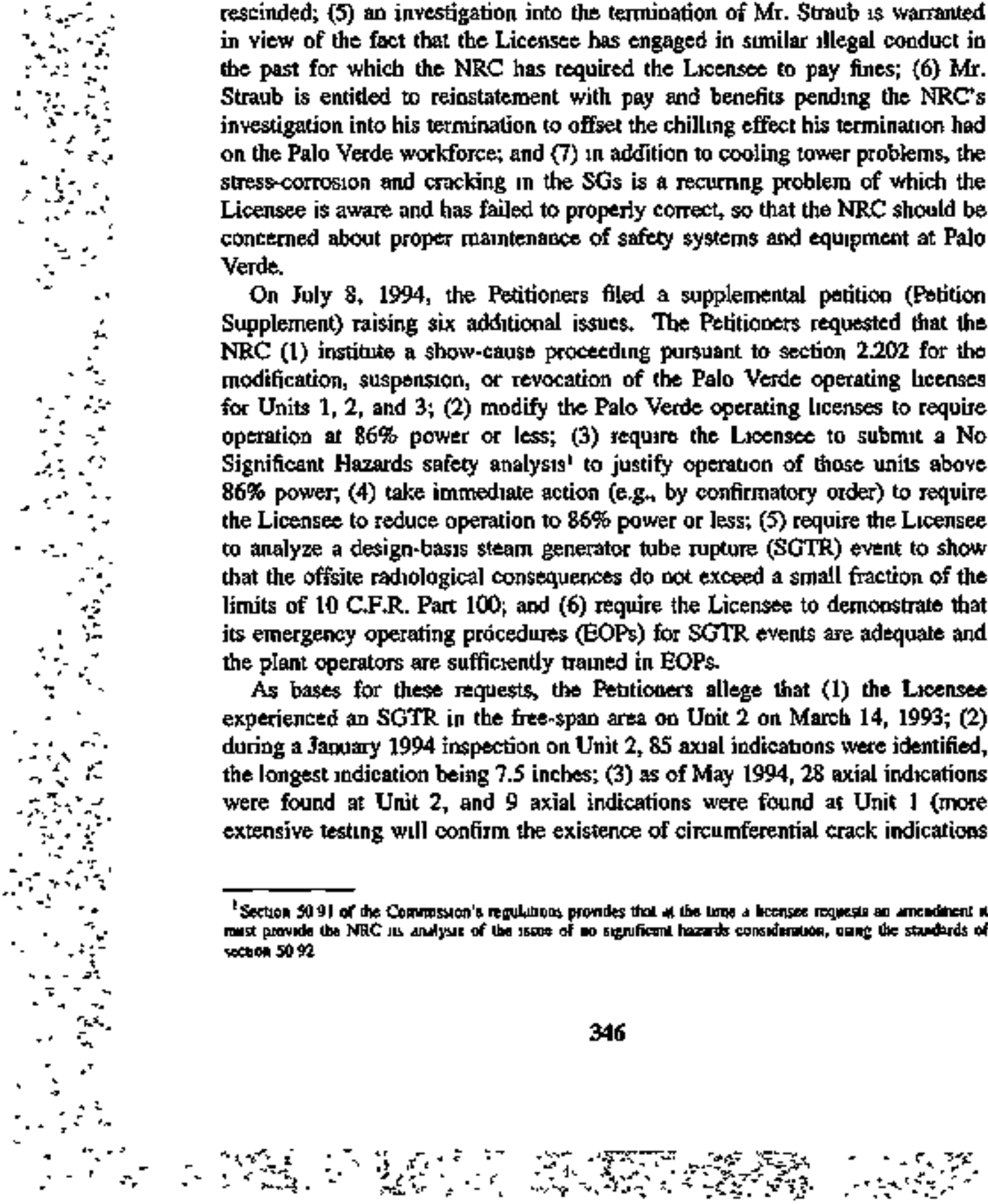


in the expansion and transition areas); (4) in May 1994, $\$ \bar{S}$ sludge ftom Lyntts $I$ and 2 indicated a lead content of 4000 to $6000 \mathrm{ppm}$, which is unusually high, accelerates the crevice corrosion process, and is believed to be caused by a feedwater source deficiency; (5) in eight instances, the Licensee failed to properly implement operational procedures during the SGTR event on March 14, 1993; (6) the Licenses's failure to comply with approved procedures in the above-mentioned event is indicative of a problem plant that wantants further NRC action; (7) in four instances, the NRC is aware of additional Licensee weaknesses regarding the SGTR event (8) the Licensee cannot enstre that the radiation dose linits are satisfied for applicable postulated accidents; (9) the Licensee is not maintaining an adequate level of public protection in that the offsite dost limits will be exceeded during an SGTR; (10) the Licensec cannot demomstrate that a Palo Verde unit can safely be shut down and depressurized to stop SG tube leakage before a loss of reactor water storage tank inventory; (11) SO wbes are an integral part of the reactor coolant boundary and tube failures could lead to containment bypass and the estape of radioactive fission products directly into the enviromment and, therefore, must be carefully considered by NRC and the Licensee; (12) the Licensee cannot demonstrate compliance witb 10 C.F.R. Part 50. Appendix A, which establishes the fundarinental requirements for $\$$ G tube integrity; (13) the License has failed to comply with NRC recommendations under NUREG-0800 to show that in the case of an SGTR event, "the offsite conditions and single failure do not exceed a small fraction of the limits of 10 CFR Part 100", and (14) the License has posed an unacceptsble risk to public health and safety by raising power on all three Palo Verde units above 86\%, considering the severe degradation of the SG tubes.

In a letter dated July 26, 1994, I acknowledged recejpt of the Petition of May 27, 1994, and the Petition Supplement of July 8, 1994, and denied the Petitioners' two requests for immediate action. The Petitioners requested the initiation of actions to require the Licensee to immediately conduct ECT on all SGs at Palo Verde (Request 7 of the May 27, 1994 Petition) and immediate action to cause the Licensee to reduce operation to $86 \%$ power or less (Request 4 of the July 8, 1994 Petition Supplement). Although these two requests for imblediate action were denied, the concems raised by the Petitioners regarding their reguests for ECT and reduced-power operation are additessed to this Decision.

The Staff informed the Petitioners that the remaining requests were being evaluated under 10 C.F.R. $\$ 2.206$ of the Commission's regulalions and that a response would be forthooming. This Decision addresses the Petitioners' contceros about ECT (Request 7 of the May 27, 1994 Petition), SG tube integrity, and emergency operating procedures for SGTR events and the remaining requests (Requests 1, 2, 3, 5, and 6) of the July 8, 1994 Supplement. The Staff has completed its review of the reminining issues in your supplemental petition. A Director's Dexision (DD-96-4, 43 NRC 309) regarding Requests 1 through 6 
in the Pettion of May 27, 1994, was issued under separate cover letter on June 3. 1996. A discussion of the Director's Dectsion follows.

\section{BACKGROUND}

The Petitioners' concerns addressed in this Decision appear to be based largely on the March 1993 SGTR event and the NRC Staff findings concerning that event set forth in the NRC Augmented Inspection Team (AIT) ${ }^{t}$ report. Palo Verde Unit 2 experienced an SGTR event do \$G No. 2 on March 14, 1993. At the time, the unit was at about $98 \%$ power. The plant operators manually tripped the reactor, declared an Unustal Event, ${ }^{3}$ which was subsequently upgraded to an Alert, ${ }^{4}$ and entered the PVNGS Functional Recovery Procedures to mitigate the event. The plant was cooled down and depressurized, and the event was terminated when Mode $5^{6}$ was achieved on March 15, 1993.

During the period March 17-25, 1993, an NRC AIT conducted an unspection at PVNGS Unit 2. Overall, the AIT conciuded that the response to the SGTR succeeded in bringing the bnit safely to a cold-shutdown condition and limitung the reiease of radioactivity so that there was no threat to pubjic health and safely. However, the AIT identified weaknesses in the Licensee's implementation of emergency płan actions, including event classification, activation of the emergency response facilthes, and prompt assignment of tasks to onsite personnei. Weakresses were also found in die procedores, equipment, and training associated with responding to an SGTR event. The AIT inspection was documented in NRC Inspection Report No. 50-529/93-14, issued on ApriI 16, 1993.

Enforcement action resulted from the AIT inspection in several areas (eg., emergency preparedness, chemistry and radiation montorng, and emergency operating procedures). All volations were isstued as \$everity Level IV.?

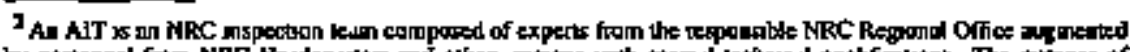

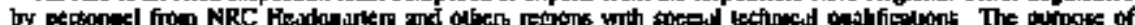

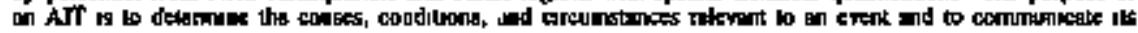

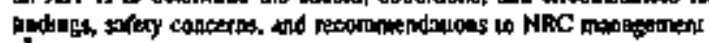

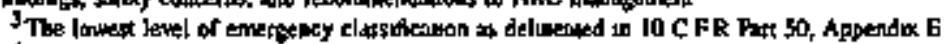

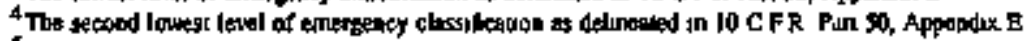

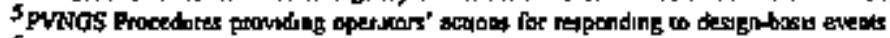

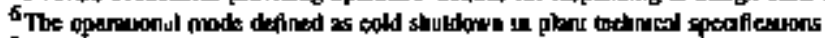

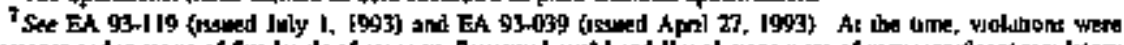

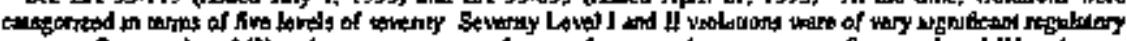

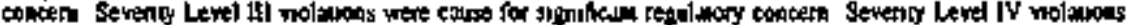

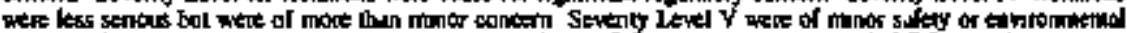

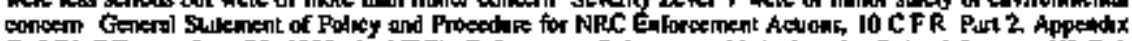

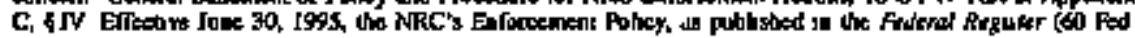
Ren 34381 is ser fonh In NUEEO.1600
} 
The NRC issued a confirmatory action letter ${ }^{8}$ (CAL) to the Licensee on June 4, 1993, for Unit 2. The NRC issted a safety evaluation by letter dated August 19,1993 , concluding that Unit 2 could sefely resume operation for 6 months, the interval between SG tube inspections. This safety evaluation closed the CAL.

The NRC issued a second CAL' on October 4, 1993, for Unit 3 (amended on Nowember 8 and 23, 1993), contirming the commitments made by the Litensee in its September 29, 1993 letter. By letter dated December 3, 1993, the Licensere reported that it had completed the actions discused in the CAL. Satisfied that the Licensee had completed the conditions of the CAL, the Staff closed the CAL by letter dated April 1, 1994.

The Licensee voluntarily reduced power to approximately $86 \%$ power in the fall of 1993 to minimize SG degradation. The Licensee evaluated and implemented several improvements to the operation of its SGs, one of which was a reduction in the reactor cocolant system hot-leg temperature. The units were all returned to $100 \%$ power by the fall of 1994 .

Foltowing a midcycle outage on Unit 2 and midcycle and refueling outages on Unit 3, the NRC issued a stafety evaluation on Jane 22, 1994, which concluded that boch Units 2 and 3 coold safely operate for 6 mopths between SG tube inspections. Since that time, there have been additional midcycle outages on Units 2 and 3 and a refueling outage on all three units. Eddycurrent inspection results and outage planting for the utits currently sapport the following operating intervals between inspections: Unit $\mathbf{l}, 16$ mombs; Unit 2 , 12 months; attd Unit 3, 1 [ months.

\section{DISCUSSION}

\section{A. Eddy-Current Testing on All Steam Generators at Palo Verde}

Item 7 of the Petitioners' letter of May 27, 1994, requested the NRC to Jequire the Licensee to conduct infmediate ECT on all SGs at Palo Verde to ascertain the integrity and life expectancy of the SG tubes. Althotohn, as itdicated above, this request for immediate action has been denied, the Petitioners' concents regarding ECT are addressed below.

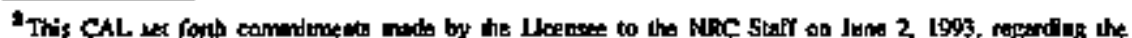

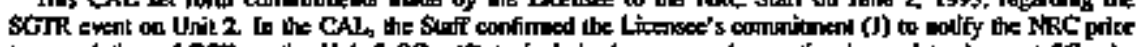

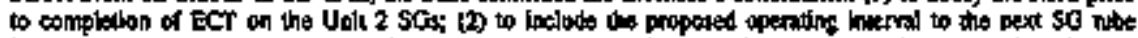

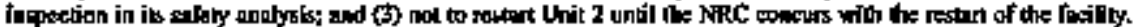

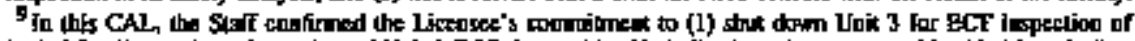

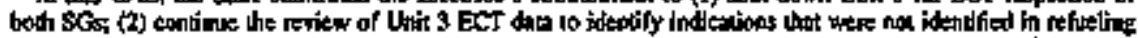

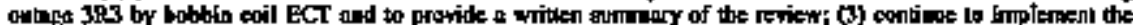

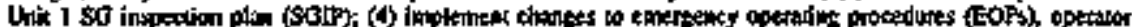

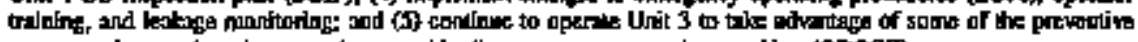

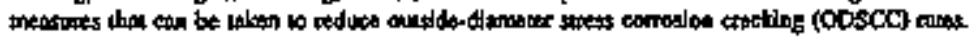


The Petitioners assert as a basis (Petition Bass 7) for thetr request concerning ECT that the Licensee's SGs have recently deweloped cracks in the free-span portion of their internal structure, that tube stress corrosion and cracking is a recurring problem in $\mathrm{SGs}_{x}$ and that there is a risk the emergency cooling system will be ungble to prevent the melting of the fuel because of tube ruptures.to

The Licensee has completed at least two eddy-current inspections on each of the Palo Verde units since the SOTR event in March 1993. The Staff issued safecy evalvations (SEs) that addressed Unit 2 and 3 operating intervals by letters dated August 19, 1993, and June 22, 1994.11 These SEs were based on the results of the Licensee's eddy-current inspections of Unit I in October 1993, of Unit 2 in May 1993 and January 1994, and of Unt 3 in December 1993 and May 1994. In summary, the Staft concluded that Units 2 and 3 could be saffly operated for up to 6 months between $\$$ G eddy-current inspections. The Lictnsee conducted five of these "minicyctes"12 (three on Unit 2 and two on Unit 3), thereby obtaining extensive SG eddy-current data, which it used to validate models used for analysis. In May 1995, the Licensee submitted a report supporting a cycle length of up to 11 months on Unit 3. Unit 1 completed a 16-month operating cycle in June 1995. After meeting with the Licensee, the Staff approved a Unit 3 cycle length of 11 months in a meeting summary dated August 22, 1995. During a September 20, 1995 meeting with the Staff, the Licensee presented its submittal and argumerts to support a 12-month cycle for Unit 2. The Staff incorporated data from the most recent Unit 3 \$G inspection in its evaluation of the Licensee's conclusion regarding a 12-month optrating cycle on Unit 2. The Staff approved the 12-month operating cycte by letter dated Marci S, 1996.

In summary, the Licensee performed the necessary eddy-cutrent inspections, and the Staff extensively reviewed and approved Palo Verde SO eddy-cursent inspection results and continues to review additional unformation regarding the integrity of the $\$ G$ intes. On the basis of its review of ECT, the Staff has concluded that the Pettitioners' concerns regarding the need for BCT have been satisfactorily addressed by the Licensee and that no further action by the NRC Staff is warranied.

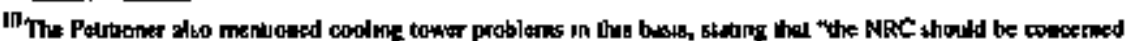

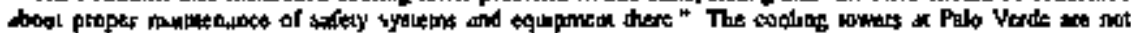

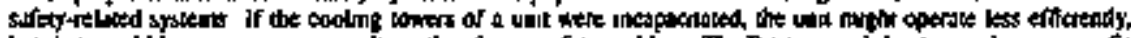

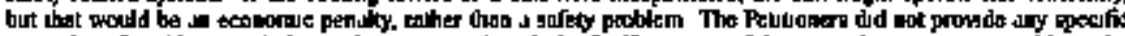

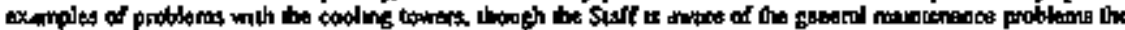

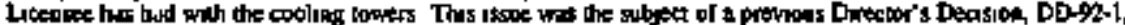

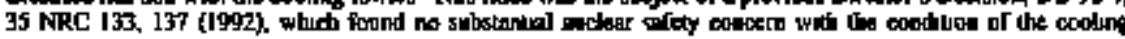
towers

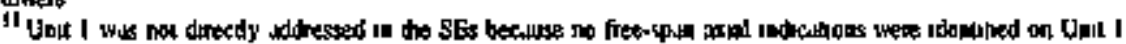
* lise true

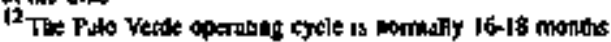




\section{B. Operation Above 86\% Power}

Requests 1, 2, 3, and 4 of the Petition Supplement, in essence, request actions requiring the Palo Verde licenses to be modified to requise operation at $86 \%$ power of less."

As bases for these tequests, the Petitioners assert that on March 14, 1993, PaIo Verde Unit 2 had an SGTR in the free-span section between the wbe supports and that in January 1994, an inspection of Palo Verde's Unit 2 SGs found 85 axial indications (longest indication, 7.5 inches) (Petition Supplement, Basis 2); and that as of May 1994, 28 axial indications were foend at Unit 2 , and 9 axjal indications foend at Unit 1 . The Petitionters believe that more extensive testing will confun the existence of circumferential crack indications in the expansion-transition atea (Petition Suppiement, Basis 3). The Petitioners also assert that in May 1994, Units 1 and 2 SG sludge jodicated a lead content of 4000-6000 ppm, which would accelerate the erevice corrosion cracking process (Petition Supplement, Basis 4). The Petitioners also stated that the operation of Palo Verde units at above $86 \%$ power is unacceptable due to severe degradation of the SG tubes (Petition Supplement, Basis 14).

\section{Axial and Curctumferential Stean Generator Thbe Indications}

With regard to the Petitioners' concern about identitable axial indications (Petition Supplement, Basis 2), it is correct that 85 axial indications in the freespan area (longest inditation, 7,5 inches) were discovered on \$G tubes at Paio Verde Unit 2 during the January 1994 inspection. However, this number was apparently based on preliminary inforstation from the Licensee's eddy-current inspection during the January 1994 eddy-current inspection. The Licensee's report of March 8, 1994, stated that actually 330 free-span axial indications were discovered during the Unit 2 first midcycle outage: 22 in $\$ G 1$ of Unit 2 (SG 21) and 308 in SG 2 of Unis 2 (SG 22). Although a number of axial indications were detecled by the Licensee, it is not the number of indications that is of a safety concers bat mather the severity of the indicalions (ie., severtity in terms of whether the tube indication had adequate structural and leakage integrity). As noled in the pelition supplement, the longest indication was 7.5 inches long. The safety significance of this indication, as with any eddy-cumrent

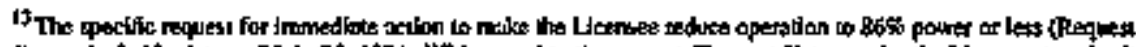

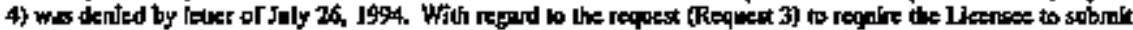

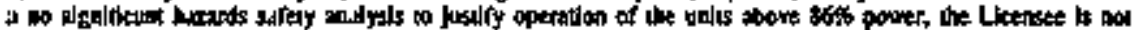

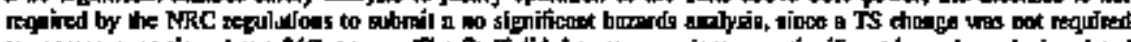

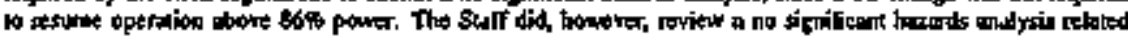

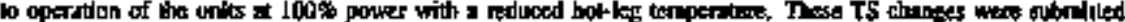

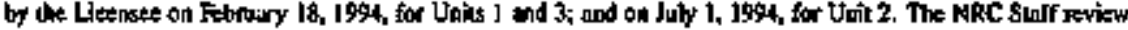

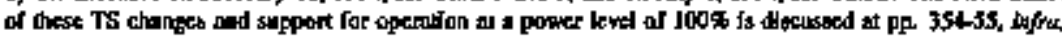


indication, depends not only on the length of the indication but also on the depth of the indication. To assess the safety sugnificance and/or severity of an indication, Jicensees size the indications un terms of Jength, depth, and/or voltage. - Howewer, eddy-curjent testing muthods have not been qualjfied for determining the depth of stress corrosion cracks. Where qualifled eddy-curtent mothods do not exist, Ireenses may pursure altornativo methods such as insitu pressure testing ${ }^{15}$ to further confitm or assess the condition of the tube (i.e., to conflom that the tube indieation could withstand the required pressure loarings; thereby demonstrating that the tube had adequate structural integrity). The Licensee did select mue tubes for in-situ pressure testing during the outage. The 7.5-inch-long indrealion did not meet the Licensee's screening criteria for selecting the more severe indications. The screening criteria, discussed in the NRC Staff's SE of June 22, 1994, cossidered the length, depth, and/or voltage of the indication. All nine tubes salisfactority passed the in-situ presstre test, thereby providing reasonable assurance that the tube indications had adequate structural integrity. Furthermore, all tubes with axial free-span indications were plugged before Unt 2 was returned to optrathon.

The Petiuoners also assert that, as of May 1994, 28 axial indicatrons were found on Unit 2, and 9 axial indications found at Unit 1, and that more extensive testing woukd confirm the existence of cireumferential erack indscations in the expansion-transituon areas (Peution Supplement, Basis 3). These numbers are incontset. Neither Untt 1 nor Unit 2 was in an outage conducting eddy-current examinations in May 1994. Unit 1 had no axial indicatuons identufied as of this date. The Unit 2 data are described above. Unit 3 was in an outage at this time and identified a total of 20 axial indications. Regardıng the performance of more extensive tesung to confirm the existence of circunferential crack indications at the expansion-transition area, the Licensee has performed inspections un this region. In general, the Licensee's SG tube inspection progran consists of an initial inspectson sample which is expanded, if necessery, based on the initial inspection sarple results. The Licensee has been exariining the expansion-transition locations with a motorized rotatung pancake coil (MRPC) probe since at least 1993. These examunations permut the Lictensee to detect circumferential crack indications. In its SEs and metting sucmmaries, the NRC Staff has reviewed the Licensee's results from its MRPC isspections and found them acceptable Is To date, Palo Verde Units 2 and 3 have exch exhubited a smalt mumber of circumferenuat crack indications per unit. Unut 1 has

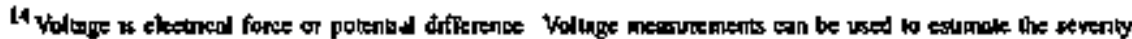
of mi andigiken

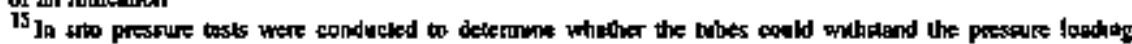

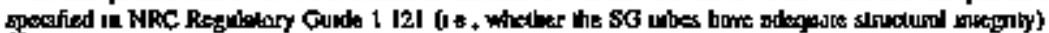

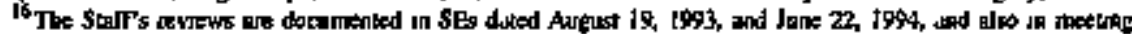

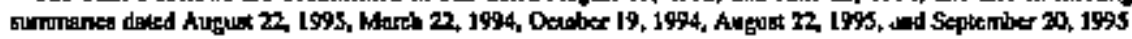

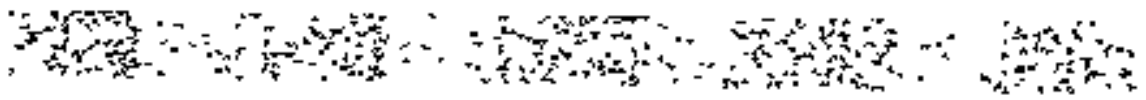

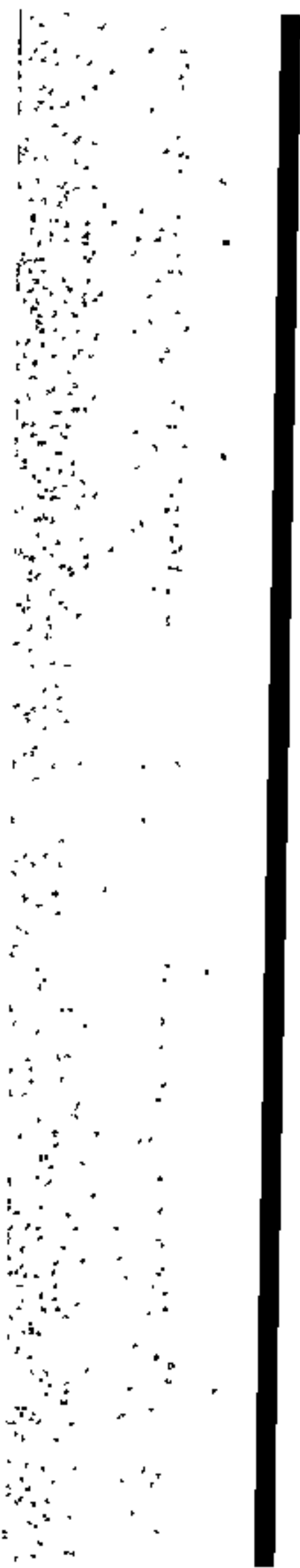


exhibited the 'most extensive circumferential cracking both in texms of number of indications and the severity of the indications when compared to Units 2 and 3. Nounetheless, the Staff concluded in a meeting. surmmasy dated October 19, 1994, that operating Unit 1 to the end of the operating cycle (April 1995) did not pose an undue risk to public health and safety in view of (1) the absence of detectsble axial free-span cracks during the previous refutling outage inspection; (2) the improved secondary water chemistry performance at Palo Verde; (3) the reduced hot-leg temperature, which is expecied to reduce crack growth rates; and (4) the implementation of enhanced MRPC inspection techniques at the expansion-transition locations. The Licensee will continue to perform extensive SG inspections at the end of each operating cycle to ensure continued safe operation of SGs.

\section{Lead Content in Steam Generotar Tube Sludge}

The Petitioners assert withoet providing any supporting basis that the SG sludge of Units 1 and 2 has a lead content of 4000-6000 ppm (Petition Supplement, Basis 4). The Licensee perforded slıdge analyses during two consecutive Unit l outages. The data, which were reponted in a letter from the Licenses dated November 2, 1993, indicate a lead content of 78 ppun (from Unit 1, Refueling 3) and 98 ppm (Unit l, Refueling 4)." Sludge samples were obtained from both Unit 2 \$Gs after the March 1993 SGTR event. The data were documented in the Licensee's report, "Equipment Root Canse of Failure" Both the Licensee and outside contractors analyzed the samples; all analyses indicated a lead content of $100 \mathrm{ppm}$ or less.

The NRC Staff condueted two Palo Verde chemistry inspections (Inspection Reports 94-15 and 94-27 on Units 50-528/50-529/50-530). The Staff veviewed films and sludge for theit lead content, and the data were consistent with the Licensee's reports. Inspection Report 50-528/50-529/50-530/94-15 specifically referred to the inspector's determination to note "whether lead was detected, because of recent work which indicated it may have a deleterious effect." In referring to examinations of the burst region ${ }^{18}$ of pulled tubes, the report stated that insignificant levels of lead were foond in the sludge and in the films examined.

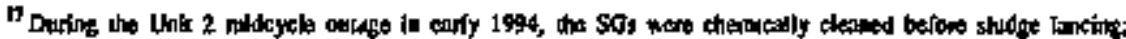

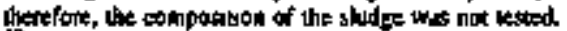

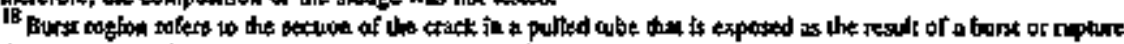

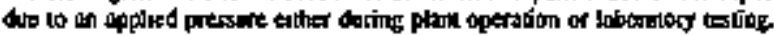


Inspection Report 50-528/50-529/50-530/94-15 also reviewed the Licensee's secondary water chemistry control progrant" The NRC inspection tearn found that the program requirements had fully conformed to the EPRI gaidelines throughont Palo Verde's operating history with respect to chenical pasameters, analytical frequency, lunits for critical paraneters, and required actions when critical parameters were exceeded. In summary, the Pettioners' assertions ragarding lead content have not been sabstantiated and do not agree with available data. The Licensee bas werified that load content in both Units 1 and 2 SGs is 100 ppm or less, not 4000-6000 pprn as asserted by the Pettioners. Additionsily, NRC Inspection Reports 94-i5 and 94-27 on Units 50-528/50\$29/50-530 have not revealed any unfordnation about elevated lead content.

\section{Steam Generator Tube Degradation and Operation at a Reduced Power Level}

The Petitioners also assert that the operation of Palo Verde units at above 86\% power is unacceptable due to severe degradation of SG tubes (Petition Supplerment, Basis 14), In Decenther 1993, the Licensee volunteered to redoce power in all three units to approxumately $86 \%$ as an interim measure to curtail SG degradation. The primary purpose of this administrative power himit was to operate with a lower reactor coolant system hot-leg temperature in order to reduce tube degradation. This specific power level had been selected because it provided for a $T_{\text {hot }}$ that approxtmated the value that would be implemented If the Licensee's proposed TS changes for operating at $100 \%$ power with a reduced $T_{\text {trx }}$ were approved by the NRC. Additionally, the Licensee's thermalbydraulic analysis indicated that, at this reduced power level, the potential for free-spen tube degradation from corrosion is reduced. The Licensee took this action volunfarily to minumuze further degradation of the SGs until corrective, mitigative, and preventive actions could be inglestented to reduce SG tube degradation.

On Jure 7, 1994, the NRC issued a TS chasge for Units 1 and 3 that poraxitted the Licensee to operats at full power with a lower $T_{\text {hut }}$ teroperature.21 The Unit 2 TS change was reviewed separately because the Licenset was coutnuing to perform analyses arising from the \$G tube plugging in Unit 2 . The Staff tssued

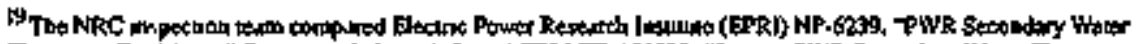

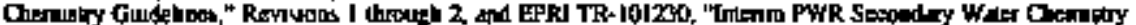

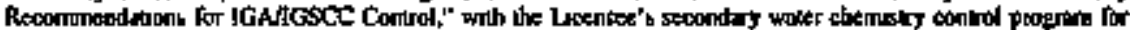
PYNGS

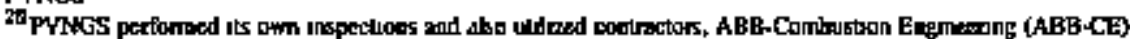

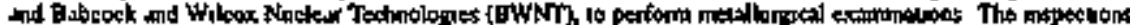

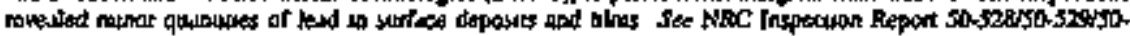
$53094-15$. dued tone 23 . 1994

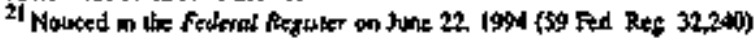

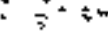


this TS change on August 12, 1994.12 These TS changes permitled operation at a power hevel of 100 , as did the Staff's post-March 1993 SGTR SEs dated August 19, 1993, and June 22, 1994, regarding the length of operating cycles of the Palo Verde units. Furthermore, as stated above, the Staff did not impose any powet restrictions or limits on the Licensee.

In sumnary, the Petitioners' concerns regarding operation of the Palo Verde units above 86\% power (including bases relating to the March 1993 SGTR event, identification of axial and citcumferential SG tube indications, alleged elevated lead contents in SG sludge) have been satisfactorily addressed, and do not warrant any forther action by the NRC Staff.

\section{Need to Reanalgze the Design-Besis SGTR Event}

Reguest 5 (of the Petition Supplement) is that the NRC require the Licenses to analyze a design-basis SGTR event to show that the offsite radiological consequences do not exceed a small fraction of the limits of 10 C.F.R. Part $t 00$. The Stafi requires an analysis such as this to be completed for all pressurizedwater reactors (PWRs) and documented in a final safety analysis report (FSAR) before plant operation. The Licensee complied with this requirement.13

The Petitioners assert in the basis (Petition Supplenent, Bases 8, 9, 10, 11, and 13) that the Licensee cannot ensure that the dose limits are satistied for applicable postulated SGTR events; the offsite dose limits would be exceoded during an SGTR event and adequate protection to the public would not be maintained; the Licensee cannot demonstrate that the plent cen be safely shut down and depressurized to stop SG tube leakage before reactor water storage tank inventory is lost; the NRC and the Licenses nnust carrefuilly consider SGTR; and "the licenste has fatled to comply with NRC requirements under NUREG0800 insofar as the licensee is required to analyze the consequences of a design basis SGTR event to show that the offsite conditions and single failure do not exceed a small fraction of Jimits of 10 C.F.R. Part J00,"

The ATT report documents findings regarding the Unit 2 SGTR ewent of March 1993. The report stated that the plant was safely brought to cold shutdown and no radionctivity was relensed off site. Additionally, the Staff's SE, dated August 19, 1993, assessed a single SGTR event and single and multiple tube reptures induced by a major secondacy-side rapid depressurization and concluded

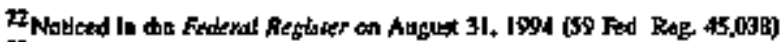

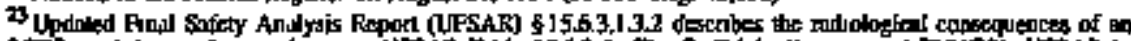

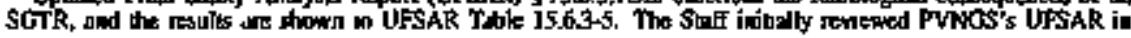
Nonoumber t9:2? 


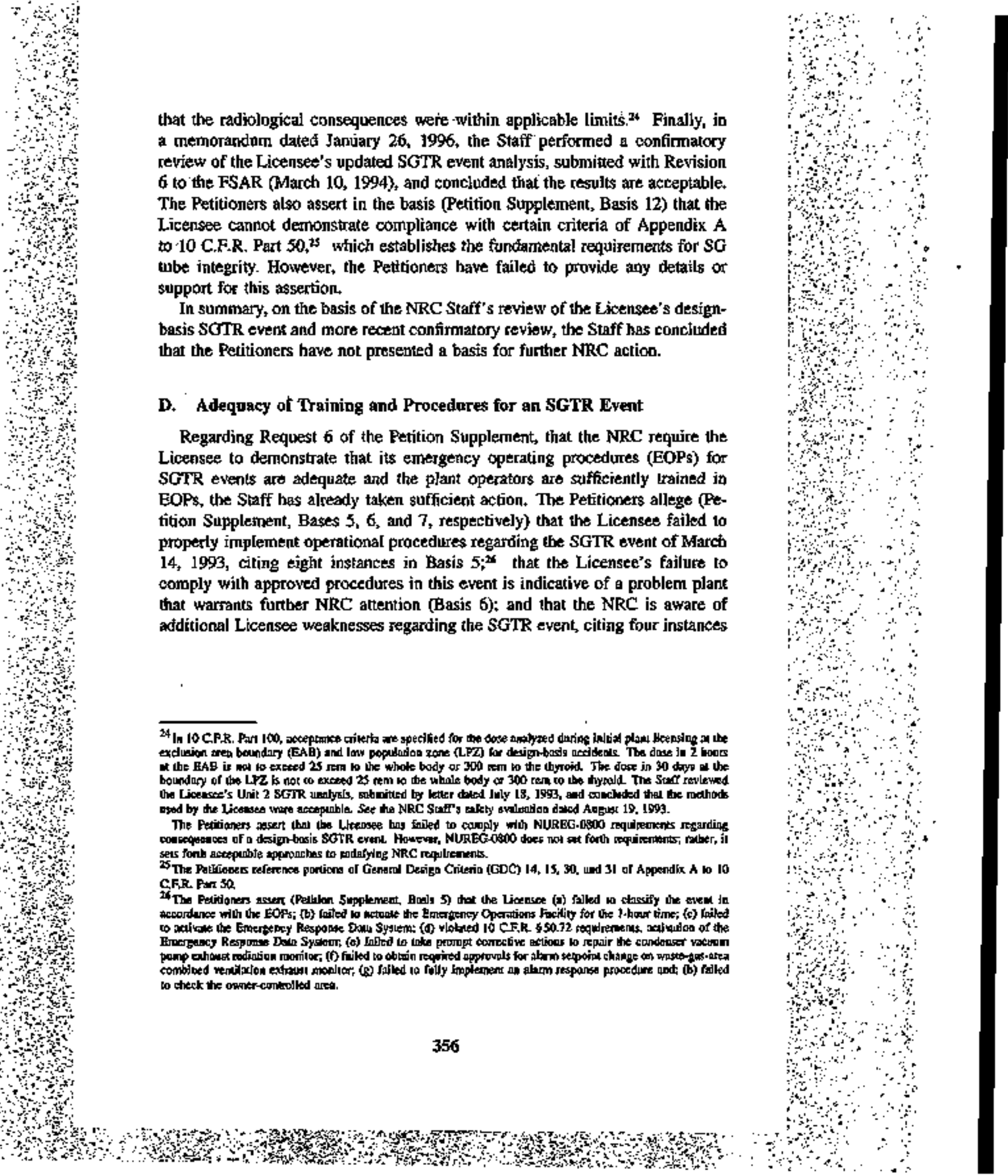


in Basis 7.27 These bases langely concen areas the Staff reviewed sfter the SGTR event on March 14, 1993. Specifically, the Petitioners repeated several of the procedural and operator wesknesses that were described and evaluated in the Slaff's AIT report (Inspection Report 50-529/93-14, dated April 16. 1993). Specifically, the AIT report stated that the ase of a diagnostic logic tree caused the operators to misdiagnose the SGTR event twice and subsequently enter a Functional Recovery Procodure, contributing substantially to the delay in isolating the fautied SG. The Staff concluded in its safery ovaluation of August 19, 1993, that the Licensed's modifications to the EOPs and the subsequent operator training provide sufficient enbancentent for both diagnosis and mitigation of various \$GTR scenarios.

Additionally, the Licensee recently revised its EOPs to make them consistent with Cambustion Engineering Owners Group (CEOG) guidance (CEN 0152, Rev. $3^{24}$ ). NRC Inspection Report 50-528/50-529/50-530/95-12, dated July 27, 1995, documents the Staff's observations on the "high-intensity team" training conoucted for each crew in preparation for implementing the EOPs. In the inspection report, the Staff stated that the EOPs enhanced crew performance and allowed for greater tlexibility in responding to events. As an example, during the simulator-based SGTK scenario, the crew was able to isolate the faulted SG within 14 minutes of the start of the event. In contrast, during the March I993 Unit 2 SGTR evem, operators took about 3 hours to isolate the faulded SG, partly because of restrictions in the EOPs in use at the time. The Staff will further evaluate the effectiveness of EOPs during future licensed-operator examinations.

On the basis of its review of the Petitioners' request that the Licensee demonstrate that its EOPs for SGTR events are adequate and that plant operators are sufficiently trained in EOPs, the Staff has concluded that the Petitioners have not presented a basis for further NRC action.

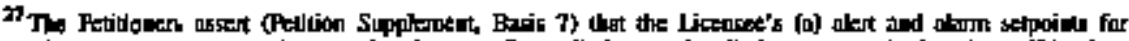

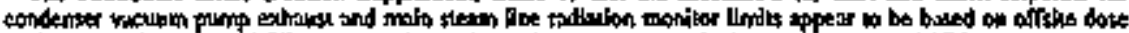

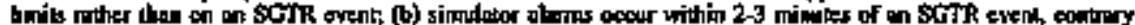

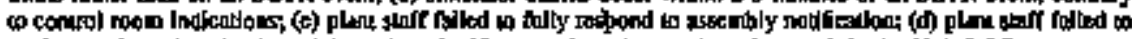

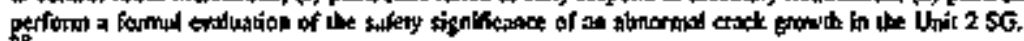

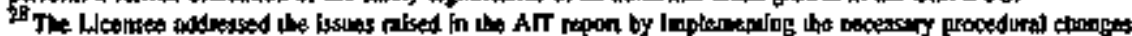

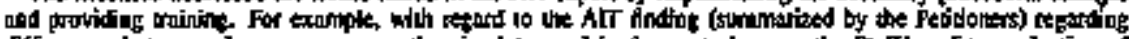

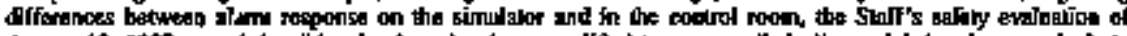

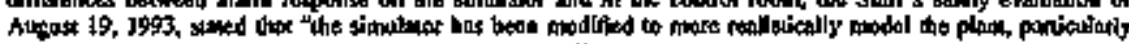

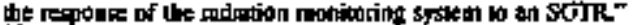

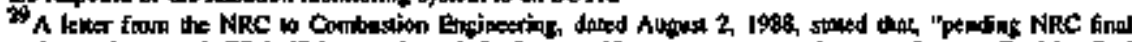

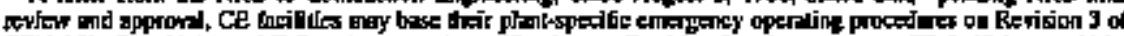

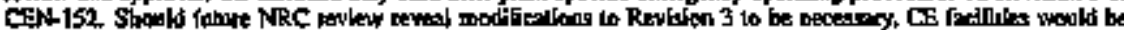

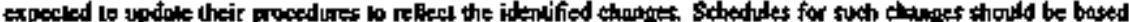

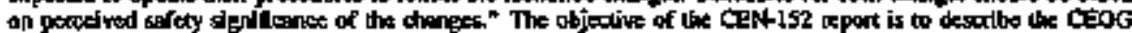

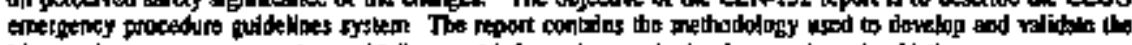

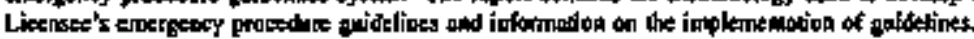

$\therefore$ 


\section{CONCLUSION}

The institution of proceedings in response to a request pursuant to Section 2.206 is appropriate only when substantial health or safecy issues bave been raised. See Consolidated Edison Co. of New York (Indian Point, Units 1, 2, and 3), CLI-75-8, 2 NRC 173, 176 (1975), and Washington Public Power Supply System (WPPSS Nuclear Project No. 2), DD-84-7, 19 NRC 899, 923 (1984). This standard has been applied to the concems raised by the Petitioners to determine whether the actions requested by the Petitioners are warranted. With regard to the specific zequests made by the Pettioners discussed heren, the NRC Staff finds no basis for taking additional actions beyond those described abowe. Accordingly, the Petitioners' requests for additional actions pursuant to section 2.206, specificalfy Reguests 1, 2, 3,5, and 6 submitted in the Petitioners' Supplement dated July \&, 1994, are denied. Accordingly, no action ptristant to section 2.206 is being taken in this matter.

A copy of this Decisjon will be filed with the Secretary of the Commission for Commission review in accordance with 10 C.F.R. $\$ 2.206$ (c) of the Commission's Iegulations. As prowided by this regulation, the Deetsion will constitute the final acton of the Commisston 25 days ator issuance, unless the Commission, on its own motion, institutes a review of the Decision within that time.

\section{FOR THE NUCLEAR REGULATORY COMMISSION}

\section{Wultam T. Russell, Director Office of Nuclear Reactor Regulation}

Dated at Rockvifle, Maryland, this 25th day of June 1996. 


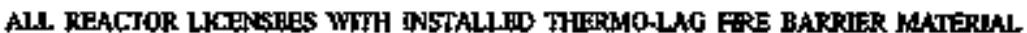

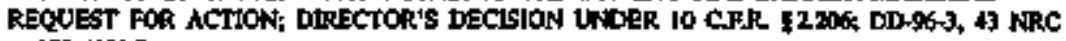
IB3 (1990)

ARTZONA PUTLIC SEXVHCE COMPANY

REQUEAT FOR ACTNON; DRECTOR'S DECLIION LRDER 10 CFR. $\$ 2.306$; DOCEA Nar. 50-528, 5i-529, 50-530, DD- $-64-4,43 \mathrm{MRC} 309$ (1995)

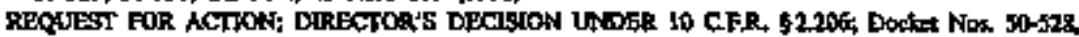
30-529, 50-530, DD-96-8, 43 MITC 344 (t996)

CLEVELAND ELECJRIC IILUMINATING COMAPANY, \& af

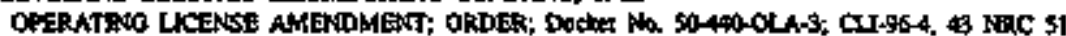
(1996)

CONSOLDATED EOHSON CONAANY OF NEW YORK

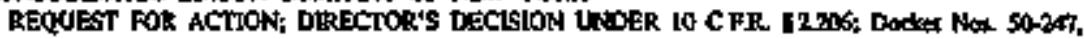

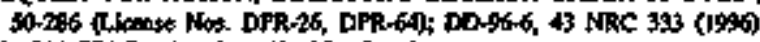

EASTERNA TESTWS AND INSPECTION, INC

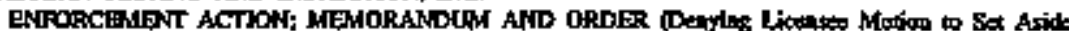

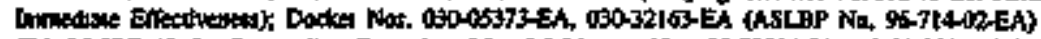

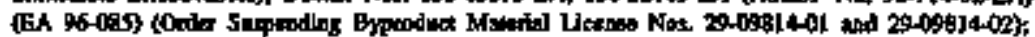
L.尹P-96-9, 4 ITRC 2tI (1996)

ENFORCEMENT ACTHON; MEMORANOUM AND ORDER (Aprowing Settlenent Agroment tod

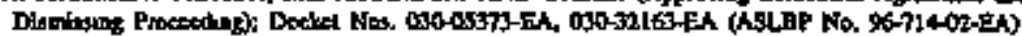

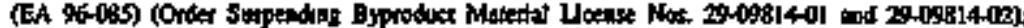
LBP-96-1I, 43 NRC 279 (19\%8)

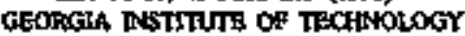

OPERATINO LICENSE RENEWAL; THIRD PREHEARANO COWFERENKE ORDER; DOchem NO

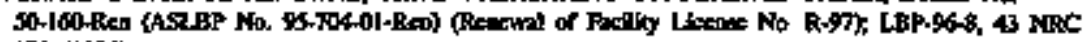
178 (1996)

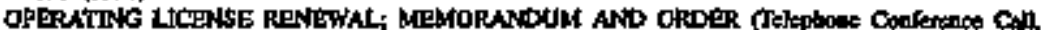

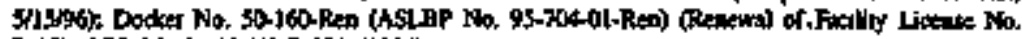

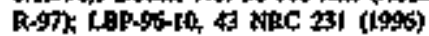

OUIF STATES UTILITES COMPANY, it al

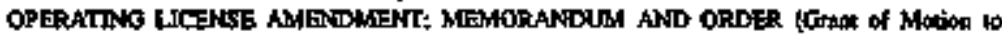

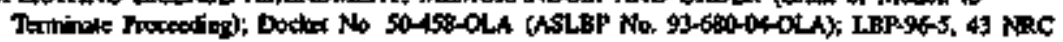
I75 (I99)

KERR-MEGES CHEMRCAL CORPORATHON

MATERIAIS IXCENSE; ORDER; DOCLE ND. 40-2061-MI; CI-96-2, 43 NRC I3 (1996)

LOUISIANA ENQROY SERVICES, LP.

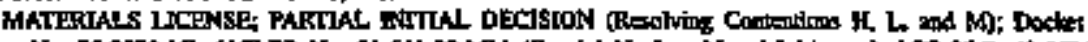

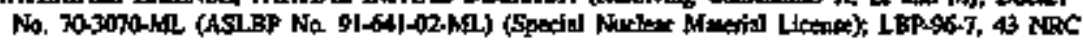
142 (1995)

NORTHEAST MUKGEAR ENIRGY COMPANY

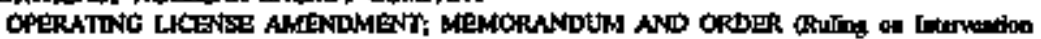

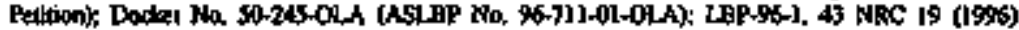

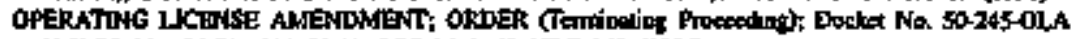
CSLLPP No, 96-711-01)-OLA), LBP-96-6. 43 NRS, I\$0 (1996) 


\section{CASE NAME INDEX}

\section{OACDLOGY SFEYTCES CORPORATON}

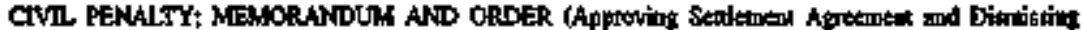

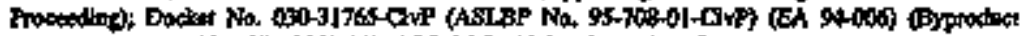

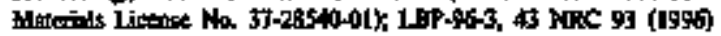

PECO ENERTY COMPANY

REQUUST FOR ACTKON; ERAAL DIRECTOR'S DECISION USDER 10 CFR. \$2206; Doctel Not. sam, sa-276; DD-96-5, 43 NRC 322 (1999)

POFTLAND G GRTKRAL EISCTREC COMIPANY

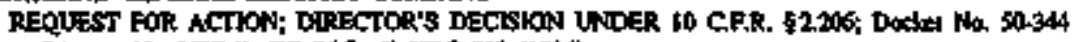

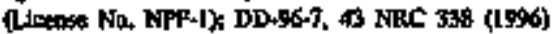

RADLTTON DNCOLOGY CANTHR AT MARLTON (ROOM)

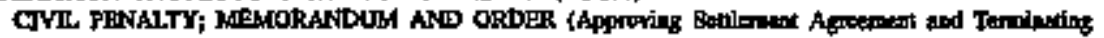

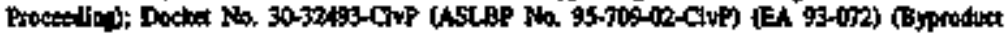

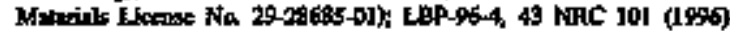

SACRANEATO MUNICPPAL UTITY DLSTRKT

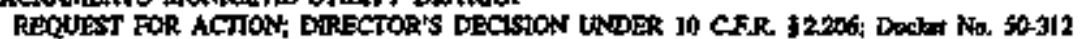

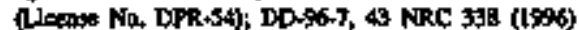

SEQUTOKAH FUELS CORPORATION

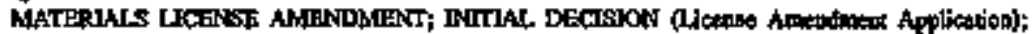

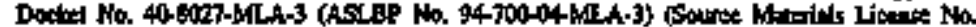
st3e-1010\%, 1.89-96-12, 43 XAC 290 (1996)

SEQUOYYAF FNEIS COKPOKATION and GENERAL. ATOHAKS

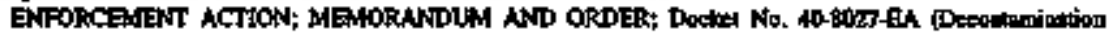
and Deconmissioning Finding); CL-96-3, 40 NRC 16 (1996)

SOUTHEFEN CAITFORIIA EDISON COMPANY

HEQUEST FOR ACTIOH, DRECTOR'S DECASTON UNDER 10 C.F.R 12206; Dochet Na. 50206 (Licanse Na DPA+13); DD-96-7, AB FRC 338 (1996)

YANDKE ATOMIC EIIETRRC COMTANY

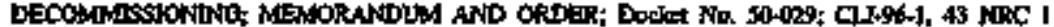
(1996)

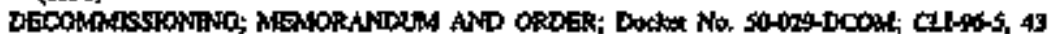
NTEC 53 (16\%)

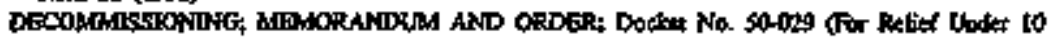
CFR. 32.200 ; CU $96-6,43$ NRC 123 (1996)

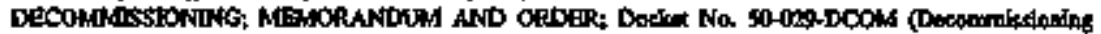
Pan); C1.96.7, 43 NRC. 275 (1986)

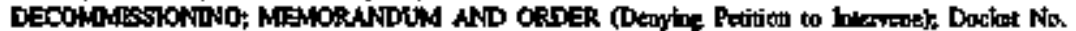

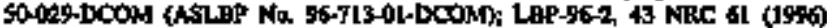

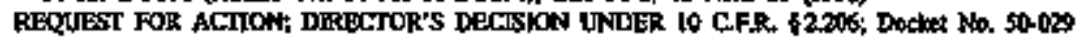

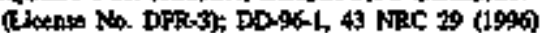

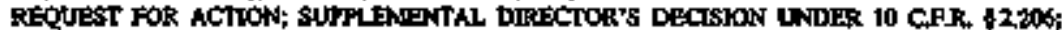

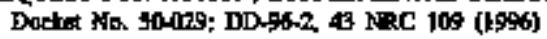

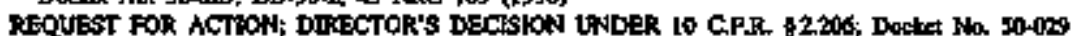
(1)ense Nh. DFA-3) DD-96-7, 43 NRC 335 (1996) 


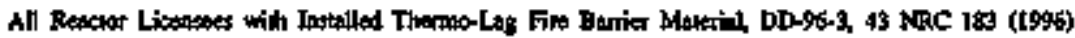

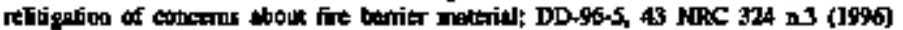

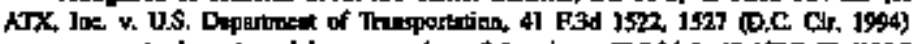

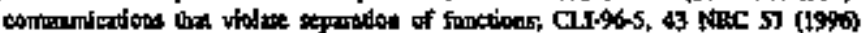

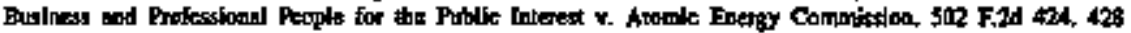
(D.C. Cir. I974) Apwifiny requitrenant for contentioss, CL1.96-7, 43 NRC 248 n.7 (1996)

CNN y, NRG, 59 E.3d 2B4, 293-92, 294 (1) Cir. 1995)

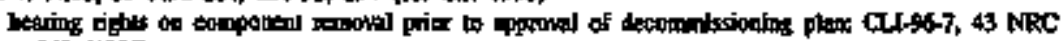
242 (1998)

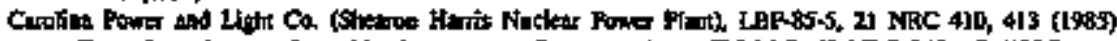

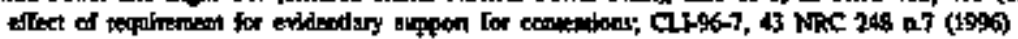

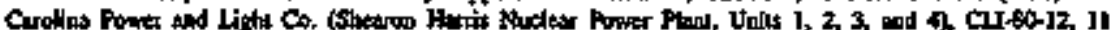
NRC 514, 517 (1980R

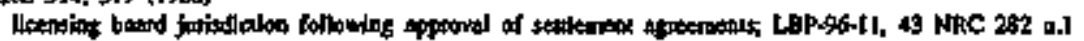
(1995)

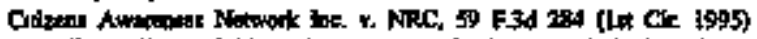

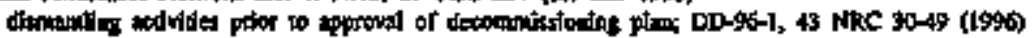
hearing rigits on decomrissiomiax plang; CL146+t, 43 NRC 5 (1996)

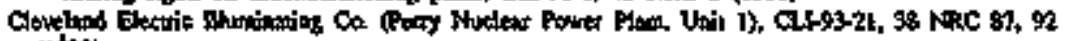
(I993)

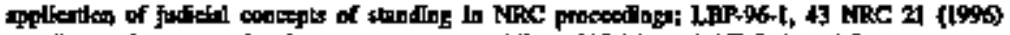

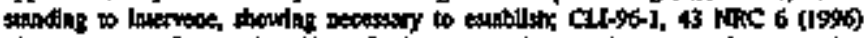

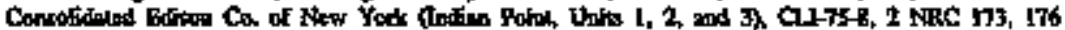
(1975)

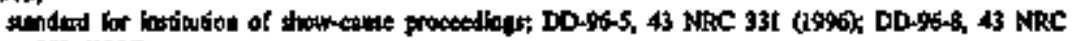
35B (1996)

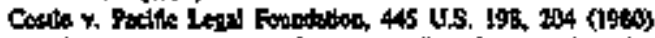

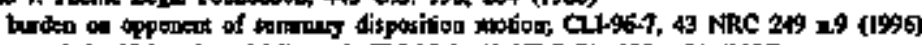

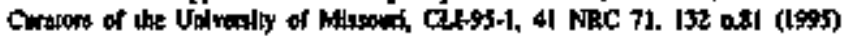

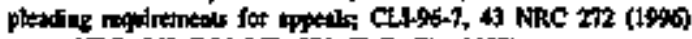

Delluing $y$, NRC, 863 E.24 958, 911 (D.C. C1., 1985)

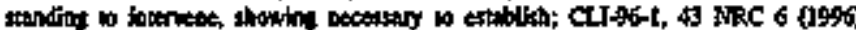

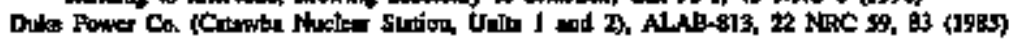

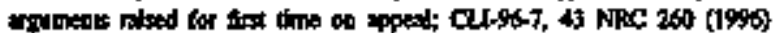

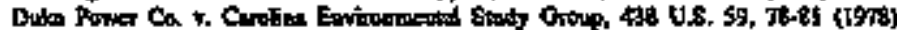

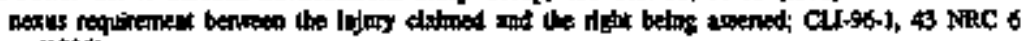
(1\$\%)

Exas v, JeAf D. 475 U.S. 717, 727 (\$9B6)

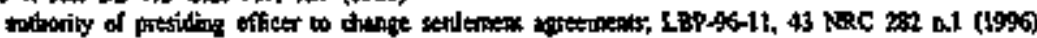

$\mathbf{1 0 3}$ 


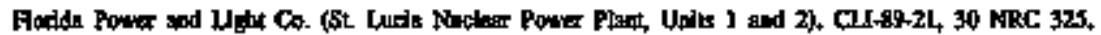
329 (1989)

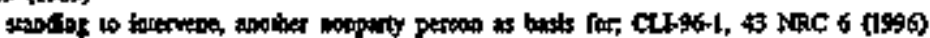

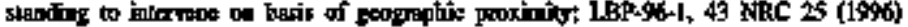

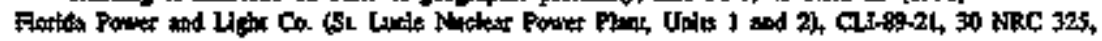
329-30 (1999)

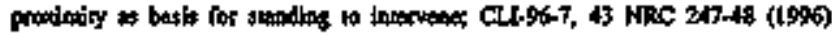

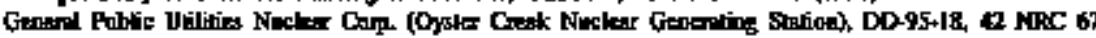
(1995)

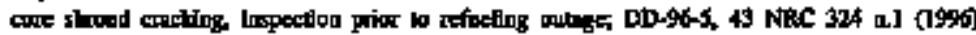

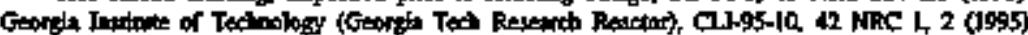

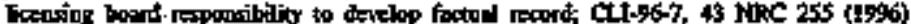

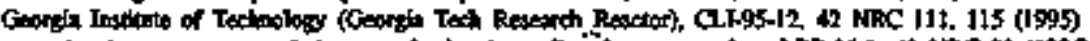

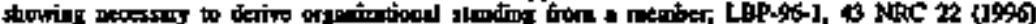

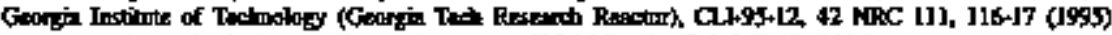

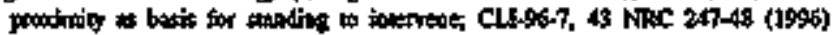

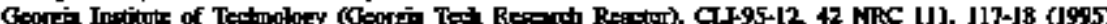

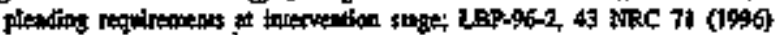

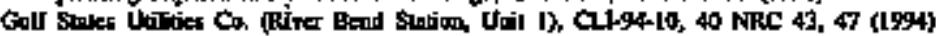

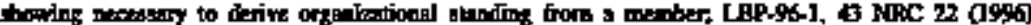

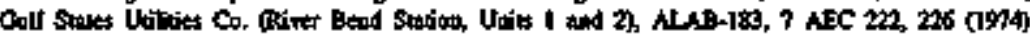
stroding to ishonene on besis of gengrephic proximity; L.HP-96+1, 43 NRC 25 (1996)

Howker v. Campoul, 461 US. 458. 467 (1983)

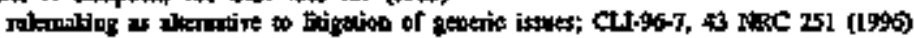

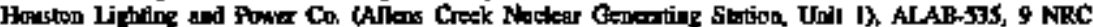
377, $390-96$ (1979)

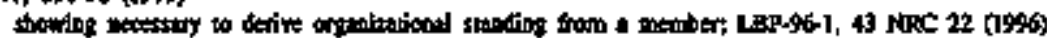

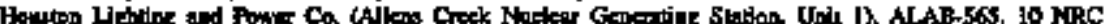
521, $\$ 25$ (1979)

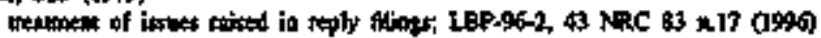

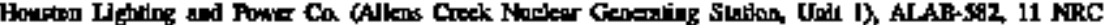
239. 240 (19a0)

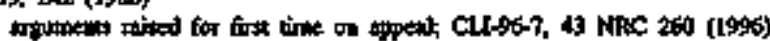

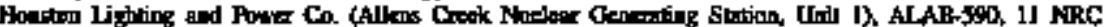
502 (1980)

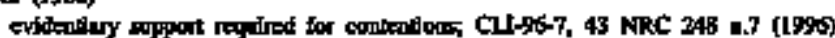

Hoopton Lighting and Powrer Ca. (Sroo'b Teoss Project, Urilg I and 27, ALAR-S49, 9 NRC 644, 646-47 (\$979)

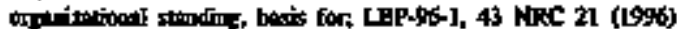

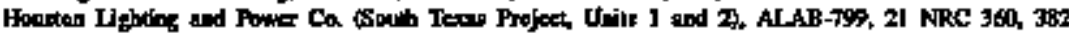
(1955)

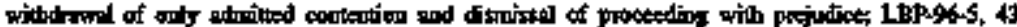
NRC 137 (1996)

Jeff D. *. Aotho, F.2d 753, 756 (9h Cr. 1989)

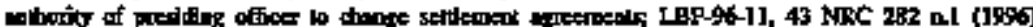

Joueph J. Maktat, CL189-18, 30 LRC 16), 169-70 (1989)

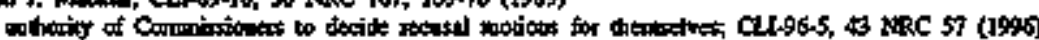

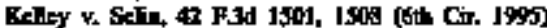

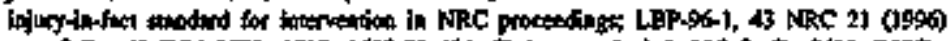

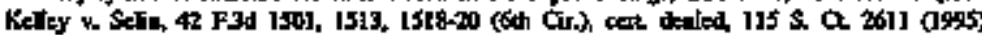

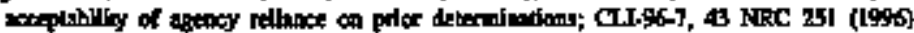

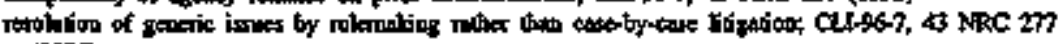
[1990) 


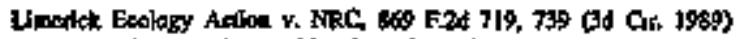

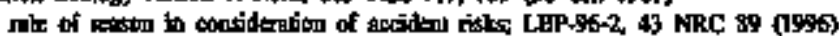

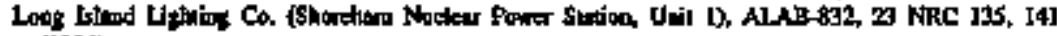
(1986)

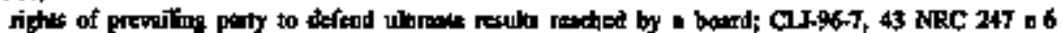
(19\%)

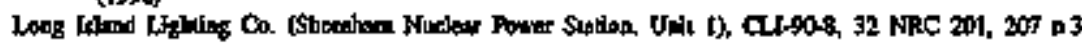
(1990)

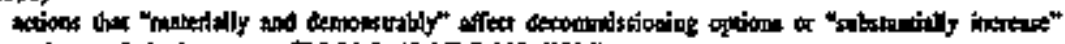

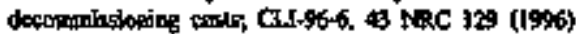

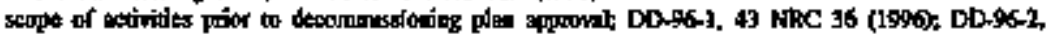
43 MRC $113(19 \% 6)$

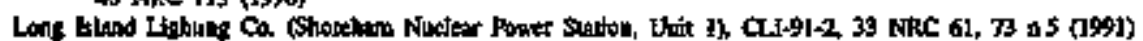

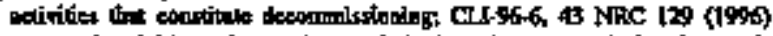

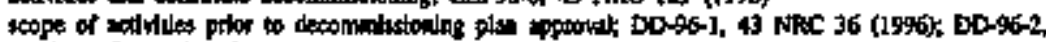
43 NRC 113 (1906)

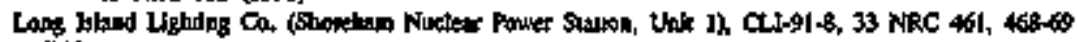
(19s)

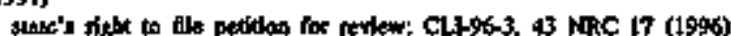

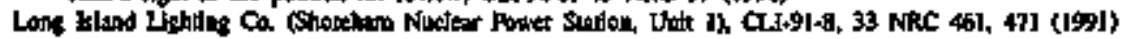

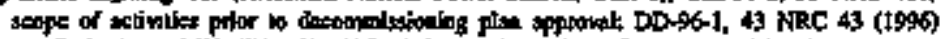

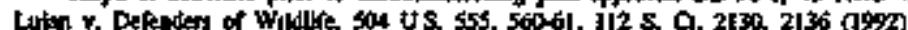

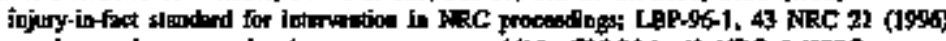

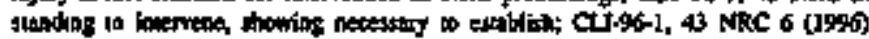

Mhall v. OStRC, $\$ 99$ U.S. IAK, 156-57 (IOS)

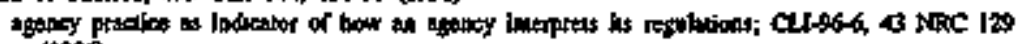
(1995)

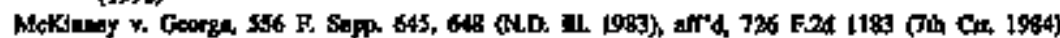

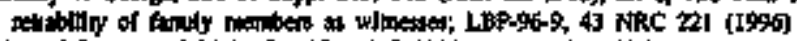

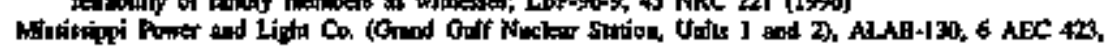
1060793

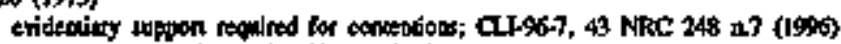

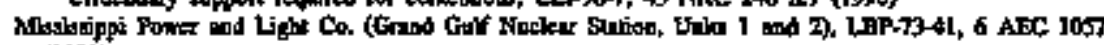
(1975)

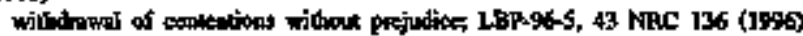

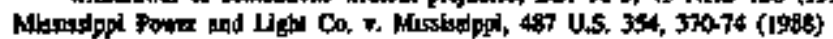

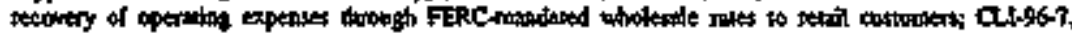
43 NRC 265 (1996)

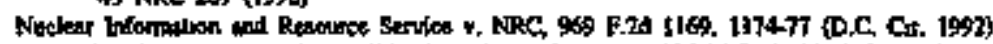

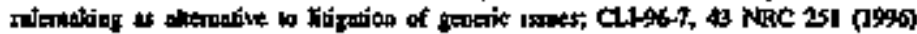

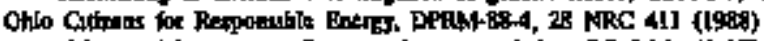

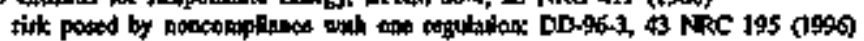

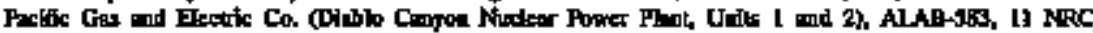
447. 448-49 0906)

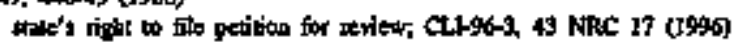

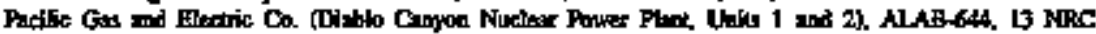
S03, 937 (1) 81 )

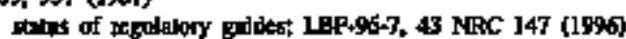

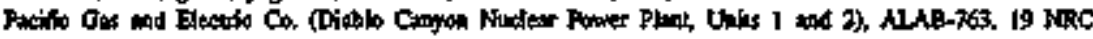
17, IT (1984)

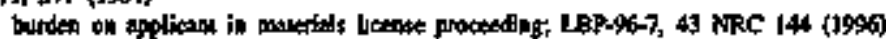




\section{LEGAL CITATTONS INDEX}

casses

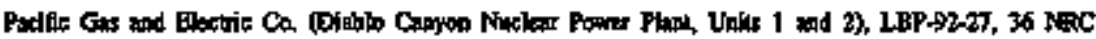
196. 199 (1952)

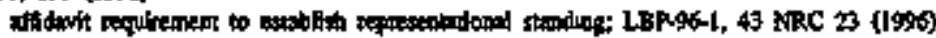

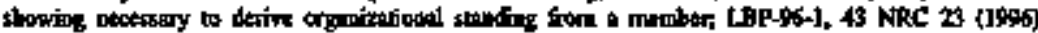

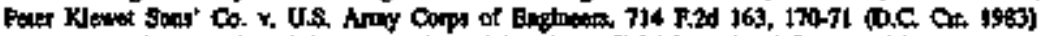

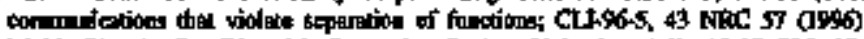

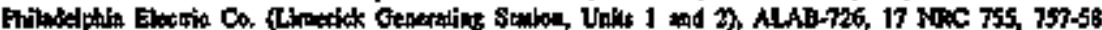
(I9:3)

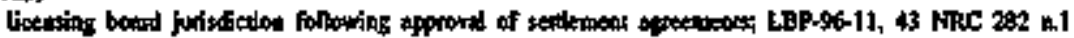
(1990)

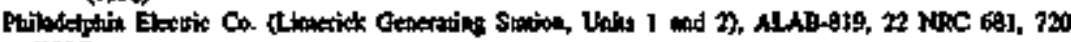
(1989)

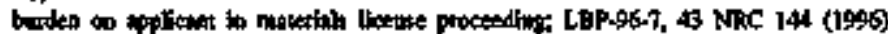

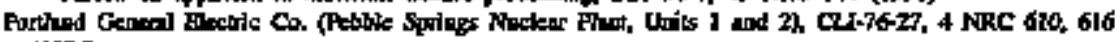
(1976)

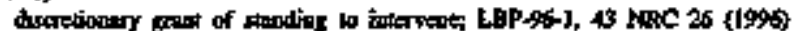

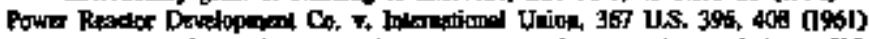

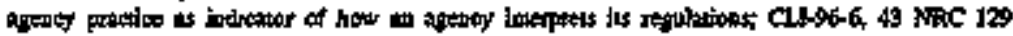
(1995)

Press Broudeadng Co. lnc v, FCC, 59 F3d 1364, 1306 (DC Cir. 1995)

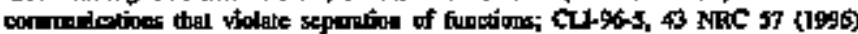

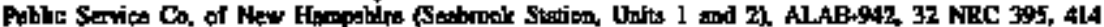
(1990)

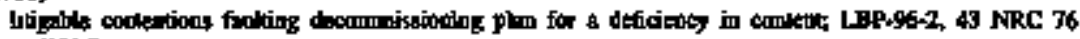
(199)

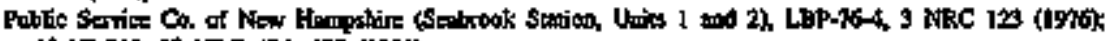
ALAB-949, 39 NRC 484, 45 (I99)

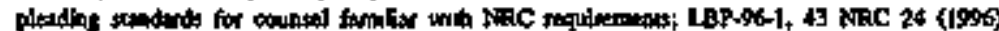

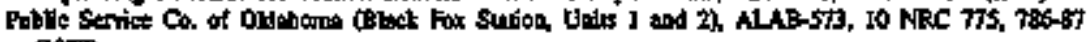
(1975)

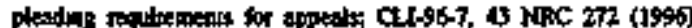

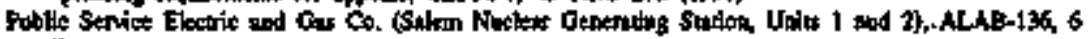

AlEC 487, 499 (1973)

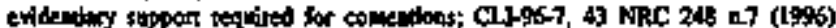

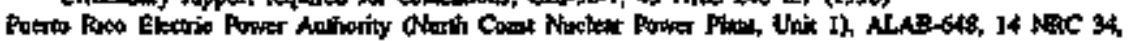
37 (IS\$)

Aggumess rised for firs time on

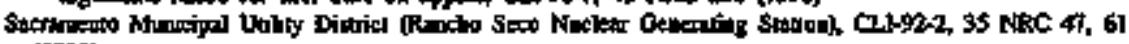
(1992)

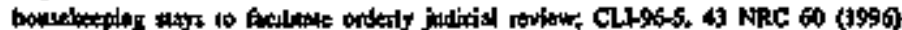

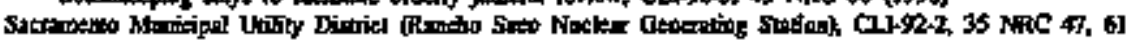
0.7 (1992)

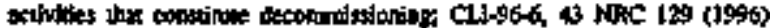

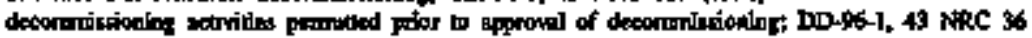

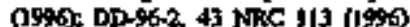

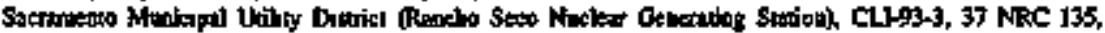
IS2 (1995)

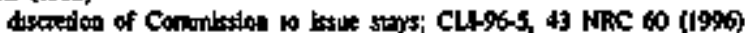

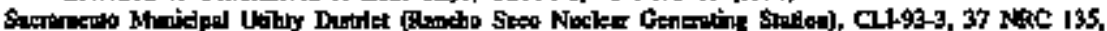
I42 (1993)

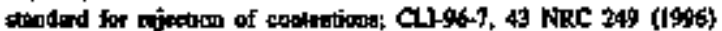




\section{LEGAL CTITIONS INDEX}

CASES

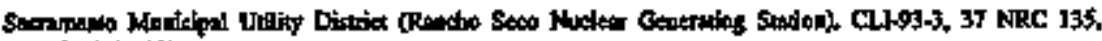
145-46 (1999)

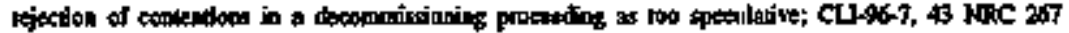
(1990)

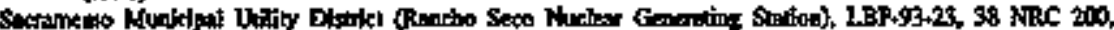

246 (1999)

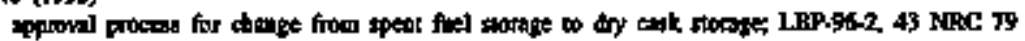
(198)

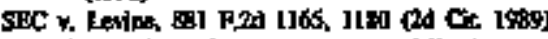

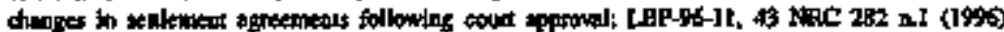

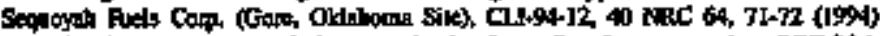

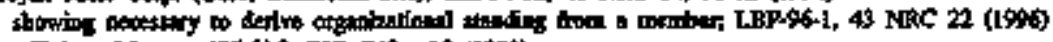

Slem Clib y. Modton 40S U.S. 72T, T40 L.15 (1972)

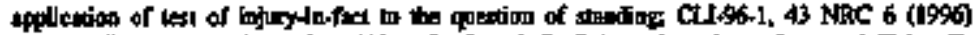

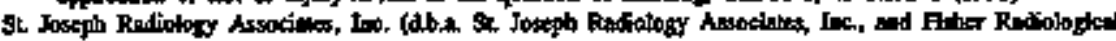
Cinic), LBP.92-34, 36 JRC 317. 321-27 (1992)

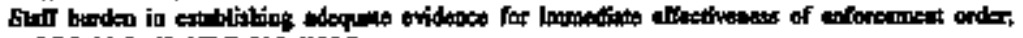
1BP-96-9, 43 NRC 216 (I990)

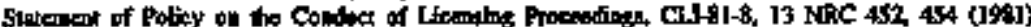

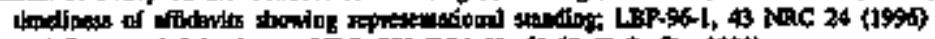

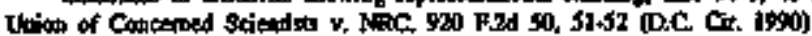

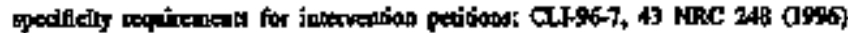

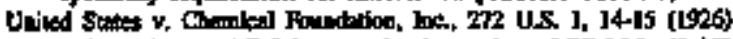

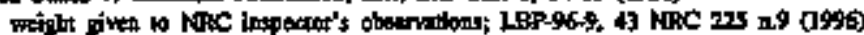

Unilod Strtes v. Knl, 500 F.20 315, 317 (St Cor. 1974)

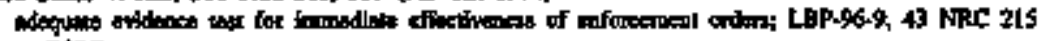
(199)

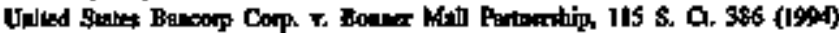

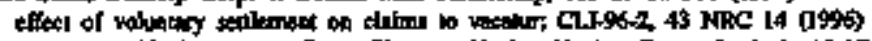

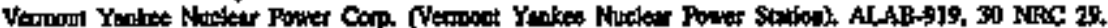

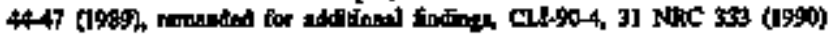

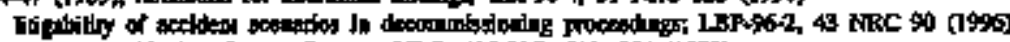

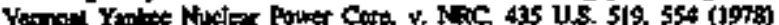

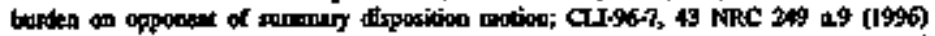

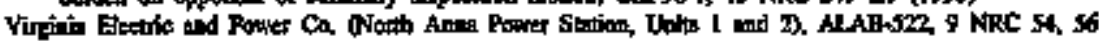
(1979)

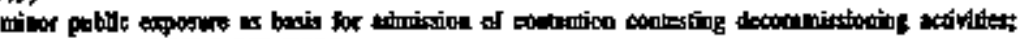
CU-96-7, $43 \mathrm{BRC} 247$ (1996)

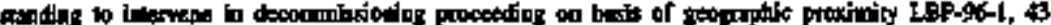
Nite 25 (1996); LBP-96-2, 43 NRC TH (I995)

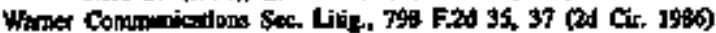

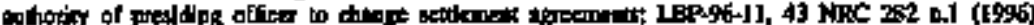

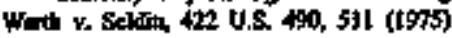

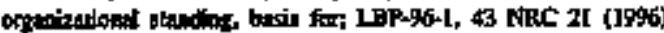

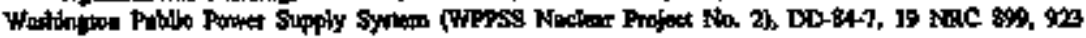
(1949]

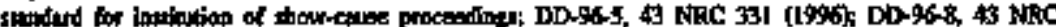
3:1. (I 1990$)$

Wener Indutifial X-Ring Inpeation Co, LBP-95-22, A2 MaC 205, 212-13 (IS95)

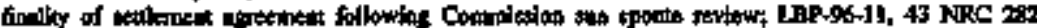
n.1 (1996)

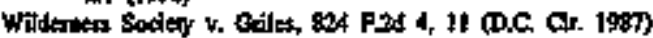

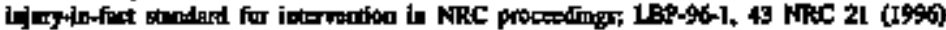

$1-7$ 


\section{LEGAL CTTATIONS INDEX}

CASES

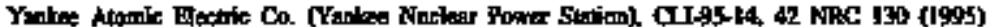

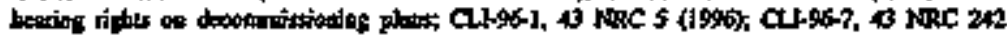
(19\%)

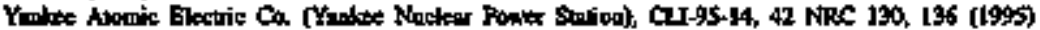

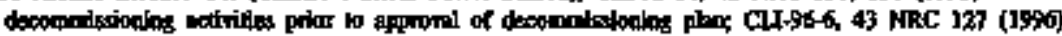




\section{LEGAL CITATIONS INDEX}

REGLIATIONS

\section{I0 CER. I.t2(d)}

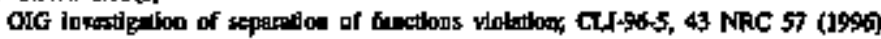
IO CF, 2.TOA(i)

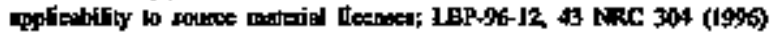

10 CF.R. 2.t04(D)

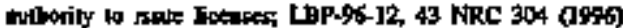

10 CFA 2 20M

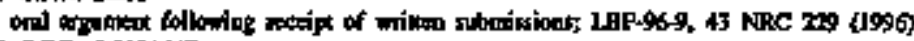

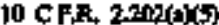

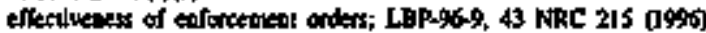

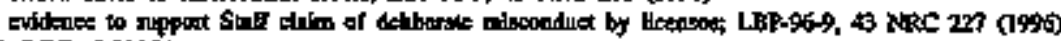

10 CFR, 2202(b)

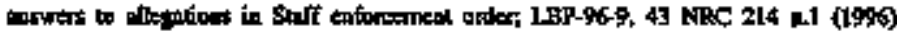

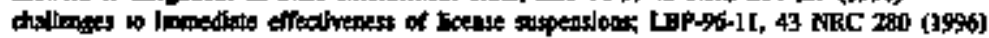

10 CFR. 2.202(c)(2)(a)

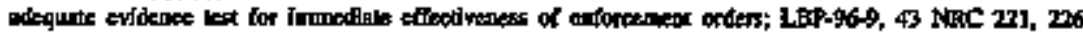
(19\%3)

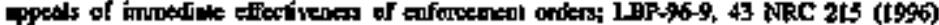

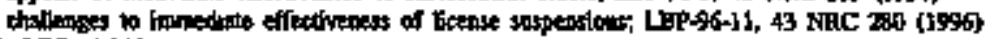

10 CER. 2203

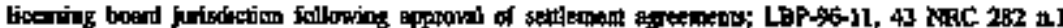
(1996)

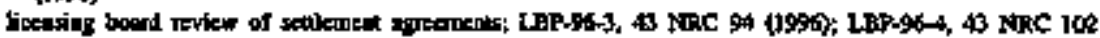
(I996)

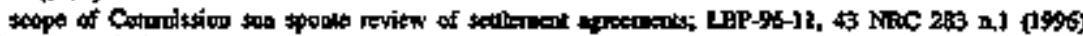

10 C.R.R. 2 .200

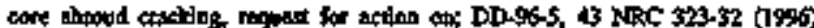

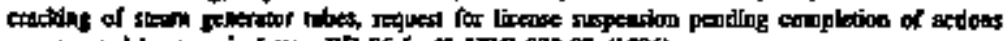
requested by generic IEtter, DD.96.6, 43 NRC 333.37 (1,9\%)

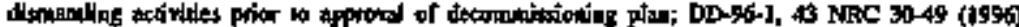

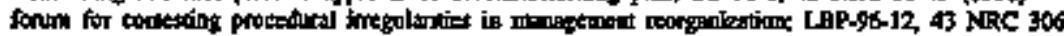
(I\$O6)

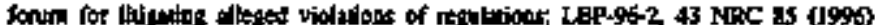

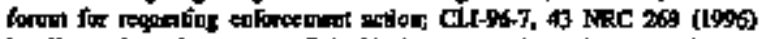

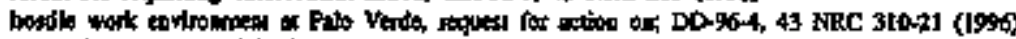

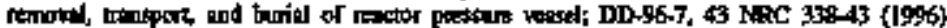

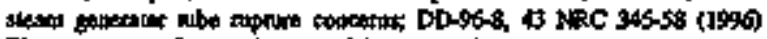

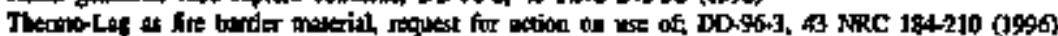

10 CP.R. 2.20 (S) (c) (a)

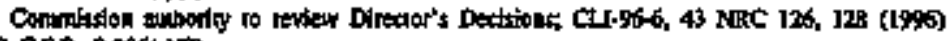

I0 C.F.R. 2.206(c) (2)

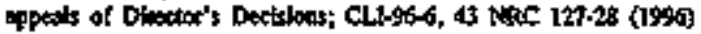


10 CFR. 2.734

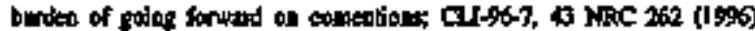

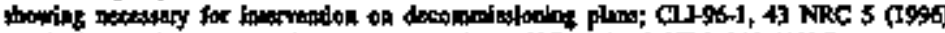

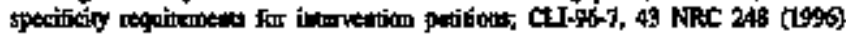

to CF, $2.714(0)$

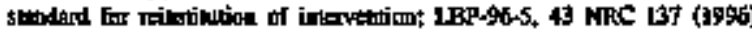

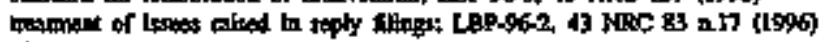

10 C.F. 2.7J4(a)(I)

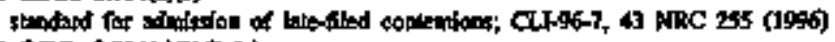

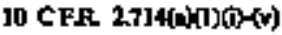

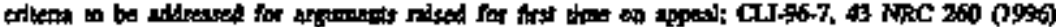

10 CFR. 2.714(a)(3)

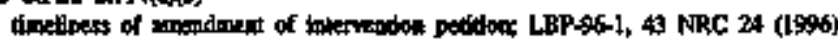

10 CER. 2.740(0)(t)

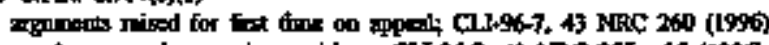

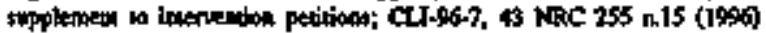

10 CFR 2714(b)(2)

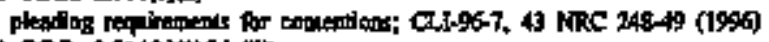

10 CPR. $2714(0)(2)$ (i) -(iti)

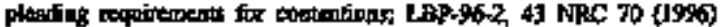

10 CFR. 2,714(b)(2)(bi)

refection of cootedion, C4-96-7, $43 \mathrm{MRC} 246$ (099)

10 CFR 2 IJU(d)(2)

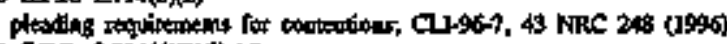

10 CFR. 27]4(d)(2) [l]-(ii)

nojoction of comantions C1196-7, 43 NRC 246 (1996)

I0 CFR 2.JT(d)(2)(i)

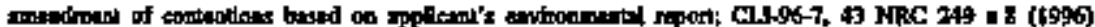

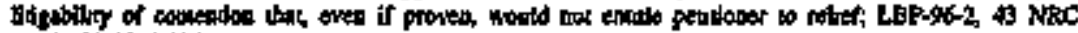
$78,91+92$ (1996)

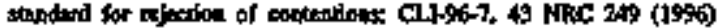

10 CFR $274(9)$

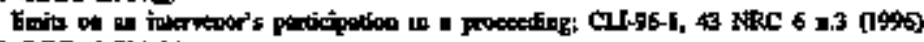

I0 CER. $27142(a)$

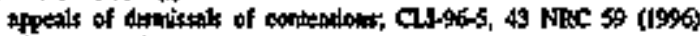

10 CFR. 2IIS(c)

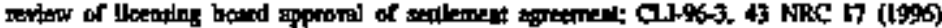

10 CER. 2.71S(d)

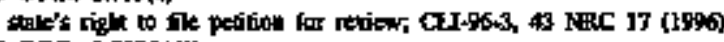

14 C.R. 27mo)(1)

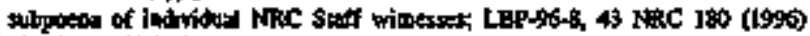

10 C.P.R. 2720(h)(2)

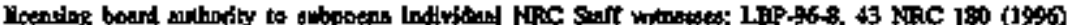

10 CF.R. 2732

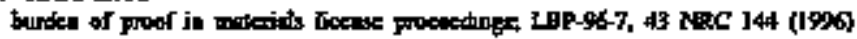

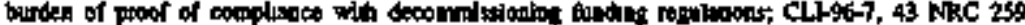
(19)

10 CF.R. 2743(c)

forman for prefiled whiten ketimons; LeP-o6-10, 43 NRC 233 (1996)

10 CP.R. 2743(9)

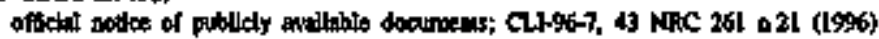

10 CPR 2758

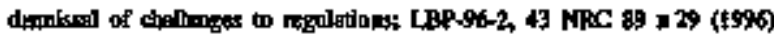

in 1 is

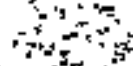

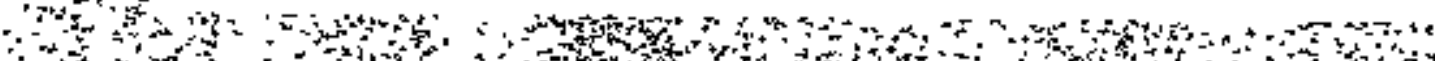
$\because x^{2}$ -

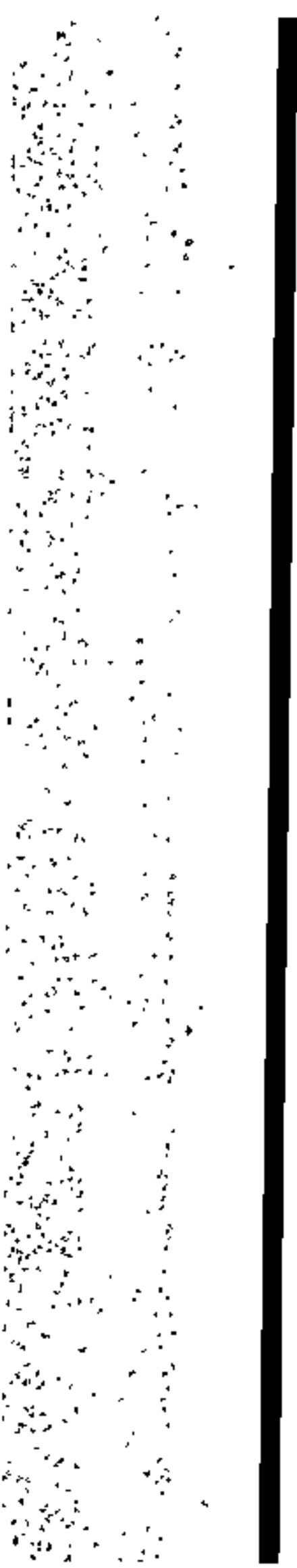


I0 C.F.R. 2760

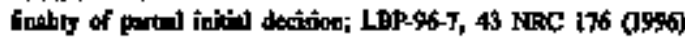

to CF,R 2.7sto(n)-(s)

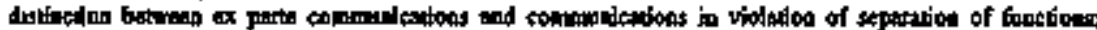
CIS6-5, 43 MRC 56 02 (1596)

10 C.R.R $2781(0)$

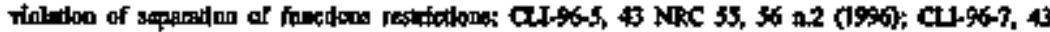
NEC 245 a3 (1996)

10 C.F.R. 2.781( $\theta$

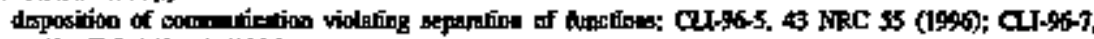
49 NRC 245 an (1996)

SO CF,R 2786

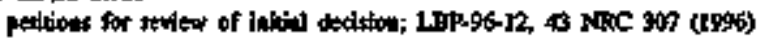

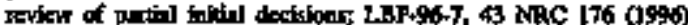

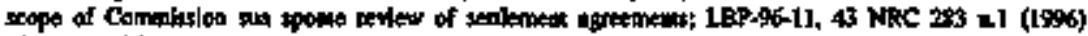

vit G.R. 2786(b)

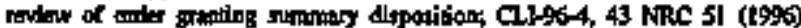

10 CPR $2786(0)(2)(3)$

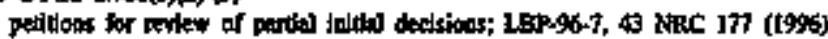

to CP,R 2.786(6)(4)

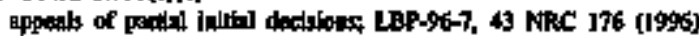

10 CF.R. 2786(d)

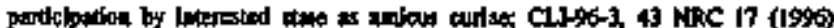

10 C.E. 2786

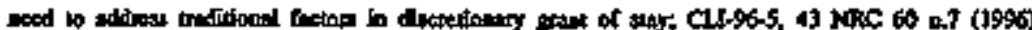

M C.P.R 2.790(0)(1)

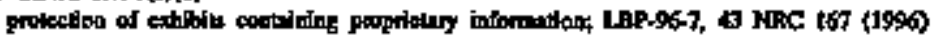

I0 CFR. Fatt 2 subpent L

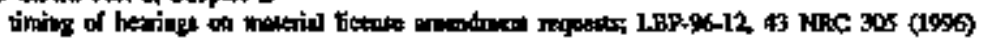

[O CFR. 2]20](0)

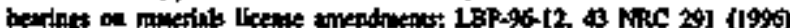

10 CER 2.1205(a)

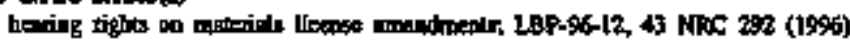

I0 CFR. 21205(0)(1)

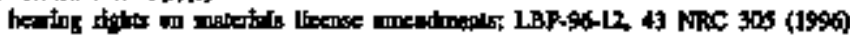

10 CPR $21205(c)(2)$

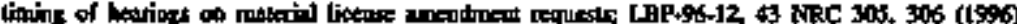

10 CER. 21205(d)(3)

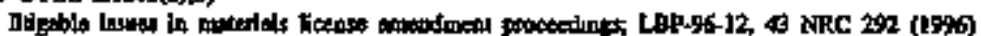

10 CEs $2.1205(0)$

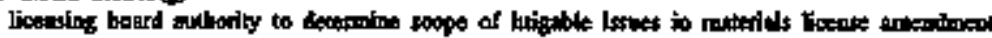
procedins; LBP-96-12, 43 NASC 292 (1996)

10 C.F.R. 2.t2as(1)(3)

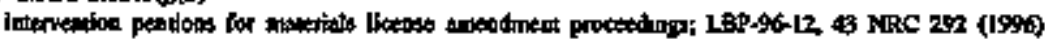

I0 CPR 2.120SD

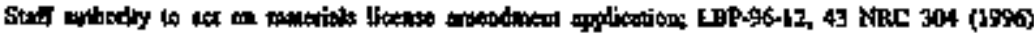

10 CFR $2.1205(\mathrm{mi})$

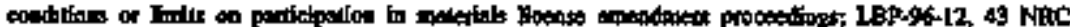
292 (1996)

10 CFR $2.1200(0)$

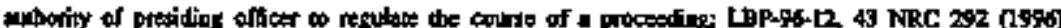

$10 \mathrm{CPR} 2123$

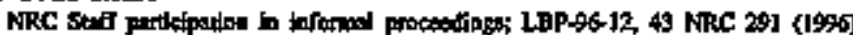

I-I1 


\section{LFGA工, CITATIONS INBEX}

REAULATHONS

10 C.F.R 3427

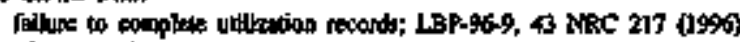

I0 CF.R 3431

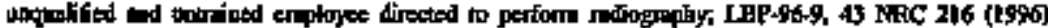
IS CF,B, 343I(b)

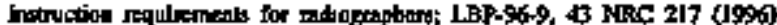

LO C.R. 34.33to

rezoping of pocket dostmesss; LBP-96-9, 43 NRC 217 (1996)

to C.P.R MA,AB)

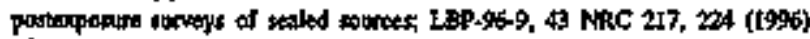

[0 C.F.R. 34.44

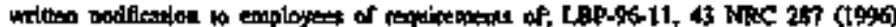

10 C.F.R.

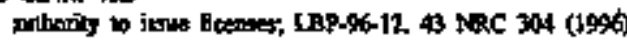

10 C.FR \$OBIf

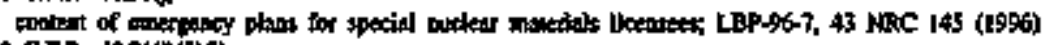

10 CFR $1031(3)(3), 0)$

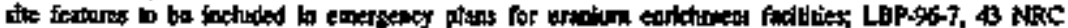
$148-50$ (1596)

to C.F.R. 40.31(0) (3), in

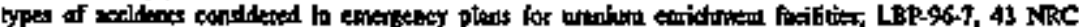
$152(1936)$

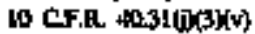

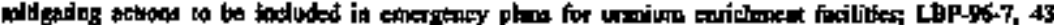
síc 153, 162 (1996)

I0 C.F.R 4031(D)(3),(vH)

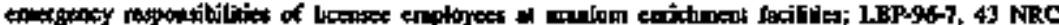
150. 159 [1955]

I0 CFR 40310)(3)(vit)

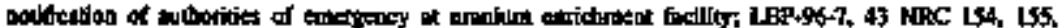
159, 163 (1996)

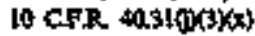

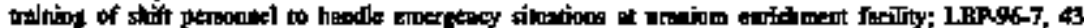
Nac 156 (1995)

I0 CF.R $4031(0)(9)(x)$

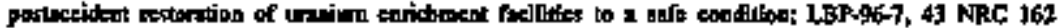
(t9os)

10. C.F.R. 4032

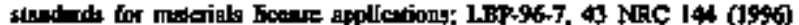

I0 CF,R 40.32(0)

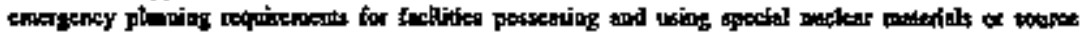

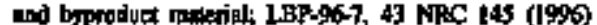

10 CFR 40.41

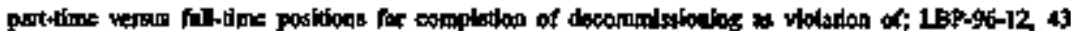
NRTC 798,799 (1996)

10 CFR. 40.41(s)

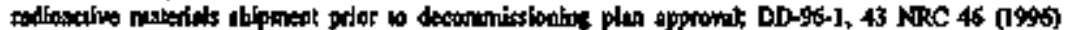

10 CER 40.42

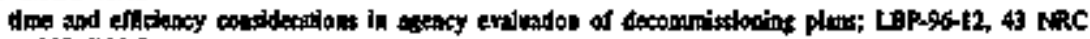
297 (1996)

10 CFR, 40,420,(6)(1r)

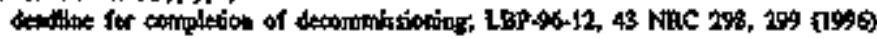

$1-13$ 


\section{LEGAL CITATTONB INDEX}

RECUILATIONS

10 CFR 40.42(c)(b) and (b)

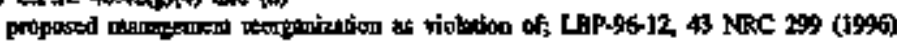

I0 C.P.R. 50.7

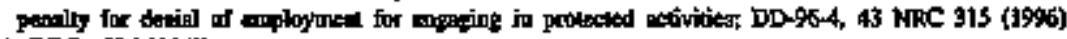

10 CFR 50360 (O)

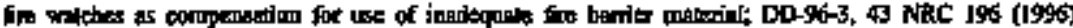

to C.F, S0.48

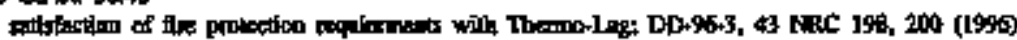

to CFR. S0.55:

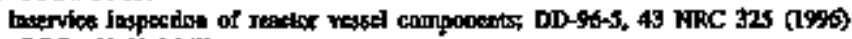

10 CFR. S0554(S)X3)

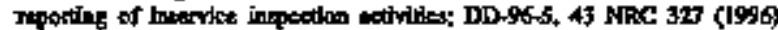

10 CER 5059

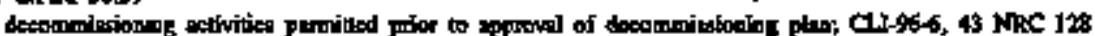
(1956) DD,96-t, 43 NRC 3t, 33. 35. 42 (19:96)

10 CPR SOSP(c)

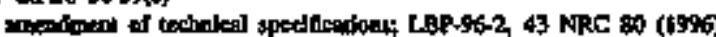

DO CFR SOSI

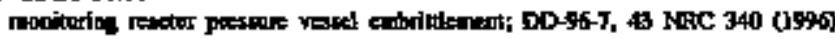

10 CFR. \$0.72

viototion of DD-86.8, 43 NAC 356 . 26 (1990)

10 C.P.R. S0.75(c) घ.I

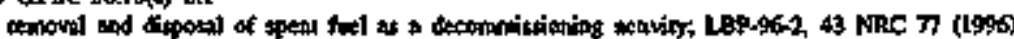

10 CFR. So.7tíf)

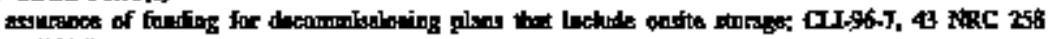
(1996)

10 CE.R. sa7sejati)

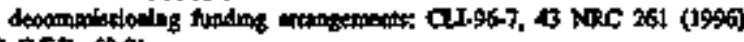

10 ctrk 5081

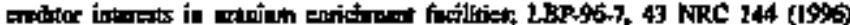

10 CFR. SOS 82

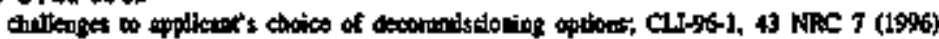

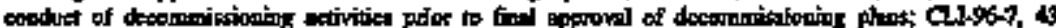
NTE 241 (1990)

I0 CER. $\$ 0$ 62(a)

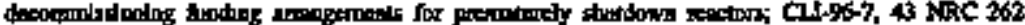
(1996)

lo Cr.R. $50.82(b)(i)$ and (z)

canter of dxompissionio phan C11967, 43 NRC 244 256-5: 0996

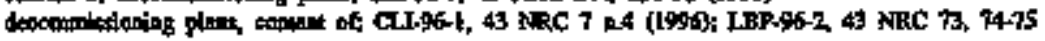
(0906)

TD CFR segeda)

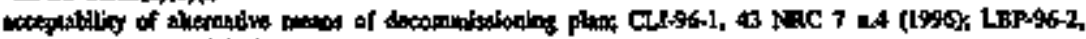
43 NRC T3 n.6 (IS96)

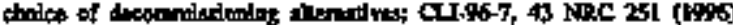

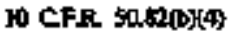

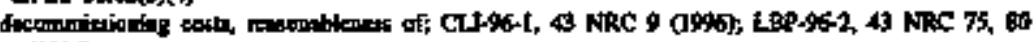
$(1986)$

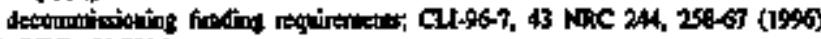

10 CF, $\$ 0.0 \%)$

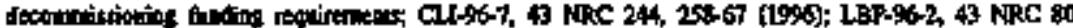
(19\%8)

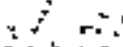

$\therefore x=$

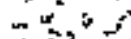

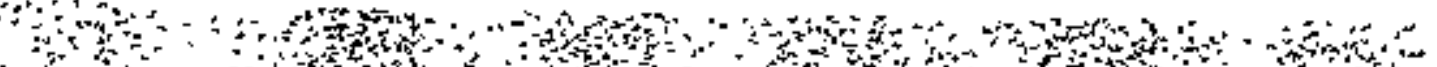<smiles>C1CCC23CCCC2CCC3C1</smiles> 


\section{LEGAL CITATIONS INDBX}

REGULATIONS

It CF,, , 50:02(d)

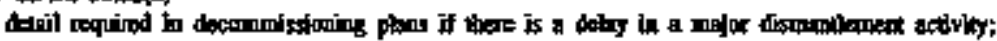
LBP-96-2, 43 NRC 79 ([596)

I0 CF, $R$, 50.02(e)

ALARA thondind applited to docommlsiming Ct1,96-7, 43 NRC 250 (1995)

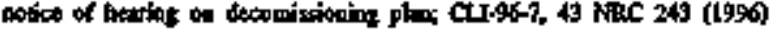

10 CF.R. 50.23(1)

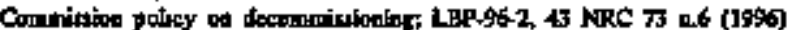

10 C.F.R. S0ss(c)(I)

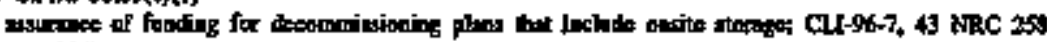
(1996)

10 CR.R. S0 as(c)(2)

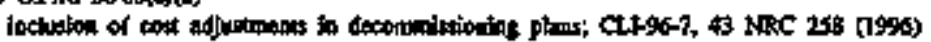

I0 C.R.R 50.91

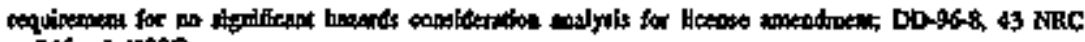
346 a.] (1996)

LO C.F, 50.92

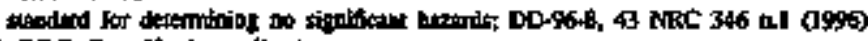

10 CER. Par 50 , Appendir A

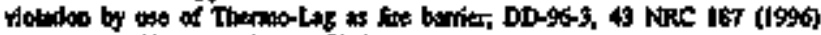

10 eF,R. Par so, Appendix A, GDC 3

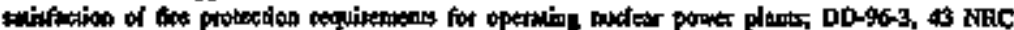

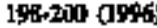

I0 C.R. Pan 50, Appondix A, GDC 14, 15, 30, and 3t

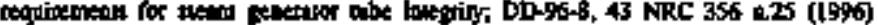

I0 CF,R Part 50 , Appondin $\mathrm{E}$

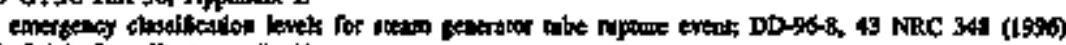

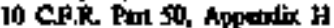

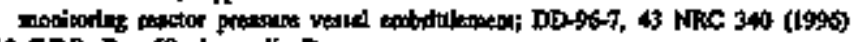

10 CF.R. Pal 50, Appendia $R$

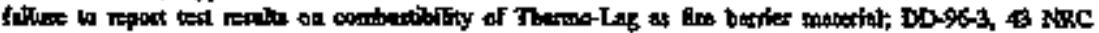
200 (1990)

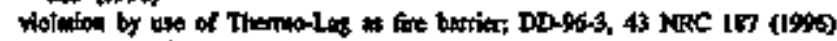

10 CP.R Fart 50 , Appendix R, i IIIT

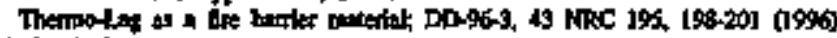

10 C.P.R. Pui SI

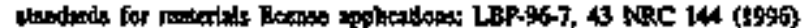

10 CF,R. 5t.22(a)

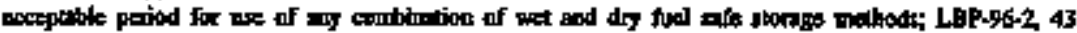
NEC T) (I99)

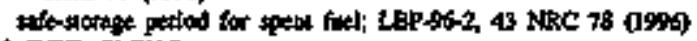

10 CFR. SI.TI(d)

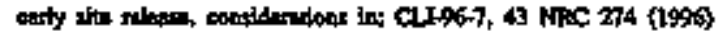

10 CF.R. 51.92

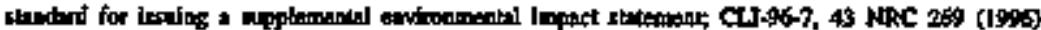

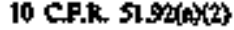

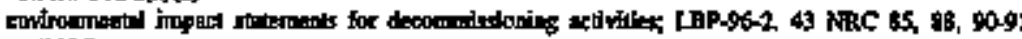
(1996)

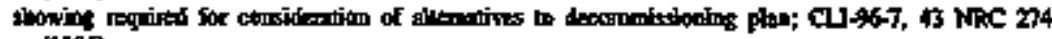
(1995)

to CFR 70.2r(b)

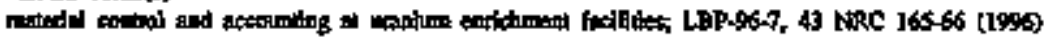

H15 


\section{LEGAL CTTATIONS INDEX}

BEGULATTONS

I0 CFR- 70.220)

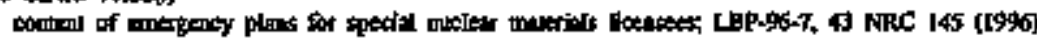
10 CE.R. 70.22(1)(3)(1)

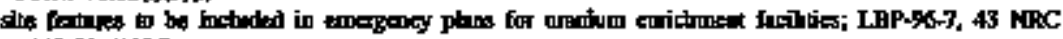
$148-50(1996)$

I0 CF, 7022(1)(3)(v)

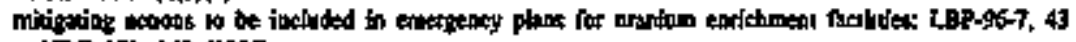
जासC 157, 162 (19\%)

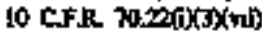

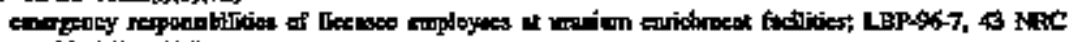
156. 159 (1996)

10 C.R. To.20(1) (5)(vii)

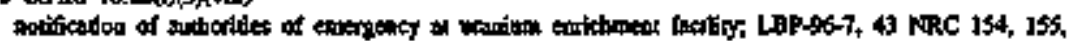
159. 163 (1990)

10 CF.R 70 2aA $)(3)(x)$

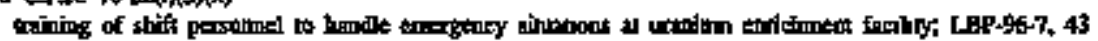
NRC 156 (2995)

IO CF.R. 70.23

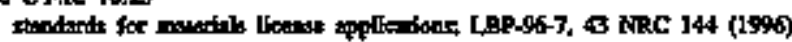

10 CF.R. 7028 (o)

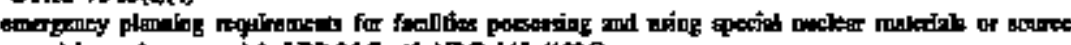

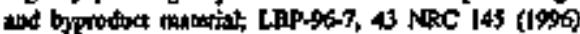

IO CFR 7023 (ai)(6)

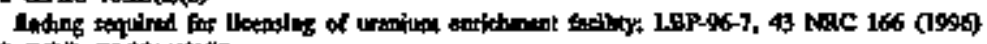

I0 CF.R. $7033(0)[3]$ (ii)

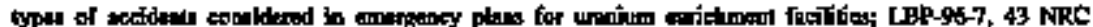
132 (19s)

10 CPR. $7033(0)(3)(x i)$

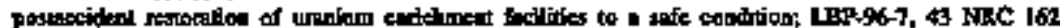
(1996)

10 C.F.R 70.41(保

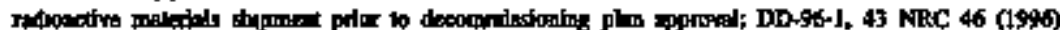

10. CF.R 7044

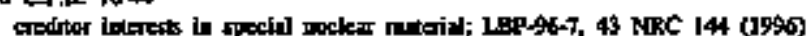

[R C.P.R Pant TI

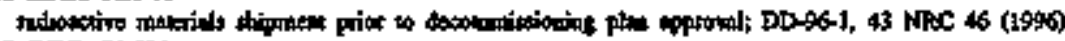

10 CFR. $11.5(0)$

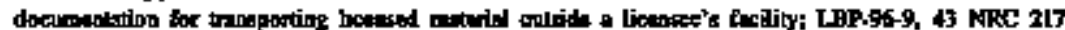
(1996)

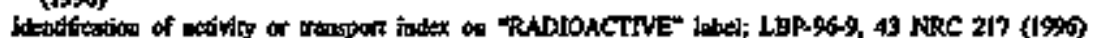

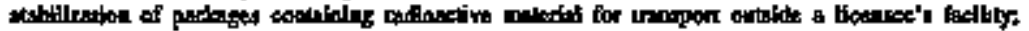
LBPA6-9, 40 NRC 216 (1996)

10 C.R. 71.73 (

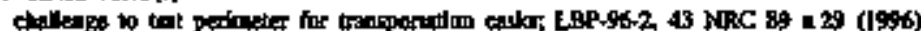

10 CFR Par 72

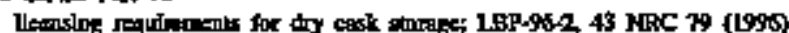

HO CFR. Part 72, Solpat L

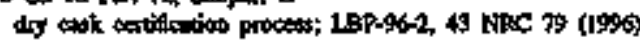

T) CER. 77.40

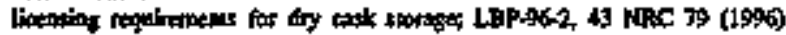

10 CFR. $7240(0)(3)$ (13)

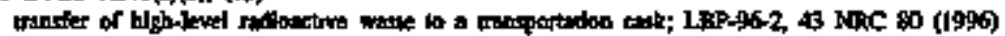


10 CFR, $724(d)$

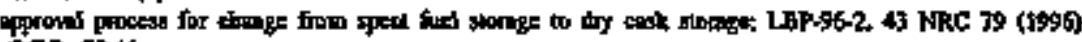
to C.F.R. 7246

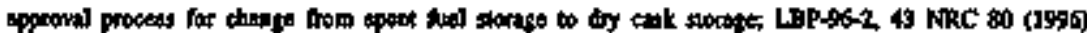

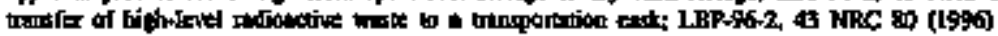

to CF, 72.48(c)

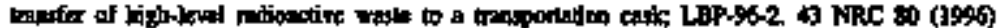

10 CF.R. 7.10\%, 22.21240)(2), (4)

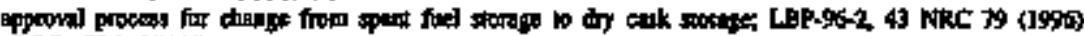
10 C.F.R. $72213(6)(4)$

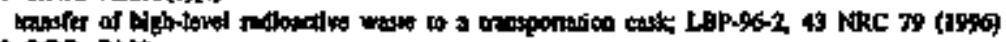

to C.F.R. 74.33

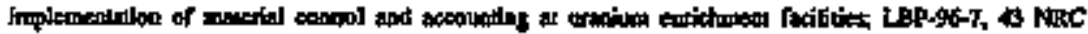
167-69, 171, $172-73$ (1996)

is CF. $7433(1)$

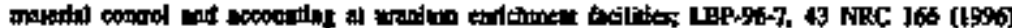

to CF.R. $7439(0)(2)$ and (3)

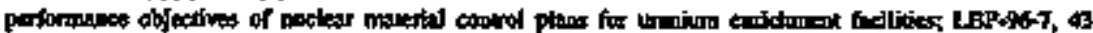
NRC $166(19 \% 6)$

10 CR.R 74334)

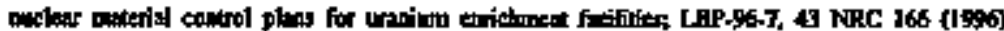

10 CF.R. $7433 /(9)(5)$

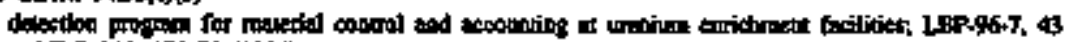
NRC $166,173-76$ (1996)

10 CP.R PaI 100

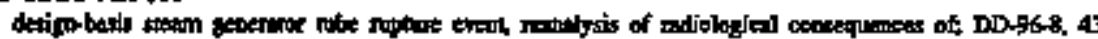
NAC 346, 347, 355, 356 =26 (19\%5)

10 CF,R, 140.15-17

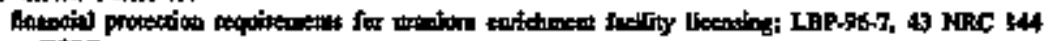
a's\%?

10 CFR Part 140, Appendin A

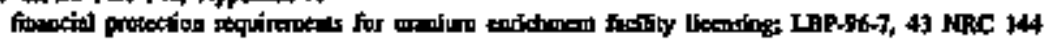
(19\%8)

49 CFR, 172409

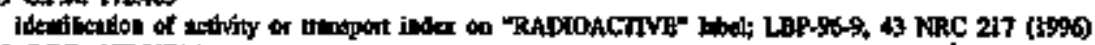

Q CER. IT $\$ 17(\mathrm{~s})$

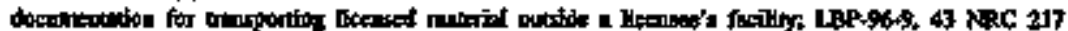
(1996)

49 CFR. In.BA2(d)

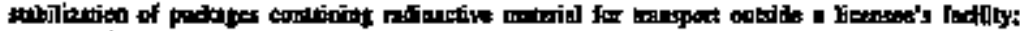
LDP-96-9, 43 VAC 218 (1996) 


\section{LEGAL CITATIONS ENDEX sTKTUTES}

Adtidistative Protare Aft, 5 U.SC. A55l(8) and (9)

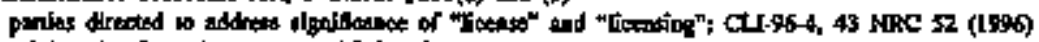

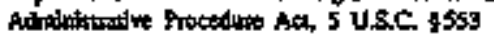

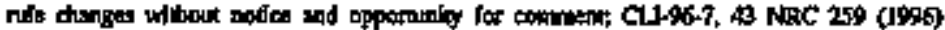

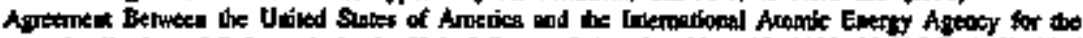

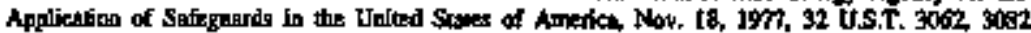
*.7. 72(b)

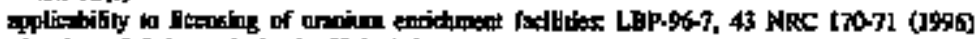

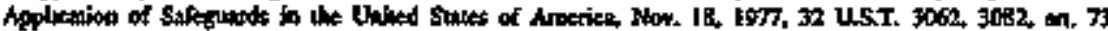

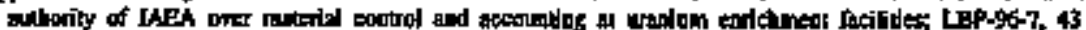
NRC 171 (1996)

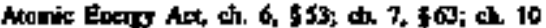

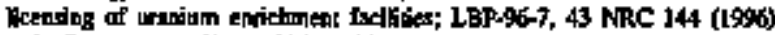

Atomio Enenty Aat 62, $\$ 2$ U.S.C. 2092

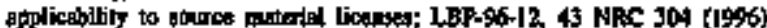

Anoinic Emery Act, 81, \$2 U.S.C. \$2111

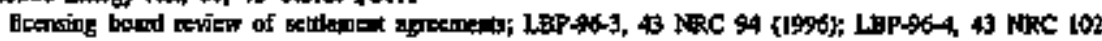
0996): LEP-96-11, 43 NRC 289 (1996)

Atorric Enery Act, 103

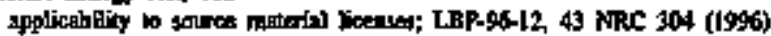

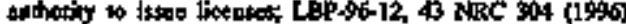

Alontit Enetgy Acl, Iflb, 42 U,S,C \$2001(b)

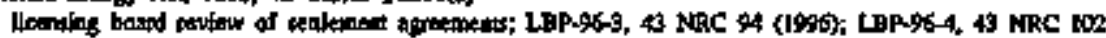
(1970): LEP496-J], A3 NRC 2BJ (L96)

Alorpic Energy Act, 16lo, 42 US,C $\$ 2201$ (0)

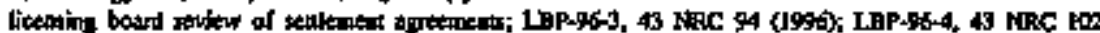
(1995). LBP.96+11, 43 NRC 281 (1996)

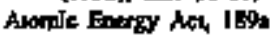

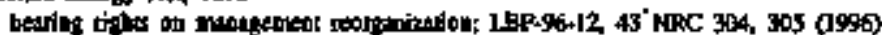

Alente Enory Ael, $189(a)(2)(A)$

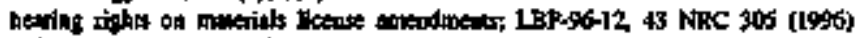

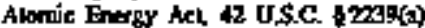

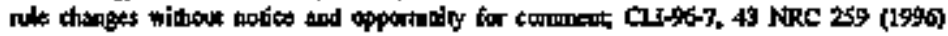

Energy Feorganis tion Aat of 1974, 210 (nes 231)

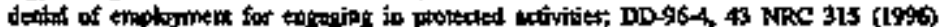

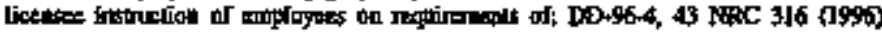

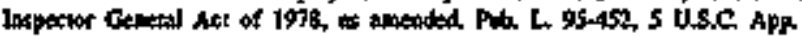

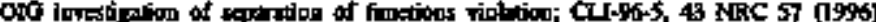

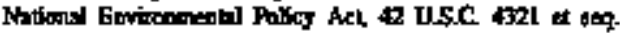

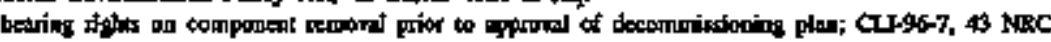
242 (19\%) 


\section{SUBJECF INDFX}

\section{ACODENTS}

redete and speentritic ditks; L.BP-96-2, 43 NRC 61 (IS96)

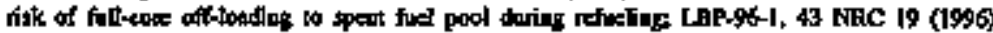
ADJUDICATORY BOARDS

role of C.196-7, 43 NRe 235 (1956)

ADJUDICATORY HEARTHCS

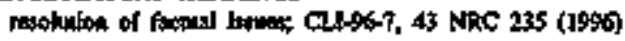

ACTREFMENTS

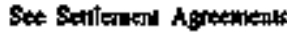

ATHRA

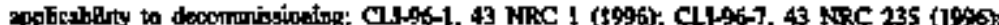

LAP-96-2, 13 NRC 61 (1996)

oosi cansidertions in deternining spplicabulty df CLL96-I, 43 NRC 1 (I996)

AMENCht向T

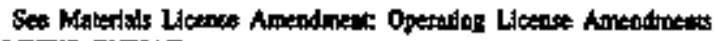

A MITCUS CURAAB

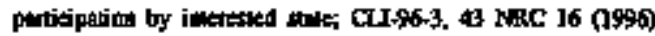

APPEALS

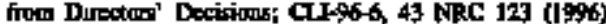

BOARDS

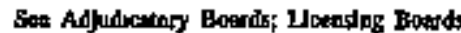

BRIERS

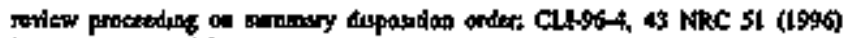

BURDEN OF PROTI

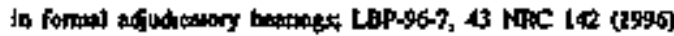

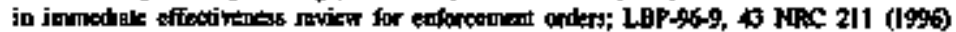

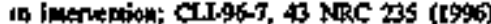

CTIL. PEWhITIES

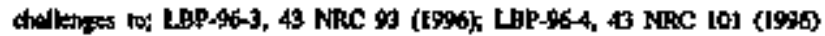

Comingsion

an spote reviow whority; Ct166-6, 43 NRC 123 (I996)

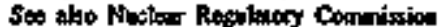

COMMINICATTONE

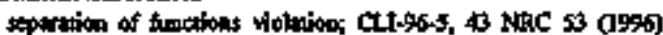

See alao Ex Pare Comuningatoos

COAPONEMT COOLIFG WATER SYSTEM

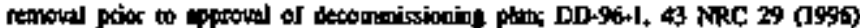

CONIENIIONS

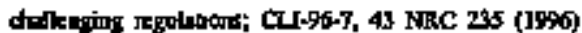

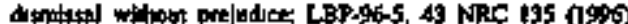

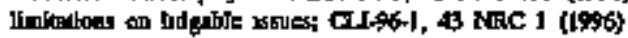

pleuthe rec

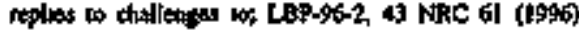




\section{SUBJECT INDEX}

\section{DHSQUAIIPXATION}

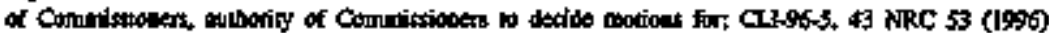
EDDY-CURRENT TESTING

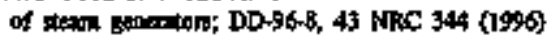

EFECTIVENESS

Ser lmimedalo Efloctivenss

FMARTILEMTINT

resark prossure vessed: DD-96-7+ 43 NRC 335 (1990)

EMERGT TCY CORE OOOLNG

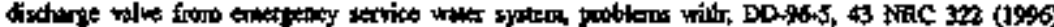

ERARGENCY OPERATING PROCBDLRES

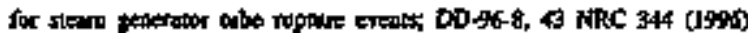

EMISRGENCY PLANS

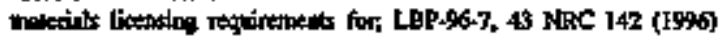

ELFIOTEES

Sex litrontex Elpologrs

ENTFORCEMENT ACTRONS

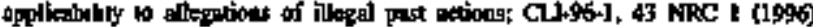

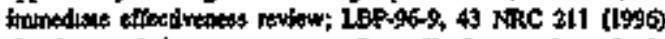

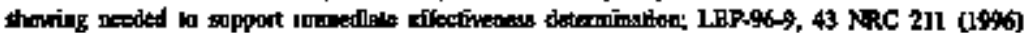

ENYRONMENTAL FINCTIONS

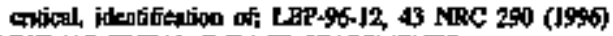

ENYRONMAENEAL RMPACT STATENENTS

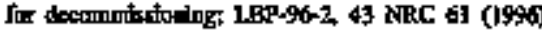

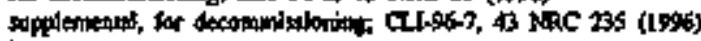

EX PARTE COMMTINICATTONS

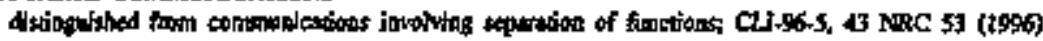

EXPOSLIRE, RADOLOGICAL

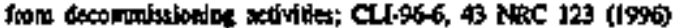

EXTENSTON OF TINE

for suin pons revew; CLFo6-6, 43 FRC 123 (1996)

FIRE

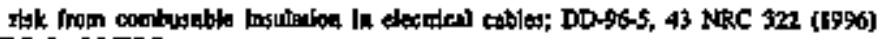

FERE BARRIERS

Thempotery metial a; DD-96-3, 43 NRC 183 (1990)

FIRE WATCHES

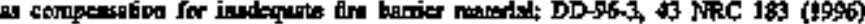

EJEL

Se: Spen fort

GENERATOHS

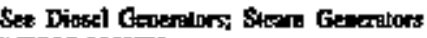

GENERIC ISSUES

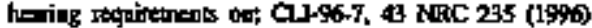

HEALTH ANO SAFETY

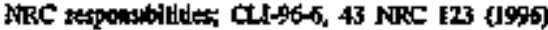

HEARDNGS

Soo Adpudtonoty Hearings.

IMRADIATE EFECTIVIENESS

Ihow]ng woedzd to suppen determinations of; LBP-96-9. 43 NRC all (1996)

IMRLIDIATE EFACTIVENASS REVIJW

buden of going forward; 1Bp-96-9, 43 NRC 231 (I995)

buden of pmof; LBP-96-9, 43 NDC 211 (1990)

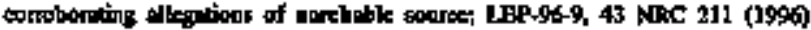




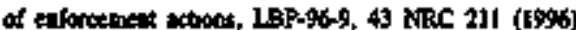

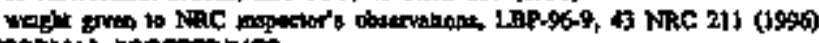

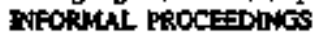

begl atuminds mpheble to, LBP-96-12, 13 NRC 290 (1996)

INSPECTHON FROÓRAMS

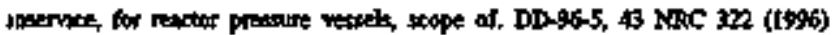
IASPECTORS

Sin MRC Inpectorts

ENERTESTED STATE

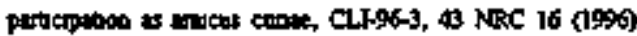

ENTEVtertak

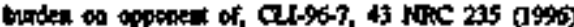

trides on pesbouren, CtI-96-7, 43 NRC 235 (1990)

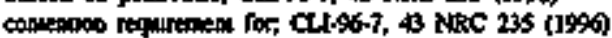

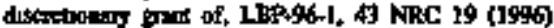

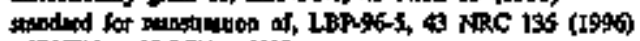

INIERVENTION PETITHONS

Hat anendmant of, 1,BP.96-t, 43 NRC 19 (1990)

pleming tefters, Ct-96-1, 43 NRC 1 (1996)

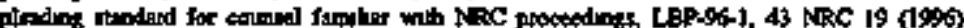

10N-EXCHLNWOE PT

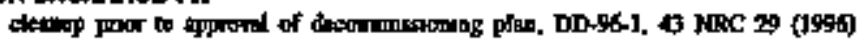

JTRISDKCTON

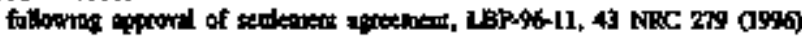

LFAD

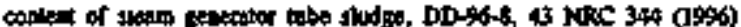

LWBDTr

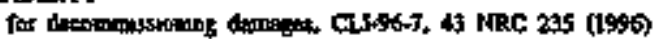

LICENSEE EATFIOTEES

boste work emrountenl, DD-95-4, 43 NRC 309 (1996)

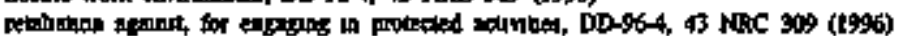

UCESERS

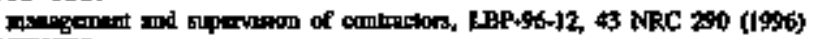

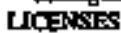

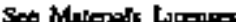

LCENSIS BOARDS

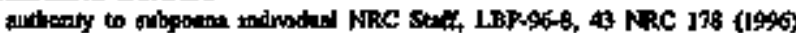

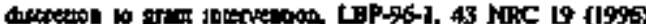

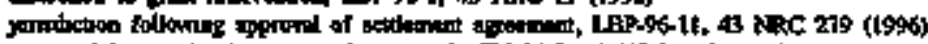

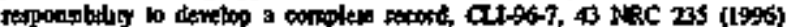

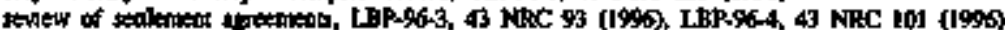

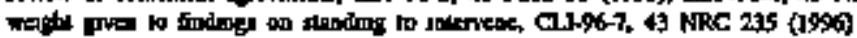

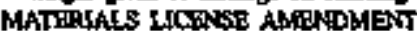

for

MATURLALS LICENSES

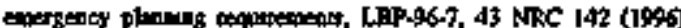

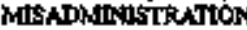

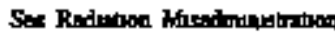

MONTHOPNG

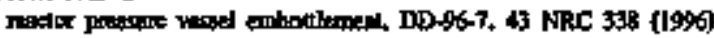

HOOTNESS

vacar of protnd of, Ctr96-2, 48 NRC 13 (1996)

$=-$
$\therefore=$
$\therefore=$

1,

:

$\cdot$,

:

$+t$

$+$

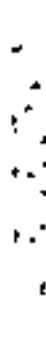

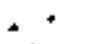

$\therefore$

$\therefore$

$\therefore$ !

$x$,

$t$

$\because$

$\therefore$

-

$\therefore$

;

1.

.

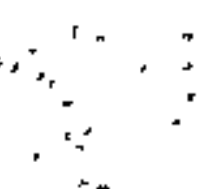

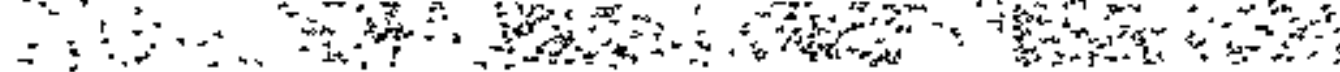


NATONAL ENTRONMENTAL POLICY ACT

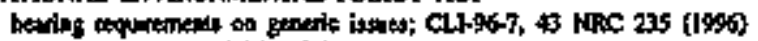

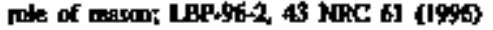

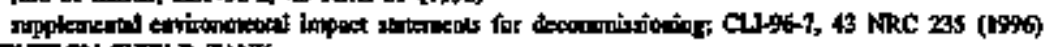

MEUTKON SHIIIED TANKK

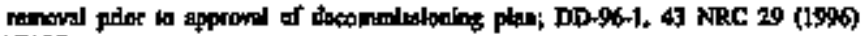

NoTICE

See OSbetal Nolices

NRC ESTPECIOts

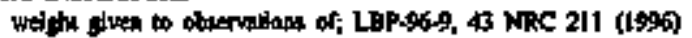

NRC STAFF

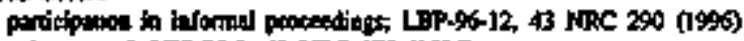

sobpoem of LDP., 8 , 43 NDC 178 (19\%9)

NUCLEAR MATERIAL CONTROL PLANS

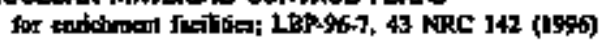

NUCLEAR FETULATORY CONMILSSTON

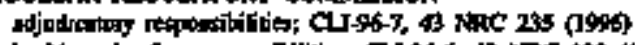

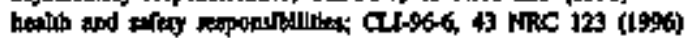

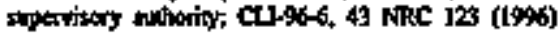

OPFClAL NOTXR

of publidy wilbble documerks, CL-96-7, 43 NRC 25 (1996)

OPERATING ULCENSE NIENDMENT PROCELDONCS

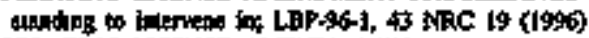

OPERATINO LCENSE NMENOMENTS

dallonges tor 1,BP-96-1, 43 NRC 19 (1996)

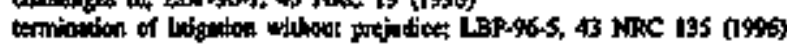

OPERATION

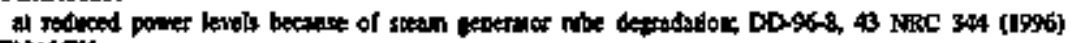

PENALTY

5eat Ond Renalities

PRECTEOENTS

eltminutor through racurar, CtI\$6-2, 43 NRC I3 (1996)

PRETUDGMENT

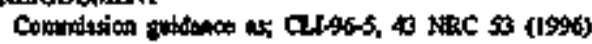

PRDMARY MUXI JARY BXI DING

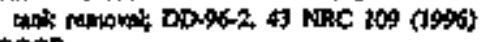

ProOP

Sed Burden of Froof

QUALINCATIONS

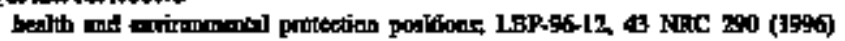

QUALTT ASSURANCE PROTRAMS

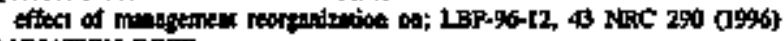

RADIATION DOSR

SeE ALARA

RADIATION WISADMINISTRATYON

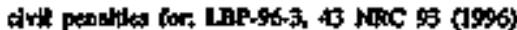

RUDLATION EROTECTION

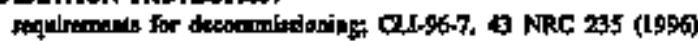

RADATION PROTECTION STANIDARDS

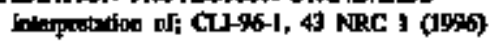

RADHOACIVE WASTE SFIIMIENTS

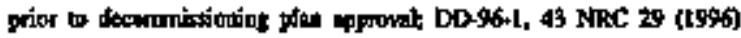

107 


\section{RADPOCRAPEIERS}

trating and cextifearion; 15P-96-9, 43 NRE 211 (1996) ;

RADIOLOGICAL SURVEYS

Fiture of perform, LBP.96-9, 43 NTC 211 (19\%)

REACTOR COFE

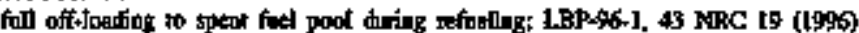

REACTOR PRESSTRE VESSEI

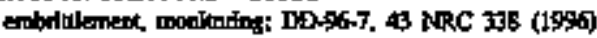

REACTOR VESSEL

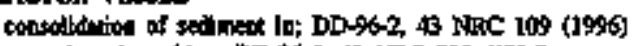

core trowed crocking, bD-56, 43 NRC 322 (1996)

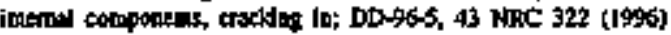

RECUSAL

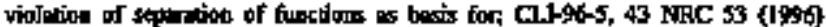

REGTULATONS

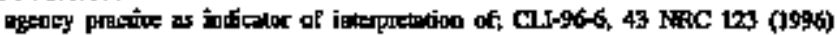
ALARA toputremerts: 01.96-1, 43 NRC I (1996)

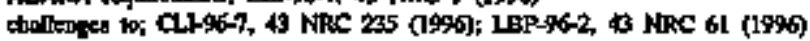

cecomrisstoning funding: c1196-7, 43 NRC 235 (1996)

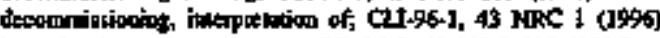

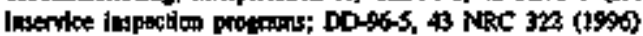

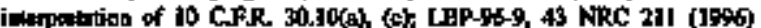

imeprestion of to CF.R. 50.82; OL166-1, 43 NiRC 235 (1996)

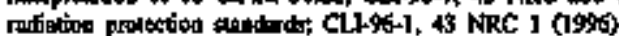

REGTRATORY GUIDES

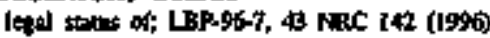

REPOKTING REQUTREMENTS

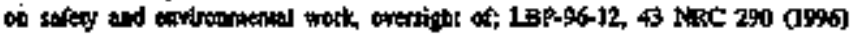

REVITW

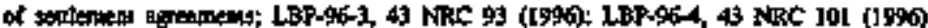

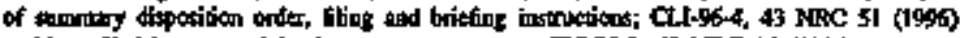

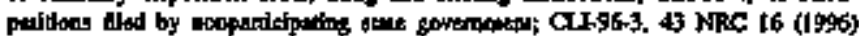

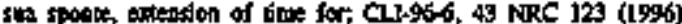

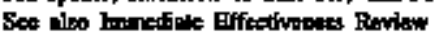

RULEMAKATNG

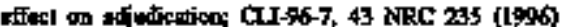

RUIES OF PRACTICE

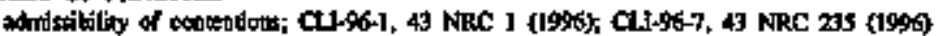

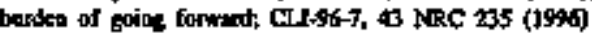

bueded of proof; CLI.96-7, 43 NRC 235 (1996); 1.BP.96-7, 43 NRC 142 (1995)

tolkenes k Comrission repolwions; Cl1-96-7, 43 NEC 235 (1996), 1,BP.96-2, 49 NRC 6I (1996)

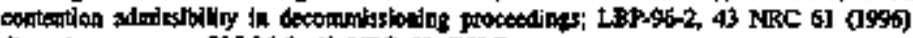

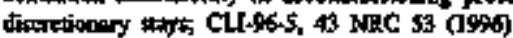

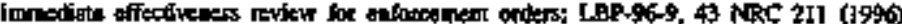

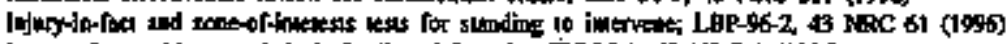

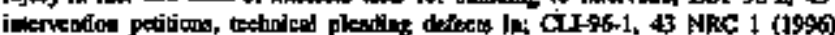

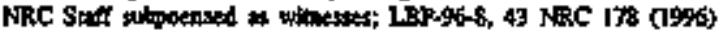

officid motien; C11-96-7, 43 MAC 235 (1996)

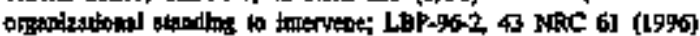

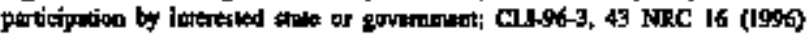

propared essimony; LBP-S6-14, 49 NRC 231 (1996)

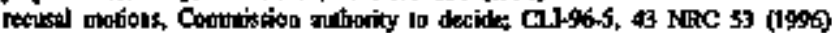

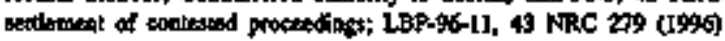

$1-28$ 
sunding 10 invervio; CLV6-7, 43 NRC 235 (1996)

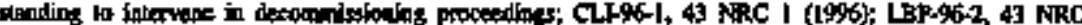
61 (1996)

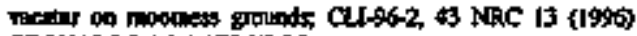

SAFEOUARDS PROCEDURES

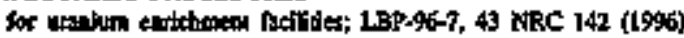

SAFETY

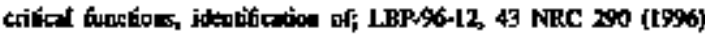

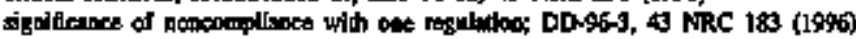

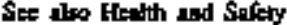

SAFET DUIECTION BULDNT .

Equjpmtat removel fiom, bD-96-2, 43 NRC 109 (1996)

SEPARATION OF FANCTIONS

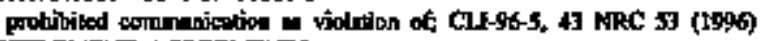

SSITLEMENT AGRERMIENTS

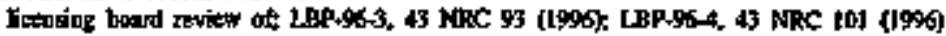

NaC policy an; LBP-X6-11. 43 NRC 279 (t996)

SHIPMENTS

See Radiloective Wate Stipmems

SPOWFCAUSE PROCEEDINCS

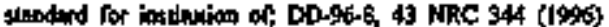

SPE्TT FUEL

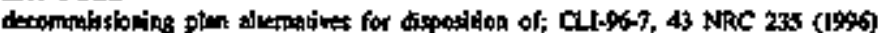

SPENT FUE COOLINO SYSTES

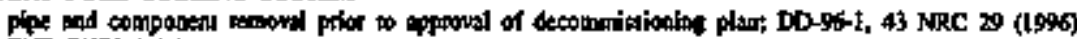
SPENT FUE, POOL

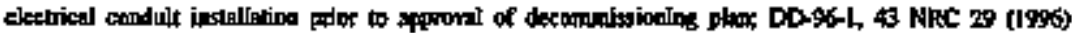

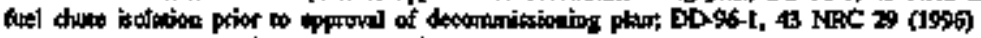
opader remorifs DD-96-2, 43 NRC I09 (19\%0)

STAFT

See NRBC Stor

STANDING TO DNTFRYFINE

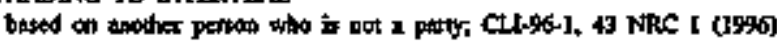

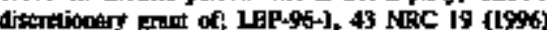

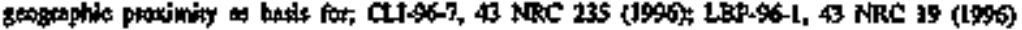

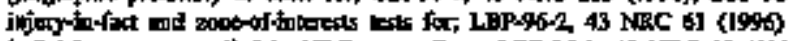

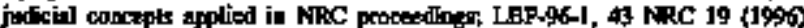

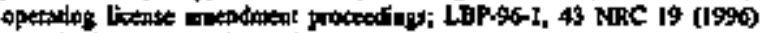

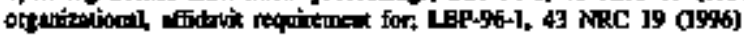

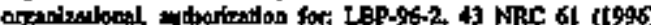

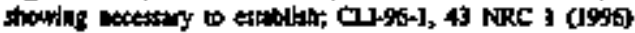

weight given to licaning bogrd'a findes on; CJ-96.7. 43 NEC 235 (1996)

STAX

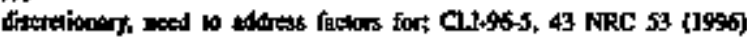

STEAM GENERATOR TUFE RITTURE

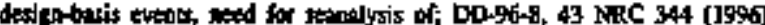

STEAM GERFRATOR TUBES

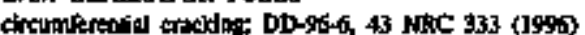

kend antent in aludge; DD-96-8, 43 NRC 344 (1996)

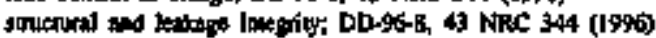

STEAM GENERATORS

eddy-aumen woting ofi DD-96-8, 43 NRC 344 (1996) 


\title{
SUBJECT INDEX
}

\author{
SLBMARKY DISPOSTIONT \\ mevien of ander grining: C1L96-4, 43 NRC S1 \{1996) \\ SURVEYS \\ Sec Radologied Surveys \\ TEFMINATION OE PROCEBDNAS

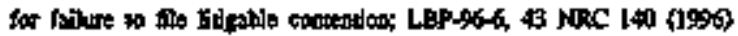

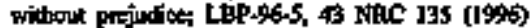 \\ TESTBNow

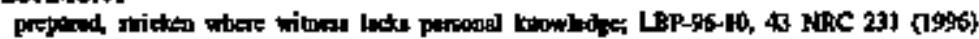 \\ TESTING \\ of rofliographes: LBP-96-9, 43 NAC 211 (1996) \\ Ses ato Edity-Cwrent Theting \\ TURBVIE BUIDTWO \\ Inoulation nowoll DD-96-2, 43 NRC 109 (1996) \\ URANIIT ENTRKCHMIEVIT EACTISTIES

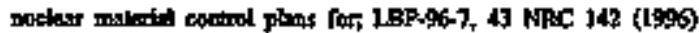 \\ VACATUR

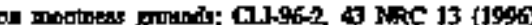 \\ VAPOR CONTADAER

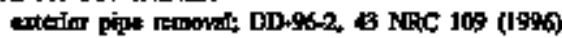 \\ VTOADNONS

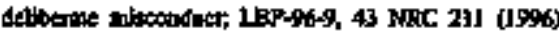

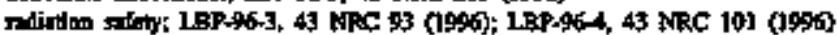 \\ WASTE \\ See Radicentive Wrow \\ WASTE PROCESSDUG SYSTIGMS

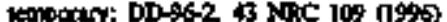 \\ WASTE TANK

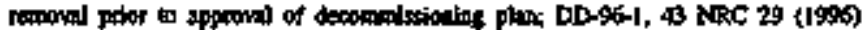 \\ WTinesses \\ NRC Strit subpenes es; 15P-968, 45 NRC I7\% (1996)

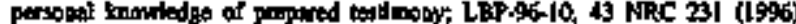

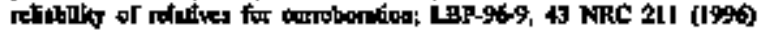




\section{FACHMY NDEX}

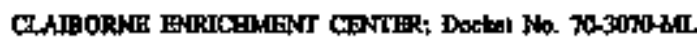

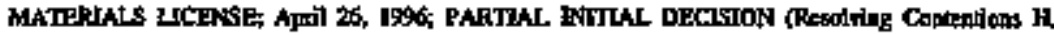
I, and M): LAP-96-7, \&3 NRC 142 (1996)

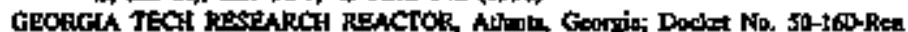
OPERATTWG LKCENSE RENEWAL: Apol 30. 1996 THIRD PREHEARRG CONPERENCE ORDER; LDP.96-8, 40 NRC 178 "(1996)

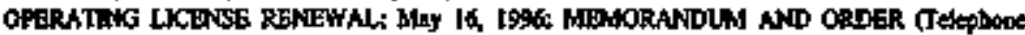

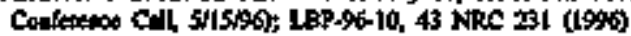

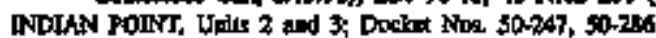

REQUIST FOR ACTION; JME 10, 19\%; DIRECTOR'S DECTSON UNDER JO CFR 52206 DD-96-6, 43 NRC 333 (1995)

MTLSTONE NIJQEAR POWER STATTON UNt I; Docket Na. S0-245-OLA

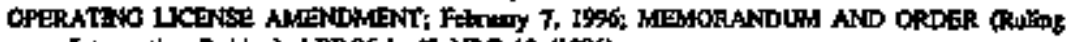
co Inveranton Peddon); LBP.96-I, 43 NRC is (I996)

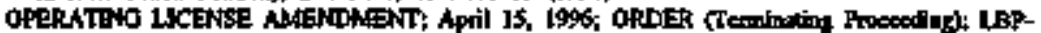
$96-6,43$ NRC 140 (19\%)

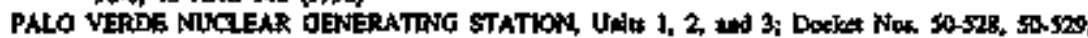
$50-530$

REQUTST FOR ACTION; JW 1. I994 DRECTOR'S DECISION UNDER 10 CER. \$2206; DO-96-4, 43 NICC 309 (1996)

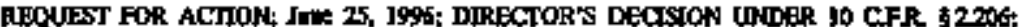
DD-96-8, 40 ARC 344 (1996)

PEACH DOTTCM ATOMIC POWER STATON, Untts $2 \mathrm{md} \mathrm{3;} \mathrm{Dacket} \mathrm{Nag,} \mathrm{st-2m.} \mathrm{sa-27s}$

REQUIST FOR ACTION; INM 10. 1996: FINAL DIRECTOR'S DECTSTON UNDER to CFR. 5 2.206; DD-96-5, 43 NRC 322 (1996)

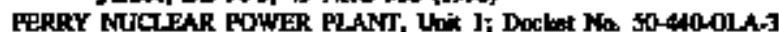

OPERATRKG LKCENSS AMENDMIONT; MWCh ?, 1996; ORDER; C4-964, 43 NRC 51 (1996)

RAKCHO SECO NUCUEAR GENERATDNG STATION; DXCT NO. 50312

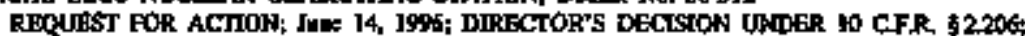
DD-96-7, 4 NRC 3B: (1996)

RVER BEND STATION, Unit I; Docks No. 50.458-01A

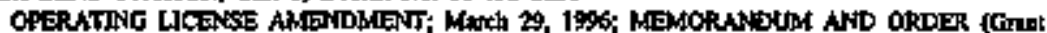

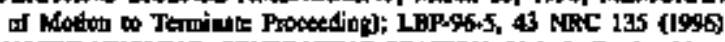

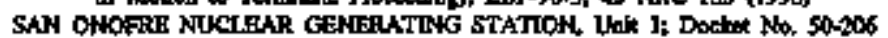

REQUEST FOR ACTTON; InN 14, I9\%; DIRECTOR'S DECCISWON UNTER IO C.F.R 52201 DD.967, 43 NAC 338 (1966)

TROLAN MUCLEAR PLANT: Docka No sas4

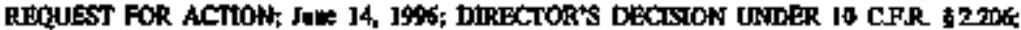
DD-S6-7, 4 NIRC 338 (I\$9)

WEST CHICAOO RARE EARTHS FACTLTYY: Dochet Na. 40-20161+Ml.

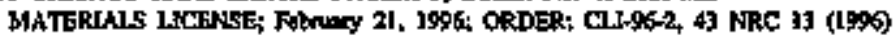




\section{FACIIIYY INDEX}

YANKTER NUCLEAR POWER STATION; Doctet 30. 50-020

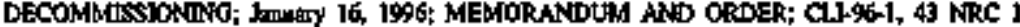
(1996)

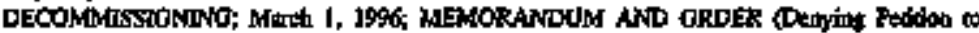
Inervent) LBP-96-2, 43 FFC 61 \{1996)

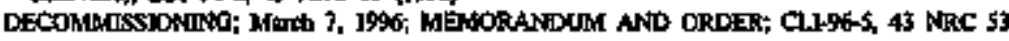
(1996)

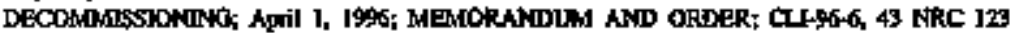
(1996)

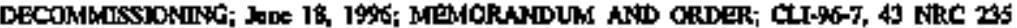
(1996)

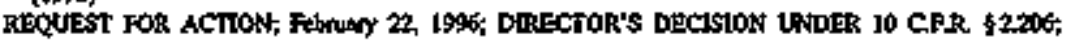
DD.96-1, 43 NRC 29 (1999)

REQUEST FOR ACTONK NATh 18, 19\%, SUPPLEMENTAL DRECTOR'S DECISION UADER 10 CF,R. \$2 2006 DD-96-2, 13 NRC 109 (1996)

REQUTEST FOR ACTION, IMP 14, 1996; DERECTOR'S DECISION UNDER 10 CFR. \$2.206; DD-96-7, 43 NRC 358 (1996) 